Environmental Restoration Division

ORNL Environmental Restoration Program

\title{
Screening of Contaminants in Waste Area Grouping 2 at Oak Ridge National Laboratory, Oak Ridge, Tennessee
}

\author{
B. G. Blaylock \\ M. L. Frank \\ F. O. Hoffman \\ L. A. Hook \\ G. W. Suter \\ J. A. Watts
}

Manuscript Completed-September 1991

First Issued-July 1992

Revision Issued_September 1992

Prepared by

Environmental Sciences Division

Oak Ridge National Laboratory

ESD Publication 3804

Prepared for

U.S. Department of Energy

Office of Environmental Restoration and Waste Management under budget and reporting code EW 20

\section{OAK RIDGE NATIONAL LABORATORY}

Oak Ridge, Tennessee 37831-6285

managed by

MARTIN MARIETTA ENERGY SYSTEMS, INC.

for the

U.S. DEPARTMENT OF ENERGY under contract DE-AC05-84OR21400 


\section{Author Affiliations}

B. G. Blaylock, M. L. Frank, F. O. Hoffman, L. A. Hook, G. W. Suter, and J. A. Watts are members of the Environmental Sciences Division, Oak Ridge National Laboratory, Martin Marietta Energy Systems, Inc. 


\section{CONTENTS}

FIGURES $\ldots \ldots \ldots \ldots \ldots \ldots \ldots \ldots \ldots \ldots \ldots \ldots \ldots \ldots \ldots \ldots \ldots \ldots$

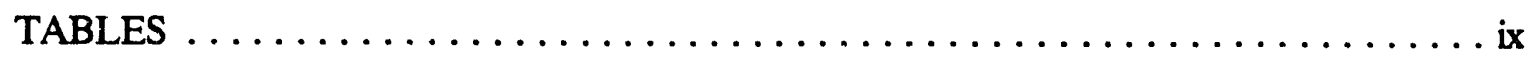

ABBREVIATIONS $\ldots \ldots \ldots \ldots \ldots \ldots \ldots \ldots \ldots \ldots \ldots \ldots \ldots \ldots \ldots \ldots \ldots$

EXECUTTVE SUMMARY $\ldots \ldots \ldots \ldots \ldots \ldots \ldots \ldots \ldots \ldots \ldots \ldots \ldots \ldots \ldots$

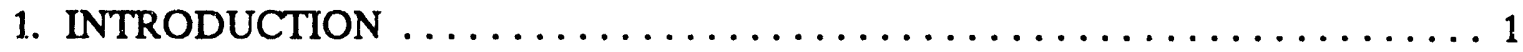

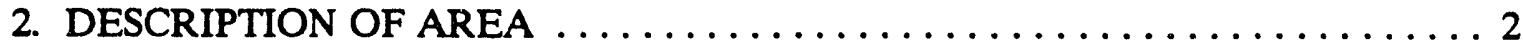

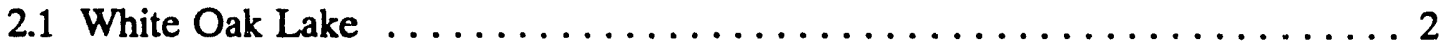

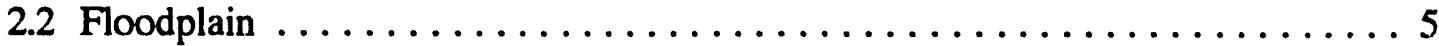

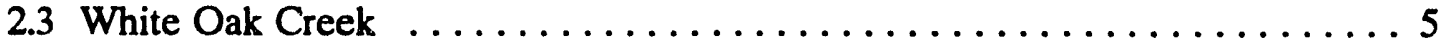

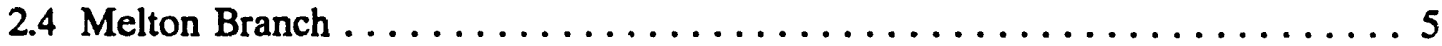

2.5 White Oak Creek Embayment $\ldots \ldots \ldots \ldots \ldots \ldots \ldots \ldots \ldots \ldots \ldots \ldots$

3. SOURCES OF INFORMATION $\ldots \ldots \ldots \ldots \ldots \ldots \ldots \ldots \ldots \ldots \ldots$

4. SCREENING RISK ASSESSMENT FOR HUMAN EXPOSURE .........9

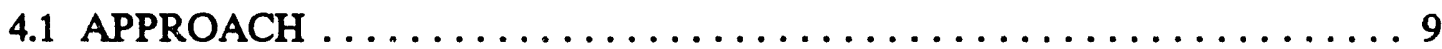

4.2 SCREENING INDICES $\ldots \ldots \ldots \ldots \ldots \ldots \ldots \ldots \ldots \ldots \ldots \ldots$

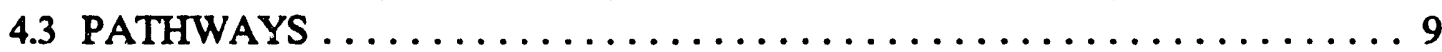

4.4 INTRUDER SCENARIO $\ldots \ldots \ldots \ldots \ldots \ldots \ldots \ldots \ldots \ldots \ldots \ldots \ldots \ldots$

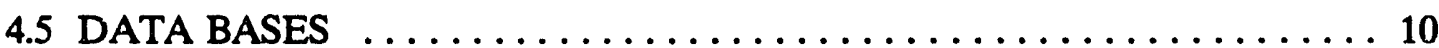

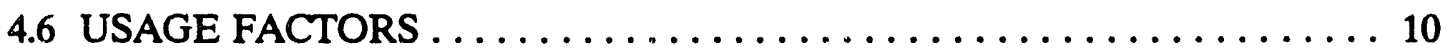

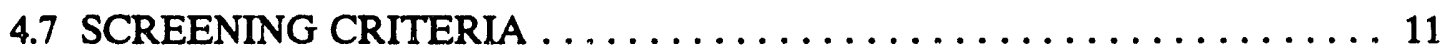

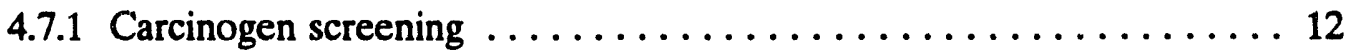

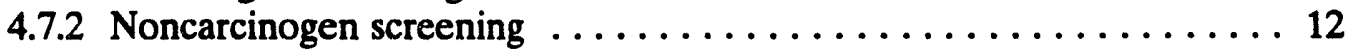

4.8 CONTAMINANT SCREENING RESULTS $\ldots \ldots \ldots \ldots \ldots \ldots \ldots \ldots \ldots$

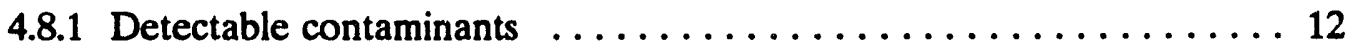

4.8.1.1 Nonconservative screening of detectable

contaminants ....................... 15

4.8.1.2 Conservative screening of detectable contaminants ...... 17

4.8.1.3 Intruder scenario . . . . . . . . . . . . . . . . 28

4.8.2 Nondetectable Contaminants ................... 30

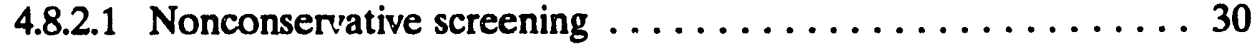

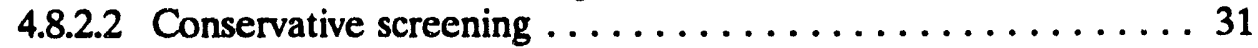

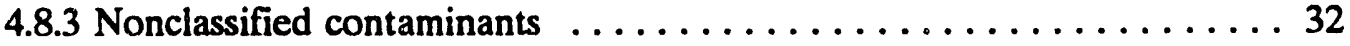

4.8 .4 Groundwater . . . . . . . . . . . . . . . . . . . . 32

4.8.4.1 Nonconservative screening of detectable

contaminants in groundwater $\ldots \ldots \ldots \ldots \ldots \ldots \ldots \ldots \ldots$

4.8.4.2 Conservative screening of detectable

contaminants in groundwater $\ldots \ldots \ldots \ldots \ldots \ldots \ldots . \ldots 38$ 
4.8.5 Special Case - Lead . . . . . . . . . . . . . . . 38

4.9 CONCLUSIONS FOR SCREENING RISK ASSESSMENT FOR HUMAN

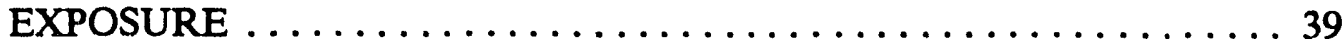

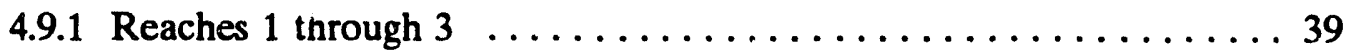

4.9.2 Results for Screening Risk Assessment for Human Exposure for the WOCE ..........................40

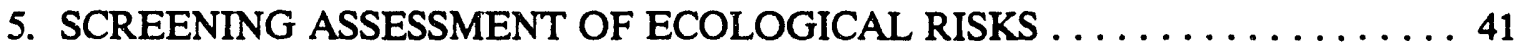

5.1 ECOLOGICAL HAZARD DEFINITION $\ldots \ldots \ldots \ldots \ldots \ldots \ldots \ldots \ldots$

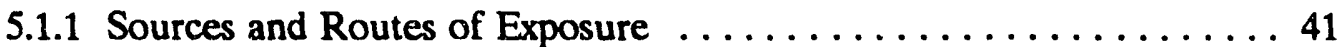

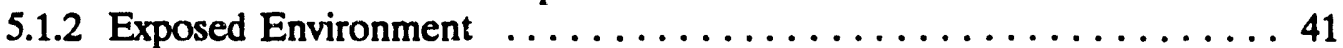

5.1.3 Ecological Endpoints ...................... 42

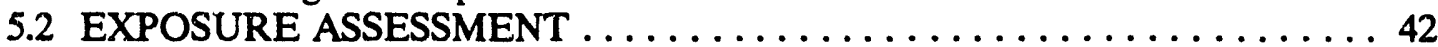

5.2 .1 Water ............................. 42

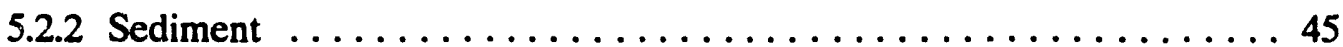

5.2.3 Tissue Concentrations as Indicators of Effects on Fish . . . . . . . . 46

5.2.4 Tissue Concentrations and Piscivorous Wildlife ............ 46

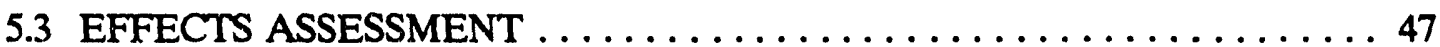

5.3.1 Methods for Deriving Benchmarks ............... 48

5.3.1.1 Water ......................... 48

5.3 .1 .2 Consumed fish flesh $\ldots \ldots \ldots \ldots \ldots \ldots \ldots \ldots \ldots$

5.3.2 Screening Criteria for Individual Chemicals $\ldots \ldots \ldots \ldots \ldots \ldots 56$

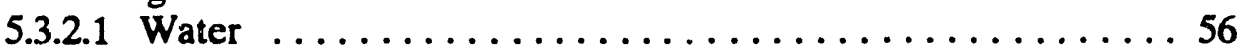

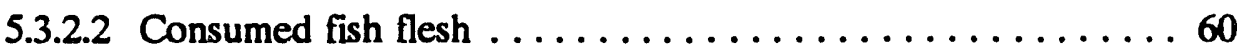

5.3.2.3 Radionuclides ........................664

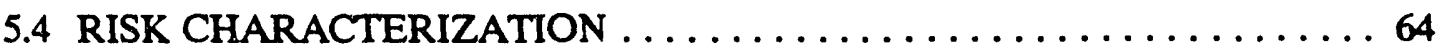

5.4.1 Exposure/Response Integration $\ldots \ldots \ldots \ldots \ldots \ldots \ldots \ldots \ldots \ldots \ldots \ldots$

5.4.1.1 Aqueous concentrations/aquatic life effects ..........64 64

5.4.1.2 Concentrations in sediment/aquatic life effects ........65

5.4.1.3 Concentrations in fish/fish effects $\ldots \ldots \ldots \ldots \ldots \ldots \ldots$

5.4.1.4 Concentrations in fish/piscivore effects ..........65

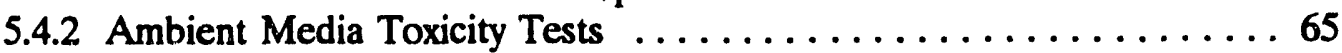

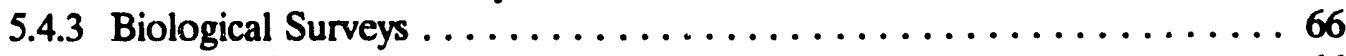

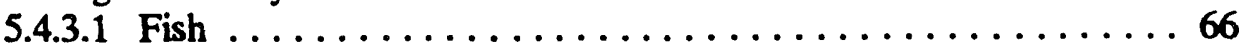

5.4.3.2 Benthic macroinvertebrates $\ldots \ldots \ldots \ldots \ldots \ldots \ldots \ldots 67$

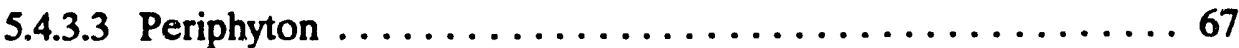

5.4.3.4 Terrestrial ...................... 67

5.4.4 Weight of Evidence and Uncertainties . . . . . . . . . . 67

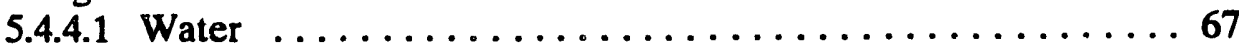

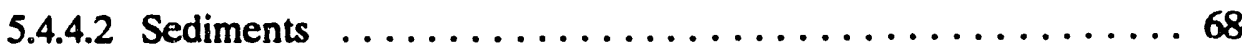

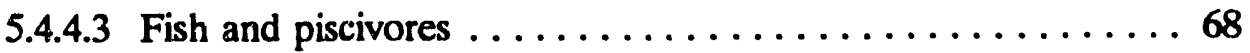

5.4.4.4 Terrestrial communities ................68

5.4.4.5 Summary of the ecological risk characterization $\ldots \ldots \ldots 68$

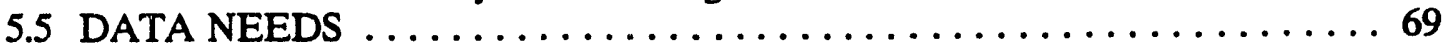

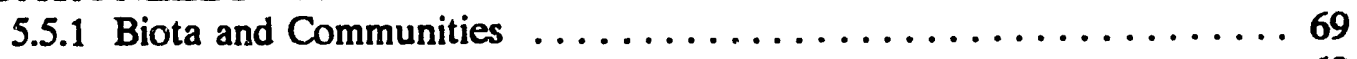

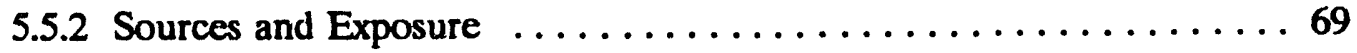




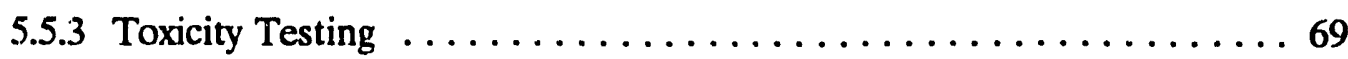

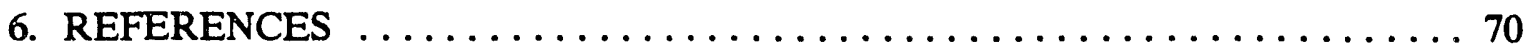

APPENDIX A NONCONSERVATIVE SCREENING OF THE

DETECTABLE CONTAMINANTS DATA BASE

FOR CARCINOGENS AND

NONCARCINOGENS

A-1

APPENDIX B CONSERVATIVE SCREENING OF THE

DETECTABLE CONTAMINANTS DATA BASE

FOR CARCINOGENS AND

NONCARCINOGENS

B-1

APPENDIX C SCREENING OF THE INTRUDER SCENARIO

FOR DETECTED CARCINOGENS AND

NONCARCINOGENS

APPENDIX D NONCONSERVATTVE SCREENING OF THE

NONDETECTABLE CONTAMINANTS DATA

BASE FOR CARCINOGENS AND

NONCARCINOGENS

D-1

APPENDIX E CONSERVATTVE SCREENING OF THE

NONDETECTABLE CONTAMINANTS DATA

BASE FOR CARCINOGENS AND

NONCARCINOGENS

APPENDIX F NONCONSERVATIVE AND CONSERVATTVE

SCREENING OF DETECTABLE

CARCINOGENS AND NONCARCINOGENS IN

GROUNDWATER

APPENDIX G DATA FOR ECOLOGICAL ASSESSMENT .......... G-1 


\section{FIGURES}

Fig.

2.1 Waste Area Grouping 2 in White Oak Creek watershed $\ldots \ldots \ldots \ldots \ldots \ldots$

2.2 Reaches in Waste Area Grouping $2 \ldots \ldots \ldots \ldots \ldots \ldots \ldots \ldots \ldots \ldots$

4.1 Screening criteria for carcinogens $\ldots \ldots \ldots \ldots \ldots \ldots \ldots \ldots \ldots \ldots \ldots \ldots$

4.2 Screening criteria for noncarcinogens $\ldots \ldots \ldots \ldots \ldots \ldots \ldots \ldots \ldots \ldots \ldots$ 


\section{TABLES}

Table

2.1 Estimated discharges of selected radionuclides from White Oak

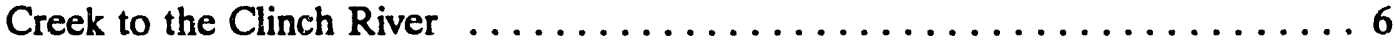

4.1 Usage factors for conservative and nonconservative screening . . . . . . . 11

4.2 Summary for nonconservative screening of detected carcinogens . . . . . . 16

4.3 Carcinogens assigned to different screening categories $\ldots \ldots \ldots \ldots \ldots \ldots$

4.4 Summary table for nonconservative screening of detected noncarcinogens $\ldots 19$

4.5 Noncarcinogens assigned to different screening categories $\ldots \ldots \ldots \ldots \ldots$

4.6 Summary table for conservative screening of detected carcinogens $\ldots \ldots \ldots 21$

4.7 Carcinogens assigned to different screening categories $\ldots \ldots \ldots \ldots \ldots \ldots$

4.8 Summary table for conservative screening of detected noncarcinogens $\ldots \ldots 25$

4.9 Noncarcinogens assigned to different screening categories $\ldots \ldots \ldots \ldots \ldots$

4.10 Summary table for intruder screening scenario for detected carcinogens . . . . 29

4.11 Summary table for intruder screening scenario for detected noncarcinogens .............................. 30

4.12 Contaminants that were reported in either the detectables or nondetectables $\ldots \ldots \ldots \ldots \ldots \ldots \ldots \ldots \ldots \ldots \ldots \ldots \ldots \ldots \ldots$

5.1 Federally and state listed threatened and/or endangered species $\ldots \ldots \ldots \ldots 3$

5.2 Summary of benchmarks for priority contaminants in freshwater . . . . . . 49 


\section{ABBREVIATIONS}

\begin{tabular}{|c|c|}
\hline ARAR & applicable or relevant and appropriate requirement \\
\hline BAF & bioaccumulation factors \\
\hline BCF & bioconcentration factors \\
\hline BMAP & Biological Monitoring and Abatement Program \\
\hline CERCLA & Comprehensive Environmental Response, Compensation, and Liability Act \\
\hline CRRFI & Clinch River RFI \\
\hline DOE & Department of Energy \\
\hline EC & effective concentration \\
\hline EPA & Environmental Protection Agency \\
\hline ER & environmental restoration \\
\hline ESP & Environmental Surveillance Program \\
\hline FFA & Federal Facility Agreement \\
\hline HEAST & Health Effects Assessment Summary Tables \\
\hline HFIR & High Flux Isotope Reactor \\
\hline HRE & Homogeneous Reactor Experiment \\
\hline HSWA & Hazardous and Solid Waste Amendments \\
\hline IRIS & Integrated Risk Information System \\
\hline LC & lethal concentrations \\
\hline LD & lethal dose \\
\hline NAWQC & National Ambient Water Quality Criteria \\
\hline NOEC & no observed effects concentration \\
\hline NPDES & National Pollutant Discharge Elimination System \\
\hline NPL & National Priorities List \\
\hline ORNL & Oak Ridge National Laboratory \\
\hline ORR & Oak Ridge Reservation \\
\hline PCB & polychlorinated biphenyl \\
\hline QSAR & quantitative structure-activity relationships \\
\hline RCRA & Resource Conservation and Recovery Act of 1976 \\
\hline RFD & reference dose \\
\hline RFI & RCRA facility investigation \\
\hline RI & remedial investigation \\
\hline RI/FS & remedial investigation/feasibility study \\
\hline SARA & Superfund Amendments and Reauthorization Act of 1986 \\
\hline SI & screening index \\
\hline TDEC & Tennessee Department of Environment and Conservation \\
\hline TVA & Tennessee Valley Authority \\
\hline TWRA & Tennessee Wildlife Resources Agency \\
\hline UCL & upper confidence limit \\
\hline WAG & waste area grouping \\
\hline WOC & White Oak Creek \\
\hline WOCE & White Oak Creek Embayment \\
\hline WOL & White Oak Lake \\
\hline WOD & White Oak Dam \\
\hline
\end{tabular}




\section{EXECUTTVE SUMMARY}

Waste Area Grouping 2 (WAG 2) of the Oak Ridge National Laboratory (ORNL) is located in the White Oak Creek Watershed and is composed of White Oak Creek Embayment, White Oak Lake and associated floodplain, and portions of White Oak Creek (WOC) and Melton Branch downstream of ORNL facilities. Contaminants leaving other ORNL WAGs in the WOC watershed pass through WAG 2 before entering the Clinch River. Health and ecological risk screening analyses were conducted on contaminants in WAG 2 to determine which contaminants were of concern and would require immediate consideration for remedial action and which contaminants could be assigned a low priority for further study.

For screening purposes, WAG 2 was divided into four geographic reaches: Reach 1, a portion of WOC; Reach 2, Melton Branch; Reach 3, White Oak Lake and the floodplain area to the weirs on WOC and Melton Branch; and Reach 4, the White Oak Creek Embayment, for which an independent screening analysis has been completed.

Screening analyses were conducted using data bases compiled from existing data on carcinogenic and noncarcinogenic contaminants, which included organics, inorganics, and radionuclides. Contaminants for which at least one sample had a concentration above the level of detection were placed in a detectable contaminants data base. Those contaminants for which all samples were below the level of detection were placed in a nondetectable contaminants data base.

Health Risk. Screening indices were used to evaluate the potential human health risk from contaminants found in WAG 2. The screening index for a ca:cinogen is an estimate of exposure (ingestion, inhalation, external) multiplied by an Environmental Protection Agency (EPA)-approved or -suggested slope factor to indicate the potential lifetime risk of excess cancer. A risk $\geq 10^{-4}$ excess cancers for a lifetime exposure to carcinogens is considered an action level by the EPA. Risks between $10^{-4}$ and $10^{-6}$ excess cancers per lifetime is a range where risk levels are of concern and negotiation on remedial action alternatives occurs and additional investigation is probably justified. A risk below $10^{-6}$ excess cancers per lifetime indicates that a carcinogen is of little concern and can be assigned a low priority for further investigation.

Screening indices for noncarcinogens are an estimate of the daily ingestion or inhalation of the contaminant divided by a "reference dose (RfD) factor". The RfD is an EPA-approved daily noncarcinogenic contaminant exposure level below which adverse effects should not occur. For noncarcinogens a screening index $\geq 1.0$ is considered an action level, an index between 0.1 and 1.0 requires further investigation before taking action, and an index $\leq 0.1$ indicates a low priority for further action.

A conservative and nonconservative screening approach was used in the health risk analysis. Conservative screening is designed to not underestimate potential risk and was used to identify contaminants with a low priority for further consideration;

nonconservative screening is designed to provide a more realistic estimate of potential risk and was used to identify contaminants that have a high priority and require immediate consideration for remedial action. In addition an intruder (illegal hunter/fisherman) 
scenario was included, which represents a realistic, although highly improbable, situation that could occur under current conditions.

Because relatively high levels of ${ }^{137} \mathrm{Cs}$ are known to exist in the sediment and floodplain soils of White Oak Lake, the area will require remedial action before public access is allowed. However, WAG 2 is surrounded by a personnel exclusion fence that is patrolled on a regular schedule, and it is highly unlikely that institutional control will be lost in the near future. Therefore, only the following four hypothetical exposure pathways were considered: (1) external exposure to sediment or floodplain soils, (2) ingestion of fish, (3) ingestion of soil, and (4) ingestion of water. Analytical results were available for all media in these pathways.

Nonconservative screening of the carcinogens in the detectable contaminants data bases identified the following as high priority for remedial action: ${ }^{60} \mathrm{Co}$ in Reaches 1,2 , and 3 for external exposure, ${ }^{137} \mathrm{Cs}$ in Reaches 1 and 3 for external exposure, PCBs (Aroclor 1254) in Reach 1 and 3 for the fish ingestion, and arsenic in Reaches 2 and 3 for the drinking water pathway. Arsenic is a possible artifact because of the small number of samples with detectable concentrations.

Ten carcinogens (dichlorobromomethane, Aroclor-1254, Aroclor- $1260,{ }^{137} \mathrm{Cs},{ }^{90} \mathrm{Sr},{ }^{3} \mathrm{H}$, ${ }^{152} \mathrm{Eu},{ }^{134} \mathrm{Cs},{ }^{154} \mathrm{Eu}$, and ${ }^{234} \mathrm{U}$ ) in the detectable contaminants data bases were classified as requiring further investigation in one or more reaches. Limited data were available for ${ }^{134} \mathrm{Cs},{ }^{152} \mathrm{Eu},{ }^{154} \mathrm{Eu}$ and ${ }^{234} \mathrm{U}$ for some of the reaches; therefore, additional analyses are needed. Although they were not classified as requiring further action, data for ${ }^{241} \mathrm{Am}$, ${ }^{244} \mathrm{Cm},{ }^{238} \mathrm{Pu}$, and ${ }^{239} \mathrm{Pu}$ were limited and additional data will be required.

Nonconservative screening of the detectable contaminants data bases for noncarcinogens identified only thallium in Reaches 1, 2, and 3 as a high priority contaminant. However, this is a possible artifact, because only one sample was analyzed in each reach; thus, additional data are needed. Mercury in Reach 1 in the fish ingestion pathway and arsenic in Reach 2 in the water ingestion pathway will also require further investigation because their screening indices were between 0.1 and 1.0 .

Conservative screening of the detectable contaminants data bases identified the following as low priority contaminants for further consideration: 3 organics, 12 radionuclides, and most metals in one or more reaches of WAG 2. However, because of limited information on some of these contaminants, additional data will be needed.

For contaminants with no detectable concentrations, a screening was conducted using the nominal value of the detection limits. Results of the nondetectable contaminants data bases should be viewed with caution because of the uncertainty associated with the contaminant concentrations. Nonconservative screening identified as high priority contaminants one organic carcinogen (acenaphthylene) in the fish ingestion pathway and two (benzidine and n-nitrosodimethylamine) in the sediment ingestion pathway as high priority contaminants. However, better detection limits are needed or a review of source-term data is appropriate. None of the noncarcinogens in the nondetectable 
contaminants data bases were identified by nonconservative screening as high priority contaminants in WAG 2.

Groundwater was screened as an independent pathway. Nonconservative screening of the detectable contaminants data base for groundwater indicated that none of the carcinogens or noncarcinogens could be assigned a high priority. However, because of the lack of verification of the limited data base, additional data will be required for groundwater. Lead was not included in the screening analysis because an EPA-approved RfD was not available, but an EPA Uptake/Biokinetic model predicted that it would be a problem in groundwater in Reaches 1 and 3.

Results of the hypothetical intruder scenario indicated that the potential lifetime risk of excess cancers was $>10^{-4}$ from the ingestion of fish in Reaches 1 and 3 and from external exposure in Reaches 1,2 , and 3. PCBs and ${ }^{137} \mathrm{Cs}$ in Reach 1 and PCBs in Reach 3 were the greatest contributors to risk in the fish ingestion pathway. Cobalt 60 and ${ }^{137} \mathrm{Cs}$ in Reaches 1 and 3 and ${ }^{60} \mathrm{Co}$ in Reach 2 had screening indices $>10^{-4}$ in the external exposure pathway.

Ecological Risk A screening assessment of ecological effects in WAG 2 was conducted concurrently with the human health assessment. This assessment considered three lines of evidence concerning the risks to nonhuman organisms posed by contaminants in WAG 2: biological surveys, toxicity tests of ambient media, and exposure/response analysis for measured contaminant concentrations. The biological survey data indicate that aquatic effects are not severe because a diverse and productive aquatic community is found in WAG 2. However, comparison of the aquatic biota to those of reference streams indicates that the composition of the benthic invertebrate community may be modified and fish reproduction may be disrupted. Biological survey data are not available for terrestrial biota.

Recent toxicity tests of water from WAG 2 do not indicate toxicity to Ceriodaphnia dubia or to larval fathead minnows in 7-day exposures. No toxicity tests have been performed on sediments or soils.

Comparison of media concentrations to toxicological benchmarks produced ambiguous results because of the large number of chemicals that were not detected but had limits of detection higher than potentially toxic concentrations. Mercury and PCBs were found at potentially toxic concentrations in both water and sediments in all reaches. Aluminum, cadmium, chromium, copper, and lead exceeded national ambient water quality criteria and state standards, and twelve other metals exceeded potentially toxic concentrations. Of the chemicals that had been detected in sediments and for which available concentrations could be estimated, barium, cobalt, mercury, silver, zinc, benzene, di-n-butyl phthalate, methylene chloride, and PCBs are potentially toxic to benthic organisms. Selenium and possibly cadmium were found in fish flesh at concentrations indicative of toxic effects. Mercury and PCBs occurred in fish flesh at concentrations that are potentially toxic to piscivorous wildlife based on dietary toxicity data, and many other chemicals occurred at concentrations that would exceed the reference dose for human health effects when wildlife consumption rates were used. No analyses could be performed for toxic effects on terrestrial organisms other than piscivorous wildlife. 
One can conclude from this evidence that ecotoxicological effects may be occurring in WAG 2, but they are not as severe as would be suggested by the expusure/response analysis using the reported chemical concentrations. This discrepancy is due in part to the conservatism of the screening criteria, but the authors believe that the principal factor is the inappropriateness of many of the analyses as estimators of bioavailable concentrations. Therefore, future activities should focus on estimation of actual exposure levels. In addition, chemical and biological data are needed from terrestrial portions of WAG 2. Future assessments will focus on improving the relevance of exposure/response estimates to conditions in WAG 2 and will continue to attempt to reconcile the three lines of evidence concerning ecological effects. 


\section{INTRODUCTION}

The purpose of this report is to present the results of a health risk and ecological risk screening analysis for Waste Area Grouping 2 (WAG 2) using available data to identify contaminants and environmental pathways that will require either further investigation or immediate consideration for remediation based on the screening indices. The screening analysis will also identify contaminants that can be assigned a low priority for further investigation and those that require additional data.

WAG 2 is located in the White Oak Creek (WOC) watershed and is the integrating WAG for the Oak Ridge National Laboratory (ORNL) because it receives effluents from many upgradient WAGs. WAG 2 receives subsurface flow and surface drainage from the ORNL Main Plant area (WAG 1), from solid waste storage areas (WAGs 3, 4, 5, and 6), liquid waste seepage pits and trenches (WAG 7), and the experimental reactor facilities (WAGs 8 and 9). Any contaminated water from these WAGs flows through WAG 2 to the Clinch River. WAG 2 is surrounded by a personnel exclusion fence that is patrolled on a regular schedule.

A full-scale Remedial Investigation (RI) and an implementation of corrective measures are not planned for WAG 2 until remediation of upgradient WAGs is completed. However, there is an obvious need to have a quantitative understanding of contaminants entering WAG 2 and the fluxes of these contaminants to (1) protect the public and environment, (2) monitor contaminants released from ORNL WAGs, and (3) develop information and data for preparing a remedial action plan for WAG 2 . The RI for WAG 2 (ORNL 1990) calls for characterizing the area, monitoring contaminant levels, performing a risk assessment, and identifying remedial action needs and alternatives.

The U. S. Department of Energy (DOE) Oak Ridge Reservation (ORR) was added to the National Priorities List (NPL) in December 1989. A Federal Facility Agreement (FFA) [under Section 120 of the Comprehensive Environmental Response, Compensation, and Liability Act (CERCLA) as amended by the Superfund Amendment and Reauthorization Act (SARA) and Section 6001 of the Resource Conservation and Recovery Act (RCRA)] between DOE, the Environmental Protection Agency (EPA) Region IV, and the Tennessee Department of Environment and Conservation (TDEC) has been signed. These parties intend to coordinate DOE's CERCLA/RCRA response obligation with the corrective measures required and conducted by DOE under its current permit under the Hazardous and Solid Waste Amendments (HSWA) of 1984 to RCRA of 1976, and they expect that the response actions under the FFA, together with corrective measures, will achieve comprehensive remediation of releases and potential releases of contaminants from ORNL. The current screening analysis is part of WAG 2's RI, which is being initiated in compliance with Section 3004(u) of the HSWA of RCRA. 


\section{DESCRIPTION OF AREA}

WAG 2 is located in the WOC watershed, which has a drainage area of approximately $16.8 \mathrm{~km}^{2}$ (6.5 sq miles) (Fig. 2.1). The creek originates on Chestnut Ridge and flows southward for approximately $2.5 \mathrm{~km}$ (1.6 miles) before entering the fenced area of ORNL. As the stream flows through ORNL, the flow rate is increased substantially by waste water entering the stream from ORNL facilities. Melton Branch, which has a drainage area of $3.8 \mathrm{~km}^{2}$ (1.5 sq miles), enters WOC at $\mathrm{km} 2.5$ (mile 1.56). White Oak Dam (WOD), a small earthen dam constructed in 1943, is located on WOC $1 \mathrm{~km}$ (0.6 miles) upstream from the Clinch River. White Oak Creek Embayment (WOCE) extends downstream from WOD to the Clinch River at km 33.5 (mile 20.8).

WAG 2 consists of the WOC drainage downstream of the ORNL discharge points and includes associated floodplain and subsurface environments. Because of the large numiber of waste sites and the hydrologic complexity at ORNL, hydrologic units that contain contiguous remedial action sites have been placed into WAGs. WAG 2 is made up of WOCE, White Oak Lake (WOL) and its former lake bed and current floodplain area, WOC and associated floodplain upstream to WOC $\mathrm{km} 3.45$ at the 7500 Bridge on Melton Valley Drive, and Melton Branch and associated floodplain to Melton Branch km 1.5 just above the tributary entering Melton Branch from the High Flux Isotope Reactor (HFIR). Detailed maps of the area are given in the WAG 2 RI (ORNL 1990). Because WAG 2 interfaces with the other WAGs, the boundaries between WAG 2 and these WAGs have not been clearly defined.

For screening purposes, WAG 2 was divided into 4 units identified as reaches (Fig. 2.2). Reach 1 extends from the weir on WOC at $\mathrm{km} 2.65$ (mile 1.56) to the 7500 bridge on Melton Valley Drive at WOC km 3.54. Reach 2 extends from the weir on Melton Branch at $\mathrm{km} 0.16$ upstream to $\mathrm{km} \mathrm{1.5,} \mathrm{which} \mathrm{is} \mathrm{just} \mathrm{above} \mathrm{the} \mathrm{tributary} \mathrm{from}$ HFIR. Reach 3 extends upstream from WOD to the WOC and Melton Branch weirs. Reach 4 is WOCE, which is not included in the current screening analysis because an independent screening analysis was completed for the embayment (Blaylock et al. 1991). For a detailed description and history of these areas, see the RI Plan for WAG 2 (ORNL 1990) and the Interim Site Characterization and Contaminant Screening Report on the WOCE (Blaylock et al. 1991).

\section{WHITE OAK LAKE}

WOL was created in 1943 by placing interlocking steel pilings and a sluice gate upstream from a culvert and road fill that was constructed at $\mathrm{km} 1.0$ on WOC by TVA in 1941. The lake is currently maintained at an elevation of $745 \mathrm{ft}$ msl which results in a standing pond behind the dam of approximately 6.9 ha (17 acres); however, the size of the standing pond has changed many times during the past five decades from the original 17.9 ha (44.2 acres) to about one acre when the lake was drained in 1955 (ORNL 1990, Blaylock et al. 1991). 


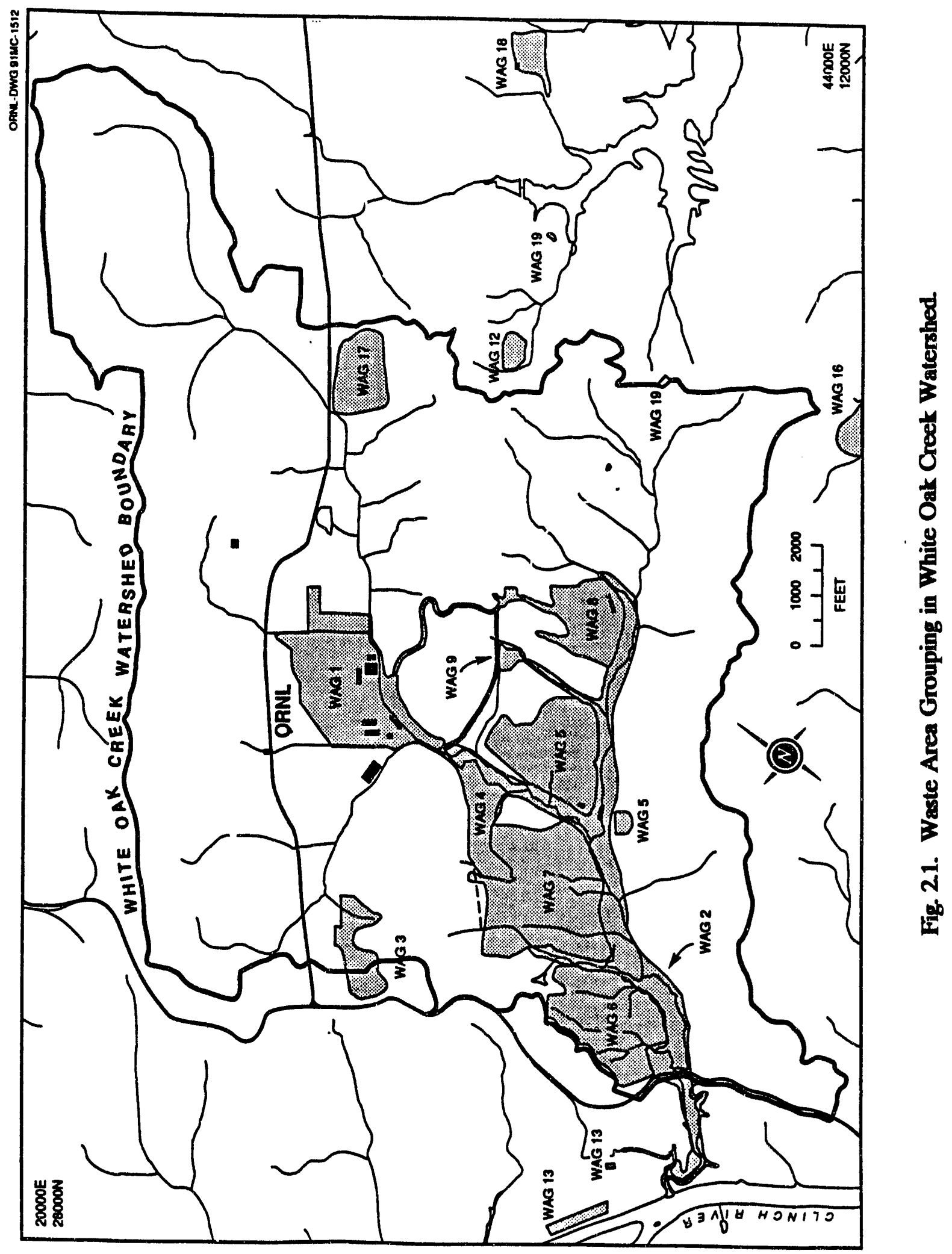




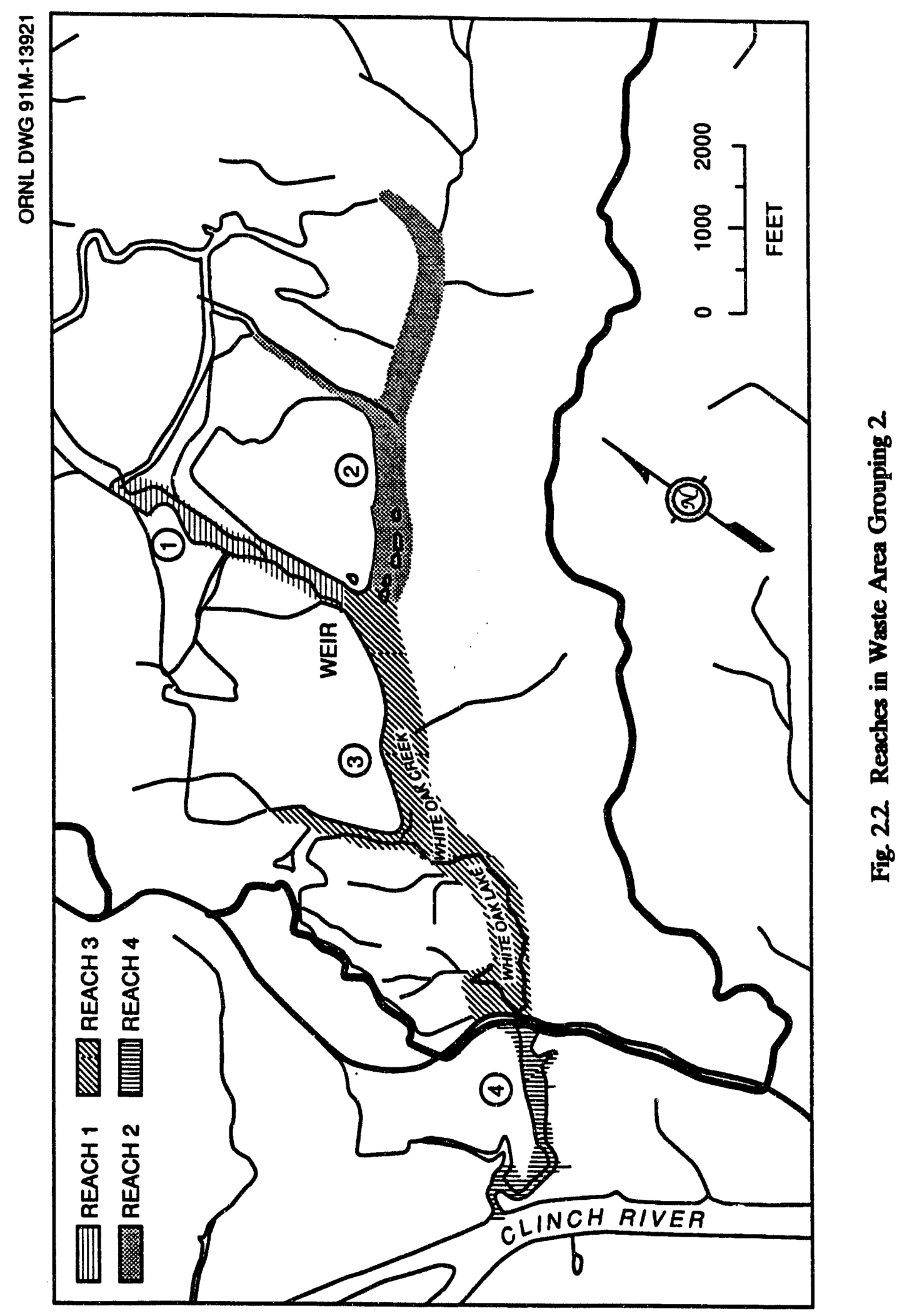


The lake has served as the final settling basin for low-level radioactive effluents from ORNL since 1943. Although low levels of radioactivity have been released over the dam since 1943, current levels are much lower than releases made in previous years (Table 2.1) (Blaylock et al. 1991). Radionuclides and other contaminants have accumulated in the bottom sediments of WOL (Lomenick and Gardiner 1965; Oakes et al. 1982; Sherwood and Loar 1987; and Loar ed. 1989). The most recent estimate of the radionuclide inventory of $434 \mathrm{Ci}$ of different radionuclides in the sediment of WOL was made by Blaylock and Mohrbacher (Loar ed. 1989) in 1988.

\section{FLOODPLAIN}

The former lake bed and floodfiain of WOL and WOC extend from the upper reaches of the standing pond at an elevation of $745 \mathrm{ft}$ msl to WOC and Melton Branch weirs. In 1943, the floodplain area was cleared of trees but is now covered with secondary growth and is being reforested with sycamore, ash, and maple trees. Since WOL is maintained at a lower elevation than when it was first formed, a large portion of the former lake bed is now exposed (ORNL 1990). The former lake bed contains concentrations of radionuclides similar to those in the sediment of WOL.

\section{WHITE OAK CREEK}

Upstream from the lake, WOC is a small stream passing through a second growth forest. The mean annual flow of WOC at the weir $(\mathrm{km} \mathrm{2.65)}$ is approximately $230 \mathrm{~L} / \mathrm{s}$ (Loar ed. 1988; 1991). The floodplain upstream from the weir is covered by forest and contains, at WOC km 3.2 and $\mathrm{km} \mathrm{3.4,} \mathrm{the} \mathrm{former} \mathrm{sites} \mathrm{of} \mathrm{two} \mathrm{earthen} \mathrm{dikes,} \mathrm{which} \mathrm{were}$ washed out in 1944. The former ponds, which contained trace quantities of ${ }^{238} \mathrm{Pu},{ }^{239.240} \mathrm{Pu}$, ${ }^{241} \mathrm{Am}$, and ${ }^{244} \mathrm{Cm}$, are now a 3-ha contaminated floodplain covered by a second growth forest. This area is estimated to contain $0.5 \mathrm{Ci}$ of ${ }^{239,240} \mathrm{Pu}$ in the top $20 \mathrm{~cm}$ of soil. Another weir and monitoring station is located just below the bridge on Melton Valley Drive at WOC km 3.4 .

\section{MELTON BRANCH}

Melton Branch, which originates at the eastern end of Melton Valley and joins WOC at $\mathrm{km} 2.6$ (Fig. 2.1), is the largest tributary of WOC. It is a small stream with an annual average flow of about $60 \mathrm{~L} / \mathrm{s}$ at the Melton Branch Weir ( $\mathrm{km} \mathrm{0.16)} \mathrm{(Loar} \mathrm{ed.} \mathrm{1988;} \mathrm{1991).}$ No flow has been recorded on several occasions during dry periods at the upper gaging station at km 1.93 (Loar ed. 1988). Stream flow in lower Melton Branch is augmented by periodic discharges from several process waste basins and by cooling tower blowdown from HFIR. Cobalt-60 and tritium $\left({ }^{3} \mathrm{H}\right)$ are the radionuclides that are found at the highest concentrations in Melton Branch. 
Table 21. Estimated discharges of selected radionuclides from White Oak Creek to the Clinch River (curies)

\begin{tabular}{|c|c|c|c|c|c|c|c|}
\hline Year & ${ }^{137} \mathrm{Cs}$ & ${ }^{106} \mathrm{Ru}$ & ${ }^{90} \mathrm{Sr}$ & ${ }^{131} I$ & ${ }^{60} \mathrm{Co}$ & ${ }^{3} \mathrm{H}$ & $T_{R} U^{2}$ \\
\hline 1949 & 77 & 110 & 150 & 77 & & $N A^{b}$ & $0.04^{c}$ \\
\hline 1950 & 19 & 23 & 38 & 19 & & & 0.04 \\
\hline 1951 & 20 & 18 & 29 & 18 & & & 0.08 \\
\hline 1952 & 10 & 15 & 72 & 20 & & & 0.03 \\
\hline 1953 & 6 & 26 & 130 & 2 & & & 0.08 \\
\hline 1954 & 22 & 11 & 140 & 4 & NA. & & 0.07 \\
\hline 1955 & 63 & 31 & 93 & 7 & 7 & & 0.25 \\
\hline 1956 & 170 & 29 & 100 & 4 & 46 & & 0.28 \\
\hline 1957 & 89 & 60 & 83 & 1 & 5 & & 0.15 \\
\hline 1958 & 55 & 42 & 150 & 8 & 9 & & 0.08 \\
\hline 1959 & 76 & 520 & 60 & 1 & 77 & & 0.68 \\
\hline 1960 & 31 & 1900 & 28 & 5 & 72 & & 0.19 \\
\hline 1961 & 15 & 2000 & 22 & 4 & 31 & & 0.07 \\
\hline 1962 & 6 & 1400 & 9 & 0.4 & 14 & & 0.06 \\
\hline 1963 & 4 & 430 & 8 & 0.4 & 14 & & 0.17 \\
\hline 1964 & 6 & 190 & 7 & 0.3 & 15 & 1,900 & 0.08 \\
\hline 1965 & 2 & 69 & 3 & 0.2 & 12 & 1,200 & 0.50 \\
\hline 1966 & 2 & 29 & 3 & 0.2 & 7 & 3,100 & 0.16 \\
\hline 1967 & 3 & 7 & 5 & 0.9 & 3 & 13,300 & 1.03 \\
\hline 1968 & 1 & 5 & 3 & 0.3 & 1 & 9,700 & 0.04 \\
\hline 1969 & 1 & 2 & 3 & 0.5 & 1 & 12,200 & 0.20 \\
\hline 1970 & 2 & 1 & 4 & 0.3 & 1 & 9,500 & 0.40 \\
\hline 1971 & 1 & 0.5 & 3 & 0.2 & 1 & 8,900 & 0.05 \\
\hline 1972 & 2 & 0.5 & 6 & 0.3 & 1 & 10,600 & 0.07 \\
\hline 1973 & 2 & 0.7 & 7 & 0.5 & 1 & 15,000 & 0.08 \\
\hline 1974 & 1 & 0.2 & 6 & 0.2 & 0.6 & 8,600 & 0.02 \\
\hline 1975 & 0.6 & 0.3 & 7 & 0.3 & 0.5 & 11,000 & 0.02 \\
\hline 1976 & 0.2 & 0.2 & 5 & 0.03 & 0.9 & 7,400 & 0.01 \\
\hline 1977 & 0.2 & 0.2 & 3 & 0.03 & 0.4 & 6,200 & 0.03 \\
\hline 1978 & 0.3 & 0.2 & 2 & 0.04 & 0.4 & 6,300 & 0.03 \\
\hline 1979 & 0.2 & 0.1 & 2.4 & 0.04 & 0.4 & 7,700 & 0.03 \\
\hline 1980 & 0.6 & 0 & 1.5 & 0.04 & 0.4 & 4,600 & 0.04 \\
\hline 1981 & 0.2 & 0.1 & 1.5 & 0.04 & 0.7 & 2,900 & 0.04 \\
\hline 1982 & 1.5 & 0.2 & 2.7 & 0.06 & 1.0 & 5,400 & 0.03 \\
\hline 1983 & 1.2 & 0.2 & 2.1 & 0.004 & 0.3 & 5,600 & 0.05 \\
\hline 1984 & 0.6 & 0.2 & 2.6 & 0.05 & 0.2 & 6,400 & 0.03 \\
\hline 1985 & 0.4 & 0.007 & 3.0 & & 0.6 & 3,700 & 0.008 \\
\hline 1986 & 1.0 & 0 & 1.8 & & 0.54 & 2,600 & 0.024 \\
\hline 1987 & 0.6 & 0 & 1.2 & & 0.12 & 2,500 & 0.006 \\
\hline 1988 & 0.4 & 0 & 1.1 & & $<0.07$ & 1,700 & \\
\hline 1989 & 1.2 & 0 & 2.9 & & 0.13 & 4,100 & \\
\hline \multirow[t]{2}{*}{1990} & 1.1 & 0 & 3.1 & & 0.12 & 3,100 & \\
\hline & $\overline{696.3}$ & $\overline{6,931.6}$ & $\overline{1,204.9}$ & $\overline{175.33}$ & $\overline{325.26}$ & $\overline{175,200}$ & $\overline{5.248}$ \\
\hline
\end{tabular}

Transuranics.

'No analysis performed.

'Estimated from measurements made during the last quarter of 1949. 


\section{WHITE OAK CREEK EMBAYMENT}

WOCE extends $1 \mathrm{~km}$ downstream from WOD and is the hydrologic link between WOD and the Clinch River. The surface area of the creek as it flows through the embayment is controlled by the summer and winter elevations of Watts Bar Reservoir. At the summer pool elevation of $741 \mathrm{ft} \mathrm{msl}$ at the mouth of the embayment, the creek covers approximately 8.5 acres; but, at the winter pool level, much of the embiyment is a mud flat with a small stream meandering through it to the Clinch River.

A screening analysis has been completed for WOCE (Blaylock et al. 1991); therefore, the embayment will not be included in the current screening analysis of WAG 2.

However, the results of the screening analysis of WOCE will be considered in the conclusions. 


\section{SOURCES OF INFORMATION}

The data used in the screening analyses include a compilation of existing data from previous and current monitoring programs, surveys, and scientific studies. Monitoring activities and scientific studies have been conducted on WOL and the WAG 2 area for more than four decades; and, as a result, a large amount of data has accumulated. A systematic review of all available data was conducted to compile a data base suitable for a screening analysis. These data were summarized to obtain source terms for predicting the risk level to humans and biota exposed to the environmental contaminants. Data from many of the earlier radiological studies were not included in the data base because many of the radionuclides previously reported are no longer released and have relatively short half-lives; therefore, the environmental concentrations of these radionuclides are very low. For example, ${ }^{106} \mathrm{Ru}$, which was one of the major dose contributors found in WOL in the early 1960 s, is practically undetectable today because of its relatively short half-life (1 year) and because it was readily transported from the WAGs in the water. The current data bases represent measurements of contaminants in sediment, surface water, groundwater, and fish. Data used in the screening analyses are contained in the appendices. 


\section{SCREENING RISK ASSESSMENT FOR HUMAN EXPOSURE}

\subsection{APPROACH}

The approach used in the current screening analysis is similar to the one used for the preliminary screening analysis of the Clinch River off-site environment (Hoffman et al. 1990) and WOCE (Blaylock et al. 1991). Because of the relatively high levels of ${ }^{137} \mathrm{Cs}$ that are known to exist in the sediments and floodplain of WOL, the area will require remedial action. In addition, WAG 2 is surrounded by a personnel exclusion fence that is patrolled on a regular schedule, and it is highly unlikely that institutional control of this area will be lost; therefore, calculations based on a homesteader scenario and inclusion of dredging and irrigation scenarios were not considered in this screening analysis. Two screening procedures-a conservative and a nonconservative approach--were used in this analysis. The conservative approach is highly unlikely to underestimate potential maximum exposures to individuals who might use the WAG 2 environment, but may substantially overestimate the majority of the actual exposures to individuals. The nonconservative screening approach provides a more realistic estimate of exposure and should not substantially overestimate the maximum exposure to individuals in the area. However, under some circumstances, nonconservative screening could underestimate maximum exposures. Calculations were also made for an intruder (illegal entry) scenario similar to the one made for the WOCE (Blaylock et al. 1991).

\subsection{SCREENING INDICES}

The screening index for a carcinogen is an estimate of exposure to the contaminant via external exposure, ingestion, or inhalation multiplied by the EPA approved or suggested slope factor for radioactive and nonradioactive substances to indicate the potential lifetime risk of excess cancer (EPA 1990). The slope factor is based upon an estimate of the lifetime risk of additional cancer incidence per unit of exposure.

The screening index for noncarcinogens is an estimate of the daily ingestion or inhalation of the contaminant divided by a "reference dose (RfD) factor". The RfD is an EPA-approved, daily noncarcinogenic-contaminant exposure level below which adverse effects should noi sccur.

To estimace the potential risk from all contaminants in a particular exposure pathway, the screening, indices are summed for all contaminants in the pathway. Summation is conducted separately for carcinogens and noncarcinogens. To estimate the potential risk from exposure to multiple pathways, the screening indices are summed across pathways.

\subsection{PATHWAYS}

Only four exposure pathways were considered: (1) external exposure from shoreline sediment and floodplain soils, (2) ingestion of sediment and floodplain soil, (3) ingestion 
of fish, and (4) the ingestion of water, both surface and groundwater. The ingestion of surface water was included in the basic screening analysis, and groundwater was screened separately (Sect. 4.8.4). Other exposure pathways were not considered because WAG 2 is surrounded by a personnel exclusion fence and it is highly unlikely that institutional control of the area will be lost in the foreseeable future. Modeling concentrations for exposure pathways was unnecessary because measured concentrations of most contaminants were available for the environmental media of concern. All scenarios are hypothetical and were created for screening purposes only.

\subsection{INTRUDER SCENARIO}

In addition to the conservative and nonconservative screening analyses, calculations were made for an intruder scenario. Such a scenario represents a more realistic, although highly improbable, situation that could occur under current conditions. The scenario selected involves an individual who illegally enters WAG 2 to hunt and fish. For fishing, he enters the area 10 days per year for 25 years and remains in the area for 4 hours per trip. He catches an average of $10 \mathrm{~kg}$ of fish per year, of which $33 \%$ is edible. The same intruder is also a deer and waterfowl hunter who enters WAG 2 to hunt deer 10 days per year for 10 years and remains in the area for 6 hours each day. The hunter kills one deer per year, which weighs $54 \mathrm{~kg}$, of which $33 \%$ is edible tissue. The intruder enters WAG 2 to hunt waterfowl 5 days per year for 10 years and remains in the area for 4 hours per day. He kills a total of 10 waterfowl per year, which weigh $1 \mathrm{~kg}$ each, of which $33 \%$ is edible tissue. The intruder is assumed to consume all the fish and game he poaches. Because of the short amount of time the intruder spends on WAG 2, the only pathway other than fish and game ingestion that was considered was external exposure from floodplain soil and shoreline sediment.

\subsection{DATA BASES}

The data were divided into two categories-detectable and nondetectable contaminants. Contaminants for which at least one measurement was above the level of detection were included in the detectable data bases. Contaminants for which all measurements were below the level of detection were included in the nondetectable data bases. For conservative screening, the upper $95 \%$ confidence limit of the arithmetic mean of the lognormally distributed data for both the detectable and nondetectable contaminant data sets was used to represent the concentration in the environmental medium. For nonconservative screening, the geometric mean of each contaminant in the detectable data set and the lowest detection limit in the nondetectable data set were used as the contaminant concentration in the environmental medium.

\subsection{USAGE FACTORS}

Usage factors for conservative and nonconservative screening are listed in Table 4.1. These factors are similar to the ones used by Hoffman et al. (1990) and Blaylock et al. 
Table 4.1. Usage factors for conservative and nonconservative screening"

\begin{tabular}{lll}
\hline $\begin{array}{c}\text { Exposure } \\
\text { route }\end{array}$ & $\begin{array}{c}\text { Conservative } \\
\text { screening }\end{array}$ & $\begin{array}{c}\text { Nonconservative } \\
\text { screening }\end{array}$ \\
\hline Ingestion & & \\
Fish & & \\
$\quad$ Carcinogens $^{b}$ & $33 \mathrm{~g} / \mathrm{d}$ & $3.3 \mathrm{~g} / \mathrm{d}$ \\
$\quad$ Noncarcinogens & & $6.5 \mathrm{~g} / \mathrm{d}$ \\
Drinking water & $65 \mathrm{~g} / \mathrm{d}$ & $0.2 \mathrm{~L} / \mathrm{d}$ \\
Sediment & $2.0 \mathrm{~L} / \mathrm{d}$ & $0.01 \mathrm{~g} / \mathrm{d}$ \\
External exposure & $0.1 \mathrm{~g} / \mathrm{d}$ & \\
Radioactive sediment & & $100 \mathrm{~h} /$ year \\
\hline
\end{tabular}

Usage factors for the intruder scenario are given in Sect. 4.4.

'Exposure duration $350 \mathrm{~d} / \mathrm{year}$ for 30 years.

Exposure duration $350 \mathrm{~d} / \mathrm{year}$ for 1 year.

(1991). However, EPA has reconsidered the maximum exposure duration and now recommends a lifetime exposure period of $\mathbf{3 5 0}$ days per year for $\mathbf{3 0}$ years. The usage factor for carcinogens is then a 30-year intake divided by a 70-year lifespan (OSWER 1991).

Noncarcinogens, unlike carcinogens, have a threshold value; therefore, a maximum intake of a noncarcinogen over a short period, which would result in exceeding the threshold value, is more critical than a long-term, low-level ingestion of the contaminant. To obtain a realistic maximum exposure for conservative screening for noncarcinogenic contaminants, the usage factor for fish ingestion was assumed to be two $0.5-\mathrm{lb}(230-\mathrm{g})$ fish meals per week or $65 \mathrm{~g} /$ day for an exposure duration of one year.

\subsection{SCREENING CRITERIA}

A risk $\geq 10^{-4}$ excess cancers for a lifetime exposure to carcinogens is considered an action level by EPA (Federal Register, March 8, 1990). Between $10^{-4}$ and $10^{-6}$ excess cancers per lifetime is a range where risk levels are of concern, negotiation on remedial action alternatives occurs, and additional investigation is probably justified. A risk below $10^{-6}$ excess cancers per lifetime indicates that a carcinogen is of little concern and can be assigned a low priority for further investigation. The conservative screening approach is 
used to identify contaminants that have a low priority for further investigation. In contrast, the nonconservative screening approach is used to identify contaminants with a high priority that require either immediate consideration for remedial action or further study.

\subsubsection{Carcinogen Screening}

Screening criteria used in this renort for carcinogens are summarized in Fig. 4.1. For conservative screening of carcinogens, substances having screening indices $\leq 10^{-6}$ are low priority for further consideration. Carcinogens with screening indices between $10^{-6}$ and $10^{-4}$ require further investigation before either taking action or designating these substances as low priority. Carcinogens with screening indices $\geq 10^{-4}$ require further investigation before taking action.

For nonconservative screening of carcinogens, substances having screening indices $\geq 10^{-4}$ are high priority substances which require immediate consideration for remedial action. Carcinogens with screening indices between $10^{-4}$ and $10^{-6}$ are substances requiring further investigation before taking action (i.e., re-examination wî the data base, checking parameter values, recalculating screening indices, etc.). Because nonconservative screening employs parameter values that should not greatly overestimate maximum exposures to a contaminant, nonconservative screening is not used to identify contaminants with low priority for further consideration.

\subsubsection{Noncarcinogen Screening}

Figure 4.2 summarizes the screening criteria for noncarcinogens. For conservative screening of noncarcinogens, contaminants with screening indices (exposure divided by an RfD) $\leq 0.1$ are low priority for further consideration, and contaminants with screening indices between 1.0 and 0.1 require further investigation before either taking action or designating the substance as a low priority substance. Noncarcinogens with conservative screening indices $\geq 1.0$ require further investigation before taking action.

For nonconservative screening of noncarcinogens, contaminants with screening indices $\geq 1.0$ are high priority substances requiring immediate consideration for remedial action, and contaminants with screening indices between 1.0 and 0.1 require further investigation before taking action. Screening indices $<0.1$ are not used to designate low priority substances for reasons similar to those previously given for nonconservative screening of carcinogens (i.e., nonconservative screening employs parameter values that should not greatly overestimate maximum exposures to a contaminant).

\subsection{CONTAMINANT SCREENING RESULTS}

\subsubsection{Detectable Contaminants}

Results of nonconservative and conservative screening for individual contaminants for each of the three reaches that had at least one value above the detection limit are given 


\section{Screening Criteria for Carcinogens}
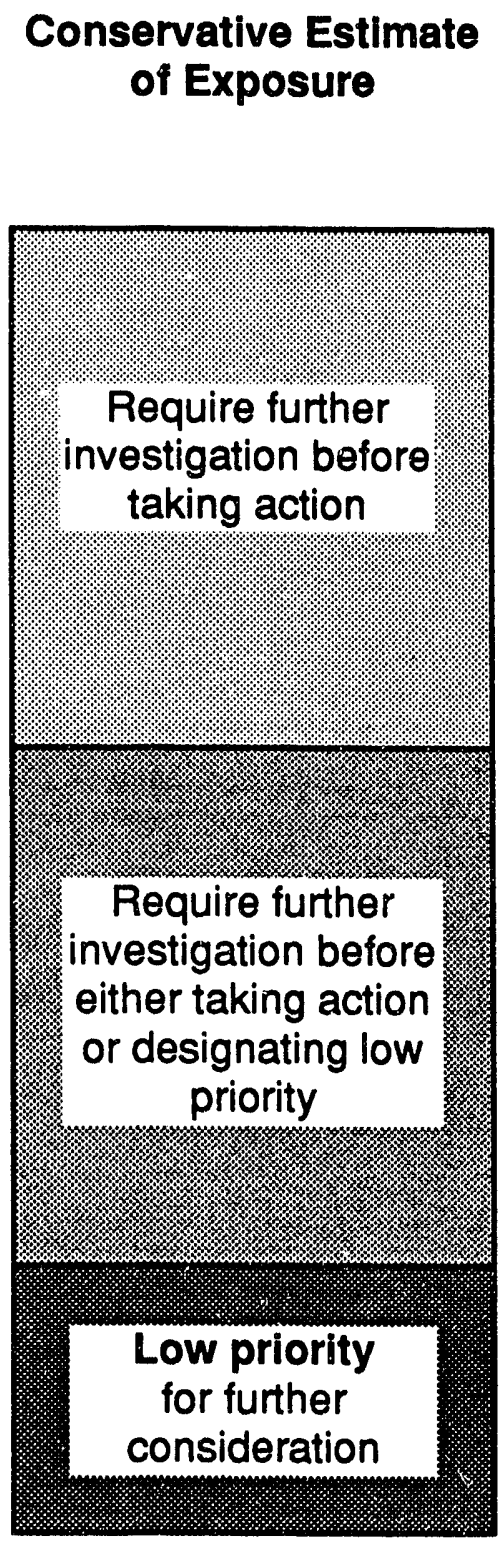

\section{Nonconservative Estimate of Exposure}

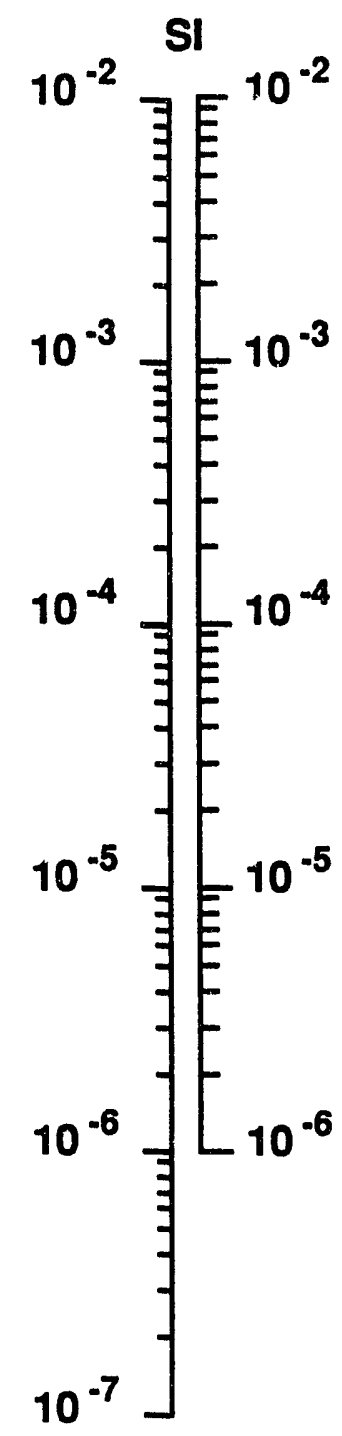

High priority-require immediate consideration for remedial action

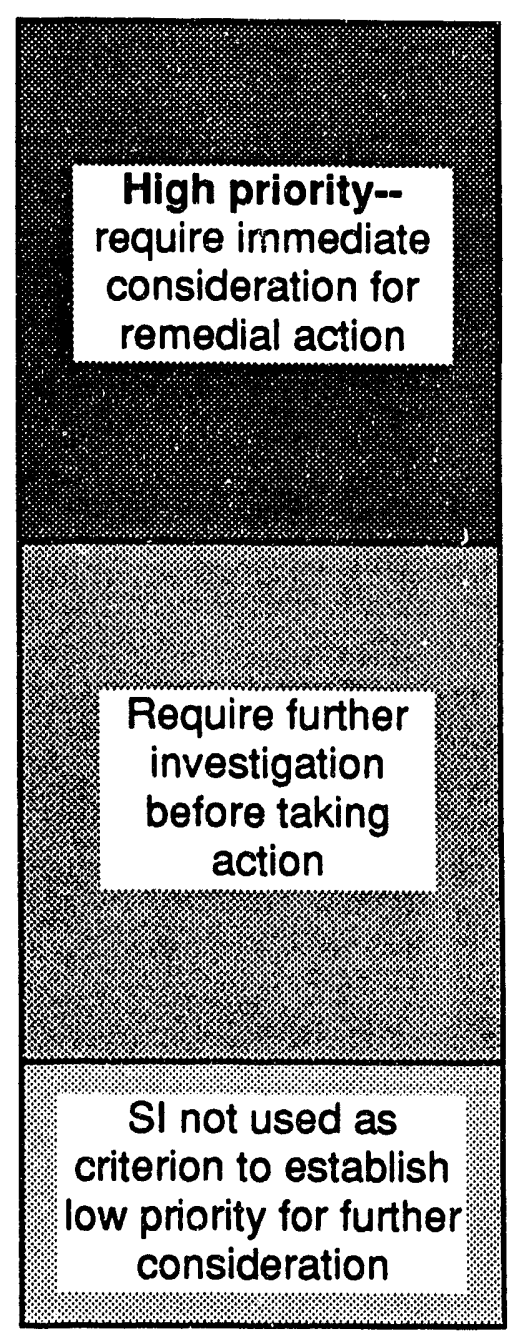

Screening index $(S I)=$ exposure multiplied by a lifetime cancer slope factor

Fig. 4.1. Criteria for conservative and nonconservative screening of carcinogens. 


\section{Screening Criteria for Noncarcinogens}
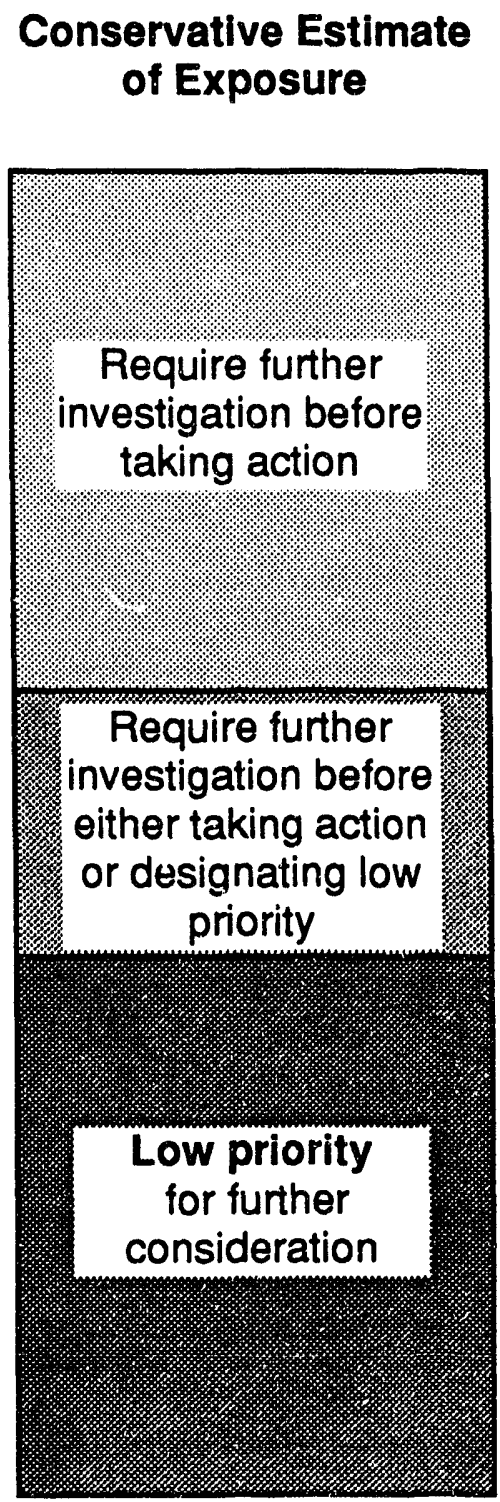

SI

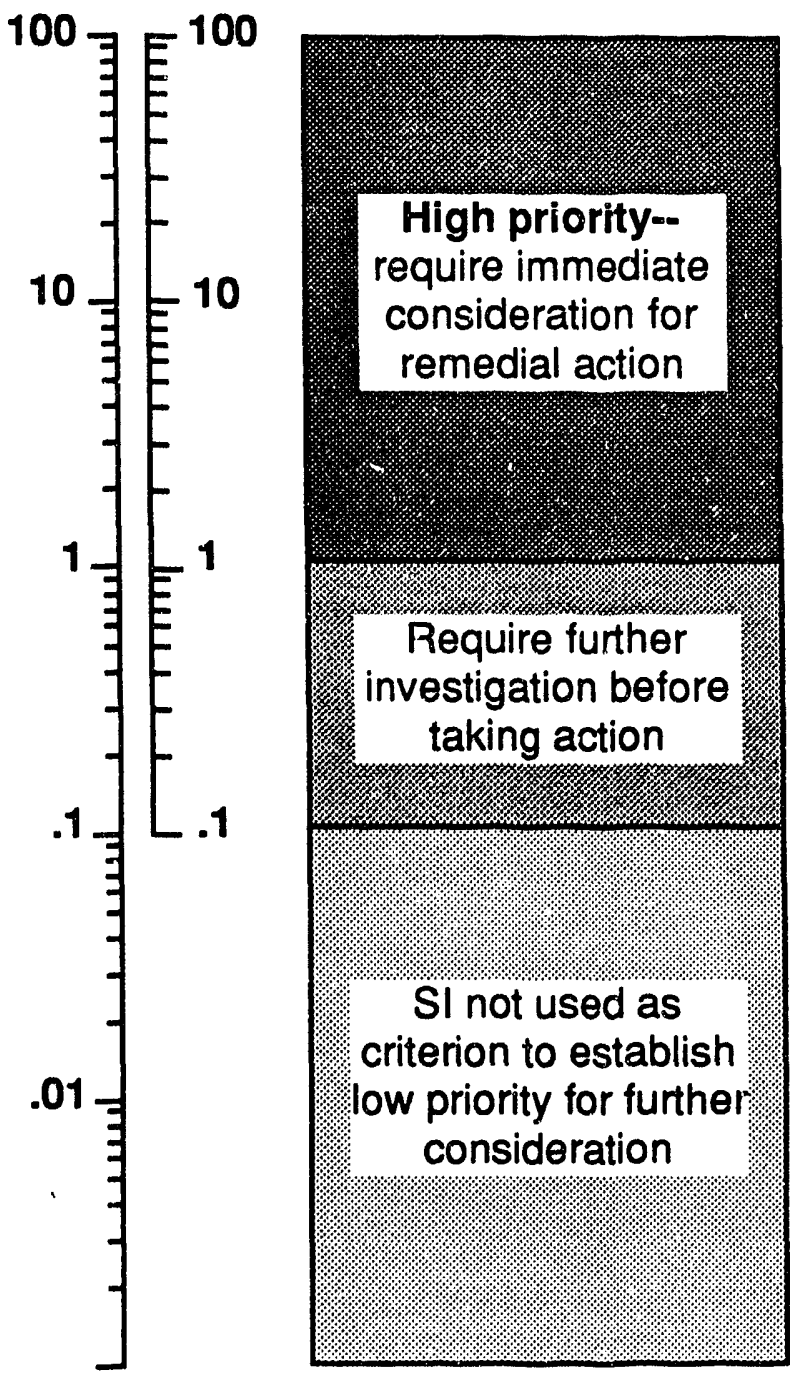

Nonconservative Estimate of Exposure

High priority-require immediate consideration for remedial action

Screening index $(S I)=$ exposure divided by reference dose factor (RfD)

Fig. 4.2. Criteria for conservative and nonconservative screening of noncarcinogens. 
in Appendix A and Appendix B. Results of the screening for the intruder scenario are given in Appendix $\mathrm{C}$.

\subsubsection{Nonconservative screening of detectable contaminants}

Nonconservative screening is conducted to identify contaminants with a high priority for immediate consideration for remedial action. In the current screening analysis, individual carcinogens that have a screening index $\geq 10^{-4}$ and noncarcinogens that have a screening index $\geq 1.0$ were classified as high priority contaminants (Figs. 4.1 and 4.2).

Carcinogens. A summary is given in Table 4.2 of nonconservative screening indices for the classes of contaminants (radionuclides, organics, and inorganics), exposure pathways, and individual reaches. Screening indices for individual carcinogens are given in Table A1 (Appendix A). Screening indices are summed for the classes of contaminants and for exposure pathways, which are then summed to obtain the total screening index for the individual reach.

All three reaches had screening indices $>10^{-4}$, requiring immediate consideration for remediation for all three (Table 4.2). Reaches 1 and 3 had screening indices $\geq 10^{-3}$. In Reach 1, the exposure pathways that contribute the greatest risk are ingestion of fish and external exposure to sediment. These pathways had screening indices of $2 \times 10^{-4}$ and $7 \times$ $10^{-4}$, respectively. Organic contaminants contribute the greatest risk in the fish ingestion pathway. Radionuclides in sediment, the only external exposure pathway, had an external exposure screening index of $7 \times 10^{-4}$. The ingestion of water, with a screening index of $7 \times$ $10^{-5}$, requires further investigation.

In Reach 2 external exposure to sediment and ingestion of water had screening indices $\geq 10^{4}$, requiring immediate consideration for remedial action (Table 4.2). Inorganics in the water ingestion pathway and radionuclides in the external exposure pathway are the primary contributors to the screening indices.

In Reach 3 all pathways, except the ingestion of sediment, had screening indices $\geq 10^{-4}$, requiring immediate consideration for remedial action (Table 4.2). External exposure to radionuclides in sediment had the highest screening index of $1 \times 10^{-3}$. Organic contaminants in the fish ingestion pathway and inorganic contaminants in the water ingestion pathway were the major contributors to the screening indices.

Individual carcinogens designated as high priority by nonconservative screening (screening indices $>10^{-4}$ ) and those requiring further investigation (screening indices $10^{-4}$ to $10^{-6}$ ) are listed in Table A1 (Appendix A) according to contaminant type, reach, and exposure pathway. The following contaminants have screening indices $\geq 10^{-4}$ and are designated as high priority contaminants that require immediate consideration for remedial action: arsenic in water in Reaches 2 and 3; PCB (Aroclor 1254) in fish in Reaches 1 and 3; external exposure from ${ }^{60} \mathrm{Co}$ in sediment in Reaches 1,2 , and 3; and external exposure from ${ }^{137} \mathrm{Cs}$ in sediment in Reaches 1 and 3. 
Table 4.2. Summary table for nonwonservative screening of detected carcinogens

\begin{tabular}{|c|c|c|c|}
\hline Reach & Media & $\begin{array}{c}\text { Contaminant } \\
\text { type }\end{array}$ & $\begin{array}{l}\text { Sums of } \\
\text { carcinogen } \\
\text { screening indices }\end{array}$ \\
\hline $\begin{array}{l}1 \\
1 \\
1 \\
\end{array}$ & $\begin{array}{l}\text { Fish } \\
\text { Fish } \\
\text { Fish }\end{array}$ & $\begin{array}{c}\text { Organic } \\
\text { Radionuclide } \\
\text { AII }\end{array}$ & $\begin{array}{l}2 \mathrm{E}-04 \\
7 \mathrm{E}-05 \\
2 \mathrm{E}-04 \\
\end{array}$ \\
\hline $\begin{array}{l}1 \\
1 \\
1 \\
1 \\
\end{array}$ & $\begin{array}{l}\text { Sediment ingestion } \\
\text { Sediment ingestion } \\
\text { Sediment ingestion } \\
\text { Sediment ingestion }\end{array}$ & $\begin{array}{c}\text { Inorganic } \\
\text { Organic } \\
\text { Radionuclide } \\
\text { All } \\
\end{array}$ & $\begin{array}{l}1 \mathrm{E}-06 \\
5 \mathrm{E}-07 \\
7 \mathrm{E}-07 \\
2 \mathrm{E}-06\end{array}$ \\
\hline $\begin{array}{l}1 \\
1 \\
\end{array}$ & $\begin{array}{c}\text { External exposure } \\
\text { Sediment }\end{array}$ & $\begin{array}{c}\text { Radionuclide } \\
\text { All }\end{array}$ & $\begin{array}{l}\text { 7E-04 } \\
\text { 7E-04 }\end{array}$ \\
\hline $\begin{array}{l}1 \\
1 \\
1 \\
\end{array}$ & $\begin{array}{l}\text { Water } \\
\text { Water } \\
\text { Water } \\
\end{array}$ & $\begin{array}{c}\text { Organic } \\
\text { Radionuclide } \\
\text { All }\end{array}$ & $\begin{array}{l}5 E-05 \\
2 E-05 \\
7 E-05 \\
\end{array}$ \\
\hline 1 & & Reach toral & $18-0$ \\
\hline $\begin{array}{l}2 \\
2 \\
2\end{array}$ & $\begin{array}{l}\text { Fish } \\
\text { Fish } \\
\text { Fibh }\end{array}$ & $\begin{array}{c}\text { Organic } \\
\text { Radionuclide } \\
\text { All }\end{array}$ & $\begin{array}{l}3 E-05 \\
2 E-05 \\
5 E-05\end{array}$ \\
\hline $\begin{array}{l}2 \\
2 \\
2 \\
2\end{array}$ & $\begin{array}{l}\text { Sediment ingestion } \\
\text { Sediment ingestion } \\
\text { Sediment ingestion } \\
\text { Sediment ingestion }\end{array}$ & $\begin{array}{c}\text { Inorganic } \\
\text { Organic } \\
\text { Radionuclide } \\
\text { AII }\end{array}$ & $\begin{array}{l}5 E-07 \\
4 E-07 \\
2 E-07 \\
1 E-06\end{array}$ \\
\hline $\begin{array}{l}2 \\
2 \\
\end{array}$ & $\begin{array}{c}\text { External exposure } \\
\text { Sediment }\end{array}$ & $\begin{array}{c}\text { Radionuclide } \\
\mathbf{N}\end{array}$ & $\begin{array}{l}\text { 5E-04 } \\
\text { 5E-04 }\end{array}$ \\
\hline $\begin{array}{l}2 \\
2 \\
2 \\
2 \\
\end{array}$ & $\begin{array}{l}\text { Water } \\
\text { Water } \\
\text { Water } \\
\text { Water } \\
\end{array}$ & $\begin{array}{c}\text { Inorganic } \\
\text { Organic } \\
\text { Radionuclide } \\
\text { All } \\
\end{array}$ & $\begin{array}{l}3 E-04 \\
2 E-05 \\
1 E-05 \\
3 E-04 \\
\end{array}$ \\
\hline 2 & & Reach tots & 9E-04 \\
\hline $\begin{array}{l}3 \\
3 \\
3\end{array}$ & $\begin{array}{l}\text { Fish } \\
\text { Fish } \\
\text { Fish }\end{array}$ & $\begin{array}{c}\text { Organic } \\
\text { Radionuclide } \\
\text { All }\end{array}$ & $\begin{array}{l}2 \mathrm{E}-04 \\
1 \mathrm{E}-05 \\
2 \mathrm{E}-04\end{array}$ \\
\hline $\begin{array}{l}3 \\
3 \\
3 \\
3\end{array}$ & $\begin{array}{l}\text { Sediment ingestion } \\
\text { Sediment ingestion } \\
\text { Sediment ingestion } \\
\text { Sodiment ingection }\end{array}$ & $\begin{array}{c}\text { Inorganic } \\
\text { Organic } \\
\text { Radionuclide } \\
\text { All } \\
\end{array}$ & $\begin{array}{l}1 \mathrm{E}-06 \\
3 \mathrm{E}-07 \\
9 \mathrm{E}-07 \\
2 \mathrm{E}-06 \\
\end{array}$ \\
\hline $\begin{array}{l}3 \\
3 \\
\end{array}$ & $\begin{array}{c}\text { External exposure } \\
\text { Sediment }\end{array}$ & $\begin{array}{c}\text { Radionuclide } \\
\text { All }\end{array}$ & $\begin{array}{l}1 E-03 \\
1 E-03\end{array}$ \\
\hline $\begin{array}{l}3 \\
3 \\
3 \\
3\end{array}$ & $\begin{array}{l}\text { Water } \\
\text { Water } \\
\text { Water } \\
\text { Water }\end{array}$ & $\begin{array}{c}\text { Inorganic } \\
\text { Organic } \\
\text { Radionuclide } \\
\text { All }\end{array}$ & $\begin{array}{l}2 E-04 \\
2 E-05 \\
5 E-05 \\
2 E-04\end{array}$ \\
\hline 3 & & Reach total & $1 \mathrm{E}-03$ \\
\hline
\end{tabular}


Arsenic was detected in only 4 of 75 water samples analyzed for Reach 2 and in only 2 of 38 samples analyzed for Reach 3 (Table A1); therefore, it is questionable whether arsenic should be assigned to the category requiring immediate consideration for remedial action.

Contaminants requiring further investigation (screening indices of $10^{-4}$ to $10^{-6}$ ) in different reaches and pathways are shown in Table 4.3. Dichlorobromomethane was detected in only 3 of 29 water samples in Reach 1 and may be an artifact of sample analysis (Table A1, Appendix A). Of the 7 radionuclides listed as requiring further investigation, limited data are available for ${ }^{134} \mathrm{Cs},{ }^{152} \mathrm{Eu},{ }^{154} \mathrm{Eu}$, and ${ }^{234} \mathrm{U}$ for some of the reaches and pathways (Table A1); therefore, additional data are needed. For the same reasons, radionuclides such as ${ }^{241} \mathrm{Am},{ }^{244} \mathrm{Cm},{ }^{238} \mathrm{Pu}$, and ${ }^{239} \mathrm{Pu}$ in sediment, which were not listed as requiring further consideration in Reach 1 because the screening was based on measurements made of only one sample, should be considered for further sampling and analysis.

Noncarcinogens. Nonconservative screening indices for reaches, classes of contaminants, and exposure pathways are summarized for the detected noncarcinogens in Table 4.4. The noncarcinogen analyses do not include an external exposure pathway because radionuclides that produce the external exposure are classified as carcinogens. Reaches 1,2 , and 3 had screening indices $\geq 1.0$ and were classified as requiring immediate consideration for remediation. In all three reaches, inorganics in the water ingestion pathway was the only class of contaminant that had screening indices $>1.0$. Inorganies in the fish ingestion pathway in Reach 1 was the only class of contaminant that had a screening index between 0.1 and 1.0 and requires further investigation before taking action (Fig. 4.2). Table 4.5 shows that thallium in the water ingestion pathway was the only contaminant that had a screening index $\geq 1.0$. Based on the screening index, thallium would be classified as a contaminant requiring immediate consideration for remedial action; however, because only one water sample from each reach was analyzed for thallium (Table A2, Appendix A), additional data are required before classifying it.

Mercury in the fish ingestion pathway in Reach 1 and arsenic in water in Reach 2 were the only contaminants that had screening indices between 0.1 and 1.0, requiring further investigation before taking action. Arsenic was detected in only 4 of 75 water samples analyzed for Reach 2; therefore, it may be an artifact of sample analysis.

\subsubsection{Conservative screening of detectable contaminants}

Conservative screening is conducted to identify contaminants that can be assigned a low priority for further investigation. In the current screening analysis, low priority contaminants include individual carcinogens that have a screening index $\leq 10^{-6}$ and noncarcinogens that have a screening index $\leq 0.1$ (Figs. 4.1 and 4.2).

Carcinogens. Screening indices for the individual contaminants are summed by classes of carcinogens (radionuclides, organics, and inorganics) for each exposure pathway. The sum for each pathway and each individual reach are given in Table 4.6. All pathways and reaches had screening indices $\geq 10^{-6}$; therefore, none of the pathways or reaches can be 
Table 4.3. Carcinogens assigned to different screening categories by nonconservative screening of data base where at least one value for each contaminant was above detection limits

\begin{tabular}{|c|c|c|c|}
\hline Contaminant type & Contaminant & Reach & Exposure pathway \\
\hline \multicolumn{4}{|c|}{$\begin{array}{l}\text { High priority-require immediate consideration for remedial action } \\
\text { Screening indices } \geq 10^{4}\end{array}$} \\
\hline Inorganic & Arsenic & 2,3 & water ingestion \\
\hline Organic & PCB-1254 (Aroclor 1254) & 1,3 & fish ingestion \\
\hline Radionuclide & $\begin{array}{l}{ }^{60} \mathrm{Co} \\
{ }^{137} \mathrm{Cs}\end{array}$ & $\begin{array}{c}1,2,3 \\
1,3\end{array}$ & $\begin{array}{l}\text { external exposure } \\
\text { external exposure }\end{array}$ \\
\hline \multicolumn{4}{|c|}{$\begin{array}{l}\text { Require further investigation before taking action } \\
\text { Screening indices } 10^{-} \text {to } 10^{6}\end{array}$} \\
\hline Organic & $\begin{array}{l}\text { Dichlorobromomemthane } \\
\text { PCB-1254 (Aroclor 1254) } \\
\text { PCB-1254 (Aroclor 1254) } \\
\text { PCB-1254 (Aroclor 1260) } \\
\text { PCBs (total) }\end{array}$ & $\begin{array}{c}1 \\
2 \\
1 \\
1,2,3 \\
1,2,3\end{array}$ & $\begin{array}{l}\text { water ingestion } \\
\text { fish ingestion } \\
\text { water ingestion } \\
\text { fish ingestion } \\
\text { water ingestion }\end{array}$ \\
\hline Radionuclide & $\begin{array}{l}{ }^{137} \mathrm{Cs} \\
{ }^{137} \mathrm{Cs} \\
{ }^{137} \mathrm{Cs} \\
{ }^{90} \mathrm{Sr} \\
{ }^{3} \mathrm{H} \\
{ }^{152} \mathrm{Eu} \\
{ }^{152} \mathrm{Eu} \\
{ }^{134} \mathrm{Cs} \\
{ }^{154} \mathrm{Eu} \\
{ }^{154} \mathrm{Eu} \\
{ }^{234} \mathrm{U}\end{array}$ & $\begin{array}{c}1,2,3 \\
2 \\
1,3 \\
1,2,3 \\
1,2,3 \\
1,2,3 \\
2 \\
1,2,3 \\
1,2,3 \\
2 \\
3\end{array}$ & $\begin{array}{l}\text { fish ingestion } \\
\text { external exposure } \\
\text { water ingestion } \\
\text { water ingestion } \\
\text { water ingestion } \\
\text { external exposure } \\
\text { water ingestion } \\
\text { external exposure } \\
\text { external exposure } \\
\text { water ingestion } \\
\text { water ingestion }\end{array}$ \\
\hline
\end{tabular}


Table 4.4. Summary table for nonconservative screening of detected noncarcinogens

\begin{tabular}{|c|c|c|c|}
\hline Reach & Medin & $\begin{array}{c}\text { Contaminant } \\
\text { type }\end{array}$ & $\begin{array}{c}\text { Sums of } \\
\text { roncarcinogen } \\
\text { screening indices }\end{array}$ \\
\hline $\begin{array}{l}1 \\
1\end{array}$ & $\begin{array}{l}\text { Fish } \\
\text { Fish }\end{array}$ & $\begin{array}{c}\text { Inorganic } \\
\text { All }\end{array}$ & $\begin{array}{l}\text { 1E-01 } \\
\text { 1E-01 }\end{array}$ \\
\hline $\begin{array}{l}1 \\
1 \\
1\end{array}$ & $\begin{array}{l}\text { Water } \\
\text { Water } \\
\text { Water }\end{array}$ & $\begin{array}{l}\text { Inorganic } \\
\text { Organic } \\
\text { All }\end{array}$ & $\begin{array}{c}4 E+\infty 0 \\
4 E-03 \\
4 E+\infty \\
\end{array}$ \\
\hline 1 & & Reach total & $4 E+\infty 0$ \\
\hline $\begin{array}{l}2 \\
2 \\
\end{array}$ & $\begin{array}{l}\text { Fish } \\
\text { Fish }\end{array}$ & $\begin{array}{c}\text { Inorganic } \\
\text { All }\end{array}$ & $\begin{array}{l}5 E-02 \\
5 E-02 \\
\end{array}$ \\
\hline $\begin{array}{l}2 \\
2 \\
2\end{array}$ & $\begin{array}{l}\text { Sediment ingestion } \\
\text { Sediment ingestion } \\
\text { Sediment ingestion }\end{array}$ & $\begin{array}{c}\text { Inorganic } \\
\text { Organic } \\
\text { All }\end{array}$ & $\begin{array}{l}3 E-03 \\
8 E-06 \\
3 E-03 \\
\end{array}$ \\
\hline $\begin{array}{l}2 \\
2 \\
2\end{array}$ & $\begin{array}{l}\text { Water } \\
\text { Water } \\
\text { Water }\end{array}$ & $\begin{array}{l}\text { Inorganic } \\
\text { Organic } \\
\text { All }\end{array}$ & $\begin{array}{c}4 E+\infty 0 \\
3 E-03 \\
4 E+\infty 0 \\
\end{array}$ \\
\hline 2 & & Reach total & $4 \mathrm{E}+00$ \\
\hline $\begin{array}{l}3 \\
3 \\
\end{array}$ & $\begin{array}{l}\text { Fish } \\
\text { Fish } \\
\end{array}$ & $\begin{array}{c}\text { Inorganic } \\
\text { All } \\
\end{array}$ & $\begin{array}{l}7 \mathrm{E}-02 \\
\mathrm{TE}-02 \\
\end{array}$ \\
\hline $\begin{array}{l}3 \\
3 \\
3\end{array}$ & $\begin{array}{l}\text { Sediment ingestion } \\
\text { Sediment ingestion } \\
\text { Sediment ingestion }\end{array}$ & $\begin{array}{c}\text { Inorganic } \\
\text { Organic } \\
\text { All } \\
\end{array}$ & $\begin{array}{l}4 E-03 \\
1 E-05 \\
4 E-03 \\
\end{array}$ \\
\hline $\begin{array}{l}3 \\
3 \\
3\end{array}$ & $\begin{array}{l}\text { Water } \\
\text { Water } \\
\text { Water } \\
\end{array}$ & $\begin{array}{c}\text { Inorganic } \\
\text { Organic } \\
\text { All }\end{array}$ & $\begin{array}{l}4 E-03 \\
1 E-05 \\
4 E-03\end{array}$ \\
\hline 3 & & Reach total & $3 E+\infty$ \\
\hline
\end{tabular}


Table 4.5. Noncarcinogens assigned to different screening categories by nonconservative screening of data base where at least one value for each contaminant was above detection limits

\begin{tabular}{|cccc|}
\hline Contaminant type & Contaminant & Reach & Exposure pathway \\
\hline \multirow{2}{*}{ High priority-require inmediate consideration for remedial action } \\
& Screening indices $\geq 1.0$ & \\
Inorganic & Thallium & $1,2,3$ & water ingestion \\
& Require further investigation before taking action & \\
& Screening indices 0.1 to 1.0 & water ingestion \\
Inorganic & Arsenic & 2 & fish ingestion \\
& Mercury & 1 &
\end{tabular}


Table 4.6. Summary table for conservative sereening of detected carcinogens

\begin{tabular}{|c|c|c|c|}
\hline Reach & Media & $\begin{array}{c}\text { Contaminant } \\
\text { type }\end{array}$ & $\begin{array}{c}\text { Sums of } \\
\text { noncarcinogen } \\
\text { rerecning indices }\end{array}$ \\
\hline $\begin{array}{l}1 \\
1 \\
1\end{array}$ & $\begin{array}{l}\text { Fish } \\
\text { Fish } \\
\text { Fish }\end{array}$ & $\begin{array}{c}\text { Organic } \\
\text { Inorganic } \\
\text { All }\end{array}$ & $\begin{array}{l}3 E-03 \\
1 E-03 \\
4 E-03\end{array}$ \\
\hline $\begin{array}{l}1 \\
1 \\
1 \\
1\end{array}$ & $\begin{array}{l}\text { Sediment ingestion } \\
\text { Sediment ingestion } \\
\text { Sediment ingestion } \\
\text { Sediment ingeation }\end{array}$ & $\begin{array}{c}\text { Inorganic } \\
\text { Organic } \\
\text { Radionuclide } \\
\text { All }\end{array}$ & $\begin{array}{l}2 \mathrm{E}-05 \\
3 \mathrm{E}-05 \\
5 \mathrm{E}-05 \\
1 \mathrm{E}-04\end{array}$ \\
\hline $\begin{array}{l}1 \\
1\end{array}$ & $\begin{array}{c}\text { External exposure } \\
\text { Sediment }\end{array}$ & $\begin{array}{l}\text { Radionuclide } \\
\text { All }\end{array}$ & $\begin{array}{l}\text { 1E-01 } \\
\text { 1E-01 }\end{array}$ \\
\hline $\begin{array}{l}1 \\
1 \\
1 \\
\end{array}$ & $\begin{array}{l}\text { Water } \\
\text { Water } \\
\text { Water }\end{array}$ & $\begin{array}{c}\text { Organic } \\
\text { Radionuclide } \\
\text { All }\end{array}$ & $\begin{array}{l}8 \mathrm{E}-04 \\
4 \mathrm{E}-04 \\
1 \mathrm{E}-03\end{array}$ \\
\hline 1 & & Reach total & 1E-01 \\
\hline $\begin{array}{l}2 \\
2 \\
2\end{array}$ & $\begin{array}{l}\text { Fish } \\
\text { Fish } \\
\text { Fish }\end{array}$ & $\begin{array}{c}\text { Organic } \\
\text { Radionuclide } \\
\text { All }\end{array}$ & $\begin{array}{l}2 E-03 \\
3 E-04 \\
2 E-03\end{array}$ \\
\hline $\begin{array}{l}2 \\
2 \\
2 \\
2\end{array}$ & $\begin{array}{l}\text { Sediment ingestion } \\
\text { Sediment ingestion } \\
\text { Sediment ingestion } \\
\text { Sediment ingestion }\end{array}$ & $\begin{array}{c}\text { Inorganic } \\
\text { Organic } \\
\text { Radionuclide } \\
\text { All }\end{array}$ & $\begin{array}{l}8 E-06 \\
2 E-05 \\
2 E-05 \\
5 E-05\end{array}$ \\
\hline $\begin{array}{l}2 \\
2\end{array}$ & $\begin{array}{l}\text { External exposure } \\
\text { Sediment }\end{array}$ & $\underset{\text { AII }}{\text { Radionuclide }}$ & $\begin{array}{l}5 E-02 \\
5 E-02\end{array}$ \\
\hline $\begin{array}{l}2 \\
2 \\
2 \\
2\end{array}$ & $\begin{array}{l}\text { Water } \\
\text { Water } \\
\text { Water } \\
\text { Water }\end{array}$ & $\begin{array}{c}\text { Inorganic } \\
\text { Organic } \\
\text { Radionuclide } \\
\text { All }\end{array}$ & $\begin{array}{l}3 E-03 \\
4 E-04 \\
1 E-03 \\
4 E-03\end{array}$ \\
\hline 2 & & Reach total & GE-OB \\
\hline $\begin{array}{l}3 \\
3 \\
3\end{array}$ & $\begin{array}{l}\text { Fish } \\
\text { Fish } \\
\text { Fish }\end{array}$ & $\begin{array}{c}\text { Organic } \\
\text { Radionuclide } \\
\text { All }\end{array}$ & $\begin{array}{l}3 E-03 \\
3 E-04 \\
4 E-03 \\
\end{array}$ \\
\hline $\begin{array}{l}3 \\
3 \\
3 \\
3 \\
\end{array}$ & $\begin{array}{l}\text { Sediment ingestion } \\
\text { Sediment ingestion } \\
\text { Sediment ingestion } \\
\text { Sediment ingestion }\end{array}$ & $\begin{array}{c}\text { Inorganic } \\
\text { Organic } \\
\text { Radionuclide } \\
\text { All }\end{array}$ & $\begin{array}{l}5 E-05 \\
4 E-05 \\
6 E-05 \\
5 E-02\end{array}$ \\
\hline $\begin{array}{l}3 \\
3\end{array}$ & $\begin{array}{l}\text { External exposure } \\
\text { Sediment }\end{array}$ & $\begin{array}{c}\text { Radionuclide } \\
\text { All }\end{array}$ & $\begin{array}{l}\text { 2E-01 } \\
\text { 2E-01 }\end{array}$ \\
\hline $\begin{array}{l}3 \\
3 \\
3 \\
3\end{array}$ & $\begin{array}{l}\text { Water } \\
\text { Water } \\
\text { Water } \\
\text { Water }\end{array}$ & $\begin{array}{c}\text { Inorganic } \\
\text { Organic } \\
\text { Radionuclide } \\
\text { All }\end{array}$ & $\begin{array}{l}2 E-03 \\
5 E-04 \\
6 E-04 \\
3 E-03\end{array}$ \\
\hline 3 & & Reach total & 2E-01 \\
\hline
\end{tabular}


given low priority for further consideration (Fig 4.1). Reaches 1 and 3 had screening indices $\geq 10^{-1}$ and Reach 2 had a screening index of $6 \times 10^{-3}$. Exposure to the sediment pathway in all reaches was the major contributor to the total screening index for each reach. Fish ingestion in Reaches 1 and 2 and the ingestion of sediment in Reach 3 were the next most important pathways.

Table 4.7 lists the carcinogens with screening indices $<10^{-6}$, which can be given a low priority for further consideration based on conservative screening. However, because of the small number of sediment samples analyzed for ${ }^{241} \mathrm{Am},{ }^{244} \mathrm{Cm},{ }^{238} \mathrm{Pu},{ }^{239} \mathrm{Pu},{ }^{234} \mathrm{U},{ }^{235} \mathrm{U}$, and ${ }^{238} \mathrm{U}$ in Reaches 1,2 , and 3 (Table B1, Appendix B), these contaminants cannot be eliminated from consideration for the sediment pathways and require further investigation. Table 4.7 also lists contaminants (screening indices $10^{-6}$ to $10^{-4}$ ) that require further investigation before either taking action or designating them as low priority and contaminants with screening indices $\geq 10^{-4}$ that require further investigation before taking action. The radionuclides already listed in this paragraph require further investigation or designation as a low priority for the water ingestion pathway. However, the data for the uranium isotopes $\left({ }^{234} \mathrm{U},{ }^{235} \mathrm{U}\right.$, and $\left.{ }^{238} \mathrm{U}\right)$ are too limited to provide reliable screening results (Table B1).

Noncarcinogens. Summaries of the conservative screening indices for the noncarcinogens in the detectable data base are given in Table 4.8. All reaches had screening indices $>0.1$ and therefore cannot be given a low priority for further consideration. The screening indices for all reaches were $\geq 3 \times 10^{1}$; however, these indices are misleading because they result primarily from concentrations of thallium obtained from a single water sample taken from each reach. For this reason, the data are insufficient other than to conclude that thallium was detected and additional sampling is needed (Table B2, Appendix B). In addition, thallium has an RED that is one to two orders of magnitude less than the RfDs for other inorganics so that concentrations near the detection limits can produce relatively high screening indices.

The sediment ingestion pathways in Reaches 1 and 2 have screening indices $<0.1$ and can be assigned low priority for further consideration, as can organics in the water ingestion pathways for all reaches. The fish ingestion pathways in Reaches 1 and 3 have screening indices $\geq 1.0$ and require further investigation before taking action (Fig. 4.2). All other sediment and fish pathways have screening indices between 0.1 and 1.0 , thus requiring further investigation before assigning the pathway a low priority or taking action.

Noncarcinogens that can be assigned a low priority in the detectable data base by conservative screening (screening indices $<0.1$ ) are listed by contaminant, reach, and exposure pathway in Table 4.9. Most inorganics for which data are available can be assigned a low priority for further study for sediment ingestion in all reaches. Barium, copper, mercury, nickel, and zinc can be assigned a low priority for further study in all reaches for the water and sediment ingestion pathways. All detectable noncarcinogenic organics in all reaches for which data are available can be assigned a low priority for further investigation (Table B2). Noncarcinogenic contaminants with screening indices of 0.1 to 1.0 , which require further investigation before taking action or designating the 
Table 4.7. Carcinogens ascigned to different screening categories by conservative scroening of data base where at least one value for each contaminant was above detection timits

\begin{tabular}{|c|c|c|c|}
\hline Contaminant type & Contaminant & Reach & Exposure pathway \\
\hline \multicolumn{4}{|c|}{$\begin{array}{l}\text { Low prionity for further consideration } \\
\text { Screening indices }<10^{6}\end{array}$} \\
\hline Organic & $\begin{array}{l}\text { Benzene } \\
\text { Chloroform } \\
\text { Methylene chloride }\end{array}$ & $\begin{array}{l}3 \\
3 \\
3\end{array}$ & $\begin{array}{l}\text { sediment ingestion } \\
\text { sediment ingestion } \\
\text { sediment ingestion }\end{array}$ \\
\hline Radionuclide & $\begin{array}{l}{ }^{241} \mathrm{Am} \\
{ }^{241} \mathrm{Am} \\
{ }^{244} \mathrm{Cm} \\
{ }^{244} \mathrm{Cm} \\
{ }^{60} \mathrm{Co} \\
{ }^{134} \mathrm{Cs} \\
{ }^{152} \mathrm{Eu} \\
{ }^{154} \mathrm{Eu} \\
{ }^{238} \mathrm{Pu} \\
{ }^{238} \mathrm{Pu} \\
{ }^{238} \mathrm{Pu} \\
{ }^{239} \mathrm{Pu} \\
{ }^{239} \mathrm{Pu} \\
{ }^{239} \mathrm{Pu} \\
{ }^{90} \mathrm{Sr} \\
{ }^{234} \mathrm{U} \\
{ }^{234} \mathrm{U} \\
{ }^{235} \mathrm{U} \\
{ }^{235} \mathrm{U} \\
{ }^{238} \mathrm{U} \\
{ }^{238} \mathrm{U}\end{array}$ & $\begin{array}{c}1,2,3 \\
1,2,3 \\
1,2,3 \\
1,2,3 \\
3 \\
1,2,3 \\
1,2,3 \\
1,2,3 \\
1,2,3 \\
1,2,3 \\
3 \\
1,2,3 \\
1,2,3 \\
3 \\
2,3 \\
1,2,3 \\
1,2,3 \\
1,2,3 \\
1,2,3 \\
1,2,3 \\
1,2,3\end{array}$ & $\begin{array}{l}\text { external exposure } \\
\text { sediment ingestion } \\
\text { external exposure } \\
\text { sediment ingestion } \\
\text { fish ingestion } \\
\text { sediment ingestion } \\
\text { sediment ingestion } \\
\text { sediment ingestion } \\
\text { external exposure } \\
\text { sediment ingestion } \\
\text { water ingestion } \\
\text { external exposure } \\
\text { sediment ingestion } \\
\text { water ingestion } \\
\text { sediment ingestion } \\
\text { external exposure } \\
\text { sediment ingestion } \\
\text { external exposure } \\
\text { sediment ingestion } \\
\text { external exposure } \\
\text { sediment ingestion }\end{array}$ \\
\hline \multicolumn{4}{|c|}{$\begin{array}{c}\text { Require further invastigation before taling action } \\
\text { or designating as low prionity } \\
\text { Screaning indices } 10^{-6} \text { to } 10^{4}\end{array}$} \\
\hline Inorganic & $\begin{array}{l}\text { Arsenic } \\
\text { Beryllium }\end{array}$ & $\begin{array}{l}1,2,3 \\
1,2,3\end{array}$ & $\begin{array}{l}\text { sediment ingestion } \\
\text { sediment ingestion }\end{array}$ \\
\hline Organic & $\begin{array}{c}\text { Benzene } \\
\text { Chloroform } \\
\text { Dichlorobromomethane } \\
\text { Methylene chloride } \\
\text { PCB-1254 (Aroclor 1254) } \\
\text { PCB-1260 (Arocior 1260) } \\
\text { Tetrachloroethylene } \\
\text { Trichloroethylene }\end{array}$ & $\begin{array}{c}1 \\
1,2,3 \\
1 \\
1,2,3 \\
1,2,3 \\
1,2 \\
1,3 \\
1,2,3\end{array}$ & $\begin{array}{l}\text { water ingestion } \\
\text { water ingestion } \\
\text { water ingestion } \\
\text { water ingestion } \\
\text { sediment ingestion } \\
\text { sediment ingestion } \\
\text { water ingestion } \\
\text { water ingestion }\end{array}$ \\
\hline
\end{tabular}


Table 4.7 (continued)

\begin{tabular}{|c|c|c|c|}
\hline Contaminant type & Contaminant & Reach & Exposure pathway \\
\hline Radionuclide & $\begin{array}{l}{ }^{241} \mathrm{Am} \\
{ }^{244} \mathrm{Cm} \\
{ }^{60} \mathrm{Co} \\
{ }^{60} \mathrm{CO} \\
{ }^{137} \mathrm{Cs} \\
{ }^{137} \mathrm{Cs} \\
{ }^{154} \mathrm{Eu} \\
{ }^{154} \mathrm{Eu} \\
{ }^{90} \mathrm{Sr} \\
{ }^{90} \mathrm{Sr} \\
{ }^{234} \mathrm{U} \\
{ }^{235} \mathrm{U} \\
{ }^{238} \mathrm{U}\end{array}$ & $\begin{array}{c}3 \\
3 \\
1,2,3 \\
1,3 \\
1,2,3 \\
2,3 \\
1 \\
2 \\
3 \\
1 \\
3 \\
3 \\
3\end{array}$ & $\begin{array}{l}\text { water ingestion } \\
\text { water ingestion } \\
\text { sediment ingestion } \\
\text { water ingestion } \\
\text { sediment ingestion } \\
\text { water ingestion } \\
\text { external exposure } \\
\text { water ingestion } \\
\text { fish ingestion } \\
\text { sediment ingestion } \\
\text { water ingestion } \\
\text { water ingestion } \\
\text { water ingestion }\end{array}$ \\
\hline \multicolumn{4}{|c|}{$\begin{array}{l}\text { Require fworthe investigation before taking action } \\
\text { Screening indices } \geq 1 \sigma^{-1}\end{array}$} \\
\hline Inorganic & Arsenic & 2,3 & water ingestion \\
\hline Organic & $\begin{array}{l}\text { PCBs (total) } \\
\text { PCB-1254 (Aroclor 1254) } \\
\text { PCB-1254 (Aroclor 1254) } \\
\text { PCB-1260 (Arocior 1260) }\end{array}$ & $\begin{array}{c}1,2,3 \\
1,2,3 \\
1 \\
1,2,3\end{array}$ & $\begin{array}{l}\text { water ingestion } \\
\text { fish ingestion } \\
\text { water ingestion } \\
\text { water ingestion }\end{array}$ \\
\hline Radionuclide & $\begin{array}{l}{ }^{60} \mathrm{Co} \\
{ }^{60} \mathrm{Co} \\
{ }^{134} \mathrm{Cs} \\
{ }^{137} \mathrm{Cs} \\
{ }^{137} \mathrm{Cs} \\
{ }^{137} \mathrm{Cs} \\
{ }^{152} \mathrm{Eu} \\
{ }^{152} \mathrm{Eu} \\
{ }^{154} \mathrm{Eu} \\
{ }^{3} \mathrm{H} \\
{ }^{90} \mathrm{Sr}\end{array}$ & $\begin{array}{c}1,2,3 \\
2 \\
1,2,3 \\
1,2,3 \\
1,2,3 \\
1 \\
1,2,3 \\
2 \\
2,3 \\
1,2,3 \\
1,2,3\end{array}$ & $\begin{array}{l}\text { external exposure } \\
\text { water ingestion } \\
\text { external exposure } \\
\text { fish ingestion } \\
\text { external exposure } \\
\text { water ingestion } \\
\text { external exposure } \\
\text { water ingestion } \\
\text { external exposure } \\
\text { water ingestion } \\
\text { water ingestion }\end{array}$ \\
\hline
\end{tabular}


Table 4.8. Summary table for conservative screening of detected noncarcinogens

\begin{tabular}{|c|c|c|c|}
\hline Reach & Media & $\begin{array}{c}\text { Contaminant } \\
\text { type }\end{array}$ & $\begin{array}{c}\text { Sums of } \\
\text { noncarcinogen } \\
\text { screening indices }\end{array}$ \\
\hline $\begin{array}{l}1 \\
1\end{array}$ & $\begin{array}{l}\text { Fish } \\
\text { Fish }\end{array}$ & $\begin{array}{c}\text { Inorganic } \\
\text { All }\end{array}$ & $\begin{array}{c}2 \mathrm{E}+00 \\
2 \mathrm{E}-00 \\
\end{array}$ \\
\hline $\begin{array}{l}1 \\
1 \\
\end{array}$ & $\begin{array}{c}\text { Sediment ingestion } \\
\text { Sediment }\end{array}$ & $\begin{array}{c}\text { Inorganic } \\
\text { All }\end{array}$ & $\begin{array}{l}\text { 9E-02 } \\
\text { 9E-02 }\end{array}$ \\
\hline $\begin{array}{l}1 \\
1 \\
1 \\
\end{array}$ & $\begin{array}{l}\text { Water } \\
\text { Water } \\
\text { Water } \\
\end{array}$ & $\begin{array}{c}\text { Inorganic } \\
\text { Organic } \\
\text { All } \\
\end{array}$ & $\begin{array}{c}4 \mathrm{E}+01 \\
6 \mathrm{E}-02 \\
4 \mathrm{E}+01 \\
\end{array}$ \\
\hline 1 & & Reach total & $4 \mathrm{E}+01$ \\
\hline $\begin{array}{l}2 \\
2 \\
\end{array}$ & $\begin{array}{l}\text { Fish } \\
\text { Fish }\end{array}$ & $\begin{array}{c}\text { Inorganic } \\
\text { All } \\
\end{array}$ & $\begin{array}{l}8 \mathrm{E}-01 \\
8 \mathrm{E}-01\end{array}$ \\
\hline $\begin{array}{l}2 \\
2 \\
2\end{array}$ & $\begin{array}{l}\text { Sediment ingestion } \\
\text { Sediment ingestion } \\
\text { Sediment ingestion }\end{array}$ & $\begin{array}{l}\text { Inorganic } \\
\text { Organic } \\
\text { All }\end{array}$ & $\begin{array}{l}4 \mathrm{E}-02 \\
2 \mathrm{E}-04 \\
4 \mathrm{E}-02 \\
\end{array}$ \\
\hline $\begin{array}{l}2 \\
2 \\
2 \\
\end{array}$ & $\begin{array}{l}\text { Water } \\
\text { Water } \\
\text { Water } \\
\end{array}$ & $\begin{array}{l}\text { Inorganic } \\
\text { Organic } \\
\text { All } \\
\end{array}$ & $\begin{array}{c}4 \mathrm{E}+01 \\
5 \mathrm{E}-02 \\
4 \mathrm{E}+01 \\
\end{array}$ \\
\hline 2 & & Reach total & $4 \mathrm{E}+01$ \\
\hline $\begin{array}{l}3 \\
3 \\
\end{array}$ & $\begin{array}{l}\text { Fish } \\
\text { Fish }\end{array}$ & $\begin{array}{c}\text { Inorganic } \\
\text { All }\end{array}$ & $\begin{array}{c}1 E+\infty 0 \\
1 E-00\end{array}$ \\
\hline $\begin{array}{l}3 \\
3 \\
3 \\
\end{array}$ & $\begin{array}{l}\text { Sediment ingestion } \\
\text { Sediment ingestion } \\
\text { Sediment ingestion }\end{array}$ & $\begin{array}{c}\text { Inorganic } \\
\text { Organic } \\
\text { All } \\
\end{array}$ & $\begin{array}{l}2 \mathrm{E}-01 \\
3 \mathrm{E}-04 \\
2 \mathrm{E}-01 \\
\end{array}$ \\
\hline $\begin{array}{l}3 \\
3 \\
3\end{array}$ & $\begin{array}{l}\text { Water } \\
\text { Water } \\
\text { Water } \\
\end{array}$ & $\begin{array}{l}\text { Inorganic } \\
\text { Organic } \\
\text { All } \\
\end{array}$ & $\begin{array}{c}3 E+01 \\
6 E-02 \\
3 E+01 \\
\end{array}$ \\
\hline 3 & & Reach total & $3 E+01$ \\
\hline
\end{tabular}


Table 4.9. Noncarcinogens aesigned to different ecreening catcgaries by conservative screening of data bene where at leat one value for each contaminant wes above detection limits

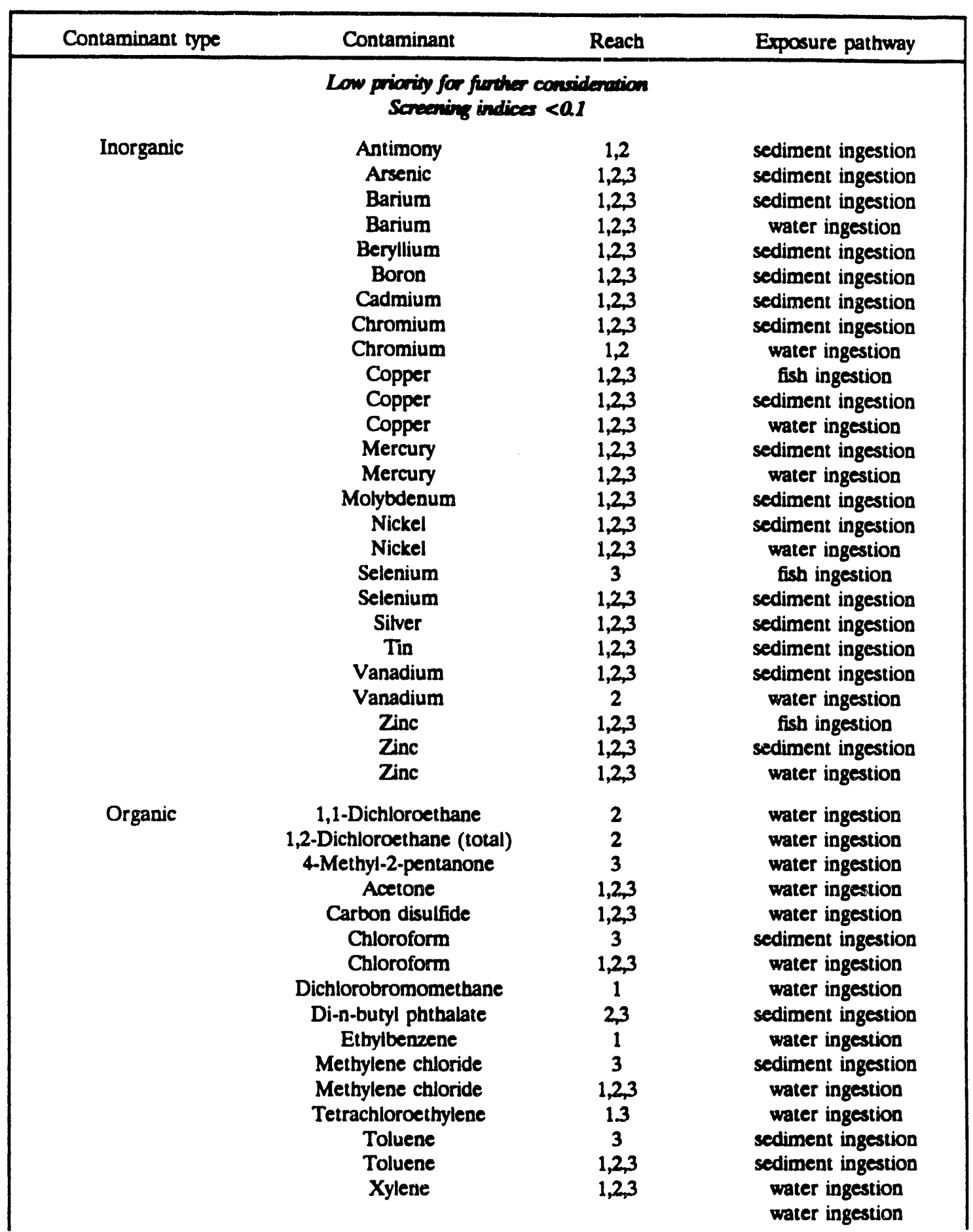


Tabic 4.9 (continued)

\begin{tabular}{|c|c|c|c|}
\hline Contaminant type & Contaminant & Reach & Exposure pathway \\
\hline \multicolumn{4}{|c|}{$\begin{array}{l}\text { Requive further investigation before taking action } \\
\text { or designating as low prianity } \\
\text { Screening indices } 0.1 \text { to } 1.0\end{array}$} \\
\hline Inorgazic & $\begin{array}{l}\text { Antimony } \\
\text { Cadmium } \\
\text { Cadmium } \\
\text { Chromium } \\
\text { Mercury } \\
\text { Selenium }\end{array}$ & $\begin{array}{c}3 \\
1,2,3 \\
2 \\
3 \\
2,3 \\
1,2,3\end{array}$ & $\begin{array}{l}\text { sediment ingestion } \\
\text { fish ingestion } \\
\text { water ingestion } \\
\text { water ingestion } \\
\text { fish ingestion } \\
\text { fish ingestion }\end{array}$ \\
\hline \multicolumn{4}{|c|}{$\begin{array}{l}\text { Require funther investigation before taking action } \\
\text { Screening indices } \geq 1.0\end{array}$} \\
\hline Inorganic & $\begin{array}{l}\text { Arsenic } \\
\text { Mercury } \\
\text { Thallium }\end{array}$ & $\begin{array}{c}2,3 \\
1 \\
1,2,3\end{array}$ & $\begin{array}{l}\text { water ingestion } \\
\text { fish ingestion } \\
\text { swater ingestion }\end{array}$ \\
\hline
\end{tabular}


contaminant as low priority, and contaminants with screening indices $\geq 1.0$, which require further investigation before taking action, are also listed in Table 4.9.

\subsubsection{Intruder scenario}

The intruder scenario is a hypothetical situation that is intended to represent is maximally exposed individual who enters WAG 2 illegally to hunt and fish and consumes game and fish from the area. Only the detectable contaminants data bases were used in: the intruder scenario. The assumptions are reasonable but would be applicable to very few individuals because of security and other safeguards that are intended to limit human access to the area. The ingestion rates used in the intruder scenario are less conservative than those used in the nonconservative screening because the intruder enters WAG 2 a limited number of times. Only the ingestion of fish, venison, and waterfowl and external exposure to radionuclides accumulated in the shore line sediment and floodplain soil were considered in this scenario. The ingestion of waterfowl was considered only for Reach 1 (Table 4.10) because most of the waterfowl are associated with WOL and the floodplain area. The ingestion of soil and the consumption of water were not considered because of the limited amount of time ( 4 to 6 hours per trip) the intruder would spend in the WAG 2 area.

Carcinogens. Calculations for the intruder scenario were made using only the detectable contaminants data base. Results of these calculations are summarized for the carcinogens in Table 4.10 for each class of contaminant (organics, inorganics, and radionuclides), for each exposure pathway, and for each reach. The screening indices for individual carcinogens are given in Table C1 (Appendix C) along with the geometric means of the data that were used as the concentration of each contaminant. All reaches had screening indices $>10^{-4}$. The fish ingestion pathway contributed the greatest risk for all reaches; radionuclides in fish contributed the greatest risk in Reaches 1 and 2, and organic contaminants in fish the greatest in Reach 3.

The screening indices for the external exposure pathway for all reaches were $>10^{-4}$, which was less than the values calculated for nonconservative screening. This result can be attributed to the relatively short time (maximum of 120 hours per year for 25 years or less) that the intruder spent in WAG 2. Individual radionuclides and their contribution to the external exposure screening indices are given in Table $C 2$ (Appendix C).

Noncarcinogens. Results of the calculations for noncarcinogens in the intruder scenario are listed in Table 4.11, and the screening indices for individual contaminants are given in Table C3 (Appendix C), along with the geometric mean for the concentrations of individual contaminants. Only the ingestion pathways were considered for the noncarcinogens, and the sums of the screening indices for noncarcinogens for all reaches were $<1.0$. The noncarcinogen showing the highest screening index $\left(1.5 \times 10^{-1}\right)$ was mercury in fish in Reach 1. 
Table 4.10. Summary table for intruder screening scenario for detected carcinogens

\begin{tabular}{|c|c|c|c|}
\hline $\begin{array}{c}\text { Reach } \\
\text { no. }\end{array}$ & $\begin{array}{l}\text { Exposure } \\
\text { pathway }\end{array}$ & $\begin{array}{c}\text { Contaminant } \\
\text { type }\end{array}$ & $\begin{array}{c}\text { Carcinogen } \\
\text { screening indices }\end{array}$ \\
\hline $\begin{array}{l}1 \\
1\end{array}$ & $\begin{array}{l}\text { Fish ingestion } \\
\text { Fish ingestion }\end{array}$ & $\begin{array}{c}\text { Radionuclide } \\
\text { Organic }\end{array}$ & $\begin{array}{l}2 E-04 \\
2 E-04\end{array}$ \\
\hline 1 & Fish total & & 3E-04 \\
\hline 1 & Venison ingestion & Radionuclide & $1 \mathrm{E}-06$ \\
\hline 1 & Total ingestion & & 3E-04 \\
\hline 1 & External Exposure & Radionuclide & 4E-04 \\
\hline 1 & Reach total & & 8E-04 \\
\hline $\begin{array}{l}2 \\
2 \\
\end{array}$ & $\begin{array}{l}\text { Fish ingestion } \\
\text { Fish ingestion } \\
\end{array}$ & $\begin{array}{c}\text { Radionuclide } \\
\text { Organic }\end{array}$ & $\begin{array}{l}4 \mathrm{E}-05 \\
3 \mathrm{E}-05 \\
\end{array}$ \\
\hline 2 & Fish total & & 8E-05 \\
\hline 2. & Venison ingestion & Radionuclide & $1 E-06$ \\
\hline & Total ingestion & & 8E-05 \\
\hline 2 & External Exposure & Radionuclide & $3 E-04$ \\
\hline 2 & Reach total & & 4E-04 \\
\hline $\begin{array}{l}3 \\
3 \\
\end{array}$ & $\begin{array}{l}\text { Fish ingestion } \\
\text { Fish ingestion } \\
\end{array}$ & $\begin{array}{c}\text { Radionuclide } \\
\text { Organic } \\
\end{array}$ & $\begin{array}{l}3 \mathrm{E}-05 \\
2 \mathrm{E}-04 \\
\end{array}$ \\
\hline 3 & Fish total & & 2E-04 \\
\hline $\begin{array}{l}3 \\
3 \\
\end{array}$ & $\begin{array}{c}\text { Venison ingestion } \\
\text { Duck flesh ingestion }\end{array}$ & $\begin{array}{l}\text { Radionuclide } \\
\text { Radionuclide } \\
\end{array}$ & $\begin{array}{l}1 \mathrm{E}-06 \\
4 \mathrm{E}-07 \\
\end{array}$ \\
\hline 3 & Game total & & $1 E-06$ \\
\hline 3 & Total ingestion & & 2E-04 \\
\hline 3 & External Exposure & Radionuclide & $6 \mathrm{E}-04$ \\
\hline 3 & Reach total & & 8E-04 \\
\hline
\end{tabular}


Table 4.11. Summary table for intruder screening scenario for detected noncarcinogens

\begin{tabular}{cccc}
\hline $\begin{array}{c}\text { Reach } \\
\text { no. }\end{array}$ & $\begin{array}{c}\text { Exposure } \\
\text { pathway }\end{array}$ & $\begin{array}{c}\text { Contaminant } \\
\text { type }\end{array}$ & $\begin{array}{c}\text { Noncarcinogen } \\
\text { screening indices }\end{array}$ \\
\hline 1 & Fish ingestion & Inorganic & $2 \mathrm{E}-01$ \\
\hline 1 & Reach total & & $2 \mathrm{E}-01$ \\
\hline 2 & Fish ingestion & Inorganic & $6 \mathrm{E}-02$ \\
\hline 2 & Reach total & $6 \mathrm{E}-02$ \\
\hline 3 & & & $9 \mathrm{E}-02$ \\
3 & Fish ingestion & Inorganic & $7 \mathrm{E}-03$ \\
\hline 3 & Duck flesh ingestion & Inorganic & $1 \mathrm{E}-01$ \\
\hline
\end{tabular}

\subsection{Nondetectable Contaminants}

The nondetectable contaminant data base contained approximately three times as many contaminants as the detectable contaminant data base. Some contaminants are included in both data bases because the contaminant was present in detectable quantities in one medium and not in another. Screening would not be complete without including the nondetectable contaminants; however, caution should be exercised in interpreting the results because of the uncertainty associated with the contaminant concentrations.

\subsubsection{Nonconservative screening}

Nonconservative screening of the nondetectable contaminants is used to identify contaminants that have a high priority for action to lower detection limits and those for which source-term data are needed to determine whether, in the past, extremely small, if any, quantities of these contaminants have been released from ORNL. Results of the nonconservative screening for the nondetectable contaminant data bases are given in Tables D1 and D2 (Appendix D). Screening indices for individual contaminants are listed according to exposure pathway and reach, and concentrations are the minimum detection limits in the data base. Pathways for which values are not given are either in the detectable contaminant data base or data were not available. Screening indices were not summed for contaminant type, pathway, or reach because the uncertainty resulting from using detection limits would make the sums overly conservative.

Carcinogens. Only three organic carcinogens-acenaphtylene in the fish ingestion pathway and benzidine and n-nitrosodimethylamine in the sediment ingestion 
pathway-had screening indices $>10^{-4}$ (Table D1, Appendix D). Normally, such screening indices would identify these carcinogens as high priority contaminants that require immediate consideration for remedial action; however, because the screening analysis was based on minimum detection limits, the indices indicate that better detection limits are needed and/or a review of source-term data is appropriate. Two inorganics and 57 organic contaminants had screening indices between $10^{-1}$ and $10^{-6}$, which would require further investigation before taking action.

Noncarcinogens. All noncarcinogens in the nondetectable contaminant data base had screening indices < 1.0 (Table D2, Appendix D); therefore, they would not be considered high priority contaminants requiring immediate consideration for remedial action. Antimony in the fish and water ingestion pathways, 4,6-dinitro-ortho-cresol in the fish ingestion pathway, and heptachlor epoxide in the sediment ingestion pathway had screening indices between 0.1 and 1.0 and would require further investigation before taking action.

\subsubsection{Conservative screening}

The purpose of conservative screening is to identify contaminants with a low priority for further consideration: contaminants that have screening indices $<10^{-6}$ for carcinogens and $<0.1$ for noncarcinogens (Figs. 4.1 and 4.2). Values for nondetectable contaminants are based on detection limits; therefore, contaminant concentrations that were used in the screening are greater than concentrations actuall; present in the samples. This bias can significantly increase the conservatism of the screening, so the number of contaminants identified as low priority will probably be small.

Carcinogens. Conservative screening of the nondetectable contaminants data base for carcinogens showed that 25 organic contaminants in the sediment ingestion pathway had screening indices $<10^{-6}$ and can be assigned low priority for further consideration (Table E1, Appendix E). Two inorganics, arsenic and beryllium, in the fish and water ingestion pathways and 46 organics in at least one pathway had screening indices $\geq 10^{-4}$ and would require further investiga:ion before taking action. The remaining organic contaminants had screening indices between $10^{-4}$ and $10^{-6}$, which would require further investigation before taking action or designating the contaminants as low priority.

Noncarcinogens. Inorganic noncarcinogens that had screening indices $<0.1$ and can be assigned low priority for further considerations include the following: chromium and nickel in the fish ingestion pathway; boron, vanadium, and tin in the water ingestion pathway; cyanide in the sediment ingestion pathway; and silver and beryllium in the fish and water ingestion pathways (Table E2, Appendix E). Thirteen organics in the fish ingestion pathway and two in the sediment ingestion pathways also had screening indices $<0.1$ and can be assigned low priority for further consideration.

Inorganic noncarcinogens that have screening indices $>1.0$ in one or more reaches and that would require further investigation before taking action are antimony in the fish ingestion and antimony and arsenic in the water ingestion pathways. Molybdenum, selenium, and cadmium in the water ingestion pathway, and thallium in the sediment 
ingestion pathway have screening indices between 0.1 and 1.0. Eight organics contaminants in the fish ingestion pathway, including two in both the fish and sediment ingestion pathways, had screening indices $>1.0$. The remaining organics listed in Table E2 (Appendix E) have screening indices between 0.1 and 1.0 and would require further consideration before taking action or designating the contaminants as low priority.

\subsection{Nonclassified Contaminants}

Contaminants in the detectable and nondetectable contaminants data bases for which RfDs or slope factors were not available are listed in Table 4.12. Dose conversion factors are available for the radionuclides listed in Table 4.12; however, the EPA has not provided slope factors for these radionuclides. Groundwater is not included in the nondetectable contaminant listing because the data are undergoing verification. Lead is the only contaminant that was detected in fish (Reaches 1 and 3) that did not have a screening factor, but it is doubtful that lead concentrations would present a problem in the fish ingestion pathway (Sect. 4.8.5).

\subsubsection{Groundwater}

Groundwater was screened independently of the other pathways for Reaches 1, 2, and 3. Either groundwater or surface water can be used for the water ingestion pathway, but because the consumption rate $(2 \mathrm{~L} / \mathrm{d})$ is limited, only one source can be summed with the other pathways to obtain a screening index for a reach. Because the data base for groundwater is being revised and additional data are becoming available, the decision was made to use surface water in the screening analysis and perform independent calculations for the groundwater pathway. In addition, the data base for the nondetectable contaminants for groundwater has not been verified; therefore, conservative and nonconservative screening will be conducted only on the detectable data base.

\subsubsection{Nonconservative screening of detectable contaminants in growindwater}

Carcinogen. Screening indices for the nonconservative screening of carcinogens in the groundwater are given in Appendix $F$ for each class of contaminant, exposure pathway, and reach. Reach 3 had a screening index for groundwater $\geq 10^{-4}$, indicating it as a high priority reach requiring immediate consideration for remedial action (Table F1, Appendix F). However, screening indices for individual contaminants in the groundwater in Reach 3 range from $2 \times 10^{-5}$ to $8 \times 10^{-9}$, and only the contaminants that have screening indices between $10^{-4}$ and $10^{-6}$ require investigation before taking action. One of the major contributors to the screening index in Reach 3 was arsenic, but because it was detected in only 2 of 74 samples analyzed, it is a possible artifact of the analytical procedure. The other major contributors to the screening index in Reach 3 were the radionuclides ${ }^{24} \mathrm{Ra}$, ${ }^{24} \mathrm{Th}$, and ${ }^{234} \mathrm{U}$. These data are questionable because of the small number of samples analyzed for these radionuclides; therefore, additional sampling is required. Reaches 1 and 2 had total screening indices $1 \times 10^{-5}$ and $2 \times 10^{-5}$, respectively, indicating that further action is required before taking action. In Reach 1 , the major contributor to the screening index was beryllium, with a screening index of $1 \times 10^{-5}$. In Reach 2, the major contributor was tritium, with a screening index of $1 \times 10^{-5}$. Additional data are needed because of the 
Table 4.12 Contaminants that were reported in either the detectables or nondetectables data beses for which scroening factors

were not available

Detectable contaminants

\begin{tabular}{|c|c|c|c|c|c|}
\hline $\begin{array}{l}\text { Media } \\
\text { name }\end{array}$ & $\begin{array}{l}\text { Contaminant } \\
\text { name }\end{array}$ & Reach & $\begin{array}{l}\text { Ratio of } \\
\text { detected } \\
\text { to total } \\
\text { samples }\end{array}$ & $\begin{array}{c}\text { Geometric } \\
\text { mean } \\
\text { (mg/kg wet) }\end{array}$ & $\begin{array}{l}95 \% \text { upper } \\
\text { conf bound } \\
\text { on mean } \\
\text { (mg/kg wet) }\end{array}$ \\
\hline Fish & Lead & 1 & $7 / 43$ & $4.3 E-02$ & $1.7 \mathrm{E}-01$ \\
\hline Fish & Lead & 3 & $7 / 36$ & $\begin{array}{l}5.6 \mathrm{E}-02 \\
(\mathrm{mg} / \mathrm{L})\end{array}$ & $\begin{array}{l}2.1 \mathrm{E}-01 \\
(\mathrm{mg} / \mathrm{L})\end{array}$ \\
\hline Groundwater & 1,2-Benzenedicarboxylic acid & 3 & $1 / 5$ & $7.9 \mathrm{E}-03$ & $1.2 \mathrm{E}-02$ \\
\hline Groundwater & 2-Pentanone(4,4-dimethyl) & 3 & $1 / 1$ & $4.0 \mathrm{E}-03$ & 4.0E-03 \\
\hline Grouncwwater & Aluminum & 1 & $13 / 19$ & $4.4 \mathrm{E}-01$ & $9.0 \mathrm{E}+00$ \\
\hline Groundwater & Aluminum & 2 & $12 / 15$ & $2.5 E-01$ & $4.7 \mathrm{E}+00$ \\
\hline Groundwater & Aluminum & 3 & $19 / 35$ & $2.4 E-01$ & $4.7 \mathrm{E}+00$ \\
\hline Groundwater & Benzenaminc, n-phenyl & 3 & $1 / 1$ & $7.0 \mathrm{E}-03$ & $7.0 \mathrm{E}-03$ \\
\hline Groundwater & Benzene, methyl & 3 & $1 / 5$ & $4.2 E-03$ & $6.1 \mathrm{E}-03$ \\
\hline Groundwater & Beta-BHC & 3 & $2 \pi$ & $6.3 E-05$ & $9.8 \mathrm{E}-0.5$ \\
\hline Groundwater & Cobalt & 1 & $3 / 19$ & $7.0 \mathrm{E}-03$ & $1.9 \mathrm{E}-02$ \\
\hline Groundwater & Cobalt & 2 & $2 / 15$ & $6.3 E-03$ & $1.2 \mathrm{E}-02$ \\
\hline Groundwater & Cobalt & 3 & $9 / 36$ & $1.2 \mathrm{E}-02$ & $2.2 \mathrm{E}-02$ \\
\hline Groundwater & Dichloromethane & 3 & $4 / 5$ & $8.9 \mathrm{E}-03$ & $1.6 \mathrm{E}-02$ \\
\hline Groundwater & Hexane,3,4-bis(1,1-dimethyl) & 3 & $1 / 1$ & $3.8 \mathrm{E}-02$ & $3.8 \mathrm{E}-02$ \\
\hline Groundwater & Lead & 1 & $1 / 19$ & $5.8 \mathrm{E}-02$ & $1.7 E-01$ \\
\hline Groundwater & Lead & 3 & $6 / 74$ & $2.4 \mathrm{E}-02$ & 6.6E-02 \\
\hline Groundwater & Lithium & 1 & $1 / 18$ & $2.2 E+00$ & $1.2 \mathrm{E}+01$ \\
\hline Groundwater & Strontium & 1 & $18 / 18$ & 3.7E-01 & $1.4 \mathrm{E}+00$ \\
\hline Groundwater & Strontium & 2 & $11 / 11$ & $1.9 \mathrm{E}-01$ & $5.8 \mathrm{E}-01$ \\
\hline Groundwater & Strontium & 3 & $13 / 13$ & $3.1 \mathrm{E}-01$ & $7.4 \mathrm{E}-01$ \\
\hline Groundwater & Titanium & 1 & $3 / 18$ & $2.1 E-02$ & $2.1 \mathrm{E}-02$ \\
\hline Groundwater & Titanium & 2 & $2 / 11$ & $2.4 \mathrm{E}-02$ & $5.0 \mathrm{E}-02$ \\
\hline Groundwater & Titanium & 3 & $5 / 13$ & $2.6 \mathrm{E}-02$ & $3.8 \mathrm{E}-02$ \\
\hline Groundwater & Total Uranium & 1 & $2 / 8$ & $5.8 \mathrm{E}-04$ & $7.8 \mathrm{E}-04$ \\
\hline Groundwater & Total Uranium & 2 & $1 / 9$ & $5.1 \mathrm{E}-04$ & $5.4 \mathrm{E}-04$ \\
\hline Groundwater & Total Uranium & 3 & $3 / 12$ & 8.1E-04 & $7.4 E-03$ \\
\hline Groundwater & Trichloromethane & 3 & $1 / 5$ & $4.5 E-03$ & $5.7 \mathrm{E}-03$ \\
\hline
\end{tabular}


Table 4.12 (continued)

Detectabic contaminants

\begin{tabular}{|c|c|c|c|c|c|}
\hline $\begin{array}{c}\text { Media } \\
\text { name }\end{array}$ & $\begin{array}{l}\text { Contaminant } \\
\text { name }\end{array}$ & Reach & $\begin{array}{l}\text { Ratio of } \\
\text { detected } \\
\text { to total } \\
\text { samples }\end{array}$ & $\begin{array}{c}\text { Geometric } \\
\text { mean } \\
\text { (mg/kg or } \\
\mathrm{Bq} / \mathrm{kg} \text { dry) }\end{array}$ & $\begin{array}{l}95 \% \text { upper } \\
\text { conf bound } \\
\text { on mean } \\
\text { (mg or } \mathrm{Bg} / \mathrm{kg} \text { ) }\end{array}$ \\
\hline Sediment & Aluminum & 1 & $31 / 31$ & $1.3 E+03$ & $5.3 E+03$ \\
\hline Sediment & Aluminum & 2 & $111 / 111$ & $6.0 \mathrm{E}+02$ & $2.0 \mathrm{E}+03$ \\
\hline Sediment & Aluminum & 3 & $58 / 58$ & $1.5 E+03$ & $1.0 \mathrm{E}+04$ \\
\hline Sediment & ${ }^{57} \mathrm{Co}$ & 2 & $4 / 4$ & $8.0 \mathrm{E}+01$ & $1.6 \mathrm{E}+02$ \\
\hline Sediment & ${ }^{57} \mathrm{Co}$ & 3 & $2 / 2$ & $2.7 \mathrm{E}+02$ & $5.9 \mathrm{E}+02$ \\
\hline Sediment & Cobalt & 1 & $31 / 31$ & $6.4 E+\infty 0$ & $8.8 E+00$ \\
\hline Sediment & Cobalt & 2 & $111 / 111$ & $1.0 \mathrm{E}+01$ & $1.1 \mathrm{E}+01$ \\
\hline Sediment & Cobalt & 3 & $54 / 58$ & $1.2 \mathrm{E}+01$ & $1.9 E+01$ \\
\hline Sediment & ${ }^{15 S} \mathrm{Eu}$ & 2 & $13 / 13$ & $1.1 E+02$ & $2.4 \mathrm{E}+02$ \\
\hline Sediment & ${ }^{155} \mathrm{Eu}$ & 3 & $8 / 8$ & $1.2 \mathrm{E}+02$ & $2.2 E+02$ \\
\hline Sediment & Lead & 1 & $15 / 31$ & $1.1 \mathrm{E}+01$ & $2.1 \mathrm{E}+01$ \\
\hline Sediment & Lead & 2 & $41 / 111$ & $3.4 \mathrm{E}+00$ & $5.6 \mathrm{E}+00$ \\
\hline Sediment & Lead & 3 & $34 / 62$ & $8.0 \mathrm{E}+00$ & $2.6 \mathrm{E}+01$ \\
\hline Sediment & Lithium & 2 & $4 / 111$ & $5.6 \mathrm{E}+00$ & $2.6 \mathrm{E}+02$ \\
\hline Sediment & Lithium & 3 & $2 / 54$ & $1.5 \mathrm{E}+01$ & $5.5 \mathrm{E}+02$ \\
\hline Sediment & ${ }^{191}$ Os & 2 & $1 / 1$ & $2.9 \mathrm{E}+01$ & $2.9 E+01$ \\
\hline Sediment & ${ }^{125} \mathrm{Sb}$ & 1 & $2 / 2$ & $7.4 \mathrm{E}+02$ & $1.7 \mathrm{E}+03$ \\
\hline Sediment & ${ }^{125} \mathrm{Sb}$ & 3 & $4 / 4$ & $2.5 E+02$ & $3.9 \mathrm{E}+02$ \\
\hline Sediment & ${ }^{75} \mathrm{Se}$ & 3 & $2 / 2$ & $8.6 \mathrm{E}+01$ & $4.2 E+02$ \\
\hline Sediment & Strontium & 1 & $31 / 31$ & $6.1 E+\infty 0$ & $9.1 \mathrm{E}+00$ \\
\hline Sediment & Strontium & 2 & $111 / 111$ & $8.2 E+00$ & $8.8 E+00$ \\
\hline Sediment & Strontium & 3 & $54 / 58$ & $6.7 \mathrm{E}+00$ & $9.5 E+00$ \\
\hline Sediment & Titanium & 1 & $22 / 31$ & $5.5 \mathrm{E}+00$ & $5.1 E+01$ \\
\hline Sediment & Titanium & 2 & $95 / 111$ & $9.0 \mathrm{E}-01$ & $2.2 \mathrm{E}+01$ \\
\hline Sediment & Titanium & 3 & $55 / 58$ & $4.9 \mathrm{E}+00$ & $7.3 \mathrm{E}+02$ \\
\hline Sediment & Total Plutonium & 3 & $4 / 4$ & $4.6 \mathrm{E}+02$ & $5.1 \mathrm{E}+02$ \\
\hline Sediment & Zirconium & 1 & $24 / 31$ & $1.9 \mathrm{E}+00$ & $2.9 \mathrm{E}+\infty 0$ \\
\hline Sediment & Zirconium & 2 & $106 / 111$ & $1.2 \mathrm{E}+00$ & $1.5 E+00$ \\
\hline Sediment & Zirconium & 3 & $53 / 58$ & $\begin{array}{c}2.3 \mathrm{E}+00 \\
(\mathrm{Mg} \text { or } \mathrm{Bq} / \mathrm{L})\end{array}$ & $\begin{array}{c}4.0 \mathrm{E}+01 \\
(\mathrm{Mg} \text { or } \mathrm{Bq} / \mathrm{L})\end{array}$ \\
\hline Surface water & 1,2-Dichloroethene (total) & 2 & $2 / 29$ & $4.9 \mathrm{E}-03$ & $6.9 \mathrm{E}-03$ \\
\hline Surface water & Aluminum & 1 & $27 / 32$ & $3.0 \mathrm{E}-01$ & 9.9E-01 \\
\hline Surface water & Aluminum & 2 & $27 / 32$ & $4.8 \mathrm{E}-01$ & 2.7E+00 \\
\hline Surface water & Aluminum & 3 & $28 / 32$ & $5.7 \mathrm{E}-01$ & $1.2 \mathrm{E}+00$ \\
\hline Surface water & ${ }^{155} \mathrm{Eu}$ & 2 & $6 / 6$ & $8.4 \mathrm{E}+00$ & $1.6 \mathrm{E}+01$ \\
\hline Surface water & Lead & 1 & $4 / 33$ & $5.4 \mathrm{E}-03$ & $1.3 E-02$ \\
\hline Surface water & Lead & 2 & $5 / 76$ & $1.4 \mathrm{E}-02$ & $2.4 \mathrm{E}-02$ \\
\hline Surface water & Lead & 3 & $7 / 33$ & $5.2 E-03$ & $1.3 E-02$ \\
\hline Surface water & ${ }^{191}$ Os & 3 & $2 / 2$ & $3.3 \mathrm{E}+00$ & $3.3 E+00$ \\
\hline Surface water & Strontium & 1 & $3 / 3$ & 8.7E-02 & $1.1 \mathrm{E}-01$ \\
\hline Surface water & Strontium & 2 & $3 / 3$ & $1.1 \mathrm{E}-01$ & $1.7 \mathrm{E}-01$ \\
\hline Surface water & Strontium & 3 & $3 / 3$ & $9.0 \mathrm{E}-02$ & $9.6 \mathrm{E}-02$ \\
\hline Surface water & Titanium & 2 & $1 / 3$ & $2.9 \mathrm{E}-02$ & $9.4 \mathrm{E}-02$ \\
\hline
\end{tabular}


Table 4.12 (continued)

Noodetectable contaminants

\begin{tabular}{|c|c|c|c|c|c|}
\hline $\begin{array}{l}\text { Media } \\
\text { type }\end{array}$ & $\begin{array}{l}\text { Contaminant } \\
\text { name }\end{array}$ & Reach & $\begin{array}{l}\text { Total } \\
\text { number of } \\
\text { samples }\end{array}$ & $\begin{array}{l}\text { Minimun } \\
\text { detection } \\
\text { limits } \\
\text { (mg/kg wet) }\end{array}$ & $\begin{array}{l}95 \% \text { upper } \\
\text { conf bound } \\
\text { on mean } \\
\text { (mg/kg wet) }\end{array}$ \\
\hline Fish & 1,3-Dichlorobenzene & 1 & 12 & $2.0 \mathrm{E}-01$ & $2.0 \mathrm{E}+00$ \\
\hline Fish & 1,3-Dichlorobenzene & 2 & 8 & $2.0 \mathrm{E}-01$ & $1.9 \mathrm{E}+00$ \\
\hline Fish & 1,3-Dichlorobenzene & 3 & 16 & $2.0 \mathrm{E}-01$ & $2.0 \mathrm{E}+\infty 0$ \\
\hline Fish & 2-Methylnaphthalene & 1 & 12 & $2.0 \mathrm{E}-01$ & $2.0 \mathrm{E}+00$ \\
\hline Fish & 2-Methylnaphthalene & 2 & 8 & $2.0 \mathrm{E}-01$ & $1.9 \mathrm{E}+00$ \\
\hline Fish & 2-Methylnaphthalene & 3 & 16 & $2.0 \mathrm{E}-01$ & $2.0 \mathrm{E}+00$ \\
\hline Fish & 2-Methylphenol & 1 & 12 & $2.0 \mathrm{E}-01$ & $2.0 \mathrm{E}+00$ \\
\hline Fish & 2-Methylphenol & 2 & 8 & $2.0 \mathrm{E}-01$ & $1.9 \mathrm{E}+00$ \\
\hline Fish & 2-Methylphenol & 3 & 16 & $2.0 \mathrm{E}-01$ & $2.0 \mathrm{E}+\infty 0$ \\
\hline Fish & 2-Nitroaniline & 1 & 12 & $1.0 \mathrm{E}+00$ & $9.8 \mathrm{E}+\infty 0$ \\
\hline Fish & 2-Nitroaniline & 2 & 8 & $1.0 \mathrm{E}+00$ & $9.5 \mathrm{E}+00$ \\
\hline Fish & 2-Nitroaniline & 3 & 16 & $1.0 \mathrm{E}+\infty 0$ & $9.9 E+\infty 0$ \\
\hline Fish & 2-Nitrophenol & 1 & 24 & $2.0 \mathrm{E}-01$ & $6.0 \mathrm{E}+\infty 0$ \\
\hline Fish & 2-Nitrophenol & 2 & 16 & 2.0E-01 & $5.5 E+00$ \\
\hline Fish & 2-Nitrophenol & 3 & 32 & 2.0E-01 & $6.2 \mathrm{E}+00$ \\
\hline Fish & 3-Nitroaniline & 1 & 12 & $1.0 \mathrm{E}+00$ & $9.8 \mathrm{E}+00$ \\
\hline Fish & 3-Nitroaniline & 2 & 8 & $1.0 \mathrm{E}+00$ & $9.5 E+\infty 0$ \\
\hline Fish & 3-Nitroaniline & 3 & 16 & $1.0 \mathrm{E}+00$ & $9.9 E+\infty 0$ \\
\hline Fish & 4-Bromophenyl phenyl ether & 1 & 12 & 2.0E-01 & $2.0 \mathrm{E}+\infty 0$ \\
\hline Fish & 4-Bromophenyl phenyl ether & 2 & 8 & $2.0 \mathrm{E}-01$ & $1.9 \mathrm{E}+00$ \\
\hline Fish & 4-Bromophenyl phenyl ether & 3 & 16 & 2.0E-01 & $2.0 \mathrm{E}+00$ \\
\hline Fish & 4-Chlorophenyl phenyl ether & 1 & 12 & 2.0E-01 & $2.0 \mathrm{E}+00$ \\
\hline Fish & 4-Chlorophemyl phenyl ether & 2 & 8 & 2.0E-01 & $1.9 \mathrm{E}+00$ \\
\hline Fish & 4-Chlorophenyl phenyl ether & 3 & 16 & $2.0 \mathrm{E}-01$ & $2.0 \mathrm{E}+00$ \\
\hline Fish & 4-Nitroaniline & 1 & 12 & $1.0 E+\infty$ & $9.8 \mathrm{E}+00$ \\
\hline Fish & 4-Nitroaniline & 2 & 8 & $1.0 \mathrm{E}+00$ & $9.5 E+\infty 0$ \\
\hline Fish & 4-Nitroaniline & 3 & 16 & $1.0 \mathrm{E}+\infty 0$ & $9.9 \mathrm{E}+00$ \\
\hline Fish & Bis(2-chlorodisopropyl)ether & 1 & 12 & $2.0 \mathrm{E}-01$ & $2.0 E+00$ \\
\hline Fish & Bis(2-chlorodisopropyl)ether & 2 & 8 & 2.0E-01 & $1.9 \mathrm{E}+00$ \\
\hline Fish & Bis(2-chlorodisopropyl)ether & 3 & 16 & 2.0E-01 & $2.0 \mathrm{E}+00$ \\
\hline Fish & Bis(2-chloroethoxy)methane & 1 & 12 & $2.0 \mathrm{E}-01$ & $2.0 \mathrm{E}+00$ \\
\hline Fish & Bis(2-chloroethoxy)methane & 2 & 8 & 2.0E-01 & $1.9 \mathrm{E}+\infty 0$ \\
\hline Fish & Bis(2-chloroethoxy)methane & 3 & 16 & 2.0E-01 & $2.0 \mathrm{E}+00$ \\
\hline Fish & Delta BHC & 1 & 12 & $5.0 \mathrm{E}-03$ & $3.9 \mathrm{E}-02$ \\
\hline Fish & Delta BHC & 2 & 8 & $5.0 \mathrm{E}-03$ & $3.8 \mathrm{E}-02$ \\
\hline Fish & Delta BHC & 3 & 16 & $5.0 \mathrm{E}-03$ & 4.0E-02 \\
\hline Fish & Dibenzofuran & 1 & 12 & 2.0E-01 & $2.0 \mathrm{E}+\infty 0$ \\
\hline Fish & Dibenzofuran & 2 & 8 & 2.0E-01 & $1.9 \mathrm{E}+\infty 0$ \\
\hline Fish & Dibenzofuran & 3 & 16 & 2.0E-01 & $2.0 \mathrm{E}+00$ \\
\hline Fish & Endosulfan sulfate & 1 & 12 & $9.0 \mathrm{E}-03$ & $2.0 \mathrm{E}-01$ \\
\hline Fish & Endosulfan sulfate & 2 & 8 & $9.0 \mathrm{E}-03$ & $1.9 \mathrm{E}-01$ \\
\hline Fish & Endosulfan sulfate & 3 & 16 & $9.0 \mathrm{E}-03$ & 2.0E-01 \\
\hline Fish & Endrin ketone & 1 & 12 & $9.0 \mathrm{E}-03$ & $3.9 \mathrm{E}-02$ \\
\hline Fish & Endrin ketone & 2 & 8 & $9.0 \mathrm{E}-03$ & $3.8 \mathrm{E}-02$ \\
\hline Fish & Endrin ketone & 3 & 16 & $9.0 \mathrm{E}-03$ & $4.0 \mathrm{E}-02$ \\
\hline
\end{tabular}


Table 4.12 (continued)

Nondetoctable contaminants

\begin{tabular}{|c|c|c|c|c|c|}
\hline $\begin{array}{l}\text { Media } \\
\text { type }\end{array}$ & $\begin{array}{l}\text { Contaminant } \\
\text { name }\end{array}$ & Reach & $\begin{array}{c}\text { Total } \\
\text { number of } \\
\text { samples }\end{array}$ & $\begin{array}{c}\text { Minimun } \\
\text { detection } \\
\text { limits } \\
\text { (mg/kg wet) }\end{array}$ & $\begin{array}{l}95 \% \text { upper } \\
\text { conf bound } \\
\text { on mean } \\
\text { (mg/kg wet) }\end{array}$ \\
\hline Fish & Lead & 2 & 19 & $2.0 \mathrm{E}-02$ & $3.4 \mathrm{E}-01$ \\
\hline Fish & Parachlorometa cresol & 1 & 12 & $2.0 \mathrm{E}-01$ & $2.0 E+\infty 0$ \\
\hline Fish & Parachlorometa cresol & 2 & 8 & $2.0 \mathrm{E}-01$ & $1.9 E+00$ \\
\hline Fish & Parachlorometa cresol & 3 & 16 & $\begin{array}{c}2.0 \mathrm{E}-01 \\
(\mathrm{mg} / \mathrm{kg} \mathrm{dry})\end{array}$ & $\begin{array}{c}2.0 \mathrm{E}+00 \\
(\mathrm{mg} / \mathrm{kg} \text { dry })\end{array}$ \\
\hline Sediment & 1,2-Dichloropropene & 3 & 2 & $1.0 \mathrm{E}-02$ & $1.0 \mathrm{E}-02$ \\
\hline Sediment & 1,3-Dichlorobenzene & 1 & 2 & $1.0 \mathrm{E}+01$ & $1.0 \mathrm{E}+01$ \\
\hline Sediment & 1,3-Dichlorobenzene & 2 & 10 & $1.0 \mathrm{E}+01$ & $1.0 \mathrm{E}+01$ \\
\hline Sediment & 1,3-Dichlorobenzene & 3 & 16 & $9.1 \mathrm{E}-01$ & $1.1 \mathrm{E}+01$ \\
\hline Sediment & 2-Chloroethyl vinyl ether & 3 & 1 & $1.0 \mathrm{E}-02$ & $1.0 \mathrm{E}-02$ \\
\hline Sediment & 2-Chlorovinyl ether & 3 & $i$ & $1.0 \mathrm{E}-02$ & $1.0 \mathrm{E}-02$ \\
\hline Sediment & 2-Methylnaphthalene & 1 & 2 & $1.0 \mathrm{E}+01$ & $1.0 \mathrm{E}+01$ \\
\hline Sediment & 2-Methylnaphthalene & 2 & 10 & $1.0 \mathrm{E}+01$ & $1.0 \mathrm{E}+01$ \\
\hline Sediment & 2-Methylnaphthalene & 3 & 14 & $1.0 \mathrm{E}+01$ & $1.0 \mathrm{E}+01$ \\
\hline Sediment & 2-Methylphenol & 1 & 3 & $1.0 \mathrm{E}+01$ & $1.0 \mathrm{E}+01$ \\
\hline Sediment & 2-Methylphenol & 2 & 10 & $1.0 \mathrm{E}+01$ & $1.0 \mathrm{E}+01$ \\
\hline Sediment & 2-Methylphenol & 3 & 14 & $1.0 \mathrm{E}+01$ & $1.0 \mathrm{E}+01$ \\
\hline Sediment & 2-Nitroaniline & 1 & 2 & $1.0 \mathrm{E}+01$ & $2.8 \mathrm{E}+02$ \\
\hline Sediment & 2-Nitroaniline & 2 & 10 & $1.0 \mathrm{E}+01$ & $4.1 \mathrm{E}+01$ \\
\hline Sediment & 2-Nitroaniline & 3 & 14 & $1.0 \mathrm{E}+01$ & $2.8 \mathrm{E}+01$ \\
\hline Sediment & 2-Nitrophenol & 1 & 3 & $1.0 \mathrm{E}+01$ & $3.1 \mathrm{E}+01$ \\
\hline Sediment & 2-Nitrophenol & 2 & 10 & $1.0 \mathrm{E}+01$ & $2.0 \mathrm{E}+01$ \\
\hline Sediment & 2-Nitrophenol & 3 & 14 & $1.0 \mathrm{E}+01$ & $2.0 \mathrm{E}+\mathrm{O} 1$ \\
\hline Sediment & 3-Nitroaniline & 1 & 2 & $1.0 \mathrm{E}+01$ & $2.8 \mathrm{E}+02$ \\
\hline Sediment & 3-Nitroaniline & 2 & 10 & $1.0 \mathrm{E}+01$ & $4.1 E+01$ \\
\hline Sediment & 3-Nitroaniline & 3 & 14 & $1.0 \mathrm{E}+01$ & $2.8 E+01$ \\
\hline Sediment & 4-Bromophenyl phenyl ether & 1 & 2 & $1.0 \mathrm{E}+01$ & $1.0 \mathrm{E}+01$ \\
\hline Sediment & 4-Bromophenyl phenyl ether & 2 & 10 & $1.0 \mathrm{E}+01$ & $1.0 \mathrm{E}+01$ \\
\hline Sediment & 4-Bromophenyl phenyl ether & 3 & 16 & $9.1 \mathrm{E}-01$ & $1.1 E+01$ \\
\hline Sediment & 4-Chlorophenyl phenyl ether & 1 & 2 & $1.0 \mathrm{E}+01$ & $1.0 \mathrm{E}+01$ \\
\hline Sediment & 4-Chlorophenyl phenyl ether & 2 & 10 & $1.0 \mathrm{E}+01$ & $1.0 \mathrm{E}+01$ \\
\hline Sediment & 4-Chlorophenyl phenyl ether & 3 & 16 & $9.1 \mathrm{E}-01$ & $1.1 E+01$ \\
\hline Sediment & 4-Nitroaniline & 1 & 2 & $1.0 \mathrm{E}+01$ & $2.8 \mathrm{E}+02$ \\
\hline Sediment & 4-Nitroaniline & 2 & 10 & $1.0 \mathrm{E}+01$ & $4.1 E+01$ \\
\hline Sediment & 4-Nitroaniline & 3 & 14 & $1.0 \mathrm{E}+01$ & $2.8 E+01$ \\
\hline Sediment & 4-Nitrophenol & 1 & 3 & $5.0 \mathrm{E}+01$ & $5.0 \mathrm{E}+01$ \\
\hline Sediment & 4-Nitrophenol & 2 & 10 & $5.0 \mathrm{E}+01$ & $5.0 \mathrm{E}+01$ \\
\hline Sediment & 4-Nitrophenol & 3 & 16 & $9.1 \mathrm{E}-01$ & $5.3 E+01$ \\
\hline Sediment & Bis(2-chloroethoxy)methane & 1 & 2 & $1.0 \mathrm{E}+01$ & $1.0 \mathrm{E}+01$ \\
\hline Sediment & Bis(2-chloroethoxy)methane & 2 & 10 & $1.0 \mathrm{E}+01$ & $1.0 \mathrm{E}+01$ \\
\hline Sediment & Bis(2-chloroethory)methane & 3 & 16 & $9.1 \mathrm{E}-01$ & $1.1 \mathrm{E}+01$ \\
\hline Sediment & Delta BHC & 1 & 2 & $1.0 E+01$ & $1.0 \mathrm{E}+01$ \\
\hline Sediment & Delta BHC & 2 & 6 & $1.0 \mathrm{E}+01$ & $1.0 \mathrm{E}+01$ \\
\hline Sediment & Delta BHC & 3 & 13 & $9.1 E-01$ & $1.1 \mathrm{E}+01$ \\
\hline Sediment & Dibenzofuran & 1 & 3 & $1.0 \mathrm{E}+01$ & $1.0 \mathrm{E}+01$ \\
\hline Sediment & Dibenzofuran & 2 & 10 & $1.0 \mathrm{E}+01$ & $1.0 \mathrm{E}+01$ \\
\hline Sediment & Dibenzofuran & 3 & 14 & $1.0 \mathrm{E}+01$ & $1.0 \mathrm{E}+01$ \\
\hline
\end{tabular}


Table 4.12 (continued)

Nondetectable coataminants

\begin{tabular}{|c|c|c|c|c|c|}
\hline $\begin{array}{l}\text { Media } \\
\text { type }\end{array}$ & $\begin{array}{l}\text { Contaminant } \\
\text { name }\end{array}$ & Reach & $\begin{array}{c}\text { Total } \\
\text { number of } \\
\text { samples }\end{array}$ & $\begin{array}{l}\text { Minimun } \\
\text { detection } \\
\text { limits } \\
\mathrm{mg} / \mathrm{kg} \text { dry }\end{array}$ & $\begin{array}{l}95 \% \text { upper } \\
\text { conf bound } \\
\text { on mean } \\
\text { mg/kg dry }\end{array}$ \\
\hline Sediment & Endosulfan sulfate & 1 & 1 & $1.0 \mathrm{E}+01$ & $1.0 \mathrm{E}+01$ \\
\hline Sediment & Endosulfan sulfate & 2 & 6 & $1.0 \mathrm{E}+01$ & $1.0 \mathrm{E}+01$ \\
\hline Sediment & Endosulfan sulfate & 3 & 13 & $9.1 \mathrm{E}-01$ & $1.1 \mathrm{E}+01$ \\
\hline Sediment & Endrin aldehyde & 1 & 1 & $1.0 \mathrm{E}+01$ & $1.0 \mathrm{E}+01$ \\
\hline Sediment & Endrin aldehyde & 2 & 6 & $1.0 \mathrm{E}+01$ & $1.0 \mathrm{E}+01$ \\
\hline Sediment & Endrin aldehyde & 3 & 13 & $9.1 \mathrm{E}-01$ & $1.1 E+01$ \\
\hline Sediment & Gallium & 1 & 18 & $2.9 E+\infty 0$ & $1.5 \mathrm{E}+01$ \\
\hline Sediment & Gallium & 2 & 98 & $3.0 \mathrm{E}+\infty 0$ & $6.2 \mathrm{E}+00$ \\
\hline Sediment & Gallium & 3 & 45 & $2.9 \mathrm{E}+00$ & $2.4 E+01$ \\
\hline Sediment & Lithium & 1 & 30 & $2.0 \mathrm{E}+00$ & $1.0 \mathrm{E}+03$ \\
\hline Sediment & Parachlorometa cresol & 1 & 2 & $1.0 \mathrm{E}+01$ & $1.0 \mathrm{E}+01$ \\
\hline Sediment & Parachlorometa cresol & 2 & 10 & $1.0 \mathrm{E}+01$ & $1.0 \mathrm{E}+01$ \\
\hline Sediment & Parachlorometa cresol & 3 & 16 & $9.1 \mathrm{E}-01$ & $1.1 E+01$ \\
\hline Sediment & Silvex & 3 & 5 & $\begin{array}{c}1.0 \mathrm{E}+01 \\
(\mathrm{Mg} \text { or } \mathrm{Bq} / \mathrm{L})\end{array}$ & $\begin{array}{c}1.0 \mathrm{E}+01 \\
(\mathrm{Mg} \text { or } \mathrm{Bq} / \mathrm{L})\end{array}$ \\
\hline Surface water & 1,2-Dichloroethene (total) & 1 & 29 & $5.0 \mathrm{E}-03$ & $7.1 \mathrm{E}-03$ \\
\hline Surface water & 1,2-Dichloroethene (total) & 3 & 28 & $5.0 \mathrm{E}-03$ & 7.2E-03 \\
\hline Surface water & 2-Hexanone & 1 & 29 & $1.0 \mathrm{E}-02$ & $1.4 \mathrm{E}-02$ \\
\hline Surface water & 1,2-Dichloroethene (total) & 2 & 29 & $1.0 \mathrm{E}-02$ & $1.4 E-02$ \\
\hline Surface water & 2-Hexanone & 3 & 28 & $1.0 \mathrm{E}-02$ & $1.4 \mathrm{E}-02$ \\
\hline Surface water & Cobalt & 1 & 3 & $4.0 \mathrm{E}-03$ & $4.0 \mathrm{E}-03$ \\
\hline Surface water & Cobalt & 2 & 3 & $4.0 \mathrm{E}-03$ & $4.0 \mathrm{E}-03$ \\
\hline Surface water & Cobalt & 3 & 3 & $4.0 \mathrm{E}-03$ & $4.0 \mathrm{E}-03$ \\
\hline Surface water & ${ }^{129} \mathrm{I}$ & 3 & 10 & $1.0 \mathrm{E}-02$ & $1.0 E-01$ \\
\hline Surface water & Lithium & 1 & 3 & $1.5 \mathrm{E}+01$ & $1.5 \mathrm{E}+01$ \\
\hline Surface water & Lithium & 2 & 3 & $1.5 \mathrm{E}+01$ & $1.5 E+01$ \\
\hline Surface water & Lithium & 3 & 3 & $1.5 \mathrm{E}+01$ & $1.5 \mathrm{E}+01$ \\
\hline Surface water & Titanium & 1 & 3 & $2.0 \mathrm{E}-02$ & $2.0 \mathrm{E}-02$ \\
\hline Surface water & Titanium & 3 & 3 & $2.0 \mathrm{E}-02$ & $2.0 \mathrm{E}-02$ \\
\hline Surface water & Zirconium & 1 & 3 & $2.0 \mathrm{E}-02$ & $2.0 \mathrm{E}-02$ \\
\hline Surface water & Zirconium & 2 & 3 & $2.0 \mathrm{E}-02$ & $2.0 \mathrm{E}-02$ \\
\hline Surface water & Zirconium & 3 & 3 & $2.0 \mathrm{E}-02$ & $2.0 \mathrm{E}-02$ \\
\hline
\end{tabular}


limitations of the data bases used in the screening analyses of groundwater; however, the detectable contaminants in the data bases are useful to verify that a contaminant is present in groundwater.

Noncarcinogen. Screening indices for the nonconservative screening of detectable noncarcinogens are listed in Table F2, Appendix F. All reaches had screening indices $<1.0$, indicating that noncarcinogens in groundwater in the three reaches are not high priority contaminants that would require immediate consideration for remedial action. Reaches 1 and 2 had screening inclices of $6.5 \times 10^{-1}$ and $1.0 \times 10^{-1}$, respectively, which would require further investigation before taking action. Antimony, with a screening index of $5.7 \times 10^{-1}$, is the only noncarcinogen that would require further investigation in Reach 1. However, this analysis is based on two detectable measurements out of a total of 20 analyzed, indicating that additional sampling is needed and that the analytical procedures should be reviewed. All other contaminants in Reach 1 have screening indices $<0.1$. For Reach 3, the screening index for inorganics was $1.0 \times 10^{-1}$; however, none of the individual contaminants had screening indices $\geq 0.1$.

\subsubsection{Conservative screening of detectable contaminants in groundwater}

Carcinogen. Conservative screening of carcinogens in groundwater did not eliminate from further investigation any of the contaminants in the detectable contaminants data base (Table F3, Appendix F). All reaches had screening indices $>10^{-3}$. Beryllium and tritium had screening indices $>10^{-4}$ in all three reaches. Strontium-90 in Reaches 1 and 2 and arsenic, ${ }^{234} \mathrm{U},{ }^{60} \mathrm{Co},{ }^{24} \mathrm{Ra},{ }^{241} \mathrm{Am}$, and ${ }^{234} \mathrm{Th}$ in Reach 3 had screening indices $>10^{-4}$. However, the data for ${ }^{234} \mathrm{U},{ }^{24} \mathrm{Ra},{ }^{241} \mathrm{Am}$, and ${ }^{234} \mathrm{Th}$ in Reach 3 is limited and should only be used to support additional data collection.

Noncarcinogen. Conservative screening of noncarcinogens in groundwater indicated that none of the reaches could be assigned low priority for further consideration (Table F4, Appendix F). Organics in Reach 3 was the only class of noncarcinogens that could be assigned a low priority for further investigation. Antimony in Reach 1 was the only carcinogen that had a screening index $\geq 1.0$. Four inorganics in Reach 1 , six in Reach 2, and five in Reach 3 had screening indices $<0.1$, but most of these cannot be eliminated from further consideration because of the limited data.

\subsubsection{Special Case-Lead}

Although an action level for lead of $0.015 \mathrm{mg} / \mathrm{L}$ has been adopted by EPA (EPA 1991), specific toxicity values are not available (Table 4.12); therefore, an EPA Uptake/Biokinetic model designed to a target population of children ( 0 to 6 years old) was used to evaluate the risk from lead in WAG 2. Results obtained using this model indicate that concentrations in groundwater in Reaches 1 and 3 would present a problem. This scenario is hypothical because WAG 2 is a fenced area where public access is not allowed. 


\subsection{CONCLUSIONS FOR SCREENING RISK ASSESSMENT FOR HUMAN EXPOSURE}

\subsubsection{Reaches 1 through 3}

Nonconservative screening of the detectable and nondetectable contaminants data bases for four exposure pathways was used to identify high priority contaminants for the three reaches of WAG 2. The carcinogens in the detectable contaminants data bases that were assigned high priority were ${ }^{60} \mathrm{Co}$ in Reaches 1,2 , and 3 and ${ }^{137} \mathrm{Cs}$ in Reaches 1 and 3 for the external exposure pathway; PCB (Aroclor 1254) in Reach 1 and 3 for the fish ingestion pathway; and arsenic in Reaches 2 and 3 for the drinking (surface) water pathway. Arsenic is a possible at tifact because of the small number of samples in which the concentration was above the limits of detection.

Ten carcinogens (dichlorobromomethane, Aroclor 1254 , Aroclor $1260,{ }^{137} \mathrm{Cs},{ }^{90} \mathrm{Sr},{ }^{3} \mathrm{H}$, ${ }^{152} \mathrm{Eu},{ }^{134} \mathrm{Cs},{ }^{154} \mathrm{Eu}$, and ${ }^{234} \mathrm{U}$ ) in the detectable contaminants data bases were classified as requiring further investigation in one or more reaches. Three of these contaminants were organics and seven were radionuclides. Limited data were available for ${ }^{134} \mathrm{Cs},{ }^{152} \mathrm{Eu},{ }^{154} \mathrm{Eu}$ and ${ }^{234} \mathrm{U}$ for some of the reaches; therefore, additional analyses are needed for these radionuclides. Limited data also were available for ${ }^{241} \mathrm{Am},{ }^{244} \mathrm{Cm},{ }^{238} \mathrm{Pu}$, and ${ }^{239} \mathrm{Pu}$; thus, although they were not classified as requiring further action, additional data are required.

For noncarcinogens in the detectable contaminants data bases, only thallium was assigned high priority for immediate consideration for remedial action in Reaches 1,2 , and 3. However, because only one sample was analyzed in each reach, thallium may be an artifact and it requires additional data. Mercury in Reach 1 in the fish ingestion pathway and arsenic in Reach 2 in the water ingestion pathway were the only noncarcinogens in the detectable contaminants data bases that would require further investigation.

Conservative screening of the detectable contaminants data bases identified 3 organic and 12 radionuclides in one or more reaches of WAG 2 as low priority carcinogens for further consideration. However, because of limited information on some of these contaminants, additional data are needed. Most inorganic noncarcinogens in the sediment ingestion pathway in all reaches can be assigned a low priority. Low priority was assigned to barium, copper, mercury, nickel, and zinc in the sediment and water ingestion pathways in all reaches.

Results of the nondetectable contaminants data bases should be viewed with caution because of the uncertainty associated with the contaminant concentrations.

Nonconservative screening identified as high-priority contaminants one organic carcinogen in the fish ingestion pathway and two in the sediment ingestion pathway. However, because the screening analysis was based on minimum detection limits, better detection limits are needed, and a review of source-term data is appropriate. None of the noncarcinogens were identified by nonconservative screening as high priority contaminants in WAG 2. 
Conservative screening of the nondetectable data bases identified 25 organic carcinogens that can be assigned low priority for further consideration in the sediment ingestion pathway. Low priority can also be given to 29 organic noncarcinogens plus chronium and nickel in the fish ingestion pathway; boron, vanadium, and tin in the water ingestion pathway; cyanide in the sediment ingestion pathway; and silver and beryllium in the fish and water ingestion pathways.

Nonconservative screening of the detectable contaminants data base for groundwater indicated that no carcinogen or noncarcinogen could be assigned a high priority. However, because of the lack of verification of the limited data base, additional data will be required for groundwater. Lead was not included in the screening analysis, but an EPA Uptake/Biokinetic model predicted that it would be a problem in groundwater in Reaches 1 and 3.

Results of the intruder scenario indicated that the greatest risk in this hypothetical scenario was from the ingestion of fish in all reaches. In the fish ingestion pathway, radionuclides contributed the greatest risk in Reaches 1 and 2 and PCBs in Reach 3.

\subsubsection{Results for Screening Risk Assessment for Human Exposure for WOCE}

As the result of a CERCLA removal action in response to uncontrolled contaminated sediments in WOCE, the information available for the extent of contamination in WOCE was more thorough than that available for the remainder of WAG 2 (Blaylock et al. 1991). A screening analysis was conducted using methods similar to those described herein. The screening analysis for carcinogens identified several substances as definitely high priority and requiring immediate consideration: arsenic in water ingestion, PCBs in fish ingestion, and ${ }^{60} \mathrm{Co}$ and ${ }^{137} \mathrm{Cs}$ in the sediment external exposure pathway. Arsenic in water was a possible artifact, because arsenic was detected in only 2 of 24 samples analyzed. Two organic contaminants, six inorganic, and six radiological contaminants 'aad screening indices that would require further investigation before taking action.

The screening for noncarcinogens did not identify any contaminant that could definitely be assigned high priority.

Screening of the WOCE nondetectable contaminants data base identified 16 organic carcinogens as definitely high priority. For these compounds it will be necessary to either improve the detection limits or to use source-term data to verify their presence. 


\section{SCREENING ASSESSMENT OF ECOLOGICAL RISKS}

As discussed in Sect. 1, the purpose of the screening risk assessment is to identify hazards associated with wastes in WAG 2, prioritize them with respect to their potential risks, and identify data needs on the basis of that analysis. The ecological assessment is concerned with risks to populations and communities of nonhuman organisms that occur on the site or may occur there in he future. The assessment uses the format of a standard risk assessment, with a hazard definition phase followed by parallel exposure and effects assessments and ending with risk characterization.

\subsection{ECOLOGICAL HAZARD DEFINITION}

The hazard definition phase of a risk assessment defines the scope of the assessment, the sources being assessed, and the endpoints of the assessment. An ecological hazard consists of a source of potentially toxic exposure combined with a valued and potentially susceptible receptor (the endpoint organisms) in a particular environment.

\subsubsection{Sources and Routes of Exposure}

WAG 2 consists of two streams (WOC and Melton Branch) and their associated floodplains, which continue to receive seepage and runoff from waste sites as well as point source emissions. Therefore, the ultimate sources of contaminant exposure in WAG 2 are the aqueous point sources, which are permitted under NPDES and are not of concern in this assessment, and the releases of contaminants by waste sites, which are the subject of the ongoing environmental restoration process. The proximate sources of exposure are (1) contaminants in the stream sediments and floodplain soils, (2) water contamination (which results from current point and nonpoint input, desorbtion and resuspension from sediments, and erosion and leaching from floodplain soils), and (3) contaminants in the biota, which act as a source of exposure for their consumers (e.g., contaminated fish eaten by herons). These sources are characterized by chemical analyses. The sources and nature of these data and the procedure used to compile them are discussed in Sect. 3; however, the existing data do not constitute a complete description of the proximate sources. In particular, contamination of floodplain soils has not been characterized for chemicals other than radionuclides.

\subsubsection{Exposed Environment}

The spatial scope of the assessment (see Sect. 2 for a more detailed description) is WOL, WOC below the main ORNL plant (i.e., WAG 1), Melton Branch, and the floodplains of the creeks and lake. WOC is coded as Reach 1, Melton Branch is Reach 2, and WOL is Reach 3. The ecology of this area is described in Loar (1988-1991), Loar et al. (1981 and 1987), Boyle et al. (1982), Mann and Kitchings (1982), Oakes et al. (1982), and Sherwood and Loar (1987).

The aquatic communities of WAG 2 are well characterized due to five years of monitoring by the Biological Monitoring and Abatement Program (BMAP) (Loar et al. 
1987, Loar 1988-1990). The BMAP has identified 14 species of fish in the watershed, including seven species of centrarchids (relatively large predatory species that could serve as game fish). Fish production is generally similar to similar streams in the region, although considerable variation occurs among reaches (Loar 1990).

The floodplains of WOC and Melton Branch are dominated by hardwood forests. The floodplain of WOL, particularly at the confluence of the creek, is dominated by shrubby vegetation, principally box elder and willows.

Although several federally listed threatened or endangered species occur in the region (Kroodsma 1987), none are known to occur on WAG 2. However, the endangered Indiana bat (Myotis sodalis) is suspected to occur on the lower East Fork Poplar Creek and may occur on WOC as well. Several state-listed species occur on the Oak Ridge Reservation and may occur on WAG 2 (Table 5.1).

Wetlands and floodplains are protected by Executive Orders 11990 and 11988, respectively. Although no official wetlands survey has been conducted for WAG 2, apparent wetlands occur in the floodplains of the creeks and the lake, and the floodplains clearly qualify as floodplains.

\subsubsection{Ecological Endpoints}

The endpoints for this assessment are those described and justified in the "Approach and Strategy for Performing Ecological Risk Assessments for the Oak Ridge Operations Environmental Restoration Program" (in press). In brief, they are (1) no reduction greater than $20 \%$ in the abundance or productivity of populations of fishes, birds, mammals, or vascular plants, (2) no injury of individuals of threatened or endangered species sufficient to impair survival or reproduction, and (3) no loss of wetland or floodplain communities. The $20 \%$ figure in the first endpoint is derived from an analysis of EPA regulatory criteria and is intended to approximate the agency's de facto but unstated level of protection (Suter et al. 1992). No particular species are chosen to represent the endpoints because most-sensitive species cannot be identified $a$ priori, and in most cases the toxicity and exposure data do not permit discrimination among individual members of taxa or trophic groups.

\subsection{EXPOSURE ASSESSMENT}

\section{Water}

Fish and invertebrates inhabiting the water column are assumed to be exposed to chemicals in the water primarily through respiratory uptake. This assumption is accurate for nearly all chemicals except for the few that bioaccumulate through food chains to a significant extent (i.e., PCBs, methyl mercury, and selenium). However, measured body burdens are more reliable measures of exposure (Sect. 5.2.3). In addition, the sample preparation and analysis techniques used to measure concentrations in water are intended to measure total contaminant concentrations rather than bioavailable concentrations. 
43

Table 5.1. Federally and state listed threatened and/or endangered species and species designated In Need of Management by the State of

Tennemee known or expected to occur on the

Oak Ridge Reservation

Common Name

Fish

Tennessee dace

Birds

Black-crowned night heron

Black Vulture

Common barn owl

Cooper's hawk

Grasshopper sparrow

Osprey

Red-shouldered hawk

Sharp-shinned hawk

Mammals

Indiana bat

Plants

Spreading false foxglove

Appalachian bugbane

Pink lady's slipper

Tall larkspur

Northern bush honeysuckle

Nutall waterweed

Mountain witch alder

Golden seal

Butternut

Canada lily
Scientific Name

Phonizus oreas

IMN
Administrative Status

INM

Coragyps atratus $\quad$ INM

Tyto alba INM

Accipiter cooperii ST

Ammodramus savannarum ST

Pandion haliaetus $\quad$ SE

Buteo lineatus ST

Accipter striatus ST

Myotis sodalis

FE,SE
Aureolaria patula ST

Cimicifuga rubifolia ST

Cypripedium acaule SE

Delphinium exaltatum SE

Diervilla lonicera ST

Elodea nuttallii SS

Fothengilla major ST

Hydrastis canadensis ST

Juglans cinerea ST

Lilium canadense ST 
Table 5.1 (continued)

\begin{tabular}{lll}
\hline Common Name & Scientific Name & Administrative Status \\
\hline Michigan lily & Lilium michiganense & ST \\
Fen orchid & Liparis loeselii & SE \\
Ginseng & Panax quinquefolium & ST \\
Tubercled rein orchid & Platanthera flava var herbiola & ST \\
Purple fringeless orchid & Platanthera peranoena & ST \\
Carey saxifrage & Saxifraga careyana & SS \\
Lesser ladies' tresses & Spiranthes ovalis & SS \\
\hline
\end{tabular}

'Status Codes:

FE - Federally Endangered

FT - Federally Threatened

SE - State Endangered

ST - State Threatened

SS - State Special Concern

INM - In Need of Management according to the State of Tennessee 
Therefore, the reported concentrations may be very conservative estimates of aqueous exposure.

\section{2 .2 Sediment}

The sediment composition data available for this assessment are concentrations in dry sediment. However, effects of a particular dry sediment concentration on sediment-dwelling (benthic) organisms are highly inconsistent, because benthic organisms are exposed primarily to chemicals in the aqueous phase of sediments (Adams et al. 1985, OWRS 1989); therefore, it is necessary to estimate the concentration in pore (interstitial) water. In riffles, the substrate consists of stones and gravels that retain relatively low concentrations of sorbed contaminants, and exchange of water occurs between the substrate and overlying water. For those areas, the surface water analyses are the best estimators of the exposure of benthic organisms to contaminants. However, there is obviously a gradient from large gravels which are bathed in surface water to fine sediments with distinct pore water.

In WOL and in pools of the streams where finer sediments collect, pore-water concentrations must be estimated from sediment concentrations. Pore-water concentrations of neutral (non-ionic) organic chemicals can be calculated by assuming equilibrium partitioning between the pore water and the organic matter fraction of the sediment (OWRS 1989). The partitioning coefficient $\left(K_{p}\right)$ is the product of the organic matter/water partitioning coefficient $\left(K_{o c}\right)$ and the fractional organic matter content of the sediment $\left(f_{o c}\right)$. Because sediment-dwelling organisms are approximately as sensitive to chemicals in water as the population of species that was used to derive the National Ambient Water Quality Criteria (NAWQC) (OWRS 1989), the same screening criteria can be used as for water but corrected for partitioning. The formula is:

$$
\begin{aligned}
& C_{s}=K_{p} C_{w}, \text { or } \\
& C_{s}=K_{o c} f_{o c} C_{w},
\end{aligned}
$$

where $C_{8}$ and $C_{w}$ are equivalent concentrations in sediment and water, respectively. $K_{o c}$ is seldom available, but it is accurately approximated by the octanol/water partitioning coefficient $\left(\mathrm{K}_{\text {ow }}\right)$ (DiToro 1985). This approach is being used by the EPA to derive sediment quality criteria (OWRS 1988).

Concentrations f ionic organic chemicals and inorganic chemicals in pore water could, in theory, also be calculated from an equilibrium partitioning model. However, these chemicals are sorbed to multiple sediment components so they would require several-phase partitioning models with a partitioning coefficient and concentration in sediment for each phase; such information is not available. We assume that ionic organics behave like neutral organics, only partitioning between water and sediment organic matter. This is a conservative assumption because partitioning to other phases would lower the aqueous-phase concentration, thereby lowering the toxicity of a given whole-sediment concentration. For metals in sediments, we use generic $\mathrm{K}_{\mathrm{p}}$ values from the International Atomic Energy Agency (1982). 
Another approach is to derive site-specific, sediment-water partitioning coefficients. Blaylock et al. (in review) have proposed a sediment-water partitioning coefficient for mercury in Watts Bar Reservoir of $10^{5}$. This value is derived from concentrations of mercury in suspended particulate matter and filtered water from Tennessee River Mile 545. It is probably a reasonable estimate of the mercury $\mathrm{K}_{\mathrm{p}}$, although suspended solids differ from bed sediments, and $\mathrm{K}_{\mathrm{p}}$ varies with solids concentration and redox potential (OWRS 1989).

Besides the risks to benthic organisms, it is necessary to consider risks to water-column species from chemicals associated with resuspended sediments. We believe that the screening criteria for benthic organisms are sufficiently conservative for this purpose. That belief is based on the following arguments: (1) the screening criteria are based on an assumption of chronic exposure, but exposures to suspended sediments would be acute; (2) dilution would rapidly decrease the aqueous concentration outside the plume and also within the plume once the particulate concentration dropped sufficiently to prevent attainment of equilibrium; and (3) the biological component of the sediment criteria is applicable because it is based primarily on water-column species.

\subsection{Tissue Concentrations as Indicators of Effects on Fish}

Tissue concentrations can be used in two ways to derive screening criteria. First, for a few chemicals there are data on the tissue concentrations at which effects occurred. When they are available, these data will be used to derive criteria. When they are not available, it is necessary to use conventional aquatic toxicity data that are expressed as aqueous concentrations. In that case, bioaccumulation factors (BAFs) or bioconcentration factors (BCFs) are used to estimate the average water concentrations to which fish have been exposed (fish tissue concentration/BAF = water concentration). When available, field-derived BAFs are used. Otherwise, laboratory-derived BCFs or BCFs derived from models of laboratory data [i.e., quantitative structure-activity relationships (QSARs)] are used. The laboratory-derived factors are likely to overestimate the water concentrations for those chemicals that are accumulated through food chains, but these overestimates will tend to highlight those chemicals. The same upper and lower criteria that are used for water concentrations are then applied to the calculated water concentration to serve as a screen for the fish tissue concentrations.

\section{Tissue Concentrations and Piscivorous Wildlife}

The contamination in fish and aquatic invertebrate tissues represents a route of exposure for piscivorous animals. Doses ( $\mathrm{mg}$ of chemical $/ \mathrm{kg}$ of animal) must be converted to concentrations in food by dividing by consumption ( $\mathrm{kg}$ of food $/ \mathrm{kg}$ of animal). Local piscivorous birds range from kingfishers to great blue herons, ospreys, and bald eagles. The highest dose would be obtained by the smallest bird (because of higher metabolism), and a predatory bird the size of a kingfisher consumes food equivalent to approximately $8 \%$ of its body weight per day (Kenaga 1973). The principal piscivorous mammal in the area is the mink. We assume that mink consume food equal to $5 \%$ of their body weight per day and that the food consists entirely of fish. The $8 \%$ figure is used to calculate the screening criteria because it is more conservative, but we consider effects on mink in the discussion of results because of their sensitivity. For the conversion of acute dose to 
concentration in diet, we assume that one day's consumption is equivalent to an acute dose.

Because the studies of chemical concentrations in fish that were conducted in the Oak Ridge area were designed for human health risk assessments, the reported concentrations refer to the "edible portion." Piscivores typically consume the entire fish, and the organs and bones contain higher levels of nearly all chemical contaminants than the muscles. Metals concentrations in whole fish (minus gut contents) tend to be approximately 1.5 to 2 times as high as in fillets or carcasses (Lemly and Smith n.d., Brumbaugh and Kane 1985). Hydrophobic organic chemicals like PCBs occur in whole fish at 2 to 3 times the concentration in fillets. Therefore, we apply a factor of 2 to metal concentrations in fish and a factor of 3 to organic chemical concentrations in fish when calculating lower screening criteria.

Another source of error is the moisture content of the food. The concentrations reported from dietary toxicity data are usually based on the weight of the food as consumed by the animal (i.e., fresh weight), but may be reported as dry weight. In addition, the water content of foods is variable and is often unreported in dietary toxicity studies. The concentrations in fish provided for this assessment are fresh weight. We assume, unless the source indicates otherwise, that the toxic concentrations are also fresh weight and that the water content of the diet and of fish fillets is approximately equal. This assumption could result in an error of approximately a factor of 5 in the results.

In addition to the uncertainties discussed above, this analysis of risks to piscivorous birds and mammals does not include other animals that feed on aquatic organisms. Reptiles and amphibians feed on aquatic invertebrates and fish, but few data exist on dietary toxicity for these taxa. Raccoons and diving ducks consume aquatic invertebrates, but tissue analyses are not available for inverti brates in the waters being assessed. We assume that, because they feed from a variety of sources other than aquatic invertebrates, these populations will be protected by the criteria for piscivores. Dabbling ducks consume aquatic macrophytes, but there are not enough data concerning contamination of these sources to perform an assessment. Dietary exposure of predatory fish to contaminated fish and invertebrates is not a significant route of exposure except for the most bioaccumulative chemicals, which are discussed along with the results on exposure to water.

\subsection{EFFECTS ASSESSMENT}

In a screening assessment the exposure/response relationship is reduced to a threshold concentration or dose below which exposures can be assumed to be safe (the lower screening criterion) and a concentration or dose above which severe effects are certain (the upper screening criterion). In this section both the approaches used to develop these benchmark values and the derivation of the individual values are explained. 


\subsubsection{Methods for Deriving Benchmarks}

\subsubsection{Water}

The NAWQC for protection of freshwater aquatic life are ARARs; therefore, they provide the basis for the screening criteria for contaminants in water. The acute NAWQC are calculated by the EPA as the fifth percentile of the distribution of $48-$ to $96-\mathrm{hr} \mathbf{L C}_{50}$ values or equivalent effective concentration $\left(\mathrm{EC}_{50}\right)$ values for each criterion chemical (Stephan et al. 1985). Hence, the acute NAWQC correspond to concentrations that would cause $50 \%$ mortality in $5 \%$ of exposed populations in a few days. This is a reasonable upper screening criterion because this assessment is concerned with continuous exposures, rather than the episodic exposures to which the acute NAWQC is applied. The chronic NAWQC are based on the threshold for statistically significant effects in chronic or subchronic toxicity tests, adjusted to estimate the concentration that would equal that threshold in 5\% of species (Stephan et al. 1985). It is intended to be protective in chronic exposures and is used in this assessment as one estimator of the lower screening criterion.

If NAWQC are not available for a chemical, they are estimated using the method of for calculating advisory values when there are insufficient data to calculate criteria. Advisory values are concentrations that would be expected to be higher than NAWQC in no more than $5 \%$ of cases. Therefore, they serve as conservative estimates of the ARARs.

For particular chemicals, the lower screening criterion could be lower than the chronic NAWQC for any one of the following five reasons. First, the chronic NAWQC are based on a threshold for statistical significance rather than biological significance. In some chronic tests, because of highly variable results, the statistical threshold corresponds to greater than $50 \%$ effect on a response parameter (Stephan and Rogers 1985, Suter et al. 1987). Second, not all important responses are included in the subchronic toxicity tests that are used to calculate many chronic NAWQC. In particular, effects on fecundity, which is the most sensitive response parameter on average in fish toxicity tests (Suter et al. 1987), are not included. Third, the chronic NAWQC are based on the most statistically sensitive $c_{\text {? }}$. the measured response parameters in each chronic or subchronic test. Therefore, cumulaive effects over the life cycle of fish and invertebrates are not considered. Fourth, the criteria are set at a level that protects "most species most of the time." A lower screening criterion should protect all species nearly all of the time. Finally, because many of the criteria have not been revised since 1980, they do not incorporate recent data. In addition, available data for most chemicals are insufficient to calculate water quality criteria.

For these reasons, we evaluate six alternative benchmarks, and, for the sake of this screening assessment, we use the lowest benchmark for each chemical as the lower screening criterion (Table 5.2). The first is the chronic NAWQC, which is discussed above (this section). The second and third are the lowest chronic values for fish and invertebrates reported in the literature. The fourth is the highest tested concentration causing less than $20 \%$ reduction in (1) the weight of young fish per initial female fish in a life cycle or partial life cycle test or (2) the weight of young per egg in an early life-stage test. The fifth is the highest tested concentration causing less than $20 \%$ reduction in the 


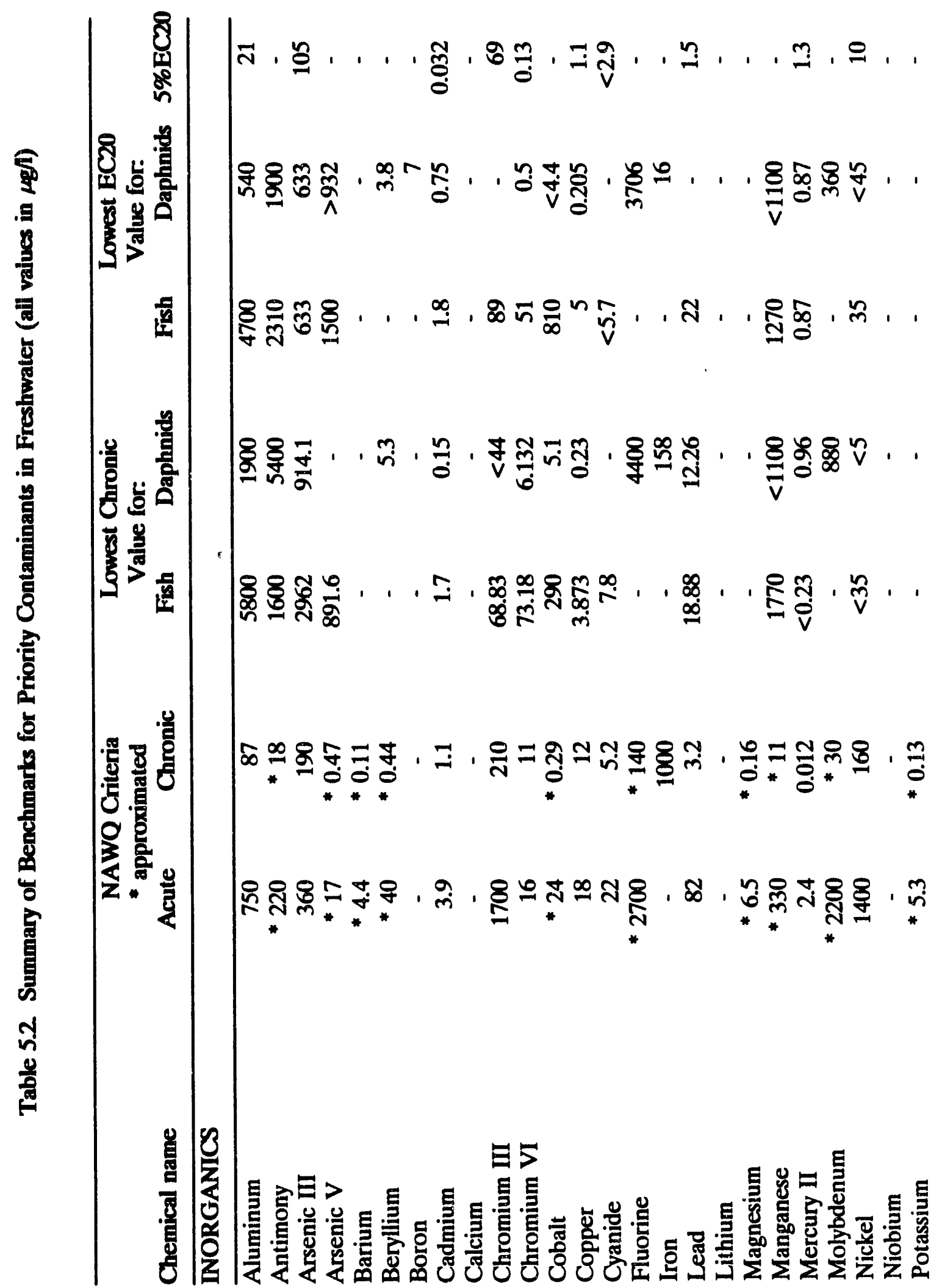




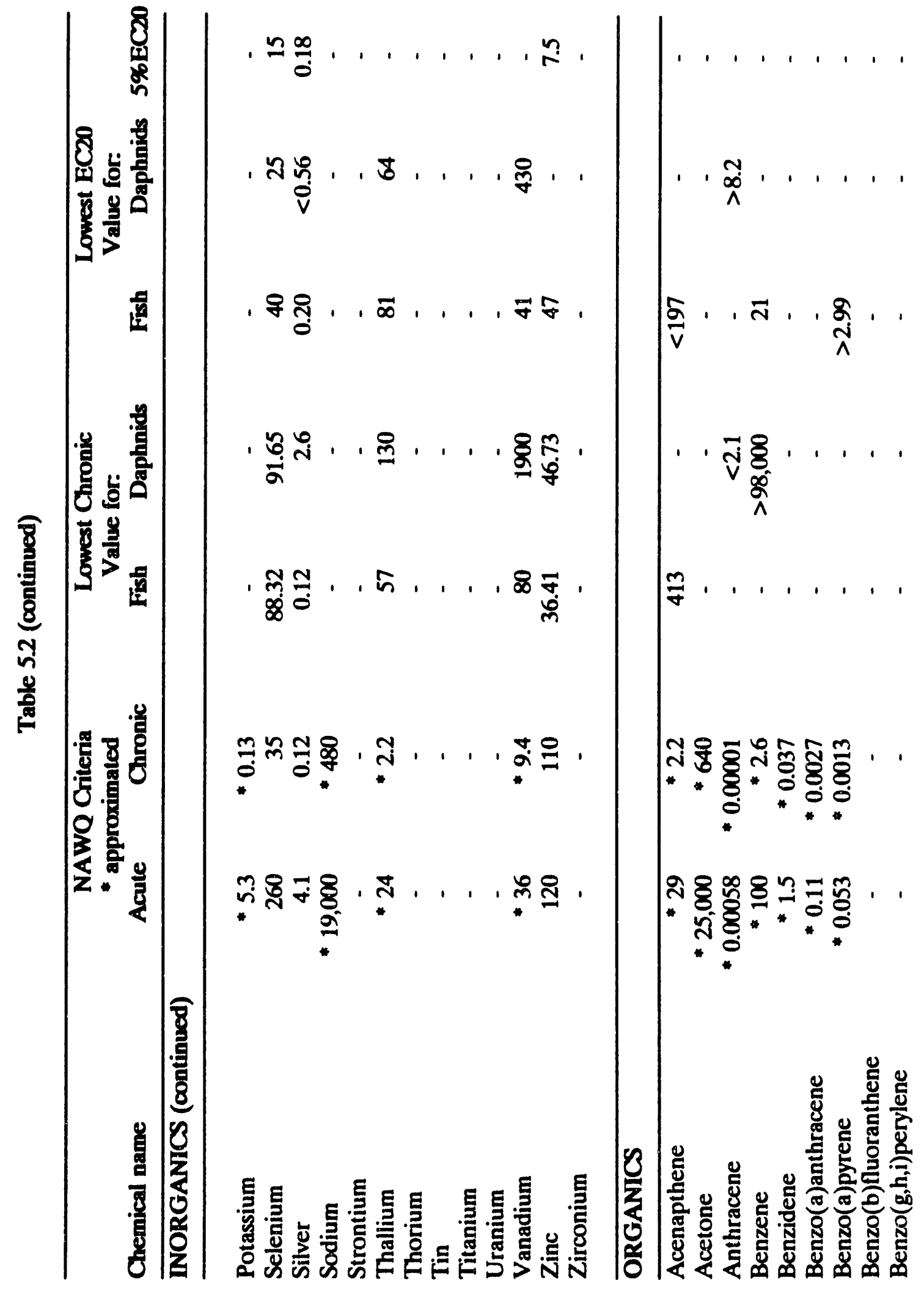




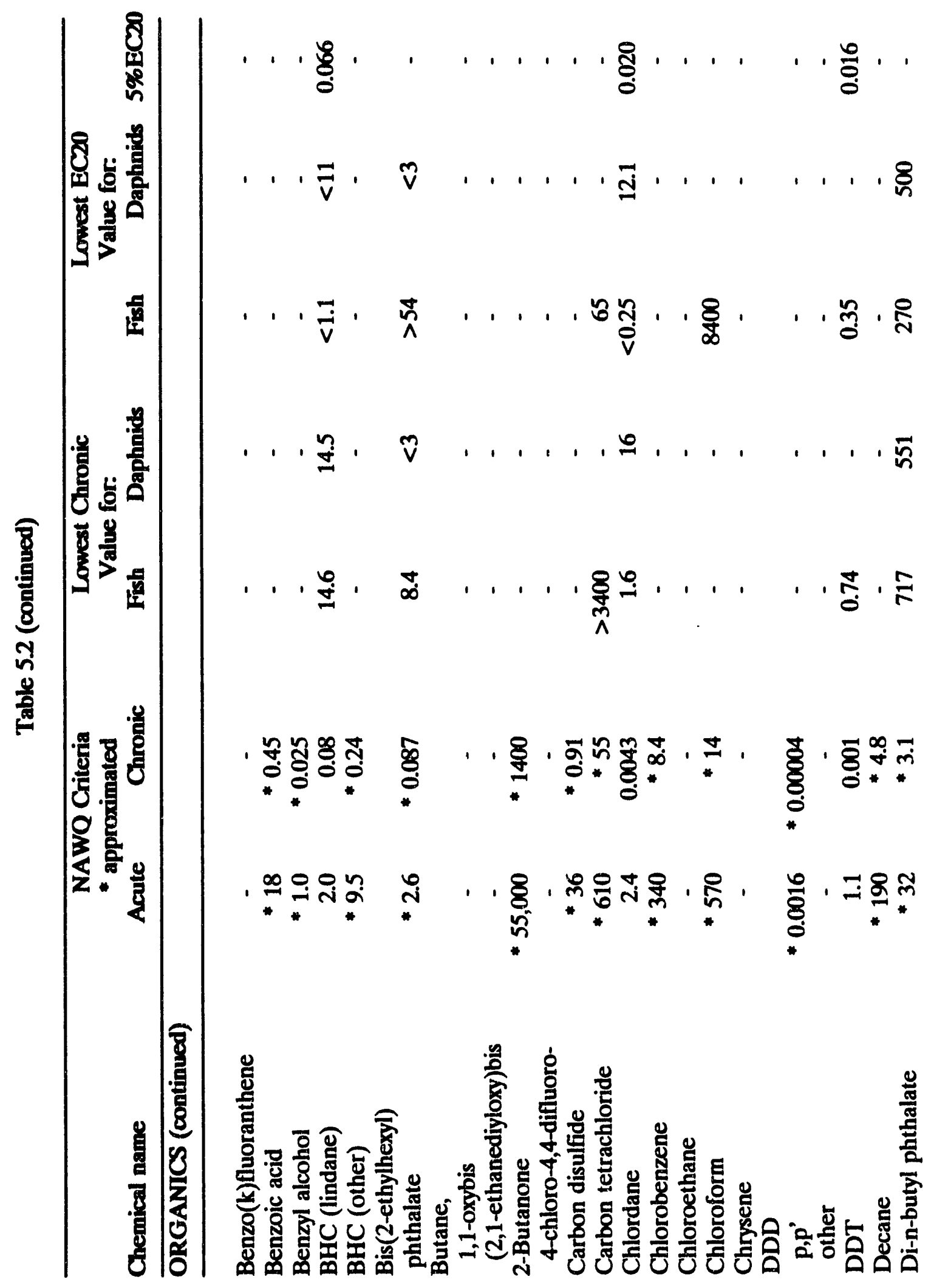




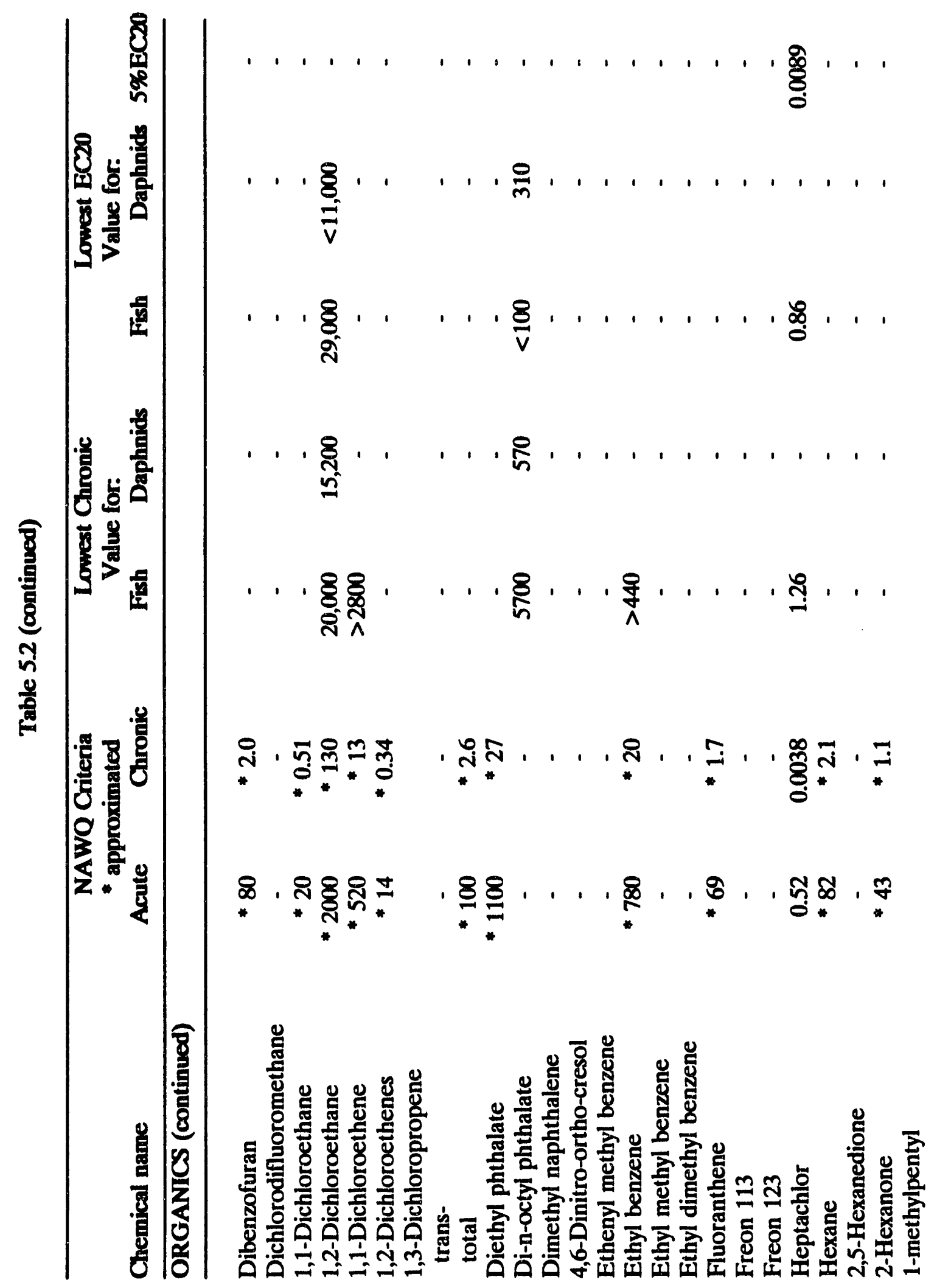




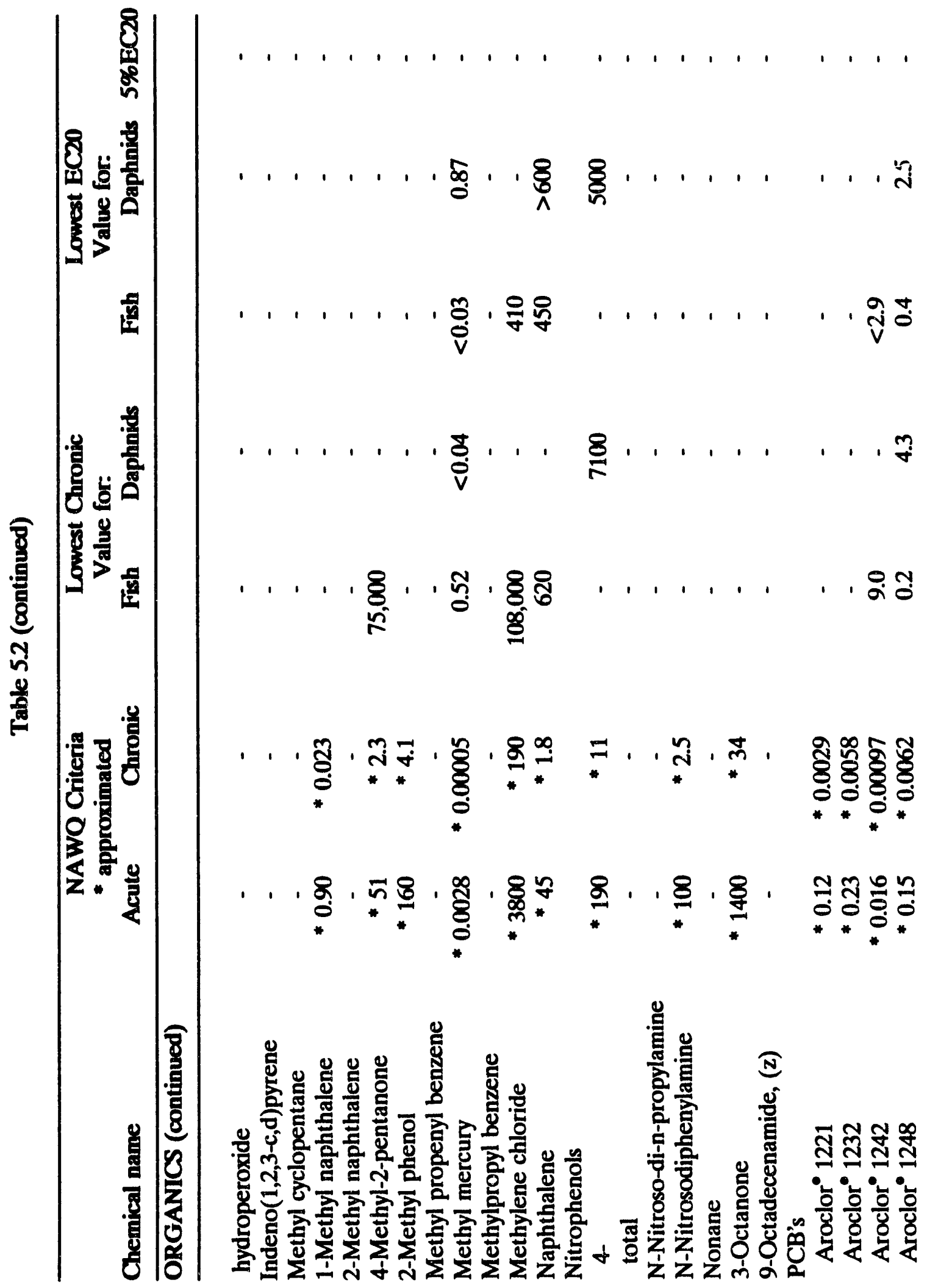




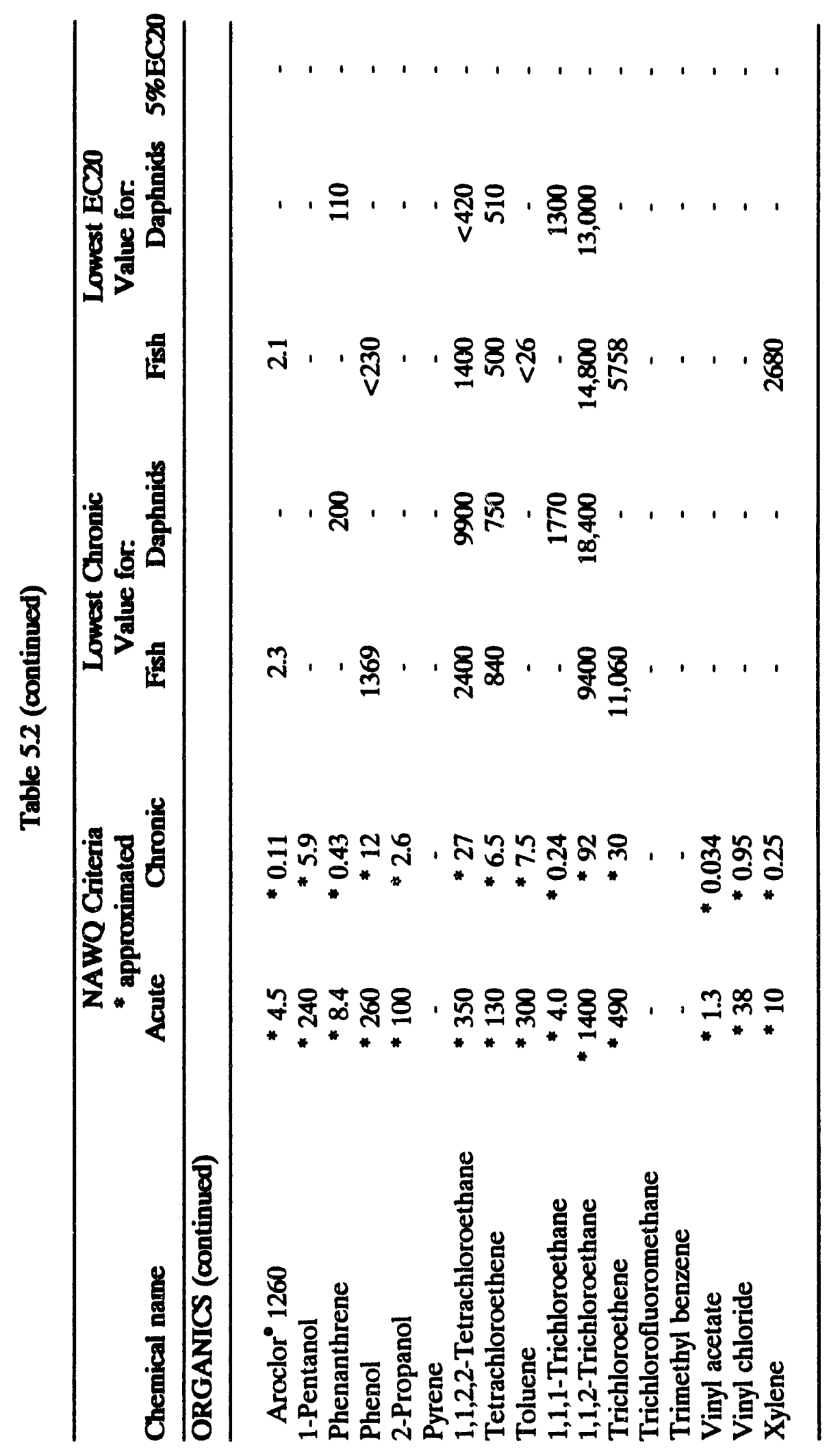


product of growth, fecundity, and survivorship in a chronic test with a daphnid species. The sixth is the lowest of benchmarks two through five, adjusted to approximate the fifth percentile of the species sensitivity distribution for the chemical as in the chronic NAWQC (Stephan et al. 1985).

NAWQC for several metals are functions of water hardness; the criteria are lower for lower hardness levels. Individual hardness measurements in WAG 2 range from 51 to 800 $\mathrm{mg} / \mathrm{L}$ with a mean of $150 \mathrm{mg} / \mathrm{L}$. Therefore, we used $100 \mathrm{mg} / \mathrm{L}$ to calculate criteria that are conservative but not extreme for WAG 2.

\subsubsection{Consumed fish flesh}

As with the other analyses, the upper screening criteria for piscivores are based on acute lethality. Usually these are acute median lethal doses $\left(\mathrm{LD}_{50}\right)$, but lethal concentrations in food $\left(\mathrm{LC}_{50}\right.$ or $\left.\mathrm{LC}_{\mathbf{x}}\right)$ are preferred.

The lower screening criteria for aquatic foodchain exposures are quite diverse, because test data for chronic oral exposures to birds and mammals are quite diverse. When data are available concerning the dietary toxicity of a chemical to wildlife, the lowest test concentration that reflects a potential effect on populations is used. If there are no wildlife data, any available data on domestic animals other than ruminants are used. In many cases, there are no useful wildlife or domestic animal data, and the same laboratory rodent data that are used for human health effects are used in the screening criteria. Toxicity data for ruminants are the least desirable because their peculiar digestive systems make their responses unrepresentative of nonruminants. Data from dietary toxicity tests are preferred to chronic oral dosing tests. The efferts include systemic toxicity, reduced reproduction, severe histological damage, and terata. An alternative benchmark for the wildlife is the RfD developed by the EPA for assessment of risks of toxic effects other than cancer in humans. We do not assess cancer induction in nonhuman species, because the higher wildlife exposure is not sufficient to overcome the extremely low frequencies of cancer induction (i.e., $10^{-6}$ ) used for the human health screening analysis. Although tumors have frequently been found in fish in other studies, effects of cancer on fish population size or productivity have not been demonstrated.

Unlike the screening criteria that are based on NAWQC, these criteria do not reflect the diversity of organisms that are exposed by this route. If chronic sublethal effects data are available for either mammals or birds but not both, a correction factor of 10 for differences in sensitivity is applied. This factor is based on limited studies that indicate that birds and mammals can differ in sensitivity by at least an order of magnitude, and either can be more sensitive (Sigal and Suter 1989). If there are data for both birds and mammals, but fewer than five species with fewer than two birds, a factor of 5 correction for differences in sensitivity is assumed. If there are data for five or more species including at least two avian species, we assume that the variance in sensitivity of the test species approximates the variance in all avian and mammalian species and apply no factor for differences among species. If the most sensitive test end point is death or another severe effect (e.g., reproductive failure), a factor of 5 is applied to estimate the threshold for effects on individuals that could result in population reductions (Tucker and Lietzke 1979). These factors are not applied to the upper criterion, which is intended to be a concentration at which effects are certain. 


\subsubsection{Screening Criteria for Individual Chemicals}

\subsubsection{Water}

The alternative aquatic toxicity benchmarks for the contaminants that have been detected on the Oak Ridge Reservation are listed in Table 5.2. The lowest benchmark for each chemical is used as the lowest screening criterion for aquatic life, and the acute criteria or estimated acute criteria are used as the upper screening criterion. The sources of data for the approximated criteria are listed in Appendix G, and sources for the other benchmarks are discussed later in this section. For chemicals that are not listed in Table 5.2, NAWQC are used as screening criteria.

\section{INORGANICS}

Aluminum. The toxicity of aluminum has been shown to vary widely with water hardness and pH (among others are Ingersoll et al. 1990a and b; Woodward et al. 1989; and Sadler and Lynam 1988). The benchmarks were calculated using only tests in circumneutral water. Lowest chronic values for fish are from Kimball (Manuscript) and for daphnids from McCauley et al. (1986). Lowest EC20 values are from Kimball (Manuscript). The 5\% EC20 is lower than the chronic criterion.

Antimony. Chronic and EC20 values for antimony are from Kimball (Manuscript).

Arsenic III. Official criteria are listed for arsenic III. The lowest chronic values for fish and daphnids are given by Call et al. (1983) and Lima et al. (1984). The EC20 values are from Lima et al. (1984) for fish and from Call et al. (1983) and Lima et al. (1984) for daphnids.

Arsenic V. The chronic and EC20 values for fish are from Defoe (1982), and the EC20 for daphnids is from Spehar et al. (1980).

Beryllium. The chronic and EC20 values for daphnids are from Kimball (Manuscript).

Boron. The EC20 value for daphnids is from Gerisch (1984).

Cadmium. There are official criteria listed for cadmium. The lowest chronic value is from Sauter et al. (1976) for fish and Chapman et al. (Manuscript) for daphnids. The EC20 values are from Carlson et al. (1982) for fish and Elnabarawy et al. (1986) for daphnids. The latter report, which post dates the latest NAWQ report (EPA 1980g), needs comment. The EC20 value is not particularly low, but the acute-EC20 ratio is unusually high. For this reason, the 5\% EC20 value varies significantly from the final chronic value.

Chromium III. Official criteria are listed for chromium III. The lowest chronic value is from Stevens and Chapman (1984) for fish and from Chapman et al. (Manuscript) for daphnids. Stevens and Chapman (1984) also provided data for the EC20 value for fish. The 5\% EC20 value is notably lower than the chronic criterion. 
Chromium VI. There are official criteria for chromium VI. The chronic and EC20 values for fish are from Sauter et al. (1976). For daphnids, the chronic value is EPA (1985b) and EC20 from Elnabarawy et al. (1986). As with cadmium, this latter report provided an unusually large acute-EC20 ratio for Chromium VI, thus explaining the orders of magnitude difference between the 5\% EC20 and the chronic criterion.

Cobalt. The chronic and EC20 values for Ccbalt are from Kimball (Manuscript).

Copper. Official criteria are listed for copper. The chronic and EC20 values for fish are from Sauter et al. (1976). The chronic and EC20 values for daphnids are from Dave (1984a). The 5\% EC -3 level is considerably lower than the chronic criterion. Dave (1984a), which was not considered in the most recent NAWQC support document (EPA 1985c), contributes unusually low EC20 and chronic values.

Cyanide. There are official criteria for cyanide. The chronic and EC20 values for fish were both from Koenst et al. (1977).

Fluoride ion. Chronic and EC20 values for daphnids are from Dave (1984b).

Iron. The data for the effects of iron on daphnids was from Dave (1984c).

Lead. There are official criteria listed for lead. The lowest chronic value for fish is from Goettl et al. (1972), Davies and Everhart (1973), and Davies et al. (1976) and for c'aphnids from Chapman et al. (Manuscript). The EC20 value for fish is from Sauter et al. (1976). The 5\% EC20 level is lower than the chronic criterion, apparently due to a high acute value in the latter report. The acute-EC20 ratio from which the 5\% EC20 was calculated had to be obtained using a species mean acute value for Salmo gairdneri (EPA 1985d), since no acute value was reported by Sauter et al.

Manganese. All chronic and EC20 values for manganese are from Kimball (Manuscript).

Mercury II. Mercury has official criteria. The chronic and EC20 values for fish are from Call et al. (1983) and those for daphnids are from Biesinger and Christensen (1972). The 5\% EC20 is higher than the chronic criterion. The acute-EC20 ratio used to calculate this value had to be derived using a species mean acute value (EPA 1985e), as no acute value was reported in Biesinger and Christensen. The EC20 derived from Call et al. was equivalent to that in Biesinger et al., but the acute-EC20 ratio for Daphnia magna (the species used in the latter report), 3.629, is lower than that of Pimephales promelas (used by Call et al.), 172.4. As a conservative measure, the lower acute-EC20 ratio was used in the calculation.

Molybdenum. The chronic and EC20 values for daphnids are from Kimball (Manuscript).

Nickel. There are official criteria for nickel. The chronic and EC20 values for fish are from Nebeker et al. (1985). For daphnids, the chronic value was from Lazareva (1985), and the EC20 was from Manzinger (1990). The EC20 value from Nebeker et al. is lower than the chronic criterion, and the acute value is higher than the 
NAWQC acute value; thus, the acute-EC20 ratio is high and the 5\% EC20 is significantly lower than the chronic criterion.

Selenium. Official criteria are listed for selenium. The chronic and EC20 values for fish are from Goettl and Davies (1976). The chronic value for daphnids is from Kimball (Manuscript), and the EC20 is from Johnston (1987). The 5\% EC20 is lower than the chronic criterion. The acute-EC20 ratio from which the latter value was calculated had to be derived using a species mean acute value for Daphnia magna (EPA 1987a), because no acute value was reported by Johnston.

Silver. There is an official acute criterion for silver. The chronic value for fish is from Davies et al. (1978). The chronic value for daphnids and the EC20 for fish are from Nebeker et al. (1983). The EC20 for daphnids is from Elnabarawy et al. (1986). The 5\% EC20 level is higher than the approximated chronic criterion, though this is expected since approximations lean heavily to the conservative side.

Thallium. All chronic and EC20 values are from Kimball (Manuscript).

Vanadium. The chronic and EC20 values for fish are from Holdway and Sprague (1979) and for daphnids from Kimball (Manuscript).

Zinc. There are official criteria for zinc. The chronic and EC20 values for fish are from Spehar (1976), and the chronic value for daphnids is from Chapman et al. (Manuscript). The acute LC50/chronic EC20 ratio calculated from Spehar's data is high, because of a relatively large acute value; in fact, the acute-chronic ratio based on a chronic value from Spehar is the highest reported by the EPA (1987b). The 5\% EC20 level, then, is considerably lower than the chronic national criterion.

\section{ORGANICS}

Acenapthene. The chronic and EC20 values for fish are from Cairns and Nebeker (1982).

Anthracene. The chronic and EC20 values for daphnids are from Holst and Giesy (1989).

Benzene. The lowest chronic value for daphnids is given by EPA (1978) and the EC20 value for fish is from Black and Birge (1982). Black and Birge conducted a series of screening tests for a large number of chemicals on several freshwater organisms. Survival was only recorded to four days post-hatch, and no statistical analysis was done on the results. These tests, then, are not representative of most of the other chronic tests cited in this report.

Benzo(a)pyrene. The EC20 for fish is derived from Hannah et al. (1982).

BHC (lindane). There are official criteria listed for lindane. All chronic and EC20 values are from Macek et al. (1976a). The 5\% EC20 level is comparable to the chronic criterion. The acute-EC20 ratio from which the 5\% EC20 was calculated was derived 
using a species mean acute value for Salvelinus fontinalis (EPA 1980s) since no acute data was reported by Macek et al.

Bis(2-ethylhexyl)phthalate. The chronic and EC20 values for fish are from Mehrle and Mayer (1976). The chronic and EC20 values for daphnids are from Mayer and Sanders (1973).

Carbon tetrachloride. The chronic value for fish is from EPA (1978), and the EC20 value is from Black and Birge (1982).

Chlordane. Official criteria are listed for chlordane. The chronic values for fish and daphnids and the EC20 value for fish are from Cardwell et al. (1977). The EC20 value for daphnids is from Cardwell et al. (1977). The 5\% EC20 level is higher than the chronic criterion.

Chloroform. The EC20 value for fish is from Black and Birge (1982).

DDT. Official criteria are listed for DDT. The chronic and EC20 values for fish are from Jarvinen et al. (1977). The 5\% EC20 level is higher than the chronic criterion.

Di-n-butyl phthalate. All chronic and EC20 values are from McCarthy and Whitmore (1985).

1,2-Dichloroethane. The chronic value for fish is from Ahmed et al. (1984), and the EC20 value for fish is from Benoit et al. (1982). The chronic and EC20 values for daphnids are from Richter et al. (1983).

1,1-Dichloroethene. The chronic value for fish is from EPA (1978).

Di-n-octyl phthalate. All chronic and EC20 values are from McCarthy and Whitmore (1985).

Ethyl benzene. The chronic value for fish is from EPA (1978).

Heptachlor. There are official criteria listed for heptachlor. The chronic and EC20 values for fish are from Macek et al. (1976b). The 5\% EC20 value was calculated using an acute-EC20 ratio that was derived from a species mean acute value for Pimephales promelas (EPA 1980r) because no acute data is available from Macek et al.

4-Methyl-2-pentanone. The chronic value for fish is from Veith et al. (1983).

Methyl mercury. The chronic and EC20 values for fish are from McKim et al. (1976). The chronic and EC20 values for daphnids are from Biesinger and Christensen. (1982).

Methylene chloride. The chronic value for fish is from Dill et al. (1987), and the EC20 value is from Black and Birge (1982).

Napthalene. The chronic and EC20 values for fish are from DeGraeve et al. (1982), and the EC20 value for daphnids is from Geiger and Buikema (1982). 
4-Nitrophenol. The chronic and EC20 values for daphnids are from Francis et al. (1986).

PCBs: Aroclor 1242 The chronic and EC20 values for fish are from Nebeker and Puglisi (1974).

PCBs: Aroclor 1248. The chronic and EC20 values for fish are from DeFoe et al. (1978), and the chronic and EC20 values for daphnids are from Nebeker and Puglisi (1974).

PCBs: Aroclor ${ }^{\circ}$ 1254. The chronic value for fish is from Mauck et al. (1978), and the EC20 value is from Nebeker and Puglisi (1974). The chronic and EC20 values for daphnids are from Nebeker and Puglisi (1974).

PCBs: Aroclor ${ }^{\circ} 1260$. The chronic and EC20 values for fish are from DeFoe et al. (1978).

Phenanthrene. The chronic and EC20 values for daphnids are from Geiger and Buikema (1982).

Phenol. The chronic and EC20 values for fish are from DeGraeve et al. (1980).

1,1,2,2-Tetrachloroethane. The chronic and EC20 values for fish are from Ahmed et al. (1984), and the values for daphnids are from Richter et al. (1983).

Tetrachloroethene. The chronic and EC20 values for fish are from Ahmed et al. (1984). The chronic and EC20 values for daphnids are from Richter et al. (1983).

Toluene. The EC20 value for fish is from Black and Birge (1982).

1,1,1-Trichloroethane. The chronic and EC20 values for daphnids are from Thompson and Carmichael (1989).

1,1,2-Trichloroethane. The chronic and EC20 values for fish are from Ahmed et al. (1984), and the chronic and EC20 values for daphnids are from Richter et al. (1983).

Trichloroethene. The chronic and EC20 values for fish are from Smith et al. (1991).

Xylene. The EC20 value for fish is from Black and Birge (1982).

\subsubsection{Consumed fish flesh}

Alternative lower screening criteria are provided by the $\mathrm{RfD}$ values for human health assessment (from IRIS and HEAST) and the values developed from dietary toxicity data using the criteria presented in Sect. 5.3.1.2. The latter are discussed next in this section, along with upper screening criteria. 


\section{INORGANICS}

Antimony. Antimony causes liver damage in rabbits at $5.5 \mathrm{mg} / \mathrm{kg}$ in diet (National Research Council 1980). Application of a factor of 10 for variance in sensitivity and 2 for the whole-fish conversion yields a lower criterion of $0.3 \mathrm{mg} / \mathrm{kg}$ for piscivores.

Arsenic. The toxicity and bioaccumulation of arsenic are highly dependent on the form. The most toxic and bioaccumulative form is inorganic trivalent arsenic (arsenite salts). Median lethal dietary concentrations for wildlife range from $99.8 \mathrm{mg} / \mathrm{kg}$ in cowbirds to $>5000 \mathrm{mg} / \mathrm{kg}$ in mallards depending on the arsenical species as well as the biological test species (National Research Council 1977, NIOSH 1988), so the upper criterion for piscivores is set at an approximate median of $1000 \mathrm{mg} / \mathrm{kg}$. Reported sublethal effects of inorganic arsenic largely fall in this interval, but there is very little information on sublethal effects on birds. The most sensitive reported dietary effect in mammals or birds is the NOEC for growth of rats of $31 \mathrm{mg} / \mathrm{kg}$ (National Research Council 1977, EPA 1985a). Applying a factor of 5 for species sensitivities and 2 for whole fish results in a lower criterion of $3 \mathrm{mg} / \mathrm{kg}$ for effects on piscivores.

Beryllium. Beryllium is a serious respiratory toxin and carcinogen, but has not been noted to cause dietary toxicity. The oral $\mathrm{LD}_{50}$ in rats is $9.7 \mathrm{mg} / \mathrm{kg}$ (EPA 1980r), giving a dietary upper screening criterion of $120 \mathrm{mg} / \mathrm{kg}$. Weight loss occurred in rats fed a diet containing $500 \mathrm{mg} / \mathrm{kg}$ beryllium (EPA 1987c). Applying a factor of 10 for variance in sensitivity and 2 for the whole-fish conversion yields a lower screening criterion of $25 \mathrm{mg} / \mathrm{kg}$ for piscivores.

Cadmium. The National Research Council (1980) set the maximum tolerable level for cadmium in animal feed at $0.5 \mathrm{mg} / \mathrm{kg}$ based on observed toxic effects in mammals on $1-\mathrm{mg} / \mathrm{kg}$ diets. This appears to be sufficient to protect birds because the lowest-reportedeffects level in birds is $4 \mathrm{mg} / \mathrm{kg}$ (Heinz et al. 1983). The factor of 2 for whole-fish concentrations gives a lower screening criterion of $0.25 \mathrm{mg} / \mathrm{kg}$ for piscivores.

Chromium. Chromium is most toxic to aquatic organisms in the hexavalent form, the form used in cooling towers, and the form that we assume for the aqueous chromium concentrations used in this assessment. However, it is likely that much of the chromium has been reduced to the trivalent form in fish tissues. There are little appropriate data for estimating chromium effects on wildlife, but young black ducks experienced reduced growth and survival at $10 \mathrm{mg} / \mathrm{kg}$ chromium (III) in diet (Eisler 1986). We apply a factor of 5 for variance in sensitivity and 2 for whole fish to derive a lower screening criterion of $1 \mathrm{mg} / \mathrm{kg}$ for piscivores.

Copper. Copper is a well-regulated essential nutrient that is seldom toxic in terrestrial vertebrates. The National Research Council (1980) set the maximum tolerable level for the most sensitive mammal (sheep) at $25 \mathrm{mg} / \mathrm{kg}$, for nonruminant mammals at 100 to $800 \mathrm{mg} / \mathrm{kg}$, and for chickens and turkeys at $300 \mathrm{mg} / \mathrm{kg}$. Applying a factor of 2 to the lowest nonruminant level yields a lower screening criterion of $50 \mathrm{mg} / \mathrm{kg}$ for piscivores.

Lead. The National Research Council (1980) recommended that lead in livestock food be limited to $30 \mathrm{mg} / \mathrm{kg}$, which appears to be protective of other species (EPA 1984a, 
Eisler 1988). We apply a factor of 2 for whole fish to derive a lower screening criterion of $15 \mathrm{mg} / \mathrm{kg}$ for piscivores.

Mercury. A U.S. Fish and Wildlife Service report has recommended that mercury in wildlife food be limited to $0.1 \mathrm{mg} / \mathrm{kg}$, because this concentration of methylmercury caused reduced reproduction in ducks (Eisler 1987). Applying a factor of 5 for threshold effects and 2 for whole fish yields a lower criterion of $0.01 \mathrm{mg} / \mathrm{kg}$ for piscivores. Lethal dietary concentrations of methylmercury range from $1 \mathrm{mg} / \mathrm{kg}$ for mink to $250 \mathrm{mg} / \mathrm{kg}$ for chickens (National Research Council 1980, Sheffy and St. Amant 1982, Wren et al. 1987, Eisler 1987). We use $30 \mathrm{mg} / \mathrm{kg}$, the approximate median $\mathrm{LC}_{50}$, as an upper criterion for piscivores. Inorganic mercury is not relevant to this endpoint, because the mercury in local fish is almost entirely methylmercury.

Nickel. The National Research Council (1980) set the maximum tolerable level of nickel at $50 \mathrm{mg} / \mathrm{kg}$, based on weight loss of cattle at $100 \mathrm{mg} / \mathrm{kg}$ in diet, but no observed effects at $50 \mathrm{mg} / \mathrm{kg}$. Chickens, the only tested bird, showed a statistically significant decrease in growth at $500 \mathrm{mg} / \mathrm{kg}$ in diet, but not at $300 \mathrm{mg} / \mathrm{kg}$ (National Research Council 1980). Application of factors of 5 for variance in sensitivity and 2 for whole-fish concentration yields a lower chronic criterion of $50 \mathrm{mg} / \mathrm{kg}$ for piscivores. The oral $\mathrm{LD}_{50}$ in rats is $350 \mathrm{mg} / \mathrm{kg}$ (National Research Council 1980). Conversion to dietary concentration yields an upper criterion of $4400 \mathrm{mg} / \mathrm{kg}$, which is consistent with the sublethal dietary toxicity data.

Selenium. Dietary selenium effects are difficult to assess because the toxic levels are near the deficiency levels, uptake is highly variable among species, and uptake is highly dependent on the form of the selenium and how it is incorporated into food. Rats experience histological damage and reduced longevity in lifetime exposures to $3 \mathrm{mg} / \mathrm{kg}$ in naturally contaminated feed, but the same effects occurred at $0.75 \mathrm{mg} / \mathrm{kg}$ in spiked feed (Eisler 1985). Five $\mathrm{mg} / \mathrm{kg}$ was a no-observed-effects level in feeding studies of mallards, and 6 to $9 \mathrm{mg} / \mathrm{kg}$ in feed reduced the hatchability of chicken eggs (Eisler 1985). Mortality and severe reproductive effects in birds occurred in an area with concentrations of 22 to $175 \mathrm{mg} / \mathrm{kg}$ in food items (Ohlendorf et al. 1986). Based on these data, the lowest observed effects level is $1 \mathrm{mg} / \mathrm{kg}$, which is just above recommended concentrations in diet to prevent selenium deficiency of 0.1 to $0.05 \mathrm{mg} / \mathrm{kg}$ (Eisler 1985). That threshold value is divided by 2 for the whole-fish conversion for a lower screening criterion of $0.5 \mathrm{mg} / \mathrm{kg}$ in fish for piscivores. The upper criterion is set at $100 \mathrm{mg} / \mathrm{kg}$, the lethal dietary concentration in mallards (Eisler 1985).

Silver. The National Research Council (1980) set the maximum tolerable level for silver in animal food at $100 \mathrm{mg} / \mathrm{kg}$ based on studies of rats, chickens, and turkeys. Application of factors of 5 for variance in sensitivity and 2 for the whole-fish conversion yields a lower screening criterion of $10 \mathrm{mg} / \mathrm{kg}$ for piscivores.

Thallium. Thallium is highly toxic to mammals, and thallium salts have been used as rodenticides (Venugopal and Luckey 1978). It is also highly toxic to birds with an acute lethal threshold in diet of $12 \mathrm{mg} / \mathrm{kg}$ in bobwhite quail (EPA 1980a). The no-observed-effect level for thallium in the diet of rats is $5 \mathrm{mg} / \mathrm{kg}$ (EPA 1980a). Applying factors of 5 for variance in sensitivity and 2 for the whole-fish conversion yields a lower 
screening criterion of $0.5 \mathrm{mg} / \mathrm{kg}$ for piscivores. The upper criterion is set at the dietary $\mathrm{LC}_{50}$ of $30 \mathrm{mg} / \mathrm{kg}$ in rats (EPA 1980a).

Zinc. The National Research Council (1980) set the maximum tolerable level for zinc in sheep feed at $300 \mathrm{mg} / \mathrm{kg}$ and in swine and poultry feed at $1000 \mathrm{mg} / \mathrm{kg}$, but adverse effects on young Japanese quail fed laboratory diets occurred at $125 \mathrm{mg} / \mathrm{kg}$ (Hamilton et al. 1979). Using the Japanese quail datum as the lowest-observed-effect level and applying a factor of 2 for the whole-fish conversion yields a lower screening criterion of $60 \mathrm{mg} / \mathrm{kg}$ for piscivores.

\section{ORGANICS}

Hexachlorobenzene (HCB). The acute lethal dose for HCB is $1000 \mathrm{mg} / \mathrm{kg}$ or greater (EPA 1980i, EPA 1984b, NIOSH 1988), so the upper criterion for concentrations in fish is $12,500 \mathrm{mg} / \mathrm{kg}$. HCB causes liver damage in Japanese quail at $5 \mathrm{mg} / \mathrm{kg}$ in diet (EPA 1980i) and causes immunosuppression in mink and ferrets (by different criteria) at 25 and 1 $\mathrm{mg} / \mathrm{kg}$ in diet (Bleavins et al. 1983). Using the $1 \mathrm{mg} / \mathrm{kg}$ level as the lowest-observedeffects level and applying a factor of 3 for whole-fish basis yield a lower screening criterion of $0.3 \mathrm{mg} / \mathrm{kg}$ for piscivores.

DD'r and metabolites. DDT and its metabolites DDD and DDE are notorious for their effects on piscivorous birds. Birds experience reduced survival or reproduction at 3 to $0.15 \mathrm{mg} / \mathrm{kg}$ in diet (Lince: 1975, Anderson et al. 1975). Applying a factor of 5 for an effects threshold and 3 for the whole-fish conversion yields a lower criterion of $0.01 \mathrm{mg} / \mathrm{kg}$ for piscivores. The acute oral $\mathrm{LD}_{50}$ for birds is approximately $1000 \mathrm{mg} / \mathrm{kg}$ (Matsumura 1985), which is equivalent to a dietary concentration of approximately $12,500 \mathrm{mg} / \mathrm{kg}$ in kingfishers, the upper criterion for piscivores. Fish themselves experience effects at 3 to $11 \mathrm{mg} / \mathrm{kg}$ body burden (EPA $1980 \mathrm{~m}$ ). Because $3 \mathrm{mg} / \mathrm{kg}$ is lethal to cutthroat trout fry, we apply the factors of 5 for an effects threshold and 3 for whole-fish basis to obtain a lower criterion of $0.2 \mathrm{mg} / \mathrm{kg}$ for protection of fish.

Polychlorinated biphenyls (PCBs). PCBs are persistent, bioaccumulative, and highly toxic. Mink are the most sensitive species to PCBs, experiencing reproductive failure at $0.64 \mathrm{mg} / \mathrm{kg}$ in diet (Ringer 1983, Fuller and Hobson 1986). Birds experience reproductive and immunotoxic effects at 10 to $40 \mathrm{mg} / \mathrm{kg}$ in diet (Peakall 1986). Because these levels induce catastrophic reproductive effects, the International Joint Commission (1988) recommends a concentration of $0.1 \mathrm{mg} / \mathrm{kg}$ in fish to protect piscivores. Using the minkeffects level and applying the factor of 5 for effects thresholds approximately yield this criterion. Applying the factor of 3 for organics in whole fish yields a lower criterion of $0.04 \mathrm{mg} / \mathrm{kg}$ for piscivores. The acute dietary $\mathrm{LC}_{50}$ in birds is 747 to $12,000 \mathrm{mg} / \mathrm{kg}$ (Peakall 1986). Using $1000 \mathrm{mg} / \mathrm{kg}$ and dividing by 3 for the whole-fish conversion yields an upper criterion of $300 \mathrm{mg} / \mathrm{kg}$.

Other organics. All of the other organic chemicals that were analyzed in fish tissues were not detected. Except for the pesticides, which are not generated or used in large amounts by DOE operations, there are very few dietary toxicity data or avian toxicity data of any sort for these chemicals. If available, RfDs were used as screening criteria for these chemicals. 


\subsubsection{Radionuclides}

Effects of radionuclides on nonhuman biota are not analyzed in this assessment for three reasons. First, previous studies of radionuclide exposure and effects in WOL found no evidence of effects or of exposures sufficient to cause effects in controlled exposures (Blaylock and Trabalka 1978). Second, the mode of action of radionuclides is the same in nonhuman organisms as in humans, so the ranking of radionuclides produced by the human health assessment, which includes bioaccumulation by fish and ingestion of fish by humans, would be applicable to ecological effects. Third, a screening assessment of radionuclide effects on nonhuman populations would have no consequences, because an extensive off-site radionuclide monitoring program will be conducted for human health assessment regardless of potential ecological effects. The results of those studies, including body burden data for fish, birds, and mammals, will be analyzed for evidence of ecological risks in future assessments.

\subsection{RISK CHARACTERIZATION}

Risk characterization is based on three independent lines of evidence. First, the estimates of exposure (Sect. 5.2) are compared to the toxicological benchmarks (Sect. 5.3) to determine for which chemicals the benchmarks are exceeded. Second, toxicity tests have been conducted with water collected from WOC and Melton Branch. These tests can be used to determine whether the waters have been toxic to standard test organisms. Third, biological surveys have been conducted in WAG 2 that can be used to estimate the actual levels of effects experienced by the receiving community.

\subsubsection{Exposure/Response Integration}

Exposure/response integration for this screening assessment is performed by calculating the quotients of chemical concentrations divided by screening criteria. For each detected chemical two exposure concentrations are used, the geometric mean and the arithmetic upper $95 \%$ confidence limit (UCL). If the calculated UCL exceeded the maximum observed concentration, the maximum value was used. These values were chosen to be consistent with the human health risk assessment (Sect. 4.5) because they are reasonable estimates of the chronic and episodic exposure levels, respectively. The concentrations, screening criteria, and quotients are presented in Tables G.2 to G.9, located in Appendix G.

\subsubsection{Aqueous concentrations/aquatic life effects}

The reported mean concentrations of most of the 17 metals and 6 out of 15 organic chemicals detected in water exceeded the lower screening criteria (Table G.2). Aluminum, cadmium, chromium, copper (UCL only), lead, and PCB concentrations exceed their chronic criteria. The largest quotients were for mercury and PCBs. In all reaches mean total mercury concentrations exceeded the lower screening criterion, which is the approximated chronic criterion for methyl mercury. (The actual chronic criterion for mercury is not used because it is based on mammalian toxicity rather than toxicity to aquatic life.) The mean and UCL total mercury concentration also exceed the lowest chronic value for daphnids and the lowest EC20 value for fish, but are well below all of 
the benchmarks for divalent mercury. The Arochlor ${ }^{\bullet} 1254$ detected in WOC (Reach 1) and the total PCB concentrations in all reaches greatly exceeded the approximated acute and chronic criteria for all of the Arochlor mixtures and barely exceeded chronic values and EC20s for fish. Based on these results, the water in all reaches should be causing toxic effects in aquatic populations.

Most of the detection limits for chemicals that were not detected in water exceeded lower screening criteria (Table G.3). In addition, arsenic, cadmium, selenium, silver, and PCB detection limits exceed chronic NAWQC.

\subsubsection{Concentrations in sediment/aquatic life effects}

Sediment $\mathbf{K}_{d}$ values could be found for only six of the metals detected in WAG 2 sediments (Table G.4). All of these (barium, chromium, cobalt, mercury, silver, and zinc), have estimated pore-water values that exceed the lower screening criteria for aquatic life. In addition, mercury, silver, and zinc are estimated to exceed their chronic NAWQC in pore-water. Of the few organic chemicals detected in WAG 2 sediments, estimated porewater concentrations exceeded lower screening criteria for benzene, di-n-butyl phthalate, methylene chloride, and PCBs. Pore-water concentrations estimated to occur at the detection limits of most of the chemicals not detected in WAG 2 exceeded lower screening criteria for aquatic life (Table G.5).

\subsubsection{Concentrations in fish/fish effects}

Only seven chemicals were detected in fish flesh (Table G.6). Of these, only selenium in Reach 1 occurred at mean concentrations that suggested that the fish may have been exposed to toxic aqueous concentrations. Upper confidence limits on the distributions of concentrations of cadmium and selenium in all reaches were barely high enough to suggest that toxic aqueous concentrations were exceeded. Seven metals and many organic compounds were not detected in fish flesh but had detection limits that exceeded concentrations that imply toxic aqueous concentrations (Table G.7).

\subsubsection{Concentrations in fish/piscivore effects}

Of the seven chemicals detected in fish flesh, only mercury and PCBs occurred at concentrations that could be toxic to piscivorous wildlife by the lower screening criteria for wildlife (Table G.8). However, cadmium, selenium, and zinc concentrations were sufficient to exceed the RfD for an organism consuming fish equal to $8 \%$ of its body weight per day (e.g., a kingfisher). Many undetected chemicals had detection limits in fish flesh that exceeded either lower screening criteria for wildlife or RfDs for kingfishers (Table G.9).

\subsubsection{Ambient Media Toxicity Tests}

The toxicity of surface waters in WOC and Melton Branch have been tested on a regular basis since 1986. Because of the major changes that have occurred in effluent input and toxicity in that interval, this discussion will emphasize the most recent results (Loar 1991). The tests employed are the standard 7-d static renewal tests measuring the growth and survival of fathead minnow (Pimephales promelas) larvae and the survival and 
growth of the daphnid cladoceran Ceriodaphnia dubia (Horning and Weber 1985). During 1990, one or both of these tests were performed monthly with water taken from WOC just above the confluence of Melton Branch and from Melton Branch just above its mouth. In all cases, survival and growth of $C$. dubia were high. Fathead minnow survival was less than $70 \%$ for the Melton Branch samples in four months and for the WOC samples in one month. However, in each case of low survival, minnow growth was good and variance in survival among replicates was high. Hence, the observations of low minnow survival were attributed to disease rather than toxicity by the authors (A. J. Stewart and L. A. Kszos in Loar 1991). Results in 1989 were similar but with a higher frequency of tests with low minnow survival (Loar 1990).

\subsubsection{Biological Surveys}

The following brief discussion of biological survey results is based on the results of studies done by the Biological Monitoring and Abatement Program at ORNL (Loar et al. 1987, Loar 1988-1991).

\subsubsection{Fish}

Redbreast sunfish (Lepomis auritus) have been collected from WOC in WAG 2 (WCK $2.2-2.7$ ) and from three reference streams for studies of the biomarkers of contaminant exposure, indicators of the health of individual fish, and population parameters. The fish from WAG 2 differed from those of the reference sites in the following ways:

1. liver detoxification enzymes were elevated;

2. creatinine levels were elevated, a possible sign of kidney damage;

3. condition indices were slightly lower; and

4. fish were larger.

The redbreast sunfish in WAG 2 appear to be exposed to organic contaminants to the extent of elevating enzymes that may affect hormone levels; they are in slightly poorer condition on average but are growing well; and they are producing abundant viable eggs, but are reproducing earlier in the season than at reference sites. The early reproduction, which may be due to elevated water temperatures, may be the cause of the larger fish. Adams and Greeley (in Loar 1991) suggest that poor early life-stage survival may also be involved, but no direct evidence currently exists for this hypothesis.

Surveys of the fish community have also been conducted by electrofishing. Thirteen of the fourteen species occurring in the WOC watershed were found in WAG 2 in 1990. The density is relatively stable at approximately $0.5 \mathrm{fish} / \mathrm{m}^{2}$. Growth rates of redbreast sunfish are indistinguishable from those at a reference stream (Brushy Fork) and bluegill (Lepomis macrochirus) growth rates are higher.

A fish/amphibian kill was observed in Melton Branch in 1990, apparently due to high temperatures associated with the operation of the HFIR reactor. Other kills that have been reported in the WOC watershed have also been associated with point-source effluents rather than wastes. 


\subsubsection{Benthic macroinvertebrates}

Surveys of benthic macroinvertebrates in WAG 2 are available only through 1987. Those surveys found low taxonomic richness and relatively high frequencies of "pollution tolerant species" (Loar 1991). However, the community characteristics are improved relative to upstream areas that are more directly exposed to point-source effluents. The cause of the apparently degraded condition of the benthic macroinvertebrate community is unclear. Possible causes include upstream point-source emissions, siltation, temperature, and natural factors as well as toxicant sources within WAG 2. Interpretation is particularly inhibited by the lack of data from reference streams; all comparisons were to reference sites that were upstream in WOC and Melton Branch.

\subsubsection{Periphyton}

Periphyton, along with allochthonous material, form the base of the food web in streams. Periphyton downstream of ORNL, including Melton Branch and WOC in WAG 2, are more productive than those in uncontaminated reference sites. This result is attributed to nutrient input and indicates that the base of the food web is unimpaired. "Chlorophyll-adjusted photosynthetic rates" of periphyton in WAG 2 (WCK 3.4, WCK 2.9, and MEK 0.6) have been low during some measurement periods, but it is not clear whether this is due to natural factors or upstream effluents. In any case, this effect has no apparent ecosystem-level consequences.

\subsubsection{Terrestrial}

The terrestrial studies conducted in WAG 2 have addressed bioaccumulation and transfer of contaminants rather than effects of contaminants. Species used in bioaccumulation studies have included turtles, small mammals, waterfowl, and vascular plants. The abundant vegetation of WAG 2 suggests that severe phytotoxic effects are not occurring. Avian and mammalian wildlife appear to be abundant on WAG 2. However, given the mobility of these species, one cannot infer from this that wildife on WAG 2 are unaffected. Even high mortality rates or very low reproductive rates could be replaced by immigrants from surrounding habitats.

\subsubsection{Weight of Evidence and Uncertainties}

\subsubsection{Water}

The analysis of chemical concentrations in water indicates that toxic effects on aquatic organisms cannot be precluded from consideration but are not likely to be severe. The toxicological benchmarks that were exceeded are intended to be conservative, and the concentrations that were reported may overestimate bioavailable concentrations, so the quotients are expected to be conservative estimators of the potential for effects. The possibility that exposure is overestimated is supported by the relatively low concentrations in fish flesh, which are suggestive of lower water concentrations than are reported in the analyses. However, this analysis is based on concentrations in fillets, which are likely to be lower than whole fish concentrations that are the basis for the bioconcentration factors. The results of recent toxicity tests with WAG 2 water do not indicate toxicity, but they include only two species and one life stage of the fish. The most recent aquatic biological 
survey results indicate that sources in WAG 2 are not causing severe toxic effects. However, fish reproduction may be disturbed in WAG 2, and the benthic invertebrate community may be affected by an unidentified source of toxic or physical stress.

\subsubsection{Sediments}

Estimated sediment pore-water concentrations of several chemicals are sufficient to cause toxic effects. However, these estimates are uncertain because they are not based on site-specific partitioning data. The apparent effects on the benthic invertebrate community are consistent with mild toxic effects, but, because riffle areas were sampled, the surface water may be the primary source of exposure. No sediment toxicity tests have been conducted with WAG 2 sediments.

\subsubsection{Fish and piscivores}

Mercury and PCB concentrations in fish flesh are high enough to indicate a hazard to piscivorous wildlife. There are no biosurvey data for piscivorous wildlife in WAG 2 , but elevated PCB and mercury concentrations have been found in eggs at a great blue heron rookery at K-25. Great blue herons that forage in WAG 2 are believed to be from this rookery.

\subsubsection{Terrestrial communities}

Nothing is known about the nonradiological contamination of the floodplain habitats in WAG 2. There is no apparent ecological damage to the floodplain community, but no studies of potential toxic effects have been conducted.

\subsubsection{Summary of the ecological risk characterization}

Because there is no complete inventory of the chemicals that have been disposed of in the White Oak Creek watershed, it is not possible to identify a list of potential contaminants of concern a priori. Instead, it is necessary to either establish that no significant toxic effects are occurring in WAG 2 or perform a survey of watershed contaminants that is sufficiently sensitive and reliable for a complete screening to be performed. This assessment was not able to complete either of these strategies. Although severe effects are not occurring in the aquatic habitats of WAG 2, there is some evidence of effects on fish reproduction and on benthic invertebrate community composition. Toxicity tests of surface water have not found toxicity, but tests have not been conducted for sediment or soil. Some chemicals in all media occurred at concentrations that are potentially toxic and many chemicals that were not detected had detection limits that were higher than both toxic and regulatory thresholds. Therefore, although it is clear that severe toxic effects are not occurring, there are still significant uncertainties concerning the ecological risks posed by WAG 2 . These uncertainties are reflected in the following list of data needs. 


\subsection{DATA NEEDS}

\subsubsection{Biota and Communities}

A survey of threatened and endangered species should be conducted.

Wetland communities and seeps where contaminants may accumulate should be identified.

Benthic invertebrate communities in fine sediments should be surveyed in WAG 2 and reference sites.

\subsubsection{Sources and Exposure}

Species of arsenic, chromium, and mercury should be deteimined in each medium.

Sediment pore-water should be extracted and analyzed at a set of sites that are representative of the range of sediments (other than gravels) found in WAG 2. These samples will be used to derive site-specific $K_{d}$ values. Percent organic matter and acidvolatile sulfides should be determined for those sediments.

Whole fish should be analyzed, including some small fish representative of the fish consumed by kingfishers. For the larger fish that are currently filleted, the non-fillet remainder of fish should be analyzed to establish fillet-to-whole-fish ratios. Whole-fish analysis is the best measure of piscivore dietary exposure and is the most generally useful measure of fish internal exposure.

Soil should be analyzed for nonradiological chemicals in areas where contaminants are likely to have accumulated. Aqueous extracts as well as the conventional acid and organic extracts should be analyzed.

Water should be analyzed for dissolved chemical concentrations.

\subsubsection{Toxicity Testing}

If pore-water analyses indicate potential sediment toxicity, sediment toxicity tests should be performed.

If soil analyses indicate potential soil toxicity, soil toxicity tests should be performed.

Tests of effects of WAG 2 waters on fish reproduction should be continued to resolve the nature and cause of apparent effects. 


\section{REFERENCES}

Adams, W. J., P. S. Ziegenfuss, W. J. Renaudette, and R. G. Mosher. 1985. Comparison of laboratory and field methods for testing the toxicity of chemicals sorbed to sediments. pp. 494-513. T. M. Posten and P. E. Purdy (eds.), Aquatic Toxicology and Environmental Fate: Ninth Volume, ASTM STP 921. American Society for Testing and Materials, Philadelphia.

Ahmed, N., D. Benoit, L. Brook, D. Call, A. Carlson, D. DeFoe, H. Huot, A. Moriarity, J. Richter, P. Shubat, G. Veith, and C. Wallbridge. 1984. Aquatic toxicity tests to characterize the hazard of volatile organic chemicals in water: A toxicity data summaryParts I and II, EPA-600/3-84-009. U.S. Environmental Protection Agency, Duluth, Minn.

Anderson, D. W., J. R. Jehl Jr., R. W. Riesbrough, L. A. Wood Jr., L. R. Deweese, and W. G. Edgecomb. 1975. Brown pelicans: Improved reproduction off the Southern California coast. Science 190:806-808.

Benoit, D. A., F. A. Puglisi, and D. L. Olson. 1982. A fathead minnow Pimephales promelas early life stage toxicity test method evaluation and exposure to four organic chemicals. Environ. Pollut. (Ser. A) 28:189-197.

Beusen, J. M., and B. Neven. 1987. Toxicity of vanadium to different freshwater organisms. Bull. Environ. Contam. Toxicol. 39:194-201.

Biesinger, K. E., and Christensen, G. M. 1972. Effects of various metals on survival, growth, reproduction, and metabolism of Daphnia magna. J. Fish. Res. Board Can. 29:1691-1700.

Black, J. A, and W. J. Birge. 1982. The aquatic toxicity of organic compounds to embryolarval stages of fish and amphibians. University of Kentucky, Water Resources Research Institute, Lexington, Kentucky.

Blaylock, B. G., and J. R. Trabalka. 1978. Evaluating the effects of ionizing radiation on aquatic organisms. Adv. Radiat. Bio. 7:103-152.

Blaylock, B. G., M. L. Frank, L. A. Hook, and F. O. Hoffman. 1991. Interim Site Characterization and Contaminant Screening Report on the White Oak Creek Embayment. ORNL/ER-81, Oak Ridge National Laboratory, Oak Ridge, Tennessee.

Bleavins, M. R., R. J. Aulerich, and R. K. Ringer. 1983. Hexachlorobenzene-induced effects on the lymphocyte blastogenic response to concanavalin $A$ in the mink and European ferret. Environ. Toxicol. Chem. 2:411-418. 
Boyle, J. W. and 12 others. 1982. Environmental analysis of the operation of the Oak Ridge National Laboratory (X-10 Site). ORNL-5870. Oak Ridge National Laboratory, Oak Ridge, Tennessee.

Brumbaugh, W. G., and D. A. Kane. 1985. Variability of aluminum concentrations in organs and whole bodies of smallmouth bass (Microprus dolomieui). Environ. Sci. Technol. 19:828-831.

Cairns, M. A, and A. V. Nebeker. 1982. Toxicity of acenaphthene and isophorone to early life stages of fathead minnows. Arch. Environ. Contam. Toxicol. 11:703-707.

Call, D. J., L. T. Brook, N. Ahmed, and J. E. Richter. 1983. Toxicity and metabolism studies with EPA priority pollutants and related chemicals in freshwater organisms, EPA-600/3-83-095. U.S. Environmental Protection Agency, Duluth, Minn.

Cardwell, R. D., D. G. Foreman, T. R. Payne, and D. J. Wilbur. 1977. Acute and chronic toxicity of chlordane to fish and invertebrates, EPA-600/3-77-019. U.S. Environmental Protection Agency, Duluth, Minn.

Carlson, A. R., J. A. Tucker, V. R. Mattson, G. L. Phipps, P. M. Cook, G. F. Olson, and F. A. Puglisi. 1982. Cadmium and endrin toxicity to fish in waters containing mineral fibers, EPA-600/3-82-053. U.S. Environmental Protection Agency, Duluth, Minn.

Chapman, G. A., S. Ota, F. Recht. Manuscript. Effects of water hardness on the toxicity of metals to Daphnia magna. U.S. Environmental Protection Agency, Cornvallis, Oregon.

Cleveland, L., E. E. Little, S. J. Hamilton, D. R. Buckler, and J. B. Hunn. 1978. Interactive toxicity of aluminum and acidity to early life stages of brook trout. Trans. Amer. Fish. Soc. 115:610-620.

Suter, Glenn W. II, Andy Red Fearn, Robin K. White, and Renee A. Shaw. 1992. Approach and strategy for performing ecological risk assessments for the DOE Oak Ridge Field Office Environmental Restoration Program, ES/ER/TM-33. Oak Ridge National Laboratory, Oak Ridge, Tennessee.

Dave, G. 1984a. Effects of copper on growth, reproduction, survival and haemoglobin in Daphnia magna. Comp. Biochem. Physiol. 78C:439-443.

Dave, G. 1984b. Effects of fluoride on growth, reproduction, and survival in Daphnia magna. Comp. Biochem. Physiol. 78C:425-431.

Dave, G. 1984c. Effects of waterborne iron on growth, reproduction, survival and haemoglobin in Daphria magna. Comp. Biochem. Physiol. 78C:433-438.

Davies, P. H., J. P. Goettl, Jr., J. R. Sinley. 1978. Toxicity of silver to rainbow trout (Salmo gairdneri). Water Res. 12:113-117.

Davies, P. H., J. P. Goettl, Jr., J. R. Sinle; and Smith. 1976. Acute and chronic toxicity of lead to rainbow trout Salmo gairdneri, in hard and soft water. Water Res. 10:199-206. 
Davies, P. H., and W. E. Everhart. 1973. Effects of chemical variations in aquatic environments: lead toxicity to rainbow trout and testing application factor concept. EPAR3-73-011C. National Technical Information Service, Springfield, Va.

DeFoe, D. L, 1982. Memorandum to Robert L. Spehar. U.S. Environmental Protection Agency, Duluth, Minn. July 9.

DeFoe, D. L., G. D. Veith, and R. L. Carlson. 1978. Effects of Aroclor 1248 and $1260 \mathrm{~cm}$ the fathead minnow (Pimephales promelas). J. Fish. Res. Board Can. 7:997-1002.

DeGraeve, G. M., R. G. Elder, D. C. Woods, and H. L. Bergman. 1982 . Effects of naphthalene and benzene on fathead minnows and rainbow trout. Arch. Environ. Contam. Toxicol. 11:478-490.

DeGraeve, G. M., D. L. Geiger, J. S. Meyer, and H. L. Bergman. 1980. Acute and embryo-larval toxicity of phenolic compounds to aquatic biota. Arch. Environ. Contam. Toxicol. 9:557-568.

Dill, D. C., P. G. Murphy, and M. A. Mayes. 198\%. Toxicity of methylene chloride to life stages of the fathead minnow, Pimephales promelas Rafinesque. Bull. Environ. Contam. Toxicol. 39:869-876.

DiToro, D. M. 1985. A particle interaction model of reversible organic chemical sorption. Chemosphee 14:1503-1538.

Eisler, R. 1985. Selenium hazards to tish, wildlife, and invertebrates: A synoptic review. U.S. Fish and Wildlife Service Biological Report 85/1.5. Laurel, Maryland.

Eisler, R. 1986. Chromium hazards to fish, wildlife, and invertebrates; A synoptic review. U.S. Fish and Wildlife Service Biological Report 85/1.6. Laurel, Maryland.

Eisler, R. 1987. Mercury hazards to fish, wildlife, and invertebrates: A synoptic review. U.S. Fish and Wildlife Service Biological Report 85/1.10. Laurel, Maryland.

Eisler, R. 1988. Lead hazards to fish, wildlife, and inve:tebrates; A synoptic review. U.S. Fish and Wildlife Service Biological Report 85/1.14. Laurel, Maryland.

Elnabarawy, M. T., A. N. Welter, and R. R. Robideau. 1986. Relative sensitivity of three daphnid species to selected organic and inorganic chemicals. Environ. Toxicol. Chem. 5:393-398.

EPA (Environmental Protection Agency). 1978. In-depth studies on health and environmental impacts of selected water pollutants. Contract No. 68-01-4646. U.S. Environmental Protection Agency, Washington, D.C. 
EPA (Environmental Protection Agency). 1980a. Ambient water quality criteria for thallium. EPA 440/5-80-074. National Technical Information Service, Springfield, Virginia.

EPA (Environmental Protection Agency). 1980b. Ambient water quality criteria for chlorinated benzenes. National Technical Information Service, Springfield, Virginia.

EPA (Environmental Protection Agency). 1980c. Ambient water quality criteria for beryllium. National Technical Information Service, Springfield, Virginia.

EPA (Environmental Protection Agency). 1980a. Ambient water quality criteria for acenaphthene. EPA 440/5-80-015. U.S. Environmental Protection Agency, Washington, D.C.

EPA (Environmental Protection Agency). 1980b. Ambient water quality criteria for antimony. EPA 440/5-80-020. U.S. Environmental Protection Agency, Washington, D.C.

EPA (Environmental Protection Agency). 1980c. Ambient water quality criteria for benzidene. EPA 440/5-80-023. U.S. Environmental Protection Agency, Washington, D.C.

EPA (Environmental Protection Agency). 1980d. Ambient water quality criteria for benzene. EPA 440/5-80-018. U.S. Environmental Protection Agency, Washington, D.C.

EPA (Environmental Protection Agency). 1980e. Ambient water quality criteria for benzidene. EPA 440/5-80-023. U.S. Environmental Protection Agency, Washington, D.C.

EPA (Environmental Protection Agency). 1980f. Ambient water quality criteria for beryllium. EPA 440/5-80-024. U.S. Environmental Protection Agency, Washington, D.C.

EPA (Environmental Protection Agency). 1980g. Ambient water quality criteria for cadmium. EPA 440/5-80-025. U.S. Environmental Protection Agency, Washington, D.C.

EPA (Environmental Protection Agency). 1980h. Ambient water quality criteria for carbon tetrachloride. EPA 440/5-80-026. U.S. Environmental Protection Agency, Washington, D.C.

EPA (Environmental Protection Agency). 1980i. Ambient water quality criteria for chlordane. EPA 440/5-80-027. U.S. Environmental Protection Agency, Washington, D.C.

EPA (Environmental Protection Agency). 1980j. Ambient water quality criteria for chlorinated benzenes. EPA 440/5-80-029. U.S. Environmental Protection Agency, Washington, D.C. 
EPA (Environmental Protection Agency). 1980k. Ambient water quality criteria for chlorinated ethanes. EPA 440/5-80-029. U.S. Environmental Protection Agency, Washington, D.C.

EPA (Environmental Protection Agency). 1980l. Ambient water quality criteria for chloroform. EPA 440/5-80-033. U.S. Environmental Protection Agency, Washington, D.C.

EPA (Environmental Protection Agency). $1980 \mathrm{~m}$. Ambient water quality criteria for DDT. EPA 440/5-80-038. U.S. Environmental Protection Agency, Washington, D.C.

EPA (Environmental Protection Agency). 1980n. Ambient water quality criteria for dichloroethylenes. FPA 440/5-80-041. U.S. Environmental Protection Agency, Washington, D.C.

EPA (Environmental Protection Agency). 19800. Ambient water quality criteria for dichloropropane and dichloropropene. EPA 440/5-80-043. U.S. Environmental Protection Agency, Washington, D.C.

EPA (Environmental Protection Agency). 1980p. Ambient water quality criteria for ethylbenzene. EPA 440/5-80-048. U.S. Environmental Protection Agency, Washington, D.C.

EPA (Environmental Protection Agency). 1980q. Ambient water quality criteria for fluoranthene. EPA 440/5-80-049. U.S. Environmental Protection Agency, Washington, D.C.

EPA (Environmental Protection Agency). 1980r. Ambient water quality criteria for heptachlor. EPA 440/5-80-052. U.S. Environmental Protection Agency, Washington, D.C.

EPA (Environmental Protection Agency). 1980s. Ambient water quality criteria for hexachloro-cyclohexane. EPA 440/5-80-054. U.S. Environmental Protection Agency, Washington, D.C.

EPA (Environmental Protection Agency). 1980t. Ambient water quality criteria for napthalene. EPA 440/5-80-059. U.S. Environmental Protection Agency, Washington, D.C.

EPA (Environmental Protection Agency). 1980u. Ambient water quality criteria for nitrophenols. EPA 440/5-80-063. U.S. Environmental Protection Agency, Washington, D.C. 
EPA (Environmental Protection Agency). 1980v. Ambient water quality criteria for phenol. EPA 440/5-80-066. U.S. Environmental Protection Agency, Washington, D.C.

EPA (Environmental Protection Agency). 1980w. Ambient water quality criteria for phthalate esters. EPA 440/5-80-067. U.S. Environmental Protection Agency, Washington, D.C.

EPA (Environmental Protection Agency). 1980x. Ambient water quality criteria for polychlorinated biphenyls. EPA 440/5-80-068. U.S. Environmental Protection Agency, Washington, D.C.

EPA (Environmental Protection Agency). 1980y. Ambient water quality criteria for silver. EPA 440/5-80-071. U.S. Environmental Protection Agency, Washington, D.C.

EPA (Environmental Protection Agency). 1980z. Ambient water quality criteria for tetrachloroethylene. EPA 440/5-80-073. U.S. Environmental Protection Agency, Washington, D.C.

EPA (Environmental Protection Agency). 1980aa. Ambient water quality criteria for thallium. EPA 440/5-80-074. U.S. Environmental Protection Agency, Washington, D.C.

EPA (Environmental Protection Agency). 1980bb. Ambient water quality criteria for toluene. EPA 440/5-80-075. U.S. Environmental Protection Agency, Washington, D.C.

EPA (Environmental Protection Agency). 1980cc. Ambient water quality criteria for trichloroethylene. EPA 440/5-80-077. U.S. Environmental Protection Agency, Washington, D.C.

EPA (Environmental Protection Agency). 1984a. Health effects assessment for lead. EPA 540/1-86-055. National Technical Information Service, Springfield, Virginia.

EPA (Environmental Protection Agency). 1984b. Health effects assessment for chlorinated benzenes. EPA 600/8-84-015F. National Technical Information Service, Springfield, Virginia.

EPA (Environmental Protection Agency). 1985a. Ambient water quality criteria for arsenic-1984. EPA 440/5-84-033. U.S. Environmental Protection Agency, Washington, D.C.

EPA (Environmental Protection Agency). 1985b. Ambient water quality criteria for chromium - 1984. EPA 440/5-84-029. U.S. Environmental Protection Agency, Washington, D.C.

EPA (Environmental Protection Agency). 1985c. Ambient water quality criteria for copper-1984. EPA 440/5-84-031. U.S. Environmental Protection Agency, Washington, D.C. 
EPA (Environmental Protection Agency). 1985d. Ambient water quality criteria for lead-1984. EPA 440/5-84-027. U.S. Environmental Protection Agency, Washington, D.C.

EPA (Environmental Protection Agency). 1985e. Ambient water quality criteria for mercury-1984. EPA 440/5-84-026. U.S. Environmental Protection Agency, Washington, D.C.

EPA (Environmental Protection Agency). 1987. Health effects assessment for beryllium. EPA 660/8-84-026F. National Technical Information Service, Springfield, Virginia.

EPA (Environmental Protection Agency). 1986. Ambient water quality criteria for nickel-1986. EPA 440/5-86-004. U.S. Environmental Protection Agency, Washington, D.C.

EPA (Environmental Protection Agency). 1987a. Ambient water quality criteria for selenium, 1987. EPA 440/5-87-006. U.S. Environmental Protection Agency, Washington, D.C.

EPA (Environmental Protection Agency). 1987b. Ambient water quality criteria for zinc, 1987. EPA 440/5-87-003. U.S. Environmental Protection Agency, Washington, D.C.

EPA (Environmental Protection Agency). 1987c. Health effects assessment for beryllium. EPA 660/8-84-026F. NTIS, Springfield, Virginia.

EPA (Environmental Protection Agency). 1988. Ambient water quality criteria for aluminum-1988. EPA 440/5-86-008. U.S. Environmental Protection Agency, Washington, D.C.

EPA (Environmental Protection Agency). 1990. Health Effects Assessment Summary Tables. NTIS No. PB90-921104.

EPA (Environmental Protection Agency). 1991. Drinking Water Regulations: Maximum Contaminant Level Goals and National Primary Drinking Water Regulations for Lead and Cooper. Federal Register, Vol. 55, No. 110, June 7, 1991, pp. 26460-26564.

Ernst, W. R., and E. T. Garside. 1987. Lethal effects of vanadium to two life stages of brook trout Salvelinus fontinalis (Mitchill). Can. J. Zool. 65:628-634.

ES/ER (Environmental Sciences Division/Environmental Restoration Division). 1990. Remedial Investigation Plan for Waste Area Grouping 2 at Oak Ridge National Laboratory, Oak Ridge, Tennessee. ES/ER-14\&D1, pp 354.

Fieser, A. H., J. L. Sykora, M. S. Kostalos, Y. C. Wu, and D. W. Weyel. 1986. Effect of fluorides on survival and reproduction of Daphnia magna. J. Water Pollut. Control Fed. 58(1):82-86. 
Francis, P. C., D. W. Grothe, and J. C. Scheuring. 1986. Chronic toxicity of 4-nitrophenol to Daphnia magna Straus under static-renewal and flow-through conditions. Bull. Environ. Contam. Toxicol. 36:730-737

Fuller, G. B., and W. C. Hobson. 1986. Effects of PCBs on reproduction in mammals. pp. 101-122. IN J. S. Waide (ed.), PCBs and the Environment, Vol. II. CRC Press, Boca Raton, Florida.

Geiger, J. G., and A. L. Buikema Jr. 1982. Hydrocarbons depress growth and reproduction of Daphnia pulex (Clodocera). Can. J. Fish. Aquat. Sci. 39:830-836.

Gerisch, F. M. 1984. Evaluation of static renewal chronic toxicity test method for Daphnia magna Straus using boric acid. Environ. Toxicol. Chem. 3:89-94.

Goettl, J. P., J. R. Sinley, and P. H. Davies. 1972. Laboratory water pollution studies. Colorado Fisheries Review 7:36-44.

Goettl, J. P., Jr., and P. H. Davies. 1976. Water pollution studies. Federal Aid Project F-33R-11. Department of Natural Resources, Colorado Division of Wildlife.

Hamilton, R. P., M. R. S. Fox, B. E. Fry, A. O. L. Jones, and R. M. Jacobs. 1979. Zinc interference with copper, iron, and manganese in young Japanese quail. J. Food Sci. 44:738.

Hannah, J. B., J. E. Hose, M. L. Landolt, B. S. Miller, S. P.Felton, and W. T. Iwaoko. 1982. Benzo(a)pyrene-induced morphologic and developmental abnormalities in rainbow trout. Arch. Environ. Contam. Toxicol. 11:727-734.

Heinz, G. H., S. D. Hazeltine, and L. Sileo. 1983. Altered avoidance behavior of young black ducks fed cadmium. Environ. Toxicol. Chem. 2:319-421.

Hoffman, F. O., B. G. Blaylock, M. L. Frank, L. Hook, E. L. Etnier, and S. S. Talmage. 1990. Screening of contaminants in the off-site environment. ORNL/ER-9. Oak Ridge National Laboratory, Oak Ridge, Tennessee.

Holdway, D. A, and J. B. Sprague. 1979. Chronic toxicity of vanadium to flagfish. Water Res. 13:905-910.

Holst, L. L., and J. P. Giesy. 1989. Chronic effects of the photoenhanced toxicity of anthracene on Daphnia magna reproduction. Environ. Toxicol. Chem. 8:933-942.

Horning, W. B., Jr. and C. I. Weber (eds.). 1985. Short-term methods for estimating the chronic toxicity of effluents and receiving waters to freshwater organisms. EPA/600/4-85/014. U.S. Environmental Protection Agency, Cincinnati, Ohio.

Ingersoll, C. G., D. D. Gulley, D. R. Mount, M. E. Mueller, J. D. Fernandez, J. R. Hockett, and H. L. Bergman. 1990a. Aluminum and acid toxicity to two strains of brook trout (Salvelinus fontinalis). Can. J. Fish. Aquat. Sci. 47:1641-1648. 
Ingersoll, C. G., D. R. Mount, D. D. Gulley, T. W. La Point, and H. L. Bergman. 1990b. Effects of $\mathrm{pH}$, aluminum, and calcium on survival and growth of eggs and fry of brook trout (Salvelinus fontinalis). Can. J. Fish. Aquat. Sci. 47:1580-1592.

International Atomic Energy Agency. 1982. Generic models and parameters for assessing the environmental transfer of radionuclides from routine releases. Safety Series No. 57. Vienna.

International Joint Commission of the United States and Canada. 1988. Great Lakes Water Quality Agreement. Amended by protocol signed November 18, 1987. Ottawa, Canada.

Jarvinen, A. W., M. J. Hoffman, and T. W. Thorslund. 1977. Long-term toxic effects of DDT food and water exposure on fathead minnows (Pimephales promelas). J. Fish. Res. Board Can. 34:2089-2103.

Johnston, P. A. 1987. Acute toxicity of inorganic selenium to Daphnia magna (Straus) and the effect of sub-acute exposure unon growth and reproduction. Aquat. Toxicol. 10:335352.

Kenaga, E. E. 1973. Factors to be considered in the evaluation of the toxicity of pesticides to birds in the environment. Environ. Qual. Saf. 2:166-181.

Kimball, G. Manuscript. The effects of lesser known metals and one organic to fathead minnows [Pimephales promelas] and Daphnia magna.

Knowles, C. O., M. J. McKee, and D. U. Palawski. 1987. Chronic effects of di-2-ethylhexyl phthalate on biochemical composition, durvival and reproduction of Daphnia magna. Environ. Toxicol. Chem. 6:201-208.

Koenst, W. M., L. L. Smith, Jr., and S. J. Broderius. 1977. Effect of chronic exposure of brook trout to sublethal concentrations of hydrogen cyanide. Environmental Science and Technology 11:883-886.

Kroodsma, R. L. 1987. Resource Management Plan for the Oak Ridge Reservation. Volume 24: Threatened and endangered animal species. ORNL/ESH-1/V24. Oak Ridge National Laboratory, Oak Ridge, Tennessee.

Lazareva, L. P. 1985. Changes in biological characteristics of Daphnia magna from chronic action of copper and nickel at low concentrations. Hydrobiol. J. 21(5):59-62.

Lemly, A. D., and G. J. Smith. n.d. Aquatic cycling of selenium: Implications for fish and wildlife. Fish and Wildlife Leaflet 12:1-10.

Lima, A. R., C. Curtis, D. E. Hammermeister, T. P. Markee, C. E. Northcott, and L. T. Brooke. 1984. Acute and chronic toxicities of arsenic(III) to fathead minnows, flagfish, daphnids, and an amphipod. Arch. Environ. Contam. Toxicol. 13:595-601. 
Lincer, J. L. 1975. DOE-induced eggshell-thinning in the American kestrel: A comparison of the field situation and laboratory results. J. Appl. Ecol. 12:781-793.

Lind, D., K. Alto, and S. Chatterton. 1978. Regional copper-nickel study; aquatic toxicology study. Minnesota Environmental Quality Board.

Loar, J. M., J. A. Solomon, and G. F. Cada. 1981. Technical background infor. ation for the ORNL Environmental and Safety Report, Vol. 2: A description of the aquatic ecology of the White Oak Creek watershed and Clinch River below Melton Hill Dam. ORNL/TM-7509/V2. Oak Ridge National Laboratory, Oak Ridge, Tennessee.

Loar, J. M. and 15 others. 1987. First annual report of the ORNL Biological Monitoring and Abatement Program. Draft ORNL/TM-10399 . Oak Ridge National Laboratory, Oak Ridge, Tennessee.

Loar, J. M. (ed.). 1988. Second annual report of the ORNL Biological Monitoring and Abatement Program. Draft ORNL/TM-10804. Oak Ridge National Laboratory, Oak Ridge, Tennessee.

Loar, J. M. (ed.). 1989. Third annual report of the ORNL Biological Monitoring and Abatement Program. Draft ORNL/TM-11358. Oak Ridge National Laboratory, Oak Ridge, Tennessee.

Loar, J. M. (ed.). 1990. Fourth annual report of the ORNL Biological Monitoring and Abatement Program. Draft ORNL/TM-11544. Oak Ridge National Laboratory, Oak Ridge, Tennessee.

Loar, J. M. (ed.). 1991. Fifth annual report of the ORNL Biological Monitoring and Abatement Program. Draft ORNLTM-1485. Oak Ridge National Laboratory, Oak Ridge, Tennessee.

Lomenick, T. F., and D. A. Gardiner. 1965. The Occurrence and Retention of Radionuclides in Sediments of White Oak Lake. Health Phys. 11:567-577.

Macek, K. J., K. S. Buxton, S. K. Derr, J. W. Dean, and S. Sauter. 1976a. Chronic toxicity of lindane to selected aquatic inve-tehrates and fish. EPA-600/3-76-046. U.S. Environmental Protection Agency, Duluth, Minn.

Macek, K. J., M. A. Lindberg, S. Sauter, K. Buxton, and P. A. Costa. 1976b. Toxicity of four pesticides to water fleas and fathead minnows. EPA-600/3-76-099. U.S. Environmental Protection Agency, Duluth, Minn.

Mann, L. K. and J. T. Kitchings. 1982. Resource data inventory for the Oak Ridge area. ORNL/TM-7941. Oak Ridge National Laboratory, Oak Ridge, Tennessee.

Matsumura, F. 1985. Toxicology of Pesticides, 2nd ed. Plenum Press, New York. 
Mauck, W. L., P. M. Mehrle, and F. L. Mayer. 1978. Effects of the polychlorinated biphenyl Aroclor 1254 on growth, survival, and bone development in brook trout (Salvelinus fontinalis). J. Fish. Res. Board Can. 35:1084-1088.

Mayer, F. L., Jr., and H. O. Sanders. 1973. Toxicology of phthalic acid esters in aquatic organisms. Environmental Health Perspectives 5:153-157.

McCarthy, J. F., and D. K. Whitmore. 1985. Chronic toxicity of di-n-butyl and di-n-octyl phthalate to Daphnia magna and the fathead minnow. Environ. Toxicol. Chem. 4:167-179.

McCauley, D. J., L. T. Brooke, D. J. Call, and C. A. Lindberg. 1986. Acute and chronic toxicity of aluminum to Ceriodaphnia dubia at various pH's. Center for Lake Superior Environmental Studies, University of Wisconsin-Superior, Superior, Wis.

McKim, J. M., G. F. Olson, G. W. Holcombe, and E. P. Hunt. 1976. Long-term effects of methylmercuric chloride on three generations of brook trout (Salvelinus fontinalis): toxicity, accumulation, distribution, and elimination. J. Fish. Res. Board Can. 33:2726-2739.

Mehrle, P. M., and F. L. Mayer. 1976. Di-2-ethylhexyl phthalate: residue dynamics and biological effects in rainbow trout and fathead minnows. Trace Subst. Env. Health 10:519-524.

Münzinger, A. 1990. Effects of nickel on Daphnia magna during chronic exposure and alterations in the toxicity to generations pre-exposed to nickel. Wat. Res. 24:845-852.

National Research Council. 1977. Arsenic. National Academy Press, Washington, D.C.

National Research Council. 1980. Mineral Tolerance of Domestic Animals. National Academy Press, Washington, D.C.

Nebeker, A. V., C. K. McAuliffe, R. Mshar, and D. G. Stevens. 1983. Toxicity of silver to steelhead and rainbow trout, fathead minnows, and Daphnia magna. Environ. Toxicol. Chem. 2:95-104.

Nebeker, A. V., C. Savonen, and D. G. Stevens. 1985. Sensitivity of rainbow trout early life stages to nickel chloride. Environ. Toxicol. Chem. 4:233-239.

Nebeker, A. V., and F. A. Puglisi. 1974. Effect of polychlorinated biphenyl (PCBs) on survival and reproduction of Daphnia, Gammanus, and Tanytarsus. Trans. Amer. Fish. Soc. 103:722-728.

Nebeker, A. V., F. A. Puglisi, and D. L. DeFoe. 1974. Effect of polychlorinated biphenyl compounds on survival and reproduction of the fathead minnow and flagfish. Trans. Amer. Fish. Soc. 103:562-568. 
NIOSH (National Institute of Occupational Safety and Health). 1988. Registry of Toxic Effects of Chemical Substances (RTECS). Washington, D.C.

Oakes, T. W., B. A. Kelly, W. O. Ohnesorge, J. S. Eldridge, J. C. Bird, K. E. Shanks, and F. S. Tsakeres. 1982. Technical background information for the ORNL Environmental and Safety Report, Vol. 4: White Oak Lake and Dam. ORNL/TM-7509/V4. Oak Ridge National Laboratory, Oak Ridge, Tennessee.

ORNL (Oak Ridge National Laboratory). 1990. Remedial Investigation Plan for Waste Area Grouping 2 at Oak Ridge National Laboratory, ES/ER-14\&D1. Oak Ridge, Tennessee.

OSWER (Office of Solid Waste and Emergency Response). 1991. OSWER Directive 9285.6-03, March 25, 1991. Office of Emergency and Remedial Response Toxics Integration Branch, U.S. EPA, Washington, D.C. 20460.

OWRS (Office of Water Regulations and Standards). 1988. Interim sediment criteria values for nonpolar hydrophobic organic contaminants. SCD \#17. U.S. Environmental Protection Agency, Washington, D.C.

OWRS (Office of Water Regulations and Standards). 1989. Briefing report to the EPA Science Advisory Board on the equilibrium partitioning approach to generating sediment quality criteria. EPA 440/5-89-012. Washington, D.C.

Ohlendorf, H. M., D. J. Hoffman, M. K. Saiki, and T. W. Aldrich. 1986. Embryonic mortality and abnormalities of aquatic birds: Apparent impacts of selenium from irrigation drainwater. Sci. Total Environ. 52:49-63.

Peakall, D. B. 1986. Accumulation and effects on birds. pp. 31-47. J. S. Waide (ed.), PCBs and the Environment, Vol. II, CRC Press, Boca Raton, Florida.

Richter, J.E., S. F. Peterson, and C. F. Kleiner. 1983. Acute and chronic toxicity of some chlorinated benzenes, chlorinated ethanes, and tetrachloroethylene to Daphnia magna. Arch. Environ. Contam. Toxicol. 12:679-684.

Ringer, R. K. 1983. Toxicology of PCBs in mink and ferrets. pp. 227-240. F. M. Itri and M. A. Kamrin. PCBs: Human and Environmental Hazards. Butterworth Publishers, Boston.

Sadler, K, and S. Lynam. 1988. The influence of calcium on aluminum-induced changes in the growth rate and mortality of brown trout, Salmo trutta L. J. Fish Biol. 33:171-179.

Sauter, S., K. S. Buxton, K. J. Macek, and S. R. Petrocelli. 1976. Effects exposure to heavy metals on selected freshwater fish. EPA-600/3-76-105. U.S. Environmental Protecion Agency, Duluth, Minn. 
Sheffy, T. B., and J. R. St. Amant. 1982. Mercury burdens in furbearers in Wisconsin. J. Wildl. Manage. 46:1117-1120.

Sherwood, C. B. and J. M. Loar. 1987. Environmental data for the White Oak Creek/White Oak Lake watershed. ORNL/TM-4662. Oak Ridge National Laboratory, Oak Ridge, Tennessee.

Sigal, L. L., and G. W. Suter II. 1989. Potential effects of chemical agents on terrestrial resources. Environ. Prof. 11:376-384.

Smith, A. D., A. Bharath, C. Mallard, D. Orr, K. Smith, J. A. Sutton, J. Vukmanich, L. S. McCarty, and G. W. Ozburn. 1991. The acute and chronic toxicity of ten chlorinated organic compounds to the American Flagfish (Jordanella floridae). Arch. Environ. Contam. Toxicol. 20:94-102.

Smith, L. R., T. M. Holsen, N. C. Ibay, R. M. Block, and A. B. de Leon. 1985. Studies on the acute toxicity of fluoride ion to stickleback, fathead minnow, and rainbow trout. Chemosphere 14(9):1383-1389.

Spehar, R. L. 1976. Cadmium and zinc toxicity to flagfish, Jondanella floridae. J. Fish. Res. Board Can. 33:1939-1945.

Spehar, R. L., J. T. Fiandt, R. L. Anderson, and D. L. DeFoe. 1980. Comparative toxicity of arsenic compounds and their accumulation in invertebrates and fish. Arch. Environ. Contam. Toxicol. 9:53-63.

Stephan, C. E., D. I. Mount, D. J. Hansen, J. H. Gentile, G. A. Chapman, and W. A. Brungs. 1985. Guidelines for deriving numerical national water quality criteria for the protection of aquatic organisms and their uses. PB85-227049. National Technical Information Service, Springfield, Va.

Stephan, C. E., and J. R. Rogers. 1985. Advantages of using regression analysis to calculate results of chronic toxicity tests. pp. 328-339. IN R. C. Bahner and D. J. Hansen (eds.), Aquatic Toxicology and Hazard Assessment: Eighth Symposium, American Society for Testing and Materials, Philadelphia.

Stevens, D. G., and G. A. Chapman. 1984. Toxicity of trivalent chromium to early life stages of steelhead trout. Environ. Toxicol. Chem. 3:125-133.

Suter, G. W., II, A. E. Rosen, E. Linder, and D. F. Parkhurst. 1987. End points for responses of fish to chronic toxic exposures. Environ. Toxicol. Chem. 6:793-809.

Thompson, R. S., and N. G. Carmichael. 1989. 1,1,1-Trichloroethane: medium-term toxicity to carp, daphnids, and higher plants. Ecotox. Environ. Safety 17:172-182. 
Tucker, R. K, and J. S. Lietzke. 1979. Comparative toxicity of insecticides for vertebrate wildlife and fish. Pharmac. Ther. 6:167-220.

Veith, G. D., D. J. Call, and L. T. Brooke. 1983. Structure-toxicity relationships for the fathead minnow, Pimephales promelas: Narcotic industrial chemicals. Can. J. Fish. Aquat. Sci. 40:743-748.

Venugopal, B., and T. D. Luckey. 1978. Metal Toxicity in Mammals-2. Plenum Press, New York.

Woodward, D. F., A. F. Farag, M. E. Mueller, E. E. Little, F. A. Vertucci. 1989. Sensitivity of endemic Snake River cutthroat trout to acidity and elevated aluminum. Trans. Amer. Fish. Soc. 118:630-643.

Wren, C. D., D. B. Hunter, J. F. Leatherland, and P. M. Stokes. 1987. The effects of polychlorinated biphenyls and methylmercury, singly and in combination, on mink. I: Uptake and toxic responses. Arch. Environ. Contam. Toxicol. 16:441-447. 


\section{APPENDIX A}

NONCONSERVATIVE SCREENING OF THE DETECTABLE CONTAMINANTS DATA BASE FOR CARCINOGENS AND NONCARCINOGENS 


\section{WHITE OAK CREEK WATERSHED REFERENCES}

The following references were reviewed for pertinent data in the development of the Risk Assessment data base.

Abee, H. H. 1953. Radioactivity in the Mud of White Oak Lake. ORNL-1580. Oak Ridge National Laboratory, Oak Ridge, Tennessee. 24 pp.

Auerbach, S. I., et al. 1957. Ecological research. pp. 10-39. IN Health Physics Division Annual Progress Report, July 31, 1957. ORNL-2384. Oak Ridge National Laboratory, Oak Ridge, Tennessee.

Auerbach, S. I., et al. 1958. Ecological research. pp. 27-52. IN Health Physics Division Annual Progress Report, July 21, 1958. ORNL-2590. Oak Ridge National Laboratory, Oak Ridge, Tennessee.

Auerbach, S. I., et al. 1959. Ecological research. pp. 18-54. IN Health Physics Division Annual Progress Report, July 31, 1959. ORNL-2806. Oak Ridge National Laboratory. Oak Ridge, Tennessee.

Auerbach, S. I., et al. 1960. Ecological research. pp. 147-166. IN Health Physics Division Annual Progress Report, July 31, 1960. ORNL-2994. Oak Ridge National Laboratory, Oak Ridge, Tennessee.

Auerbach, S. I., et al. 1961. White Oak Lake bed studies. pp.81-105. IN Health Physics Division Annual Progress Report, July 31, 1961. ORNL-3189. Oak Ridge National Laboratory, Oak Ridge, Tennessee.

Auerbach, S. I., et a!. 1962. Radiation ecology. pp. 47-72. IN Health Physics Division Annual Progress Report, July 31, 1962. ORNL-3347. Oak Ridge National Laboratory, Oak Ridge, Tennessee.

Auerbach, S. I., et al. 1963. Radiation ecology. pp. 81-115. IN Health Physics Division Annual Progress Report. June 30, 1963. ORNL-3492. Oak Ridge National Laboratory, Oak Ridge, Tennessee.

Auerbach, S.I., et al. 1975. Tritium concentration in a forest ecosystem contaminated by seepage. pp. 86-87. IN Environmental Sciences Division Annual Progress Report, for period ending Sept. 30, 1974. ORNL-5016. Oak Ridge National Laboratory, Oak Ridge, Tennessee.

Auerbach, S. I. et al. 1976. Tritium-contaminated floodplain. pp. 106-109. IN Environmental Sciences Division Annual Progress Report for Period Ending September 30, 1975. ORNL-5193. Oak Ridge National Laboratory, Oak Ridge, Tennessee.

Auerbach, S. I., and D. A. Crossley, Jr. 1958. Strontium-90 and cesium-137 uptake by vegetation under natural conditions. pp. 494-499. IN Proc., Second Int. Conf. on Peaceful Uses of Atomic Energy, Vol. 18, Geneva. Pergamon Press, London. 
Auerbach, S. I., and J. S. Olson. 1963. Biological and environmental behavior of ruthenium and rhodium. pp. 509-519. IN V. Schultz and A. W. Klement, Jr., Eds. Proc., First National Symposium on Radioecology. Reinhold Publishing Co., New York, and AIBS, Washington, DC.

Blaylock, B. G. 1965. "Chromosomal aberrations in natural population of Chironomus tentans exposed to chronic low-level radiation." Evolution 19(3):421-429.

Blaylock, B. G. 1966. "Chromosomal polymorphism in irradiated natural populations of Chironomus." Genetics 53(1):131-136.

Blaylock, B. G. 1966. “Cytogenetic study of a natural population of Chironomus inhabiting an area contaminated by radioactive waste." pp. 835-846. IN Disposal of Radioactive Wastes into Seas, Oceans, and Surface Waters, International Atomic Energy Agency, Vienna.

Blaylock, B. G. 1969. "The fecundity of a Gambusia affinis population exposed to chronic environmental radiation." Radiat. Res. 37:108-117.

Blaylock, B. G., and T. J. Mitchell. 1969. "The effect of temperature on the dose response of Gambusia affinis affinis from two natural populations." Radiat. Res. 40(3):503-511.

Bondietti, E. A., S. A. Reynolds, and M. H. Shanks. 1976. Interaction of plutonium with complexing substances in soils and natural waters. pp. 273-287. IN Transuranium Nuclides in the Environment. IAEA, Vienna.

Bondietti, E. A., and C. T. Garten. (1986). Speciation of Tc-99 and Co-60: Correlation of laboratory and field observations. pp. 79-92. IN Speciation of Fission and Activation Products in the Environment, University of Oxford, April, 1985.

Bondietti, E. A, and F. H. Sweeton. 1977. Transuranic speciation in the environment. pp. 449-476. IN M. G. White and P. B. Dunaway, Eds. Transuranics in Natural Environments. NVO-178. NTIS, Springfield, Virginia.

Bondietti, E. A, and T. Tamura. 1980. Physiochemical associations of plutonium and other actinides in soils. pp. 145-164. IN W. C. Hanson, Ed. Transuranic Elements in the Environment. DOE/TIC-22800. NTIS, Springfield, Virginia.

Bondietti, E. A., J. R. Trabalka, C. T. Garten, and G. G. Killough. 1979. Riogeoc'semistry of astinides: a nuclear fuel cycle perspective. pp. 241-265. IN S. Fried, Ed. Radioactive Waste in Geologic Storage, ACS Symposium Series 100. American Chemical Society, Washington, DC.

Boyle, J. W., R. Blumberg, S. J. Cotter, G. S. Hill, C. R.Kerley, R. H. Kettelle, R. L. Kroodsma, D. W. Lee, R. C. Martin, R. D. Roop, D. N. Secora, W. P. Staub, and R. E. Thoma. 1982. Environmental Analysis of the Operation of the Oak Ridge National Laboratory (X-10 Site). ORNL-5870. Oak Ridge National Laboratory, Oak Ridge, Tennessee. $185 \mathrm{pp}$. and appendices. 
Cerling, T. E., and B. P. Spalding. 1981. Areal distribution of Co-60, Cs-137, and Sr-90 in streambed gravels of White Oak Creek Watershed, Oak Ridge, Tennessee.

ORNL/TM-7318. Oak Ridge National Laboratory, Oak Ridge, Tennessee.

Cerling, T. E. and B. P. Spalding. 1982. "Distribution and relationship of radionuclides to streambed gravels in a small watershed." Environ. Geol 4:99-116.

Childs, H. E., and G. E. Cosgrove. 1966. "A study of pathological conditions in wild rodents in radioactive areas." Amer. Midl. Nat. 76:309-324.

Cooley, J. L. 1973. "Effects of chronic environmental radiation on a natural population of the aquatic snail Physa heterostropha." Radiat. Res. 54(1):130-140.

Dahlman, R. C., and P. Van Voris. 1976. Cycling of Cs-137 in soil and vegetation of a flood plain 30 years after initial contamination. pp. 291-298. IN C. E. Cushing, Jr., Ed. Radioecology and Energy Resources. Dowden, Hutchinson, and Ross, Inc., Stroudsburg, Pennsylvania.

Delaney, M. S., R. C. Dahlman, and R. B. Craig. 1979. An investigation of plutonium concentration and distribution in burrowing crayfish from the White Oak Creek floodplain. ORNL/TM-6702. Oak Ridge National Laboratory, Oak Ridge, Tennessee.

DeSelm, H. R., and R. E. Shanks. 1967. "Vegetation and floristic changes on a portion of White Oak Lake bed." Ecology 48:419-425.

Elwood, J. W. 1973. Tritium behavior in fish from a chronically contaminated lake. pp. 435-439. IN D. J. Nelson, Ed. Radionuclides in Ecosystems. Proc., Third National Symposium on Radiooecology. CONF-710501. 1268 pp.

Kaye, S. V., and P. B. Dunaway. 1962. "Bioaccumulation of radioactive isotopes by herbivorous small mammals." Health Phys. 7:205-217.

Kolehmainen, S. E. 1972. "The balances of Cs-137, stable cesium and potassium of bluegill (Lepomis macrochirus Raf.) and other fish in White Oak Lake." Health Phys. 23:301-315.

Kolehmainen, S. E. and D. J. Nelson. 1969. The balances of 137cesium, stable cesium, and the feeding rates of bluegill (Lepomis macrochinus Raf.) in White Oak Lake. ORNL-4445. Oak Ridge National Laboratory, Oak Ridge, Tennessee.

Kornegay, F. C., D. C. West, S. T. Goodpasture, C. W. Kimbrough, M. F. Tardiff, V. A. Jacobs (ed.), and A. R. Wilson (ed.). 1990. Oak Ridge Reservation Environmental Report for 1989. Volume 2: Data Presentation. ES/ESH-13/V2. Martin Marietta Energy Systems, Inc., Oak Ridge, Tennessee. 
Loar, J. M., F. A. Burkhart, G. F. Cada, J. W. Huckabee, J. T. Kitchings, K. D. Kumar, A. M. Sasson, J. A. Solomon, and J. D. Story. 1981. Ecological studies in the vicinity of the Oak Ridge Gaseor's Diffusion Plant. ORNL/TM-6714. Oak Ridge National Laboratory, Oak Ridge, Tennessee. 329 pp.

Lomenick, T. F., H. J. Wyrick, R. M. Richardson, W. M. McMasters, and T. W. Hodge, Jr. 1962. Study of the White Oak Creek drainage basin. pp. 27-34. IN Health Physics Division Annual Progress Report for period ending July 31, 1962. ORNL-3347. Oak Ridge National Laboratory, Oak Ridge, Tennessee.

Martin Marietta Energy Systems, Inc. 1984. Environmental Monitoring Report, United States Department of Energy Oak Ridge Facilities, Calendar Year 1983. Y/UB-19. Martin Marietta Energy Systems, Environment, Safety, and Health Division, Oak Ridge, Tennessee. 123 pp.

Martin Marietta Energy Systems, Inc. 1985. Environmental Monitoring Report, United States Department of Energy Oak Ridge Facilities, Calendar Year 1984. ORNL-6209. Martin Marietta Energy Systems, Environment, Safety, and Health Division, Oak Ridge, Tennessee. 143 pp.

Martin, R. E., S. I. Auerbach, and D. J. Nelson. 1964. Growth and movement of smallmouth buffalo, Ictobus bubalus, in Watts Bar reservoir, Tennessee. ORNL 3530. Oak Ridge National Laboratory. Oak Ridge, Tennessee. 100 pp.

Neal, E. C., B. C. Patten, and E. E. DePoe. 1967. "Periphyton growth on artificial substrates in a radioactively contaminated lake." Ecology 48(6):918-924.

Nelson, D. J., and B. G. Blaylock. 1963. The preliminary investigation of salivary gland chromosomes of Chironomus tentans Fabr. from the Clinch River. pp. 367-372. IN V. Schultz and A. W. Klement, Eds. Proc., First National Symposium on Radioecology. Reinhold Publishing Co., New York and AIBS, Washington, DC.

Oakes, T. W., B. A. Kelly, W. F. Ohnesorge, J. S. Eldridge, J. C. Bird, K. E. Shank, and F. S. Tsakeres. 1982. Technical Background Information for the Environmental and Safety Report, Vol. 4: White Oak Lake and Dam. ORNL-5681. Oak Ridge National Laboratory, Oak Ridge, Tennessee.

Oak Ridge National Laboratory. 1985. Environmental Monitoring Report, United States Department of Enengy Oak Ridge Facilities Calendar Year 1984. Oak Ridge National Laboratory. ORNL-6209. Oak Ridge, Tennessee. 143 pp.

Ohnesorge, W. F. 1986. Historical releases of radioactivity to the environment from ORNL. Oak Ridge National Laboratory. ORNL/M-135. Oak Ridge, Tennessee. 25 pp. and appendix.

Reed, J. L. 1971. "Uptake and excretion of Co-60 by black bullheads Ictalurus melas (Rafinesque)." Health Phys. 21:835-844. 
Rosenthal, G. M., Jr., D. J. Nelson, and D. A. Gardiner. 1965. "Deposition of strontium and calcium in snail shell." Nature 207(4992):51-54.

Tamura, T. 1976. Physical and chemical characteristics of plutonium in existing contaminated soils and sediments. pp. 213-222. IN Transuranium Nuclides in the Environment. IAEA, Vienna.

Trabalka, J. R., and C. P. Allen. 1977. "Aspects of fitness of a mosquitofish Gambusia affinis population exposed to chronic low-level environmental radiation." Radiat. Res. 70:198-211.

Tennessee Valley Authority (TVA). 1985a. Instream contaminant study, Task 2: sediment characterization Volume I. Report to United States Department of Energy, Oak Ridge Operations Office. Tennessee Valley Authority, Office of Natural Resources and Economic Development. Knoxville, Tennessee. 82 pp.

Tennessee Valley Authority (TVA). 1985b. Instream contaminant study, Task 2: sediment characterization Volume II-Appendices report to United States Department of Energy, Oak Ridge Operations Office. Tennessee Valley Authority, Office of Natural Resources and Economic Development. Knoxville, Tennessee. 450 pp.

Tennessee Valley Authority (TVA). 1985c. Instream contaminant study, Task 4: fish sampling and analysis. Report to United States Department of Energy, Oak Ridge Operations Office. Tennessee Valley Authority, Office of Natural Resources and Economic Development, Knoxville, Tennessee.

Tennessee Valley Authority (TVA). 1985d. Instream contaminant study, Task I: water sampling and analysis. Report to United States Department of Energy, Oak Ridge Operations Office. Tennessee Valley Authority. Knoxville, Tennessee.

Willard, W. K 1960. "Avain uptake of fission products from an area contaminated by low-level atomic wastes." Science 132:148-150. 


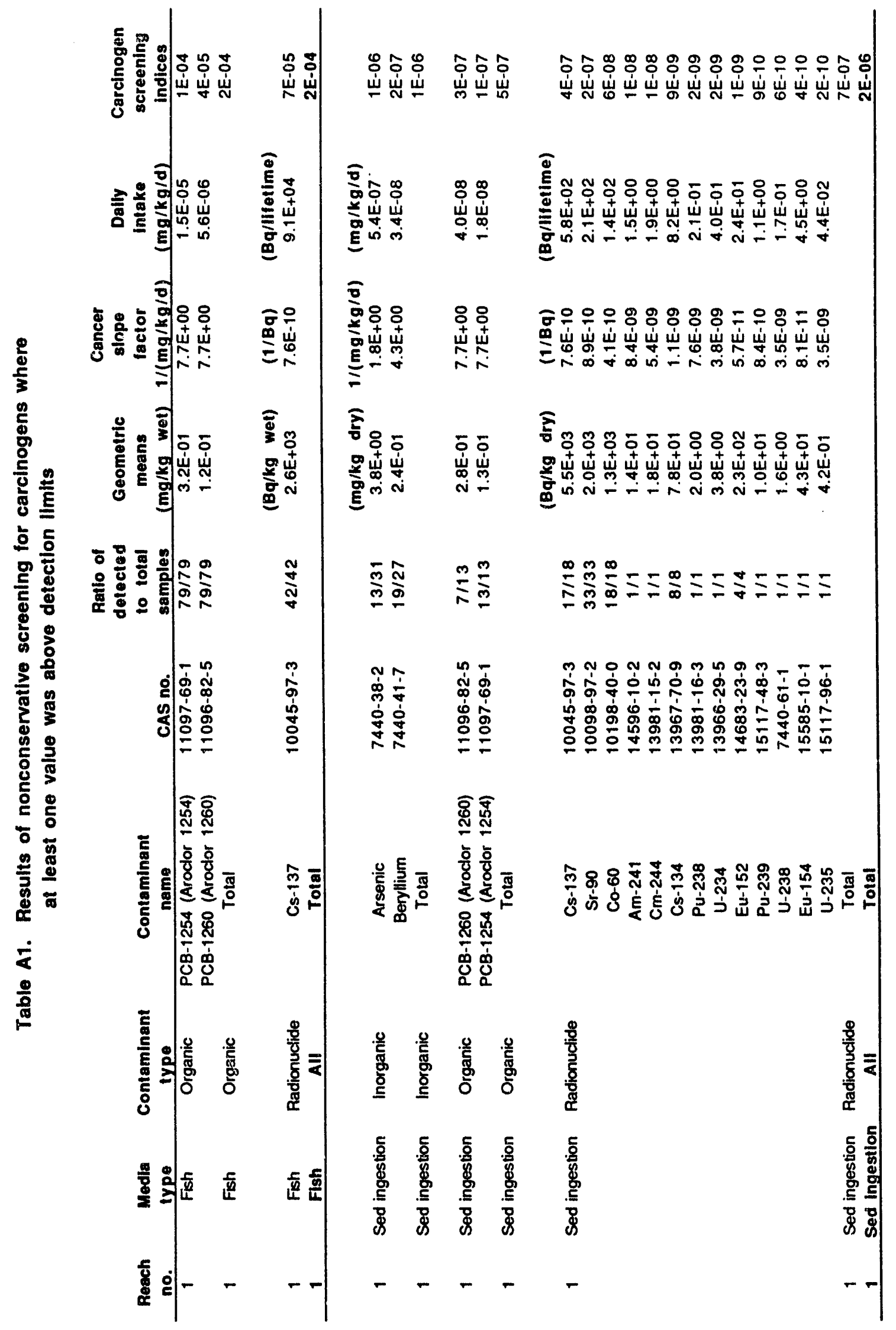




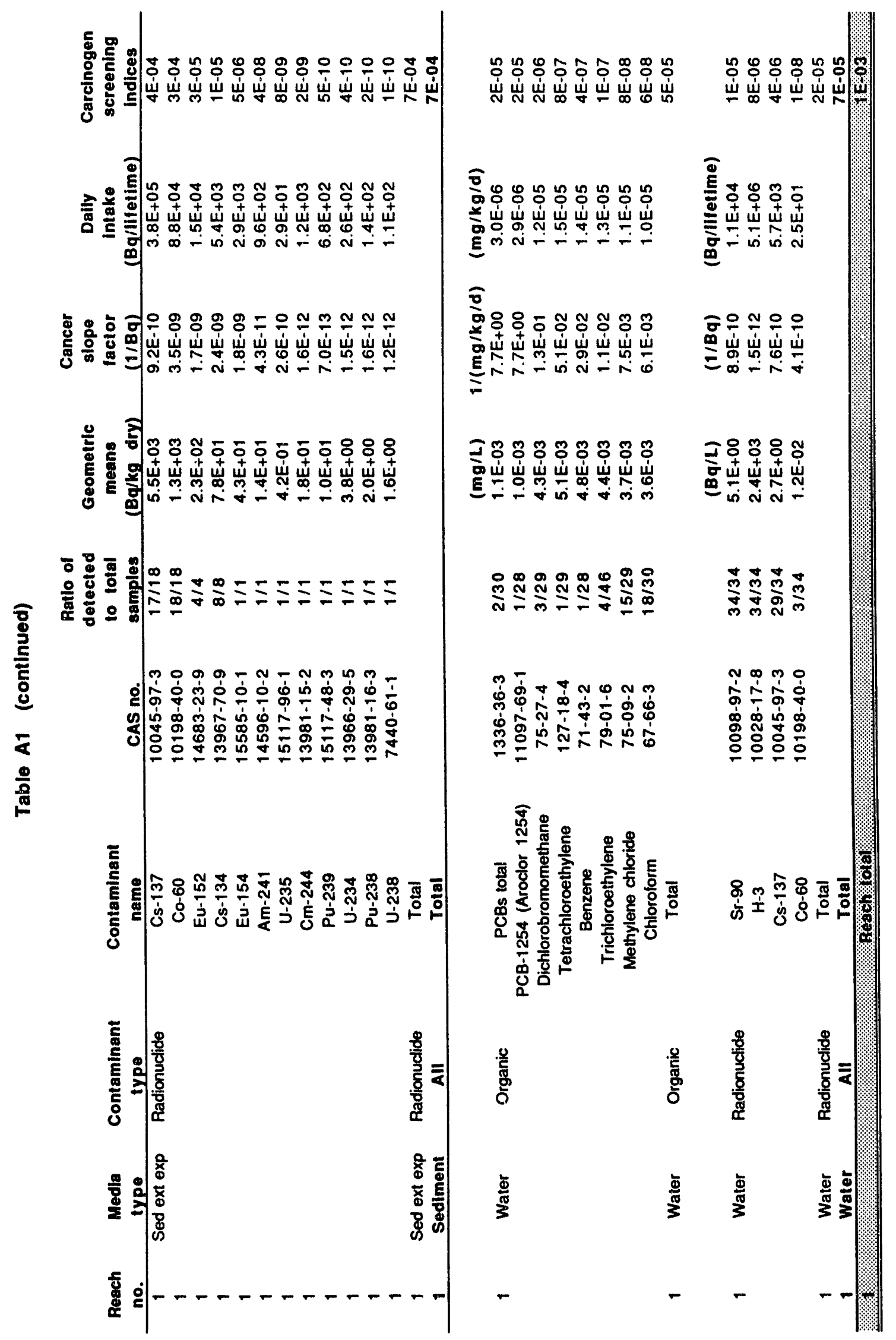




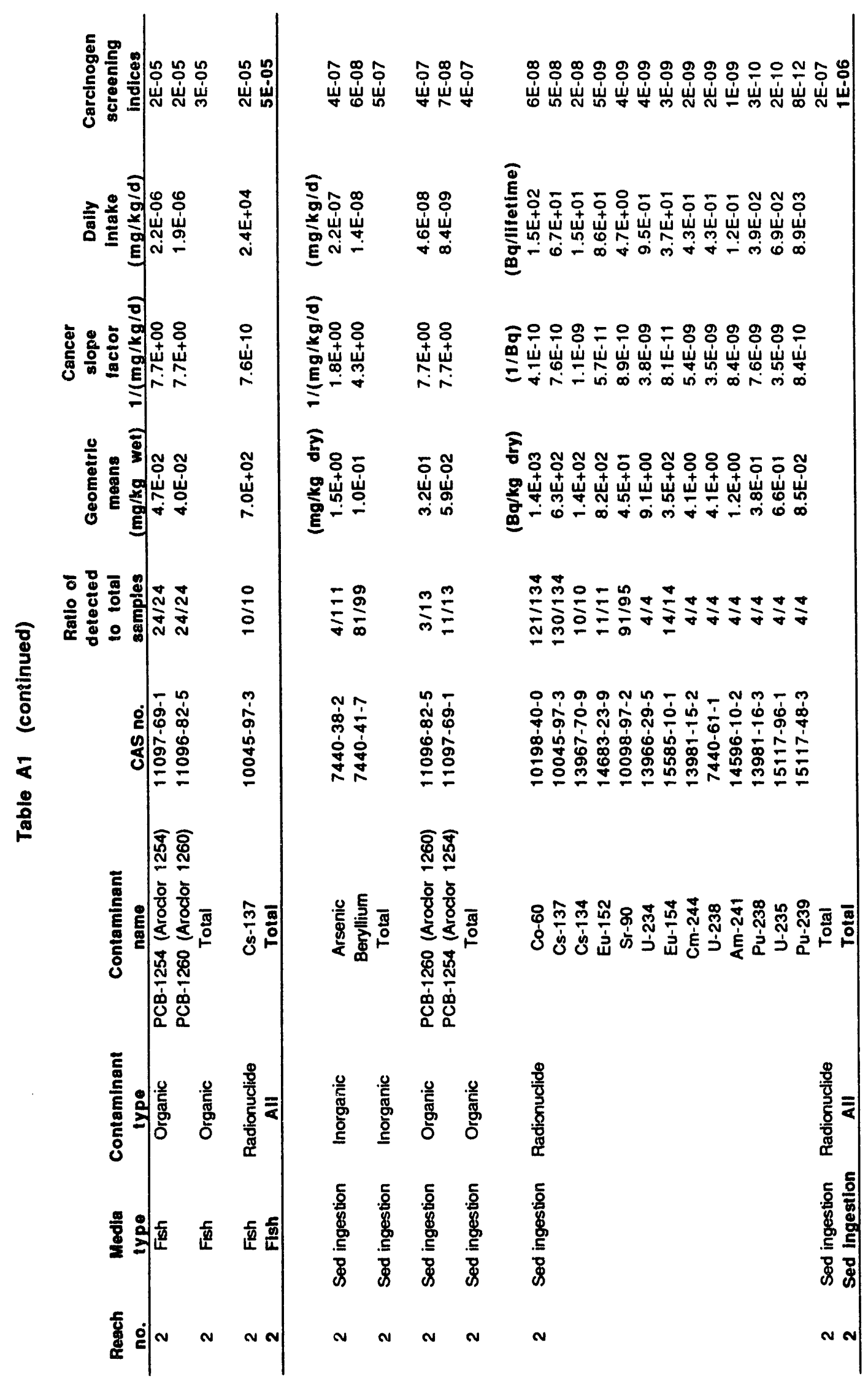




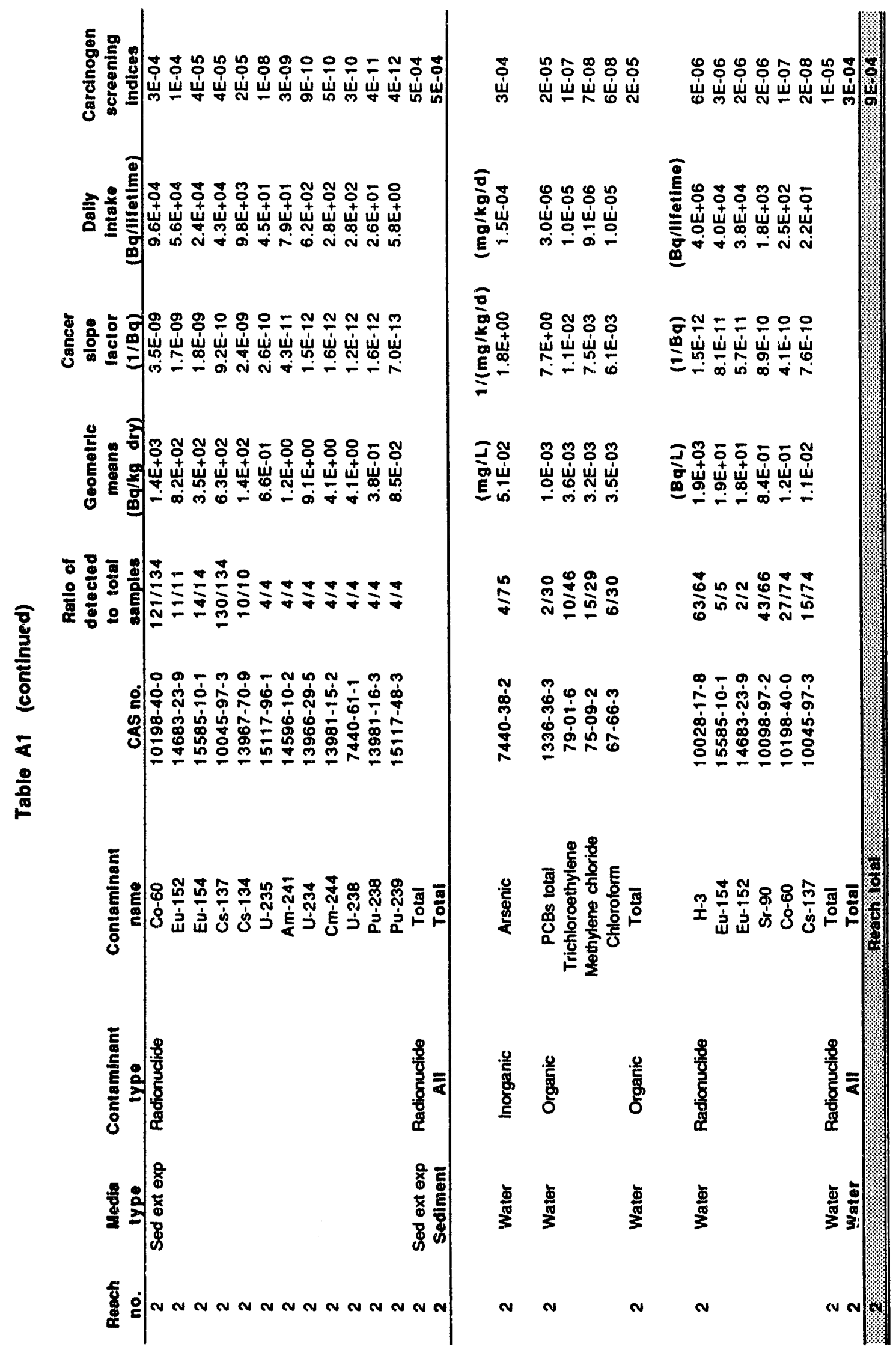




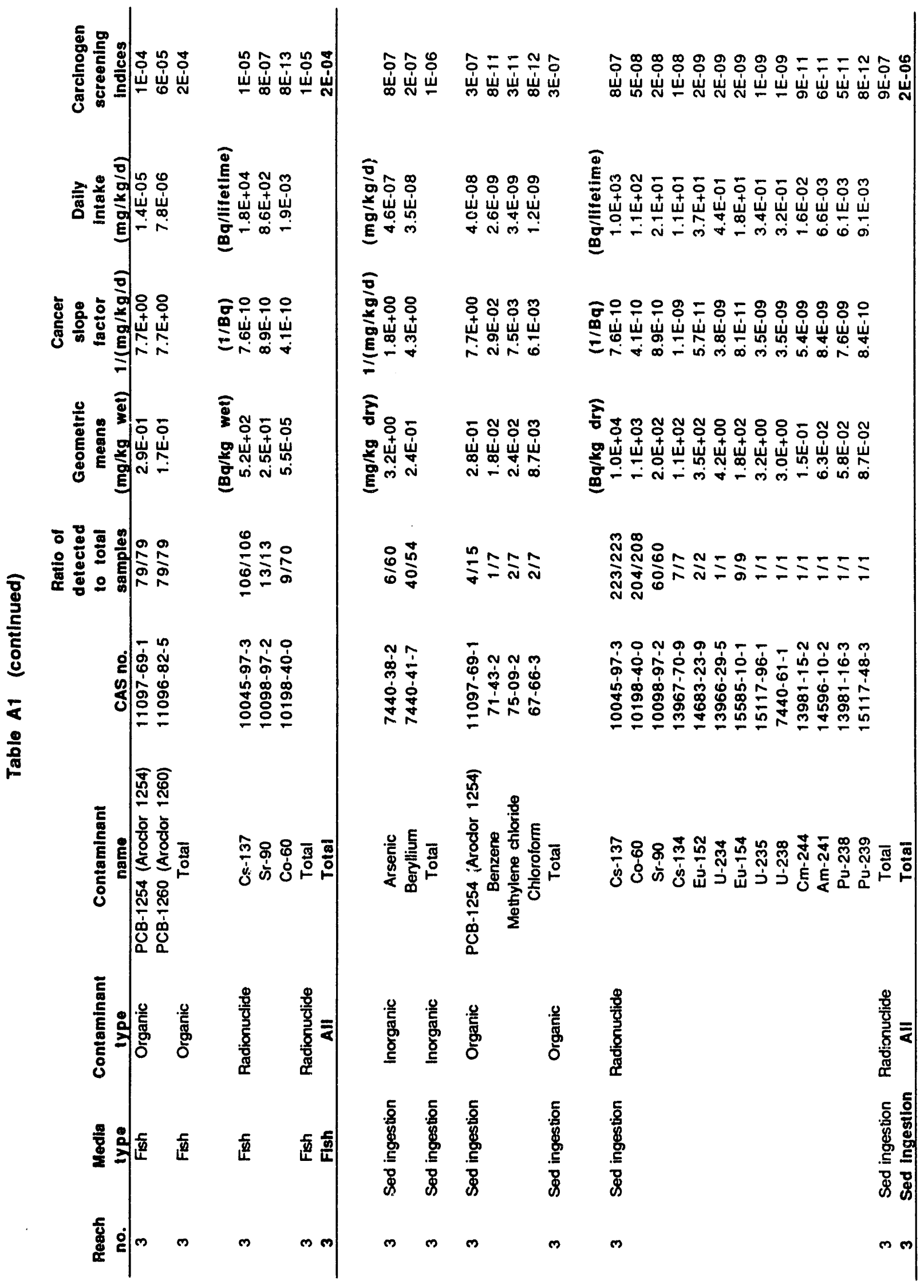




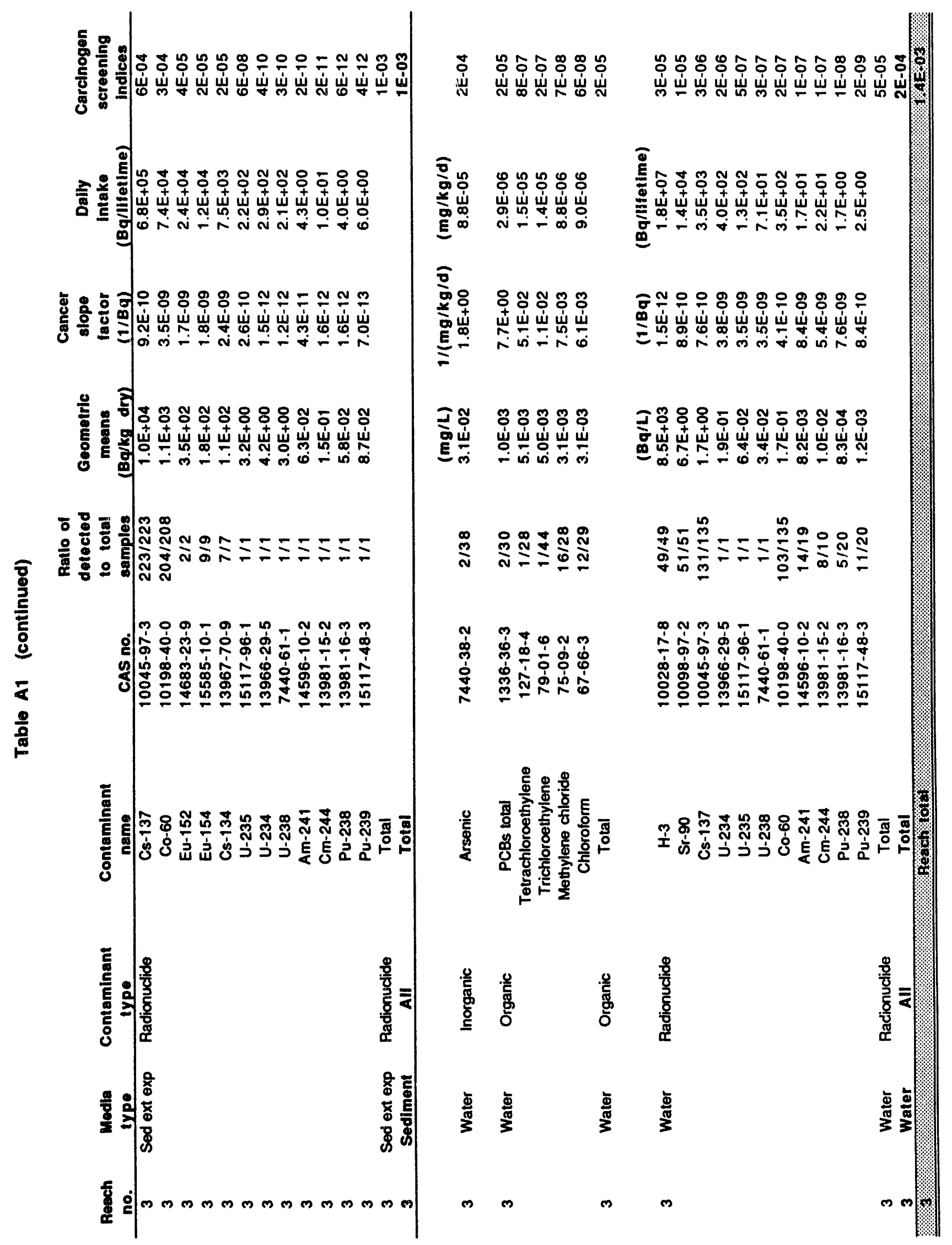




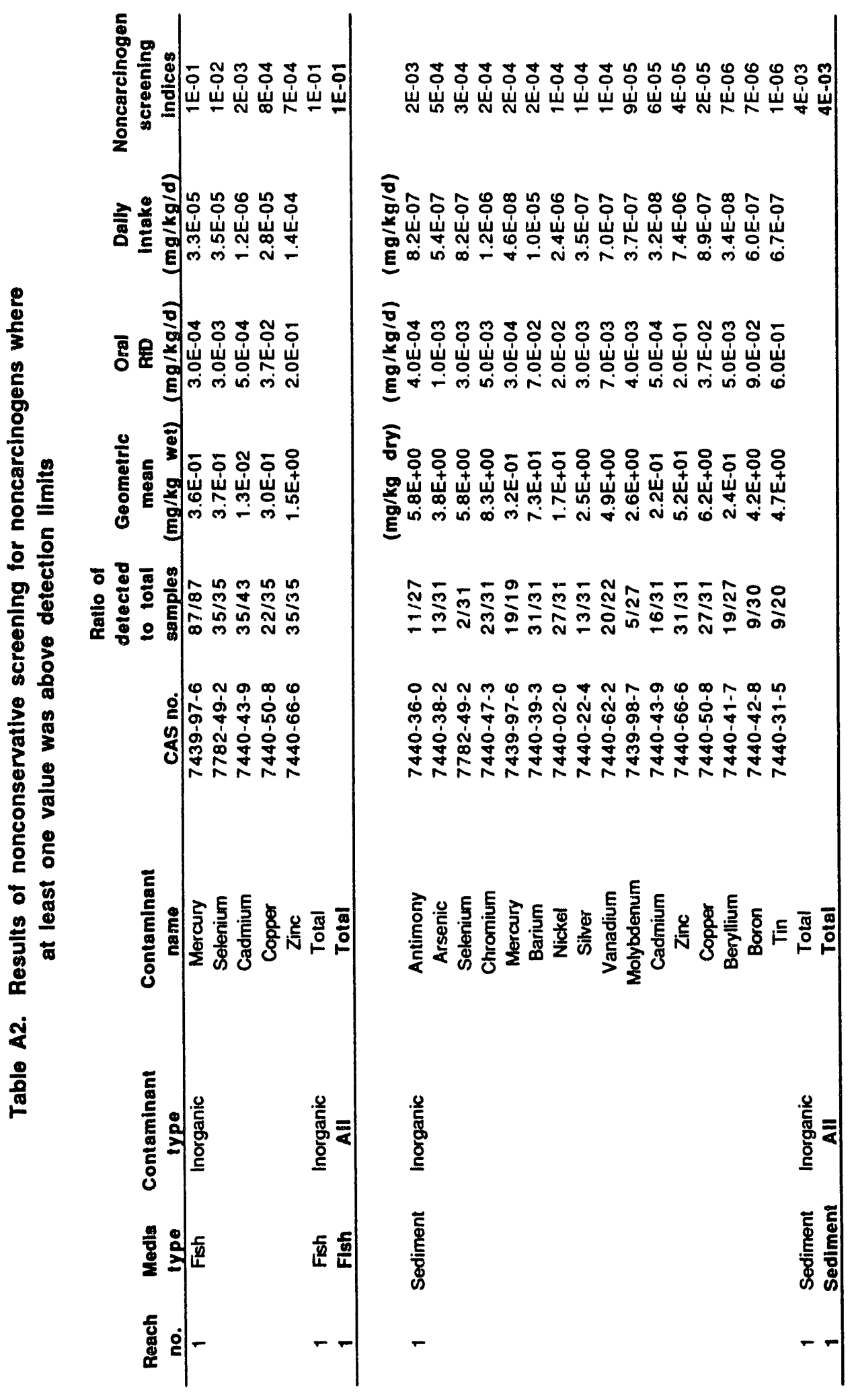




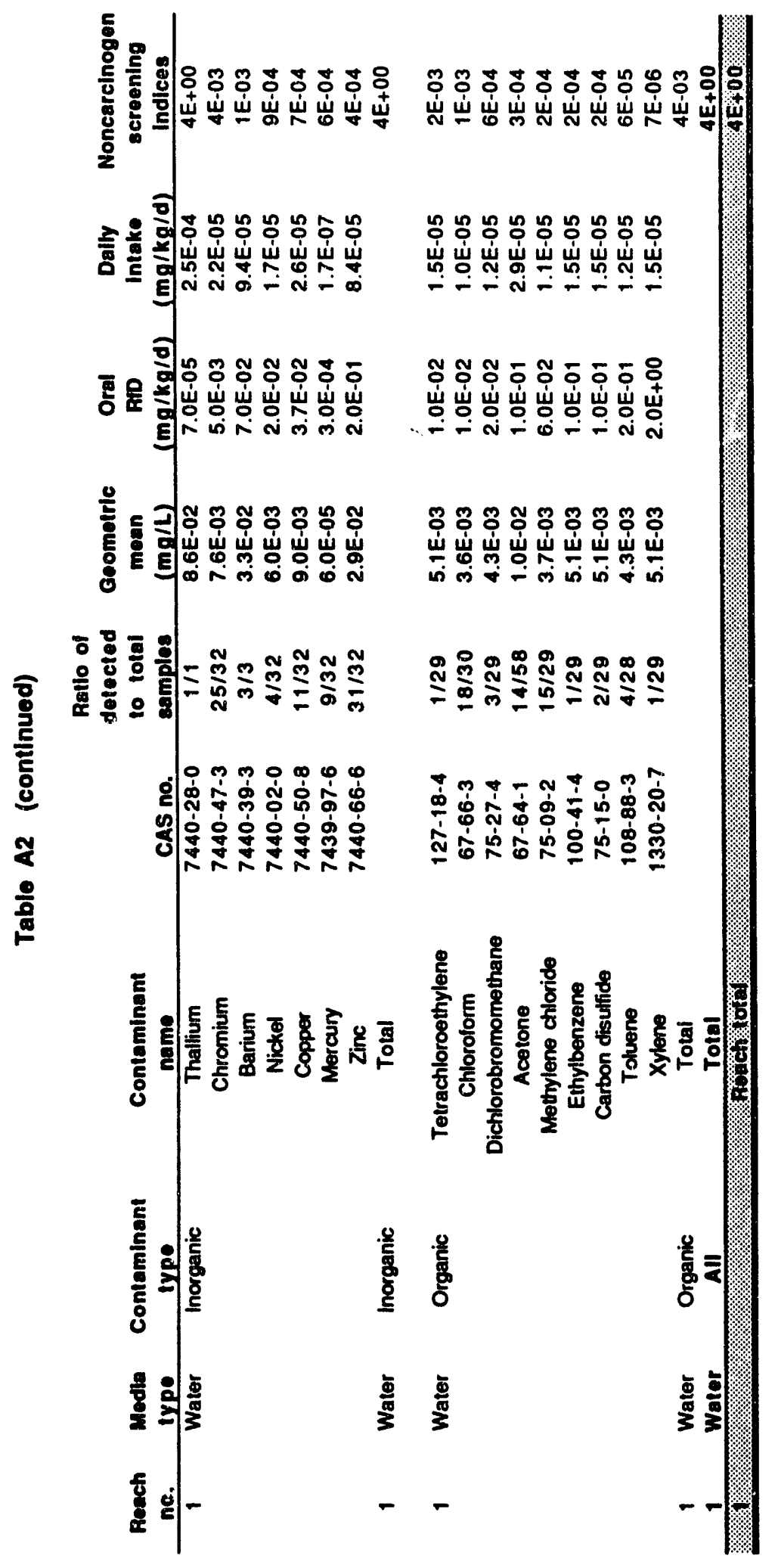




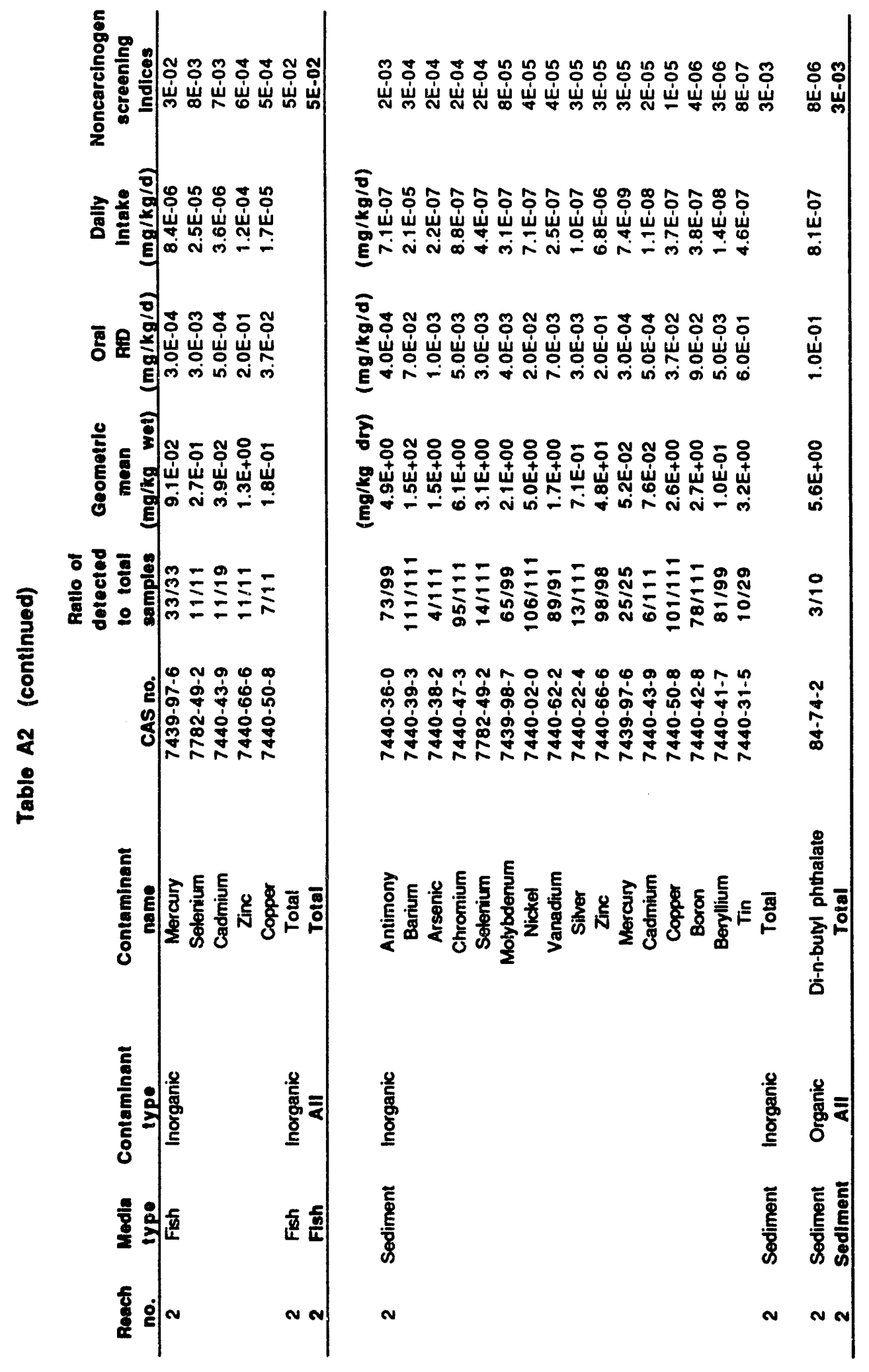




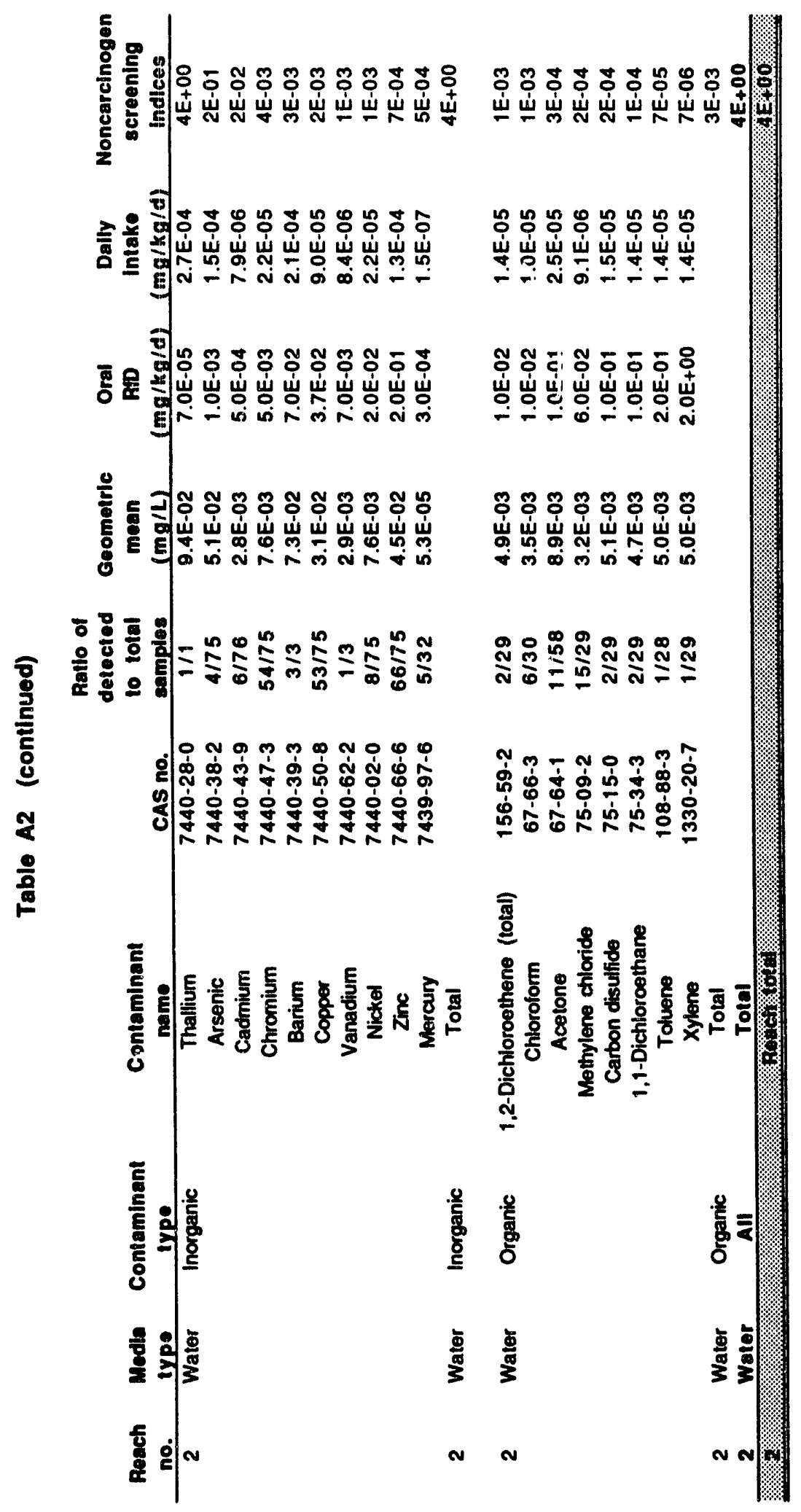




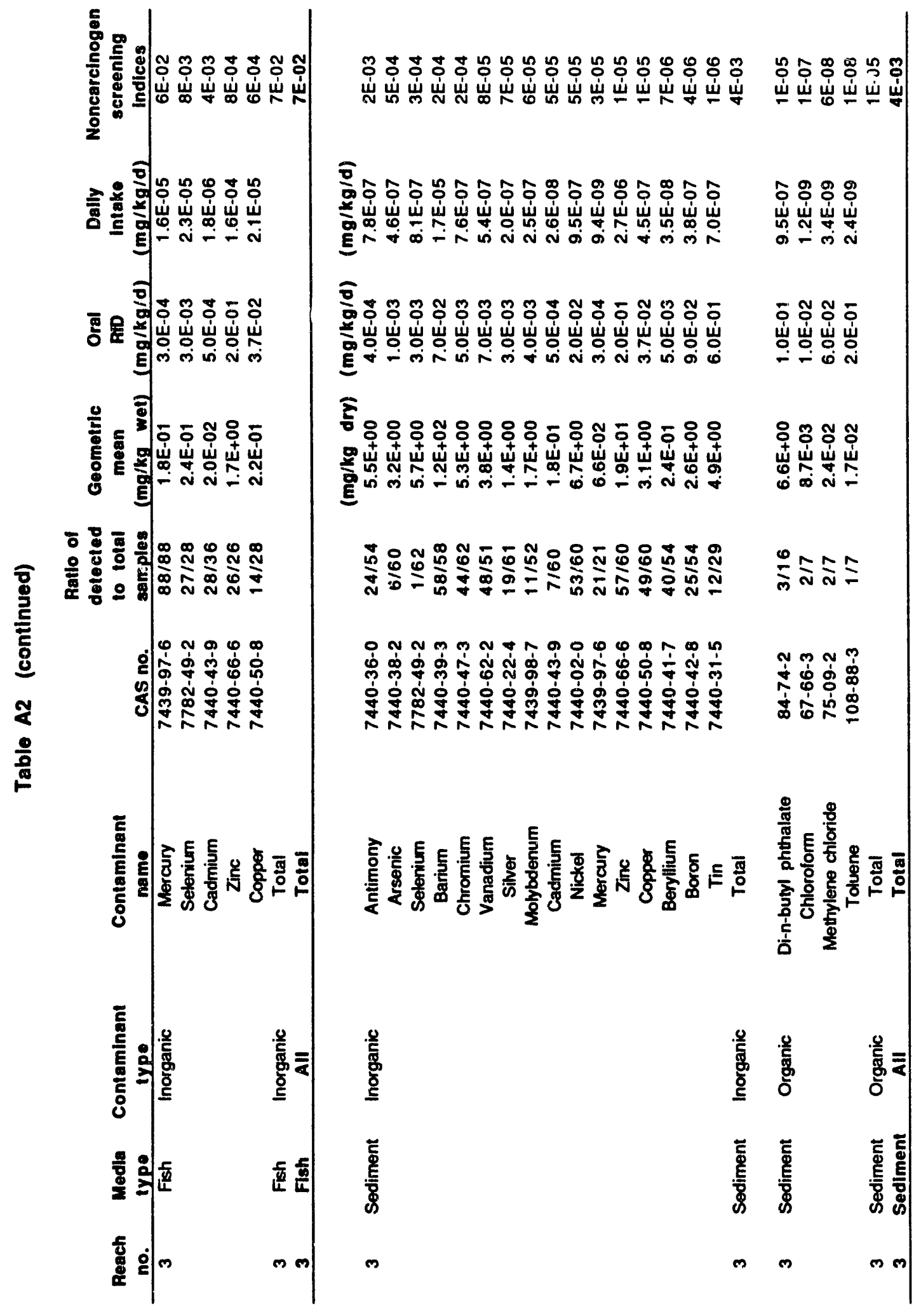




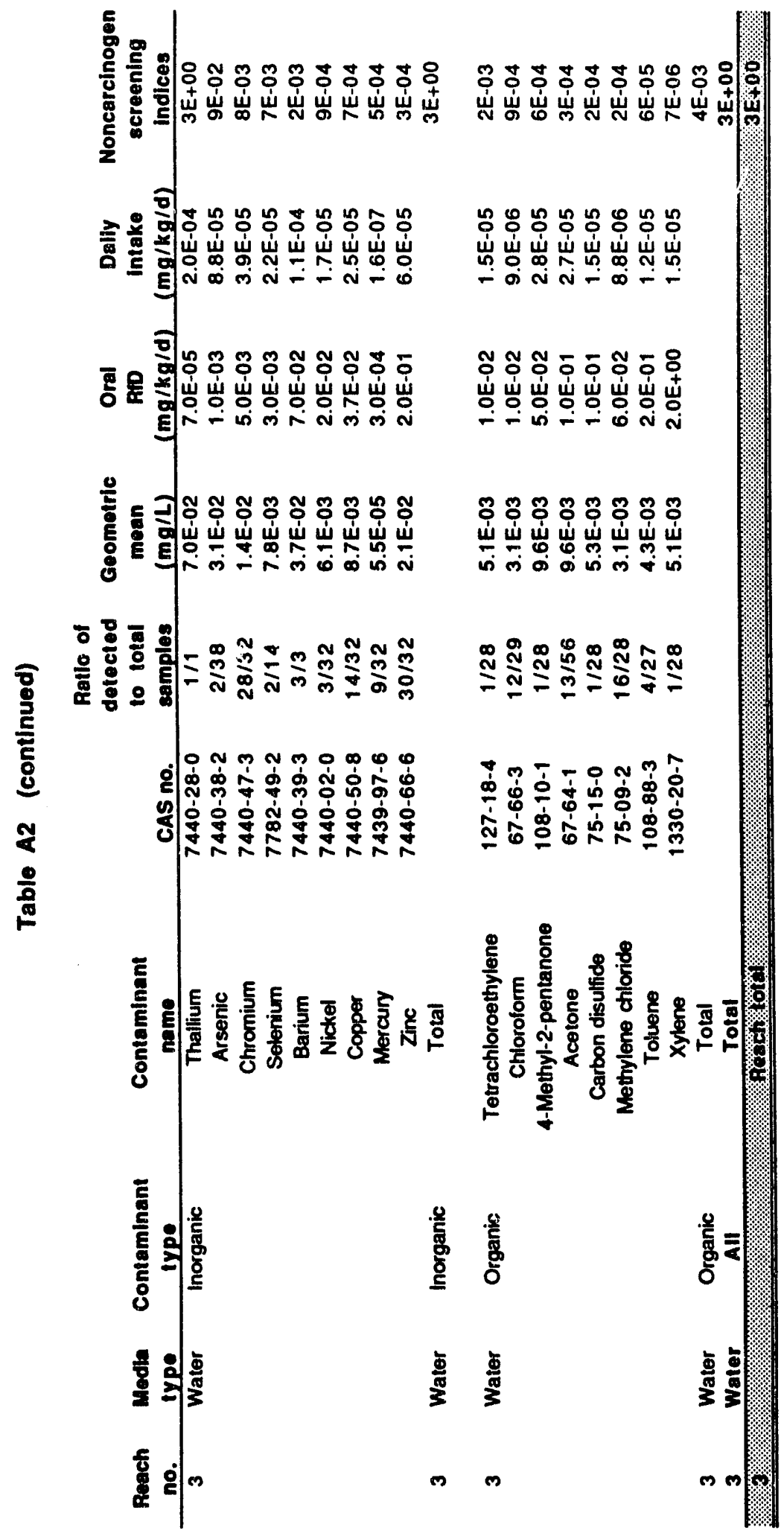


APPENDIX B

CONSERVATIVE SCREENING OF THE DETECTABLE CONTAMINANTS DATA BASE FOR CARCINOGENS 


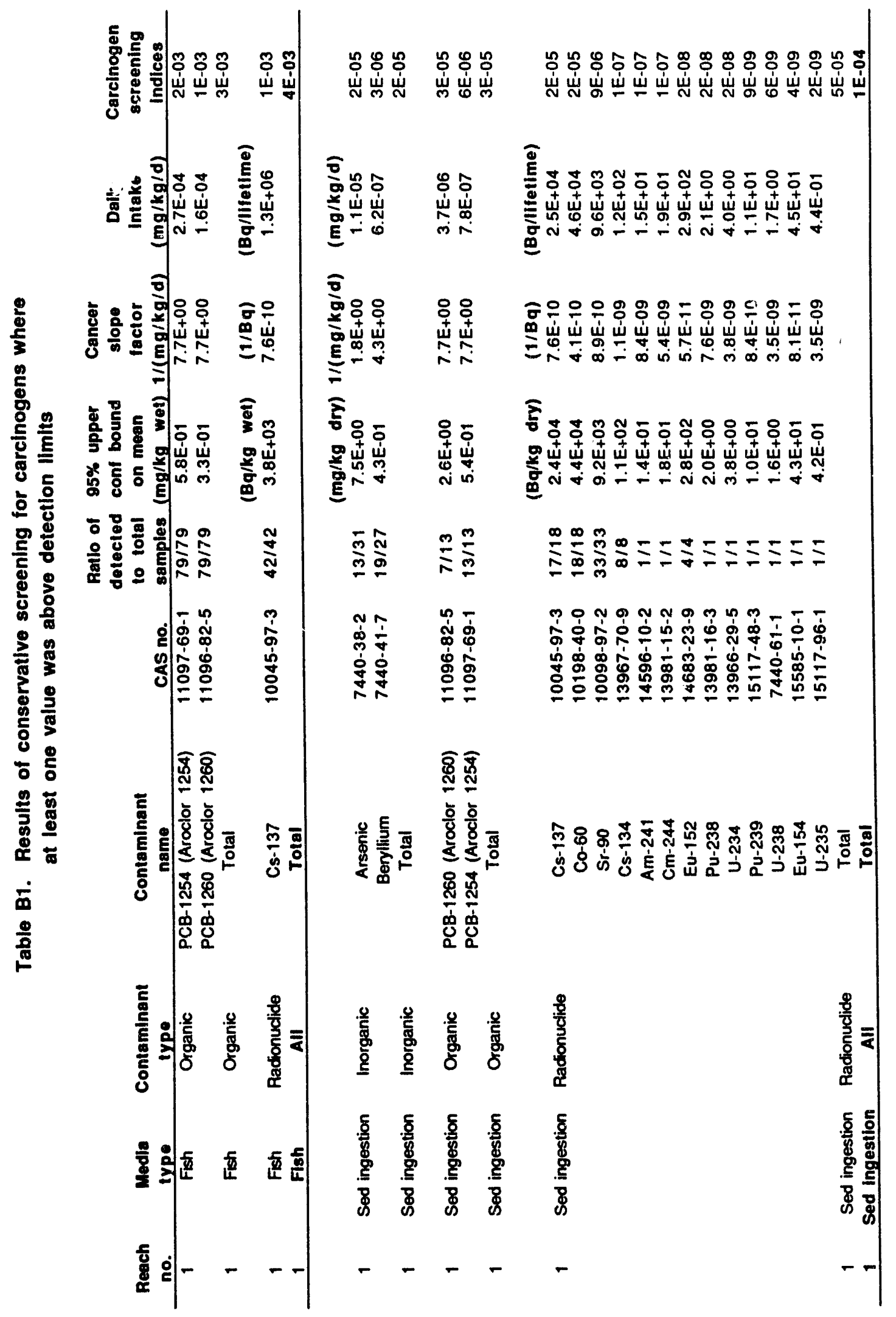




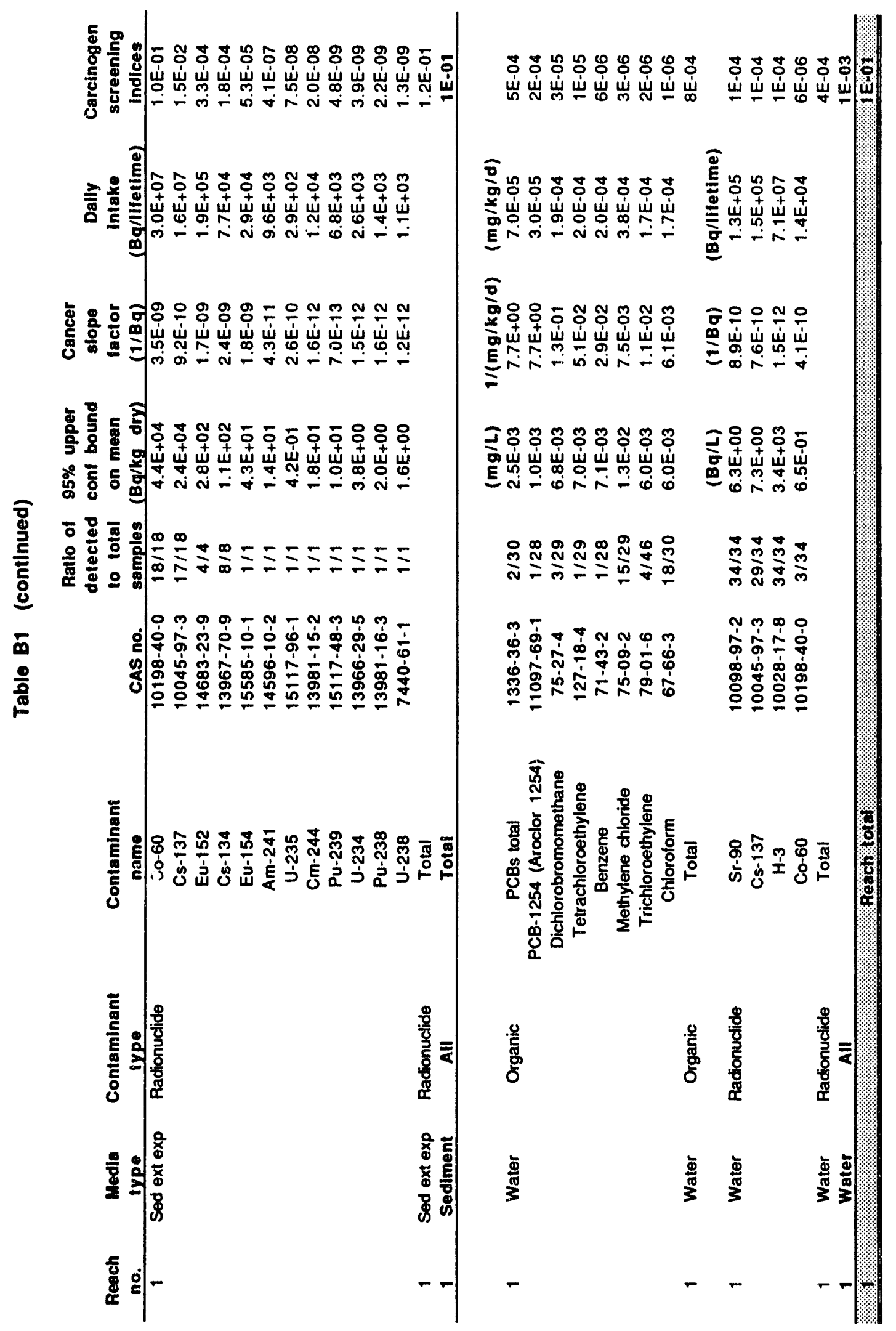




\section{B-5}

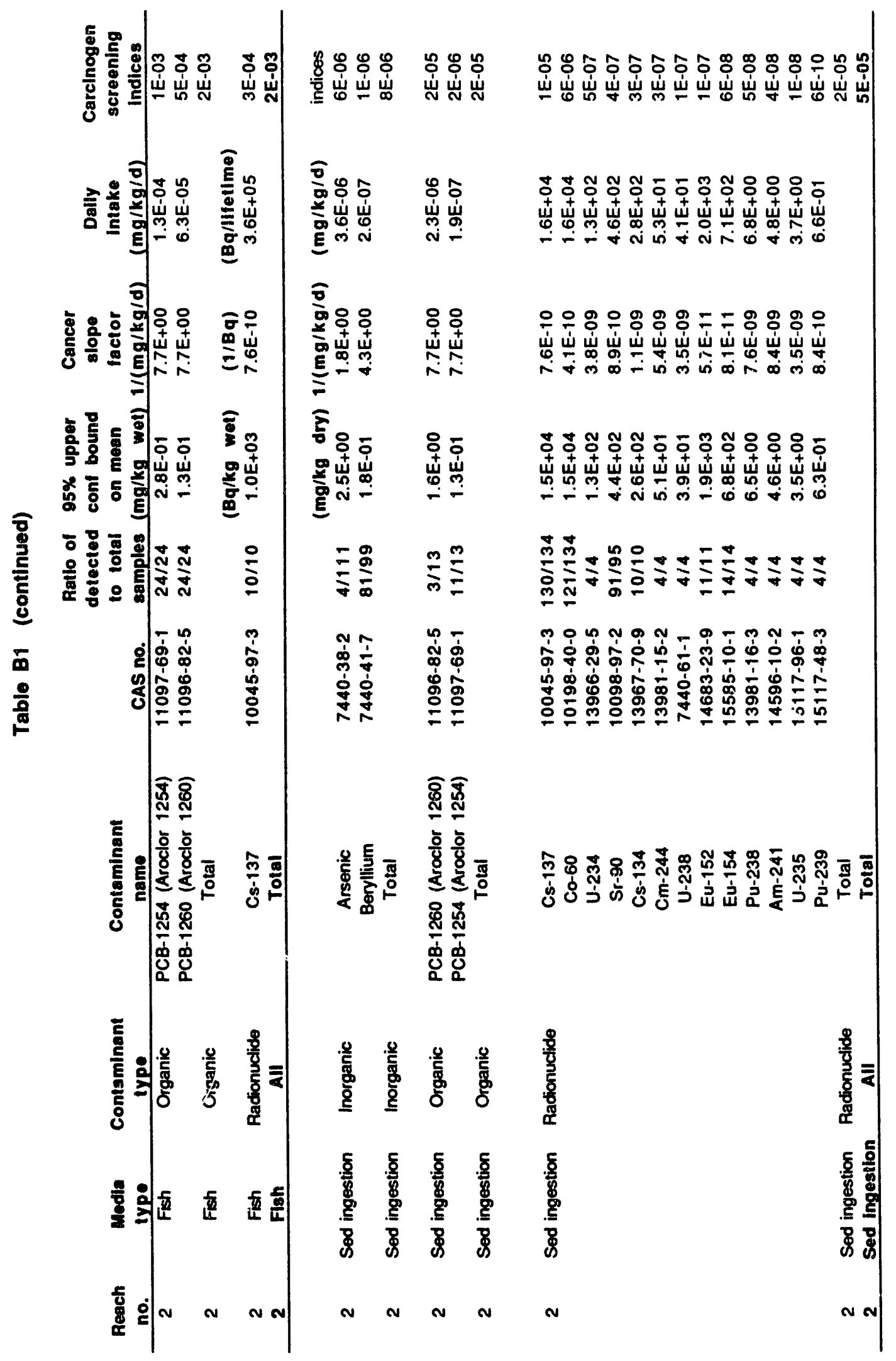




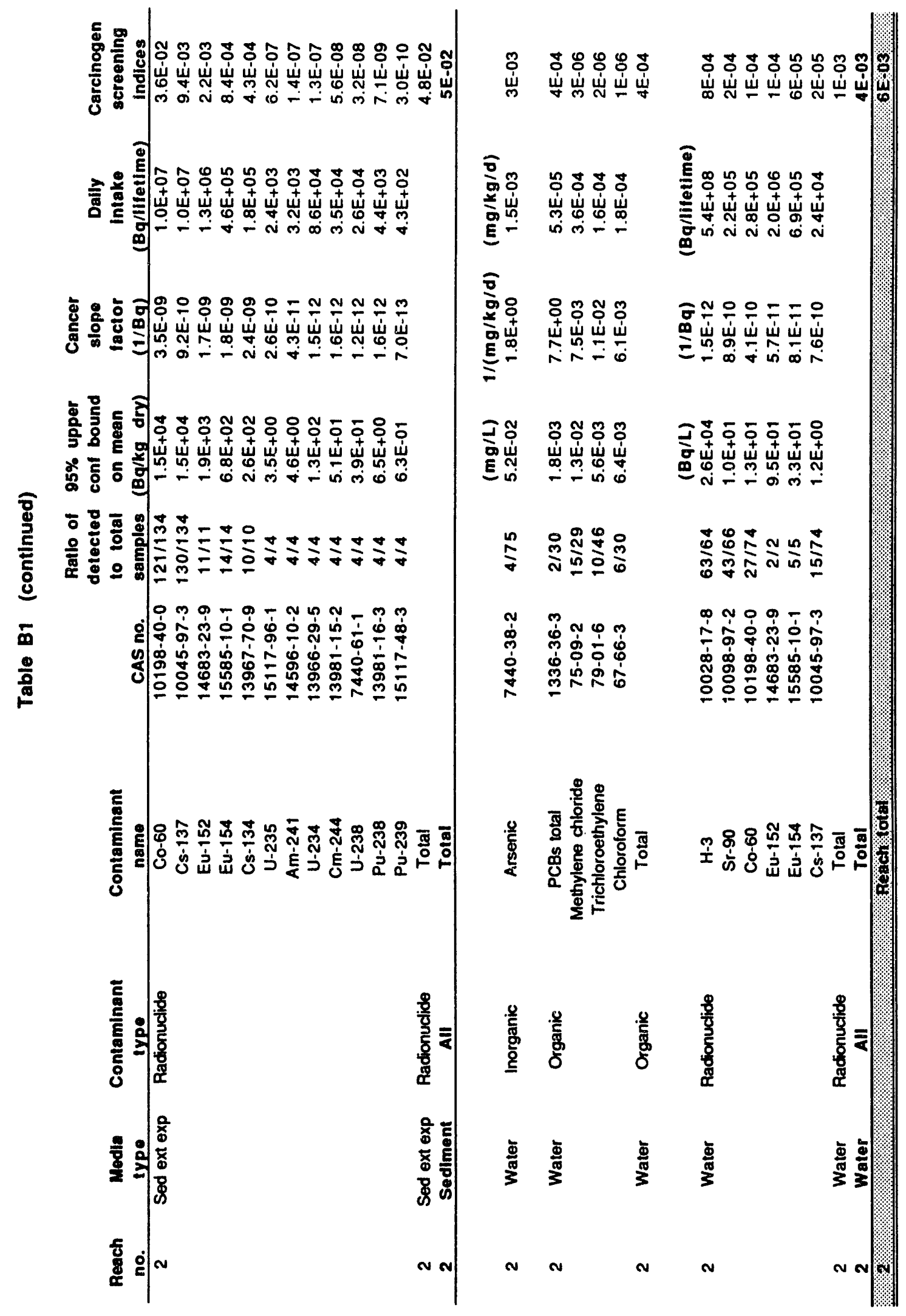




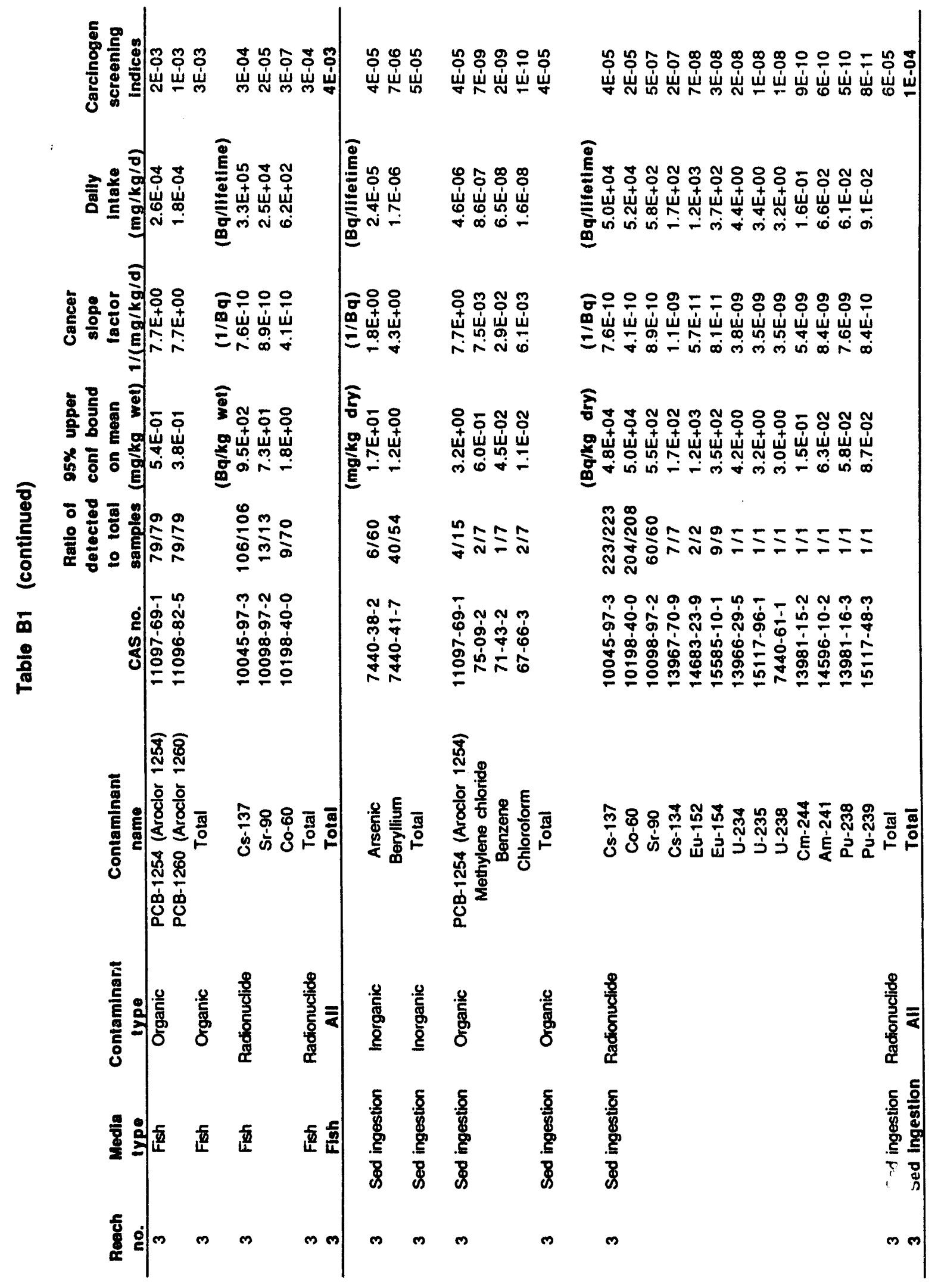




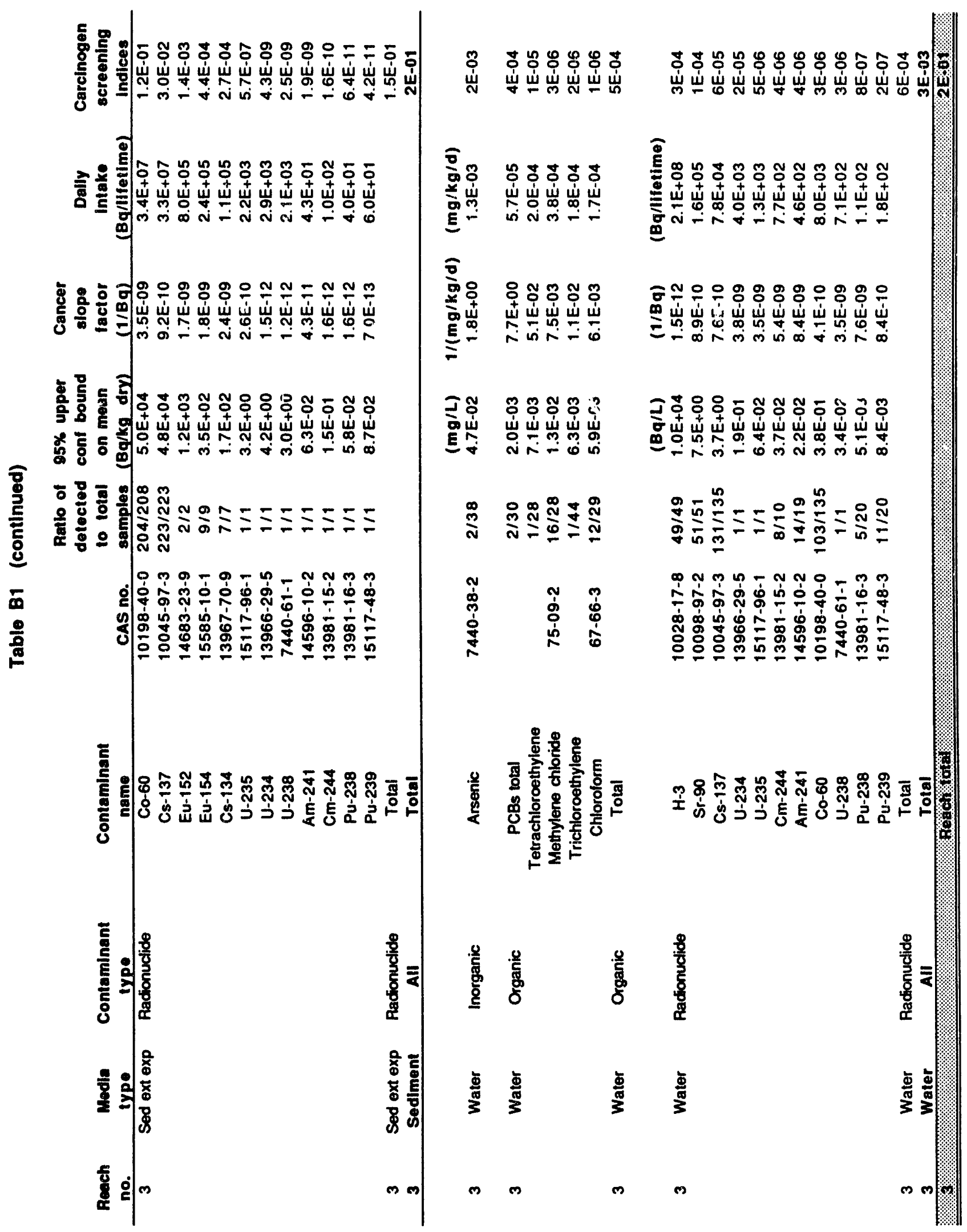




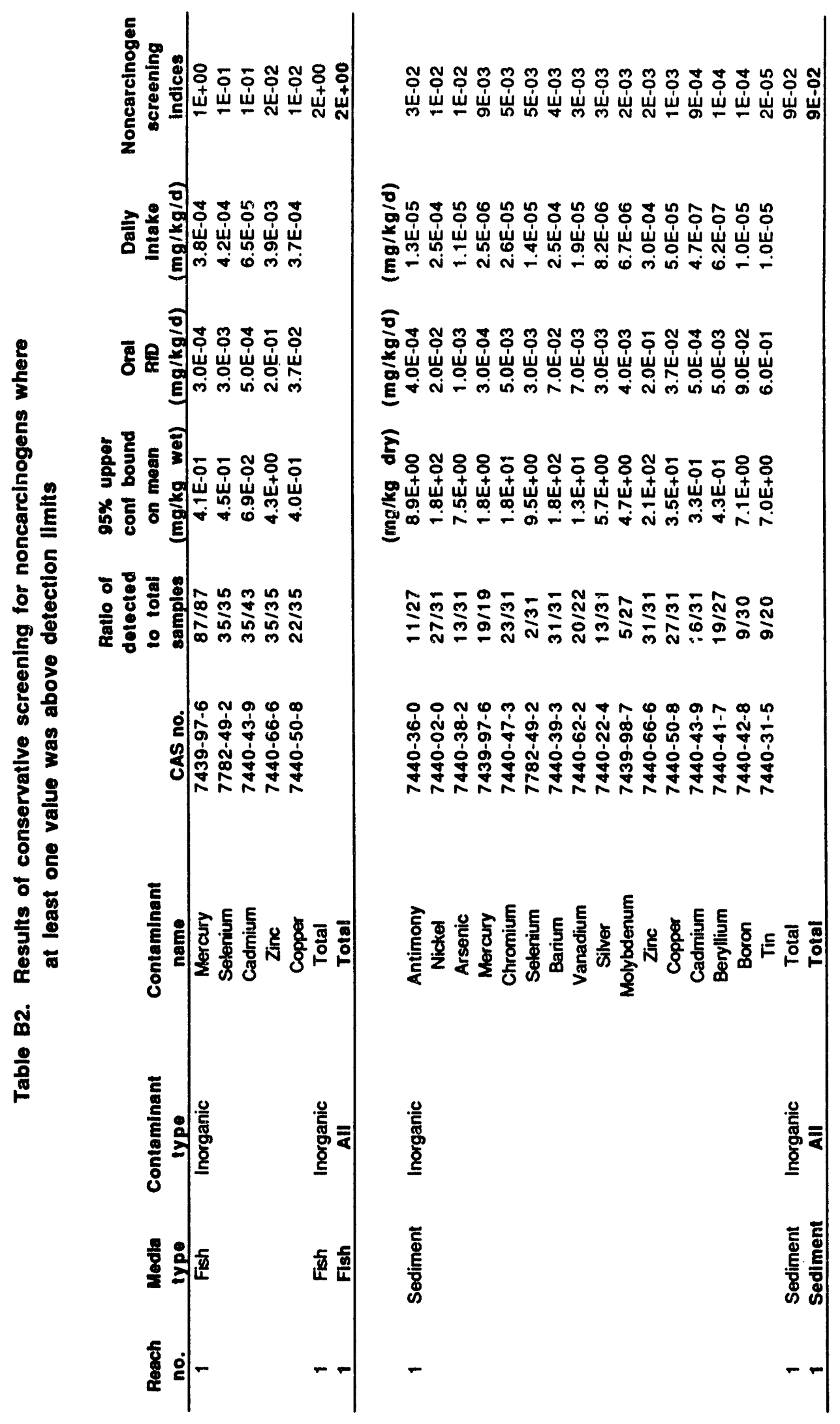




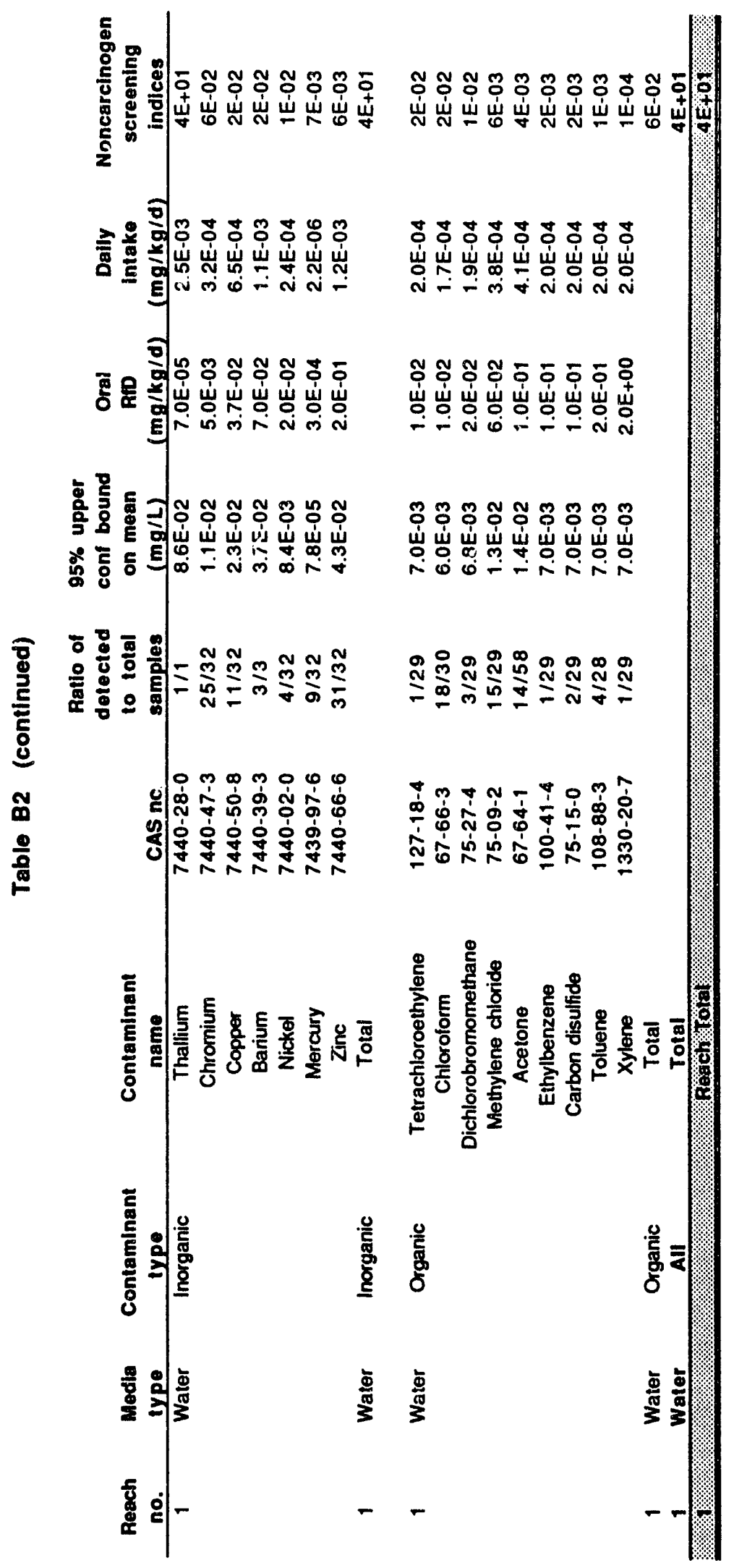




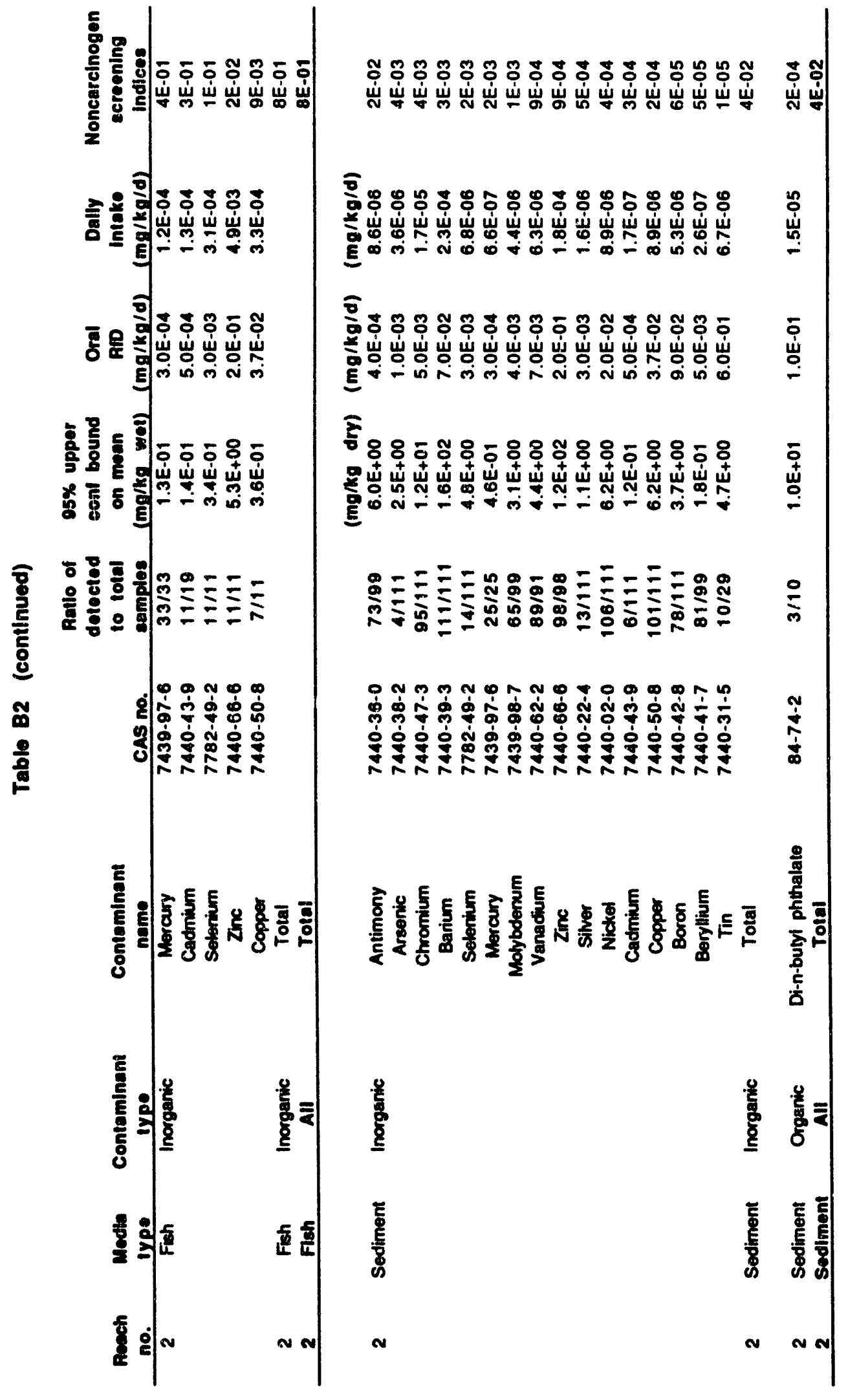




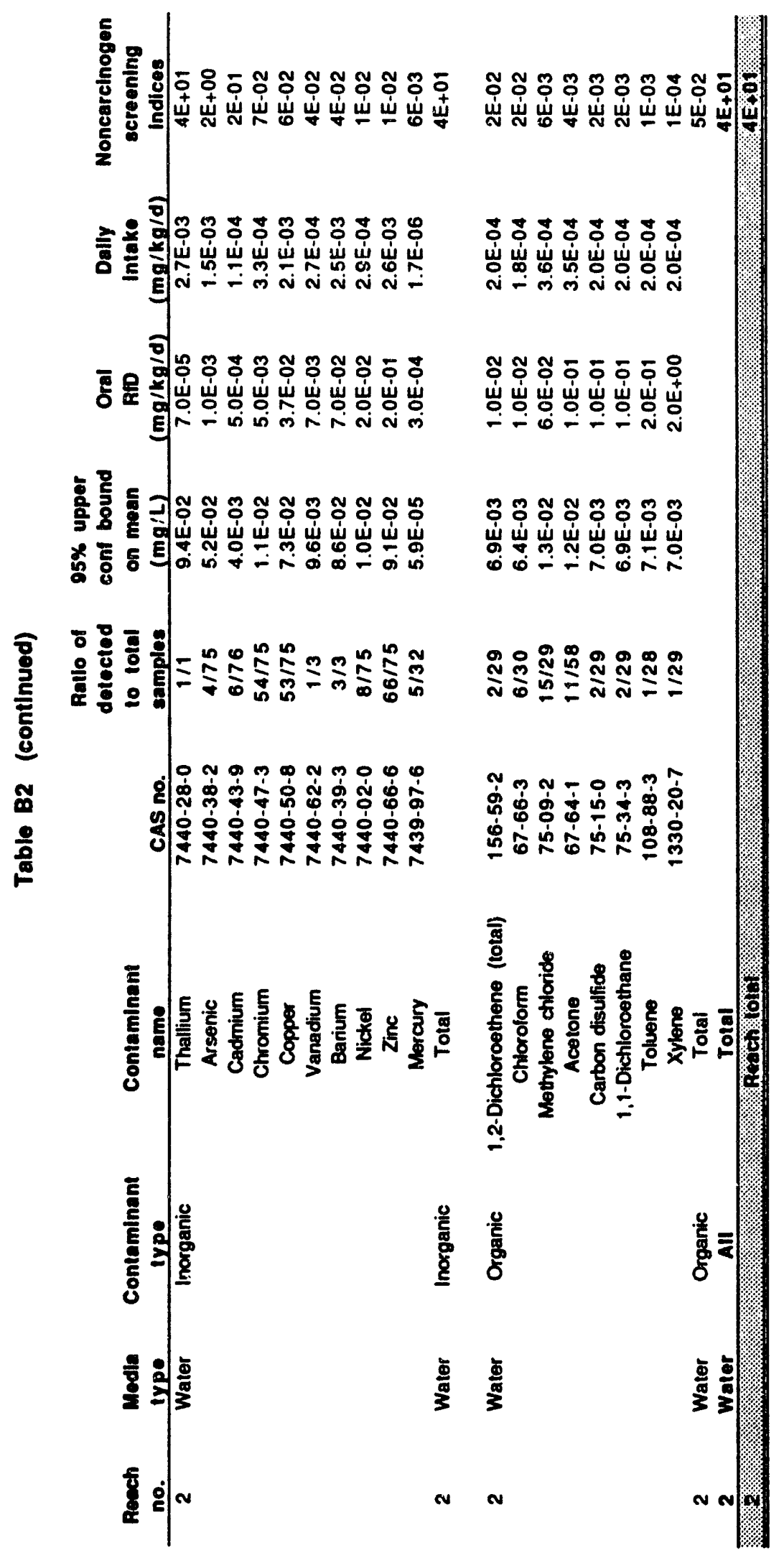




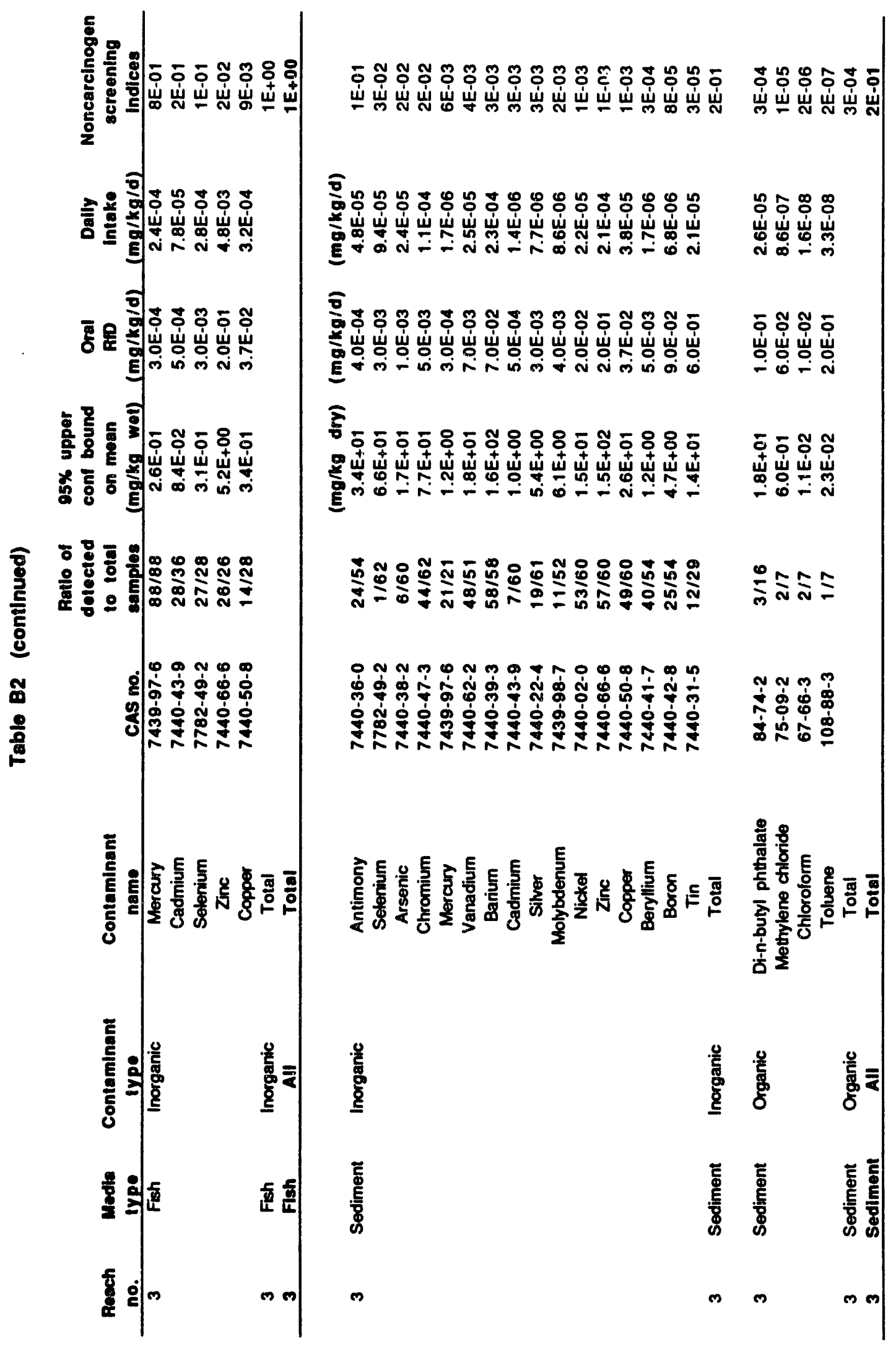




\section{B-14}

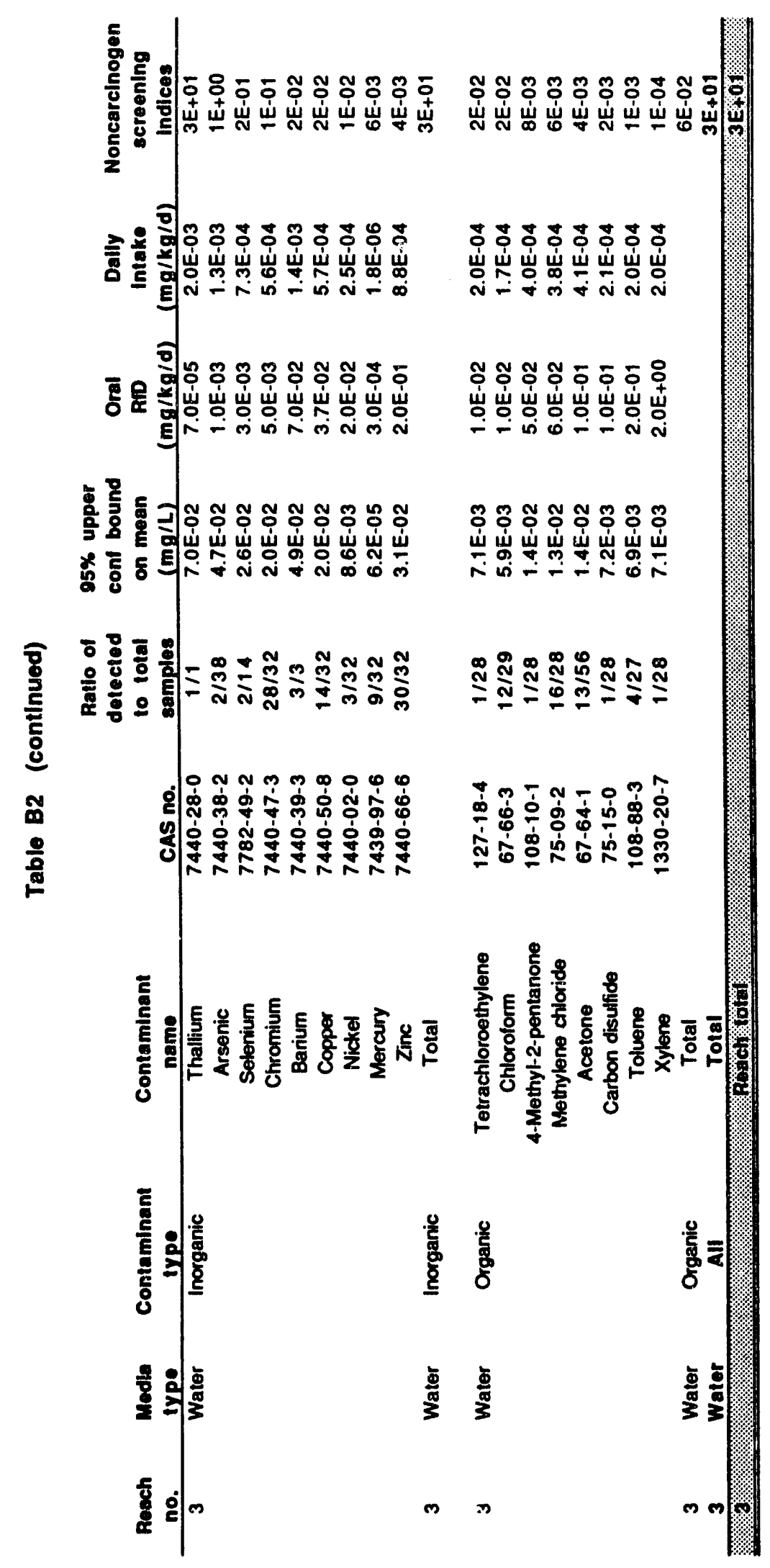




\section{APPENDIX C \\ SCREENING OF THE INTRUDER SCENARIO FOR DETECTED CARCINOGENS AND NONCARCINOGENS}


C-3

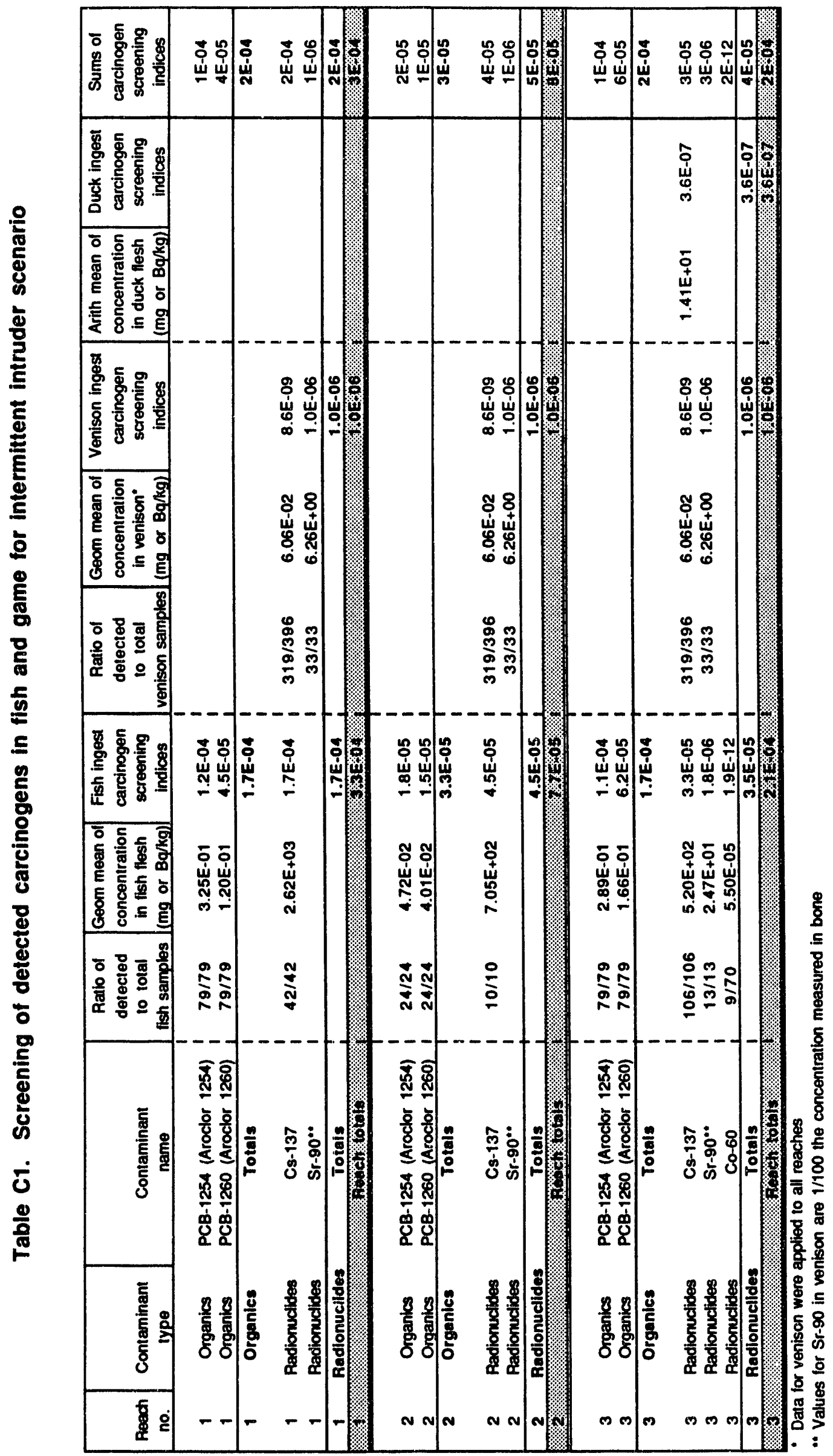


Table C2. Screening indices for external exposure to intermittent intruder from gamma radiation

in surface sediments

\begin{tabular}{|c|c|c|c|c|c|}
\hline $\begin{array}{c}\text { Reach } \\
\text { no. }\end{array}$ & $\begin{array}{c}\text { Contaminant } \\
\text { type }\end{array}$ & Radionuclide & $\begin{array}{c}\text { Ratio of } \\
\text { detected } \\
\text { to total } \\
\text { sed samples }\end{array}$ & $\begin{array}{c}\begin{array}{c}\text { Geom mean of } \\
\text { concentration } \\
\text { in sediment } \\
(\mathrm{Bg} / \mathrm{kg})\end{array} \\
\end{array}$ & $\begin{array}{c}\text { Screening } \\
\text { indices for } \\
\text { exposure exposure } \\
\text { to sediment }\end{array}$ \\
\hline 1 & Radionuclide & Cs -137 & $17 / 18$ & $5.52 E+03$ & 2.1E-04 \\
\hline 1 & Radionuclide & Co-60 & $18 / 18$ & $1.29 E+03$ & 1.9E-04 \\
\hline 1 & Radionuclide & Eu-152 & $4 / 4$ & $2.26 E+02$ & $1.6 E-05$ \\
\hline 1 & Radionuclide & Cs-134 & $8 / 8$ & $7.83 E+01$ & 7.7E-06 \\
\hline $\begin{array}{l}1 \\
1\end{array}$ & Radionuclide & Eu-154 & $\begin{array}{l}1 / 1 \\
1 / 1\end{array}$ & $4.30 E+01$ & $\begin{array}{l}3.2 E-06 \\
25 F-08\end{array}$ \\
\hline 1 & Radionuclide & U.235 & $1 / 1$ & $4.20 E-01$ & 4.5E-09 \\
\hline 1 & Radionuclide & $\mathrm{Cm}-244$ & $1 / 1$ & $1.80 E+01$ & 1.2E.09 \\
\hline 1 & Radionuclide & Pu-239 & $1 / 1$ & $1.00 E+01$ & $2.9 \mathrm{E}-10$ \\
\hline 1 & Radionuclide & U.234 & $1 / 1$ & $3.80 E+00$ & $2.3 E-10$ \\
\hline 1 & Radionuclide & Pu-238 & $1 / 1$ & $2.00 E+00$ & $1.3 E-10$ \\
\hline 1 & Radionuclide & U.238 & $1 / 1$ & $1.60 E+00$ & $7.9 E-11$ \\
\hline 1 & 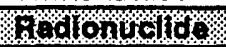 & & & Roan rot & WOENO \\
\hline 2 & Radionuclide & Co-60 & $121 / 134$ & $1.40 E+03$ & 2.0E-04 \\
\hline 2 & Radionuclide & Eu-152 & $11 / 11$ & $8.22 E+02$ & 5.7E-05 \\
\hline $\begin{array}{l}2 \\
2\end{array}$ & $\begin{array}{l}\text { Radionuclide } \\
\text { Radionuclide }\end{array}$ & $\begin{array}{l}\text { Eu-154 } \\
\text { C8-137 }\end{array}$ & $\begin{array}{c}14 / 14 \\
130 / 134\end{array}$ & $\begin{array}{l}3.51 E+02 \\
6.34 E+02\end{array}$ & $\begin{array}{l}2.6 E-05 \\
2.4 E-05\end{array}$ \\
\hline 2 & Radionuclide & Cs.134 & $10 / 10$ & $1.43 E+02$ & $1.4 \mathrm{E}-05$ \\
\hline 2 & Radionuclide & $M n-54$ & $7 / 7$ & $2.37 E+02$ & 1.3E-05 \\
\hline 2 & Radionuclide & $U-235$ & $4 / 4$ & 6.59E-01 & 7.0E-09 \\
\hline 2 & Radionuclide & Am-241 & $4 / 4$ & $1.16 E+00$ & 2.0E-09 \\
\hline 2 & Radionuclide & U-234 & $4 / 4$ & $9.07 E+00$ & $5.6 E-10$ \\
\hline 2 & Radionuclide & $\mathrm{Cm}-244$ & $4 / 4$ & 4.11E+00 & 2.7E-10 \\
\hline 2 & Radionuctide & U-238 & $4 / 4$ & $4.12 E+00$ & $2.0 E-10$ \\
\hline 2 & Radionuclide & Pu-238 & $4 / 4$ & $3.76 E-01$ & $2.5 E-11$ \\
\hline 2 & Radionuclide & Pu-239 & $4 / 4$ & 8.52E-02 & $2.5 E-12$ \\
\hline r. & Godonvold & & & 8 bach ola & OS ENo \\
\hline 3 & Radionuclide & Cs-137 & $223 / 223$ & $9.97 E+03$ & $3.8 E-04$ \\
\hline 3 & Radionuclide & Co. 60 & $204 / 208$ & $1.07 E+03$ & $1.5 E-04$ \\
\hline 3 & Radionuclide & Eu-152 & $2 / 2$ & $3.48 E+02$ & 2.4E-05 \\
\hline 3 & Radionuclide & Eu-154 & $9 / 9$ & $1.75 E+02$ & $1.3 E-05$ \\
\hline 3 & Radionuclide & Cs-134 & $7 / 7$ & $1.09 E+02$ & 1.1E-05 \\
\hline 3 & Radionuclide & U.235 & $1 / 1$ & $3.20 E+00$ & $3.4 E-08$ \\
\hline 3 & Radionuclide & Total Pu* & $4 / 4$ & $4.56 E+02$ & 1.3E-08 \\
\hline 3 & Radionuclide & U.234 & $1 / 1$ & $4.20 E+00$ & $2.6 E-10$ \\
\hline 3 & Radionuclide & U.238 & $1 / 1$ & $3.00 E+00$ & $1.5 E-10$ \\
\hline 3 & Radionuclide & Am-241 & $1 / 1$ & 6.30E-02 & $1.1 E-10$ \\
\hline 3 & Radionuclide & $\mathrm{Cm}-244$ & $1 / 1$ & $1.50 E-01$ & $9.9 E-12$ \\
\hline 3 & Radionuclide & Pu-238 & $1 / 1$ & $5.80 E-02$ & $3.8 E-12$ \\
\hline 3 & Radionuclide & Pu-239 & $1 / 1$ & $8.70 E-02$ & $2.5 E-12$ \\
\hline 3 & A adionuclld 6 & & & Heach ola & $80 \mathrm{E} 04$ \\
\hline
\end{tabular}

Used risk factors for Pu-239 
C. 5

옹

0
0
0
0
0
8
8
8
8
8
0

8

음

\begin{tabular}{|c|c|c|c|c|}
\hline 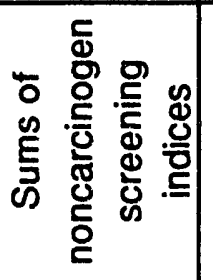 & 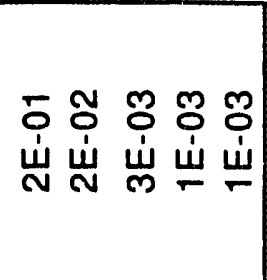 & & 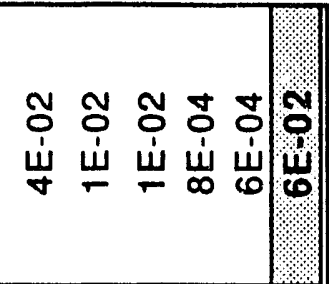 & 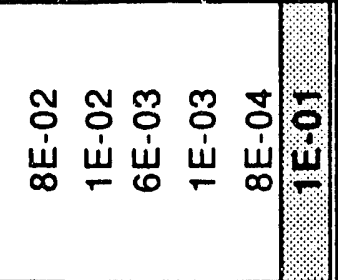 \\
\hline 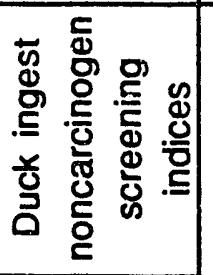 & & & & 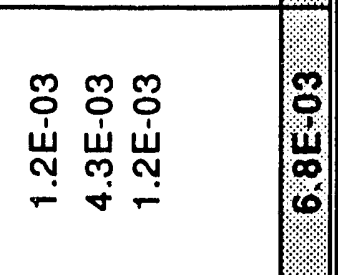 \\
\hline 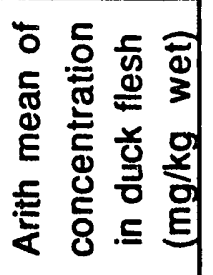 & & & & 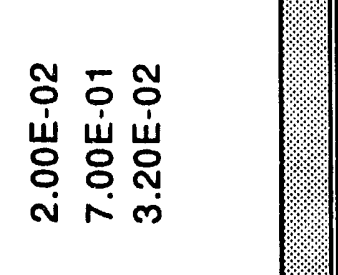 \\
\hline 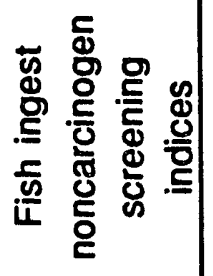 & 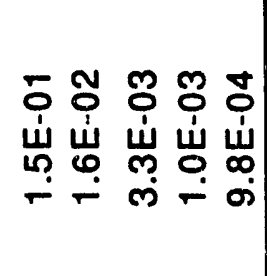 & ? & 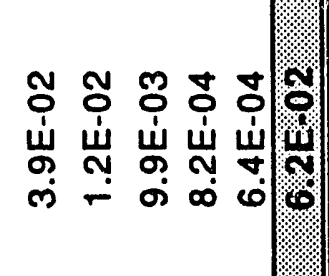 & 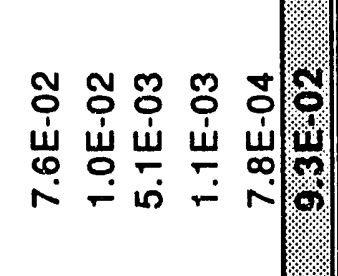 \\
\hline 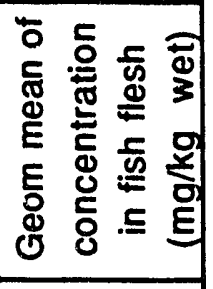 & 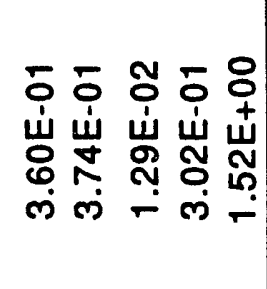 & & 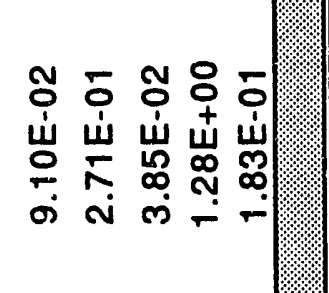 & 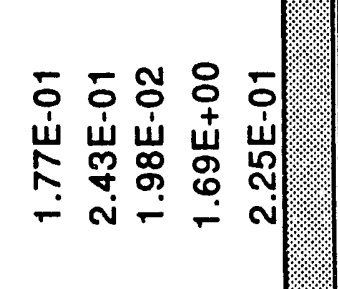 \\
\hline 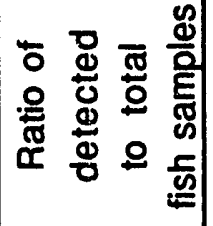 & 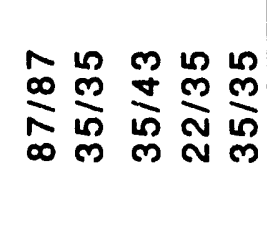 & & 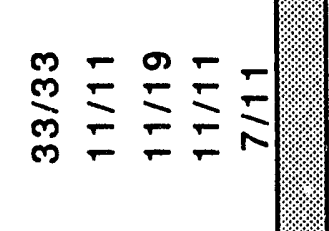 & 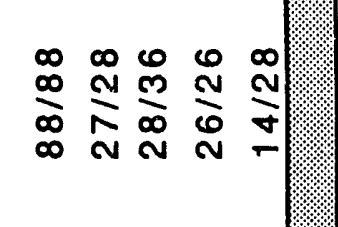 \\
\hline 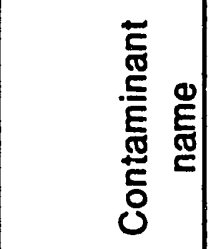 & 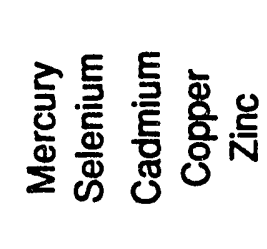 & : & 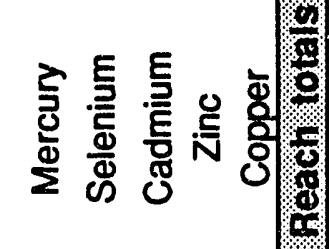 & 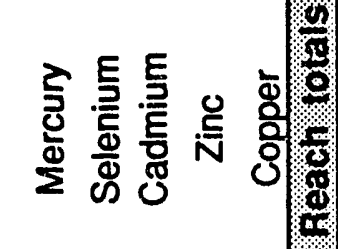 \\
\hline 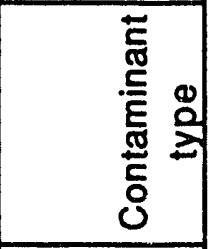 & 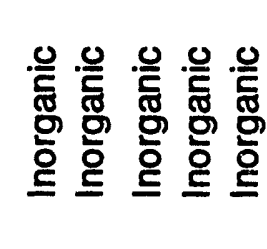 & $\frac{9}{20}$ & 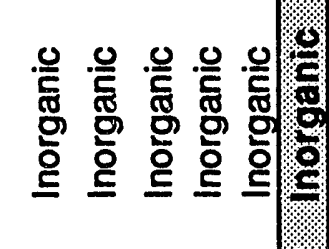 & 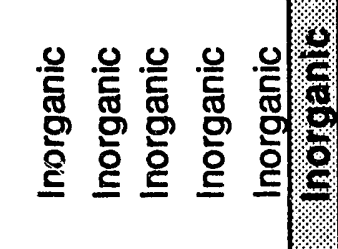 \\
\hline $\begin{array}{l}\frac{5}{\tilde{g}} \\
\underset{\mathbb{d}}{\alpha}\end{array}$ & - & S & $N \sim \sim \sim N /$ & 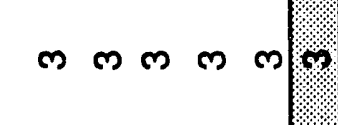 \\
\hline
\end{tabular}




\section{APPENDIX D}

NONCONSERVATIVE SCREENING OF THE NONDETECTABLE CONTAMINANTS DATA BASE FOR CARCINOGENS AND NONCARCINOGENS 


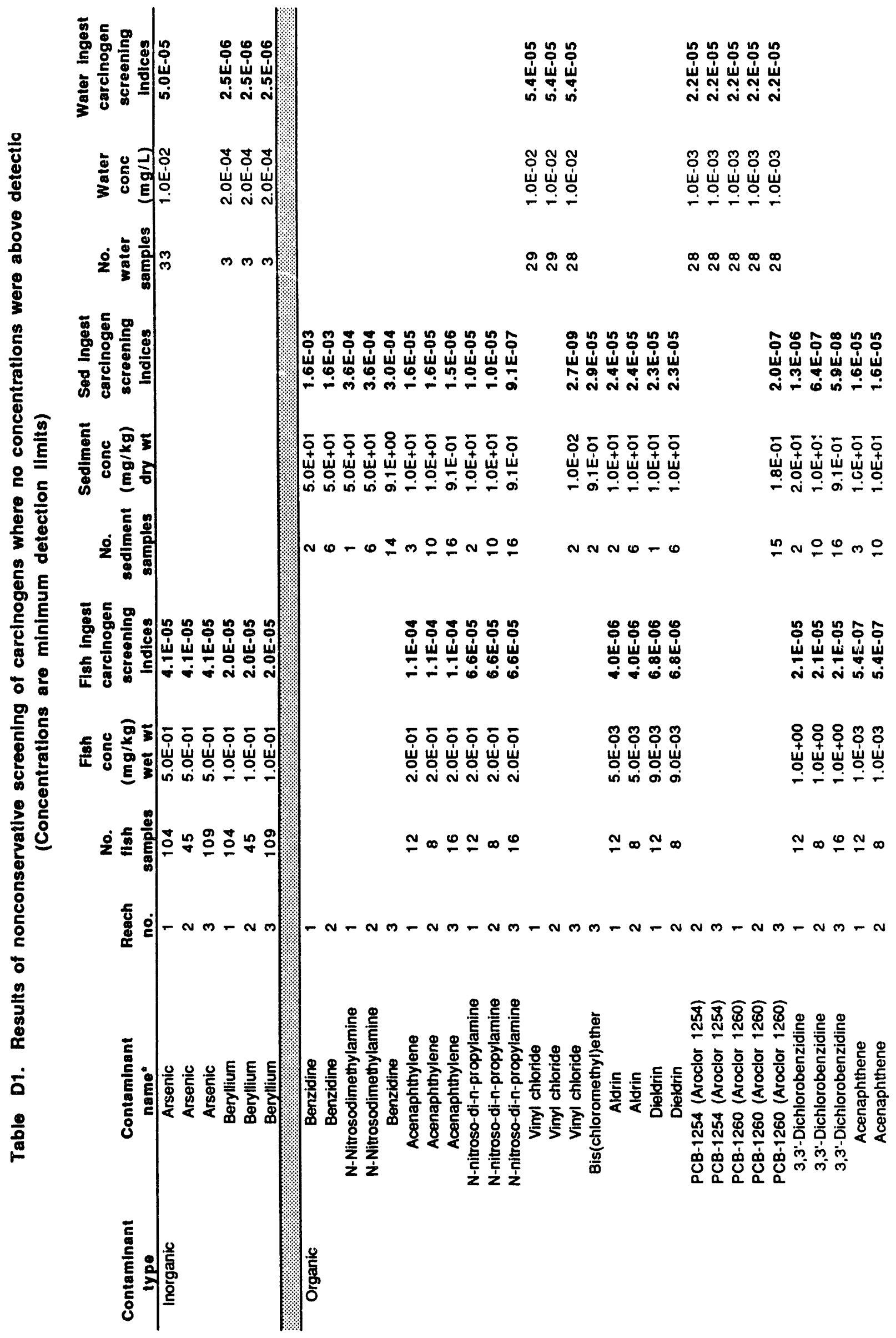




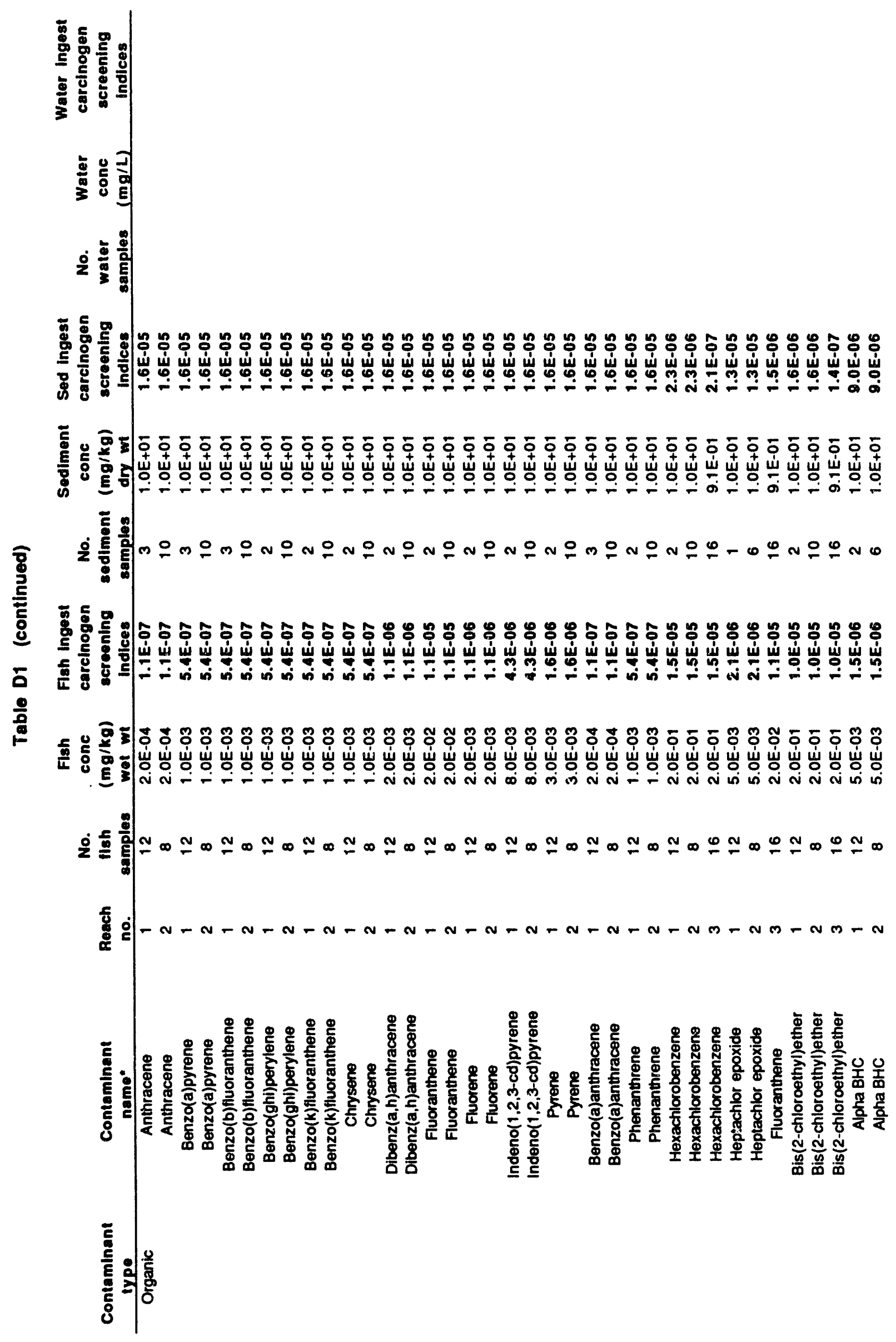




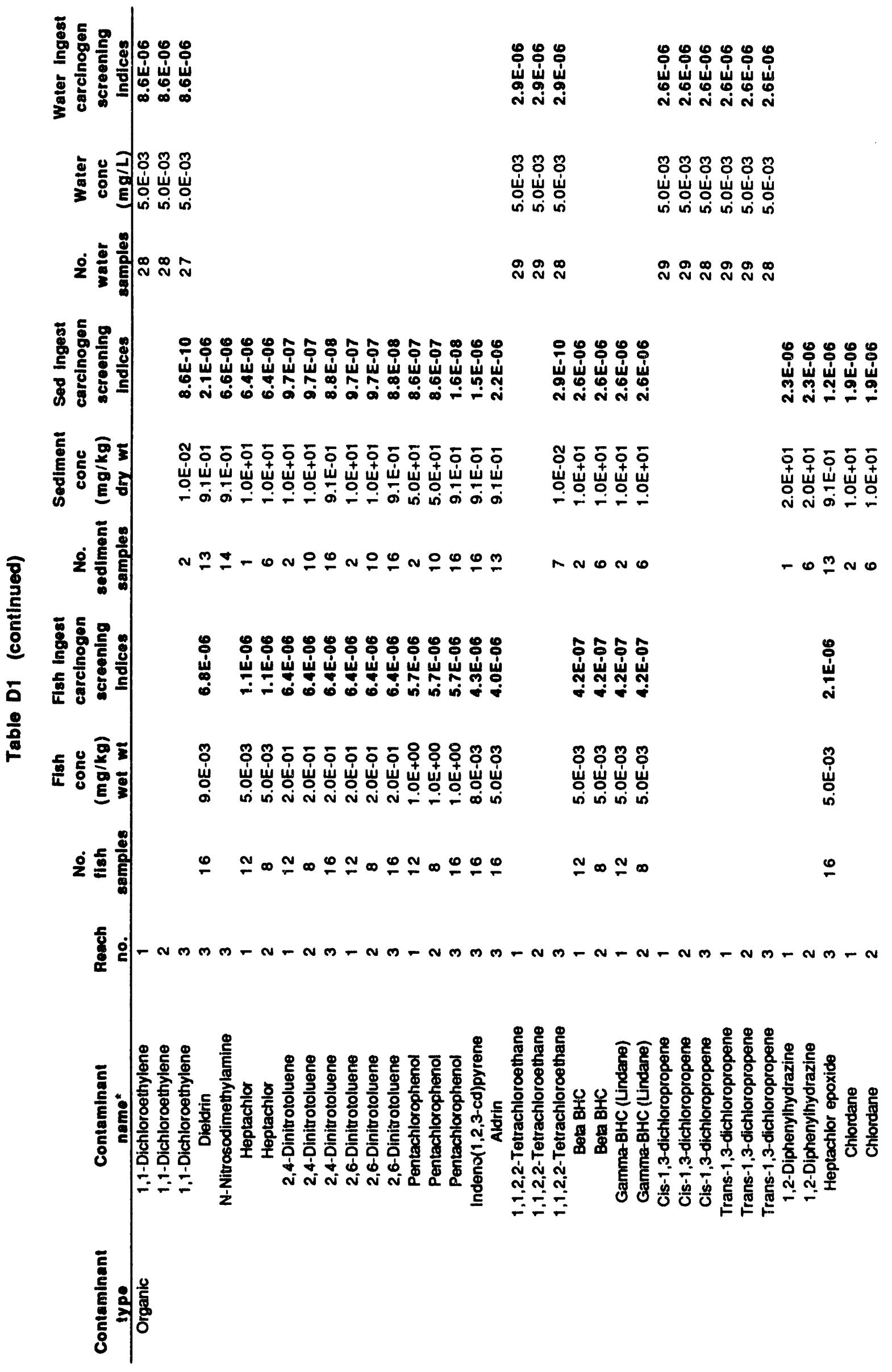




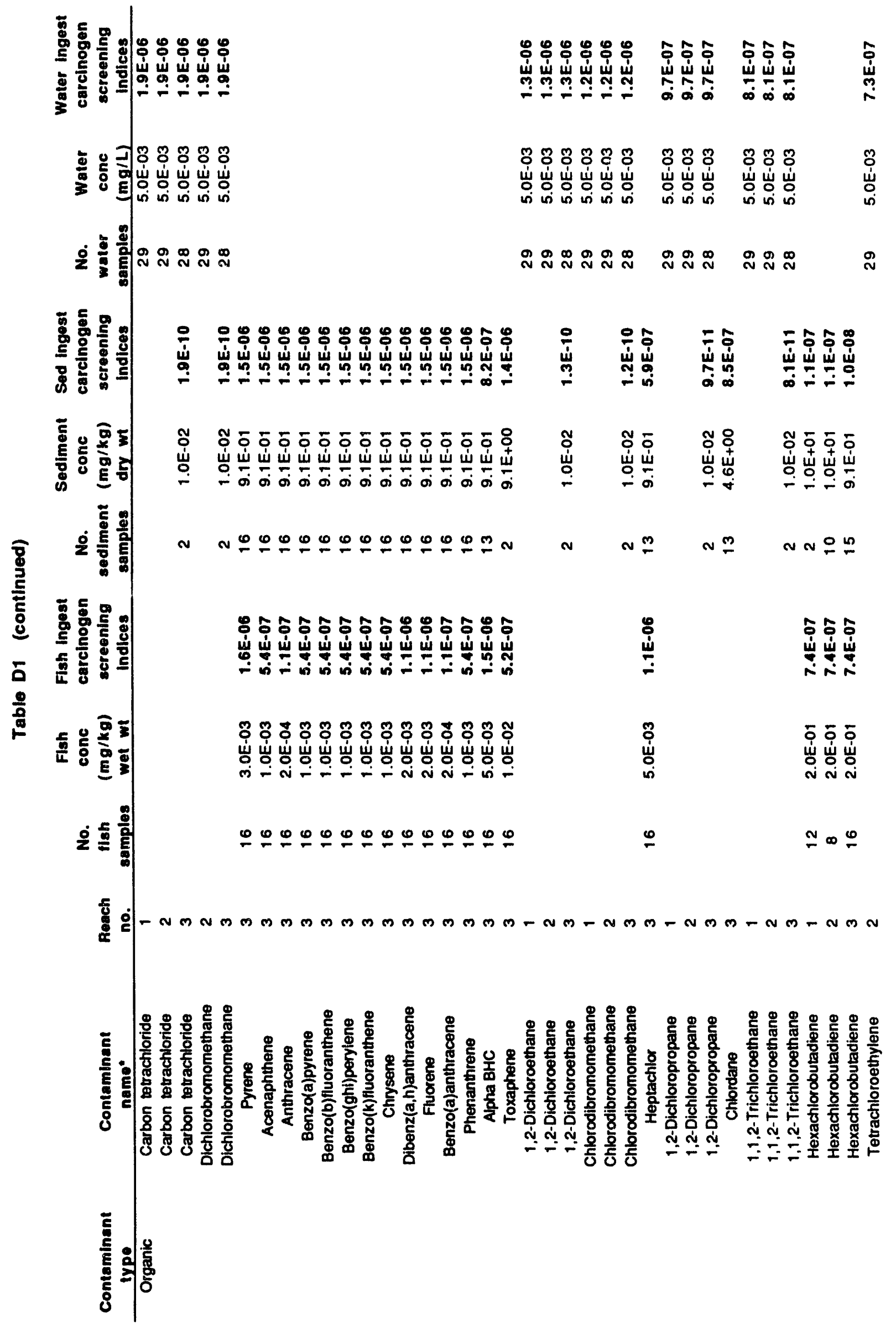




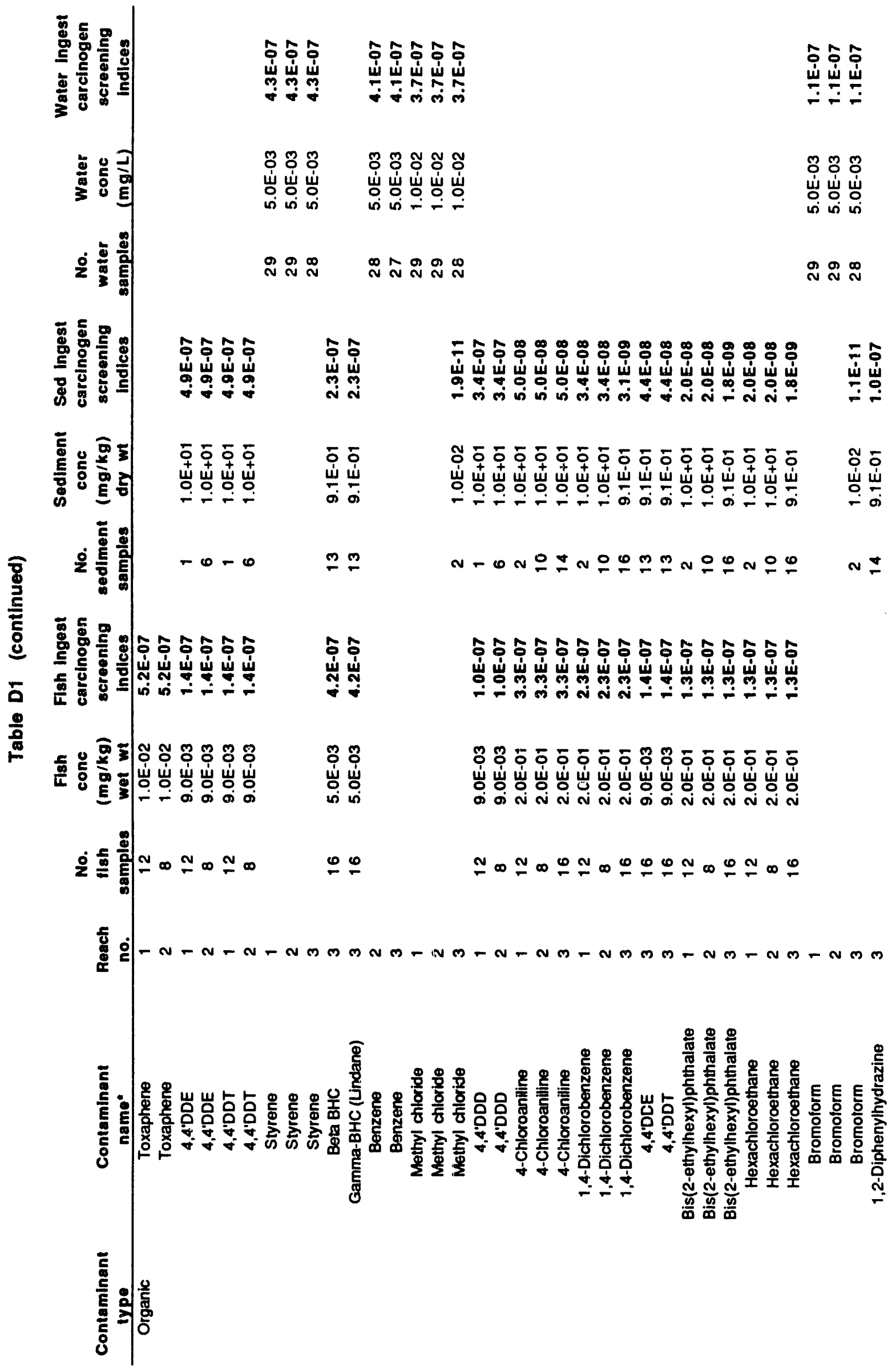




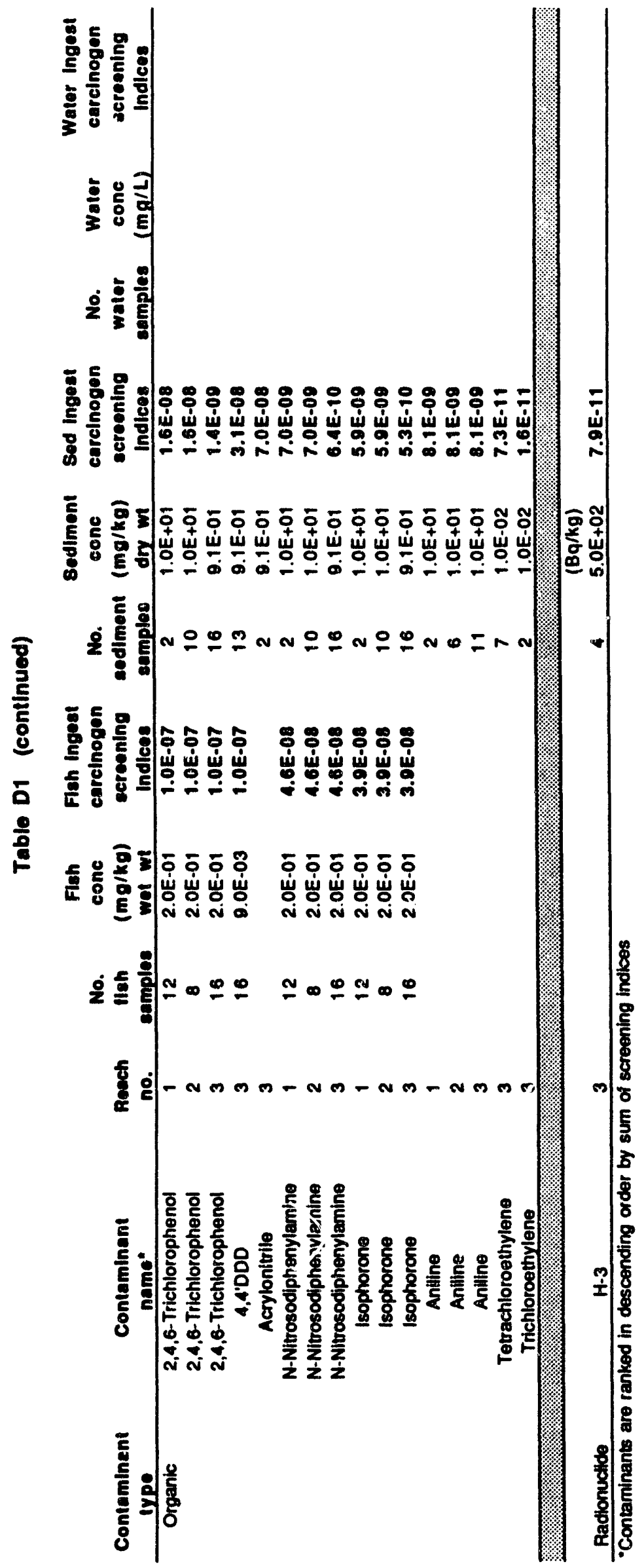




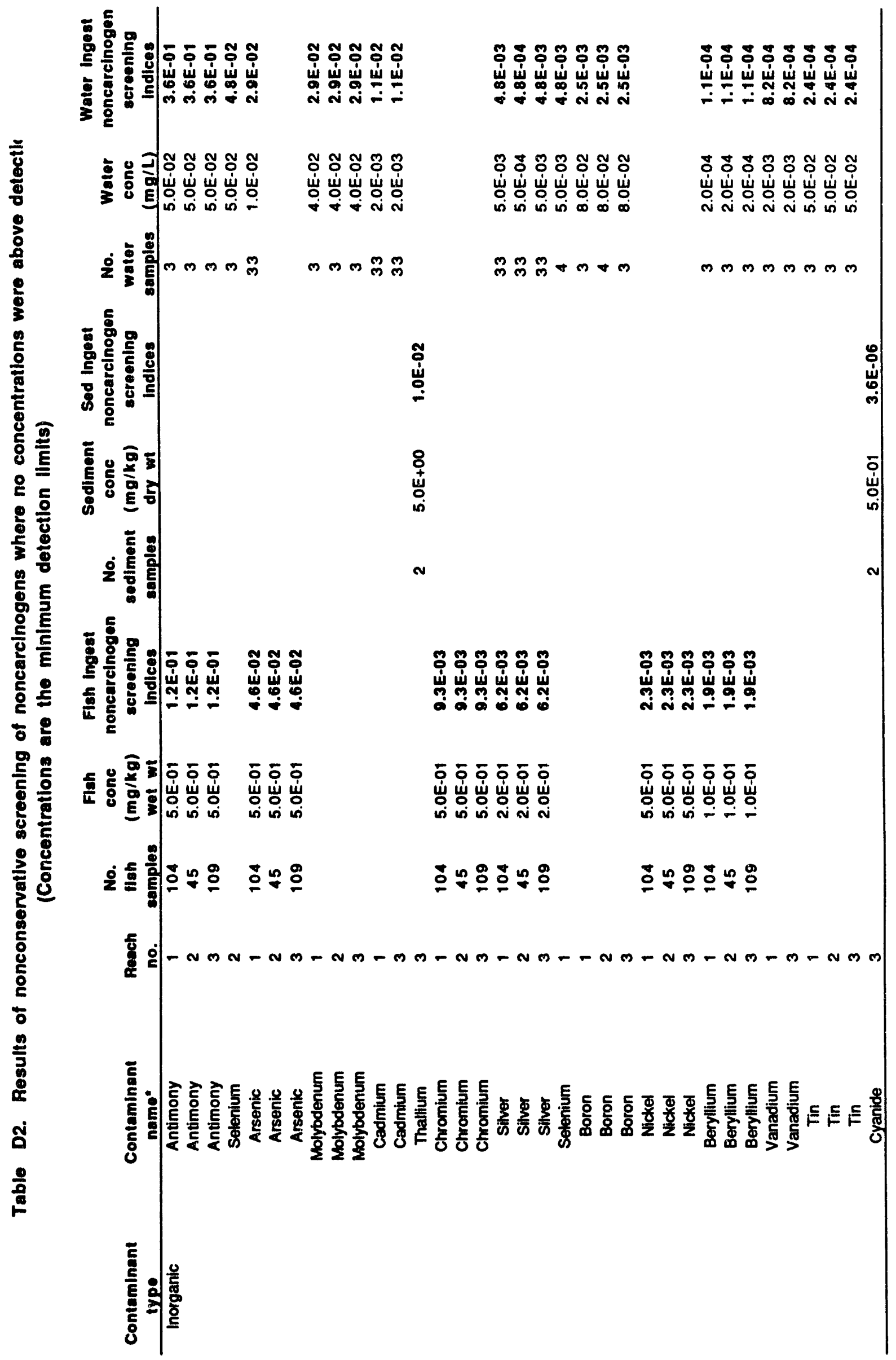




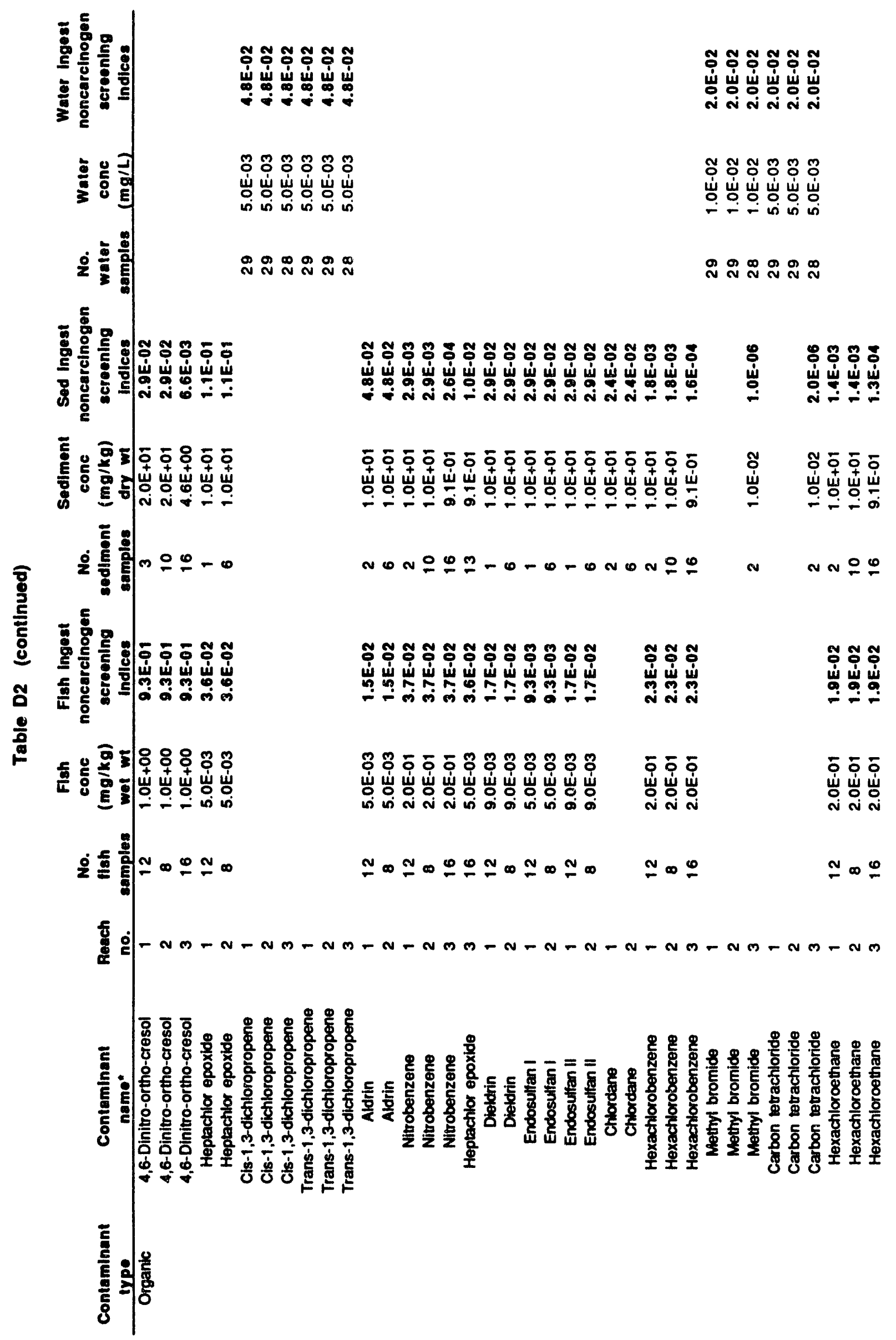




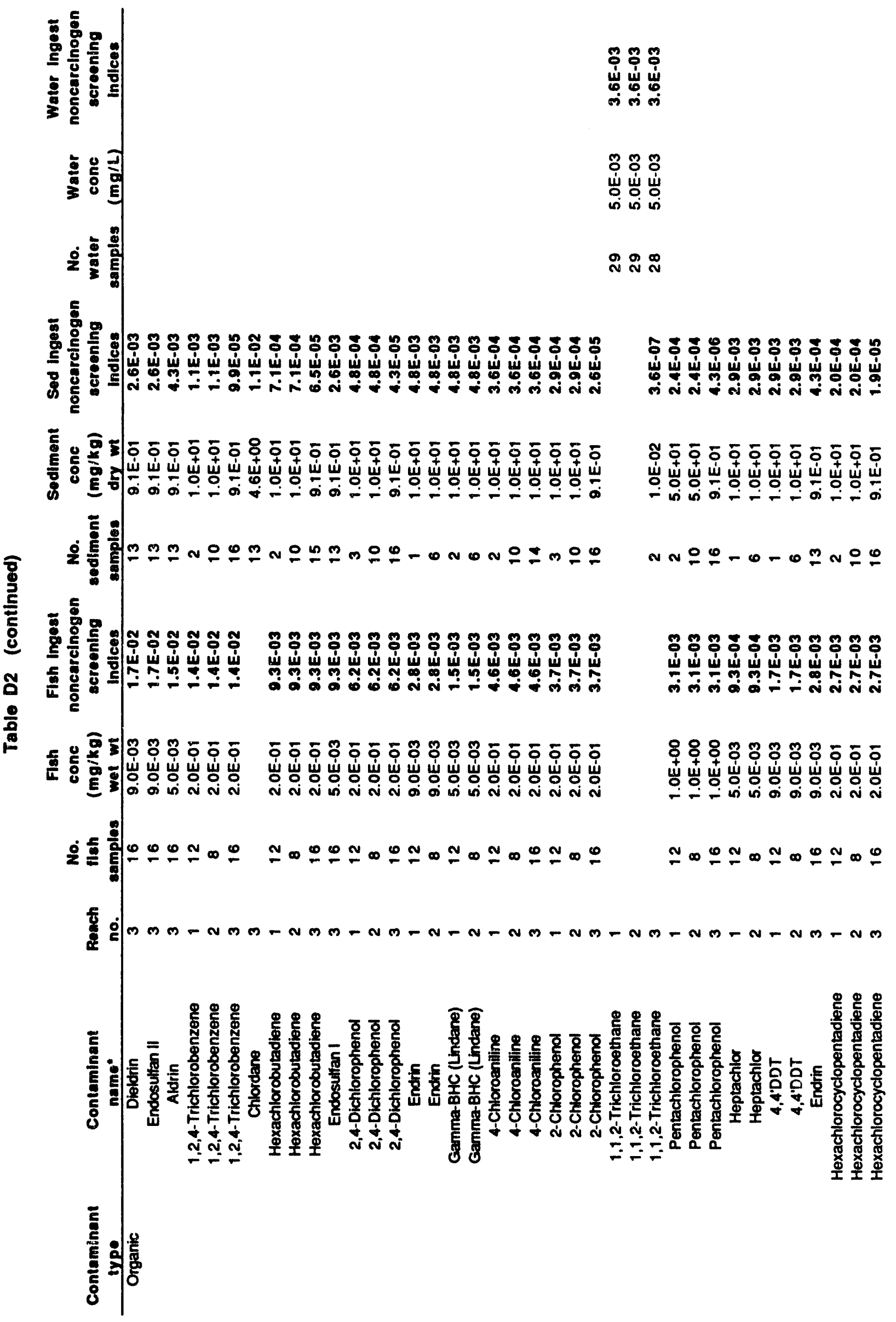




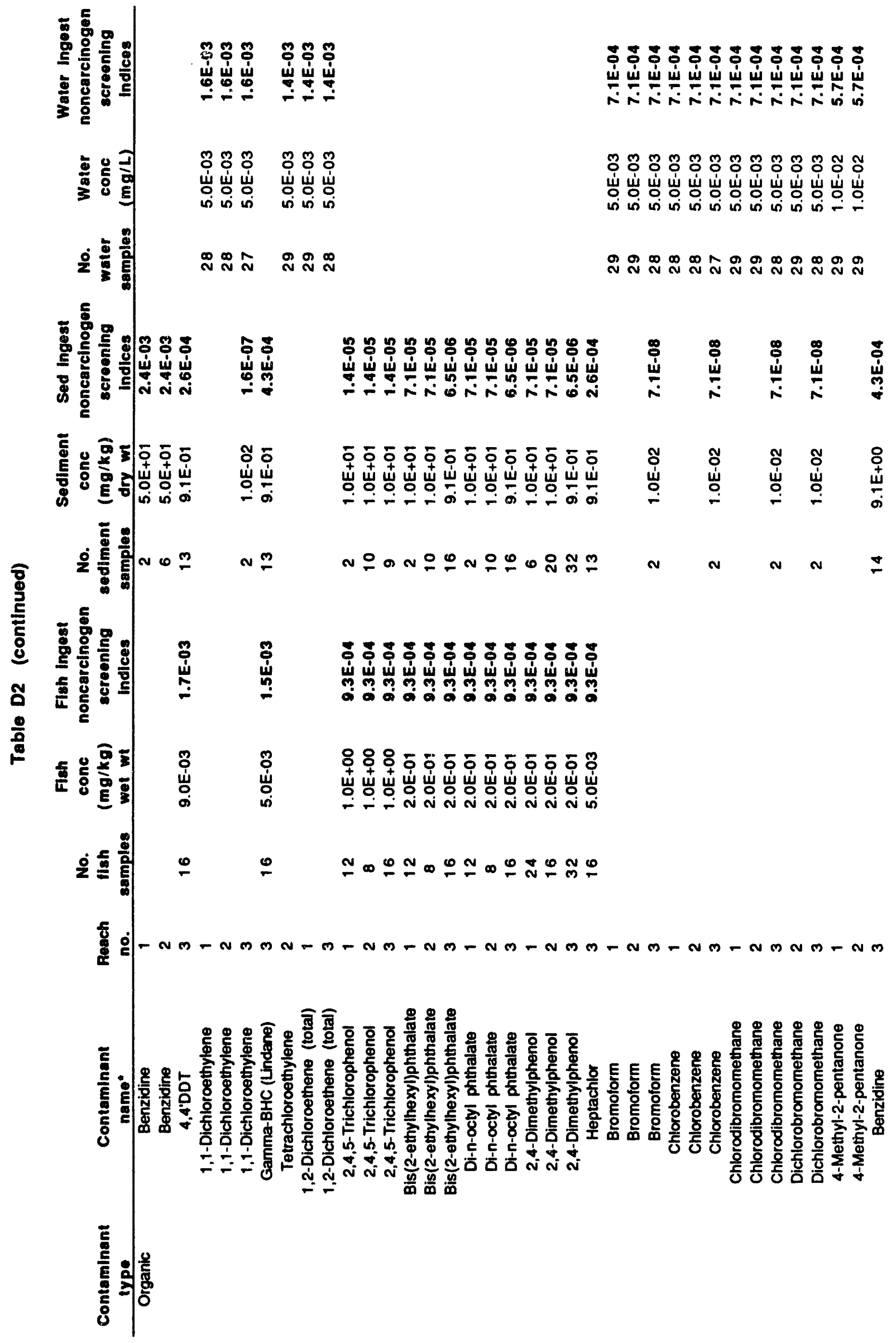




\section{D-13}

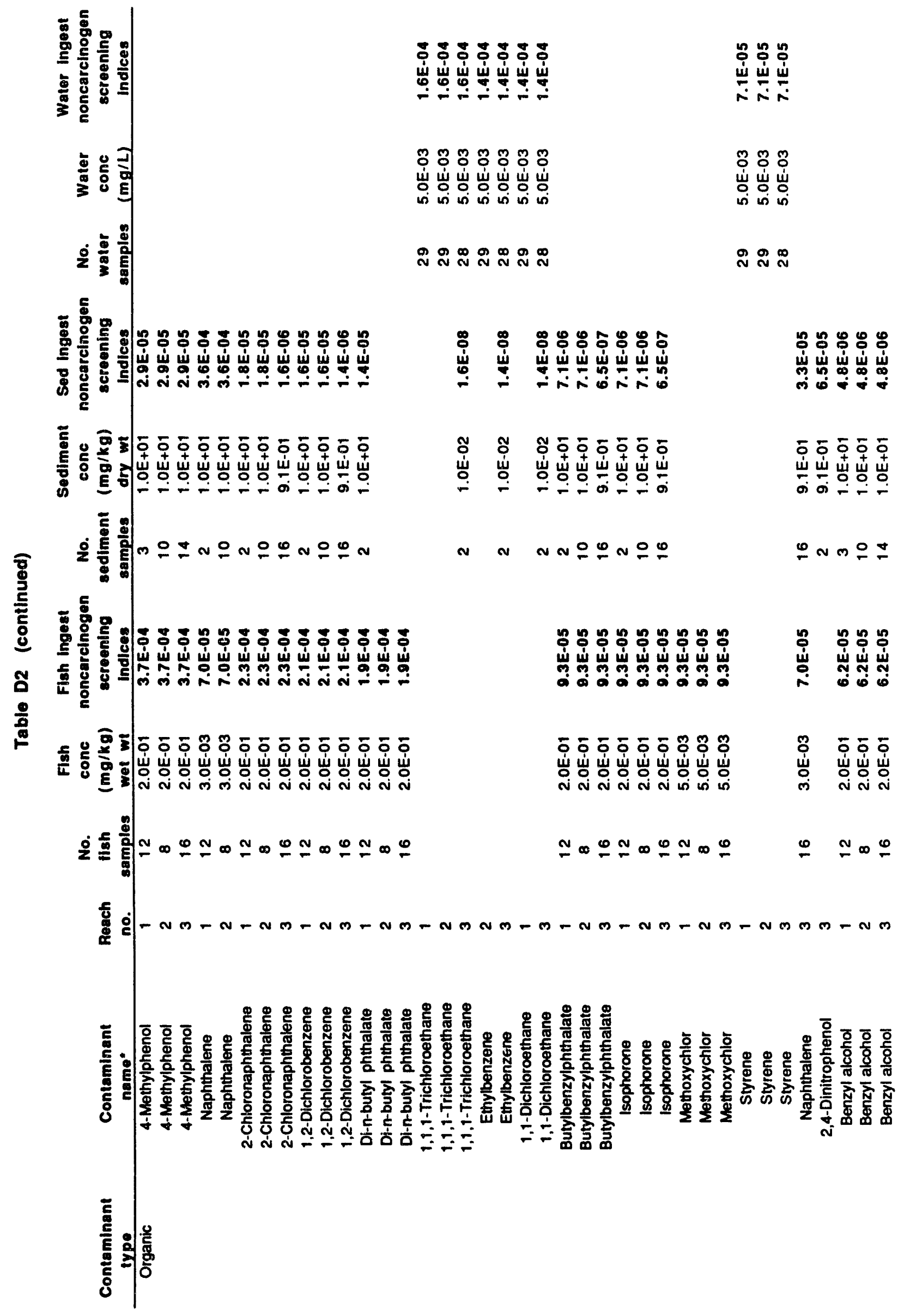




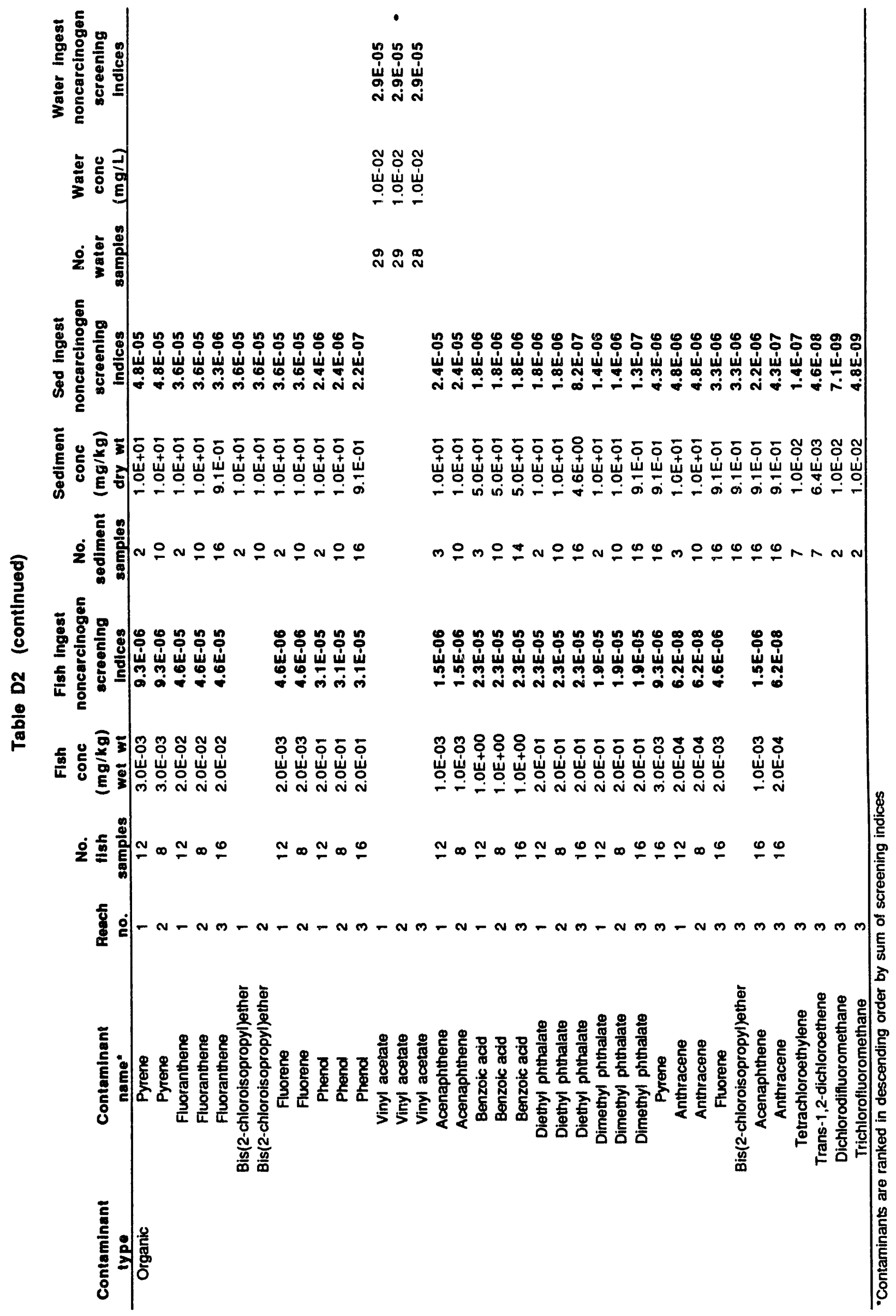




\section{APPENDIX E}

CONSERVATIVE SCREENING OF THE DETECTABLE CONTAMINANTS DATA BASE FOR CARCINOGENS AND NONCARCINOGENS 


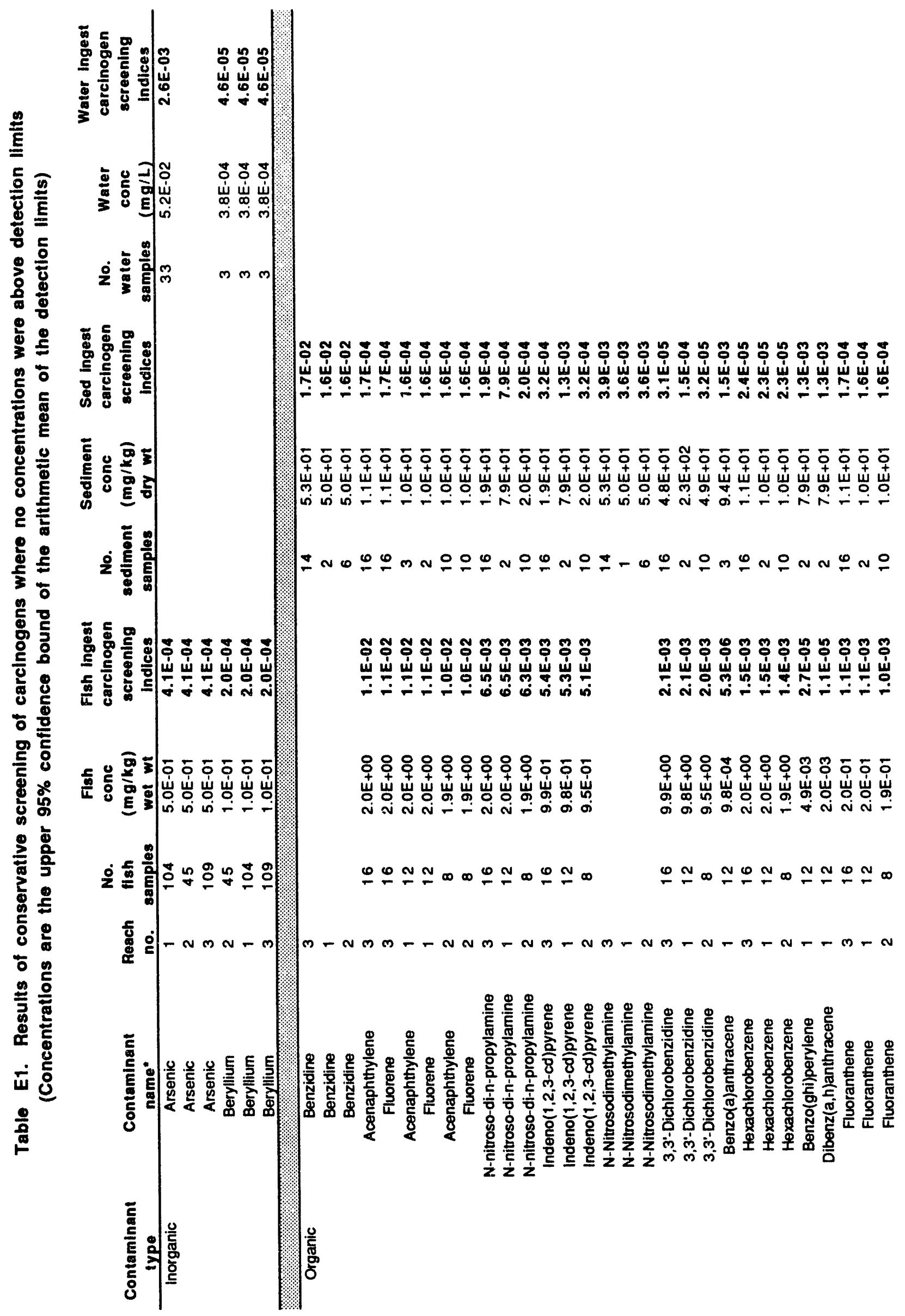




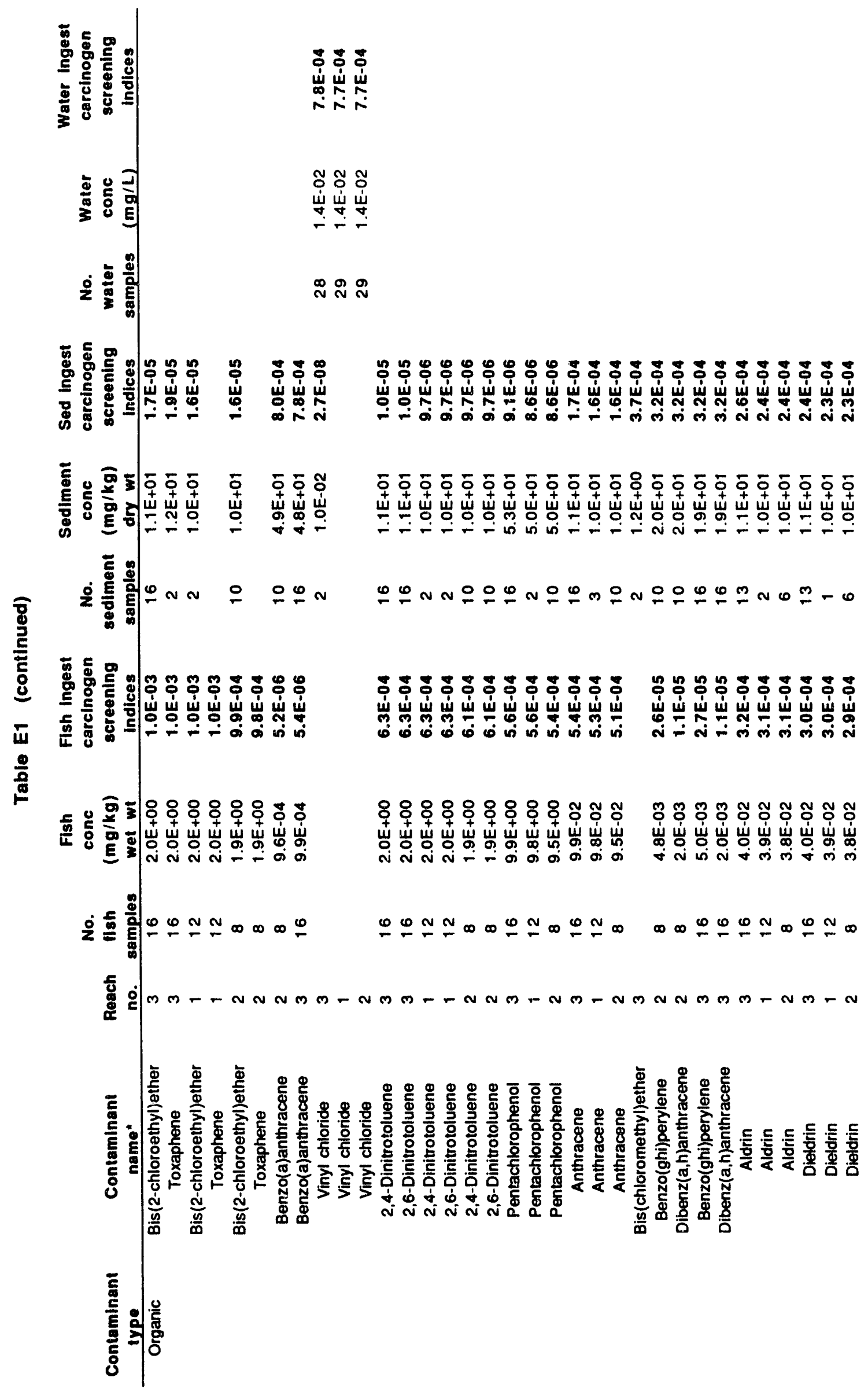




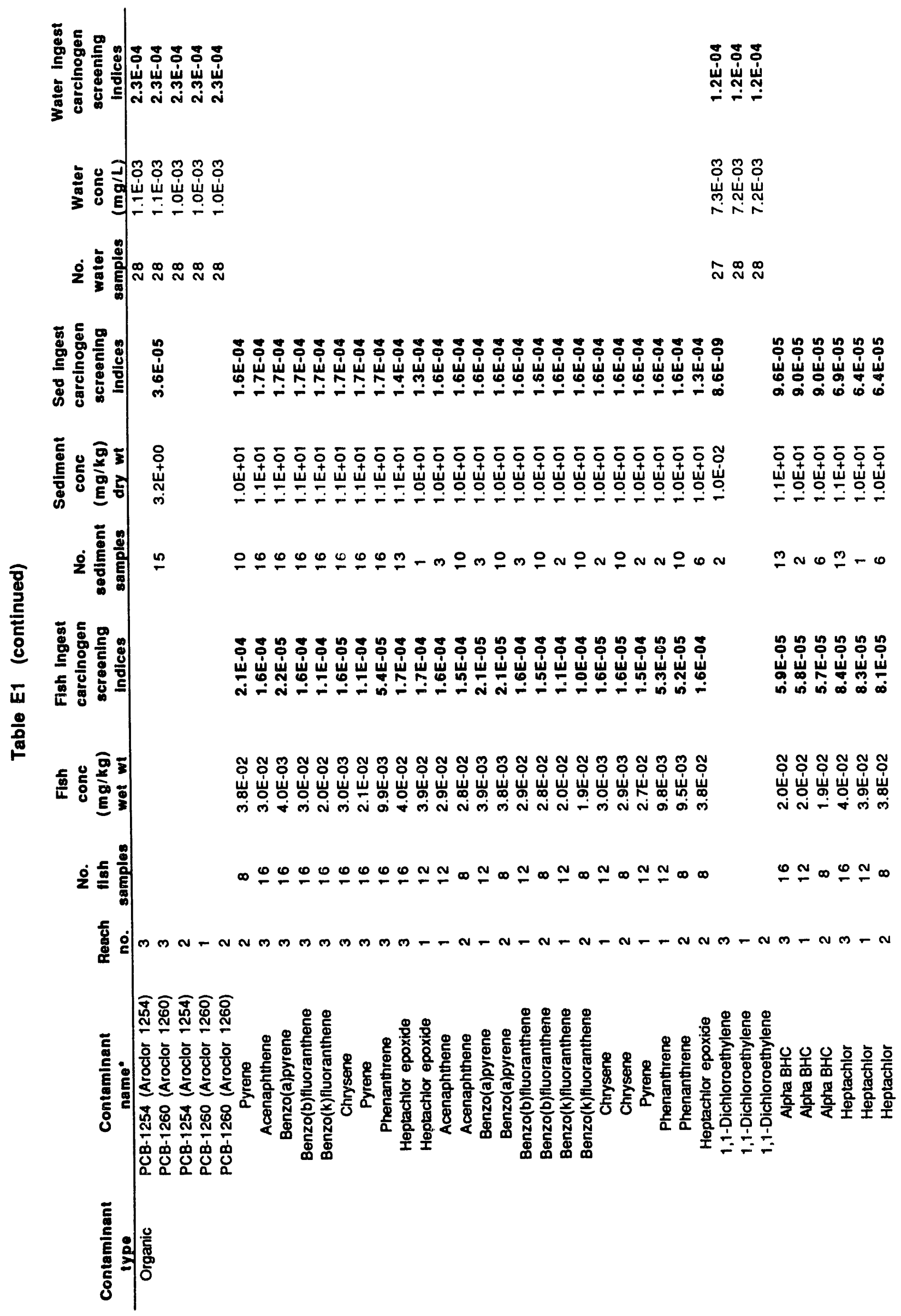




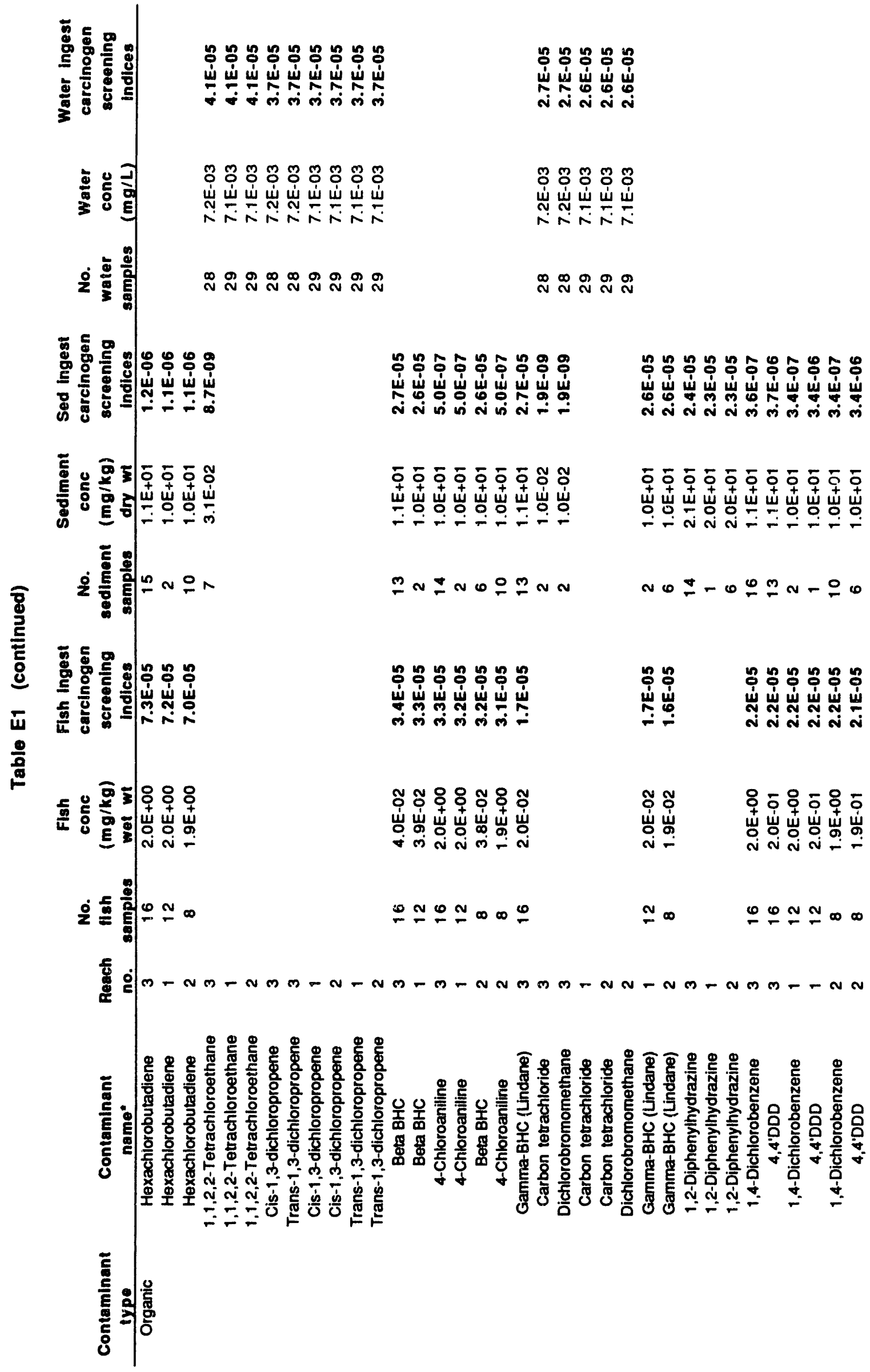


E-7

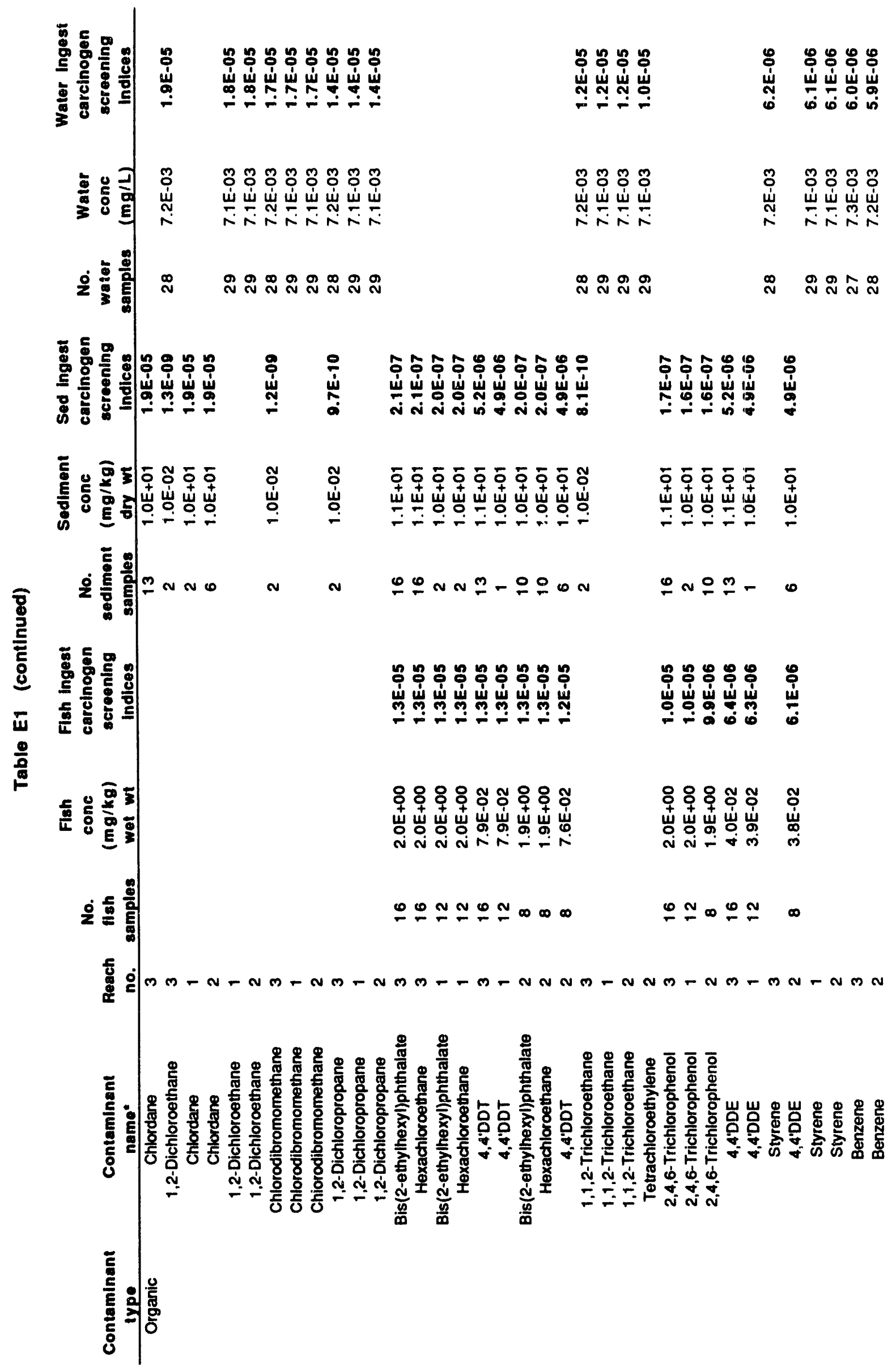




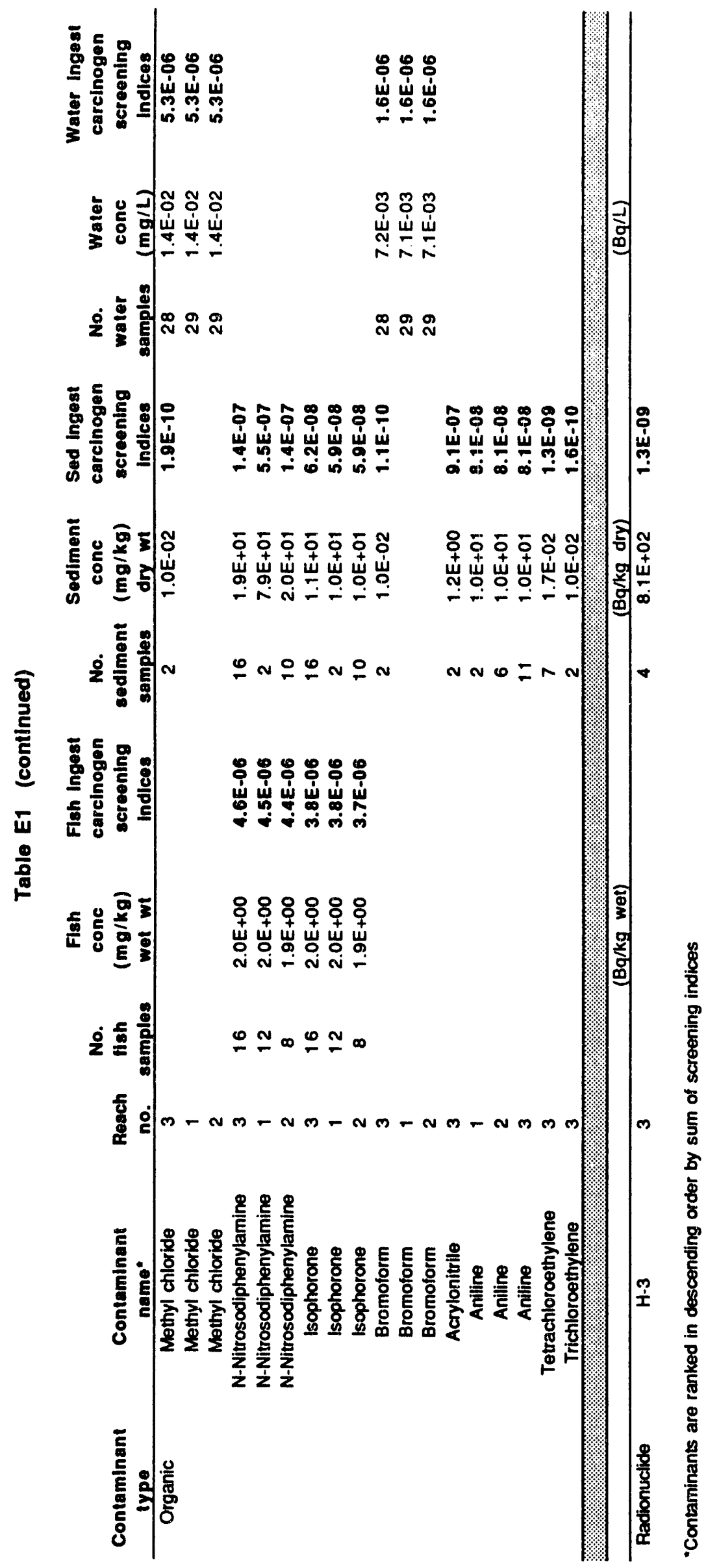




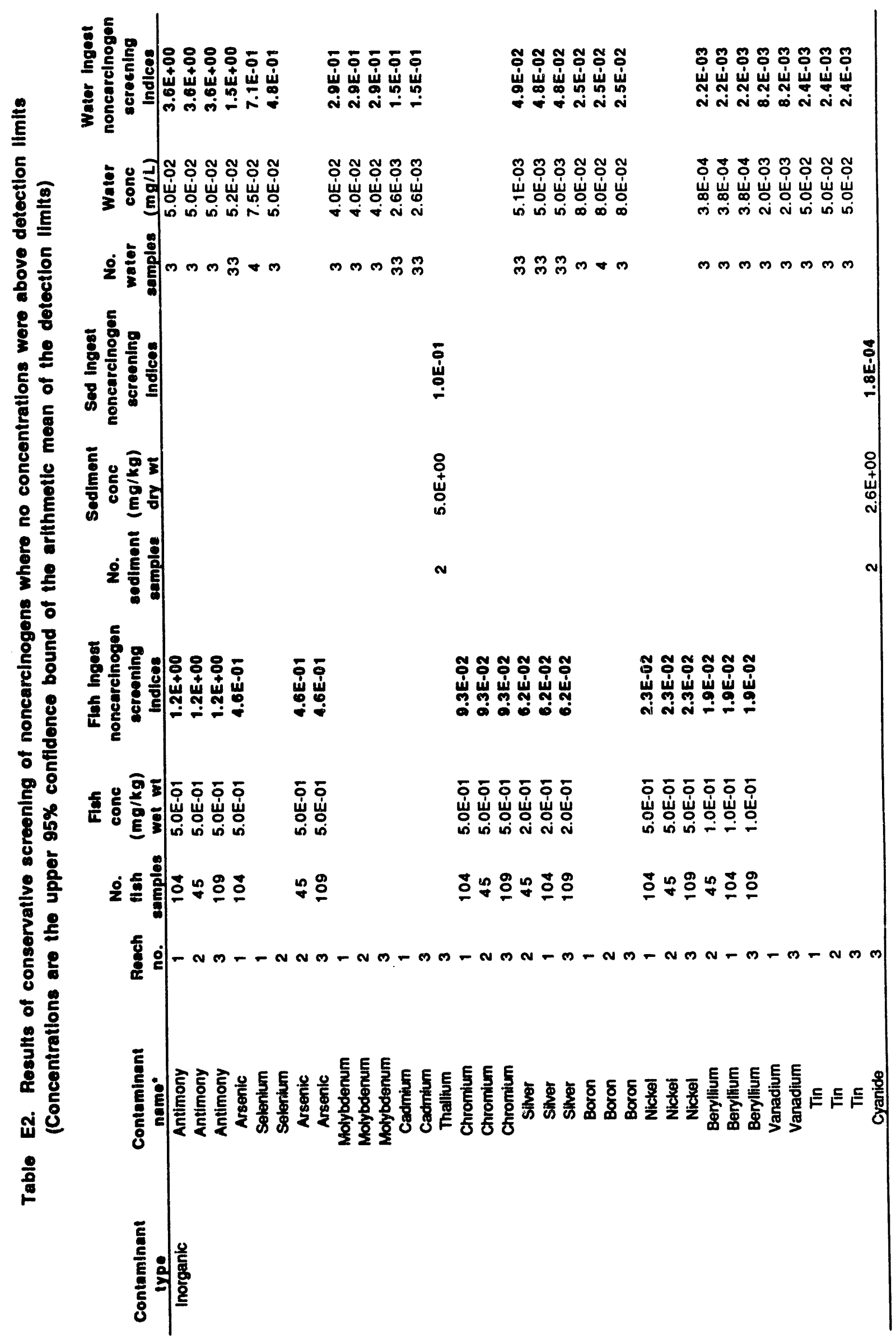




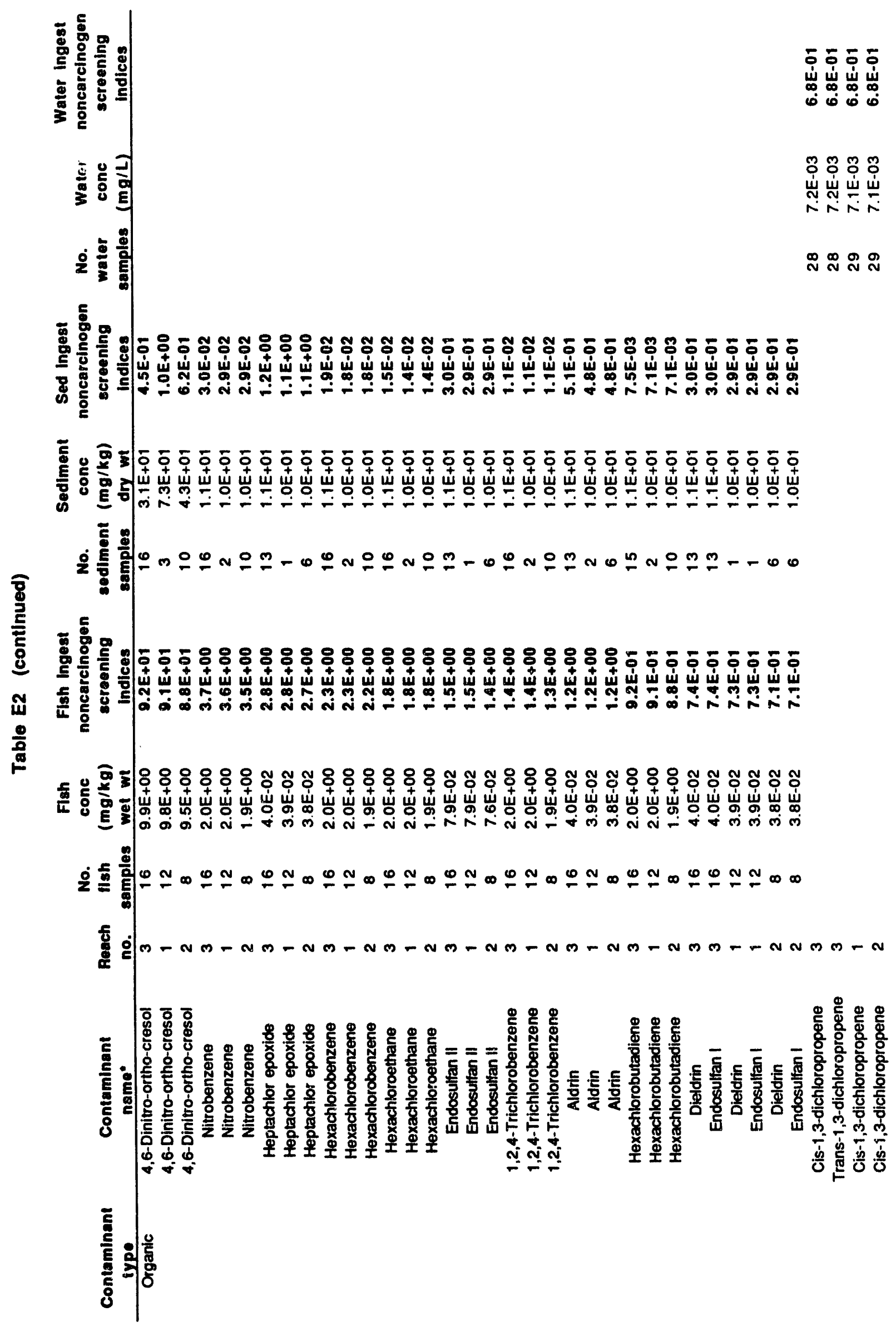




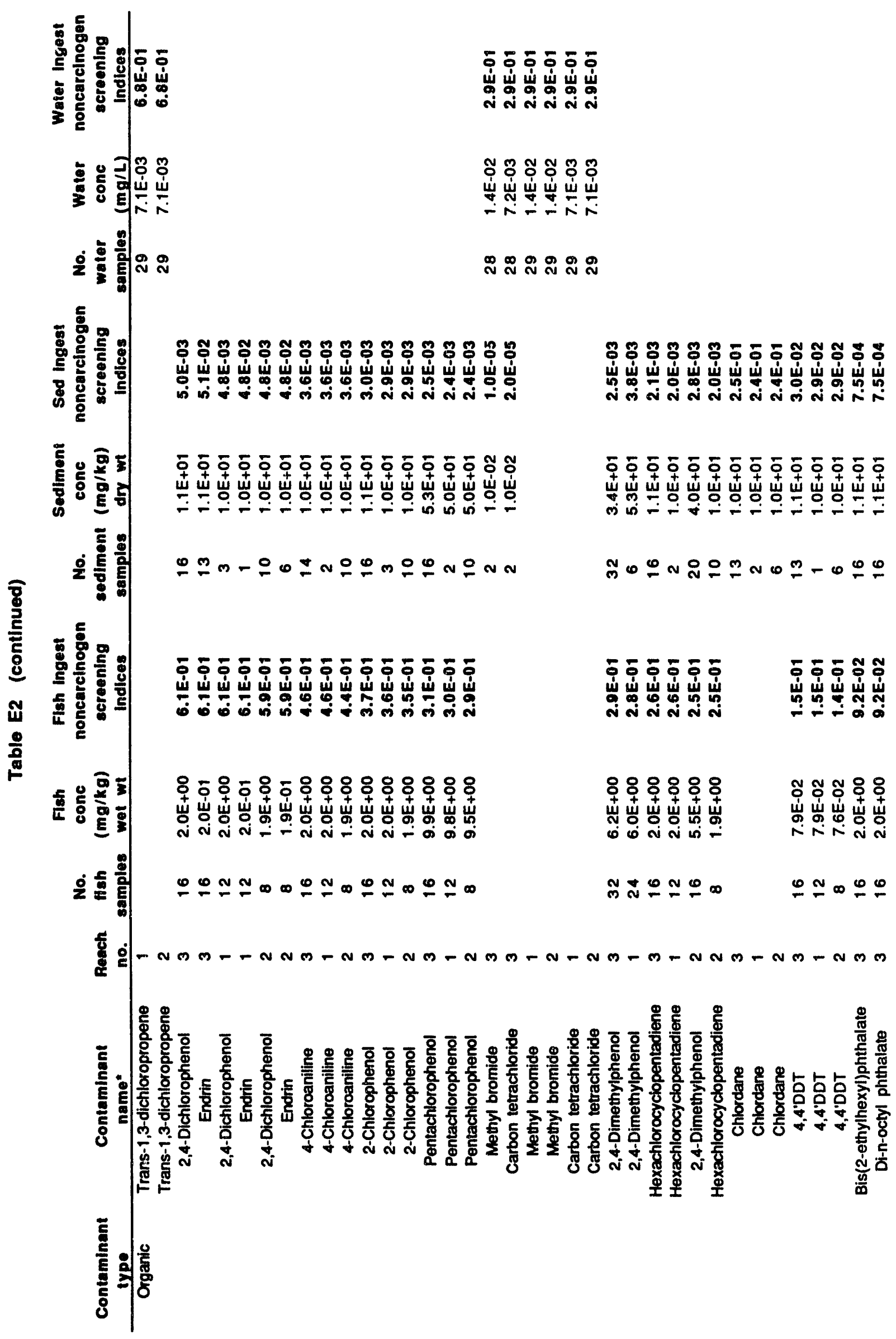




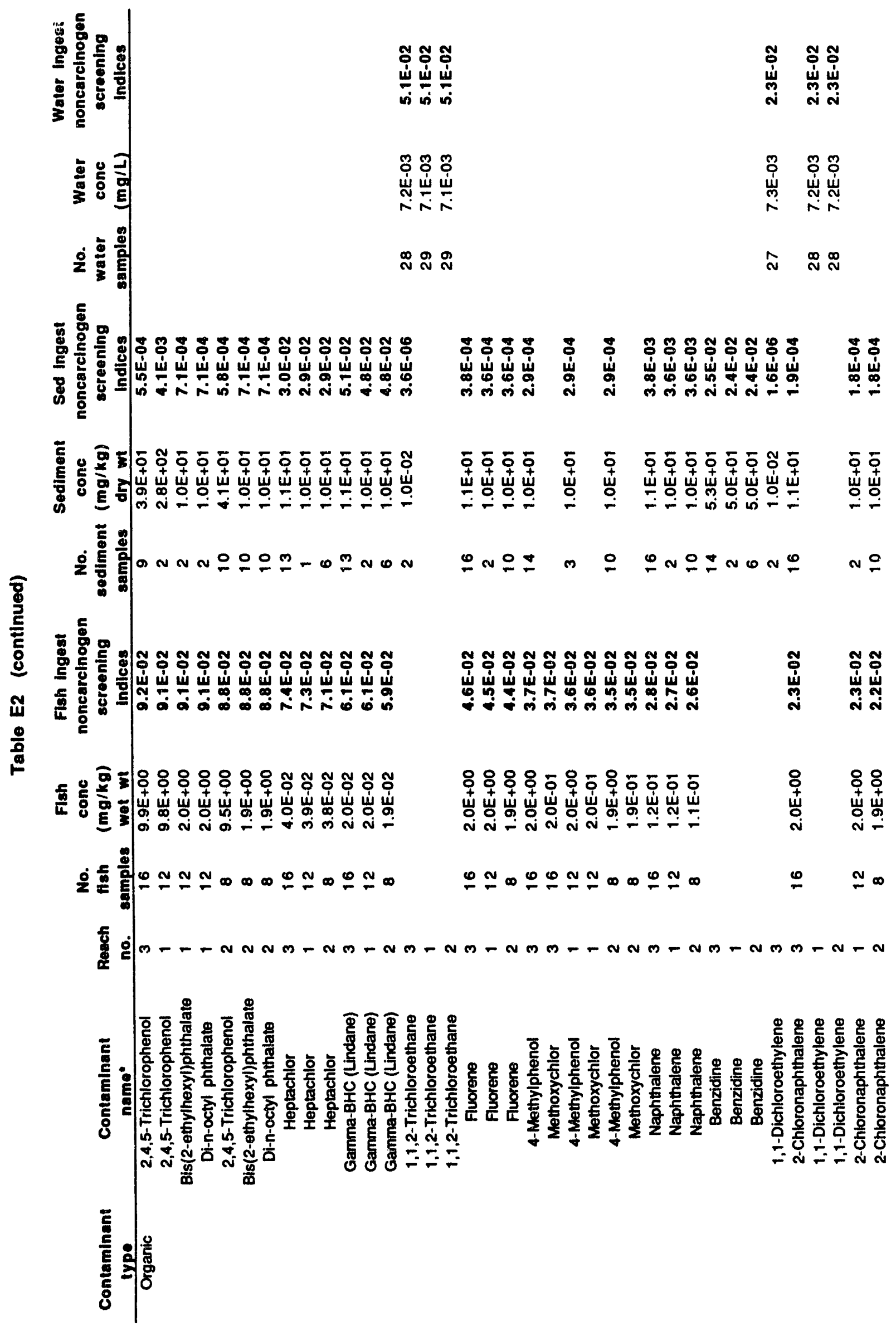




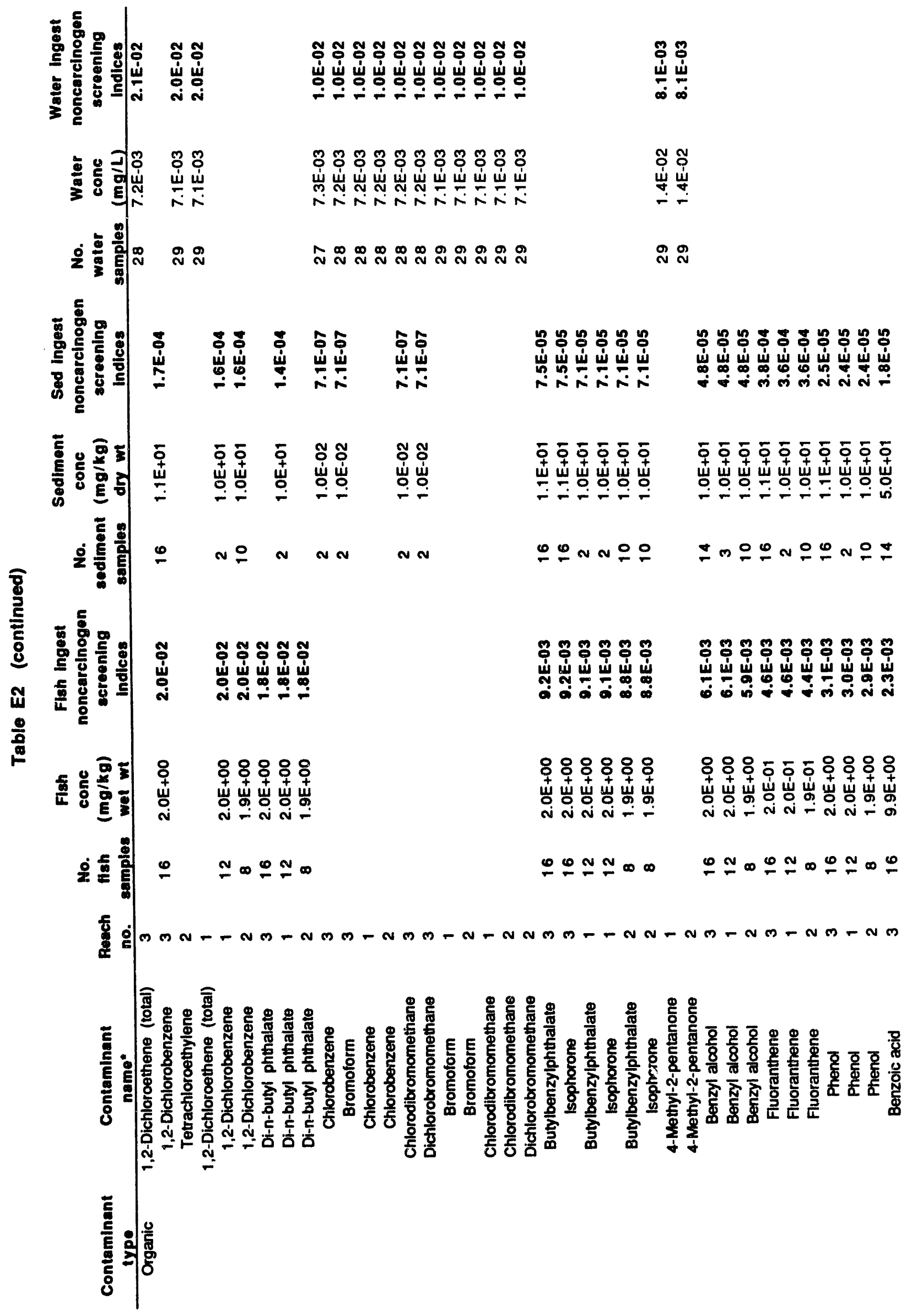




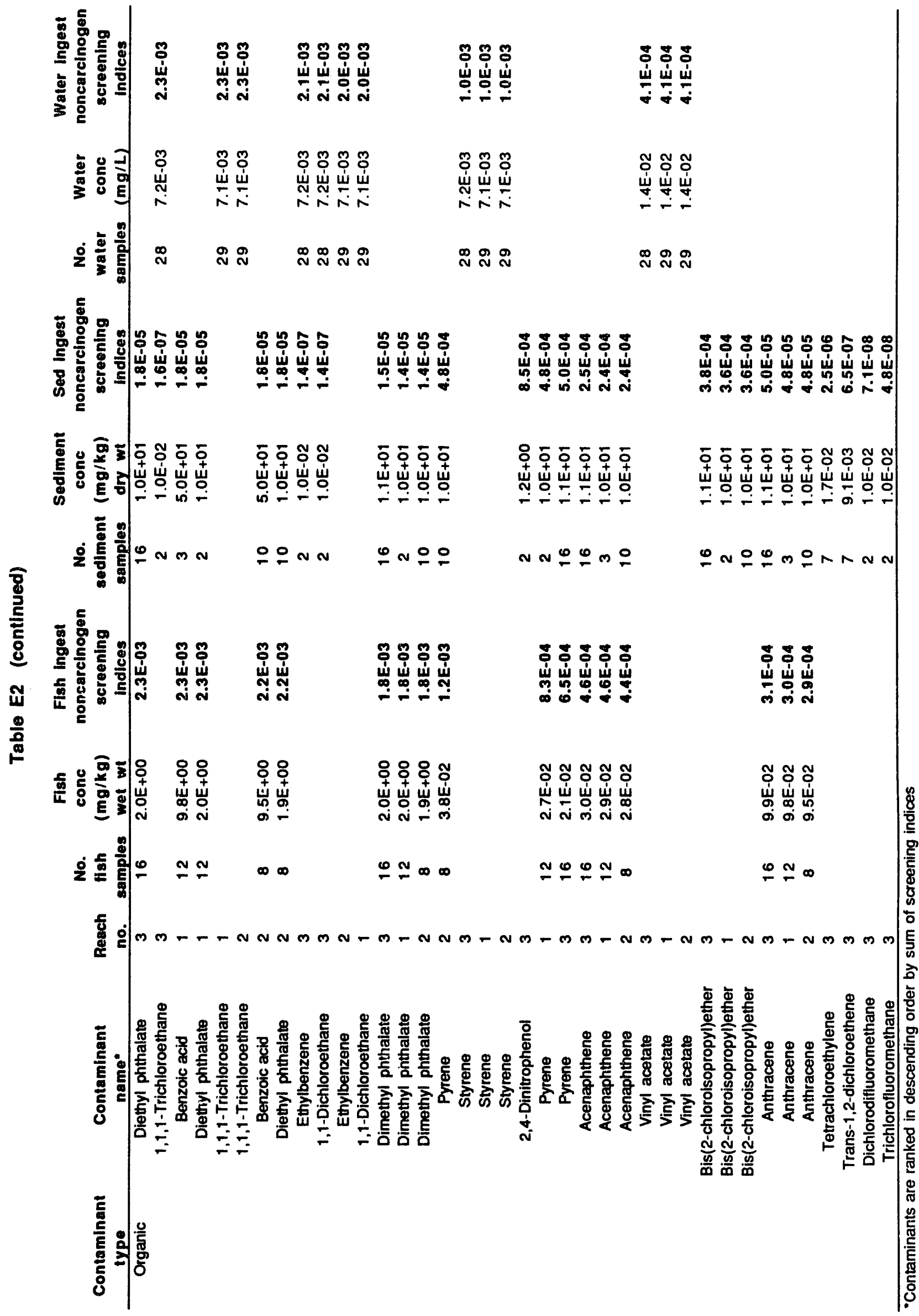




\begin{abstract}
APPENDIX F
NONCONSERVATIVE AND CONSERVATIVE SCREENING OF DETECTABLE CARCINOGENS AND NONCARCINOGENS IN GROUNDWATER
\end{abstract}




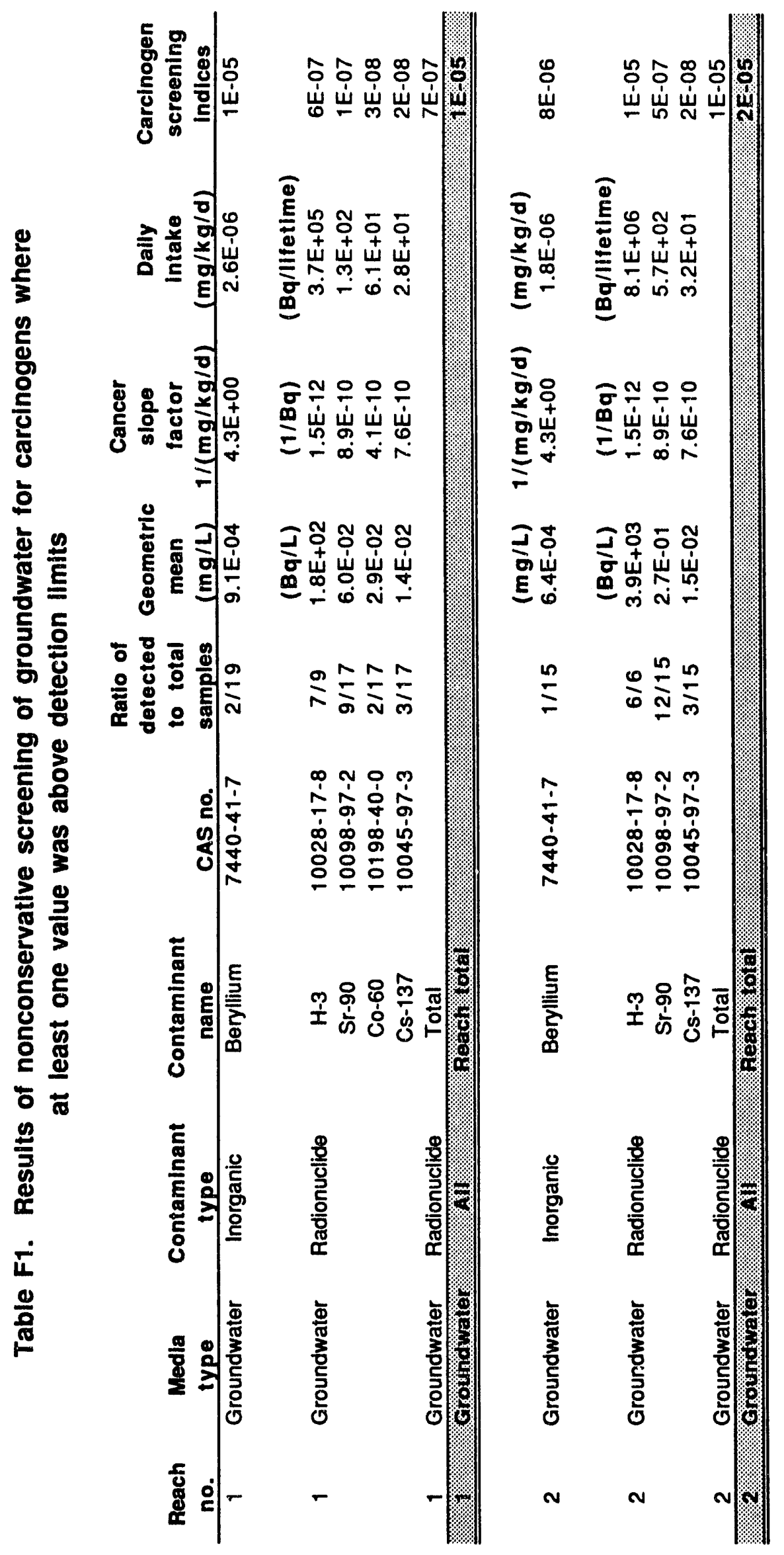




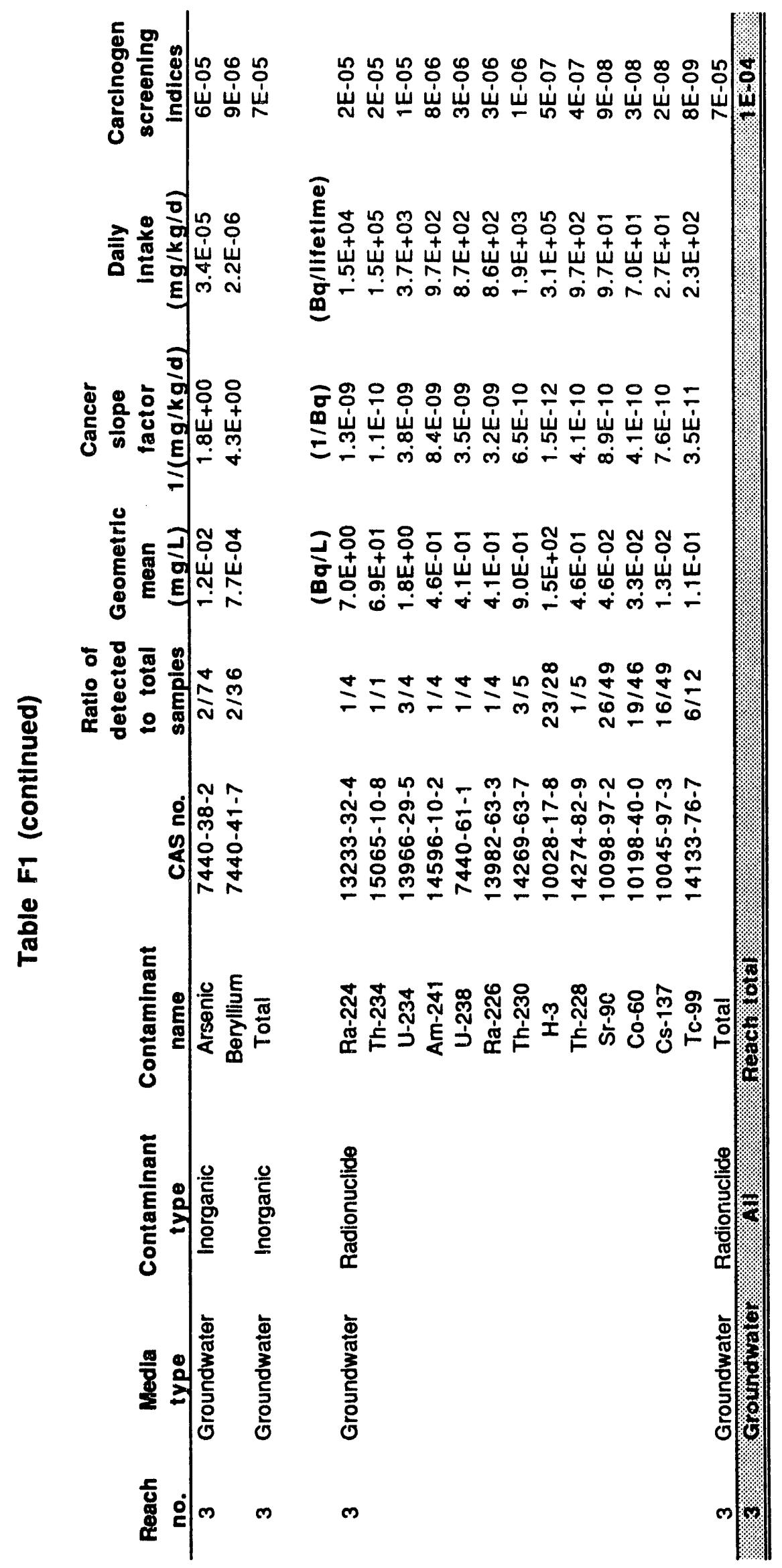




\section{$\frac{9}{3}$}

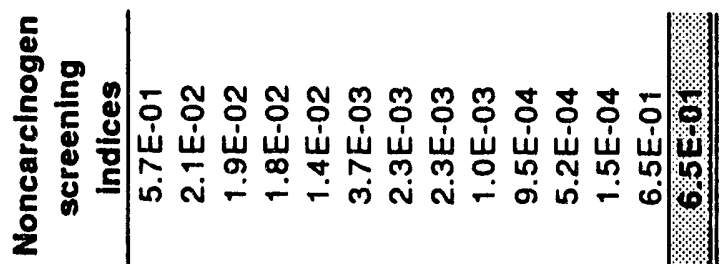

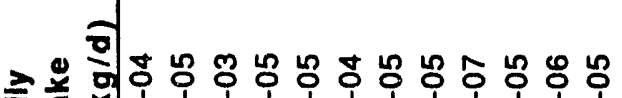
ह $\frac{8}{8}$

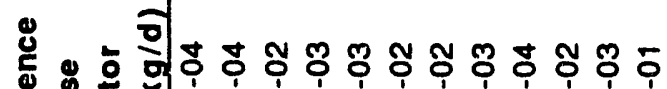

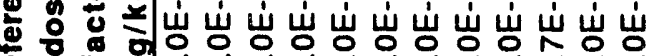

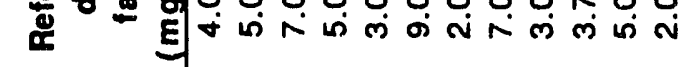

은 홍 ธ

8



.

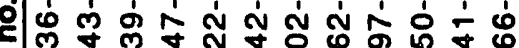

ต

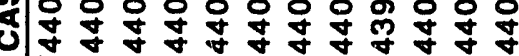

ธ 웡 瓀过

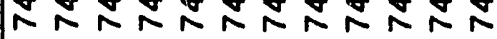

กั

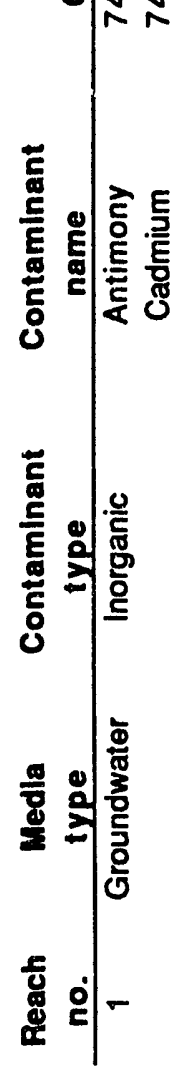

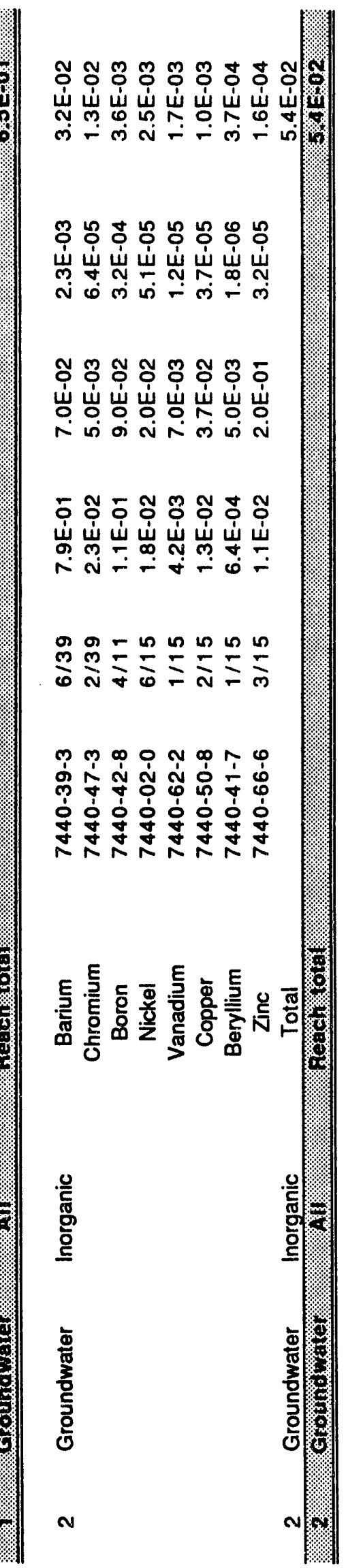




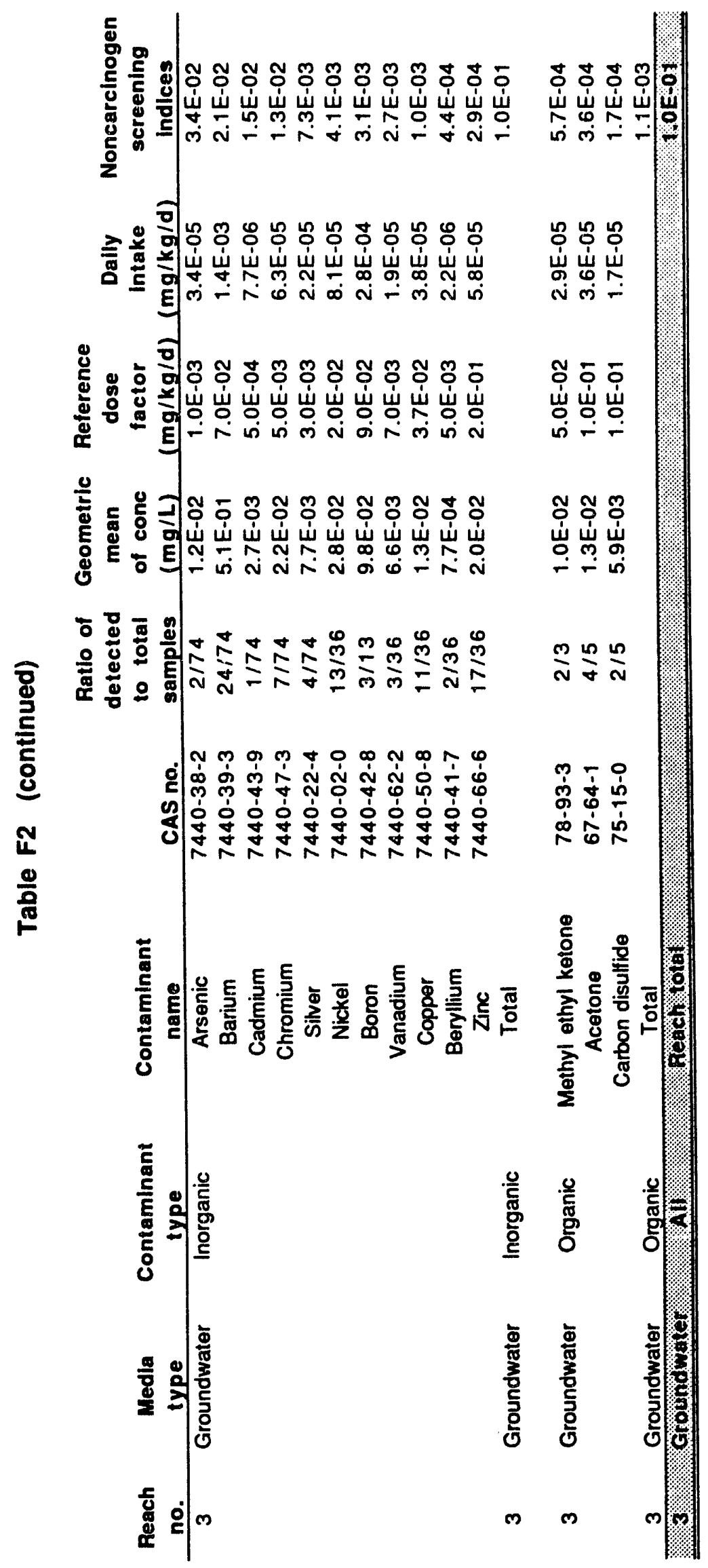




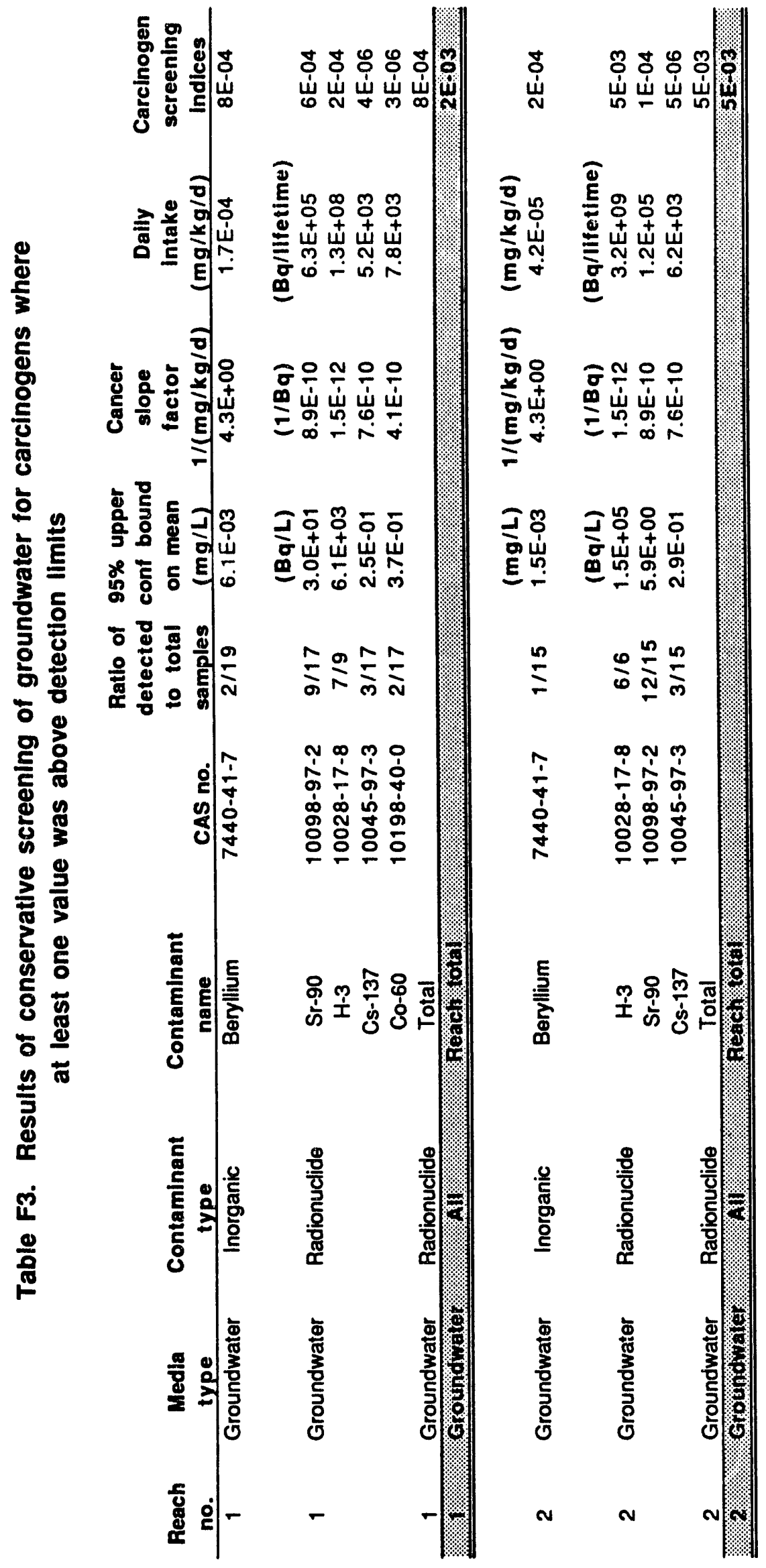




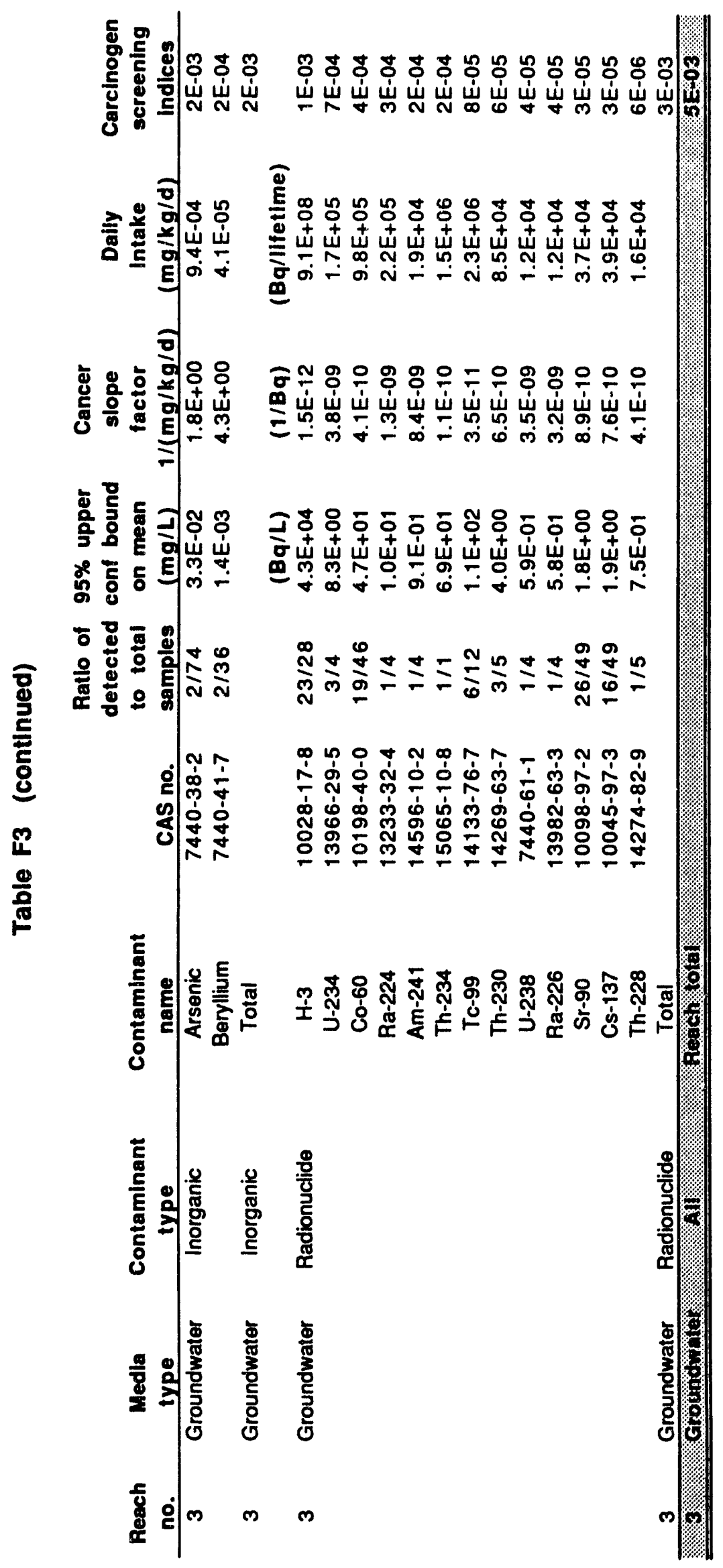




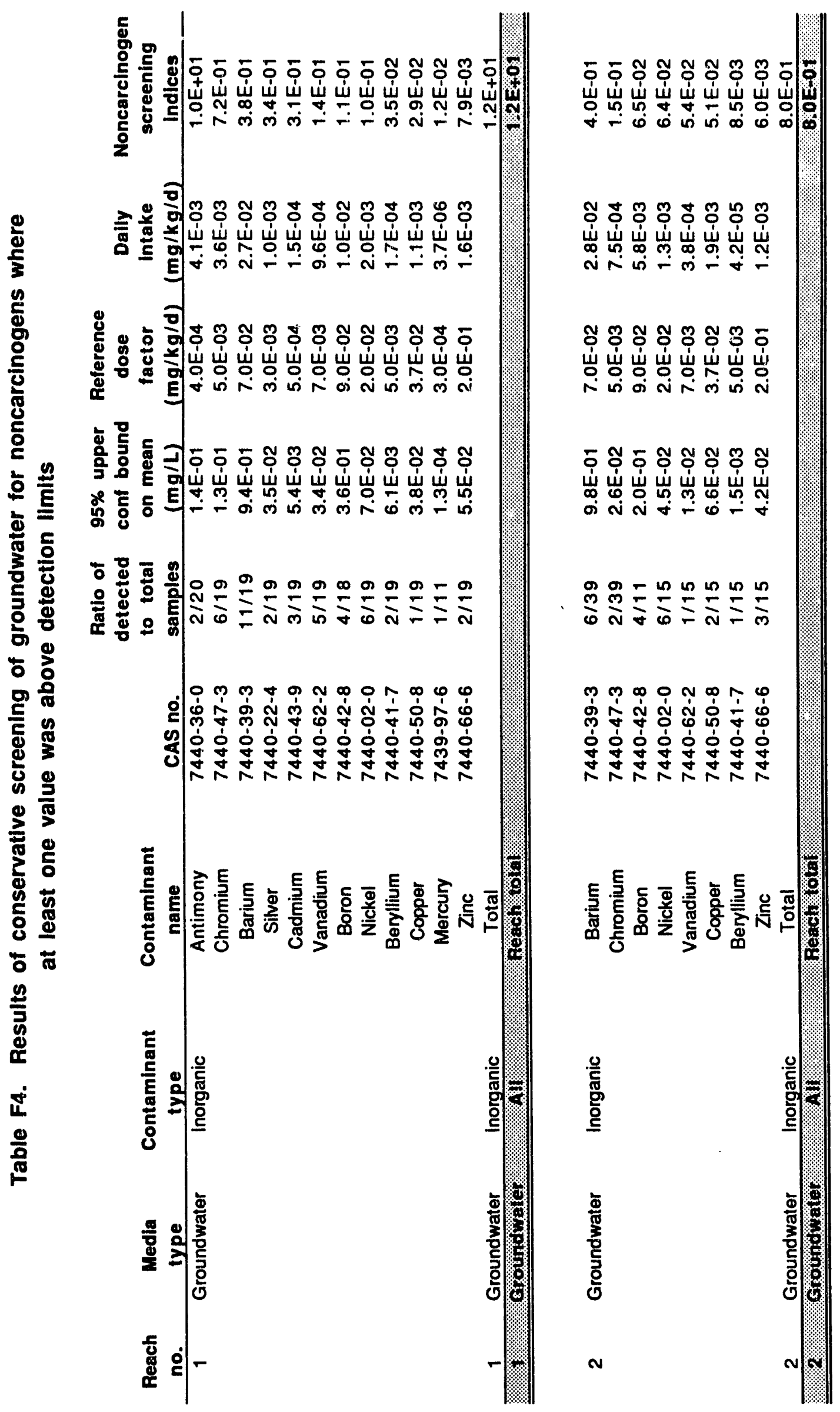




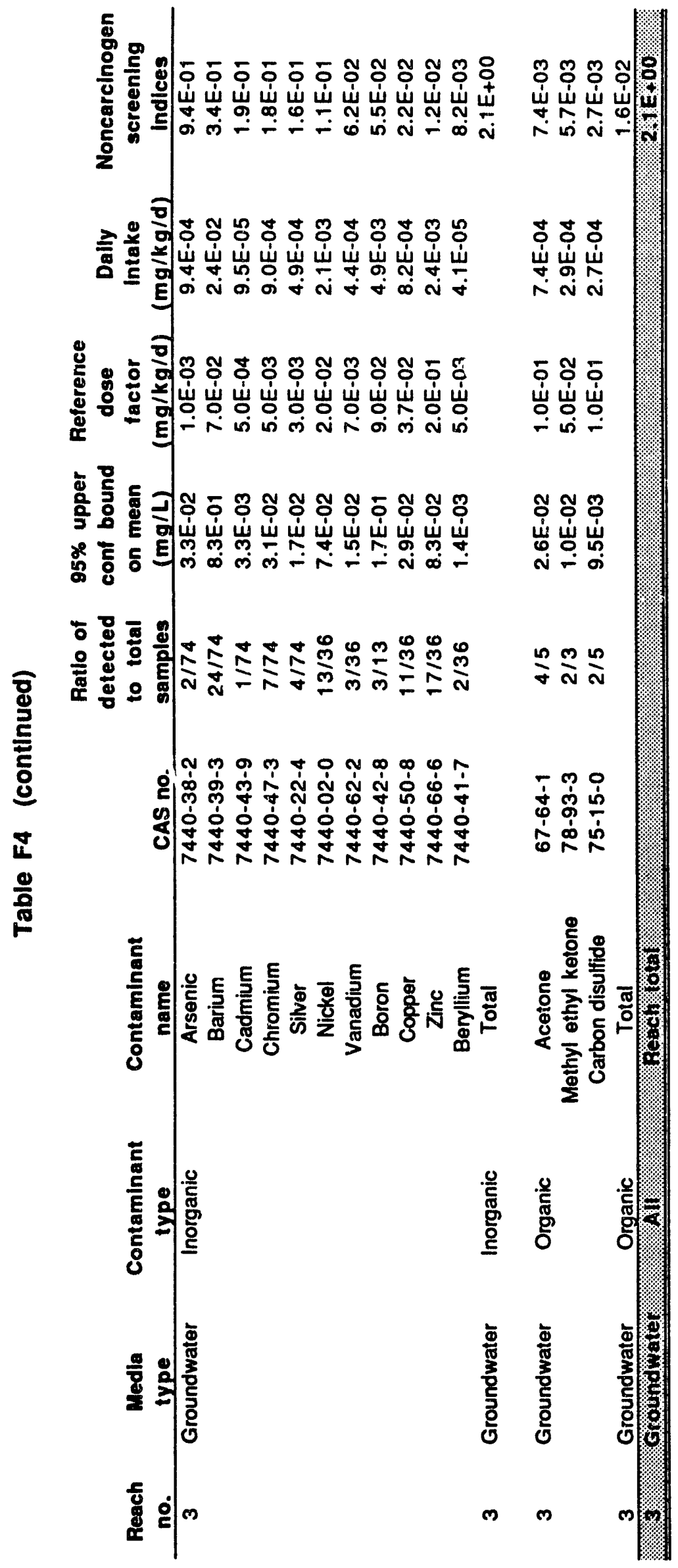




\section{APPENDIX G}

\section{DATA FOR ECOLOGICAL ASSESSMENT}


G-3

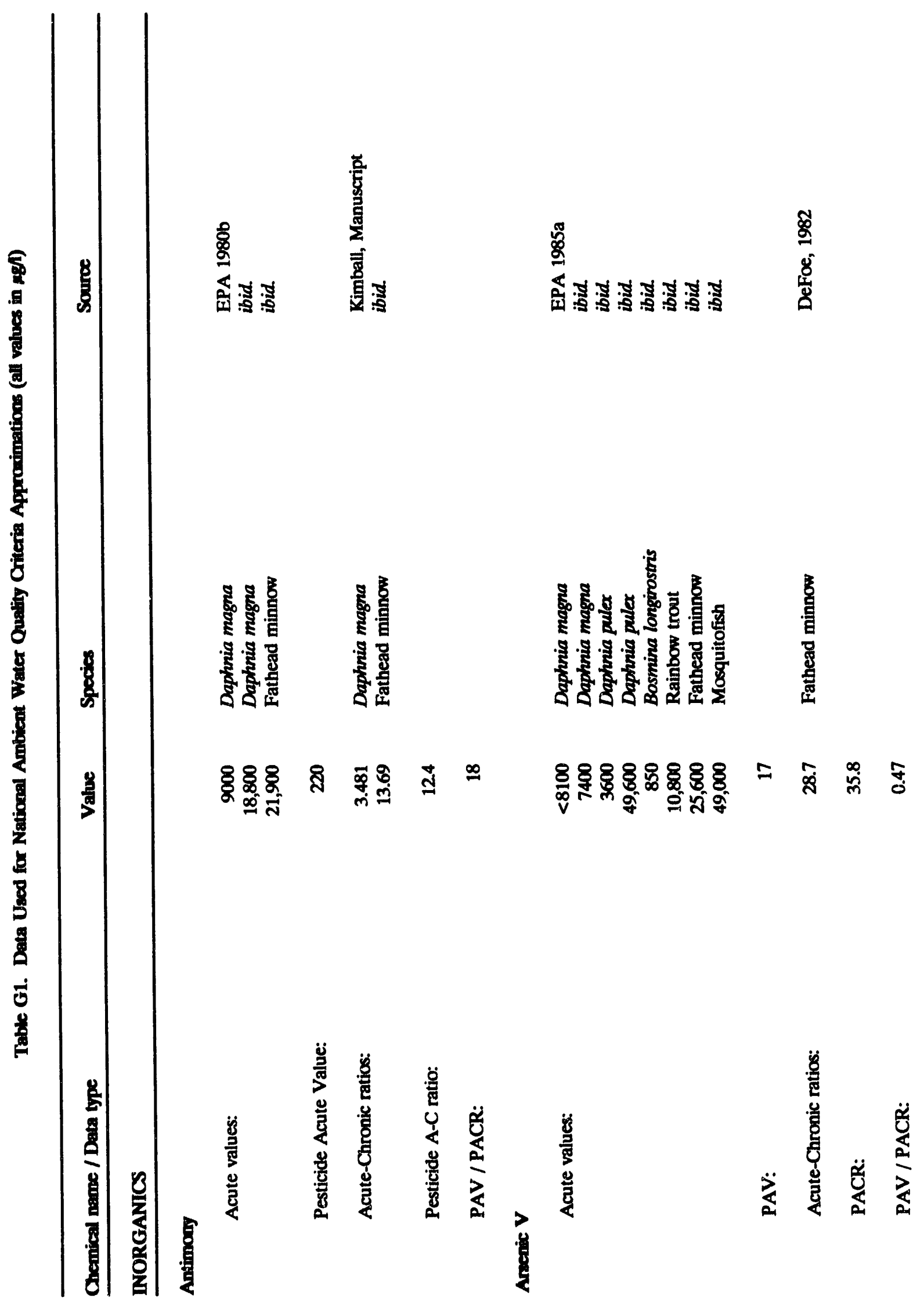


G-4

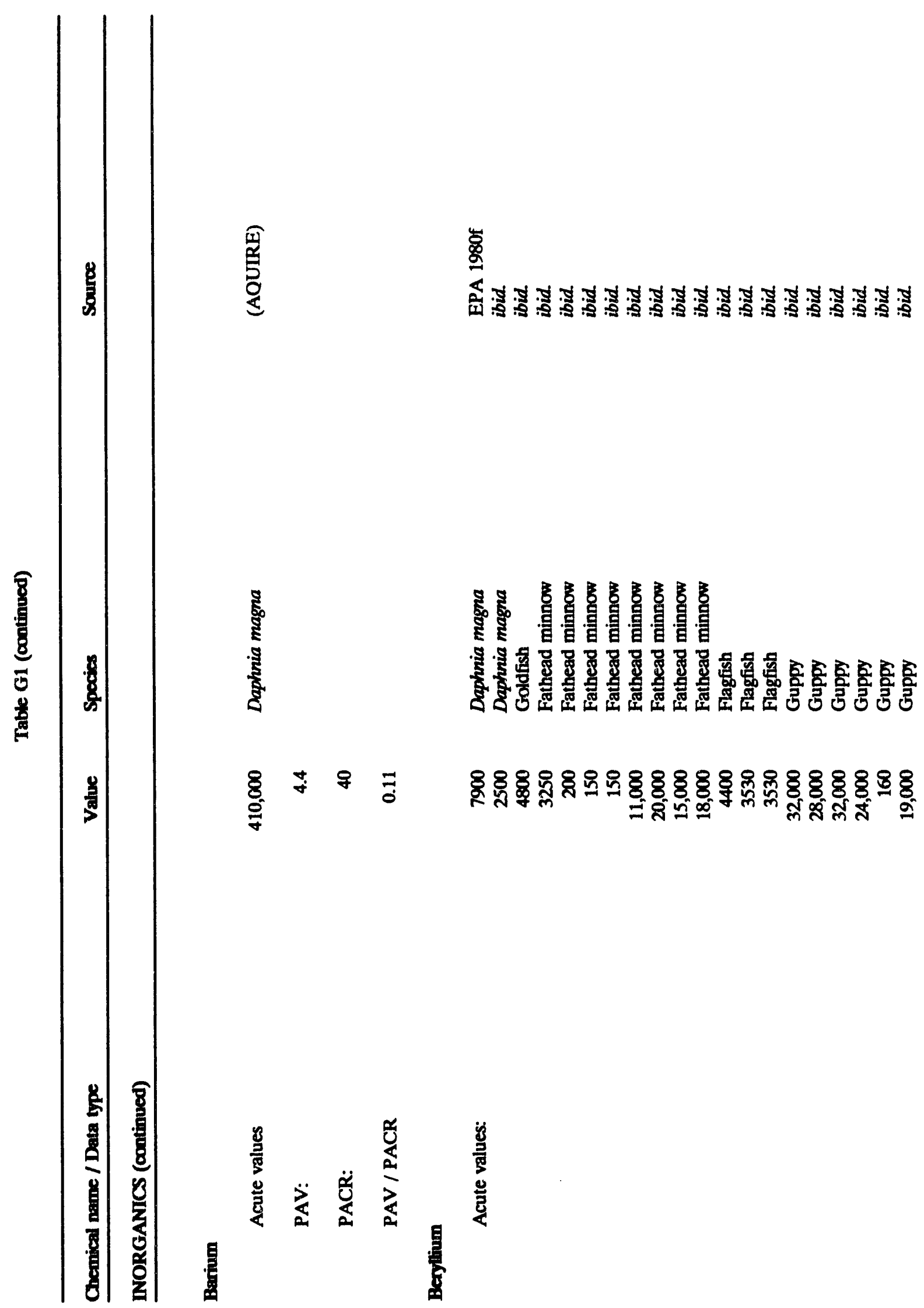


G-5

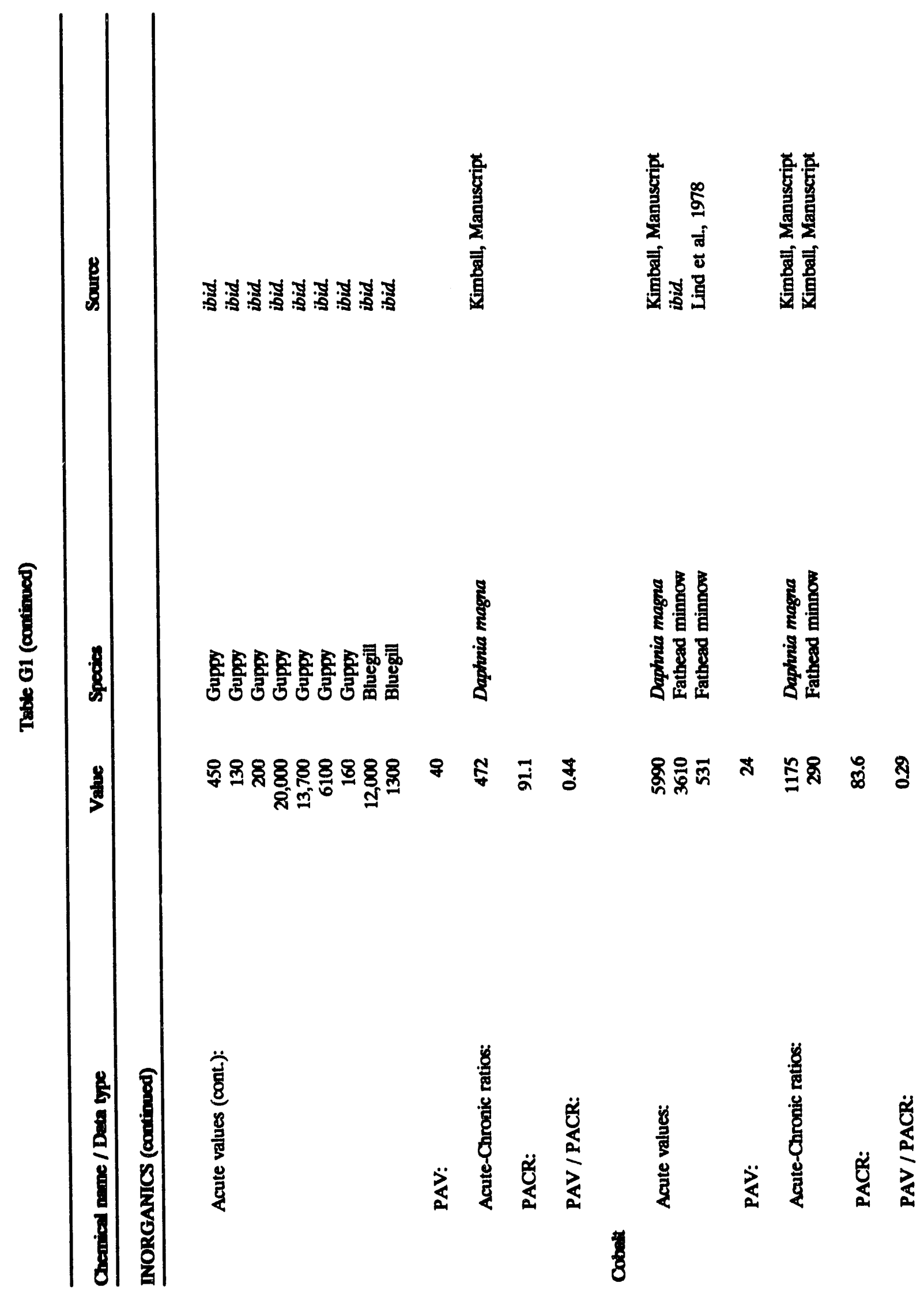




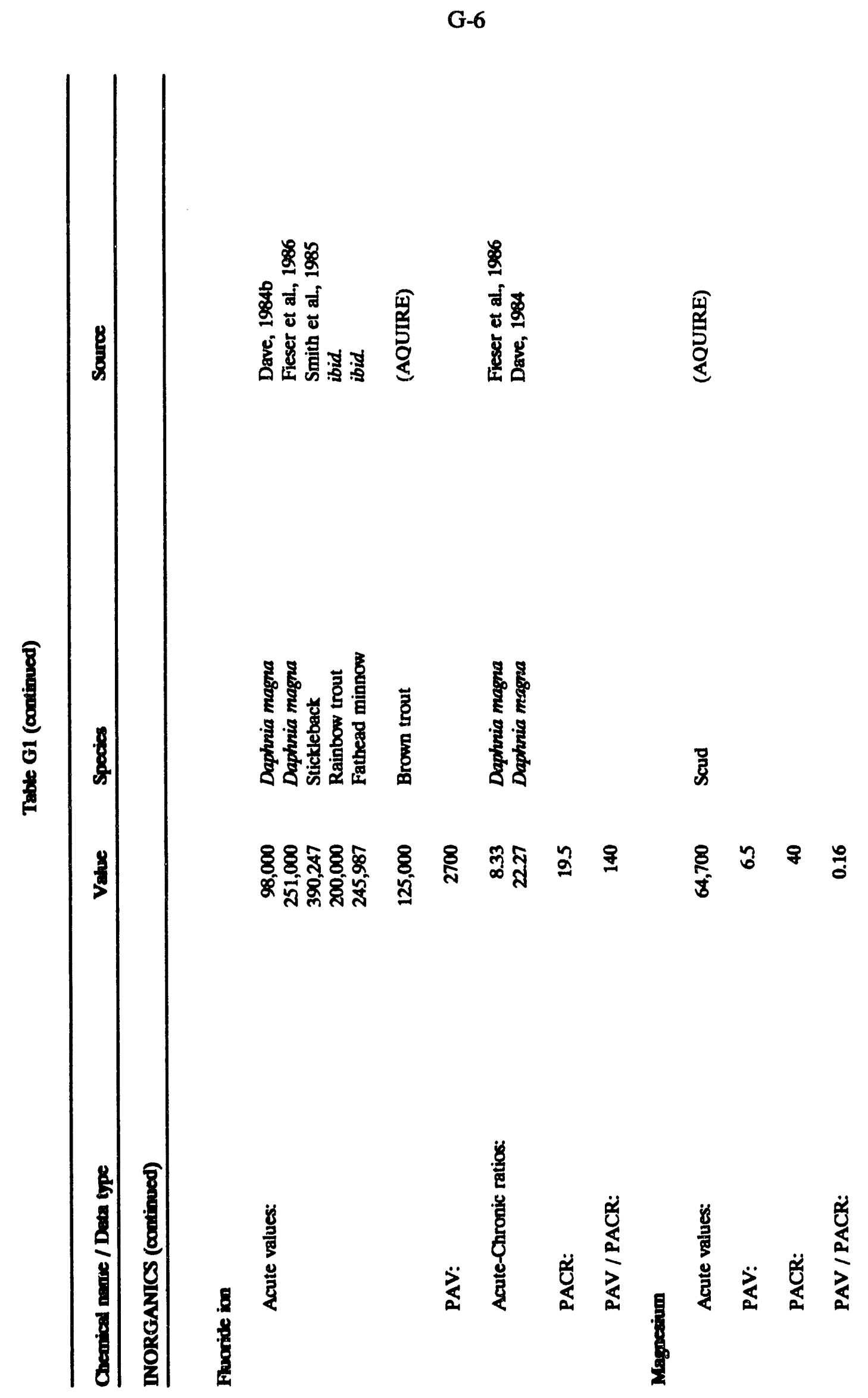


G-7

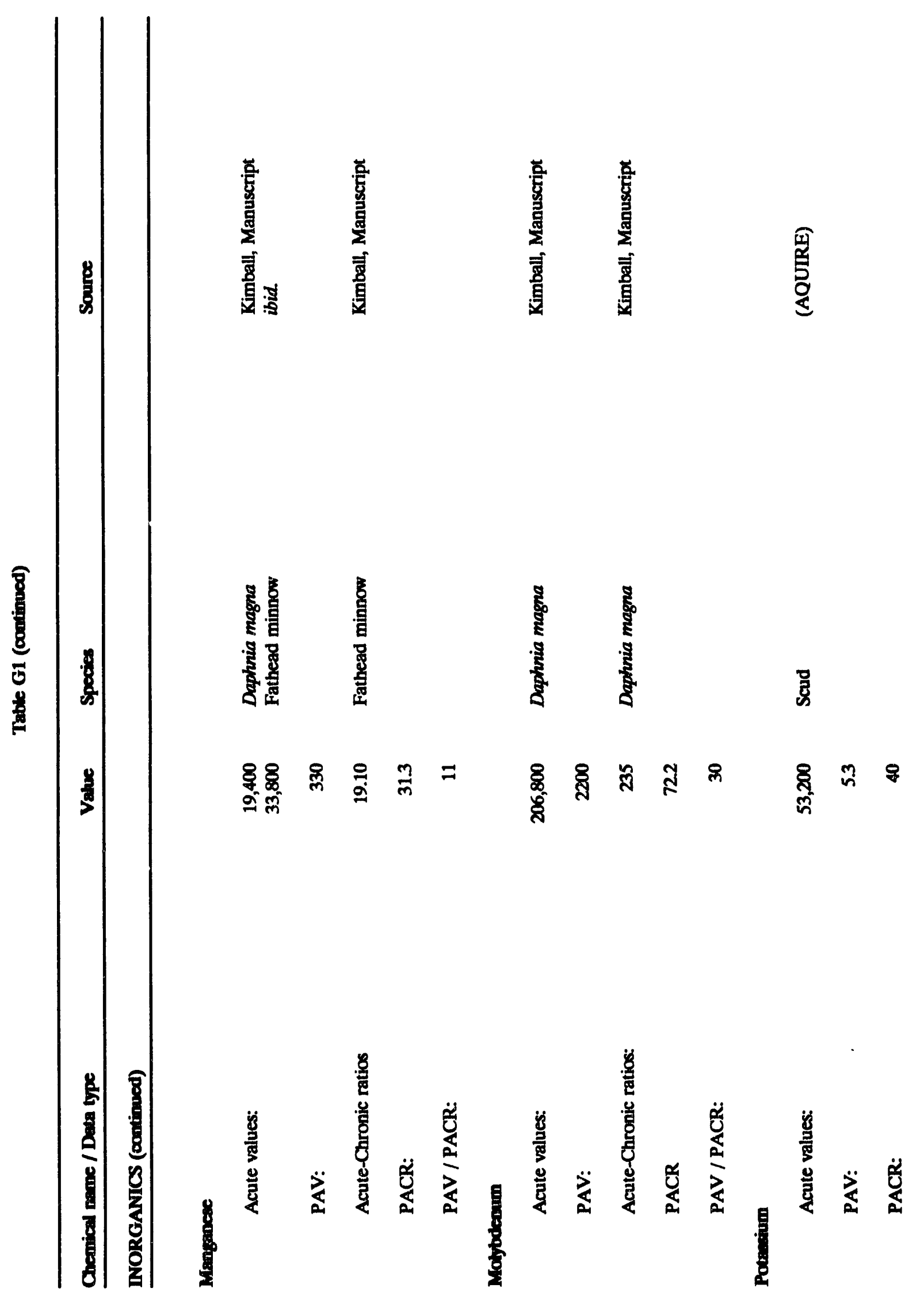




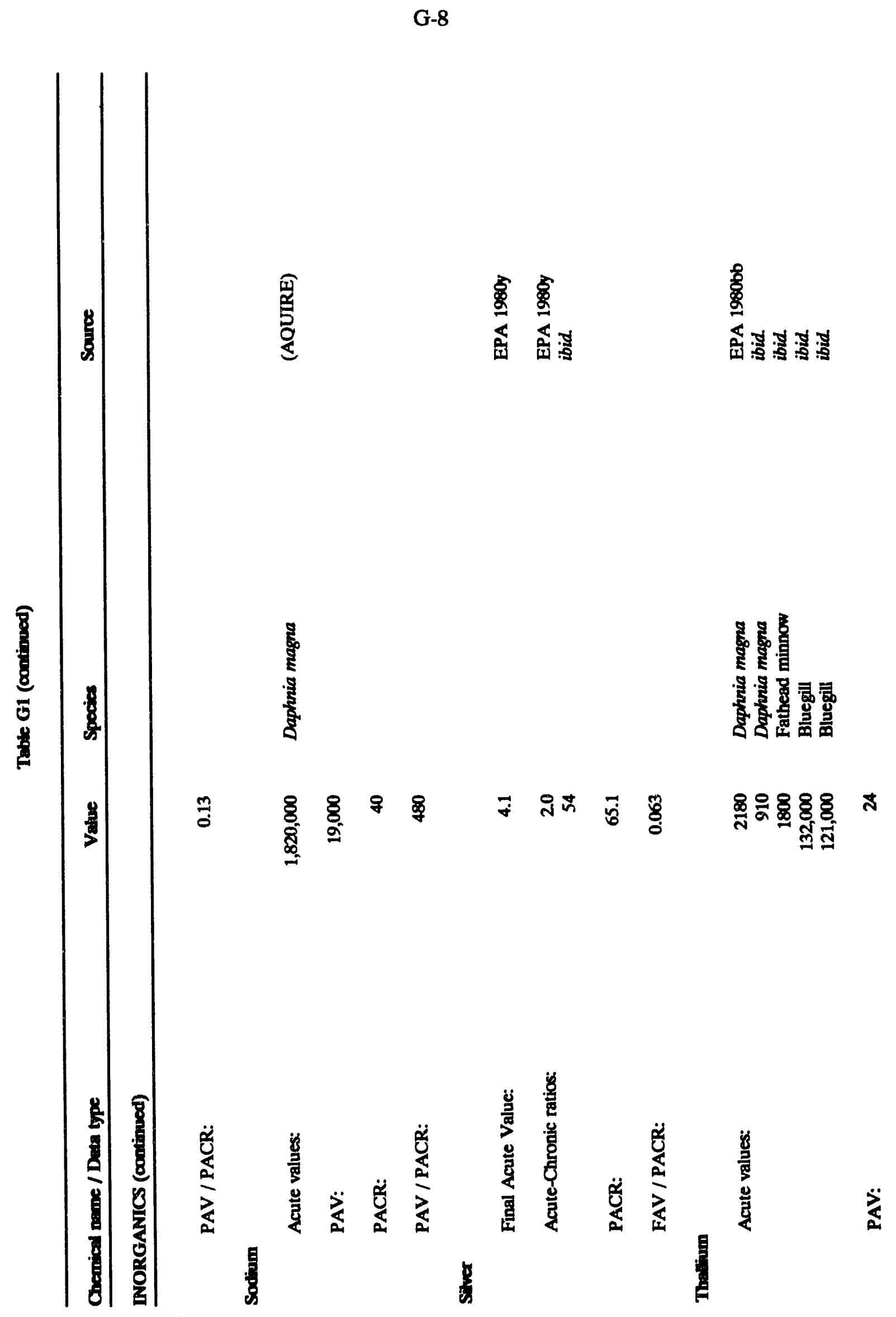


G-9

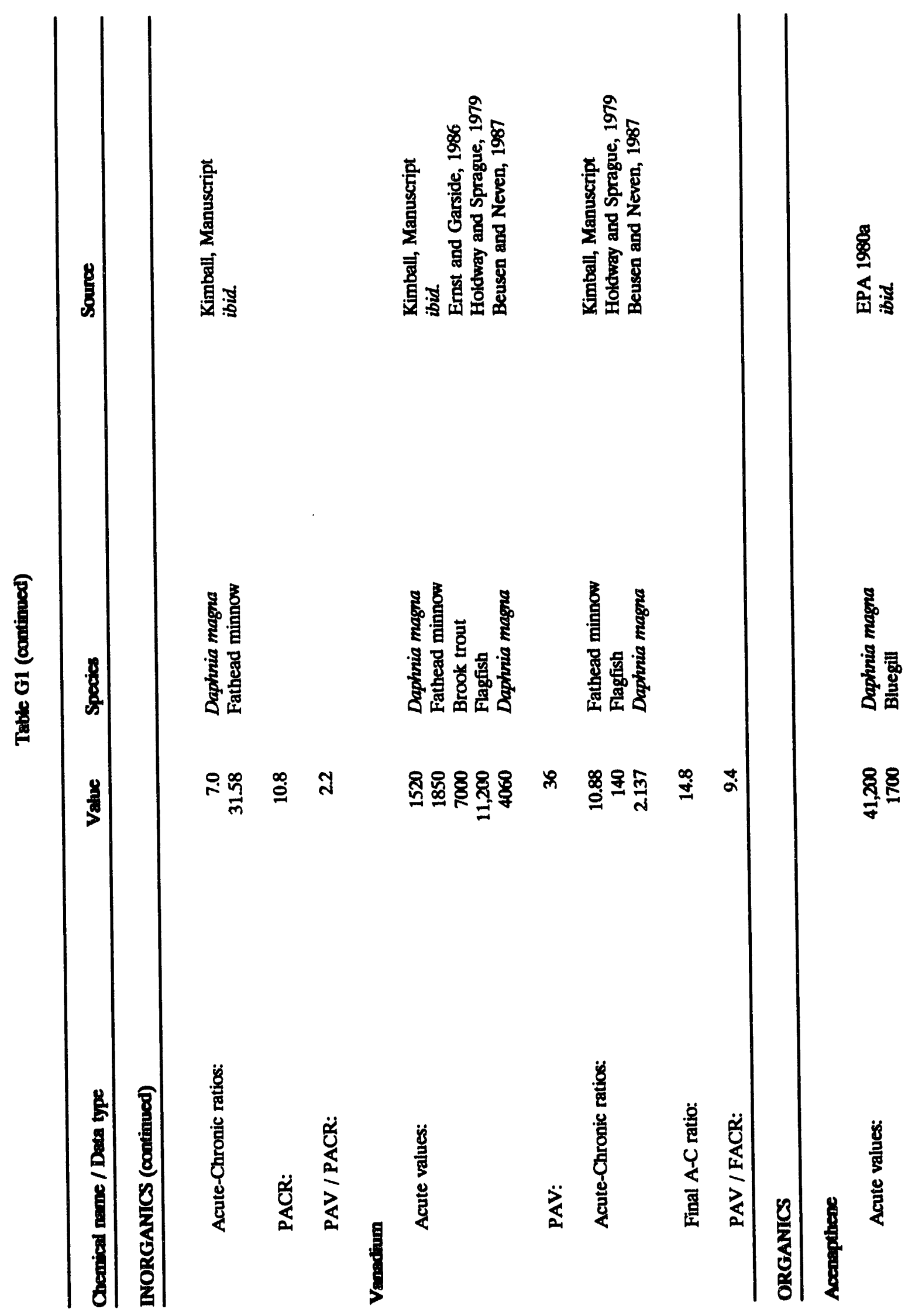




\section{G-10}

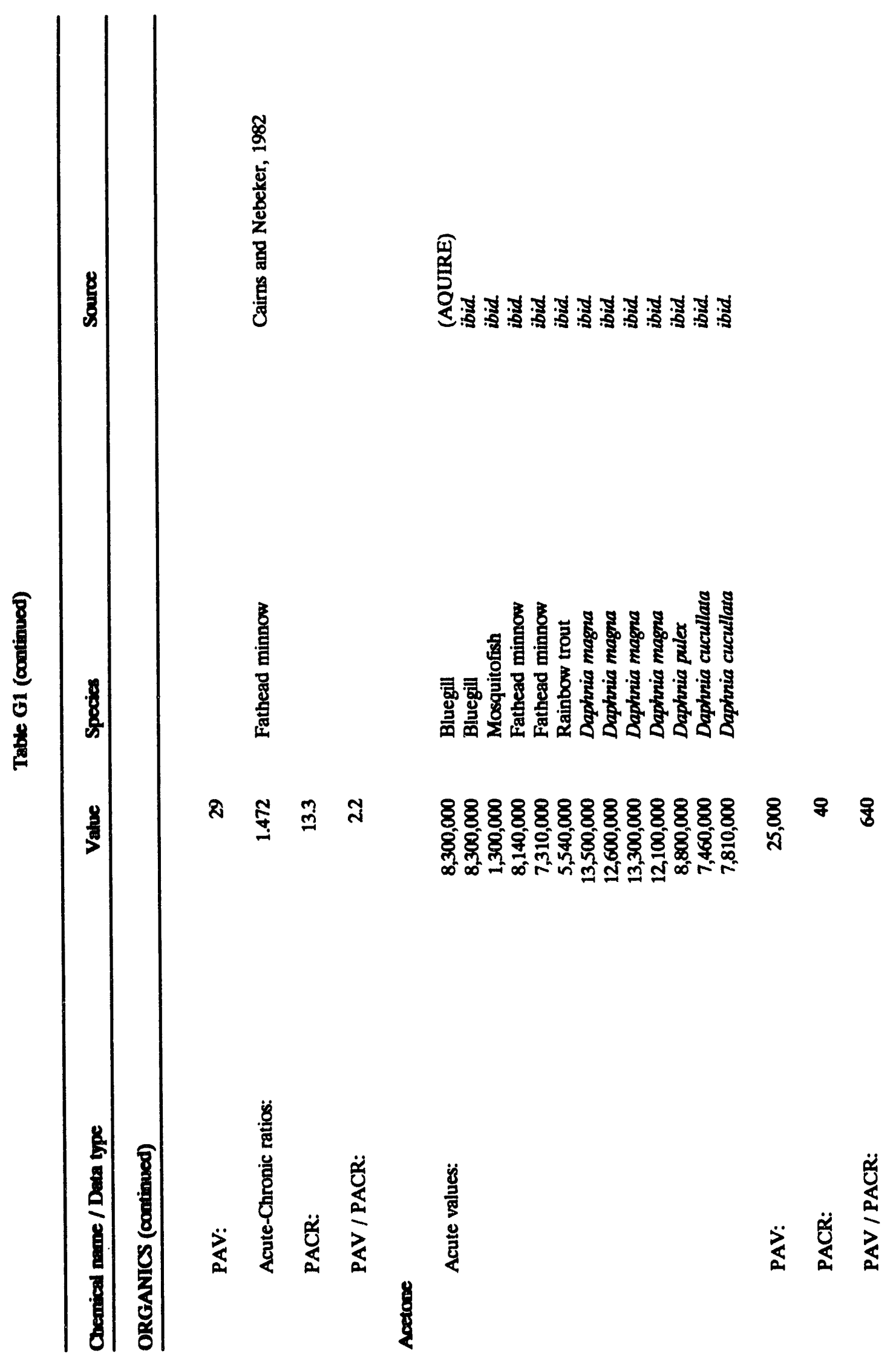


G-11

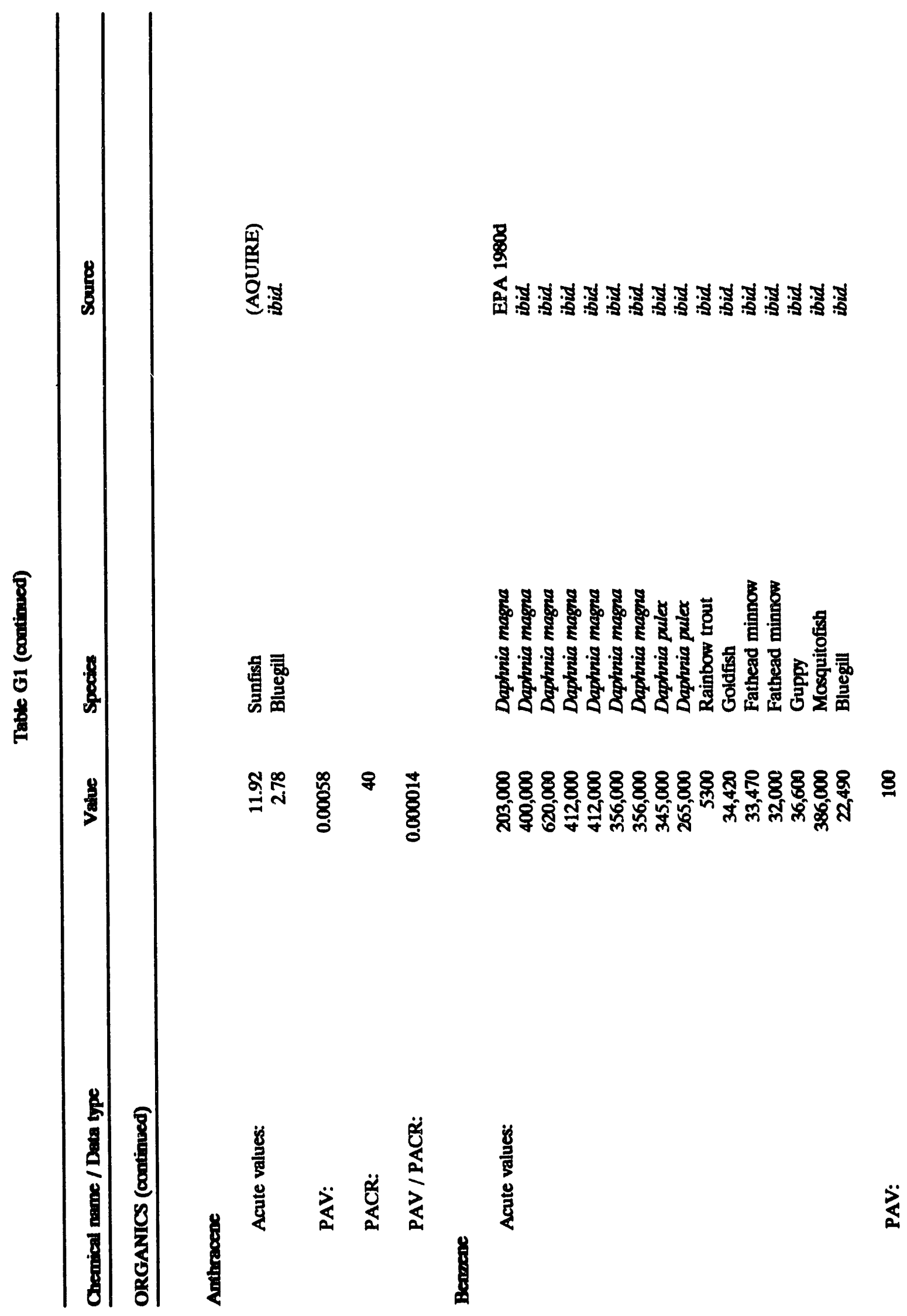


G-12

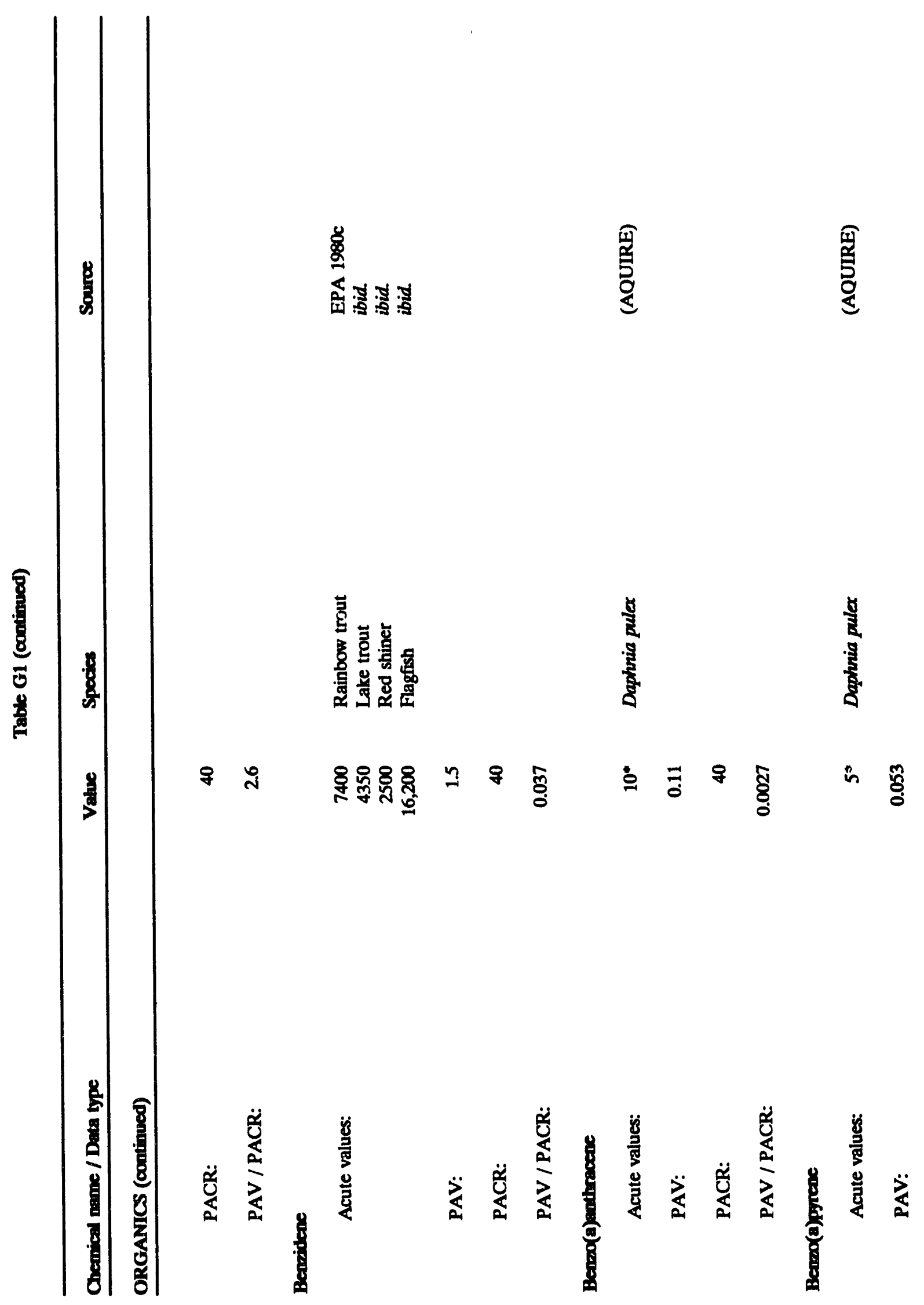


G-13

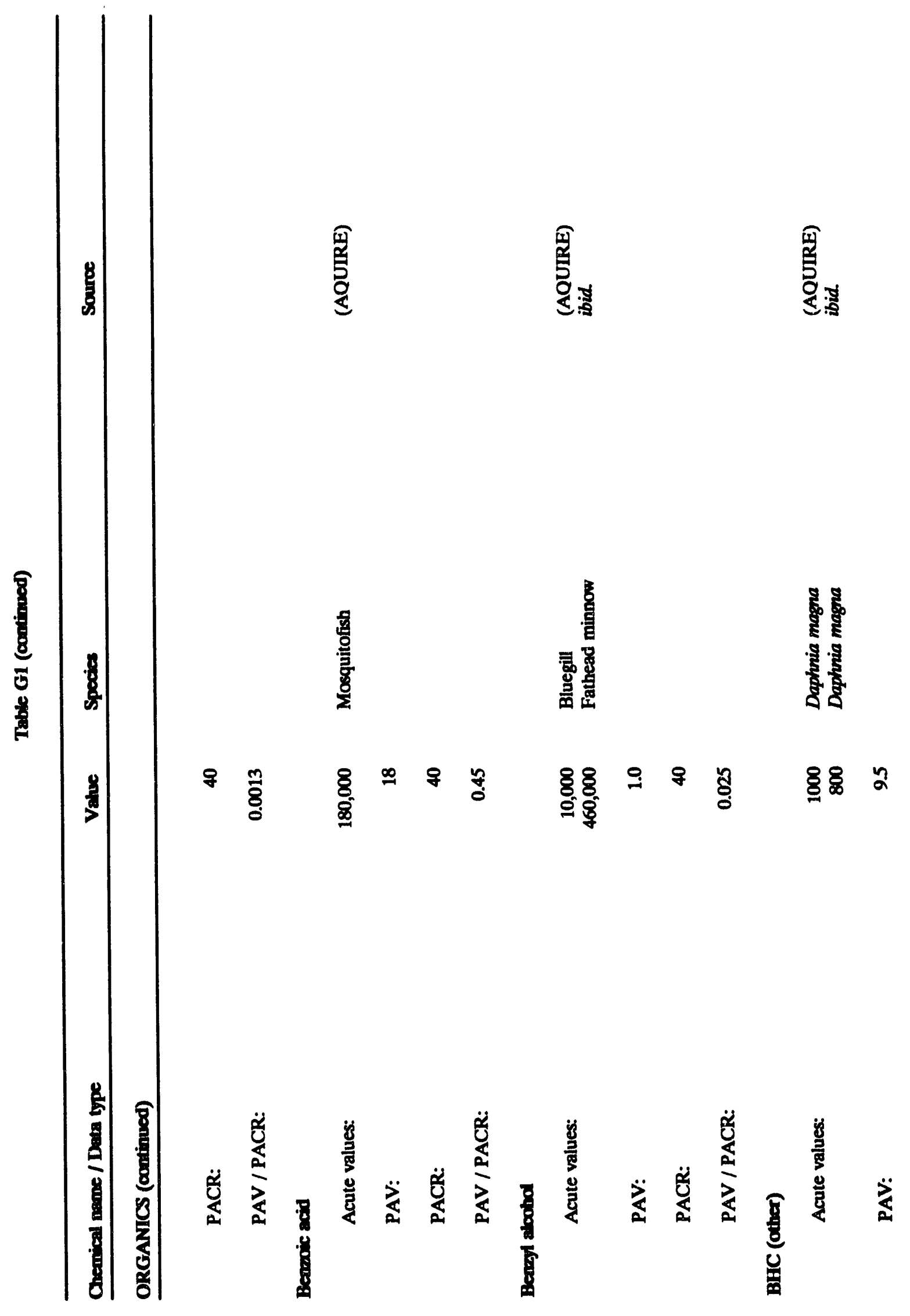




\section{G-14}

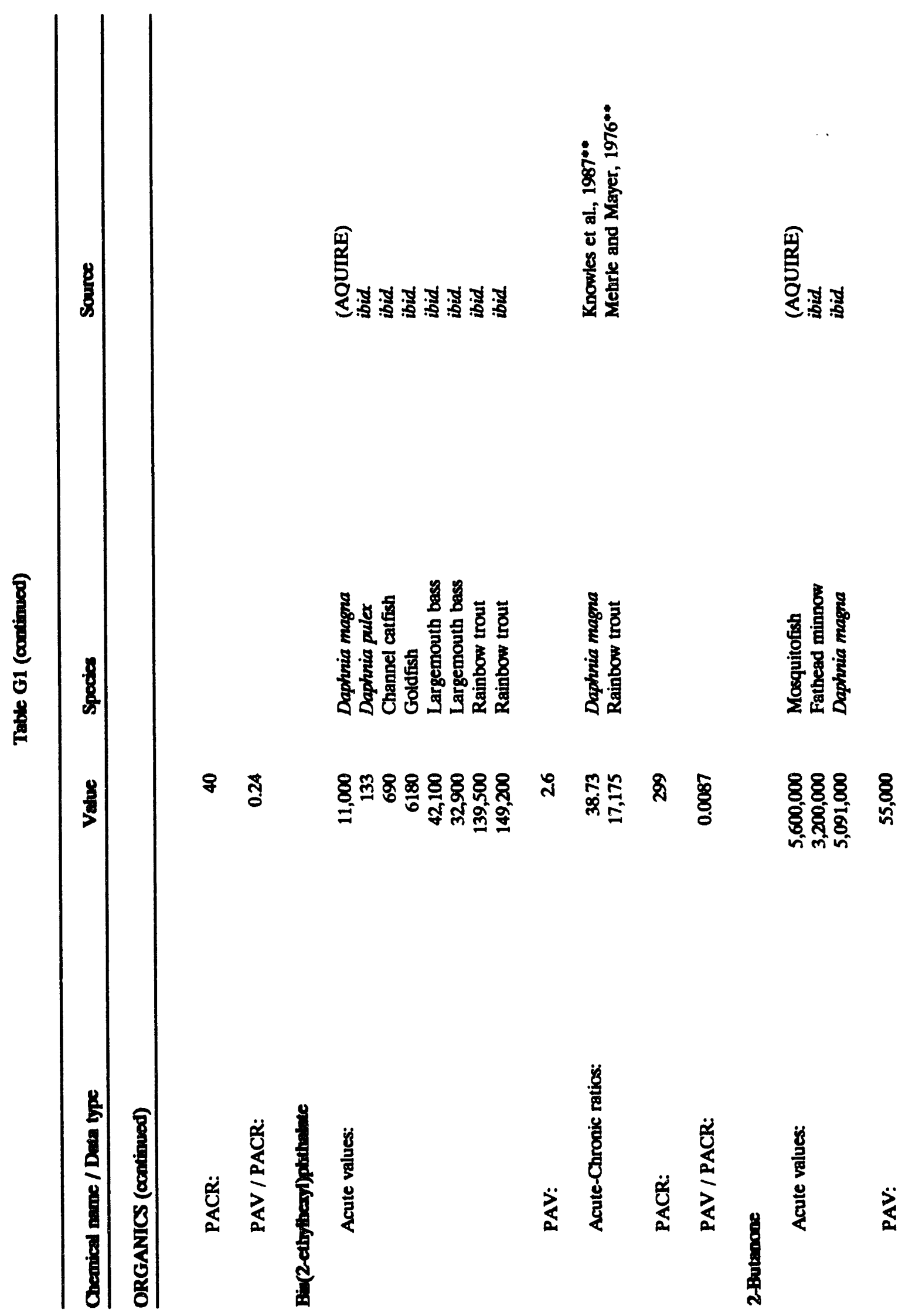


G-15

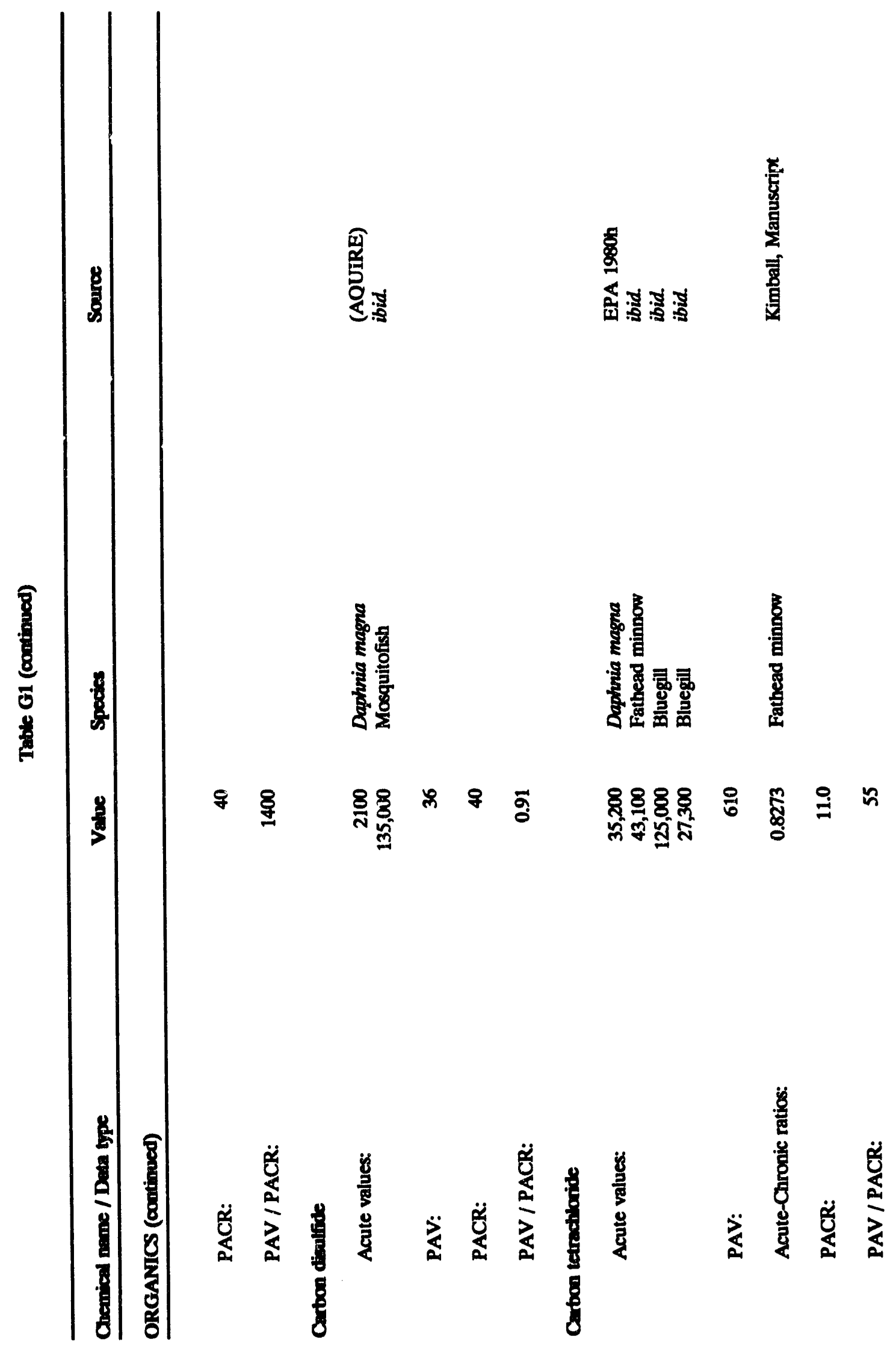


G-16

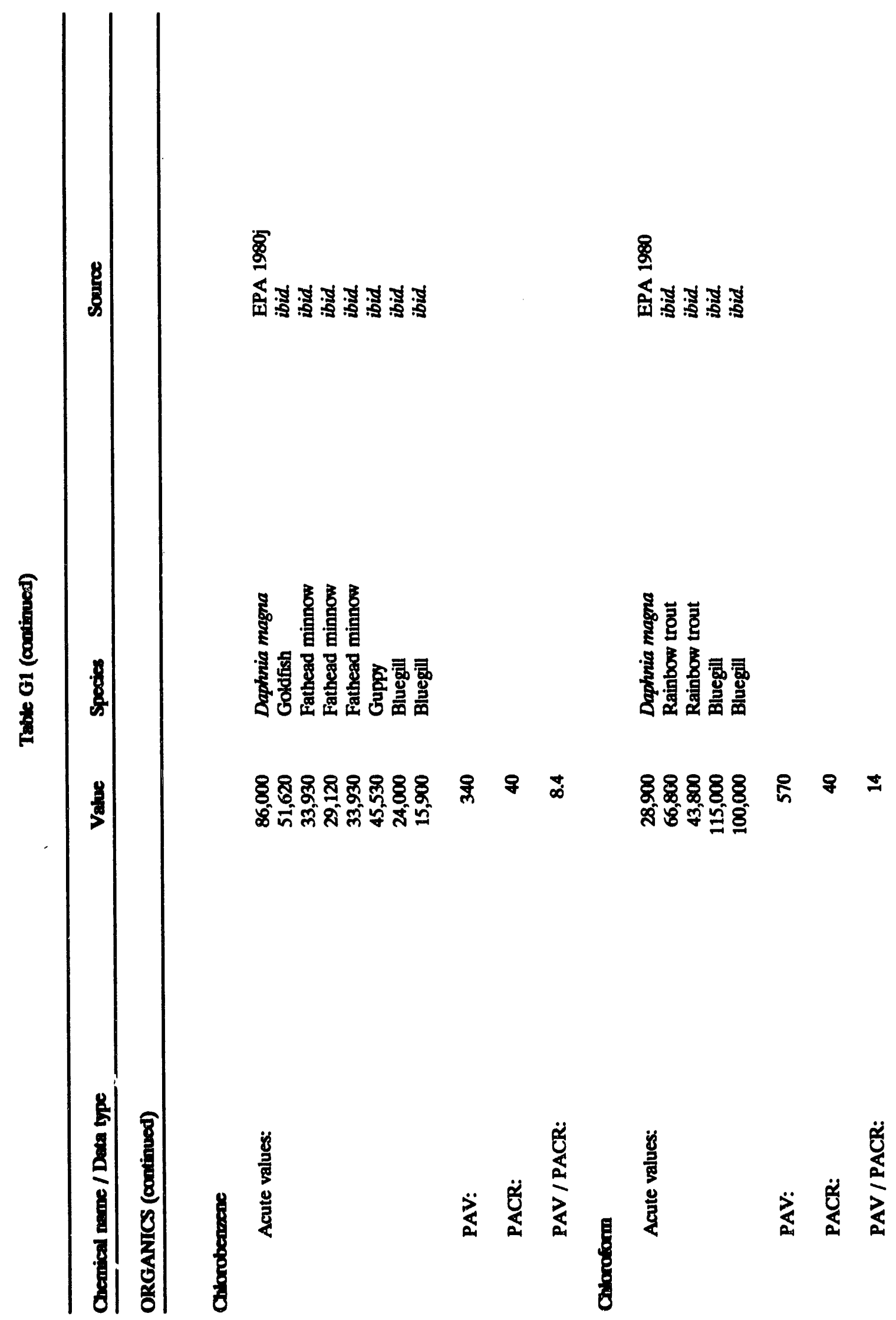


G-17

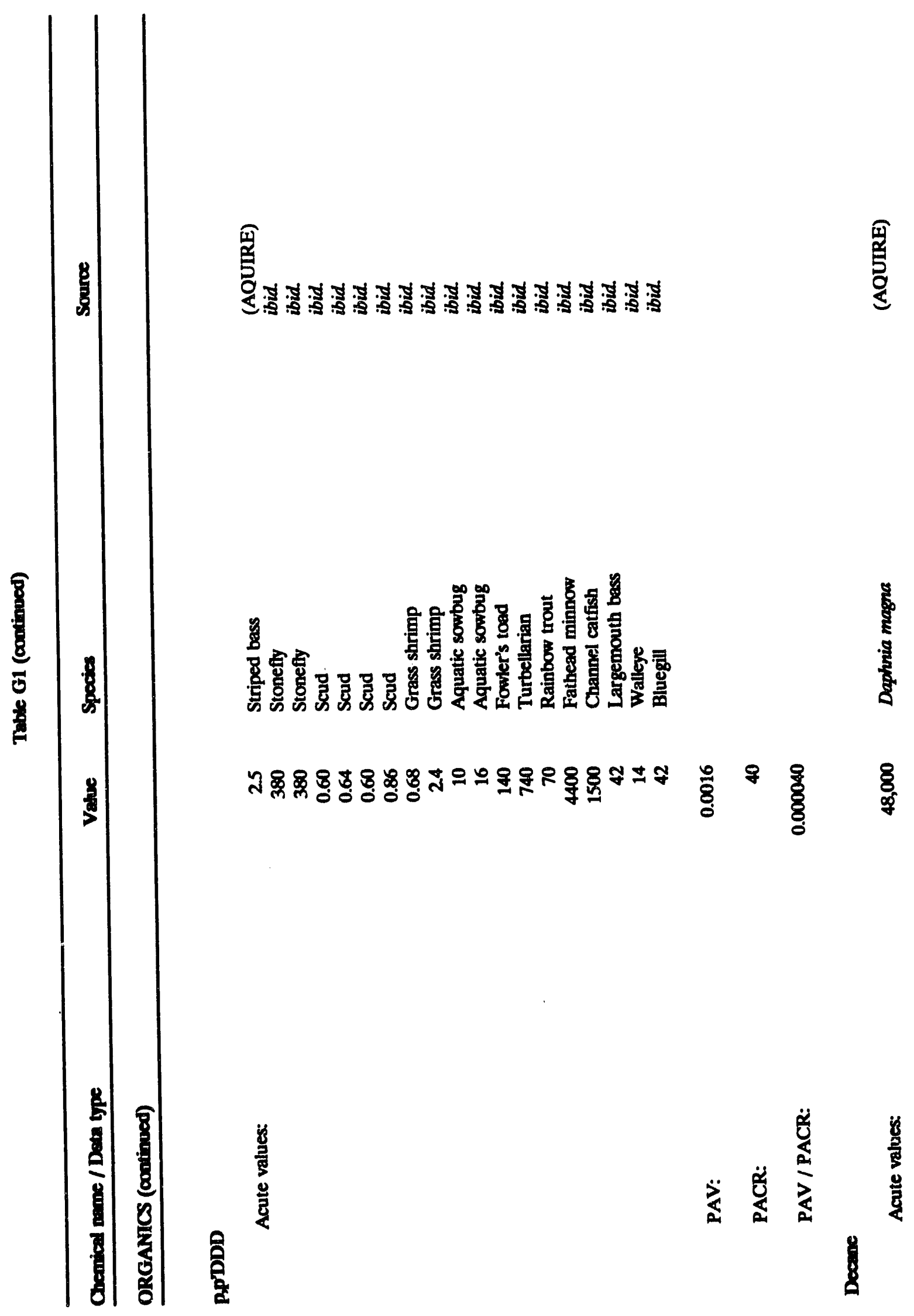


G-18

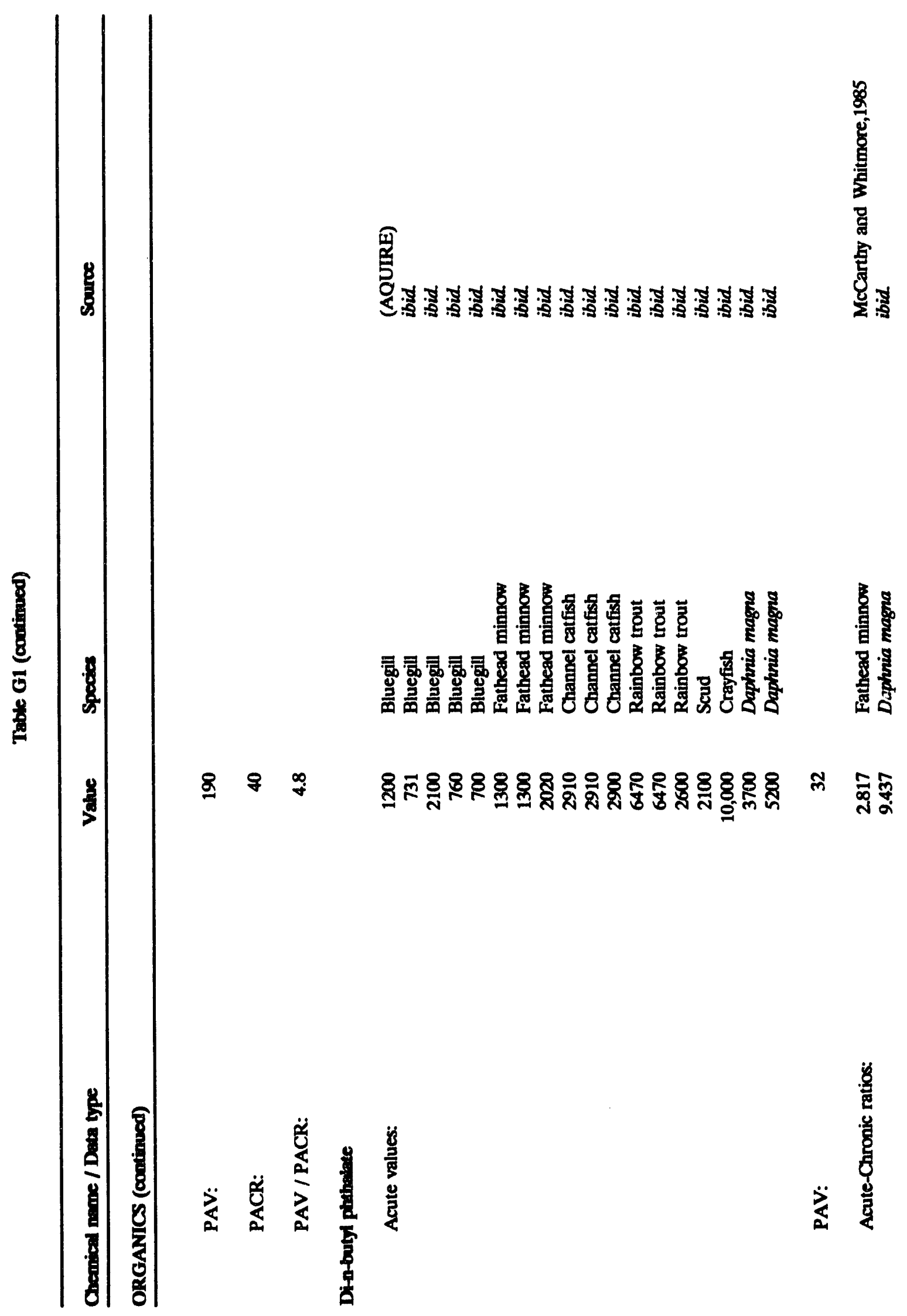


G-19

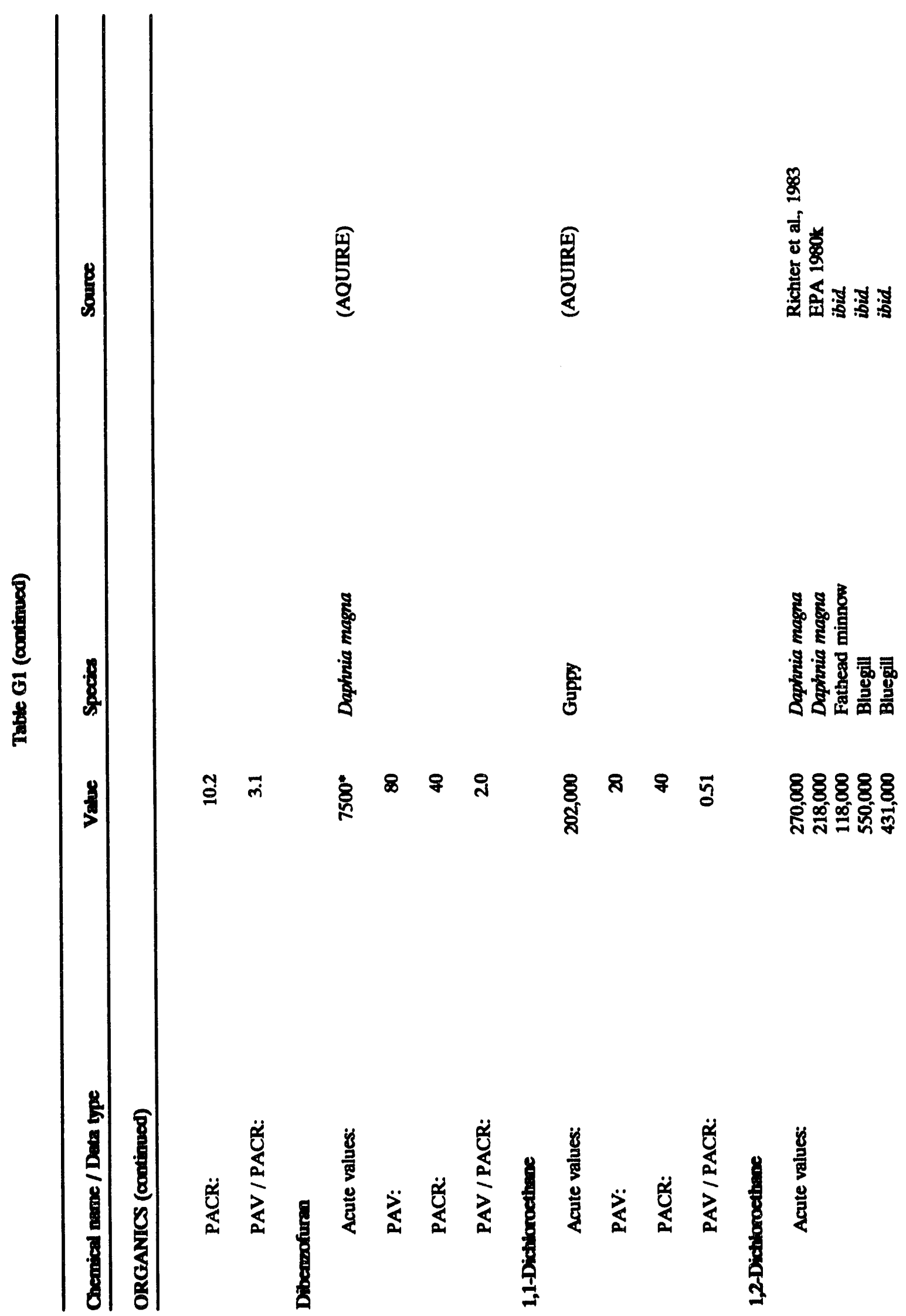




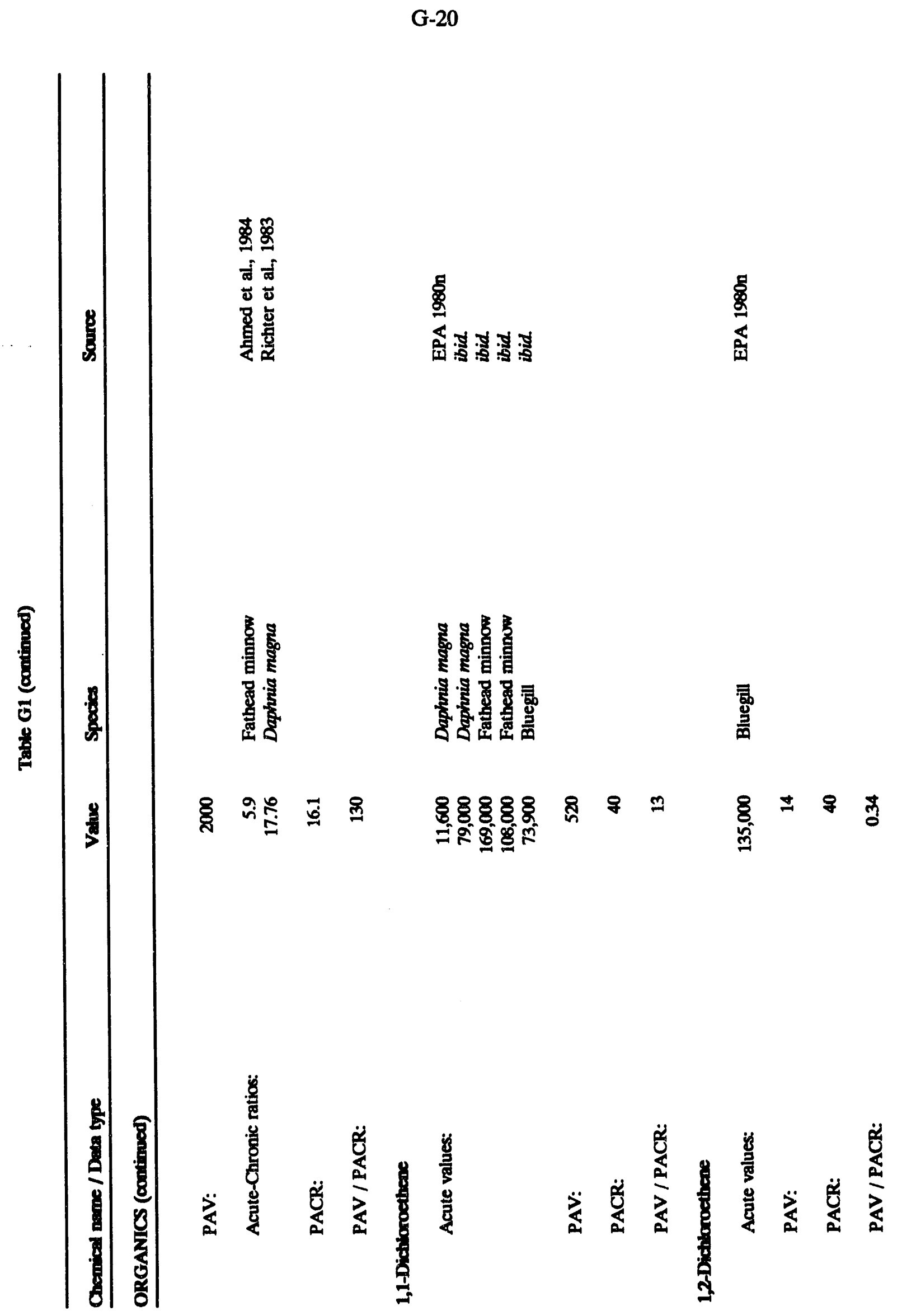


G-21

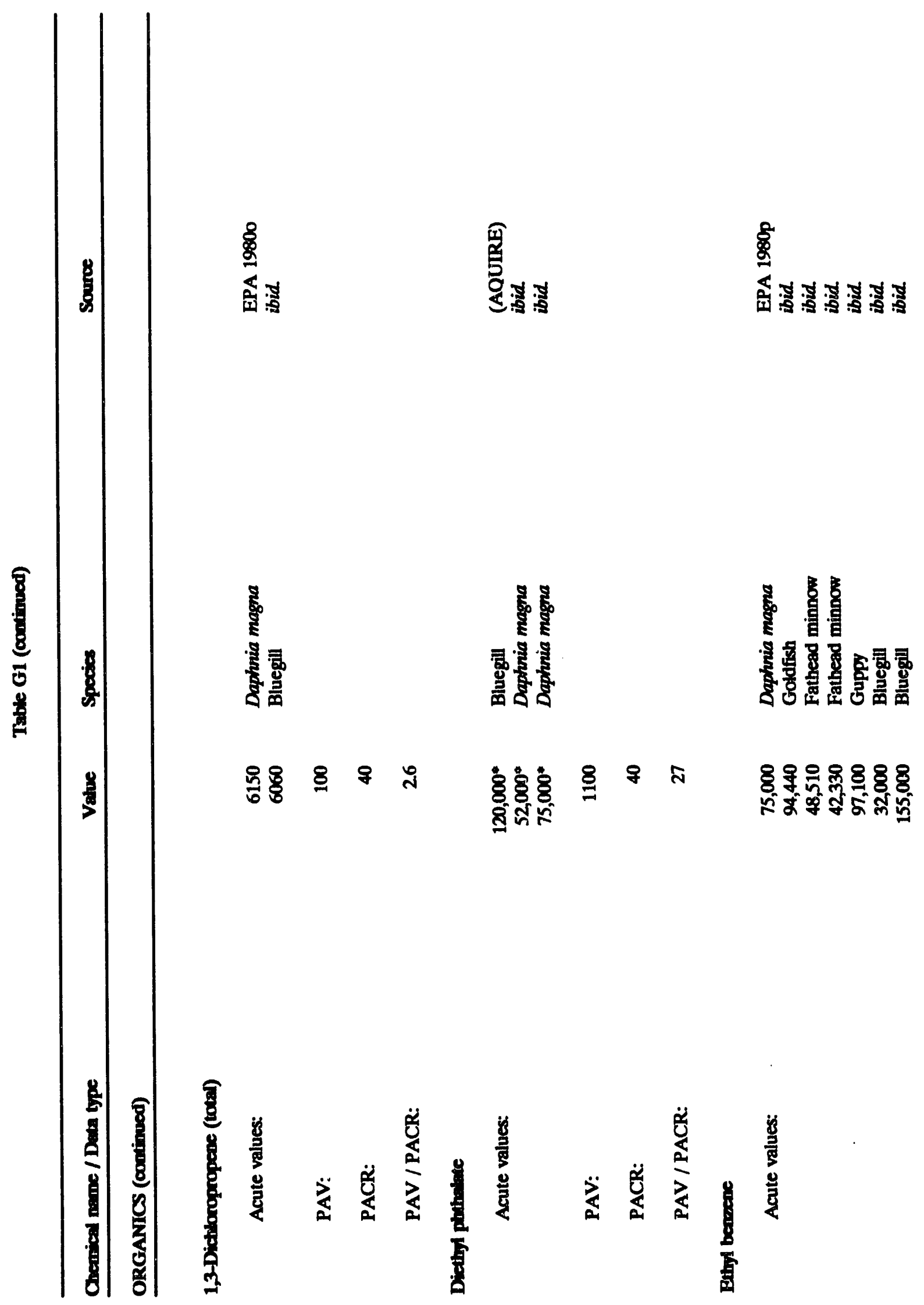




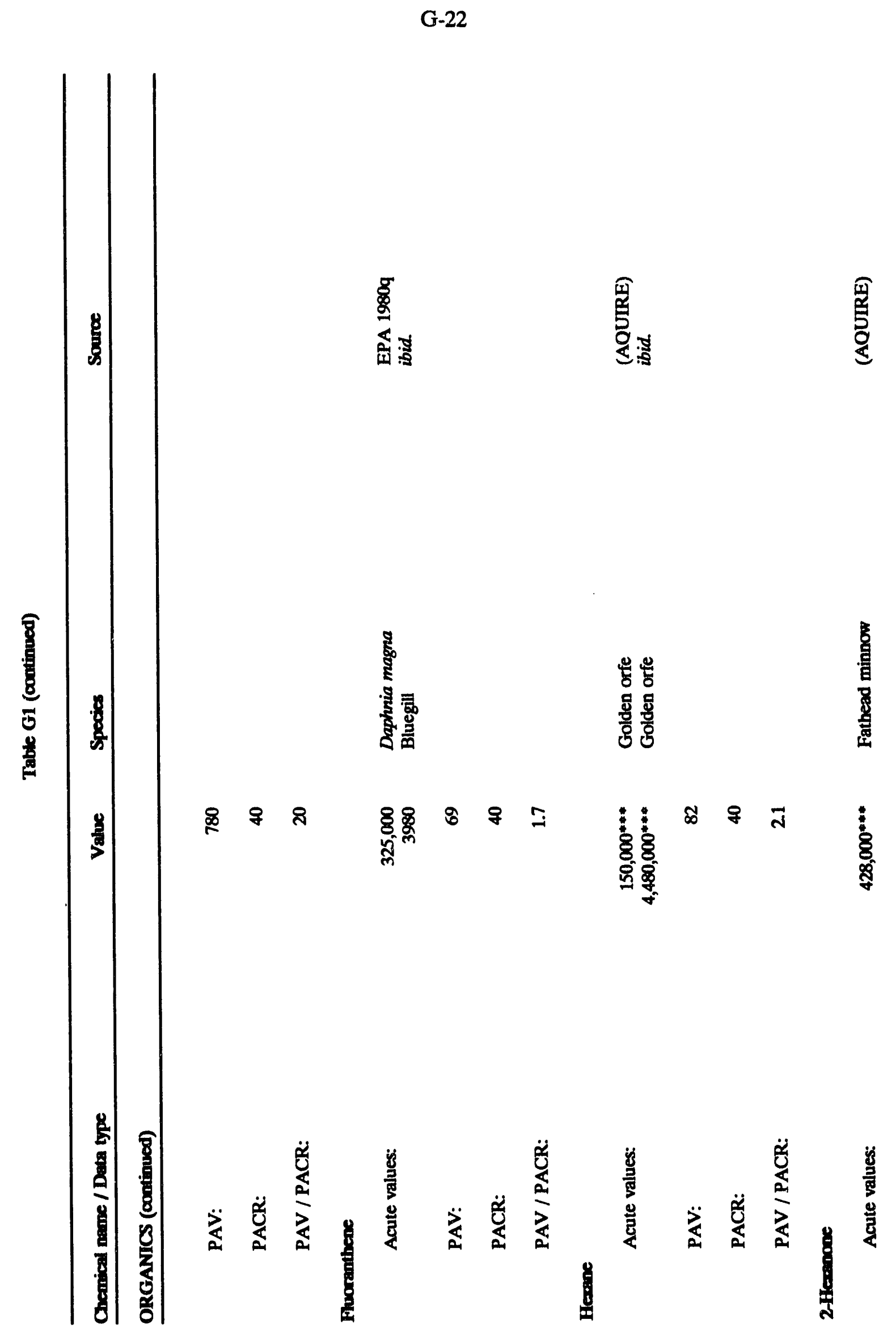


G.23

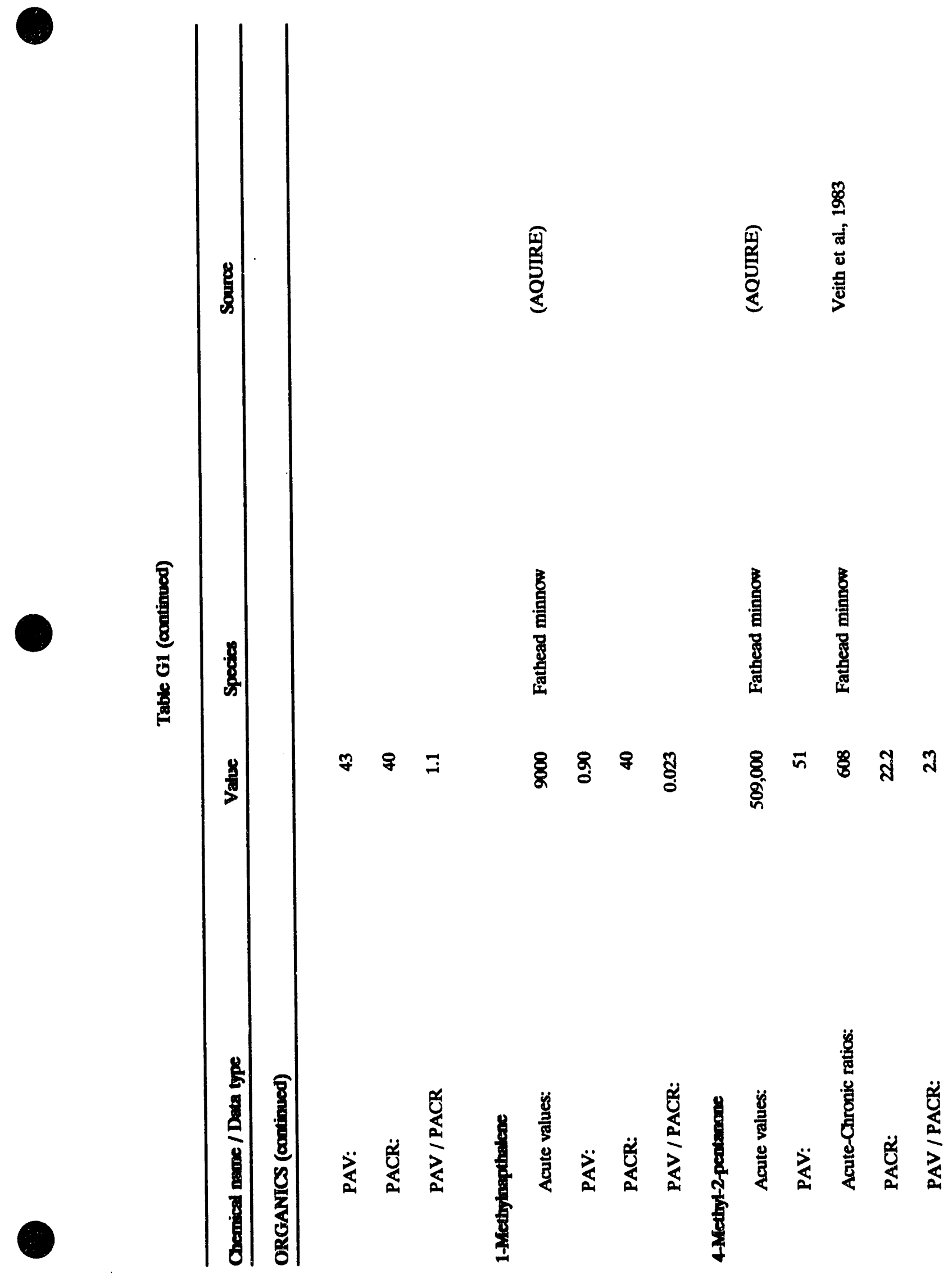




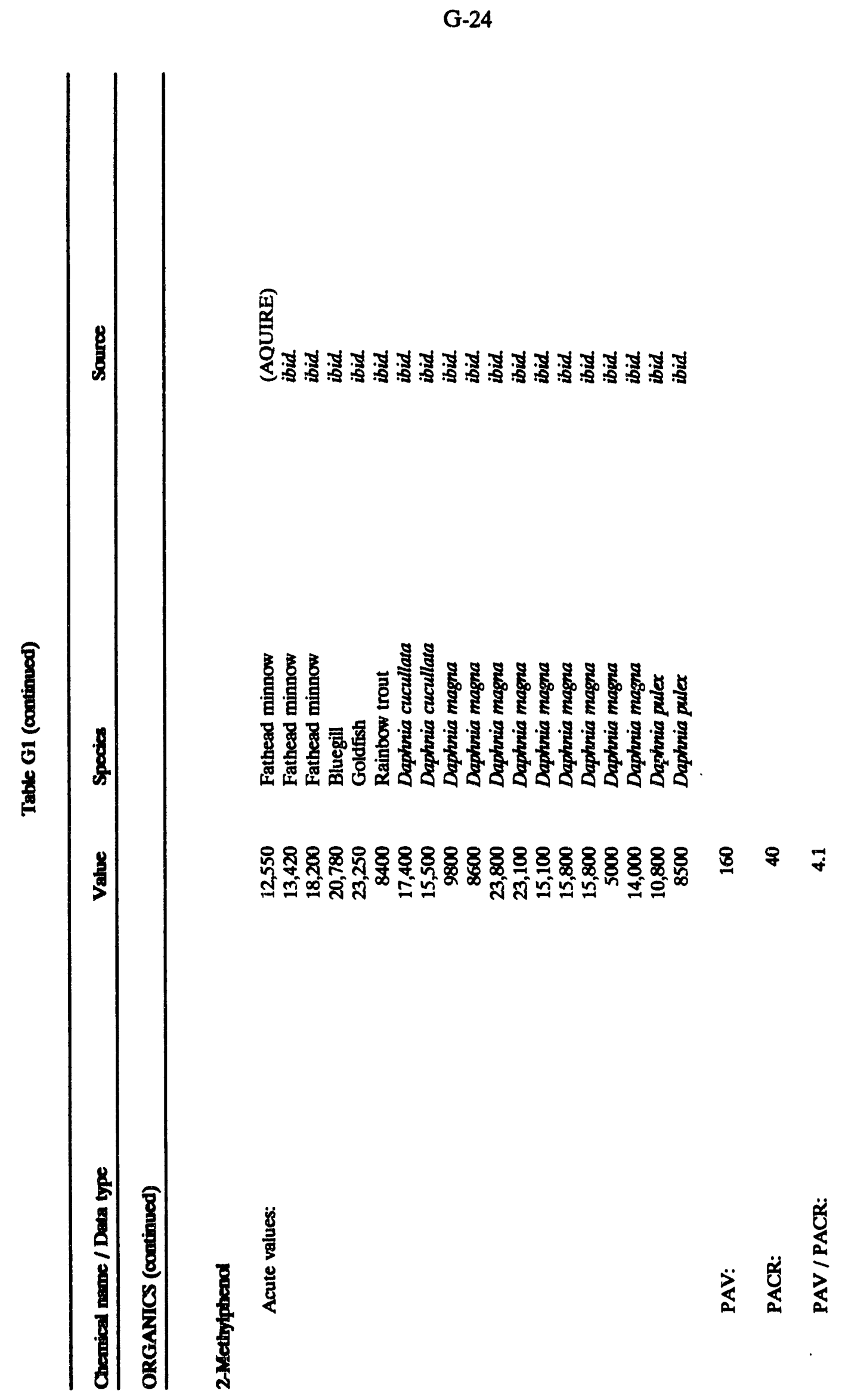


G-25

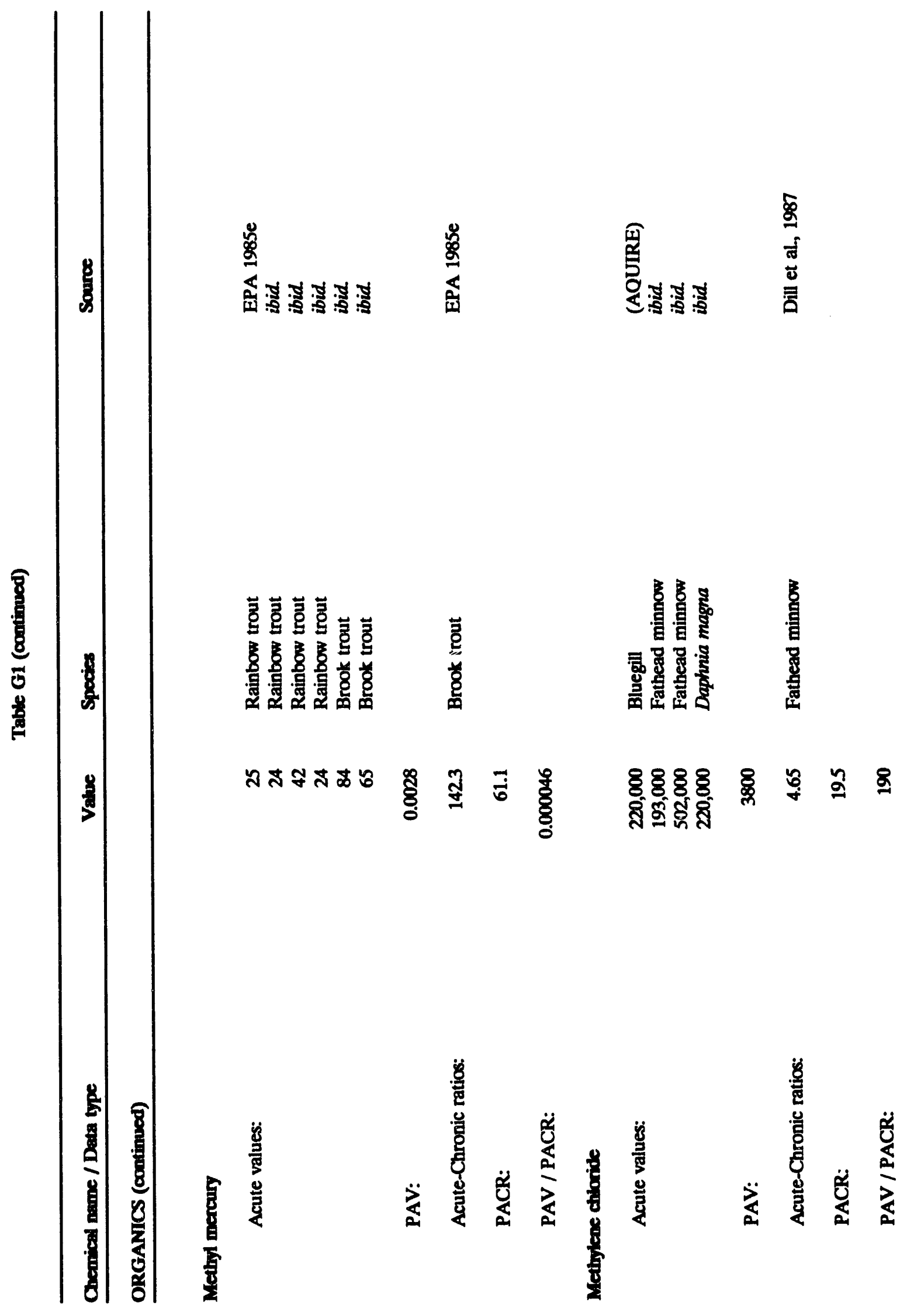


G-26

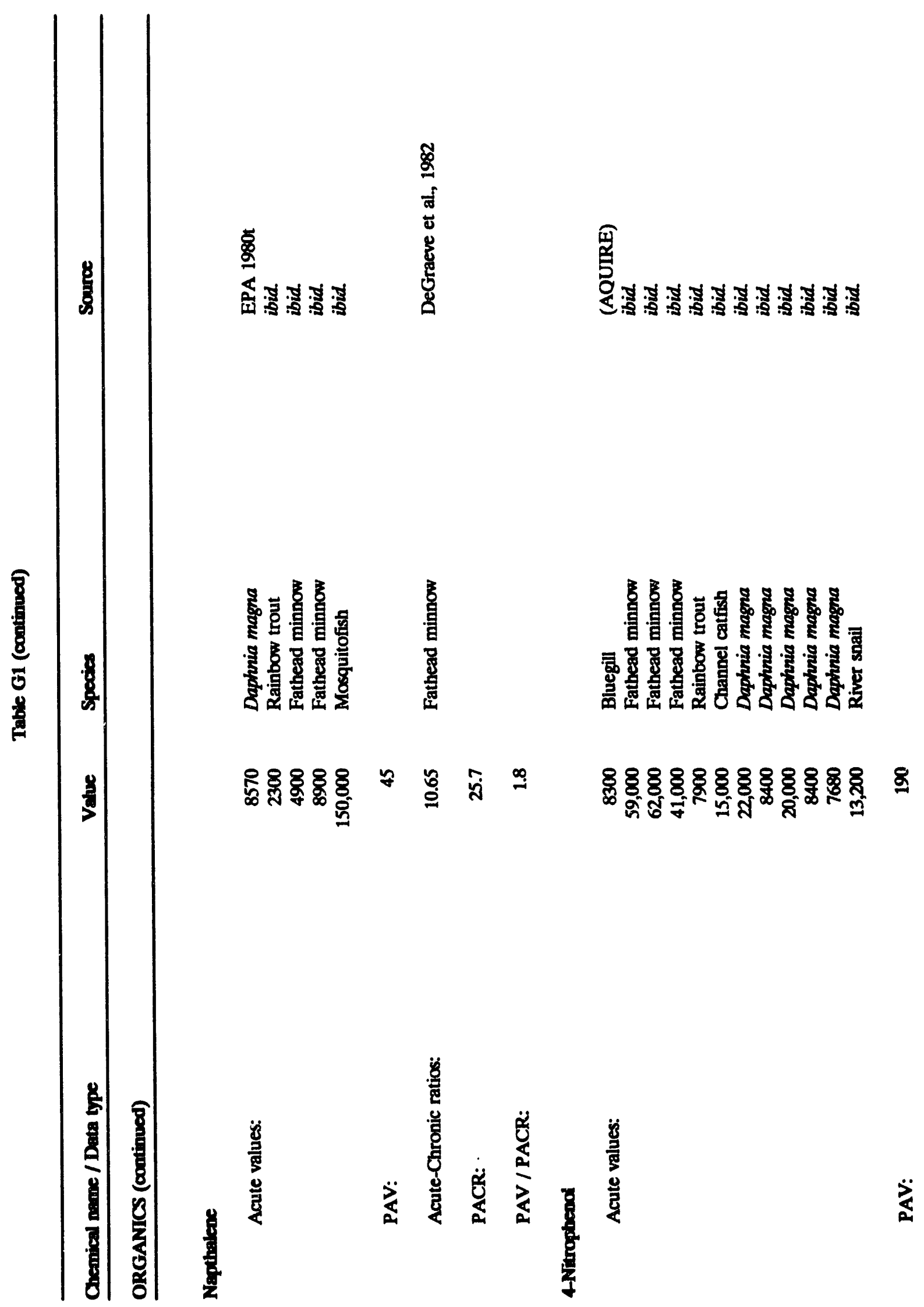




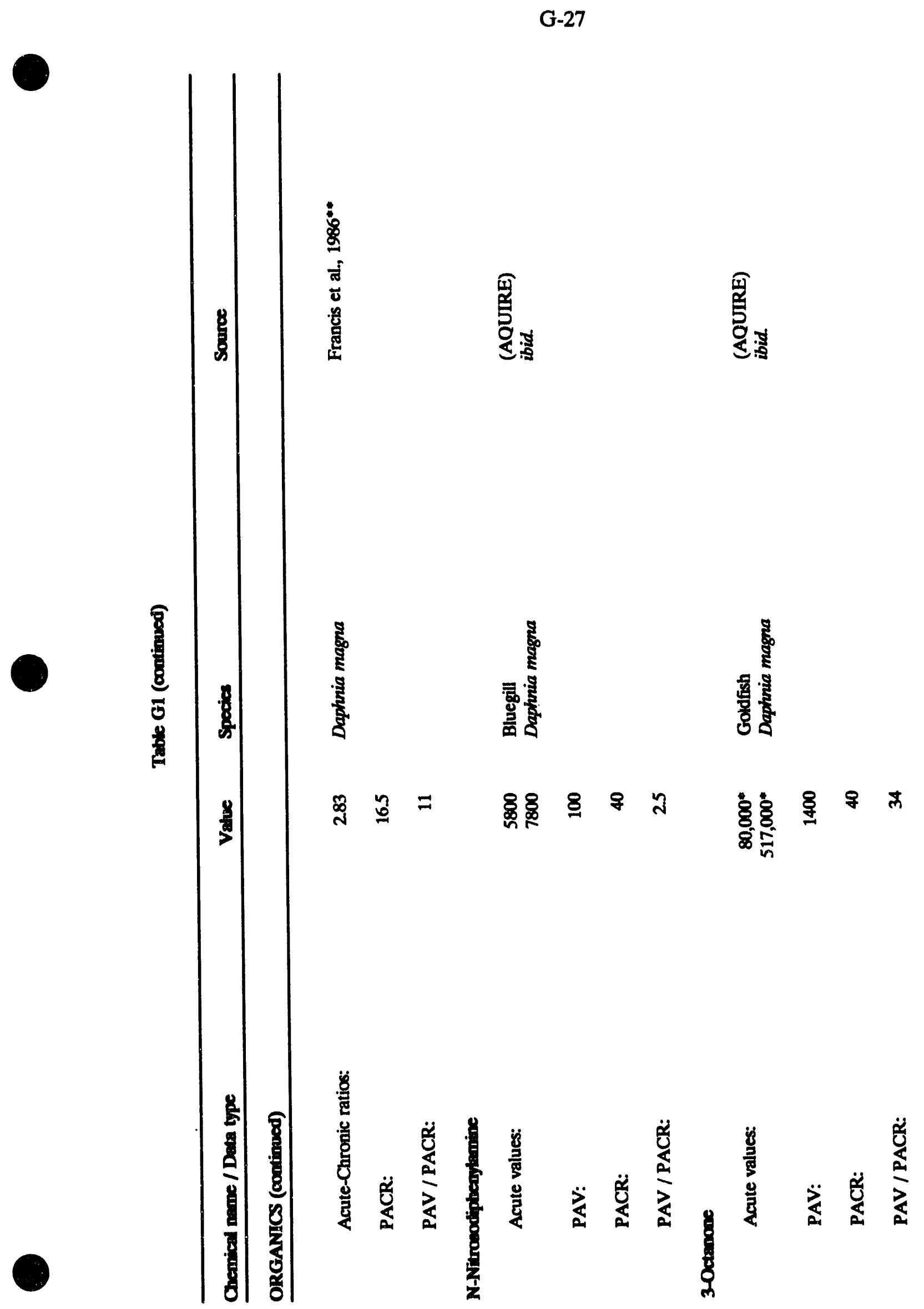


G-28

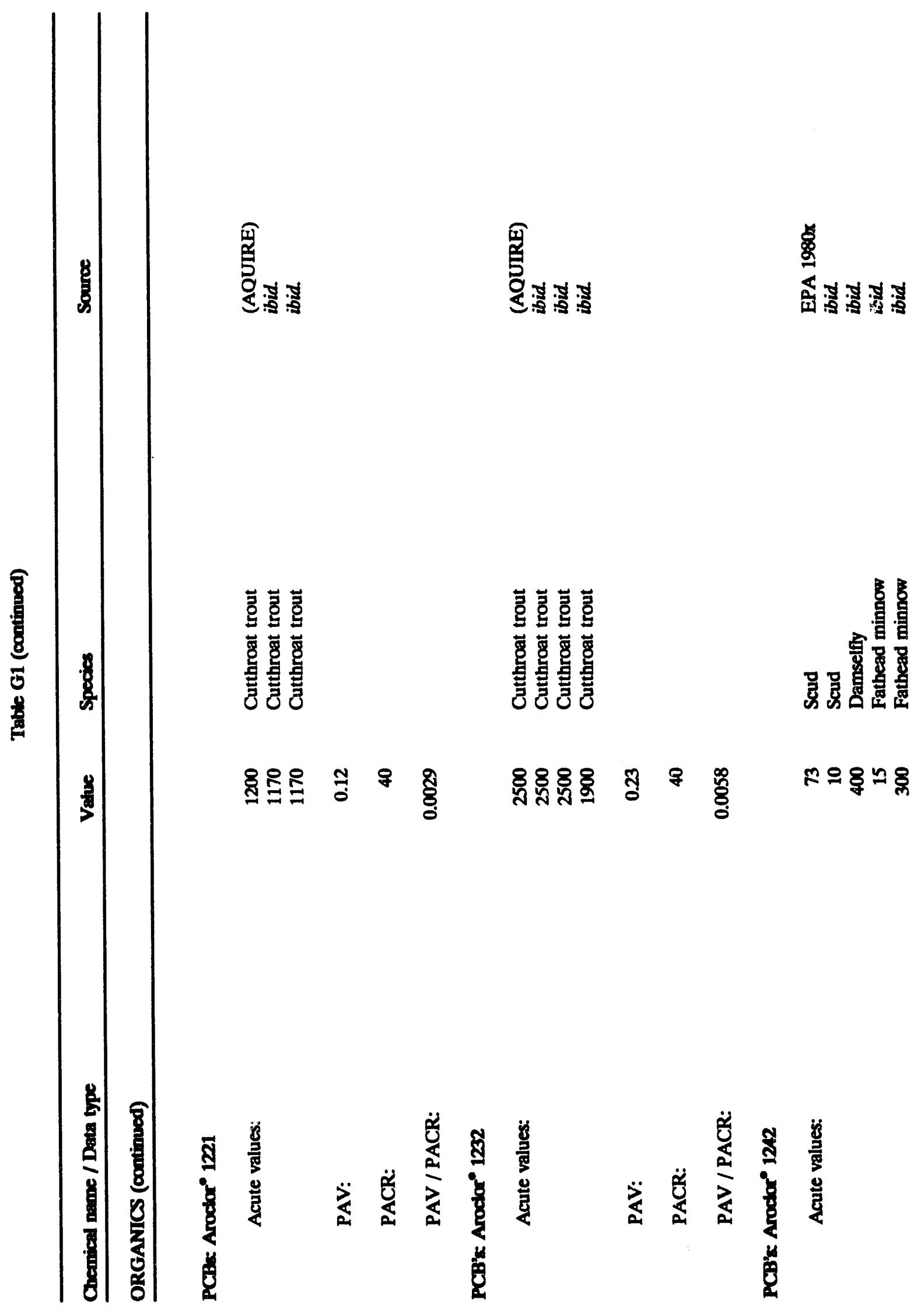


G-29

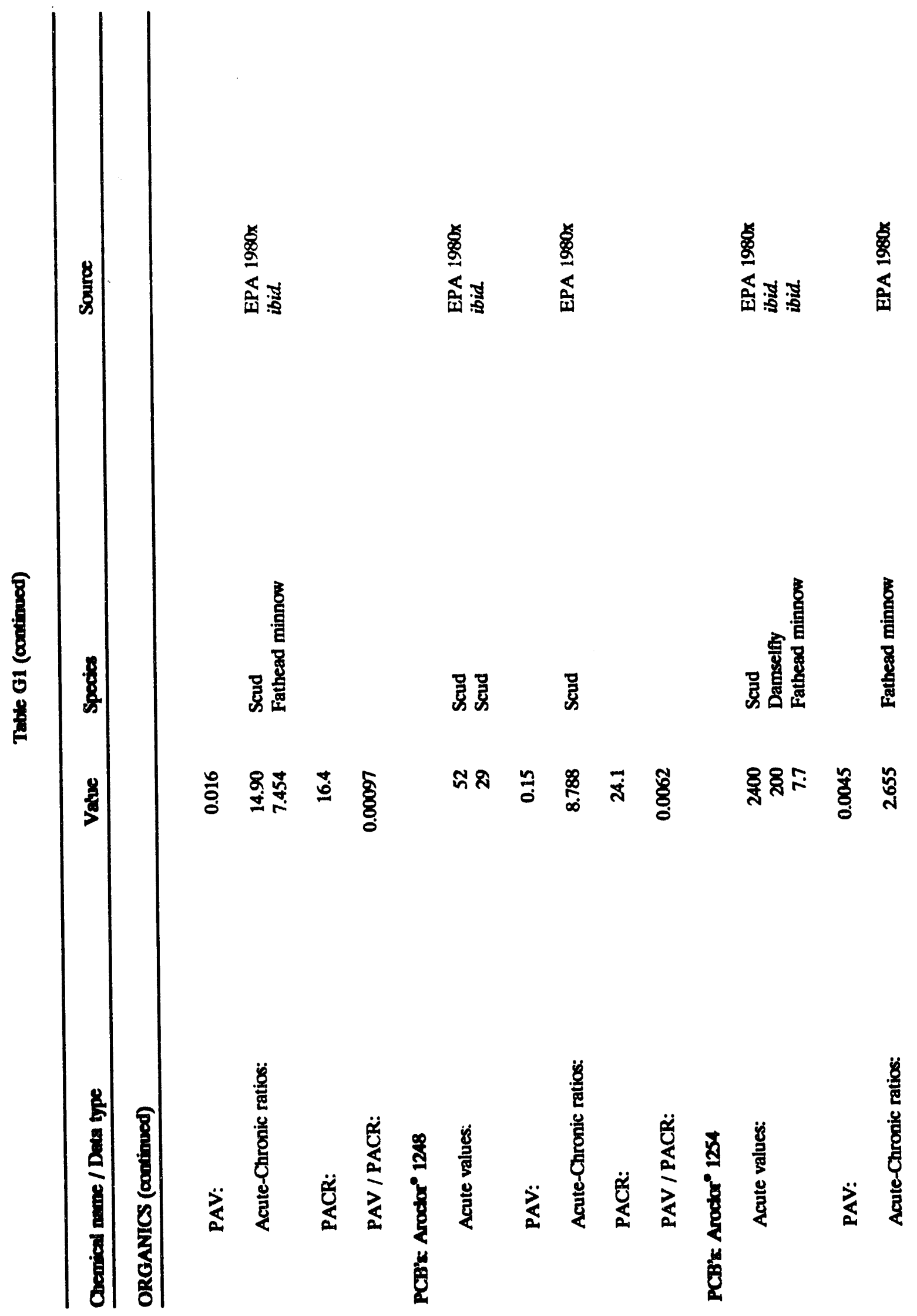




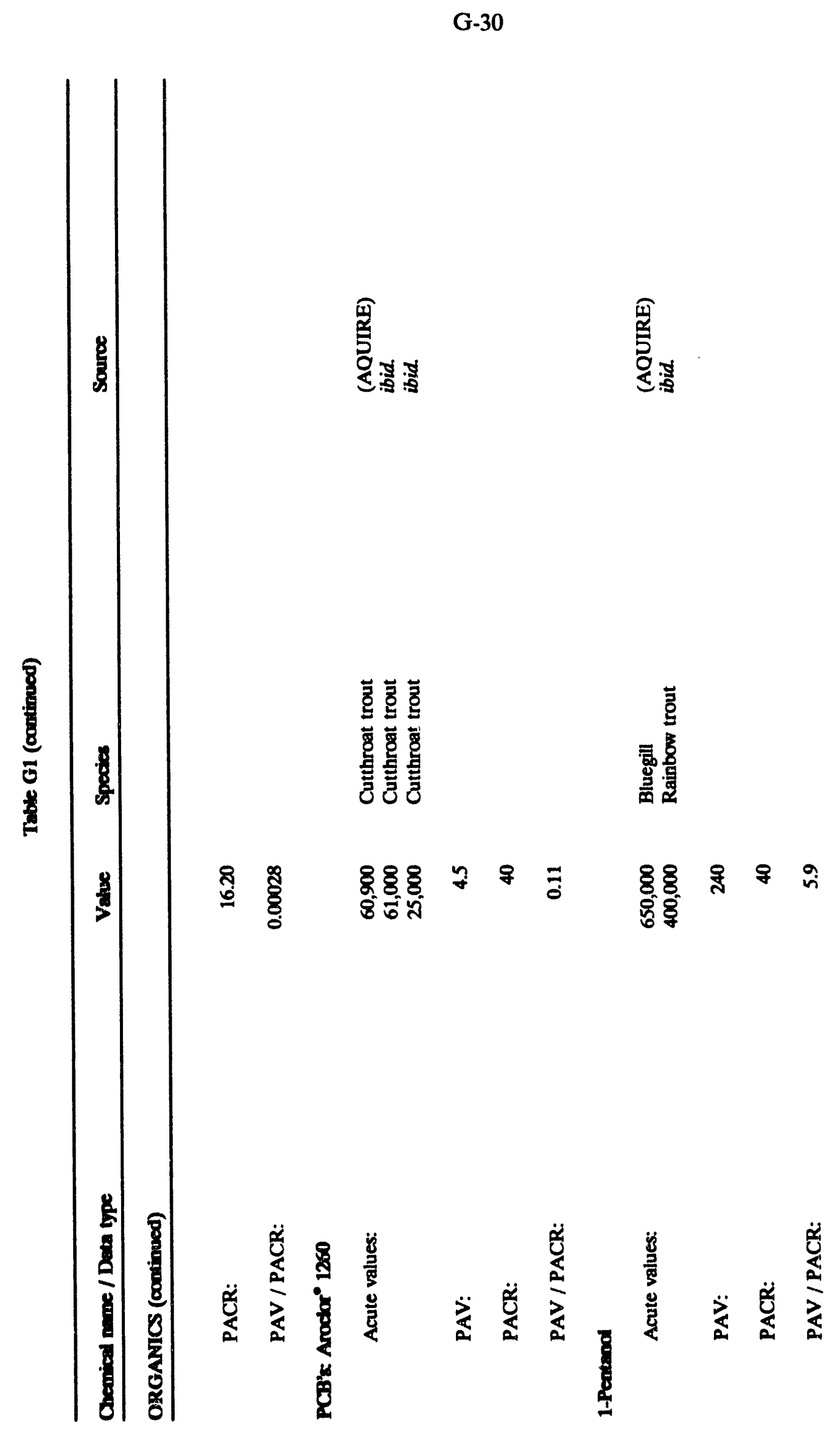


G-31

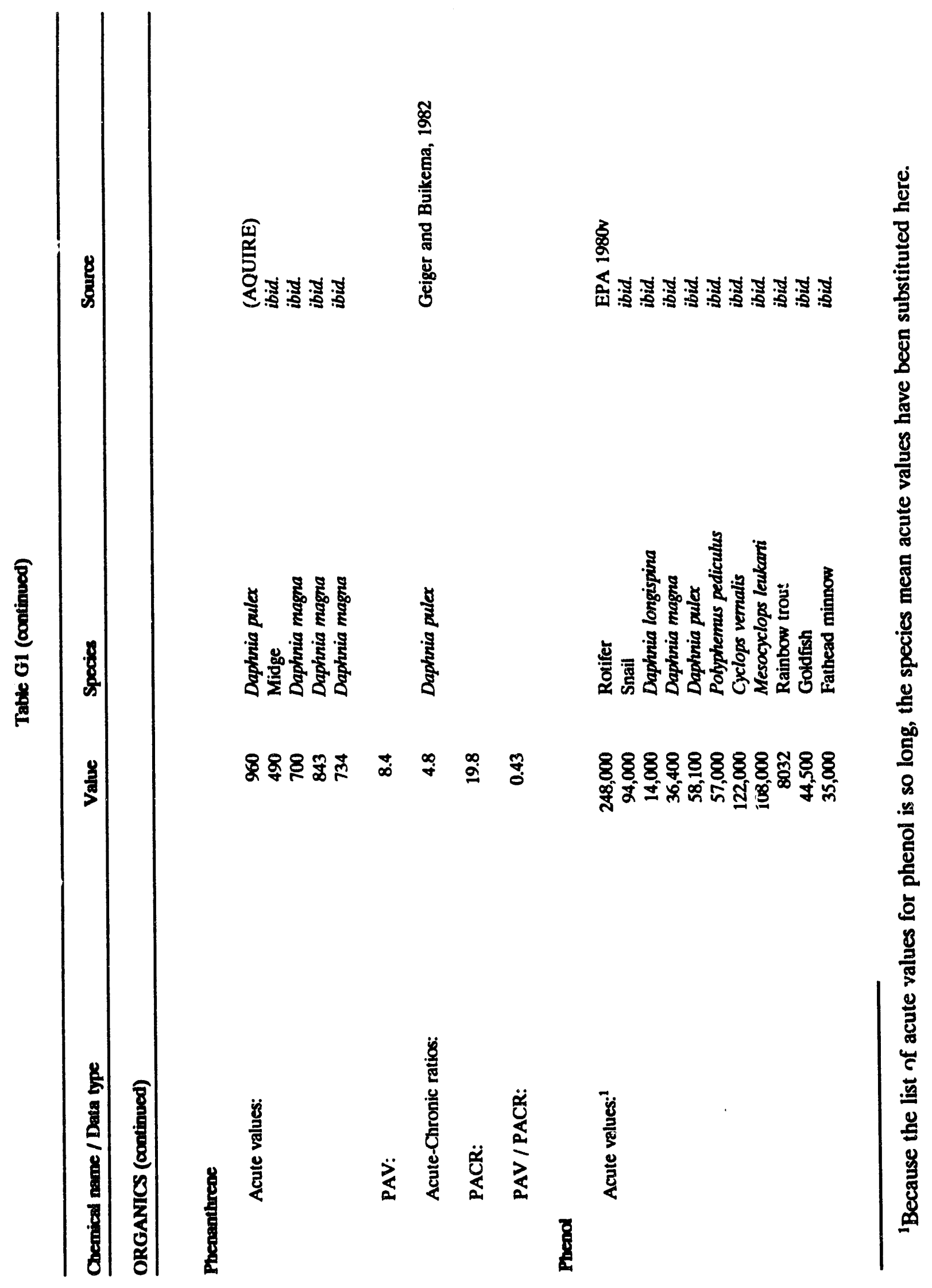


G-32

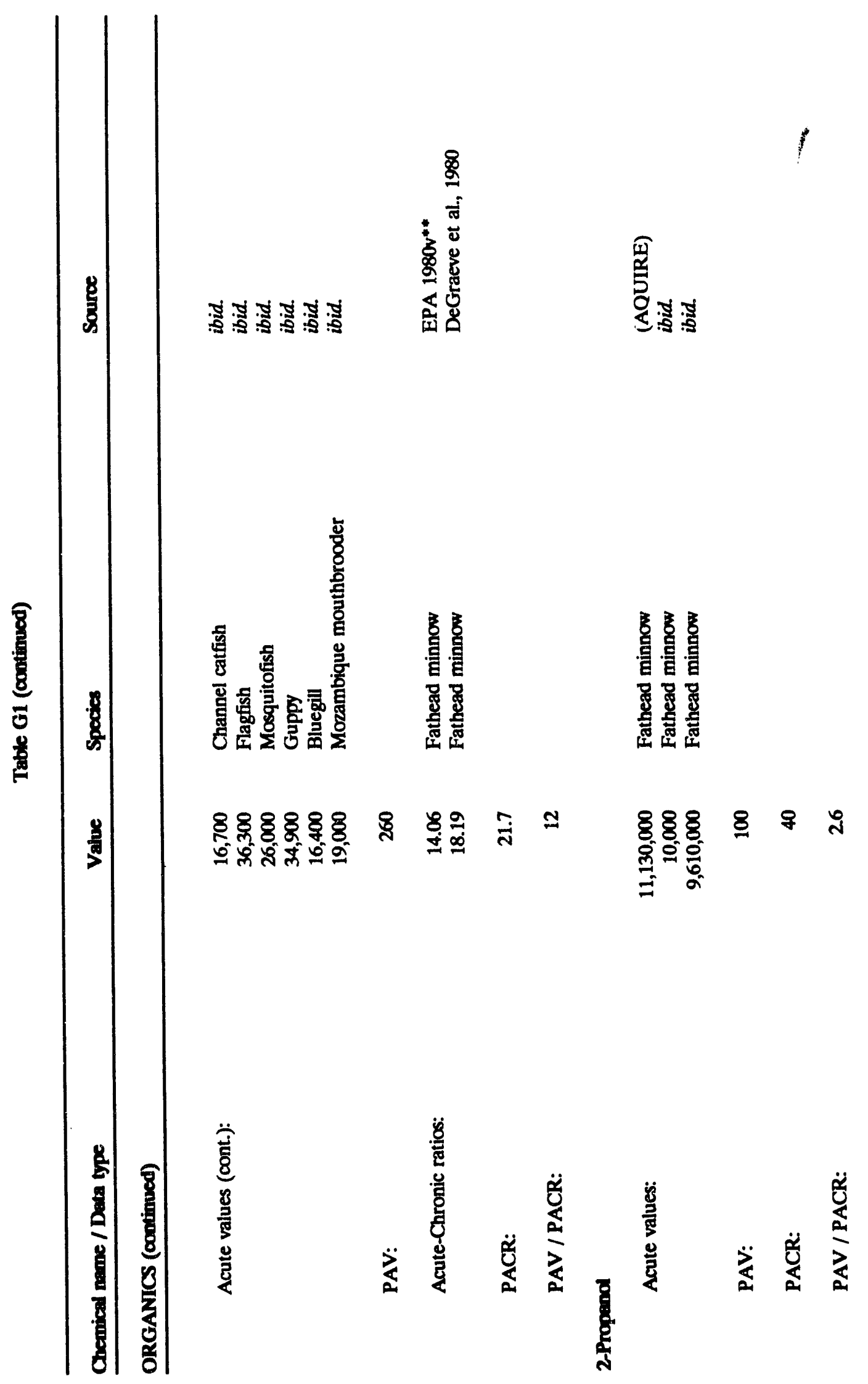




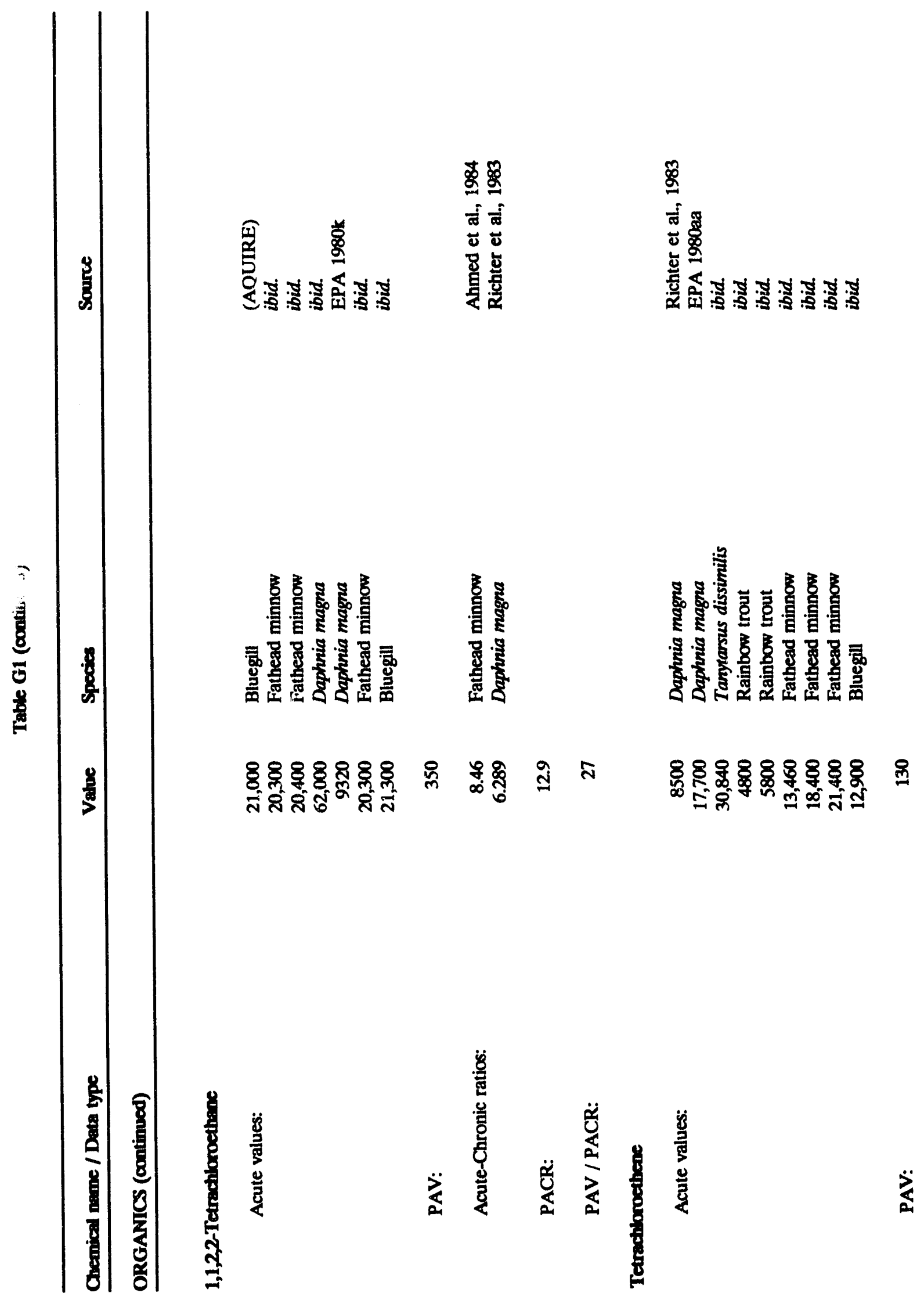


G-34

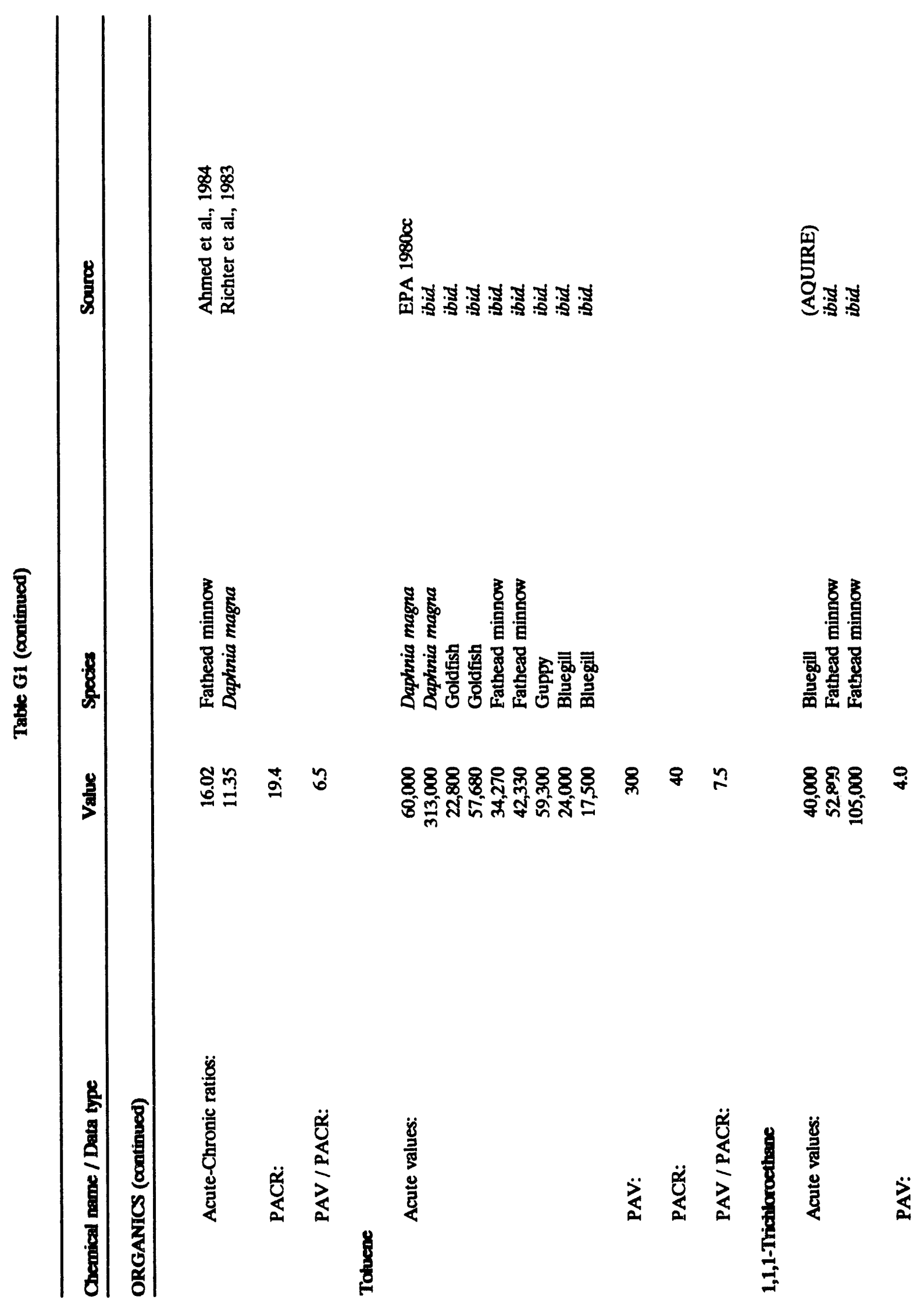


G-35

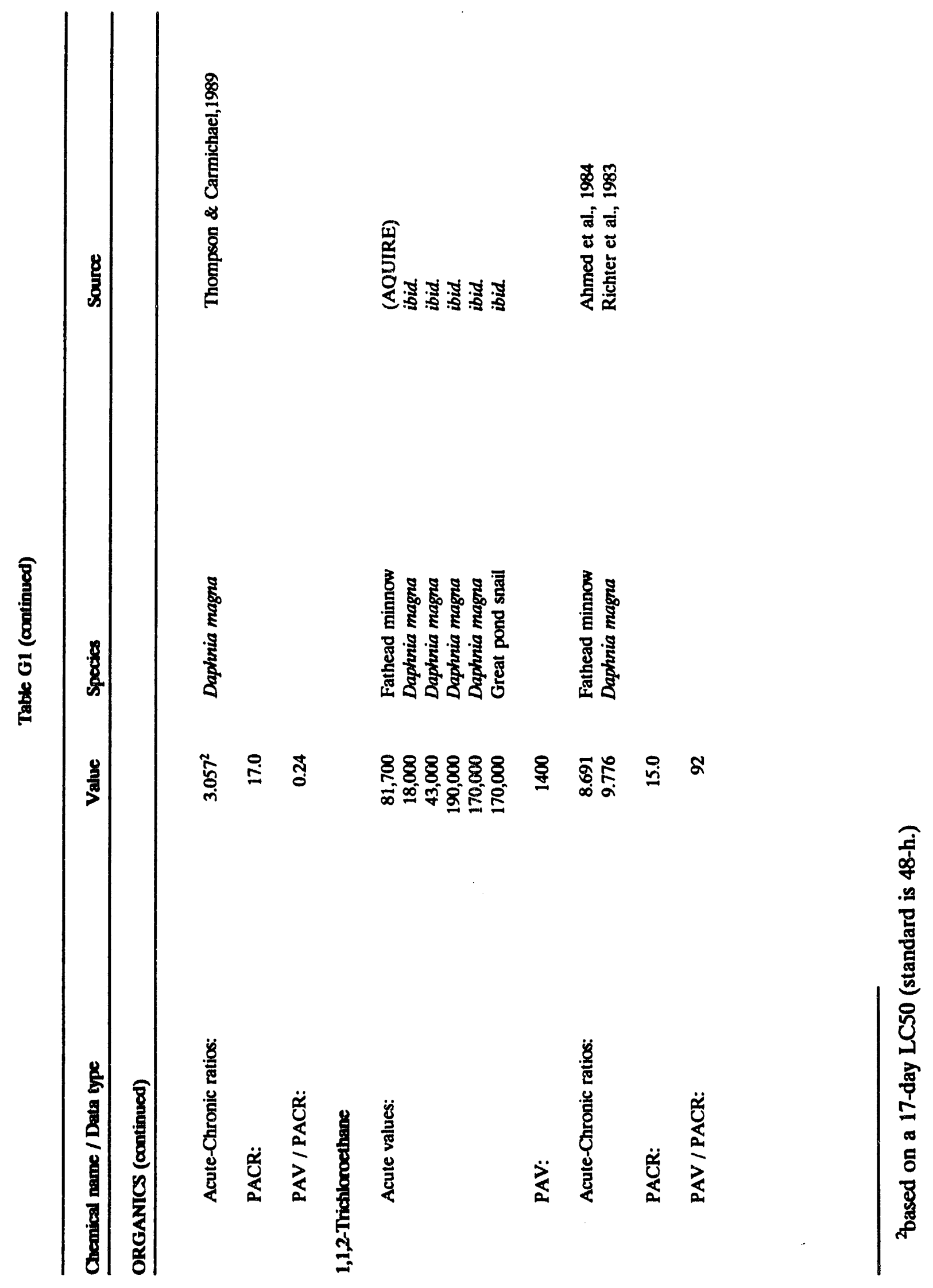




$$
\text { G-36 }
$$

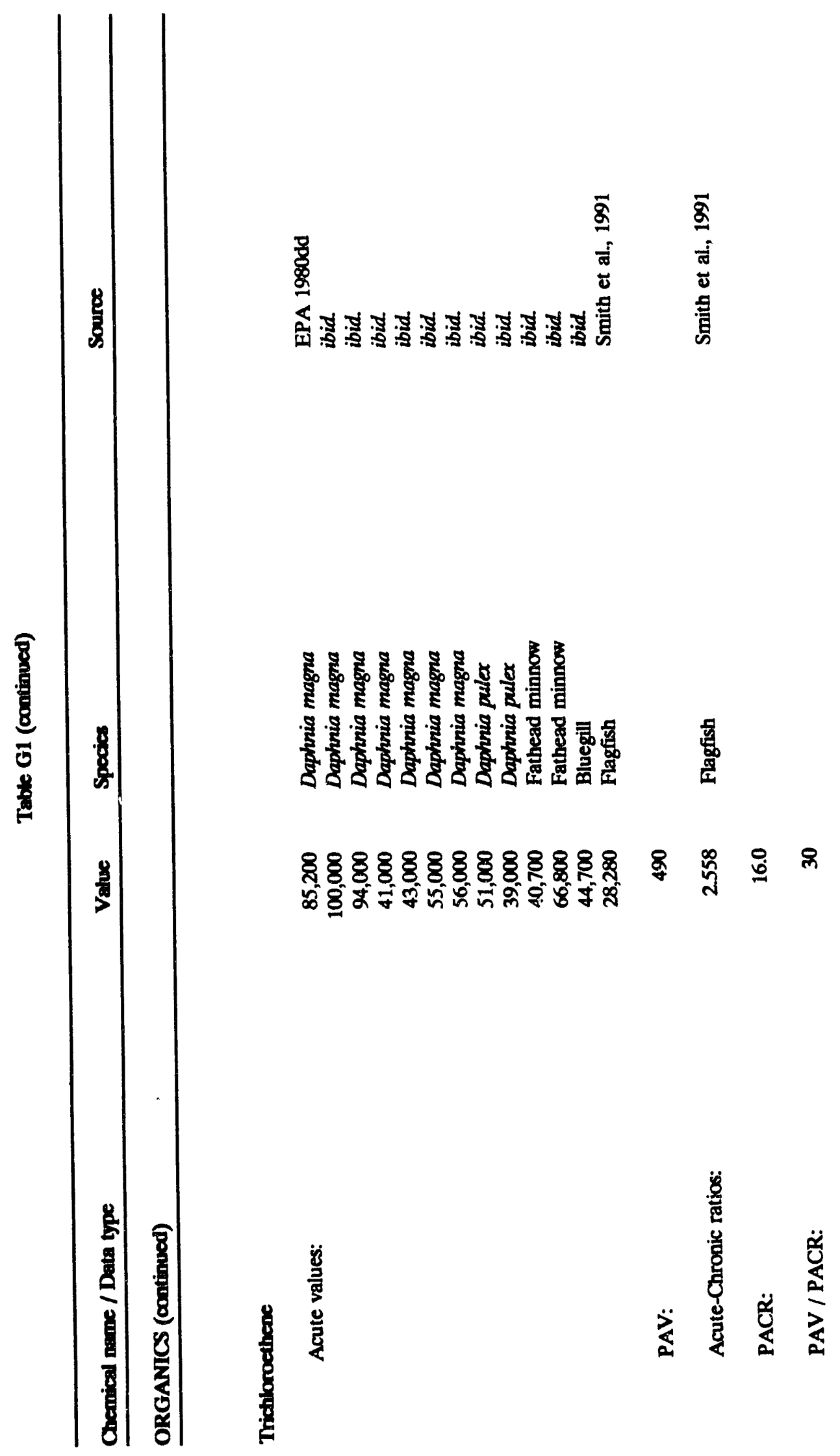


G-37

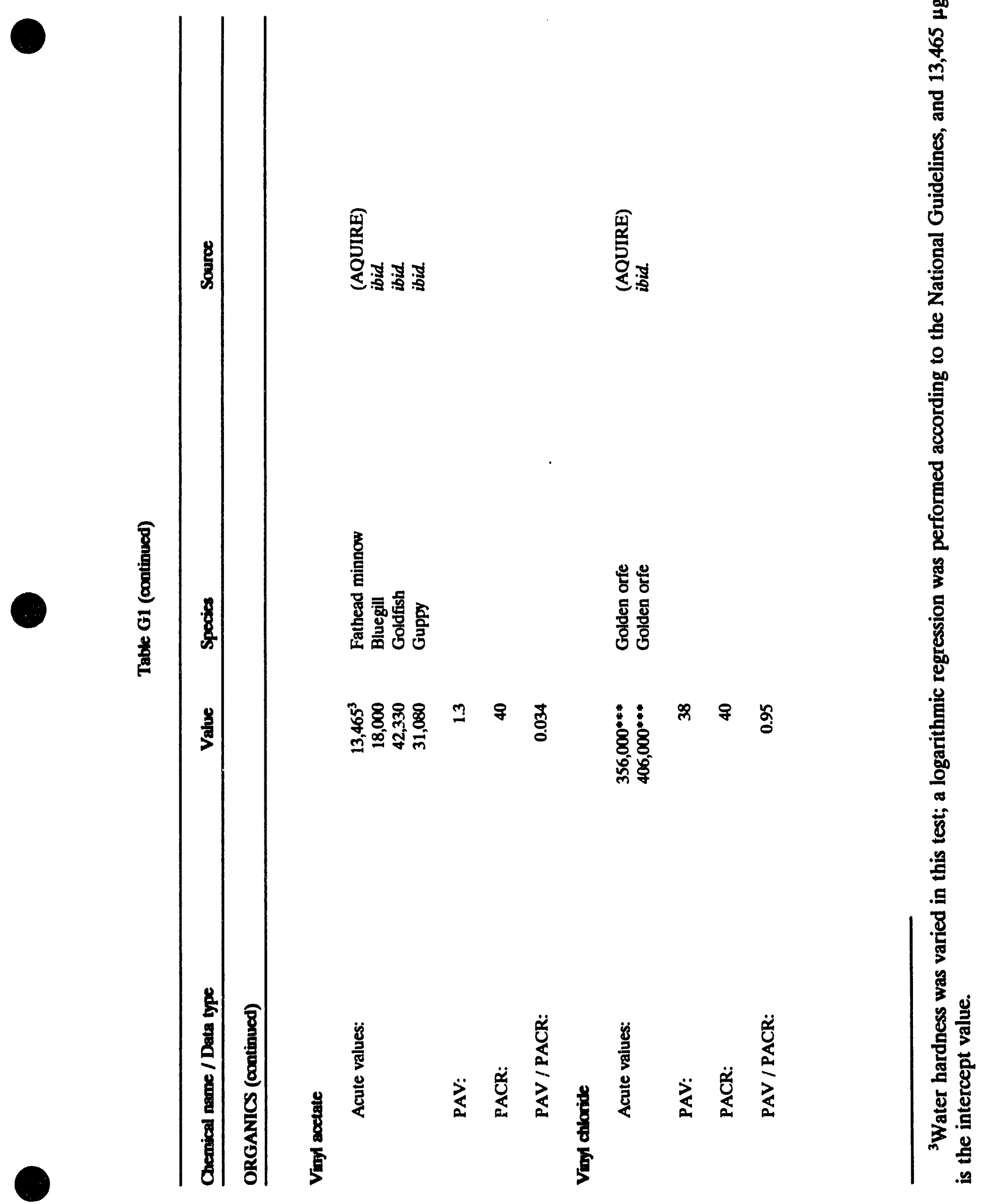




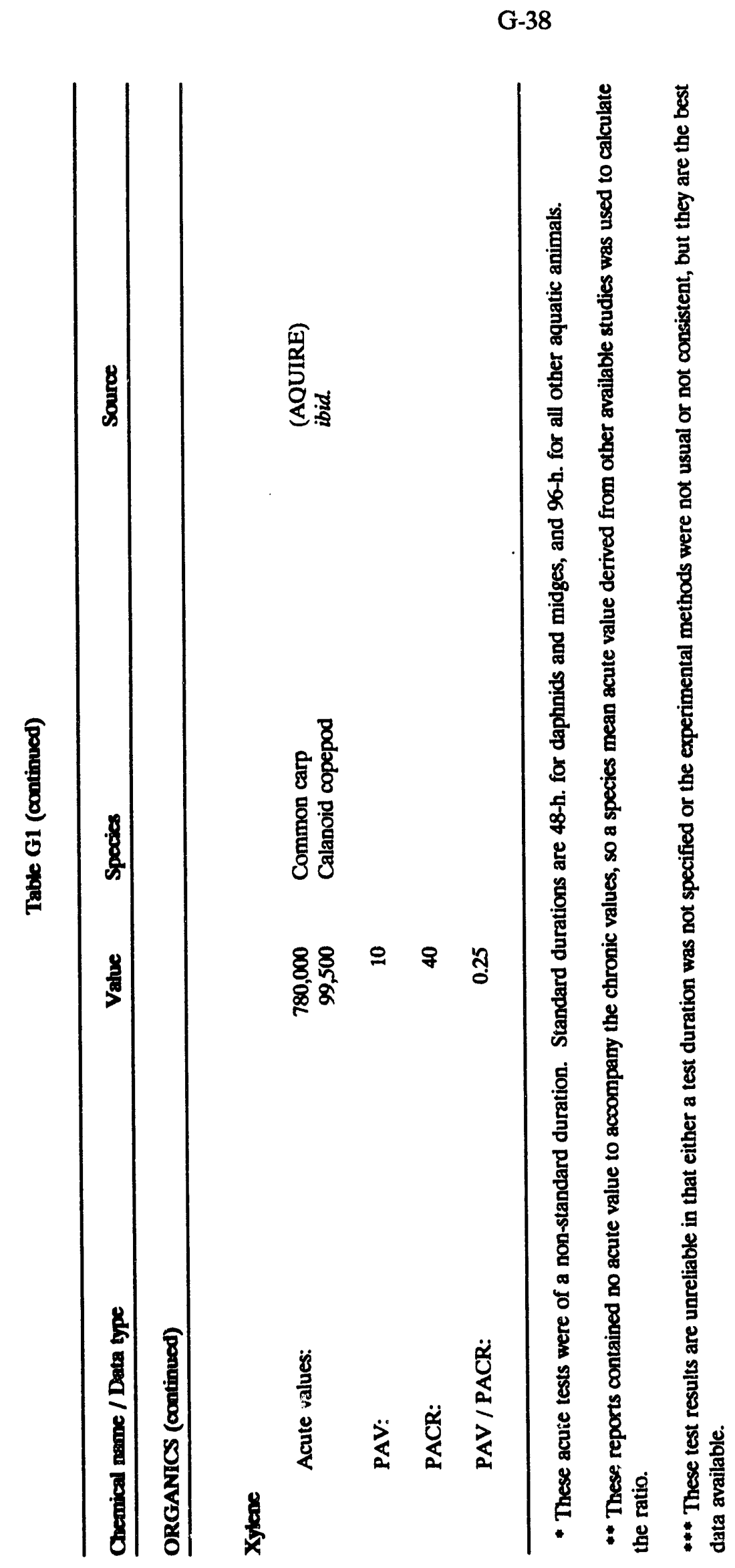




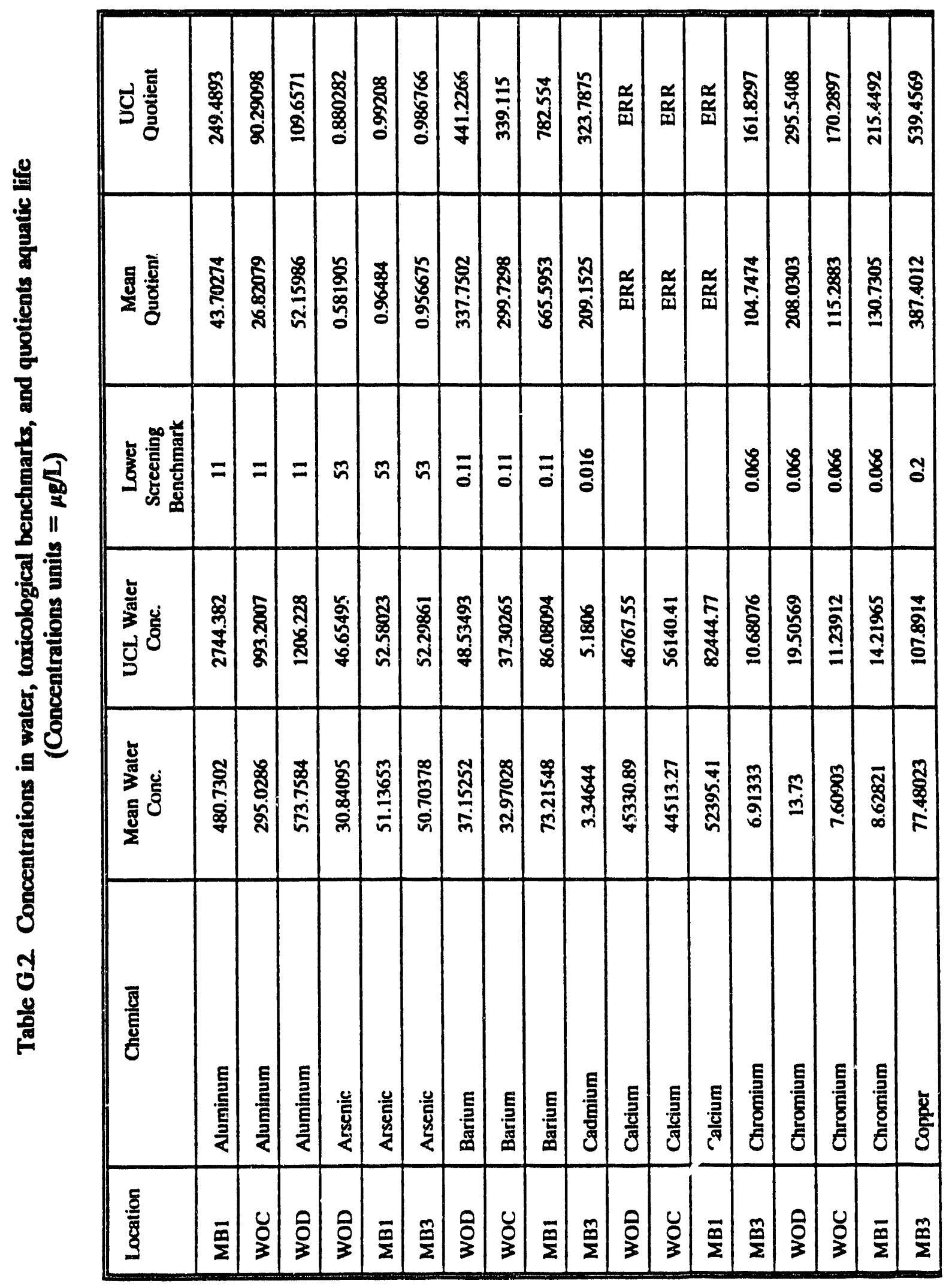




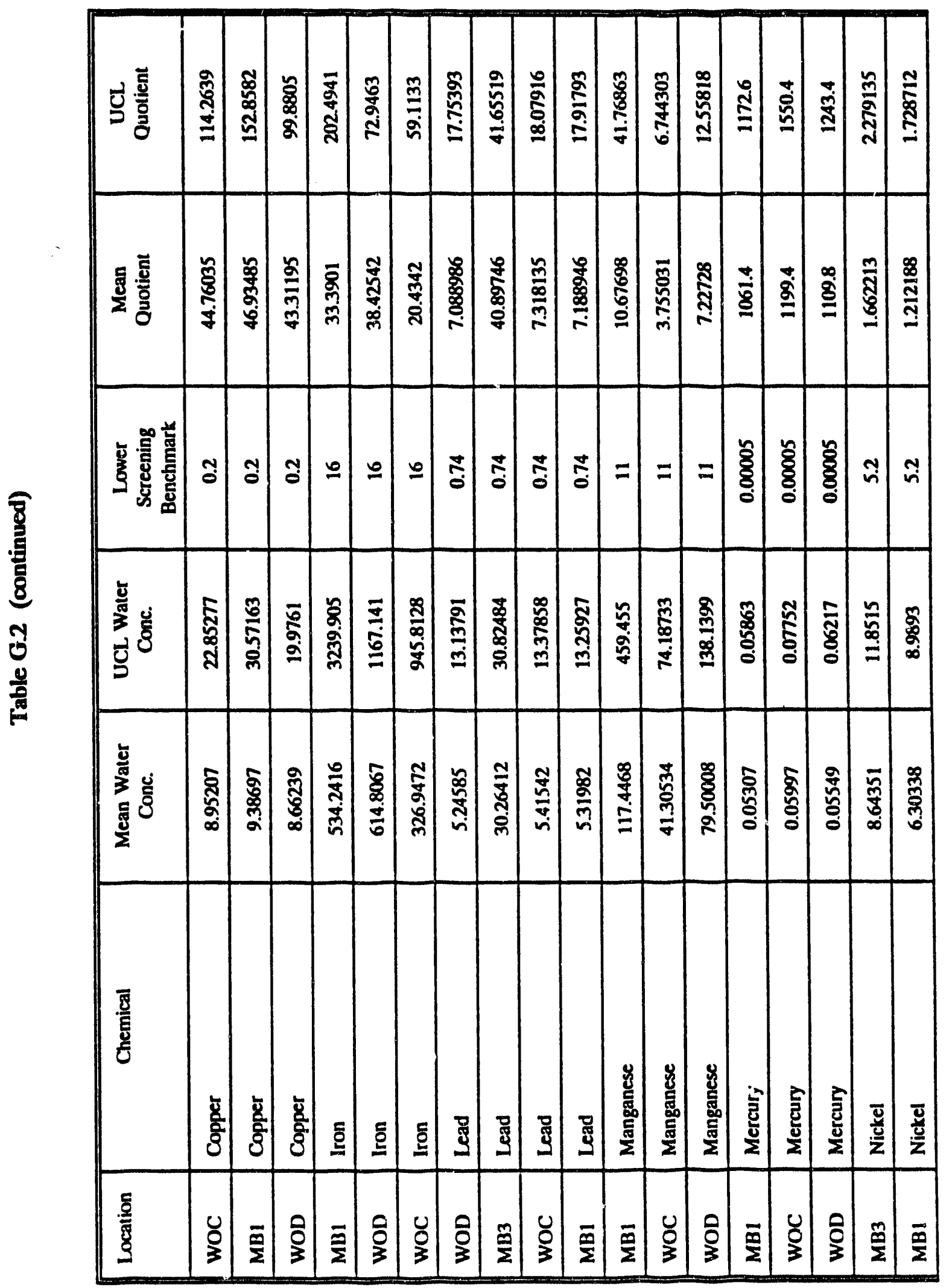




\begin{tabular}{|c|c|c|c|c|c|c|c|c|c|c|c|c|c|c|c|c|c|c|c|c|}
\hline 巳ِ & 宅 & 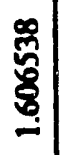 & 㪰 & 若 & $\begin{array}{l}\stackrel{\mathscr{a}}{\widetilde{\alpha}} \\
\text { 㟧 }\end{array}$ & 莡 & 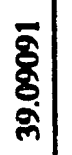 & $\frac{\frac{\infty}{\infty}}{\frac{\infty}{m}}$ & స్ & 畓 & 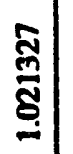 & 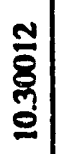 & 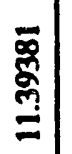 & $\stackrel{\varpi}{\infty}$ & $\begin{array}{l}\frac{0}{5} \\
\frac{5}{8} \\
\dot{m}\end{array}$ & 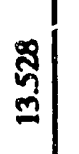 & 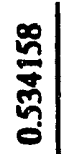 & $\frac{2}{6}$ & 文 & 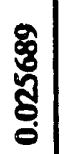 \\
\hline 宽 & 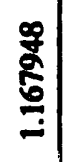 & 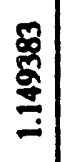 & ఫ్ & 点 & 善 & 径 & $\begin{array}{l}\overline{8} \\
\bar{g} \\
\text { g. }\end{array}$ & $\frac{\infty}{\infty}$ & $\begin{array}{l}\tilde{N} \\
\frac{\pi}{2} \\
\mathcal{N}\end{array}$ & 吕 & $\frac{8}{\frac{\sigma}{n}}$ & 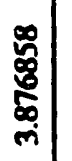 & 疍 & $\begin{array}{l}\text { శ్ } \\
\text { ผूे } \\
\text { ผ }\end{array}$ & 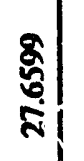 & 落 & 疍 & $\stackrel{8}{\infty}$ & $\begin{array}{c}\frac{N}{n} \\
\frac{\tilde{O}}{0}\end{array}$ & 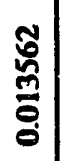 \\
\hline 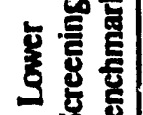 & กี & ஸี & $\stackrel{0}{\circ}$ & & & & Ñ & N & ปี & & $\ddot{a}$ & $\stackrel{\infty}{m}$ & $\stackrel{\infty}{m}$ & $\stackrel{\infty}{m}$ & $\stackrel{\infty}{\infty}$ & $\bar{z}$ & $\underline{m}$ & 2) & 영 & है \\
\hline 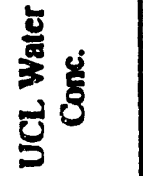 & ఫ్ర్రి & $\underset{\infty}{\mathbf{n}}$ & $\begin{array}{l}\frac{n}{\partial} \\
\frac{\partial}{0} \\
\text { aे }\end{array}$ & 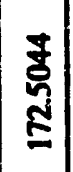 & $\begin{array}{l}\frac{n}{\sigma} \\
\bar{g} \\
\frac{g}{2}\end{array}$ & 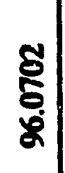 & 8 & $R$ & $\$$ & స్ & 蘦 & $\frac{n}{\frac{n}{2}}$ & 僦 & 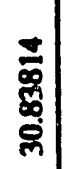 & 亮 & 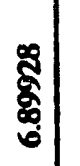 & 咅 & 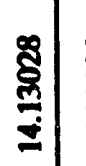 & 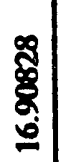 & $\frac{5}{\frac{\delta}{7}}$ \\
\hline 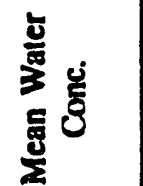 & 旁 & 命 & $\underset{\sim}{\stackrel{\infty}{二}}$ & $\begin{array}{l}2 \\
2 \\
8 \\
0\end{array}$ & 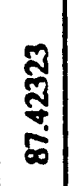 & $\begin{array}{l}\frac{\mathbb{J}}{m} \\
\frac{m}{m}\end{array}$ & 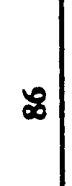 & $R$ & 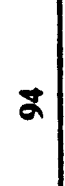 & $\frac{2}{0}$ & $\frac{2}{\bar{n}}$ & 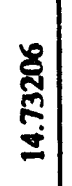 & 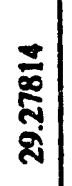 & $\begin{array}{l}\tilde{\delta} \\
\bar{\delta} \\
\overline{\tilde{g}}\end{array}$ & 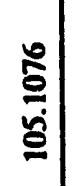 & 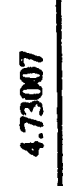 & $\frac{\pi}{2}$ & స్ట్రి & $\frac{m}{\frac{m}{\sigma}}$ & $\underset{\substack{\alpha \\
\infty}}{\infty}$ \\
\hline $\begin{array}{l}\overline{\frac{E}{0}} \\
\bar{E}\end{array}$ & $\frac{\bar{y}}{\frac{y}{z}}$ & $\frac{\bar{g}}{\frac{s}{z}}$ & 톨 & 틀 & हE & 톨 & 豆 & E & 点 & 苨 & 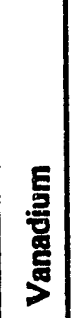 & :ू & $\stackrel{\mathscr{E}}{\mathbf{N}}$ & $\stackrel{0}{5}$ & 号 & 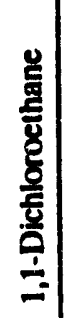 & 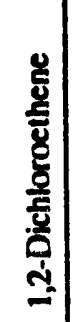 & 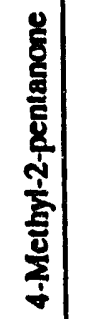 & 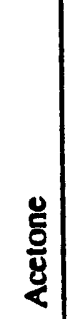 & 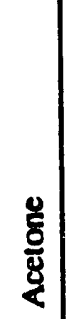 \\
\hline$\underline{\underline{\delta}}$ & 을 & $\begin{array}{l}\circlearrowright \\
\vdots \\
3\end{array}$ & $\stackrel{\circ}{ٍ}$ & $\overline{\mathbf{x}}$ & $\begin{array}{l}\text { ठ } \\
\vdots \\
3\end{array}$ & $\begin{array}{l}0 \\
\vdots \\
\vdots\end{array}$ & $\begin{array}{l}\circlearrowright \\
\vdots\end{array}$ & $\begin{array}{l}\text { ○े } \\
\vdots\end{array}$ & $\overline{\underline{z}}$ & $\bar{\Sigma}$ & $\overline{\bar{z}}$ & $\bar{\Xi}$ & $\begin{array}{l}U \\
\vdots \\
3\end{array}$ & $\begin{array}{l}0 \\
0 \\
\vdots\end{array}$ & $\tilde{B}$ & $\overline{\underline{\underline{\Sigma}}}$ & $\overline{\bar{E}}$ & $\begin{array}{l}0 \\
\vdots\end{array}$ & $\begin{array}{l}\text { Ð } \\
\vdots\end{array}$ & $\begin{array}{l}0 \\
0 \\
3\end{array}$ \\
\hline
\end{tabular}




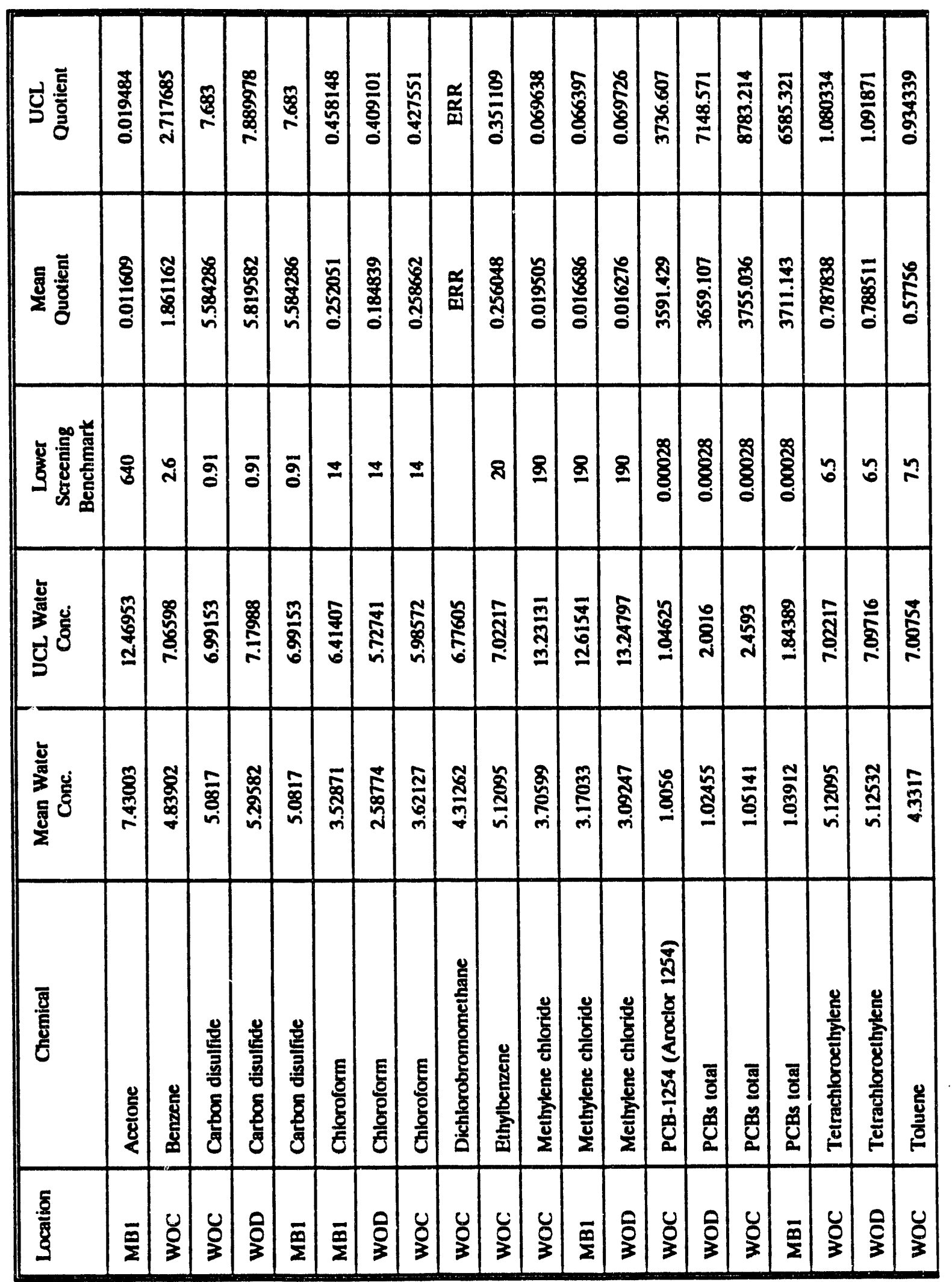




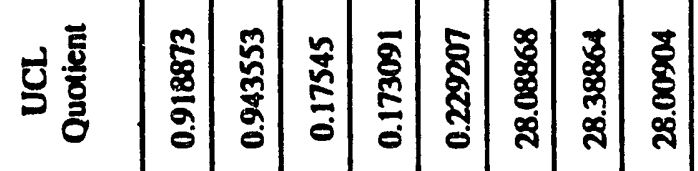

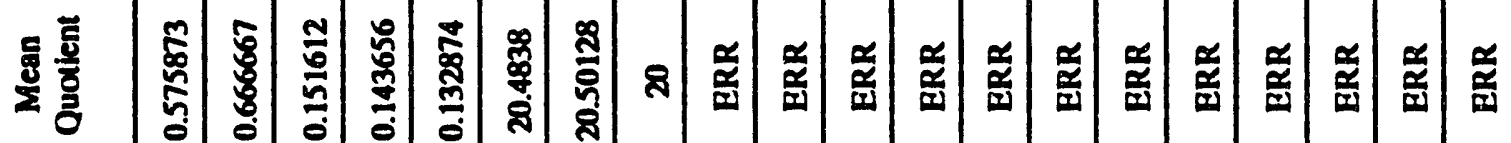

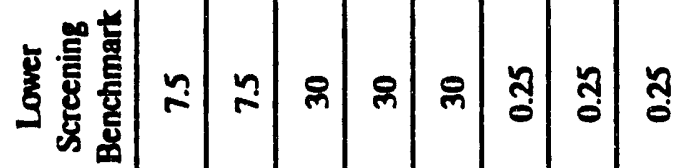

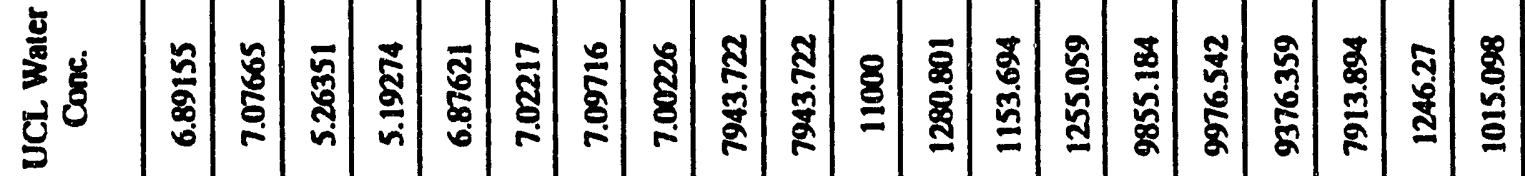

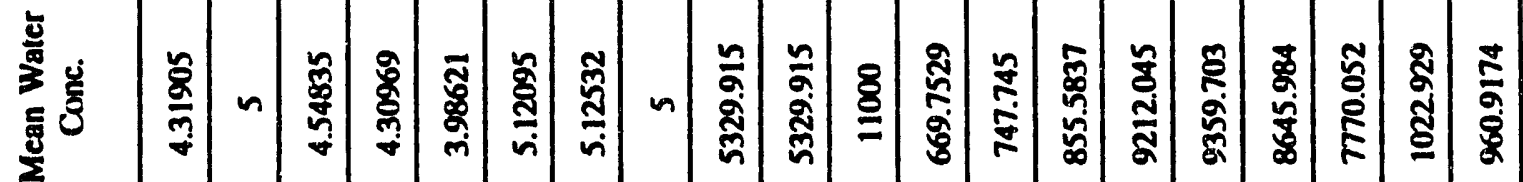

$\frac{\overline{8}}{\text { है }}$

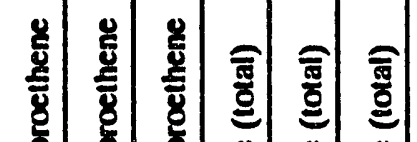

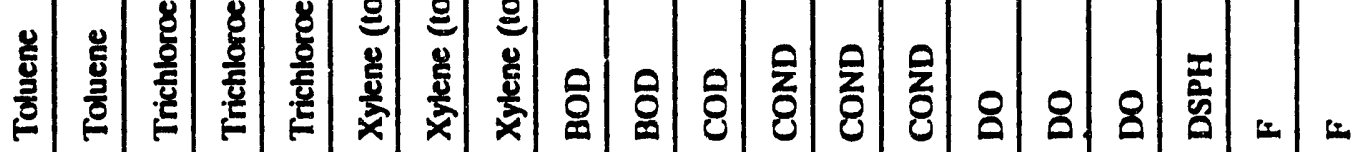

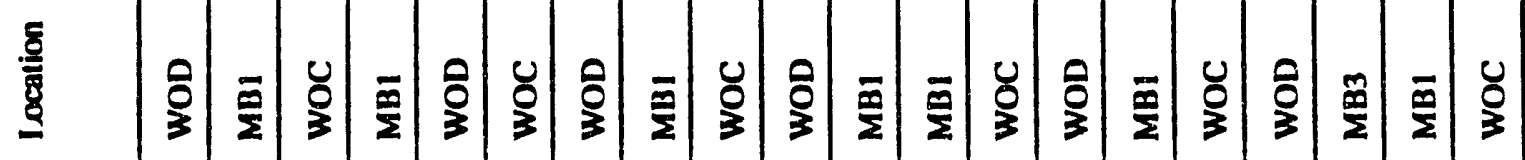




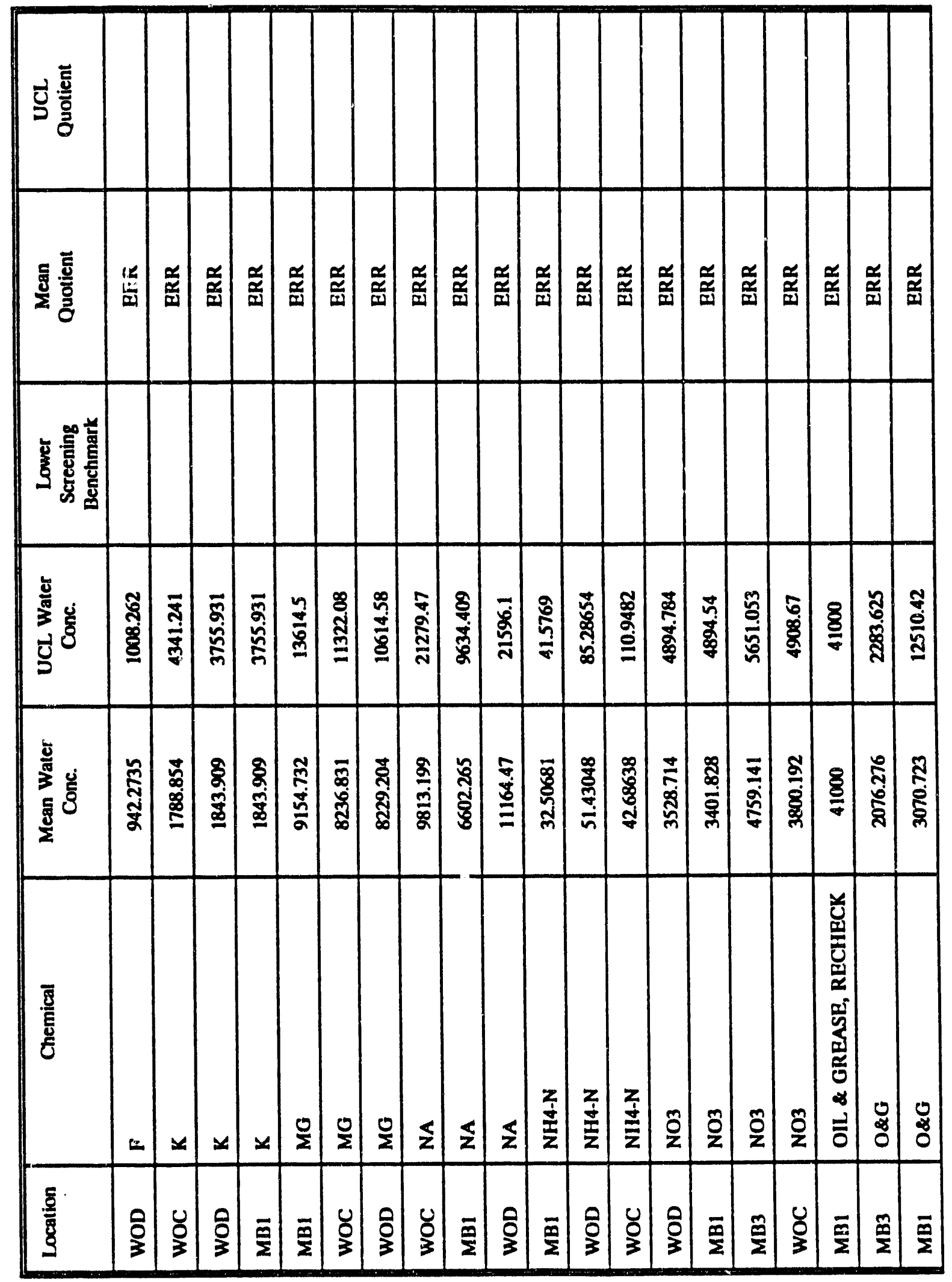




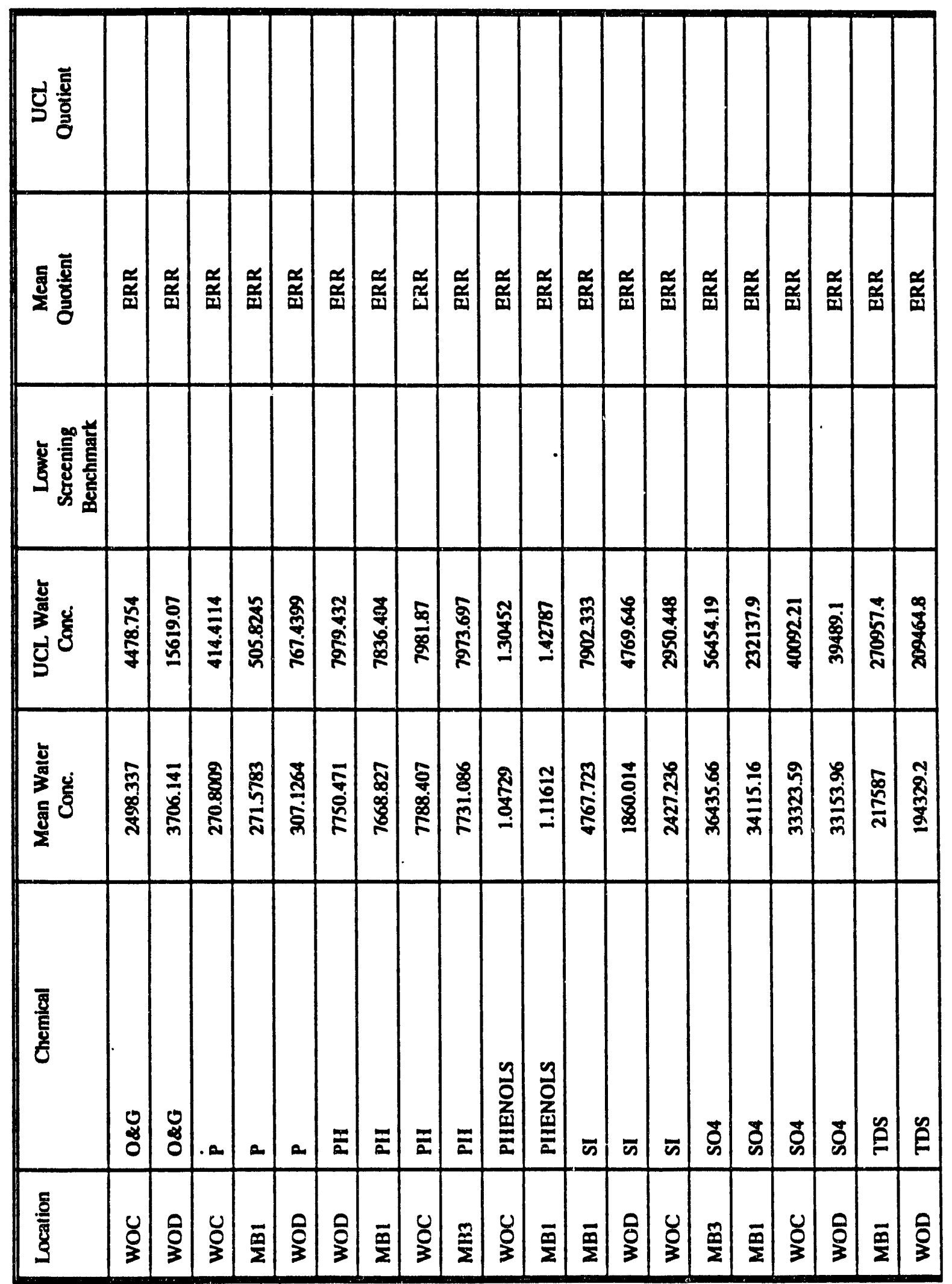




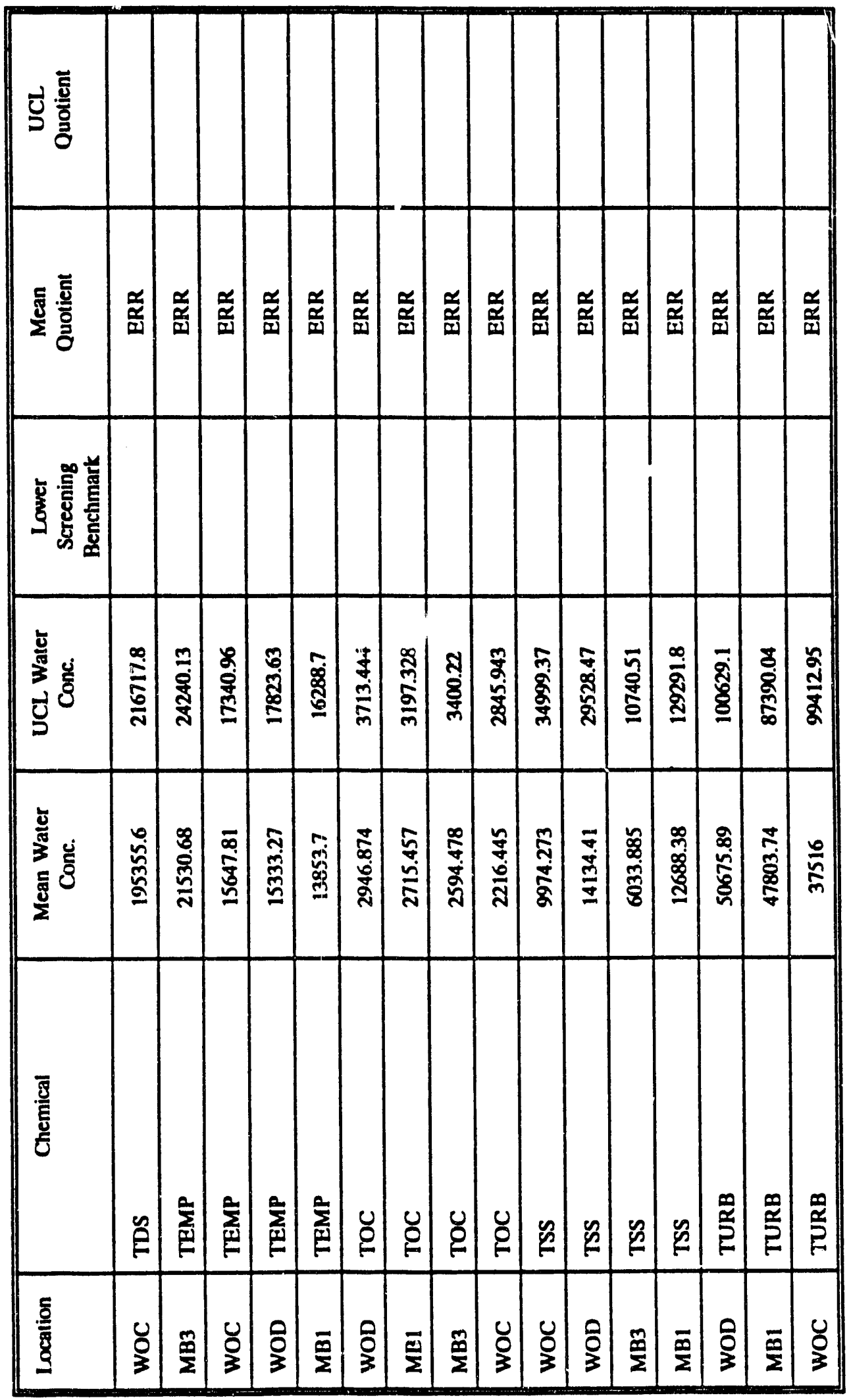




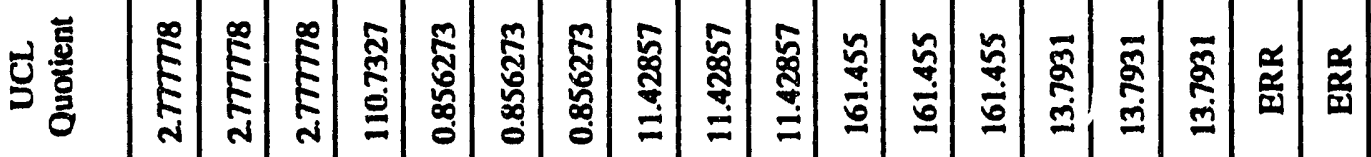

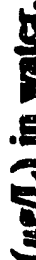

苜语

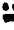

㝵苟

롤

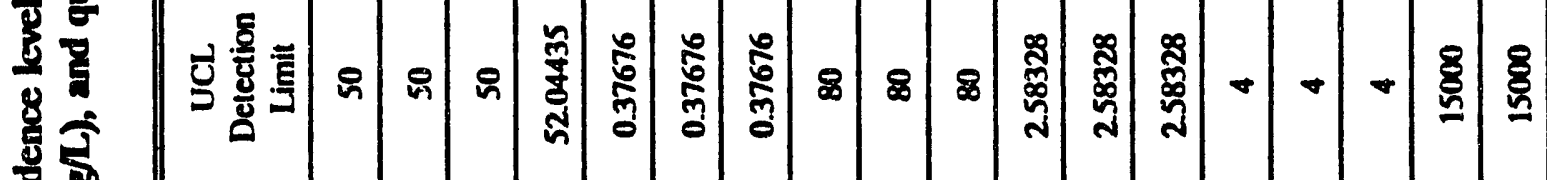

28

Кू

是

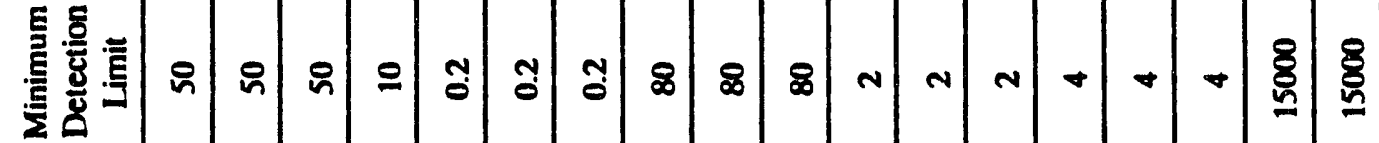

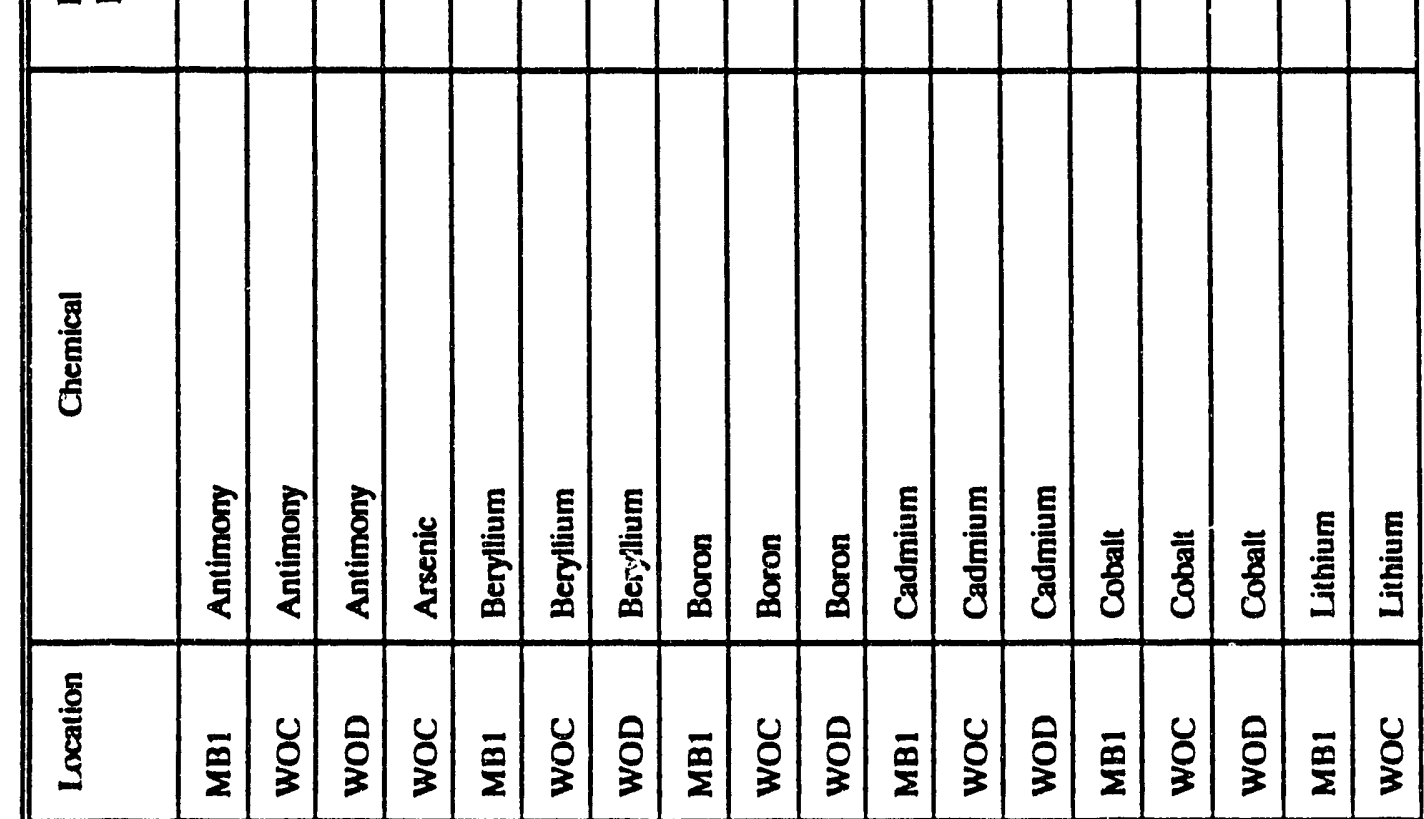




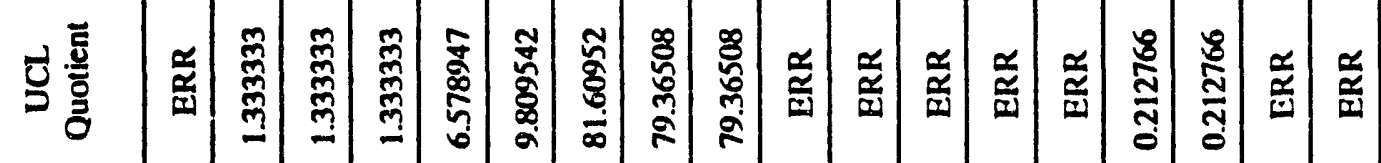

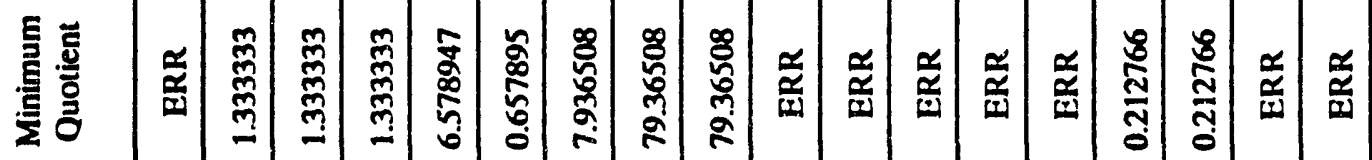

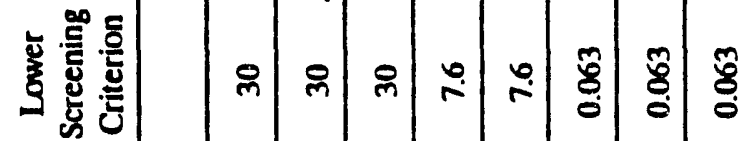

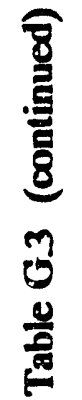

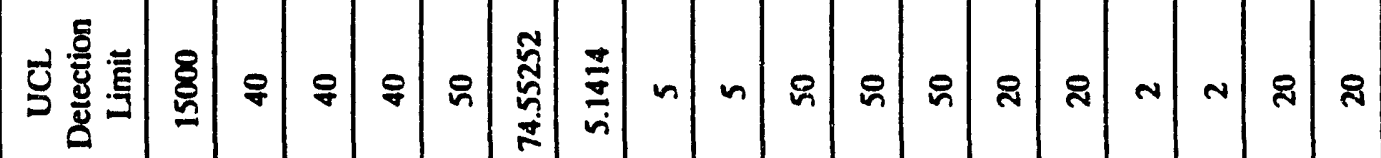

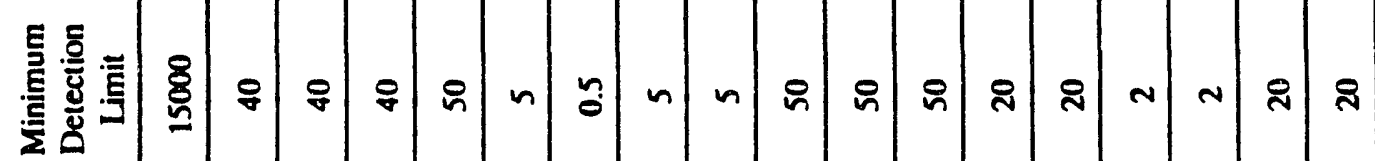

$\frac{\text { घ. }}{\text { है }}$

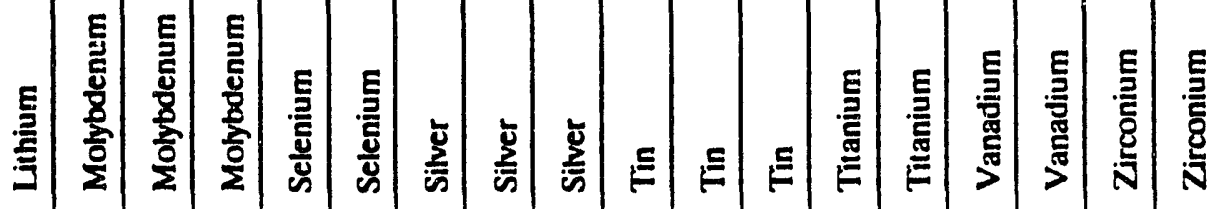

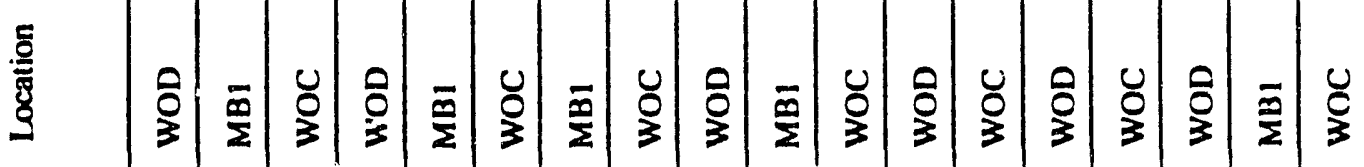




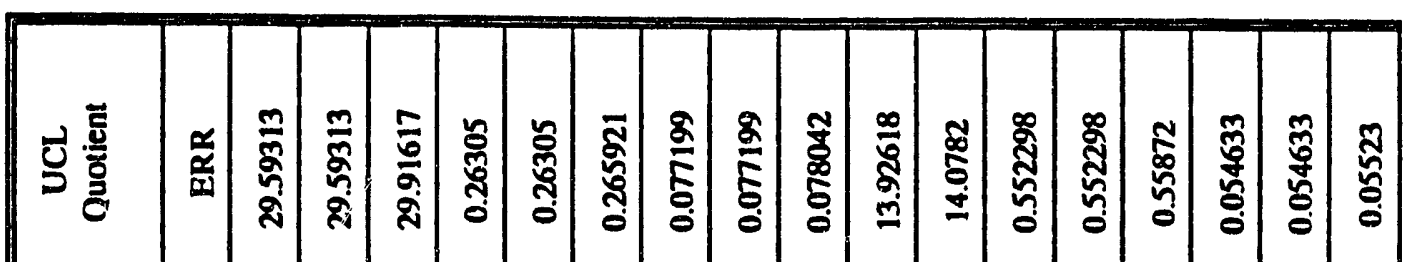

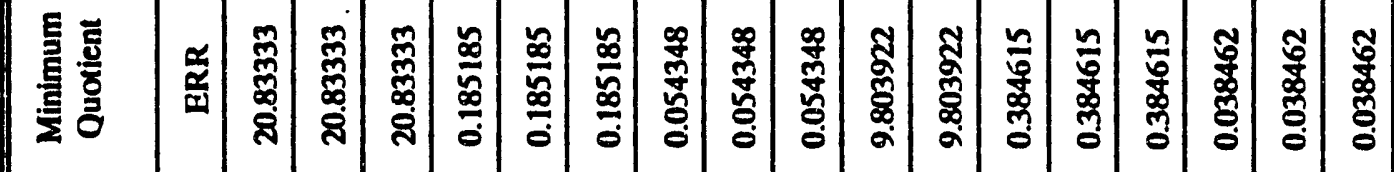

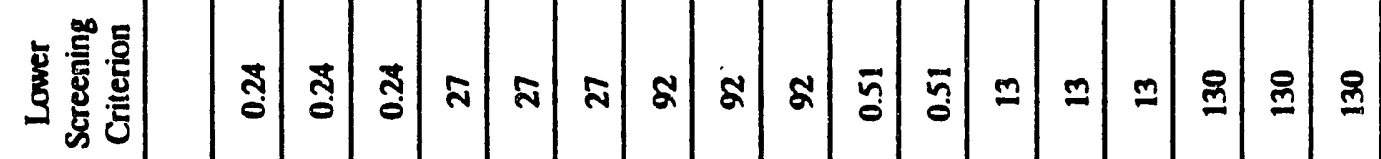

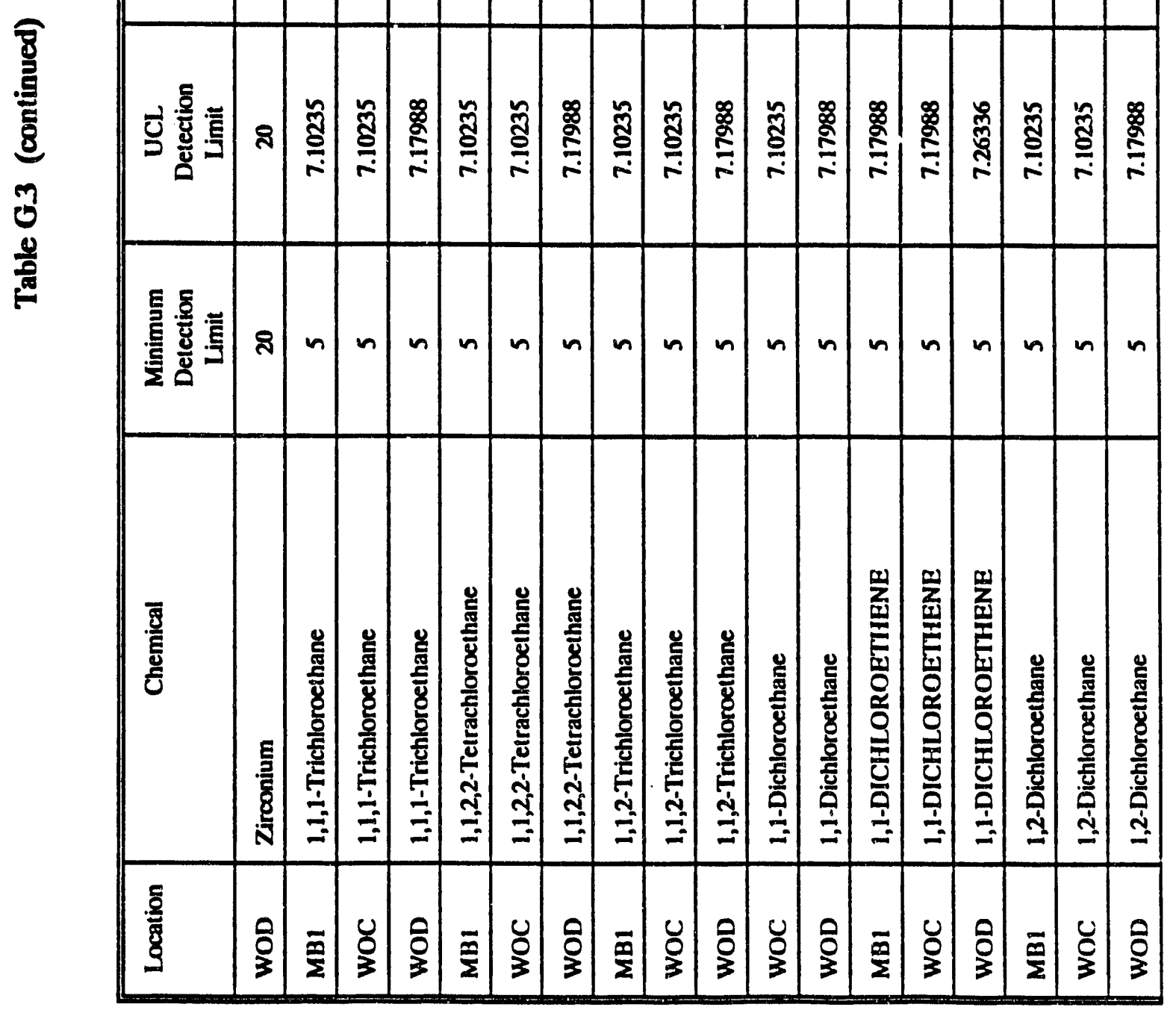




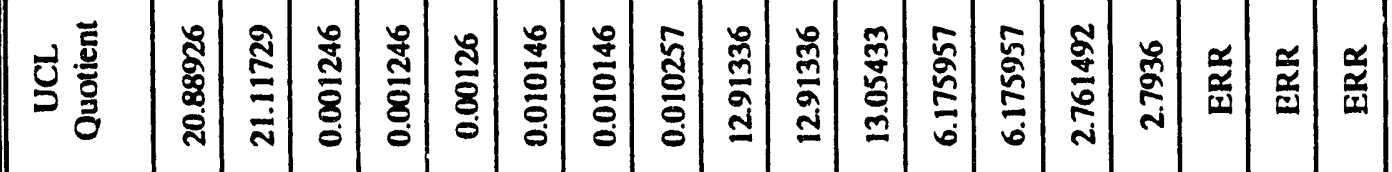

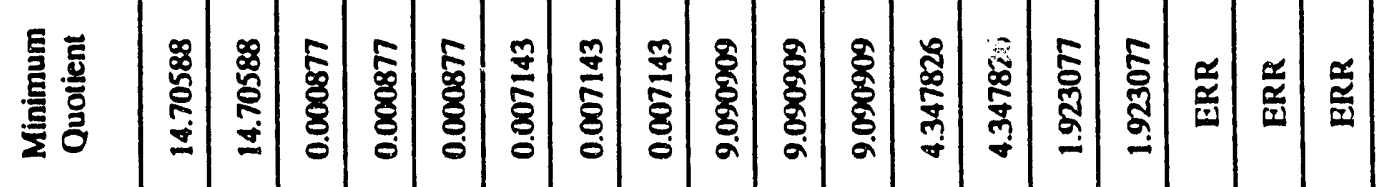

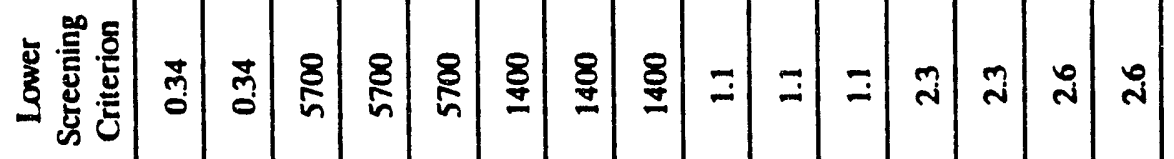

8
8
8
8
0
0
0
0

\begin{tabular}{|c|c|c|c|c|c|c|c|c|c|c|c|c|c|c|c|c|c|c|}
\hline $\begin{array}{l}\overline{\bar{E}} \\
\bar{E} \\
\underline{E}\end{array}$ & 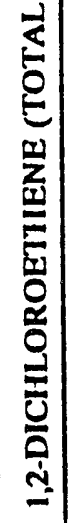 & 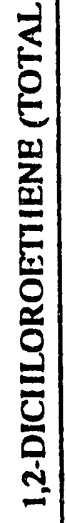 & 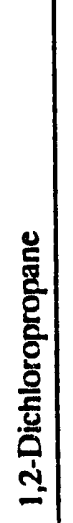 & 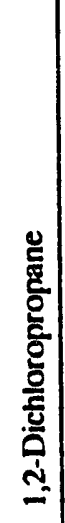 & 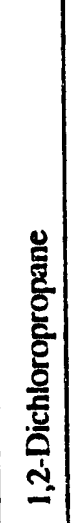 & $\begin{array}{l}0 \\
z \\
0 \\
z \\
\leq \\
\vdots \\
\vdots \\
\dot{n}\end{array}$ & $\begin{array}{l}\frac{0}{2} \\
0 \\
z \\
\leq \\
\vdots \\
\vdots \\
\dot{\sim}\end{array}$ & $\begin{array}{l}\mathbf{n} \\
\mathbf{z} \\
0 \\
z \\
\mathbf{c} \\
\vdots \\
0 \\
\dot{n}\end{array} \mid$ & 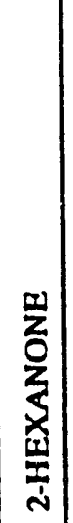 & 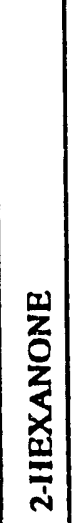 & 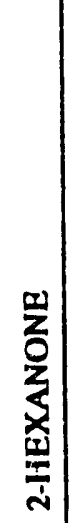 & 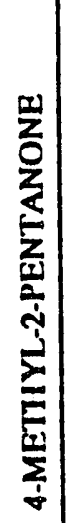 & 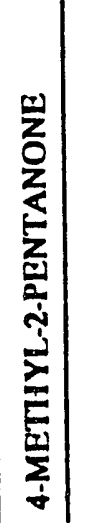 & 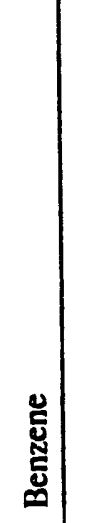 & 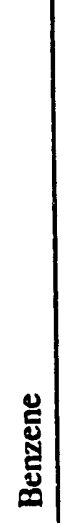 & 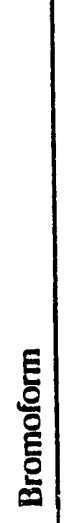 & 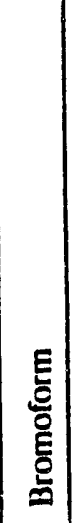 & 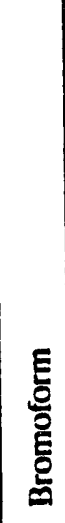 \\
\hline 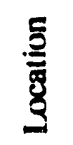 & $\begin{array}{l}u \\
\vdots \\
\vdots\end{array}$ & $\begin{array}{l}0 \\
3\end{array}$ & $\overline{\bar{x}}$ & $\begin{array}{l}\text { O } \\
3\end{array}$ & $\widehat{\widehat{C}}$ & $\overline{\frac{\rho}{\Sigma}}$ & $\begin{array}{l}0 \\
0 \\
3\end{array}$ & $\begin{array}{l}0 \\
0 \\
3\end{array}$ & $\overline{\bar{\varepsilon}}$ & $\begin{array}{l}U \\
\vdots \\
3\end{array}$ & $\begin{array}{l}0 \\
\wp\end{array}$ & $\overline{\bar{z}}$ & 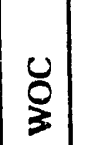 & $\overline{\bar{\Sigma}}$ & 仓ิ & $\bar{\Xi}$ & ๖ & 仓ิ \\
\hline
\end{tabular}

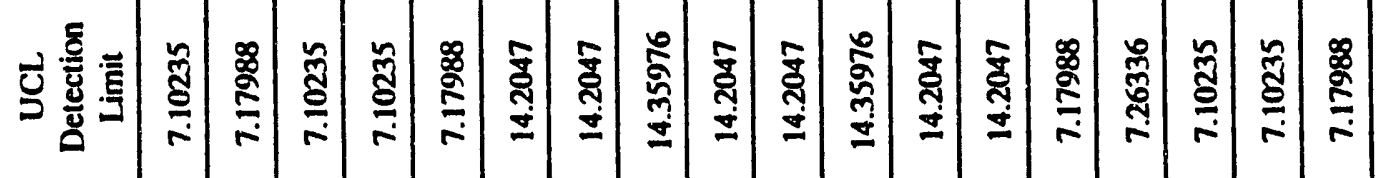

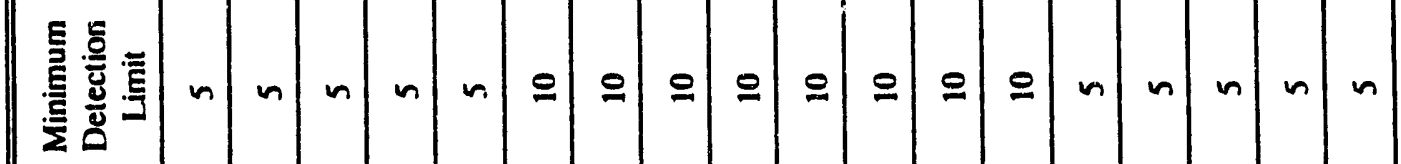




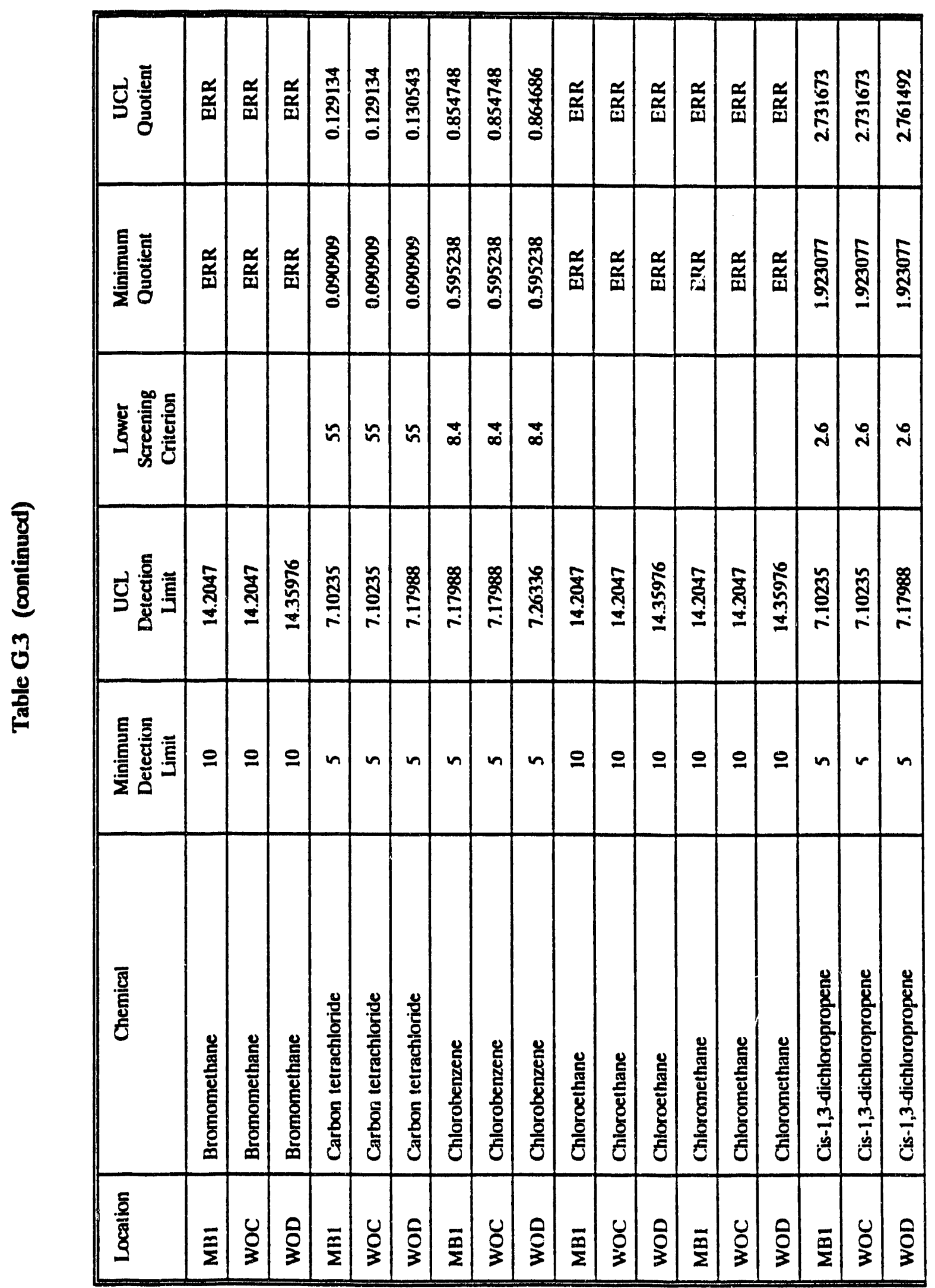




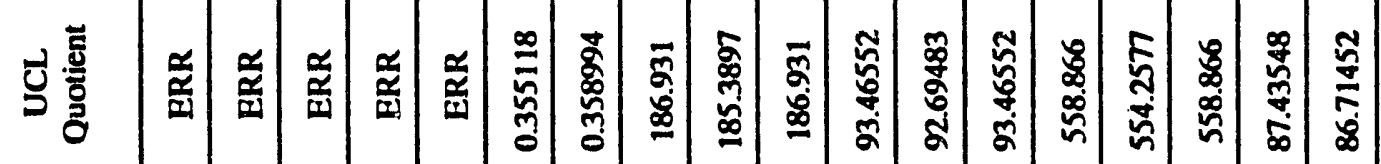

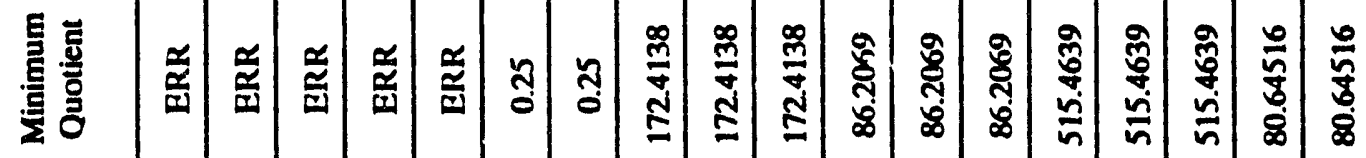

产总总

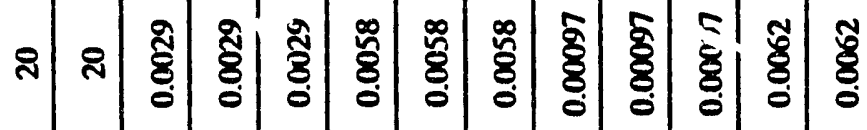

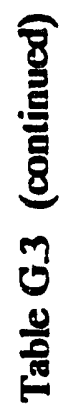

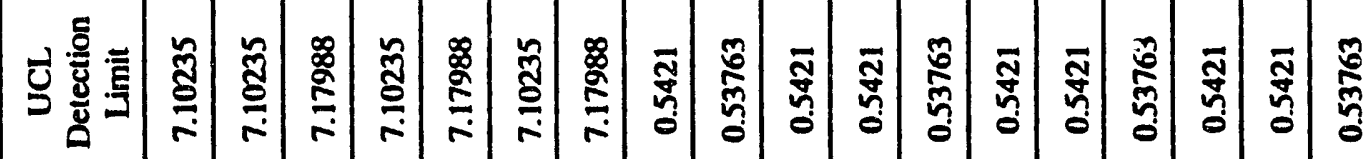

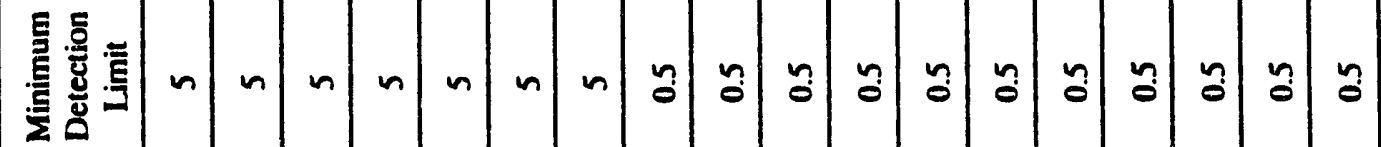

\begin{tabular}{|c|c|c|c|c|c|c|c|c|c|c|c|c|c|c|c|c|c|c|}
\hline हु & 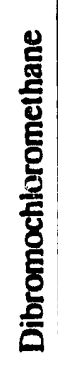 & 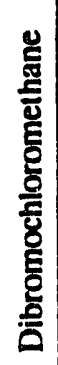 & 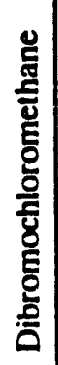 & 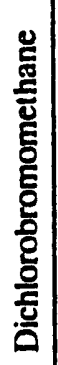 & 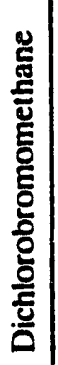 & 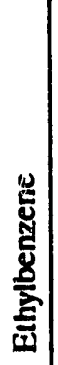 & 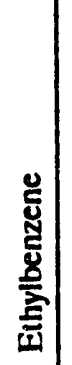 & 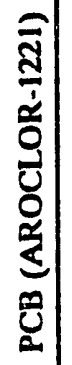 & 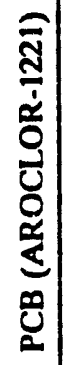 & 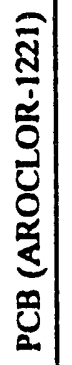 & 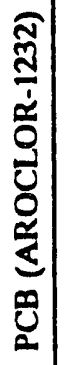 & 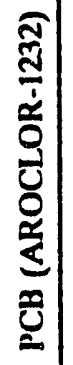 & 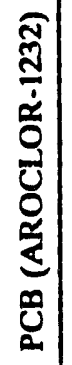 & 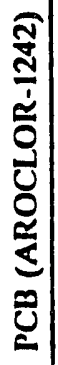 & 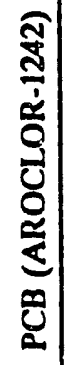 & 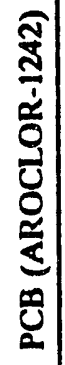 & 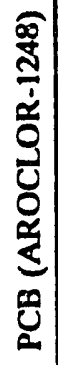 & 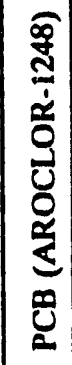 \\
\hline 8 & $\bar{\Sigma}$ & ְֶ & $\stackrel{0}{3}$ & $\bar{\Sigma}$ & ฏิ & $\overline{\mathbf{m}}$ & 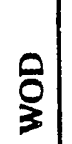 & $\overline{\mathbf{m}}$ & $\begin{array}{l}0 \\
\vdots \\
3\end{array}$ & $\begin{array}{l}0 \\
\vdots\end{array}$ & $\overline{\bar{\Sigma}}$ & ญ & $\begin{array}{l}0 \\
0 \\
3\end{array}$ & $\bar{\Sigma}$ & $\begin{array}{l}U \\
\vdots \\
3\end{array}$ & $\begin{array}{l}0 \\
0 \\
3\end{array}$ & $\overline{\overline{\tilde{x}}}$ & $\begin{array}{l}\text { O } \\
3\end{array}$ \\
\hline
\end{tabular}




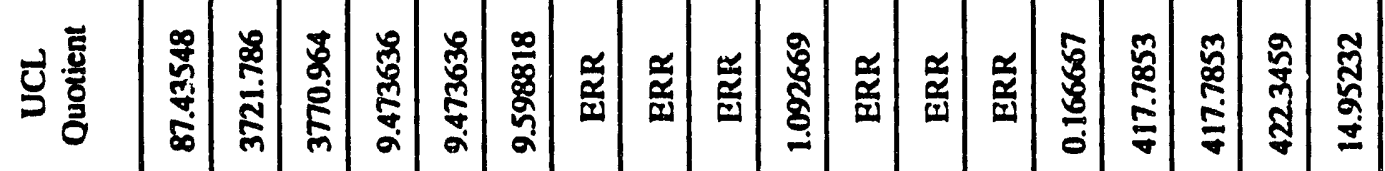

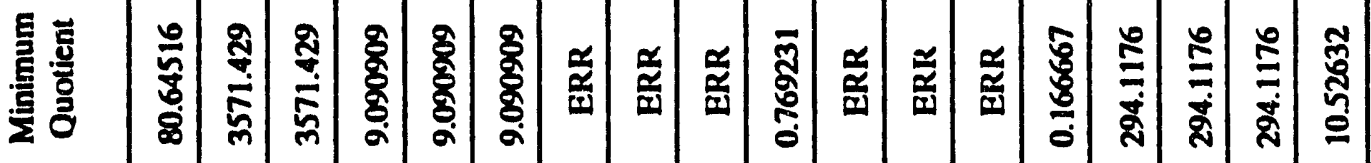

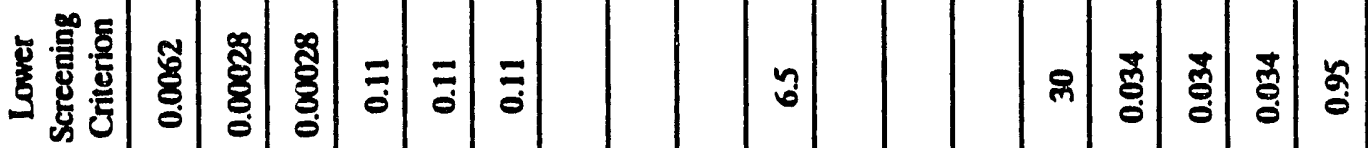

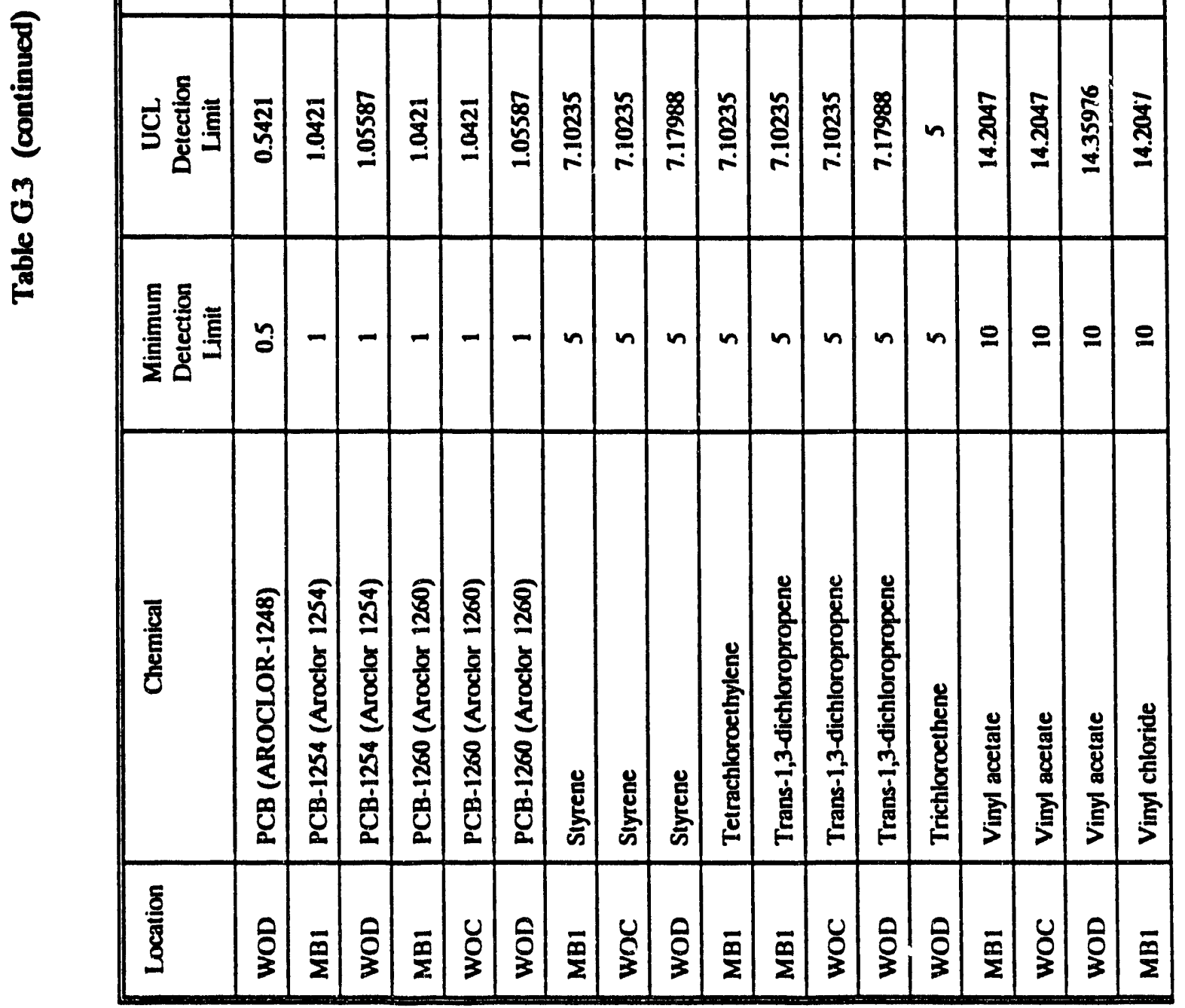




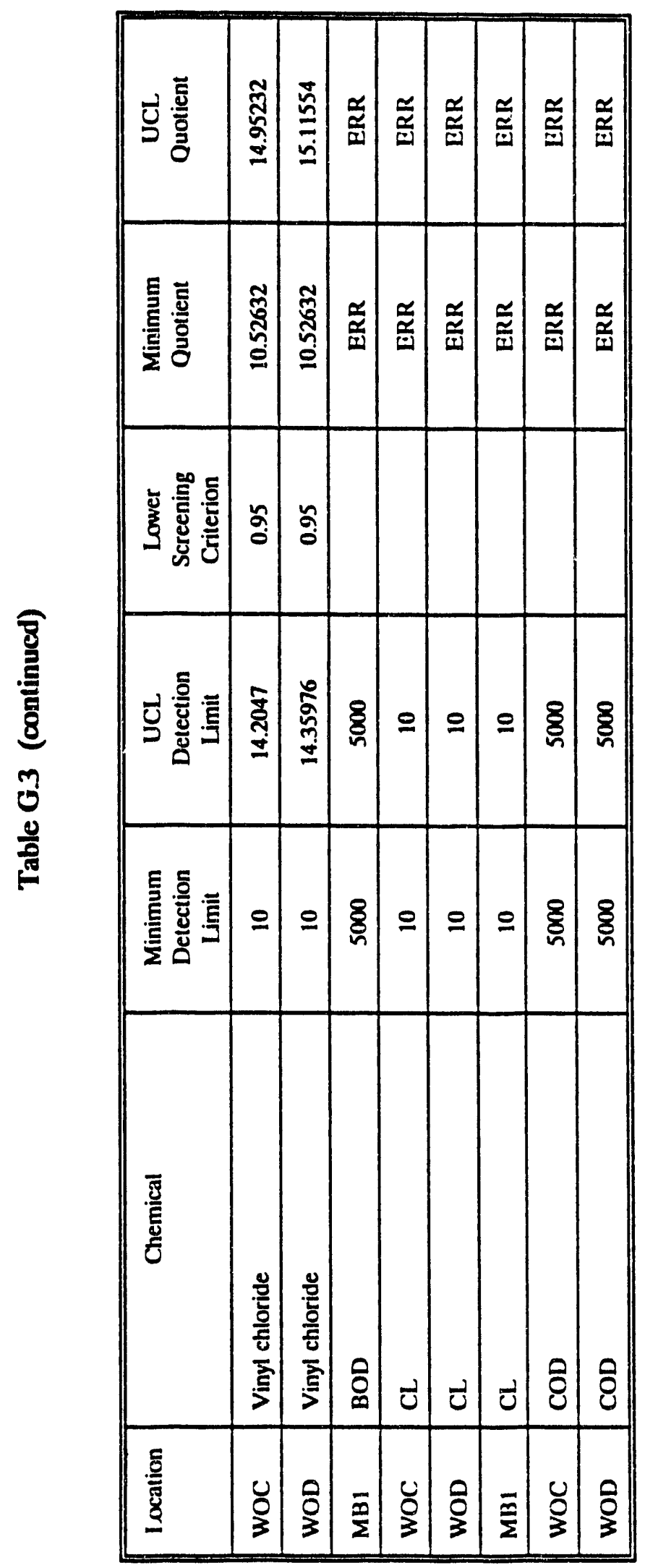




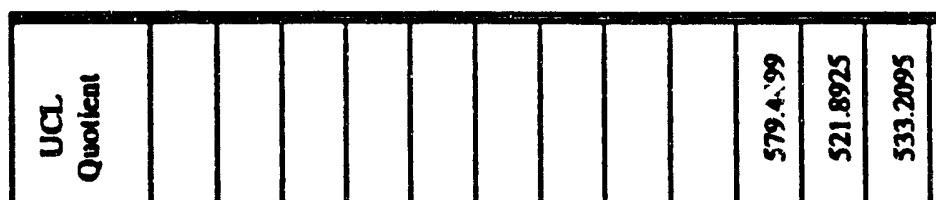

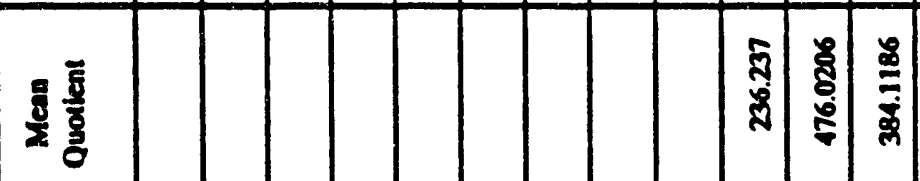

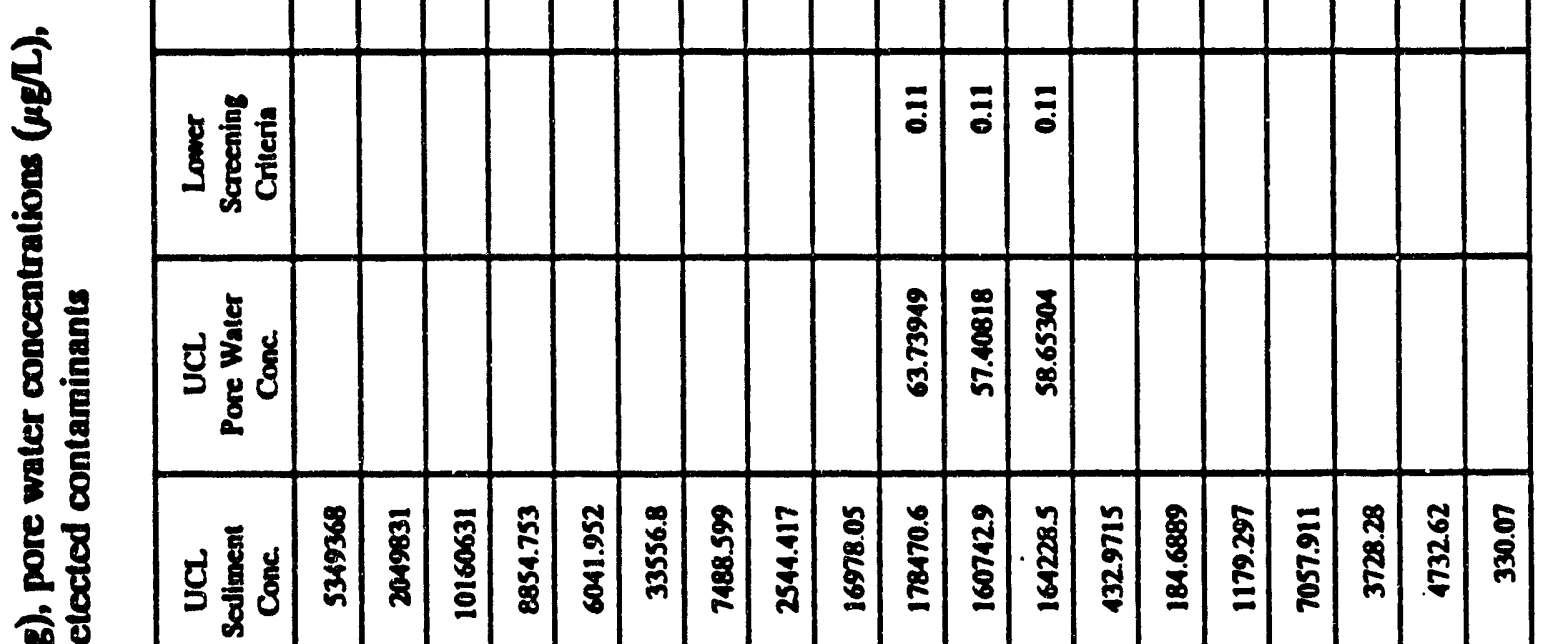

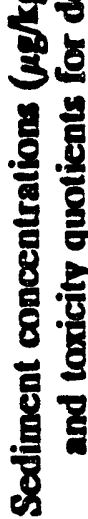

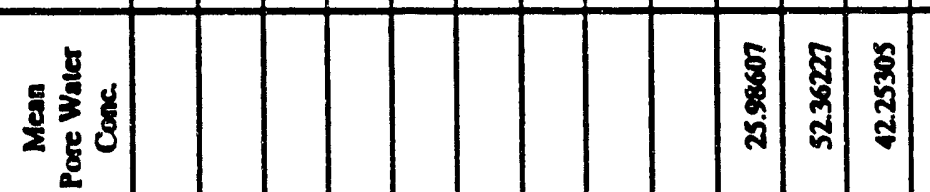

章

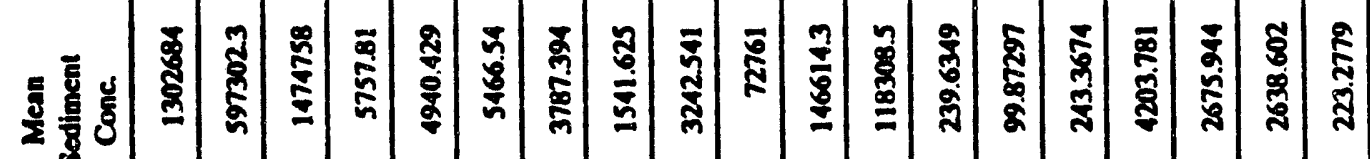

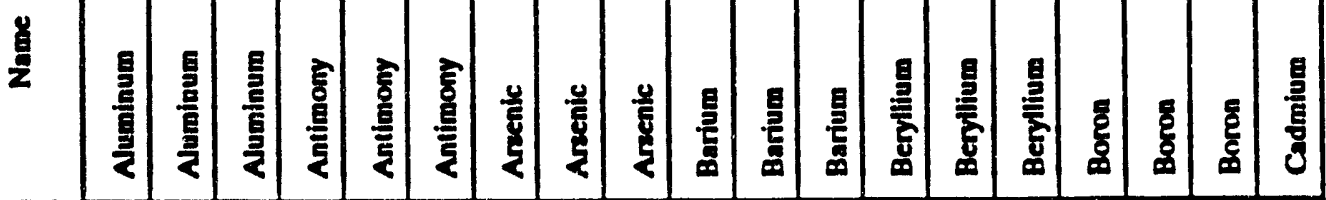

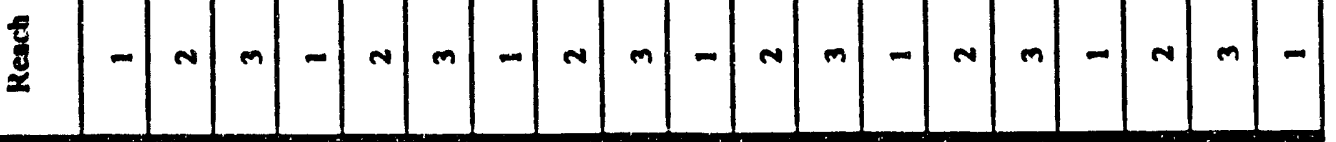




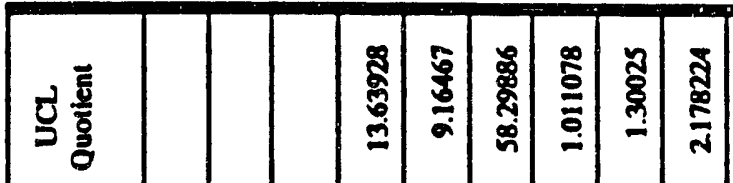

\begin{tabular}{|c|c|c|c|c|c|}
\hline$\sum$ & & & 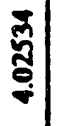 & 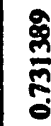 & \\
\hline
\end{tabular}

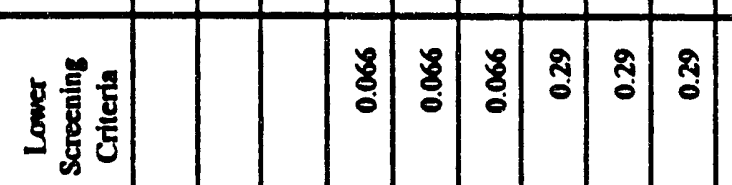

\begin{tabular}{|c|c|c|c|c|c|}
\hline 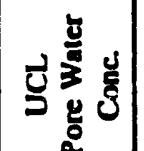 & హ్ & 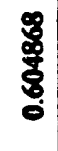 & 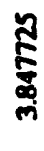 & 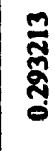 & 点 \\
\hline
\end{tabular}

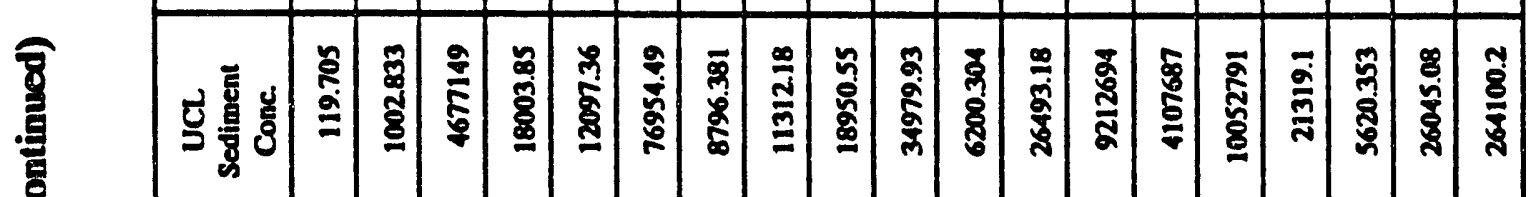

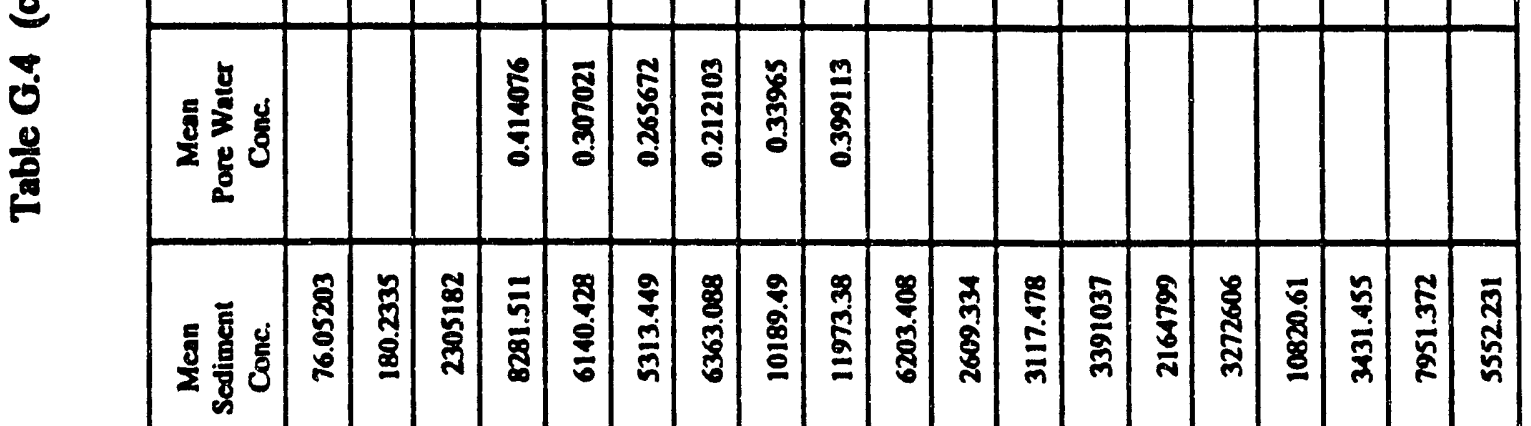

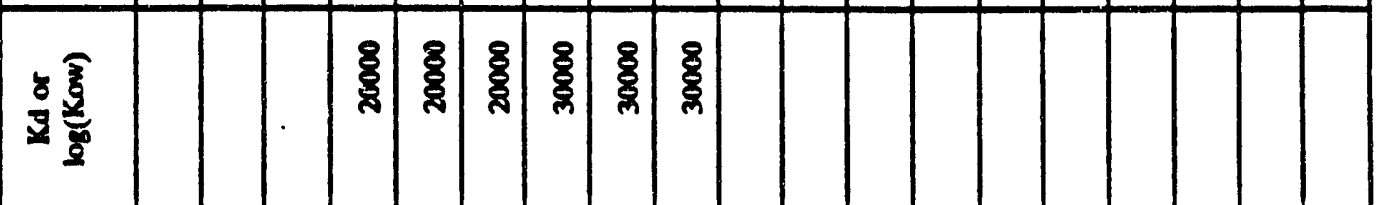

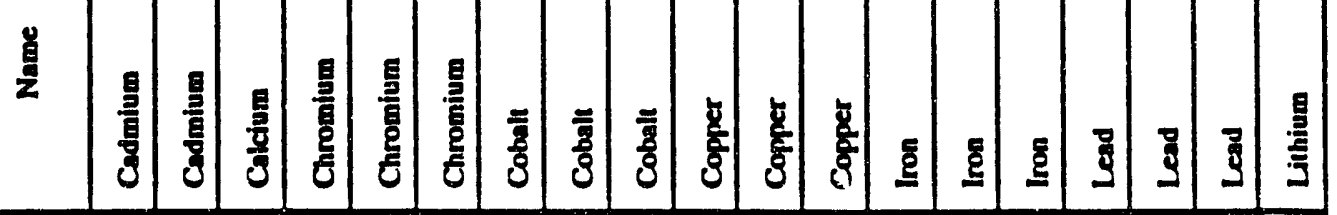

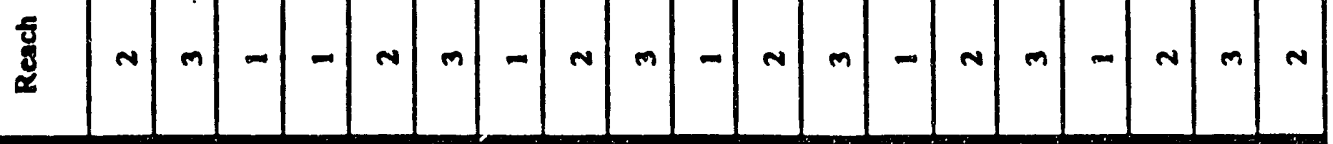


G-57

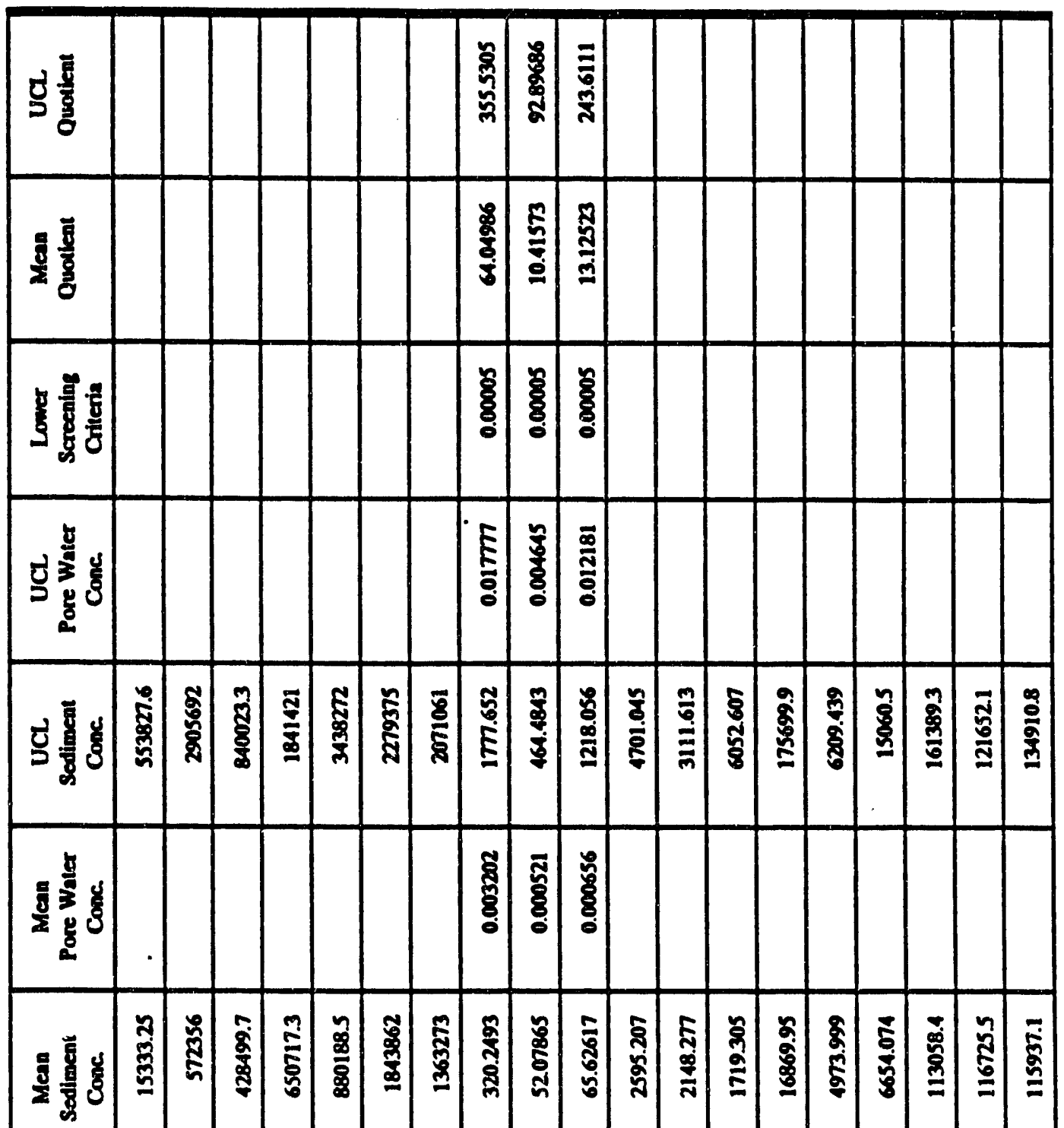

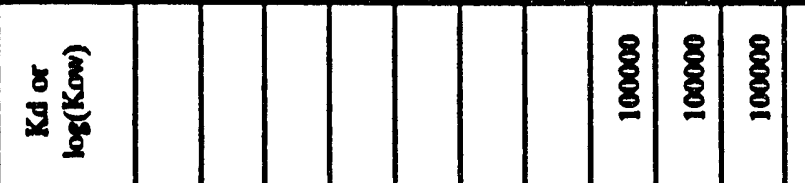

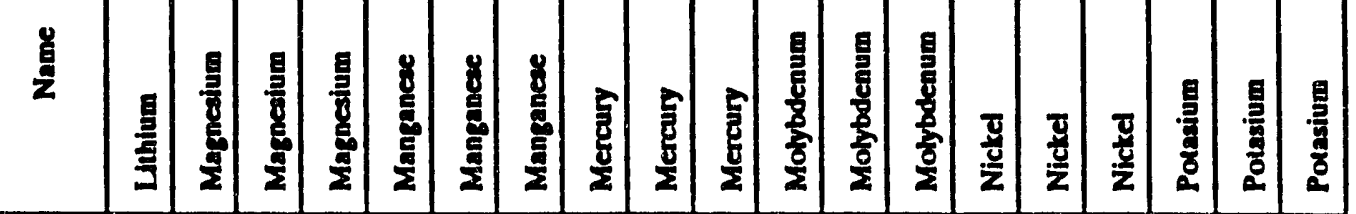

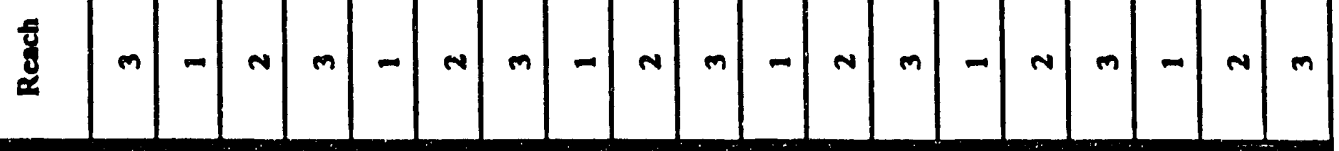




\begin{tabular}{|c|c|c|c|c|c|c|c|c|c|c|c|c|c|c|c|c|c|c|c|}
\hline 它 & & & & & & & $\stackrel{m}{=}$ & 怘 & 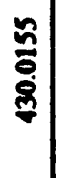 & & & & & & & & & & \\
\hline 量离 & & & & & & & 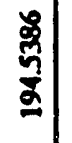 & 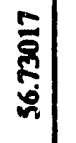 & $\begin{array}{l}\delta \\
\frac{\delta}{\mathfrak{a}} \\
\Xi\end{array}$ & & & & & & & & & & \\
\hline 3 & & & & & & & 势 & $\begin{array}{l}\tilde{z} \\
0 \\
0\end{array}$ & : & & & & & & & & & & \\
\hline 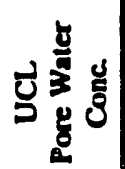 & & & & & & & 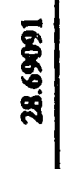 & 衰 & 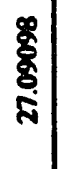 & & & & & & & & & & \\
\hline 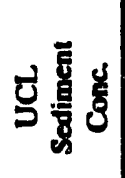 & ะั่ & 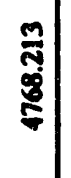 & है: & 㝘 & 京 & $\begin{array}{l}n \\
\mathbf{z} \\
: \\
\tilde{m} \\
m\end{array}$ & 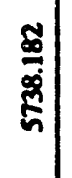 & స్ & $\frac{\alpha}{\infty}$ & ప్ & $\begin{array}{c}\mathbb{\Phi} \\
\stackrel{\tilde{m}}{=}\end{array}$ & 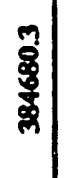 & $\begin{array}{l}E \\
\dot{\omega} \\
\vdots \\
a\end{array}$ & 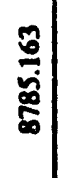 & 蒿 & : & 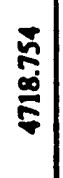 & 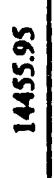 & 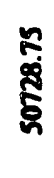 \\
\hline 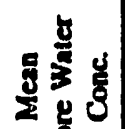 & & & & & & & 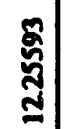 & $\begin{array}{l}\bar{్} \\
\vdots \\
\vdots\end{array}$ & 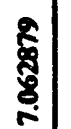 & & & & & & & & & & \\
\hline 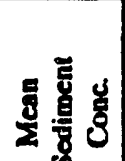 & 累 & 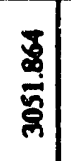 & 营 & 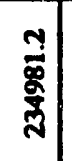 & 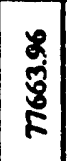 & 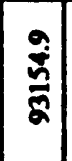 & & $\begin{array}{l}\overline{\mathbf{z}} \\
\dot{\sigma} \\
\dot{z}\end{array}$ & $\begin{array}{l}\vdots \\
\vdots \\
\vdots\end{array}$ & 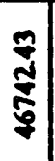 & $\bar{\vdots}$ & 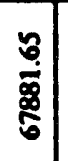 & $\frac{0}{\frac{0}{0}}$ & 㐫 & $\begin{array}{l}E \\
\vdots \\
\vdots \\
\vdots \\
0\end{array}$ & $\begin{array}{l}\overline{0} \\
\text { है }\end{array}$ & 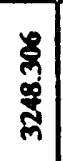 & 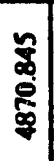 & స్ \\
\hline
\end{tabular}

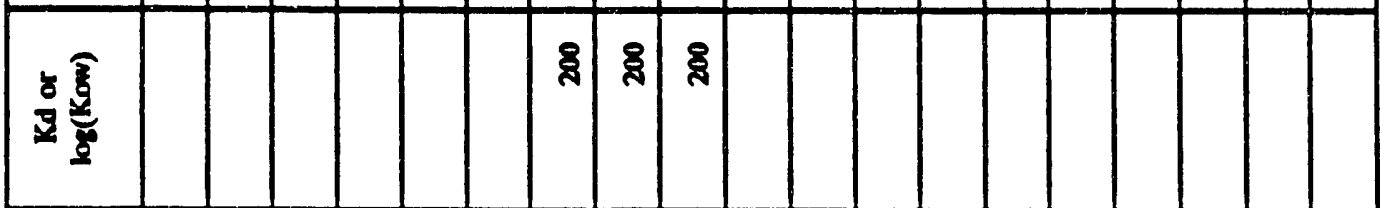

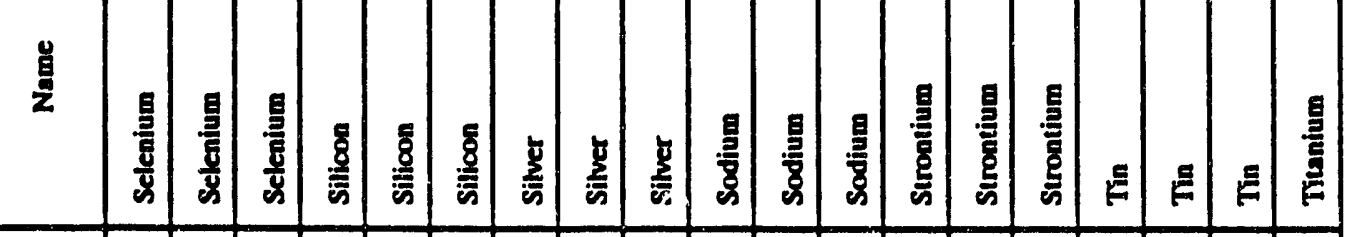

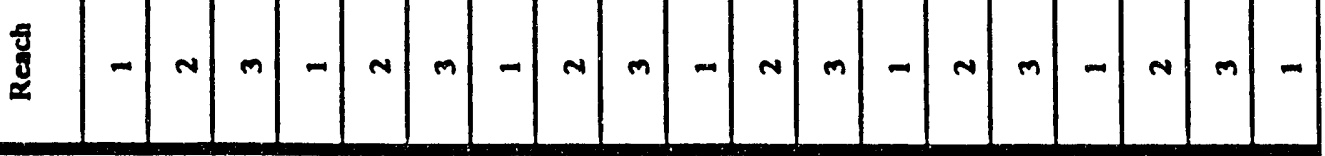


G-59

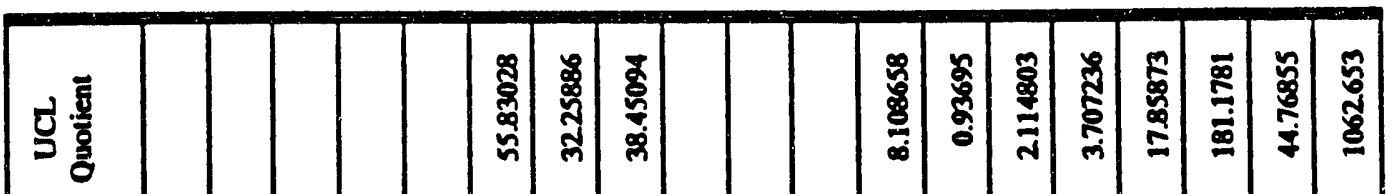

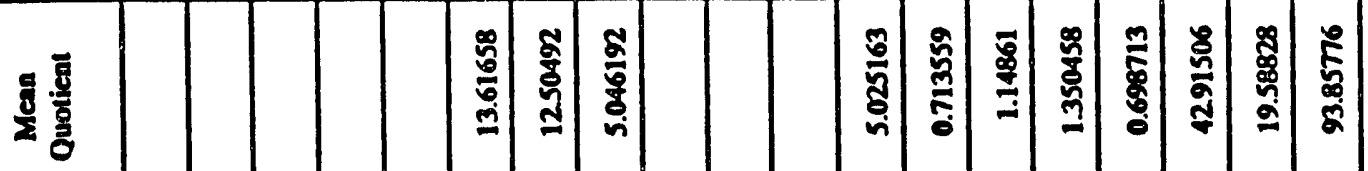

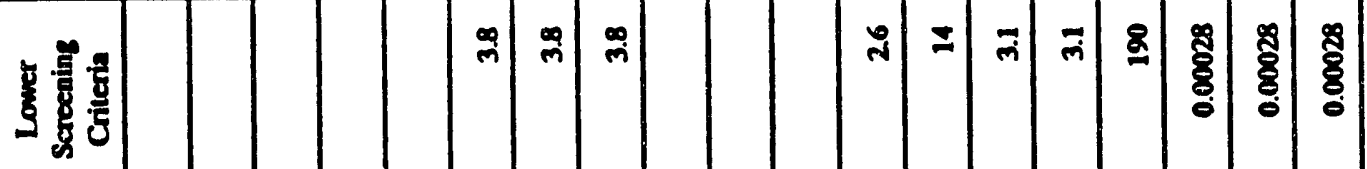

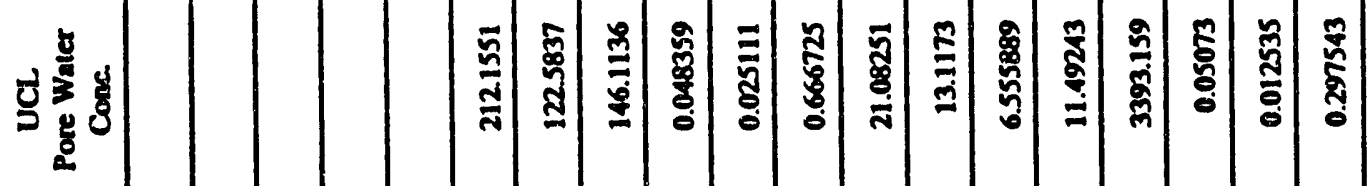

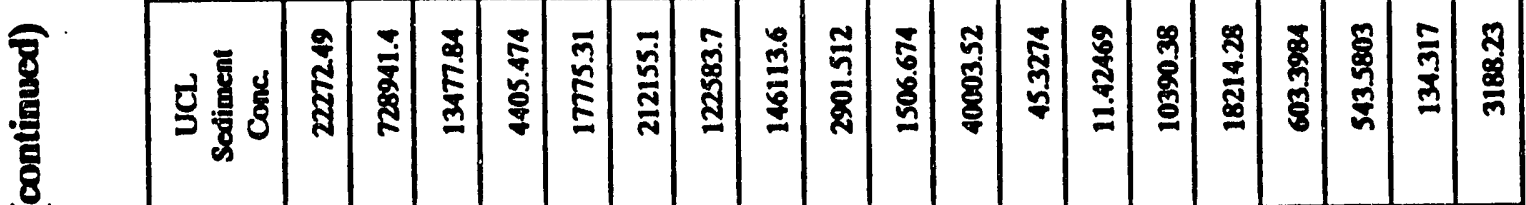

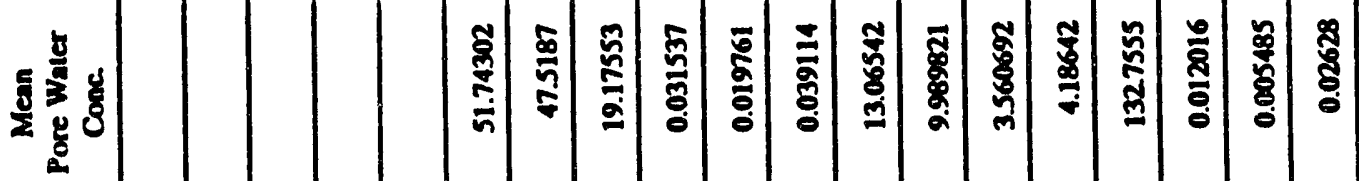

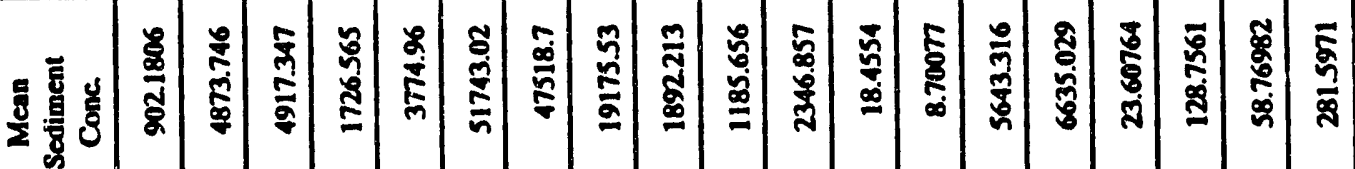

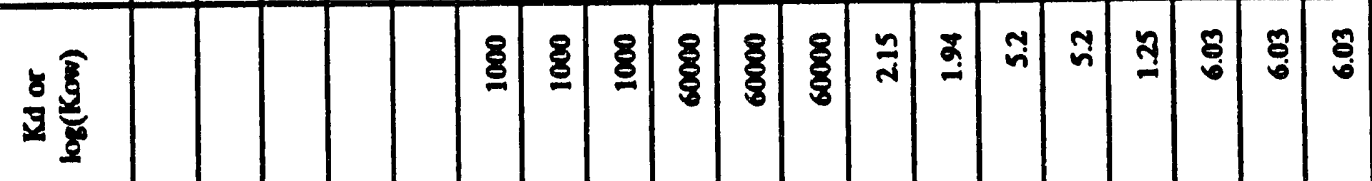

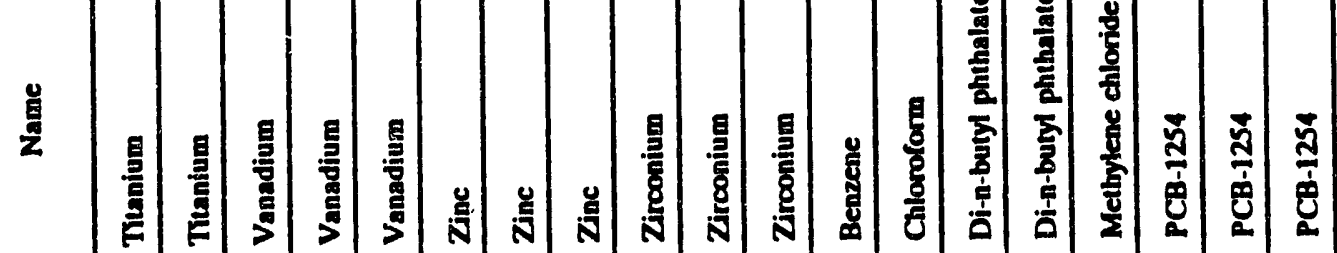

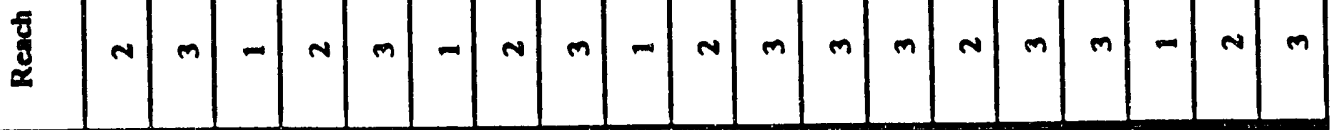


G-60

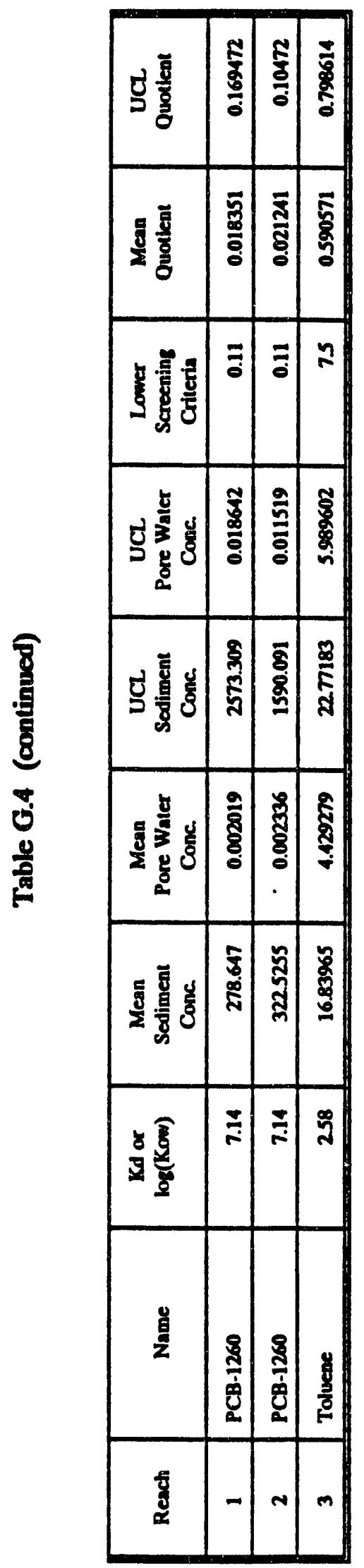




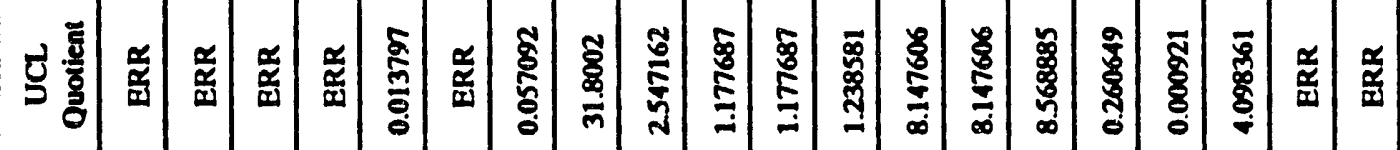

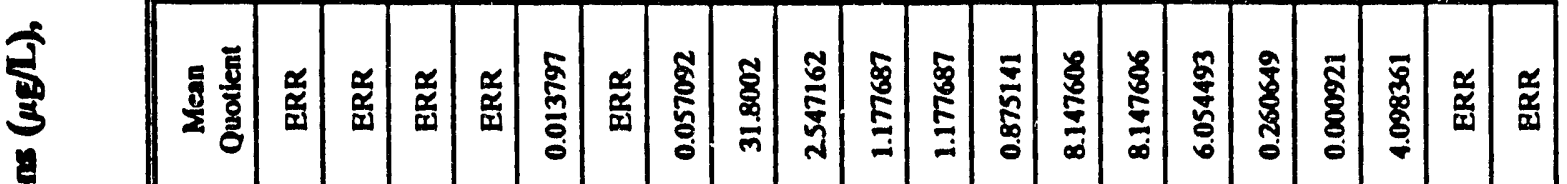

\begin{tabular}{|c|c|c|c|c|c|c|c|c|c|c|c|c|c|c|c|}
\hline 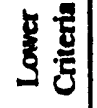 & \& & & $\curvearrowleft$ & $\bar{్}$ & $m$ & ஜి & 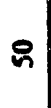 & $\nexists$ & ह & $\stackrel{n}{\circ}$ & 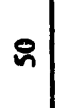 & ని & $\frac{8}{5}$ & $\bar{\vdots}$ & \\
\hline 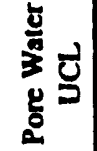 & $\stackrel{\bar{m}}{\bar{m}}$ & 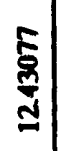 & $\stackrel{\bar{m}}{\stackrel{\bar{m}}{\bar{m}}}$ & 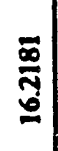 & $\stackrel{\vec{m}}{\vec{m}}$ & 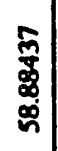 & 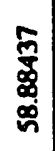 & 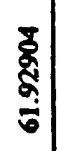 & $\begin{array}{l}\text { 离 } \\
\stackrel{్}{\sigma}\end{array}$ & 耪 & \begin{tabular}{l}
$\frac{m}{\sigma}$ \\
\multirow{\gamma}{*}{}
\end{tabular} & 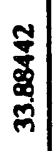 & 令 & ళ్ర్త & 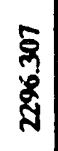 \\
\hline
\end{tabular}

$\frac{8}{8}$

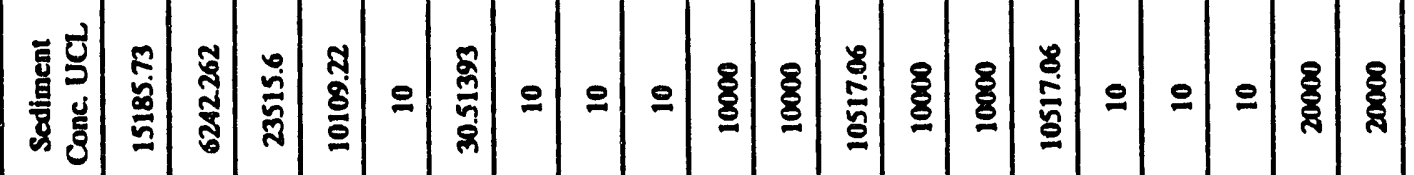

串

\begin{tabular}{|c|c|c|c|c|c|c|c|c|c|c|c|c|c|c|c|c|c|c|c|c|}
\hline 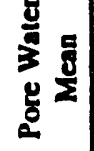 & & & & & 흘 & 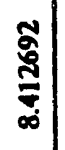 & $\stackrel{\bar{m}}{\bar{m}}$ & \begin{tabular}{l}
$\overline{0}$ \\
\multirow{2}{*}{} \\
0
\end{tabular} & $\stackrel{\overline{\bar{m}}}{\bar{m}}$ & $\begin{array}{l}\overline{\mathbf{p}} \\
\mathbf{8} \\
\stackrel{\infty}{\infty}\end{array}$ & 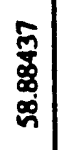 & $\begin{array}{l}\stackrel{0}{q} \\
\hat{\alpha} \\
\hat{p}\end{array}$ & 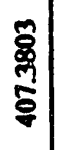 & 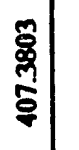 & 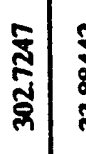 & 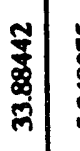 & 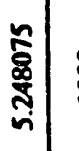 & $\underset{乛}{-8}$ & 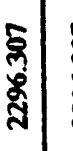 & 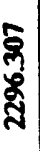 \\
\hline 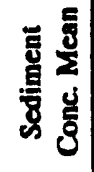 & $\begin{array}{l}\text { ম்ุ } \\
\text { ఫ్ }\end{array}$ & 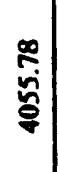 & $\frac{n}{\alpha}$ & 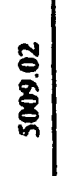 & 이 & 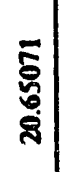 & 9 & 인 & 正 & ళ్రి & 8 & 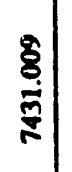 & ళ్రి & ళ్ & 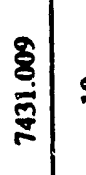 & ㅇ & 은 & $=$ & క్ర్రి & క్ర్సి \\
\hline$\Xi \underline{\underline{c}}$ & & & & & $\stackrel{\infty}{\sim}$ & $\stackrel{\grave{j}}{\mathbf{~}}$ & $\stackrel{\infty}{*}$ & $\stackrel{9}{=}$ & $\stackrel{\infty}{=}$ & $\stackrel{7}{7}$ & ตุ & จุ & i్m & 商 & के & $\mp$ & సి & & בू & స̃ \\
\hline 夏 & 苞 & 昙 & 昱 & 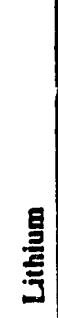 & 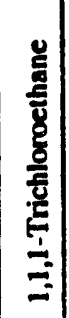 & 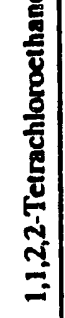 & 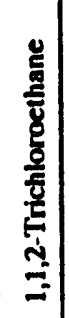 & 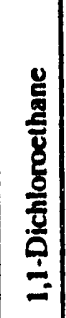 & 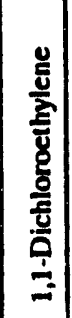 & 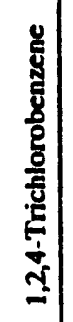 & 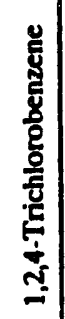 & 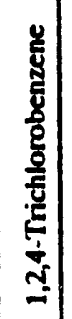 & 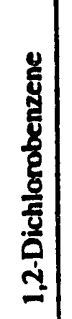 & 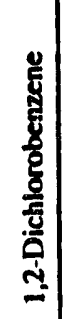 & 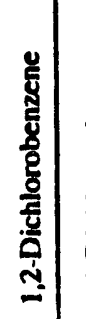 & 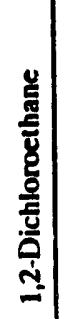 & 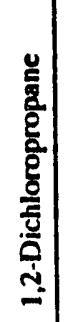 & 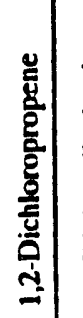 & 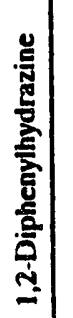 & 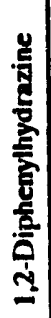 \\
\hline 递 & - & $N$ & m & - & m & $m$ & $m$ & $m$ & $m$ & - & $N$ & $m$ & - & $N$ & $m$ & $m$ & $m$ & $m$ & - & $N$ \\
\hline
\end{tabular}




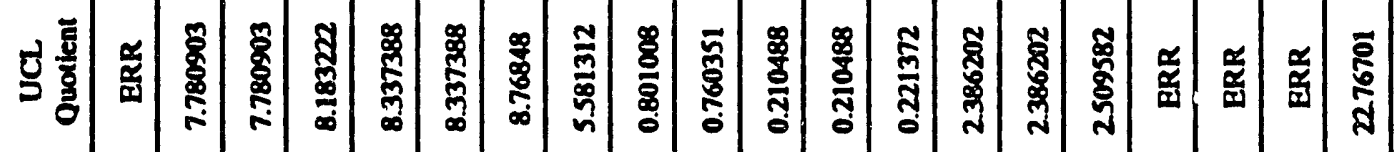

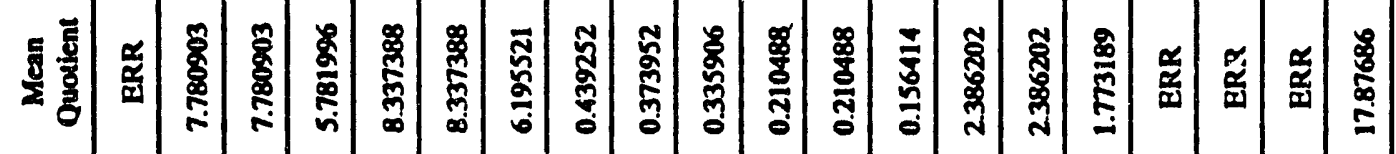

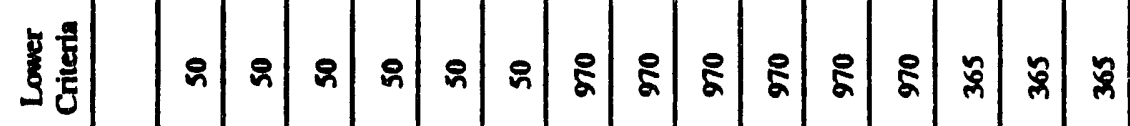

ถ

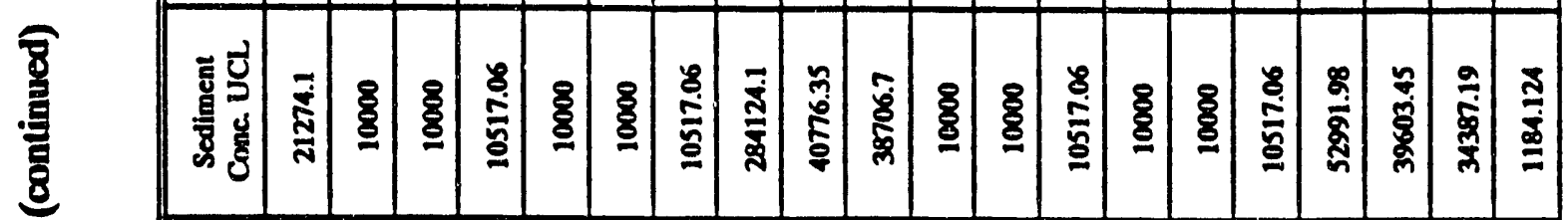

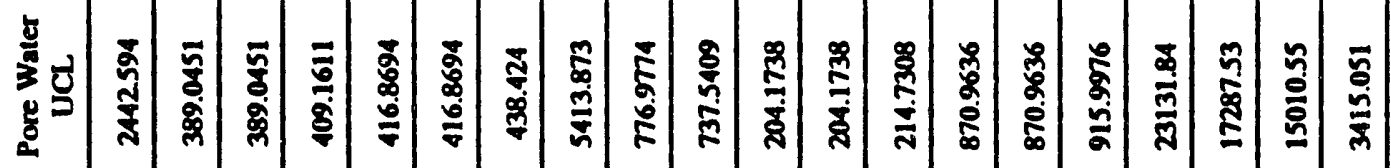

\begin{tabular}{|c|c|c|c|c|c|c|c|c|c|c|c|c|c|c|c|c|c|c|c|c|}
\hline 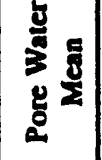 & $\ddot{D}$ & 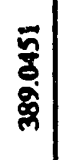 & $\begin{array}{l}\overline{5} \\
\text { ㅎํㅇ }\end{array}$ & $\begin{array}{l}\text { 量 } \\
\text { 尊 }\end{array}$ & $\begin{array}{l}\bar{z} \\
\mathbf{3} \\
6 \\
\bar{\sigma}\end{array}$ & 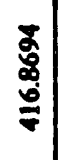 & $\begin{array}{l}\stackrel{5}{\circ} \\
\text { s. }\end{array}$ & 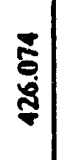 & 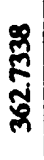 & $\begin{array}{l}\text { డ్ట్ } \\
\text { ఫ్లె }\end{array}$ & 㿣 & 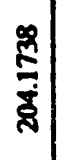 & $\frac{\tilde{\pi}}{\bar{\Xi}}$ & 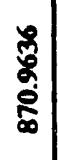 & 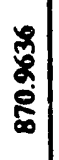 & $\begin{array}{l}\stackrel{2}{\mathbf{n}} \\
\frac{5}{3}\end{array}$ & 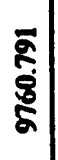 & 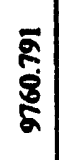 & 杀 & \\
\hline
\end{tabular}

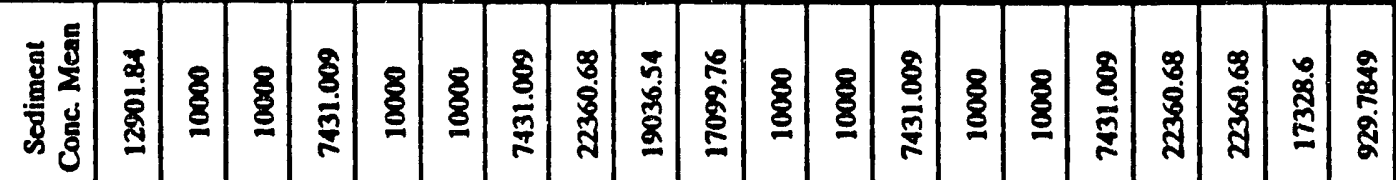

跕

\begin{tabular}{|c|c|c|c|c|c|c|c|c|c|c|c|c|c|c|c|c|c|c|c|c|}
\hline 疍 & 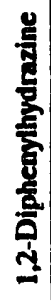 & 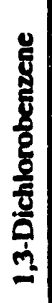 & 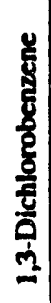 & 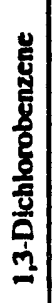 & 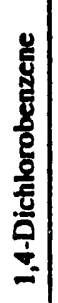 & 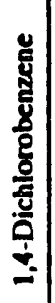 & 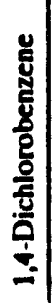 & 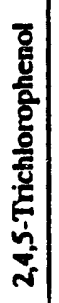 & 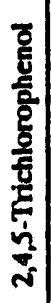 & 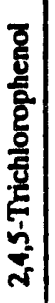 & 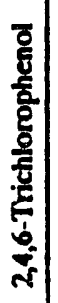 & 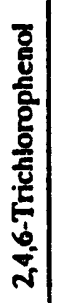 & 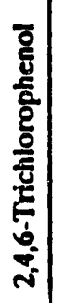 & 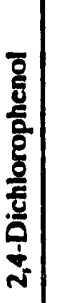 & 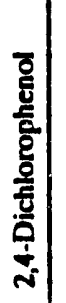 & 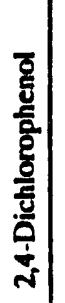 & 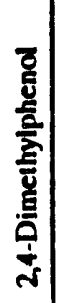 & 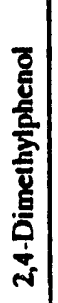 & 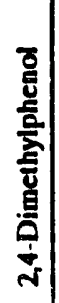 & 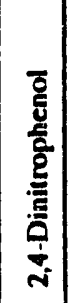 \\
\hline ठే & $m$ & - & $N$ & $m$ & -1 & $N$ & $m$ & -1 & $N$ & $m$ & - & $N$ & $m$ & - & $N$ & $m$ & - & $N$ & $m$ & \\
\hline
\end{tabular}




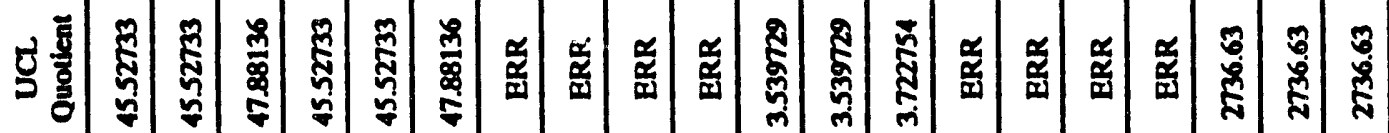

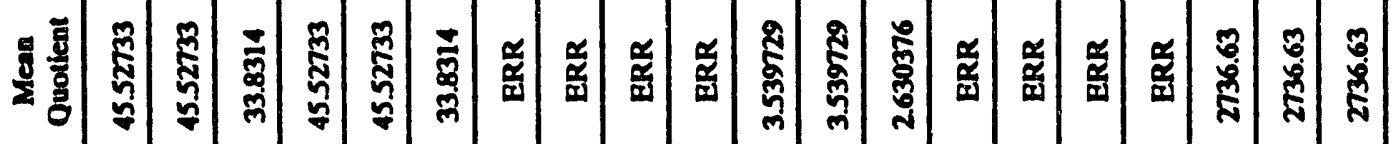

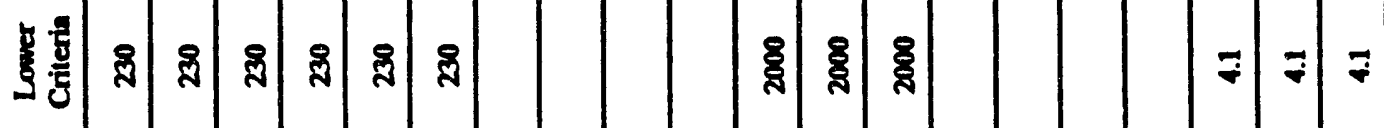

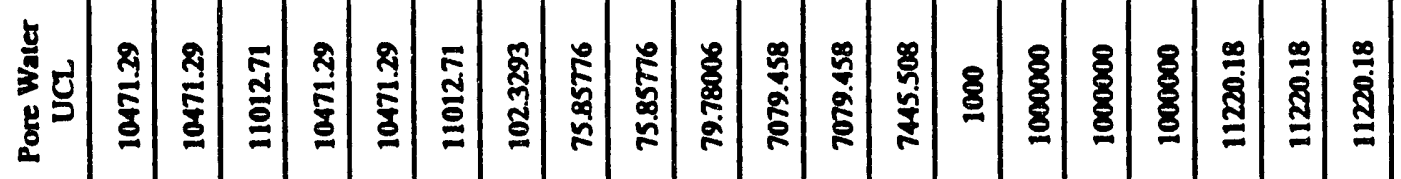

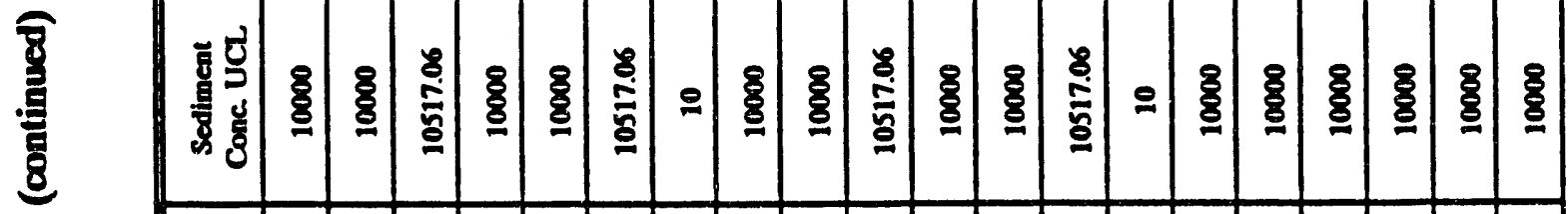

3

总

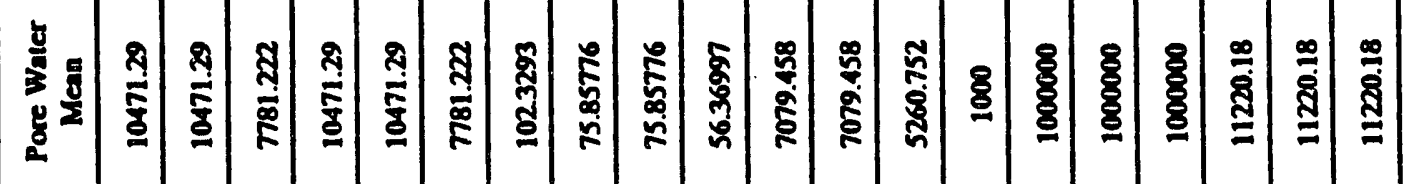

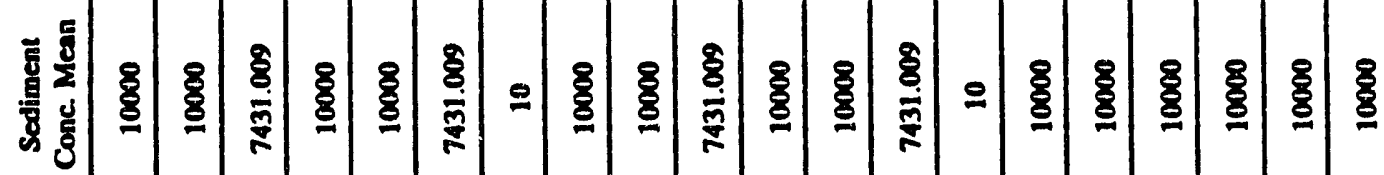

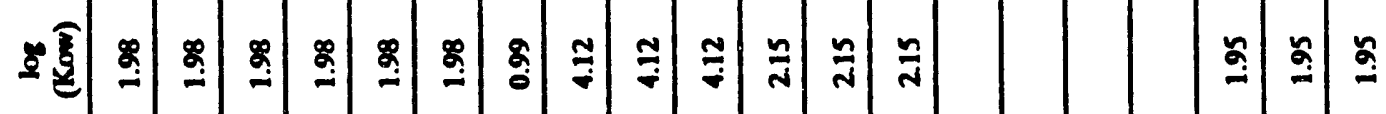

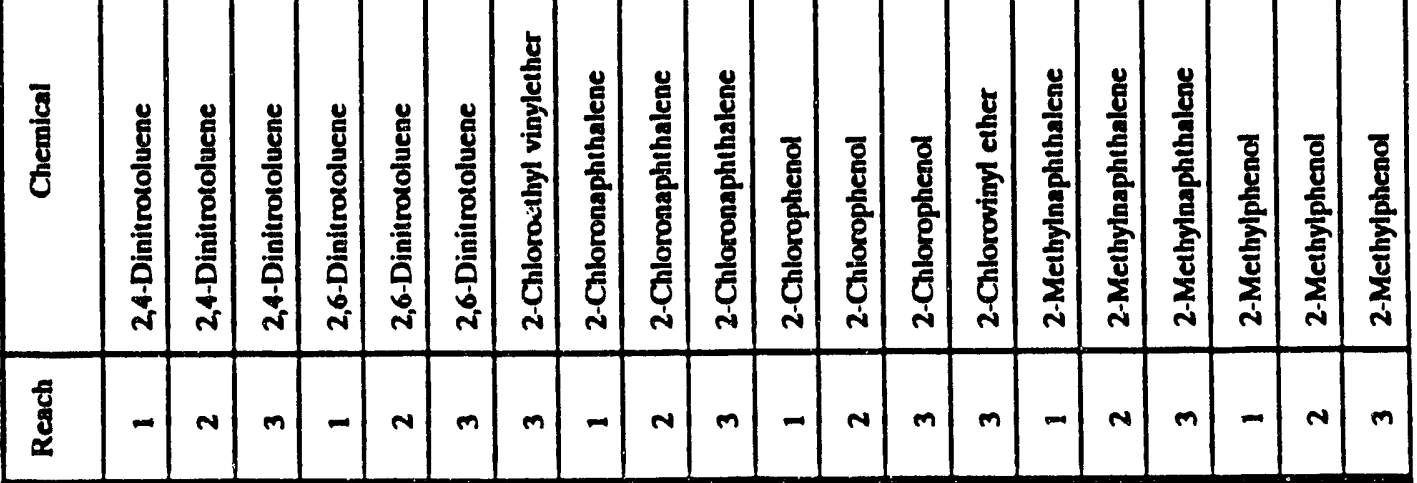




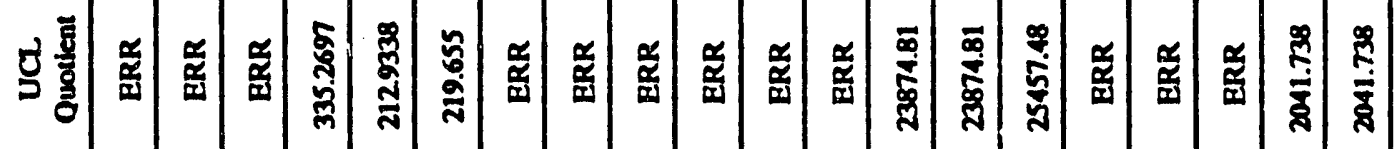

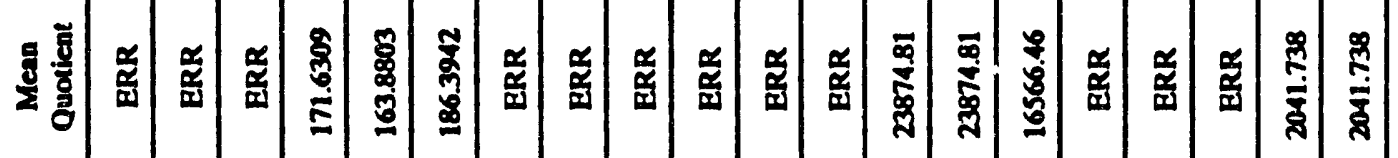

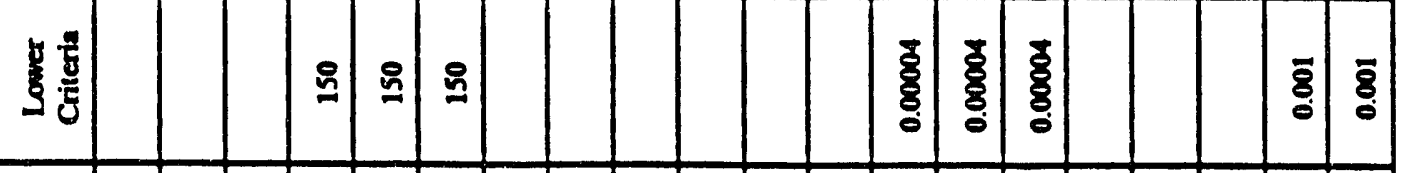

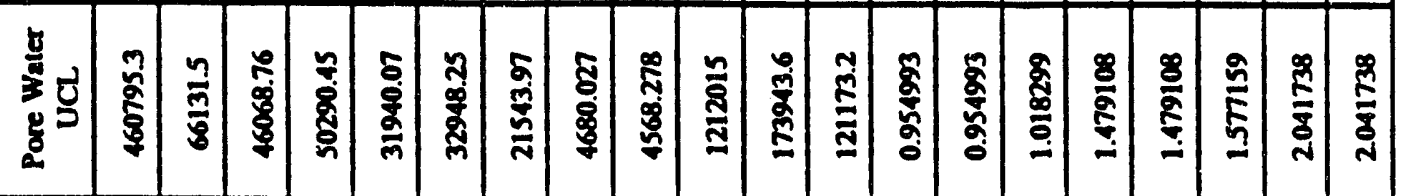

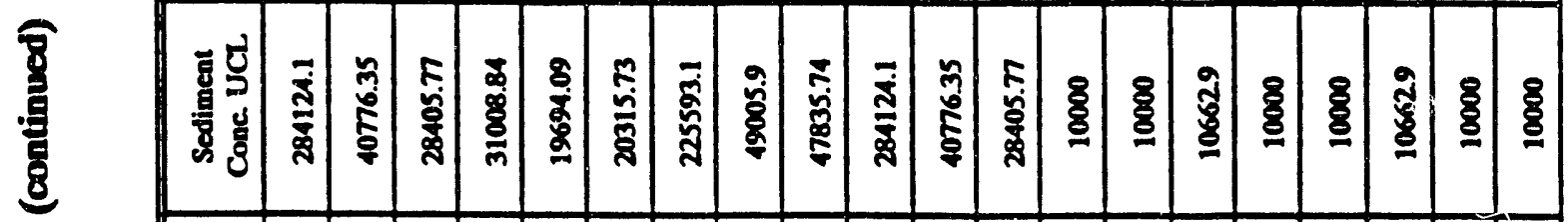

染

\begin{tabular}{|c|c|c|c|c|c|c|c|c|c|c|c|c|c|c|c|c|c|c|c|}
\hline$\frac{8}{2}$ & $\begin{array}{l}0 \\
\vdots \\
\vdots \\
\vdots \\
\vdots\end{array}$ & 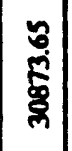 & 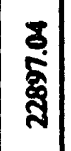 & $\begin{array}{l}0 \\
0 \\
\vdots \\
\vdots \\
\vdots\end{array}$ & 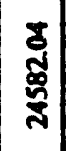 & 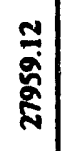 & $\begin{array}{c}\tilde{\alpha} \\
\vdots \\
\vdots \\
\bar{\alpha}\end{array}$ & 号 & 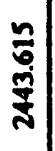 & $\begin{array}{l}8 \\
0 \\
0 \\
\vdots \\
2\end{array}$ & 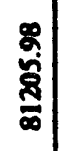 & & & 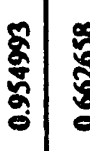 & 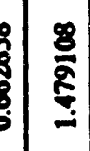 & 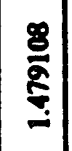 & 宽 & 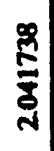 & $\frac{\text { है }}{3}$ \\
\hline 它 & 8 & $\mid \begin{array}{c}5 \\
\overline{5} \\
\vdots \\
\vdots\end{array}$ & 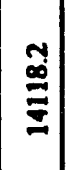 & $\begin{array}{l}\overline{0} \\
\overline{\mathbf{w}} \\
\end{array}$ & 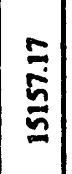 & 足 & 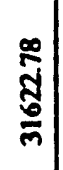 & 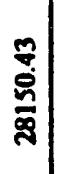 & $\stackrel{1}{5}$ & 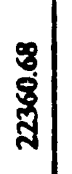 & 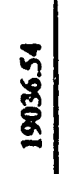 & $\stackrel{\tilde{D}}{\Xi}$ & ક్ & ఫ్రి & 8 & క్రి & 8 & $\underline{8}$ & \\
\hline
\end{tabular}

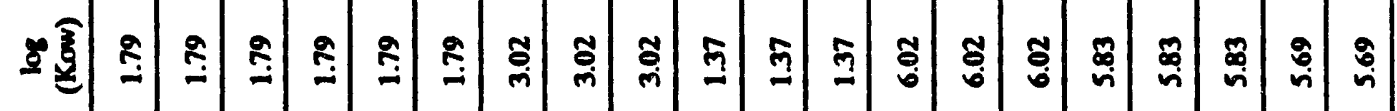

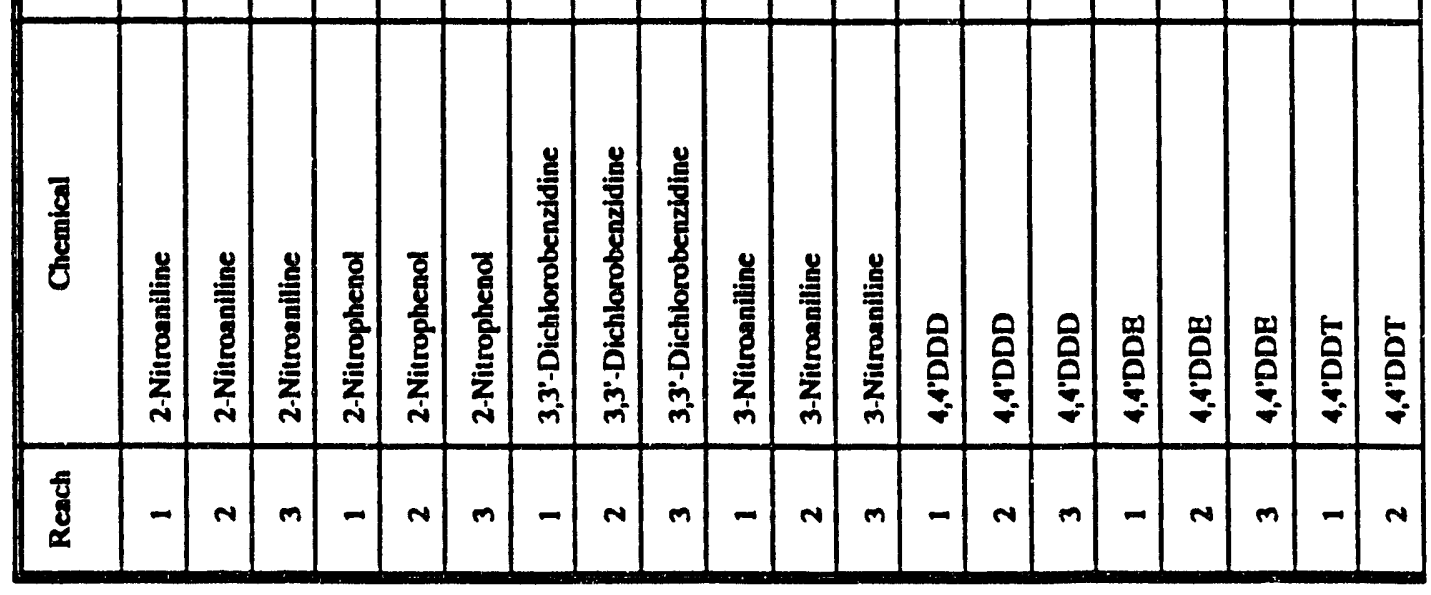


G-65

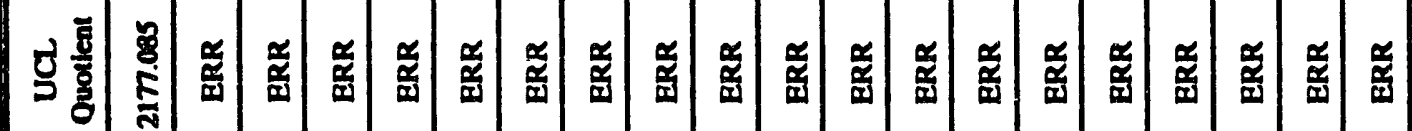

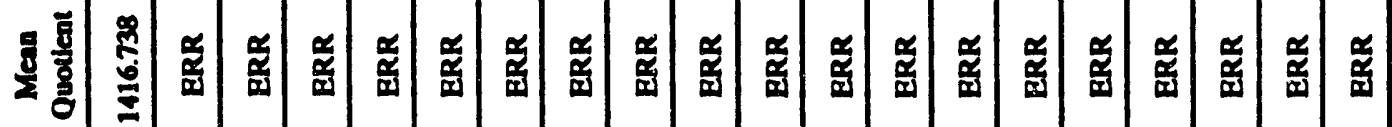

उ.

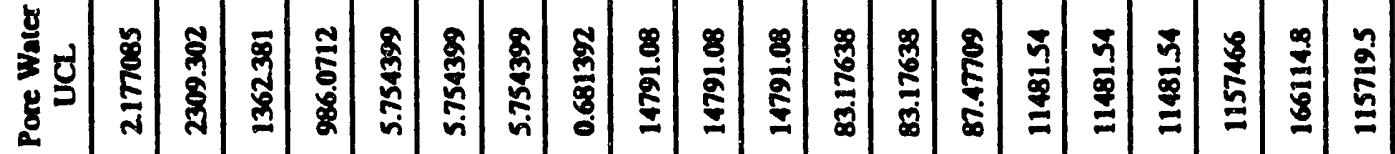

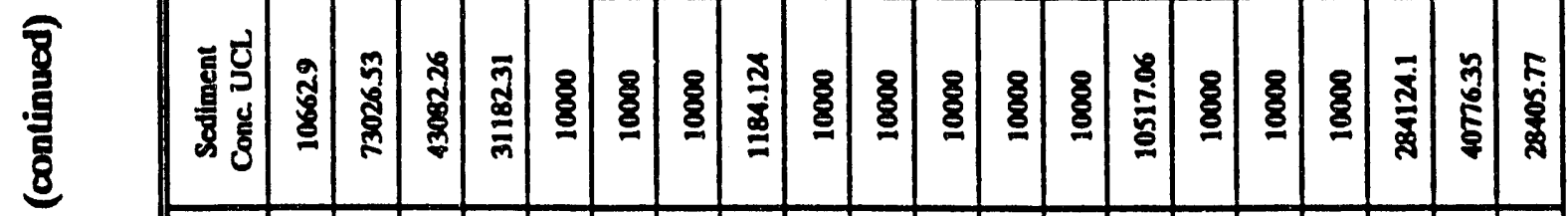

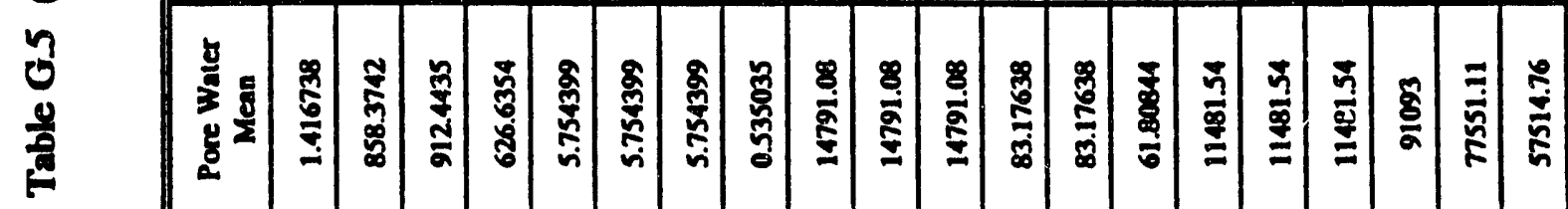

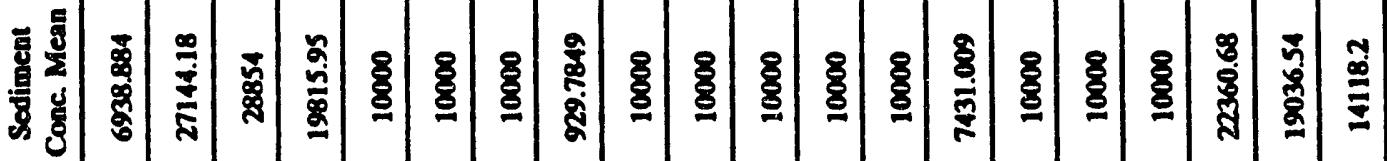

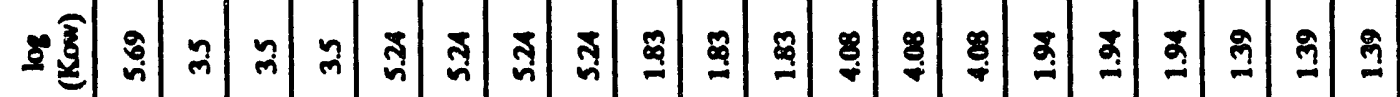

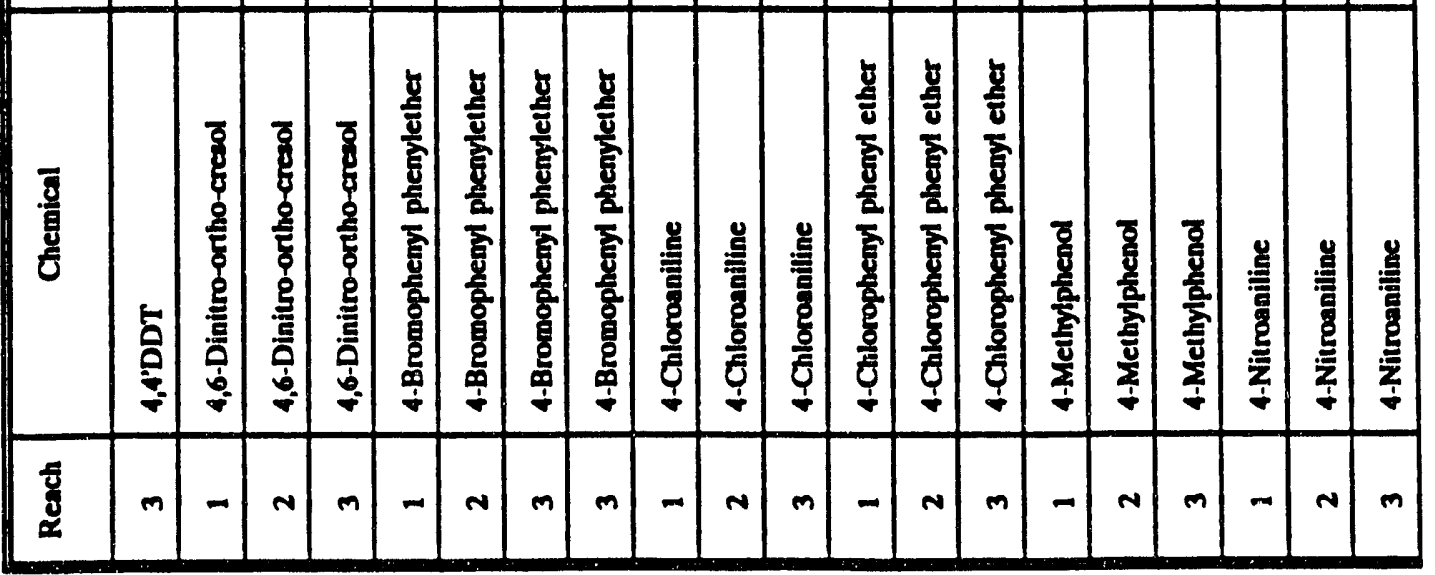




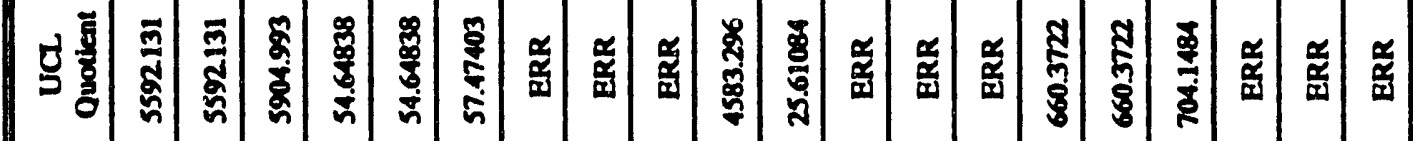

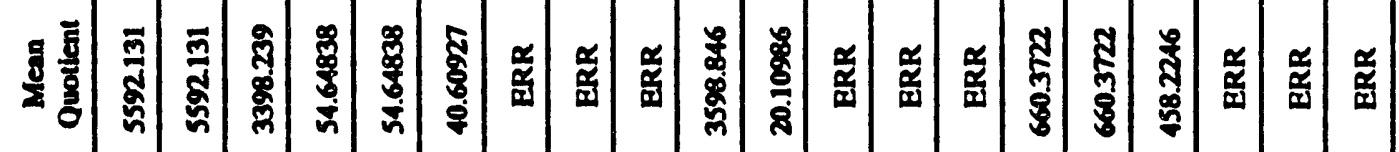

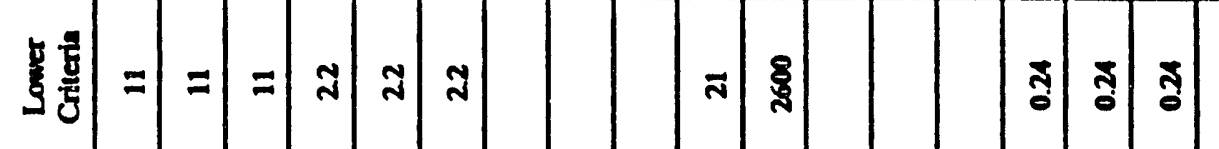

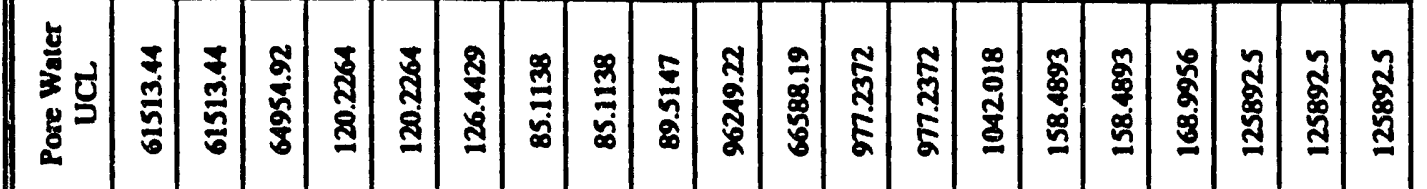

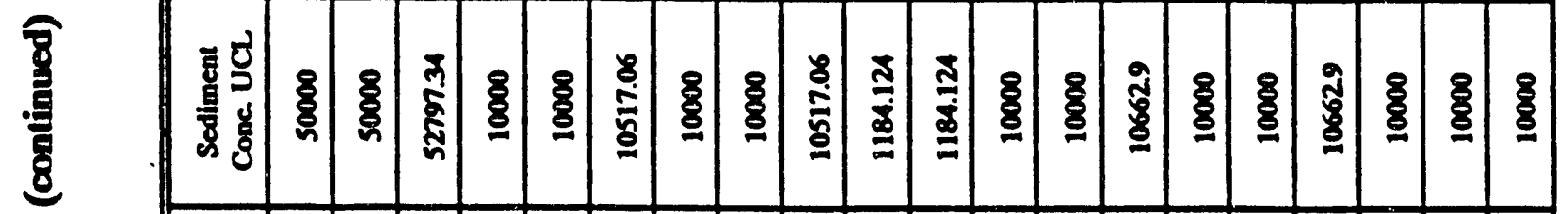

高

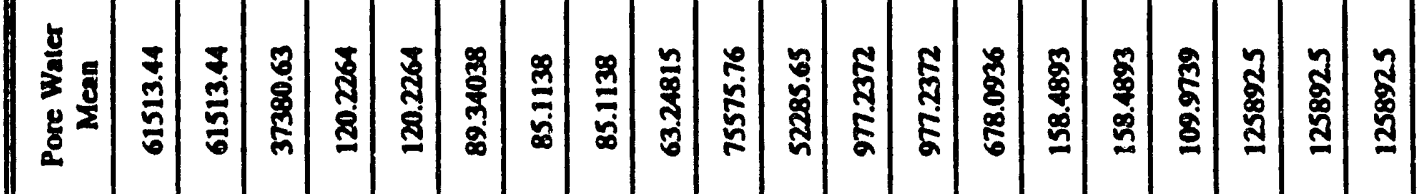

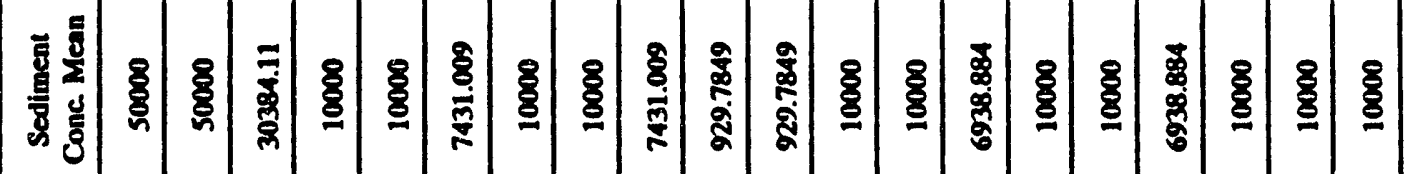

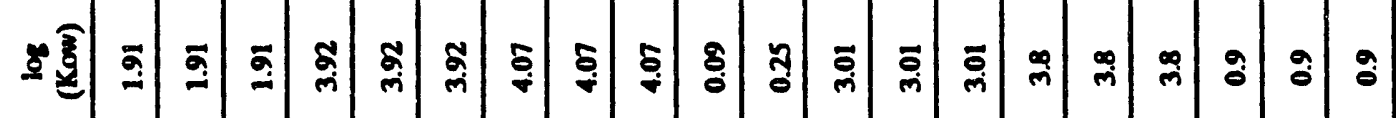

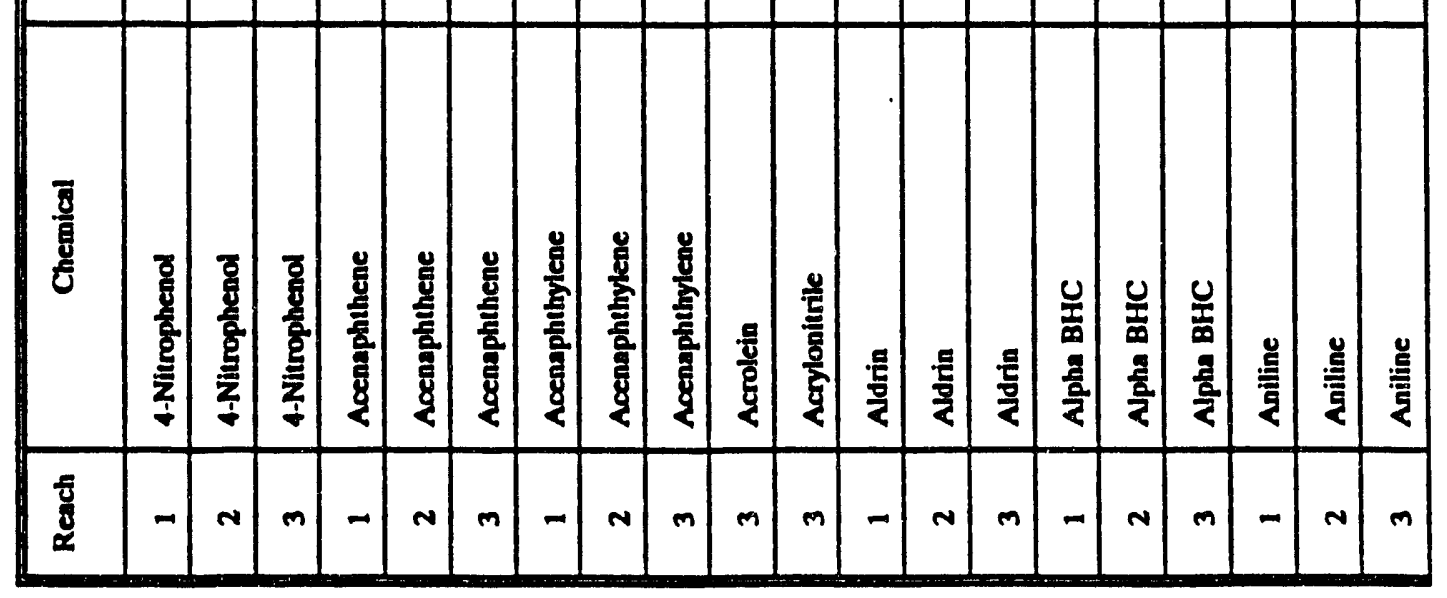




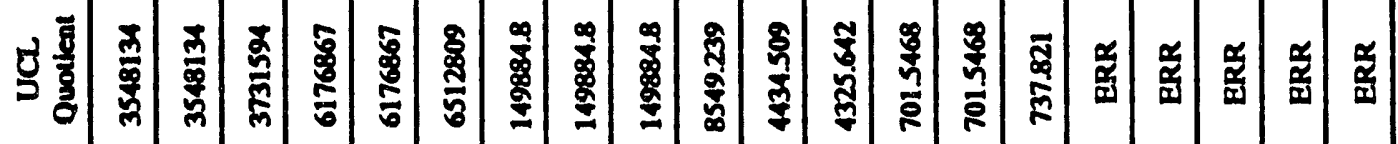

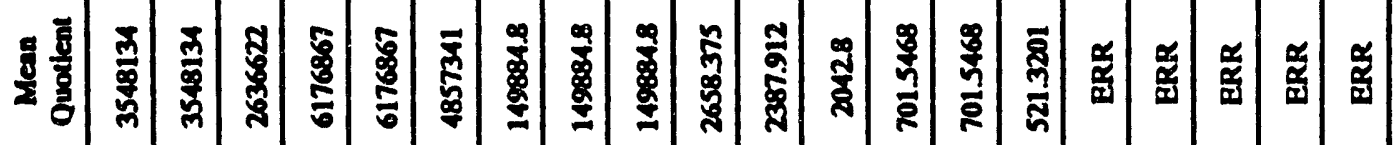
క

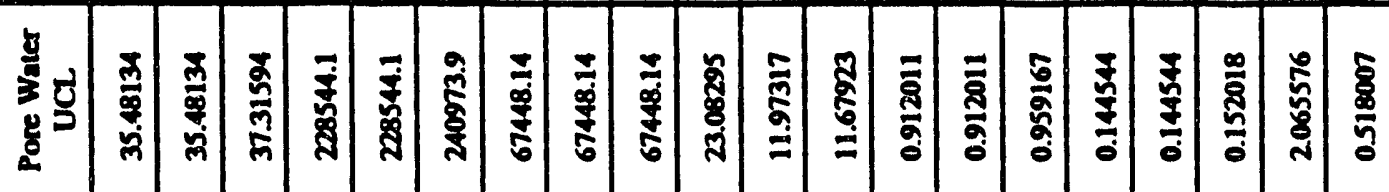

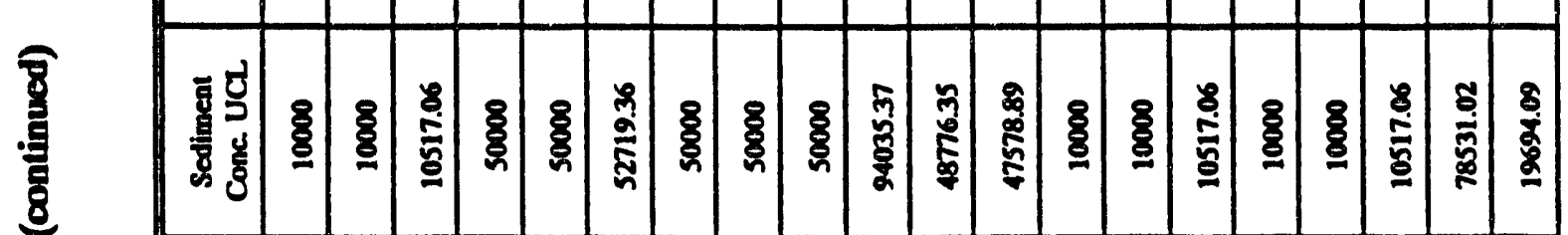
要

\begin{tabular}{|c|c|c|c|c|c|c|c|c|c|c|c|c|c|c|c|c|c|c|c|}
\hline 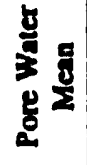 & 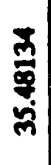 & 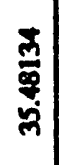 & 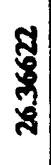 & $\begin{array}{l}\overline{\mathbf{y}} \\
\text { శ్ }\end{array}$ & 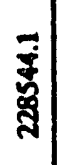 & 号 & $\begin{array}{l}5 \\
\frac{0}{0} \\
5 \\
5\end{array}$ & $\begin{array}{l}5 \\
\frac{0}{0} \\
\frac{1}{5} \\
0\end{array}$ & $\frac{7}{5}$ & 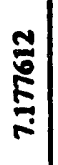 & 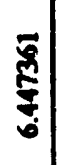 & 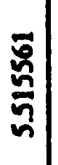 & $\begin{array}{l}\overline{\bar{\alpha}} \\
\bar{\alpha} \\
\end{array}$ & 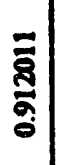 & 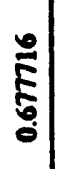 & $\frac{5}{\frac{5}{3}}$ & $\begin{array}{l}\frac{7}{2} \\
\frac{5}{2} \\
\frac{0}{0}\end{array}$ & $\frac{\overline{\mathbf{s}}}{\overline{\mathbf{s}}}$ & گ్ \\
\hline 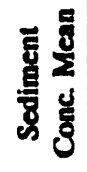 & ర్రి & ళ్రి & $\frac{8}{\frac{8}{2}}$ & ళ్ర్లి & ళ్ర్లి & $\begin{array}{l}\vec{\Phi} \\
\stackrel{0}{\bar{n}} \\
\text { pen }\end{array}$ & ళ్ర్టి & శ్ర్లి & ళ్రి & $\begin{array}{l}\frac{\infty}{0} \\
\frac{0}{5} \\
\frac{3}{2}\end{array}$ & 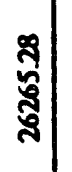 & $\begin{array}{l}\overline{\text { जे }} \\
\text { aे̀े }\end{array}$ & $\begin{array}{l}8 \\
8 \\
8\end{array}$ & ళ్రి & 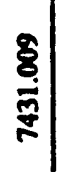 & ఫ్ళ్రి & ళ్ర్రి & $\frac{\text { శ్ }}{\text { m. }}$ & $\stackrel{\bar{N}}{\bar{I}}$ \\
\hline & 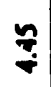 & 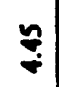 & $\approx$ & స్ & ฐ & 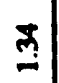 & $\stackrel{5}{-\infty}$ & $\Phi$ & 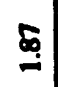 & $\begin{array}{c}\overrightarrow{0} \\
\dot{0}\end{array}$ & 㐫 & $\begin{array}{c}\vec{b} \\
\dot{0}\end{array}$ & $\begin{array}{l}\delta \\
0\end{array}$ & $\underset{0}{\tilde{b}}$ & $\overbrace{0}$ & 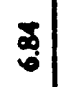 & $\underset{\sqcup}{\mathbb{5}}$ & 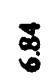 & ڤ్ \\
\hline
\end{tabular}

睍

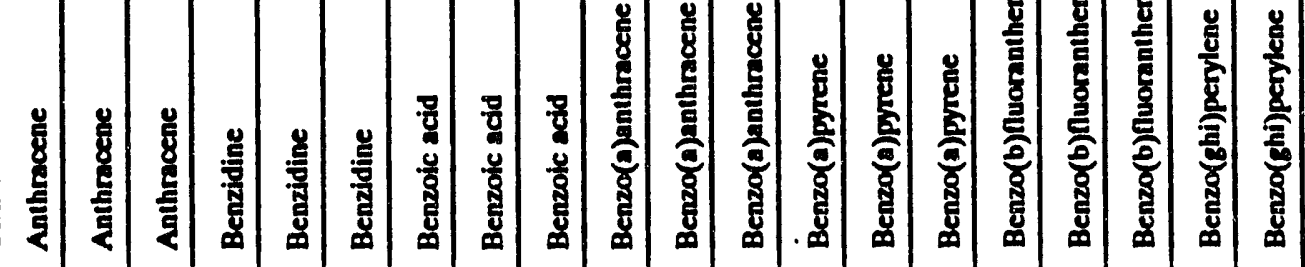

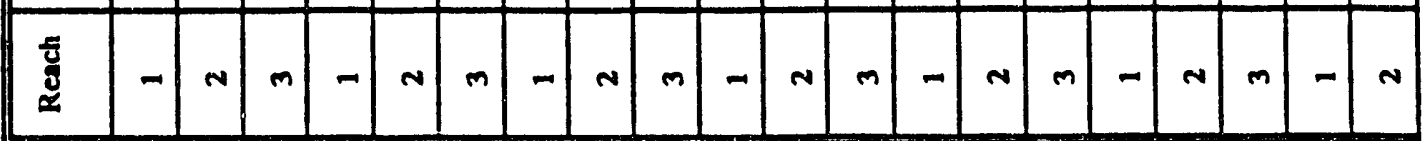




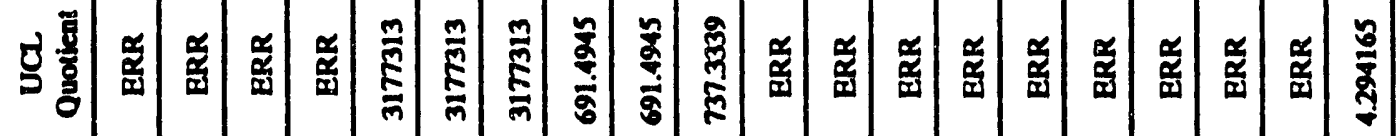

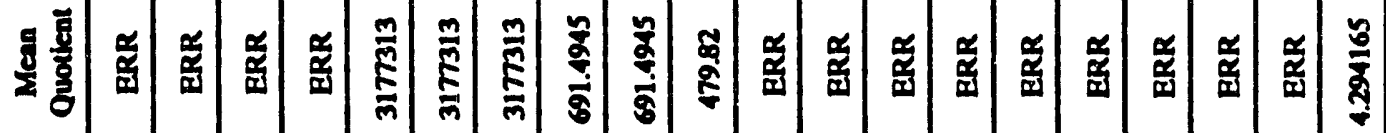

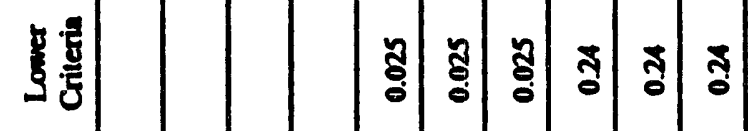

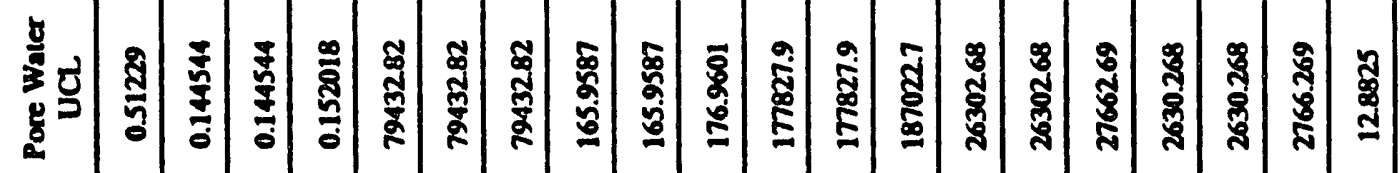

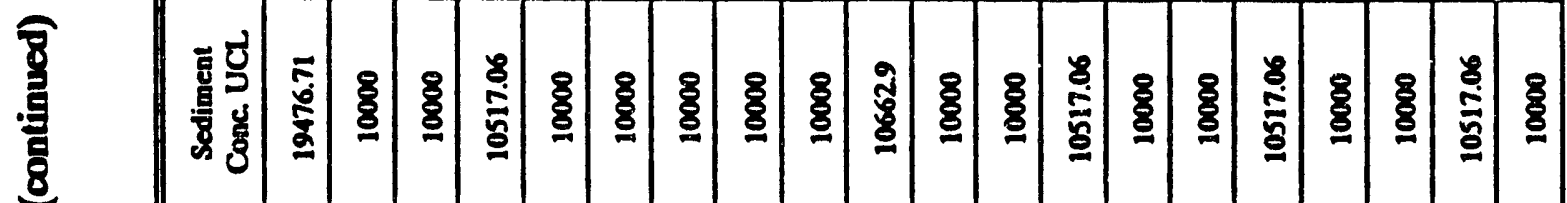

资

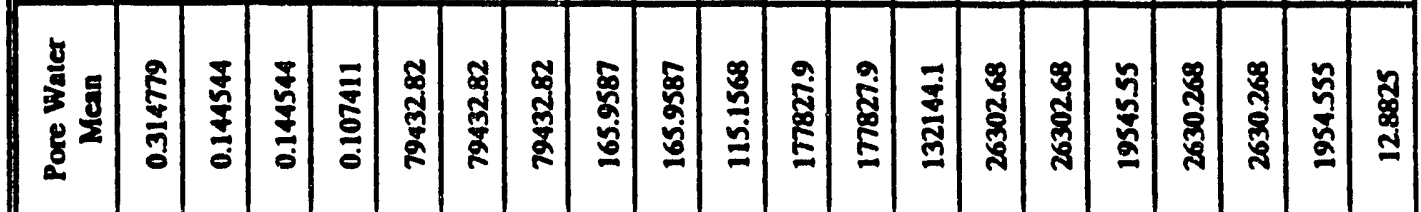

兽哥

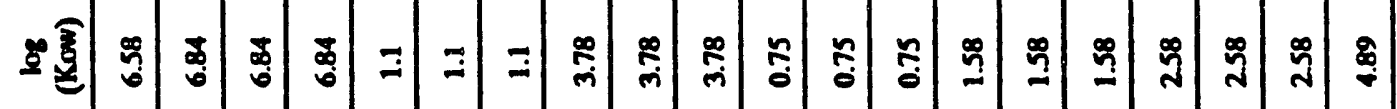

\begin{tabular}{|c|c|c|c|c|c|c|c|c|c|c|c|c|c|c|c|}
\hline$\overline{8}$ & 迨 & & & & & 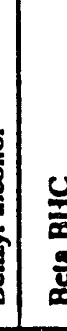 & $\mid$\begin{tabular}{|}
0 \\
$\frac{1}{\mathbf{w}}$ \\
$\frac{\mathbf{x}}{2}$
\end{tabular} & 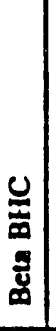 & & 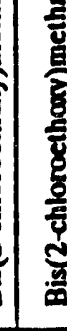 & $\frac{\frac{m}{m}}{m}$ & & & 害 & \\
\hline घू & $m$ & - & $m$ & - & & & N & & & c & . & & & - & \\
\hline
\end{tabular}




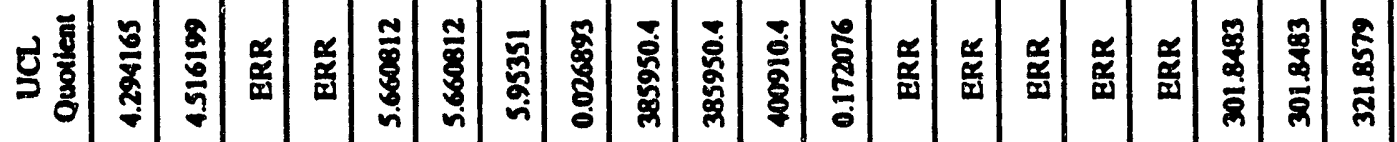

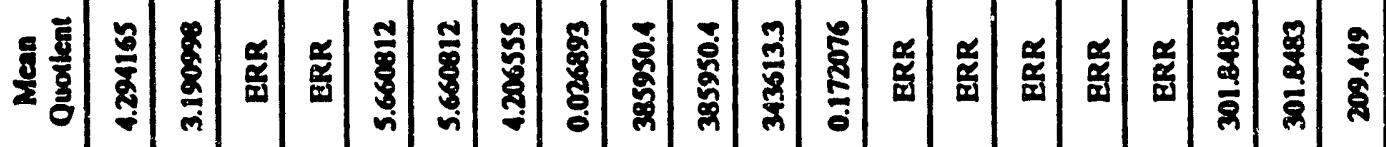

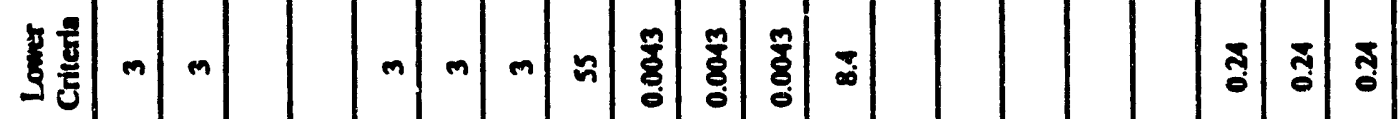

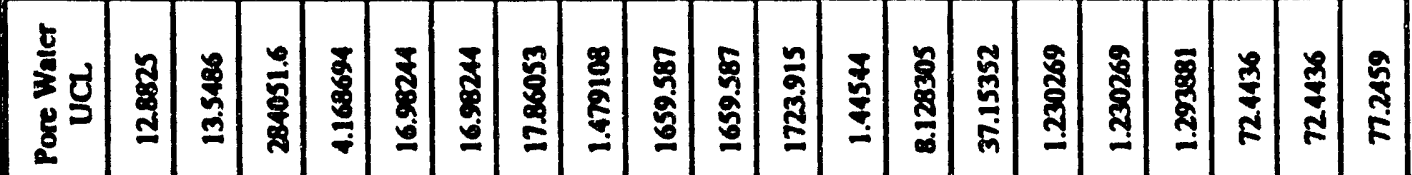

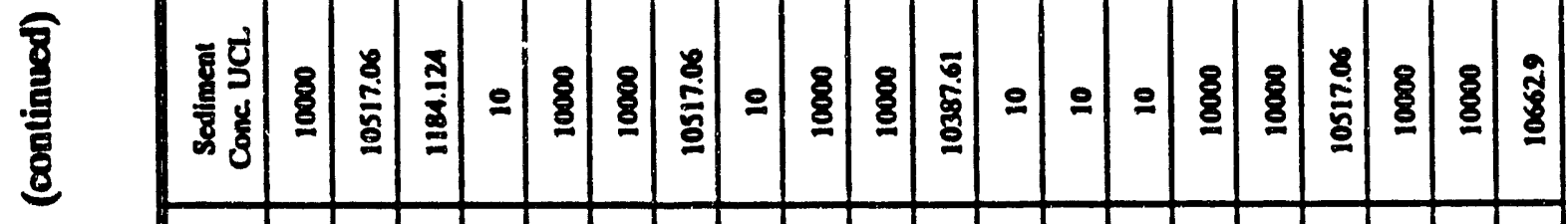

$\frac{1}{2}$

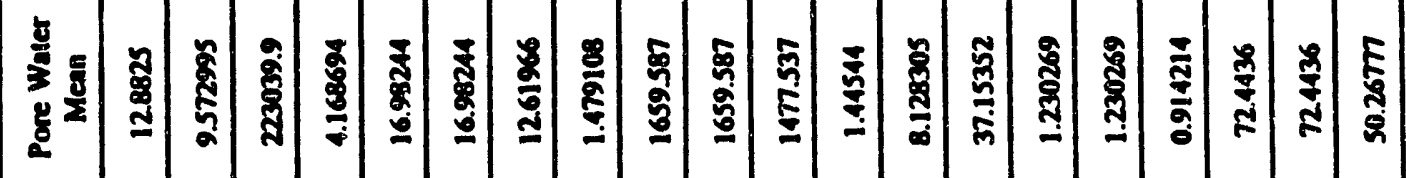

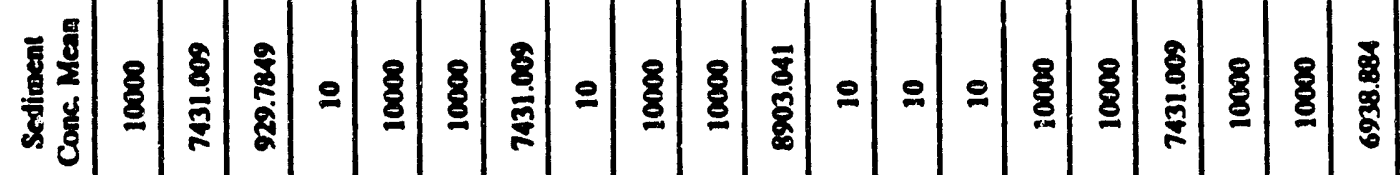

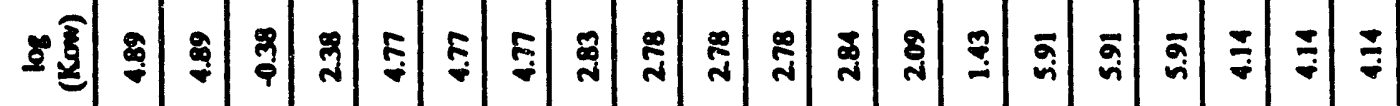

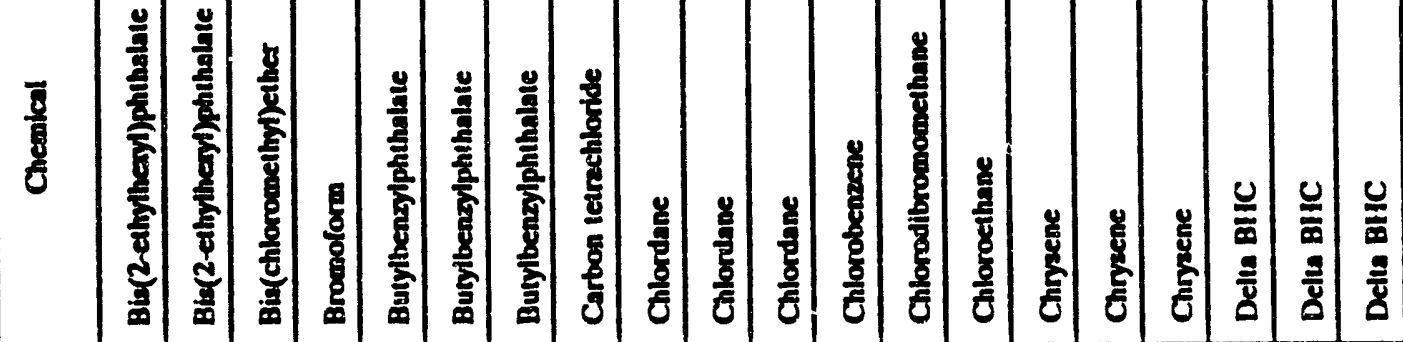

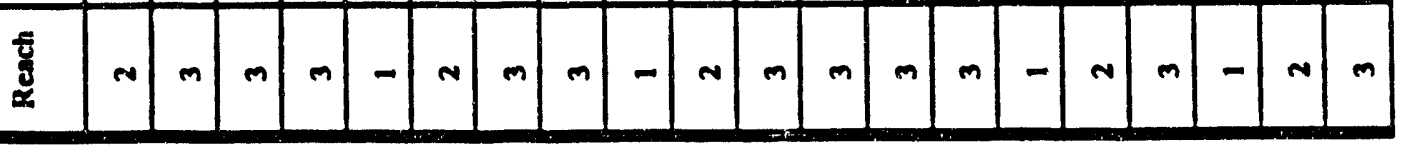




\begin{tabular}{|c|c|c|c|c|c|c|c|c|c|c|c|c|c|c|c|c|c|c|c|c|}
\hline త్ & $\begin{array}{l}\text { \% } \\
\text { హ్ } \\
\tilde{n}\end{array}$ & $\begin{array}{l}\text { \% } \\
\text { \%ू. } \\
\stackrel{n}{n}\end{array}$ & 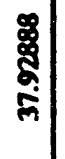 & 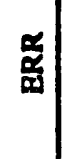 & 䍃 & 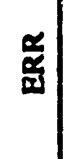 & 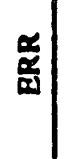 & 㟢 & 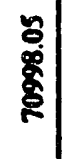 & 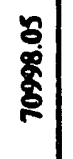 & 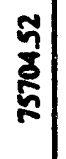 & 离 & $\begin{array}{l}\text { క్ } \\
\text { ప్ }\end{array}$ & 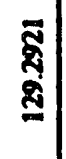 & $\begin{array}{l}\text { క్ } \\
\text { ఫ్ } \\
\text { స్ }\end{array}$ & $\begin{array}{l}\text { క్ } \\
\text { สุ }\end{array}$ & $\begin{array}{l}\text { ڤ్ } \\
\text { ڤ్ }\end{array}$ & $\stackrel{\infty}{\frac{\pi}{\sigma}}$ & 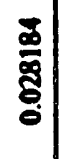 & $\begin{array}{l}\bar{\Phi} \\
\text { 兽 }\end{array}$ \\
\hline 造案 & $\begin{array}{l}\text { \% } \\
\text { \% } \\
\tilde{n}\end{array}$ & 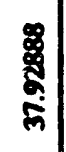 & $\begin{array}{l}\text { : } \\
\text { sू. } \\
\hat{\kappa}\end{array}$ & 响 & 总 & 慈 & 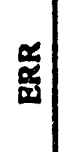 & 总 & 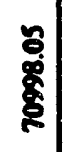 & 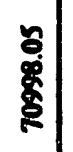 & 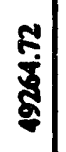 & $\begin{array}{l}\text { క్ } \\
\text { ప్ }\end{array}$ & 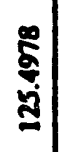 & $\underset{\Xi}{\Xi}$ & $\begin{array}{l}\text { ज్ } \\
\text { ఫ్ }\end{array}$ & $\begin{array}{l}\text { క్ } \\
\text { హ్ }\end{array}$ & 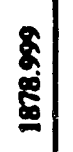 & $\stackrel{\infty}{\frac{\infty}{5}}$ & 竒 & $\begin{array}{l}\bar{\Phi} \\
\overline{8} \\
\\
0\end{array}$ \\
\hline 3 를 & $N$ & $\boldsymbol{N}$ & $N$ & & & & & & $\frac{2}{8}$ & $\frac{9}{8}$ & 잉 & $\pi$ & 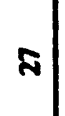 & $\mathrm{F}$ & $m$ & $m$ & $m$ & $m$ & $\Xi$ & 8 \\
\hline 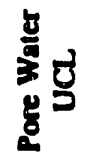 & 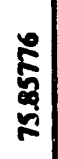 & 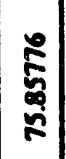 & 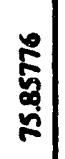 & 䜌 & 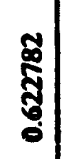 & 高 & 产 & ్ָ & 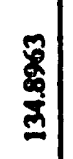 & 参 & 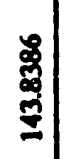 & 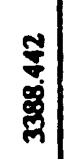 & 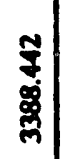 & 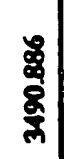 & 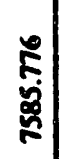 & 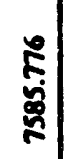 & 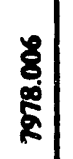 & $\begin{array}{l}\text { ב్ } \\
\text { ป్ }\end{array}$ & 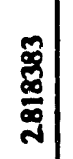 & 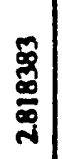 \\
\hline $\begin{array}{l}\overline{8} \\
\text { 兽 } \\
8 \\
8\end{array}$ & క్రి & ్ㅗㅇ & 8 & 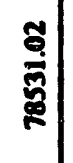 & $\begin{array}{l}\mathbf{8} \\
\overline{\mathbf{\alpha}} \\
\mathrm{\alpha}\end{array}$ & 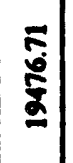 & 인 & 이 & 8 & 8 & 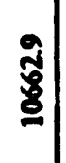 & 8 & ళ్ & 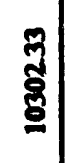 & ఫ్ & 8 & 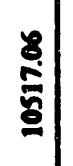 & 8 & 8 & ళ్ \\
\hline $\begin{array}{l}\frac{y}{9} \\
\frac{0}{8} \\
\frac{g}{2}\end{array}$ & 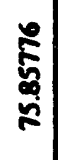 & 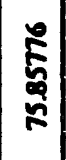 & 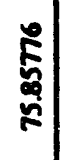 & $\frac{\mathbf{Z}}{\mathbf{\Sigma}}$ & $\frac{N}{\tilde{n}}$ & 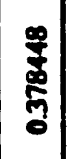 & 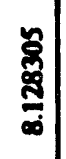 & $\begin{array}{c}\overline{0} \\
\bar{\sigma} \\
\bar{b}\end{array}$ & 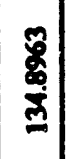 & 产 & 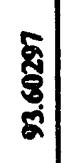 & 声 & 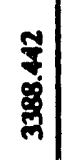 & 弯 & 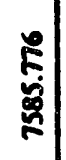 & 官 & $\begin{array}{l}\delta \\
\delta \\
\vdots \\
\vdots \\
\vdots\end{array}$ & ב్ & 芯 & 兽 \\
\hline 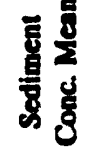 & 8 & 8 & ళ్రి & $\bar{\Sigma}$ & $\begin{array}{l}\overline{5} \\
\frac{5}{n}\end{array}$ & $\begin{array}{l}\overline{5} \\
\frac{\alpha}{2} \\
=\end{array}$ & 인 & 음 & 8 & ళ్రి & $\begin{array}{l}\mathbf{8} \\
\text { 总 } \\
\text { : }\end{array}$ & 8 & 8 & 疍 & 8 & ళ్రి & $\frac{\xi}{\bar{m}}$ & 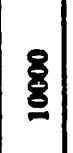 & 8 & 8 \\
\hline$\notin \widehat{s}$ & 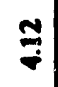 & $\dddot{7}$ & 7 & ที & ทे & 0 & స్ & $\frac{1}{N}$ & వ్ & $\underset{m}{\Phi}$ & 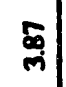 & 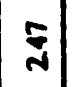 & $\bar{N}$ & 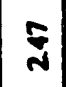 & సี & 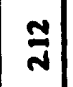 & $\frac{\pi}{N}$ & $\stackrel{9}{\nabla}$ & స్ & ఓૂે \\
\hline $\begin{array}{l}\overline{8} \\
\text { 尊 }\end{array}$ & $\begin{array}{l}\text { हू. } \\
\frac{2}{2} \\
\frac{8}{6} \\
\frac{8}{6}\end{array}$ & 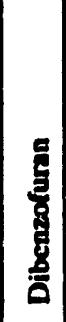 & 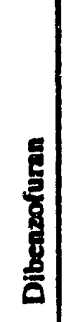 & 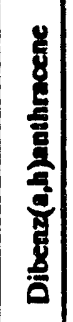 & 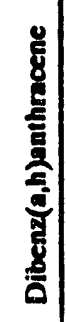 & 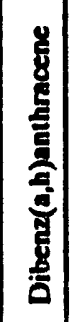 & 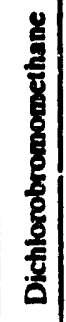 & 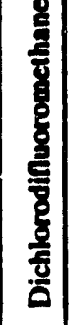 & 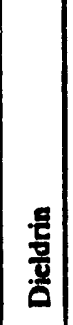 & 超 & $\begin{array}{l}\frac{\pi}{5} \\
\frac{7}{0} \\
\frac{0}{0}\end{array}$ & 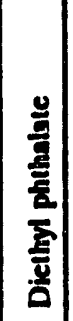 & 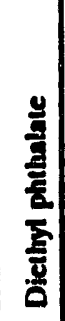 & 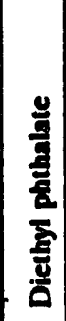 & 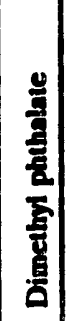 & 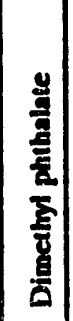 & 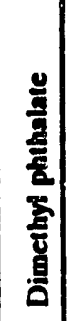 & 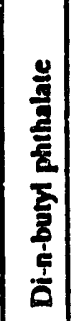 & 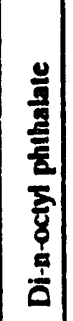 & 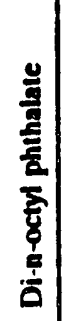 \\
\hline$\underset{\mathbb{\alpha}}{\mathbb{Z}}$ & - & $N$ & $m$ & - & $\mathbf{N}$ & $m$ & $m$ & $\mathrm{~m}$ & - & $N$ & $m$ & -1 & $N$ & $m$ & -1 & $N$ & $\mathrm{~m}$ & - & -1 & $N$ \\
\hline
\end{tabular}




\begin{tabular}{|c|c|c|c|c|c|c|c|c|c|c|c|c|c|c|c|c|c|c|c|c|}
\hline 잉 & 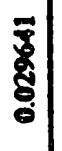 & ఫ్ & | & 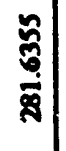 & 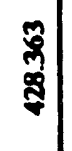 & 象 & 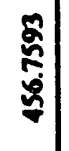 & 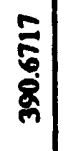 & $\begin{array}{l}: \\
\vdots \\
\vdots \\
\vdots\end{array}$ & 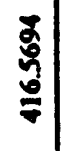 & ్ㅗㅀ & $\frac{2}{8}$ & 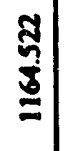 & $\frac{\nexists}{8}$ & ב্ & 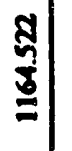 & 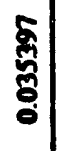 & 京 & 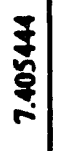 & 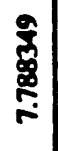 \\
\hline 倦 & 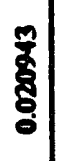 & స్ & 高 & 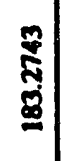 & 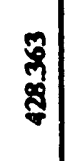 & 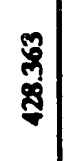 & 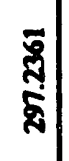 & 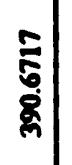 & 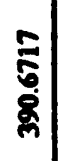 & 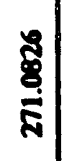 & ำ & ำ & 离 & בุ & ఫ్ & ลุ. & 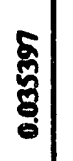 & 享 & $\begin{array}{l}\mathbf{y} \\
\vdots \\
⿱ 亠 䒑 \\
\end{array}$ & 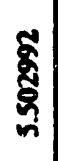 \\
\hline 3 然 & 8 & ڤั & ฉุ & ஜ̆ & ஜั & ڤั & ถั? & ஸั & ஸ్రి & ڤั & ్ㅗㅇ & ఫ్ & ఫ్ & ఫ్ & ఫ్ర్ & 웅 & ฉి & $\Xi$ & $\Xi$ & $\Xi$ \\
\hline 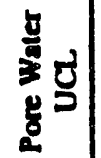 & $\begin{array}{l}\overline{7} \\
\bar{్}\end{array}$ & 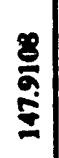 & $\begin{array}{l}\frac{8}{2} \\
a \\
\vdots \\
\vdots\end{array}$ & 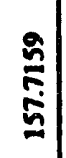 & $\begin{array}{l}\text { : } \\
\text { aे } \\
\text { సิ }\end{array}$ & $\begin{array}{l}\text { कू } \\
\text { ă }\end{array}$ & 产 & 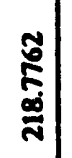 & 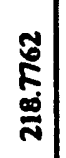 & है & 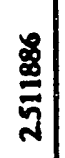 & $\frac{ \pm}{\overline{7}}$ & क్ & $\stackrel{8}{\bar{z}}$ & $\frac{8}{\overline{7}}$ & 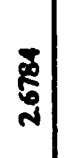 & 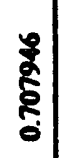 & 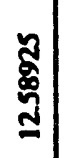 & $\begin{array}{l}\text { ఫ్ } \\
\bar{y} \\
\text { }\end{array}$ & $\begin{array}{l}\frac{a}{0} \\
\text { à } \\
\text { m. }\end{array}$ \\
\hline 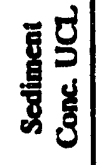 & & 8 & 8 & కి & 8 & ఫ్రి & స్త్రి & 8 & 总 & ఫे & ళ్రి & 8 & $\begin{array}{l}\text { స్ } \\
\text { క్ }\end{array}$ & 8 & ర్ర్త & ఫิ & o & ళ్ర్తి & 8 & \\
\hline 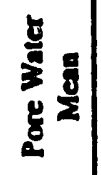 & 帝 & $\begin{array}{l}8 \\
\frac{8}{9} \\
\vdots\end{array}$ & $\begin{array}{l}\frac{8}{2} \\
\frac{2}{2} \\
\vdots\end{array}$ & $\begin{array}{l}\mathbf{6} \\
\mathbf{5} \\
\mathbf{\delta}\end{array}$ & 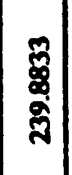 & 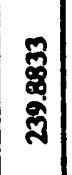 & 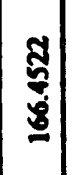 & 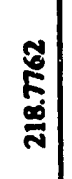 & $\begin{array}{l}\stackrel{\sigma}{\sigma} \\
\stackrel{\infty}{*}\end{array}$ & 宮 & $\stackrel{2}{\overline{3}}$ & $\stackrel{8}{\bar{\Xi}}$ & $\underset{5}{2}$ & $\stackrel{\Xi}{\bar{\Xi}}$ & $\stackrel{ \pm}{\overline{7}}$ & $\frac{8}{8}$ & 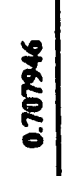 & 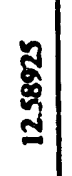 & 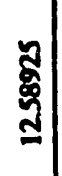 & 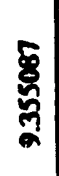 \\
\hline 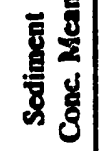 & : & ళ్ర్రి & ళ్రిత్రి & $\begin{array}{l}\mathbf{5} \\
\mathbf{8} \\
\mathbf{8} \\
\mathbf{5}\end{array}$ & ళ్రి & ఫ్ర్రి & $\begin{array}{l}\mathbf{8} \\
8 \\
8 \\
8\end{array}$ & $\begin{array}{l}\text { ఫ్ర్రి } \\
\end{array}$ & ళ్ర్తి & $\begin{array}{l}\mathbf{8} \\
\mathbf{8} \\
\text { हैं }\end{array}$ & ళ్రి & \&్ర్రి & $\begin{array}{l}\$ \\
\$ \\
8 \\
8\end{array}$ & ళ్రి & $\mid \begin{array}{l}8 \\
\\
\end{array}$ & 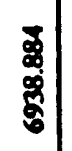 & 음 & 8 & ళ్రి & క్ \\
\hline 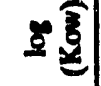 & $\tilde{n}$ & ळ & $\underset{m}{\nexists}$ & $\underset{m}{\mathscr{m}}$ & $\tilde{\mathrm{n}}$ & 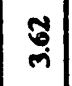 & : & 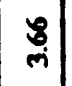 & 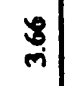 & 8 & $\stackrel{\bullet}{\circ}$ & $\stackrel{\bullet}{\sim}$ & $\stackrel{\bullet}{\sim}$ & نே & $\stackrel{\circ}{n}$ & $\ddot{\dot{m}}$ & $\frac{n}{m}$ & 9 & 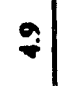 & 9 \\
\hline 㿣 & 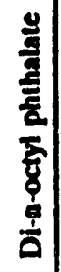 & $\begin{array}{l}\overline{\mathrm{g}} \\
\overline{\mathrm{z}} \\
\mathrm{z}\end{array}$ & 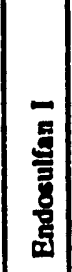 & 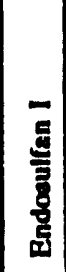 & 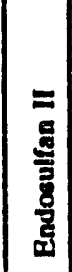 & 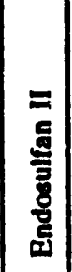 & 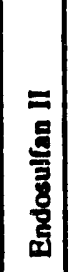 & 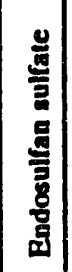 & 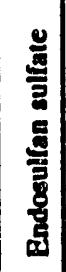 & 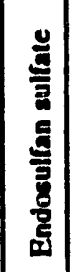 & 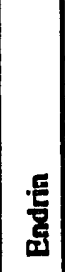 & 를 & 를 & 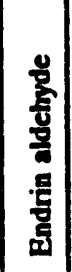 & 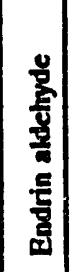 & 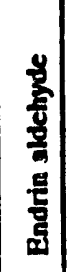 & 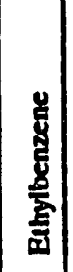 & 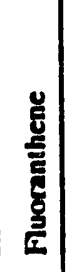 & 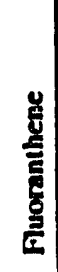 & 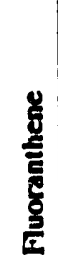 \\
\hline हू & $m$ & - & $N$ & $m$ & - & $N$ & $m$ & -1 & $N$ & $m$ & - & $N$ & m & - & $N$ & m & $m$ & - & $N$ & $m$ \\
\hline
\end{tabular}




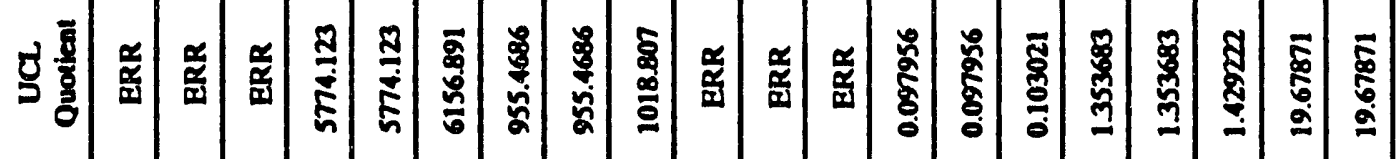

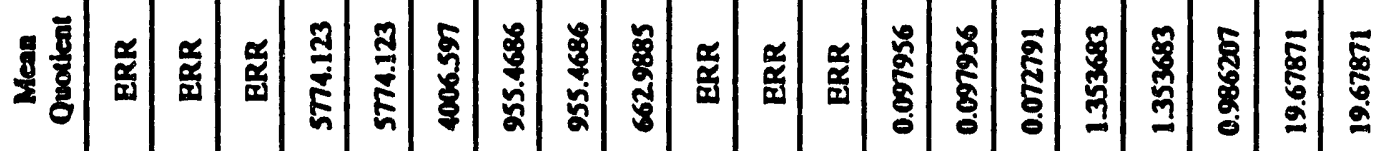

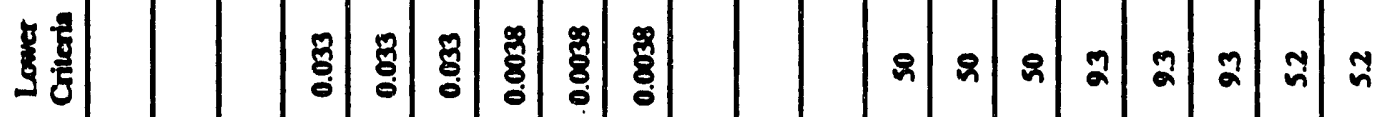

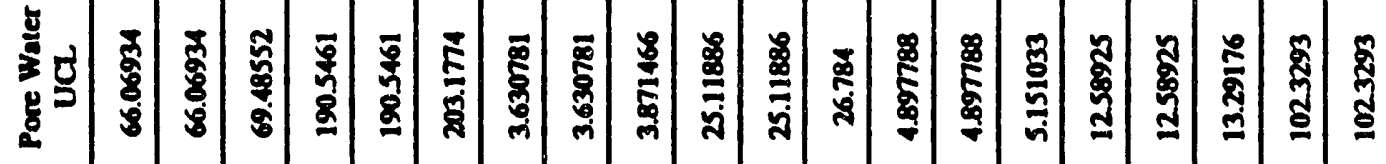

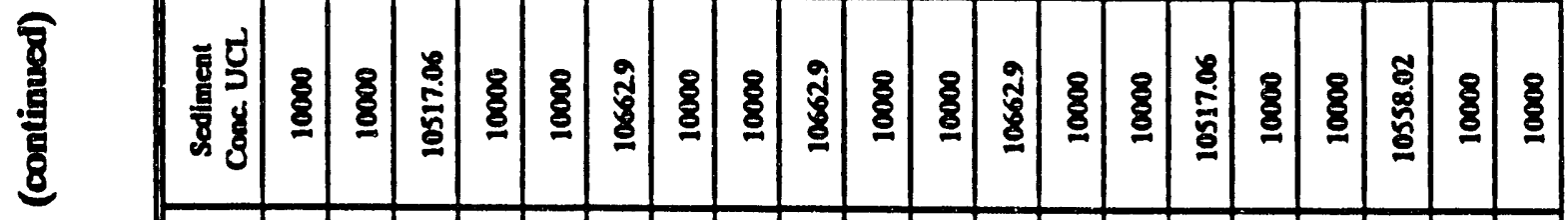

on

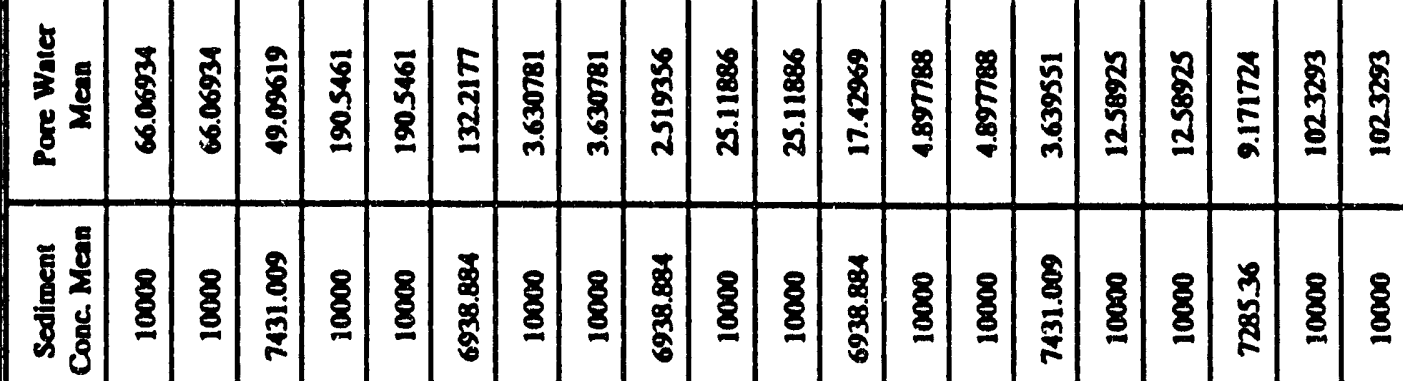

๘气

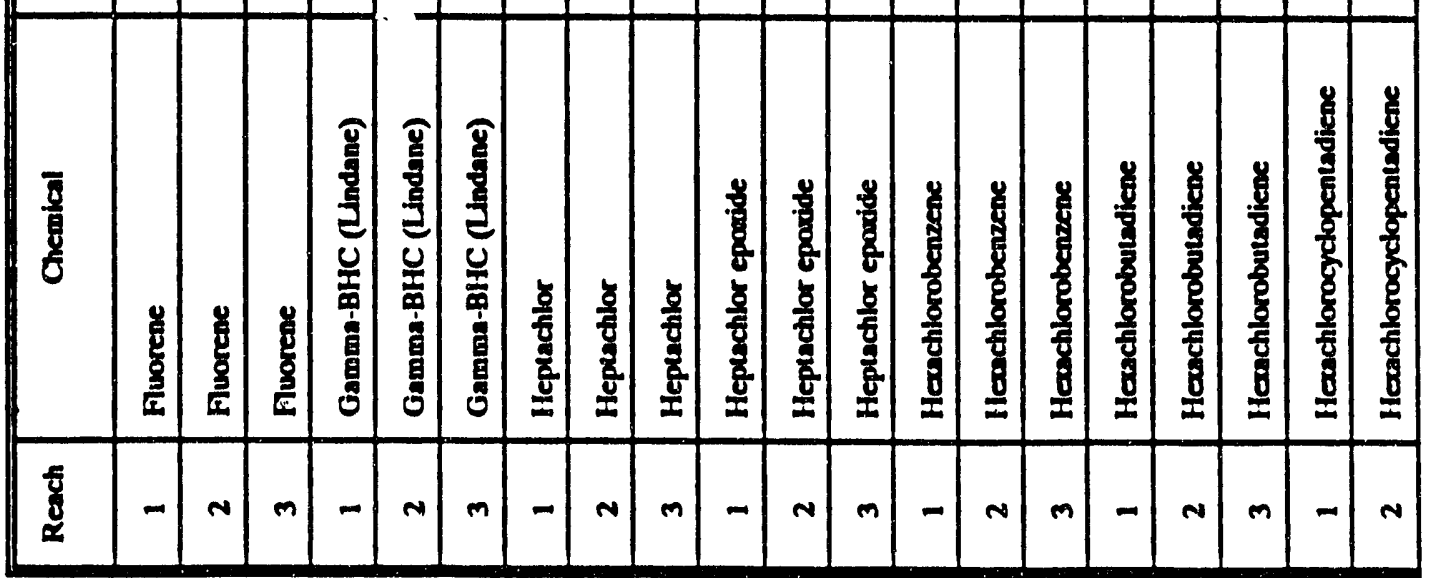




\begin{tabular}{|c|c|c|c|c|c|c|c|c|c|c|c|c|c|c|c|c|c|c|c|c|}
\hline 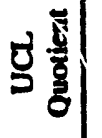 & 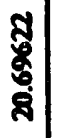 & 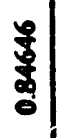 & 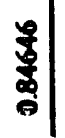 & 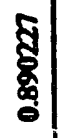 & 尌 & 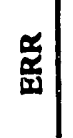 & $\begin{array}{l}\frac{x}{\alpha} \\
\frac{\alpha}{a} \\
\end{array}$ & 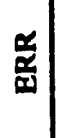 & 美 & $\begin{array}{l}\frac{\alpha}{z} \\
\frac{\mathbf{a}}{\mathbf{g}}\end{array}$ & 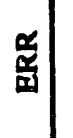 & 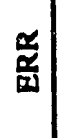 & \begin{tabular}{l}
$\$$ \\
\multirow{2}{*}{} \\
$\vdots$
\end{tabular} & \begin{tabular}{l} 
\$ \\
\multirow{2}{*}{} \\
$\vdots$
\end{tabular} & 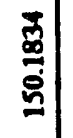 & 紊 & $\begin{array}{l}\frac{x}{x} \\
\frac{x}{x}\end{array}$ & 畜 & 紊 & $\begin{array}{l}\underset{z}{\alpha} \\
\frac{\alpha}{w}\end{array}$ \\
\hline 흘 & 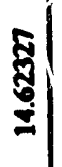 & 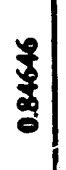 & $\begin{array}{l}0 \\
\text { 章 } \\
0\end{array}$ & | & 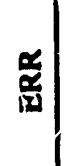 & $\begin{array}{l}\mathbf{u} \\
\stackrel{\alpha}{\alpha}\end{array}$ & \begin{tabular}{l|}
$\frac{\alpha}{\mathbf{a}}$ \\
面
\end{tabular} & 茎 & 蛹 & 畐 & 罳 & $\frac{\underline{z}}{\underline{a}}$ & \begin{tabular}{l} 
总 \\
\multirow{2}{*}{} \\
$\vdots$
\end{tabular} & $\begin{array}{l}\text { 总 } \\
\vdots \\
\vdots\end{array}$ & $\stackrel{p}{\square}$ & 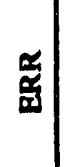 & 䍃 & 啚 & $\underset{\widetilde{a}}{\tilde{a}}$ & 章 \\
\hline 3 & (ี) & 是 & 윰 & 욤 & & & & & & & & & 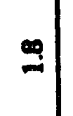 & $\ddot{q}$ & $\stackrel{\infty}{-1}$ & & & & & \\
\hline 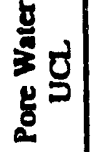 & 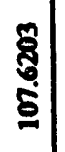 & $\begin{array}{l}\mathbf{8} \\
\vdots \\
5 \\
5\end{array}$ & 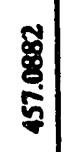 & 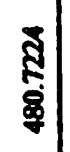 & हొ & ఫ్ & $\begin{array}{l}\text { ఫ్ } \\
\text { చ్ర }\end{array}$ & 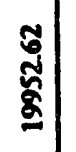 & 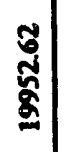 & 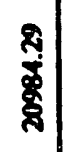 & 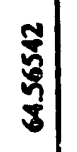 & 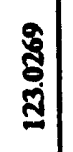 & 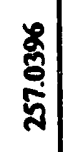 & 号 & 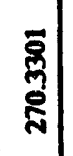 & ב⿱: & 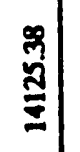 & 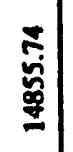 & 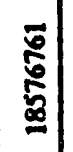 & $\begin{array}{l}\overline{5} \\
\vdots \\
\vdots \\
=\end{array}$ \\
\hline 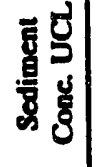 & & $\begin{array}{l}\mathbf{8} \\
\text { క్ర }\end{array}$ & శ్ర్రి & 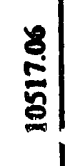 & 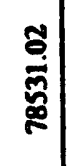 & $\begin{array}{l}8 \\
\dot{d} \\
\$ \\
\vdots\end{array}$ & 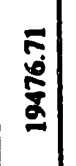 & 8 & ళ్రిత్ర & & 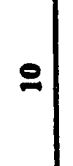 & ㅇ & ళ్రి & 8 & है & ఫ్ & 8 & 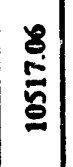 & 总 & ళ్ \\
\hline 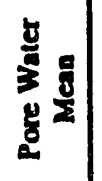 & $\begin{array}{l}\overline{\vec{j}} \\
\dot{0} \\
0\end{array}$ & $\begin{array}{l}\mathbf{8} \\
8 \\
5 \\
5\end{array}$ & : & 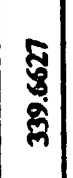 & 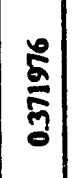 & 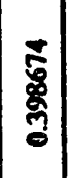 & 产 & $\begin{array}{c}\tilde{6} \\
\tilde{\sigma} \\
\sigma \\
\sigma\end{array}$ & 总 & $\begin{array}{l}\overline{\mathbf{g}} \\
\bar{\xi} \\
\bar{q}\end{array}$ & 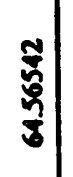 & ఫ్ & 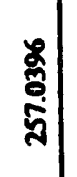 & 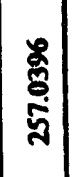 & $\begin{array}{c}5 \\
\vdots \\
\vdots \\
\vdots \\
\vdots\end{array}$ & 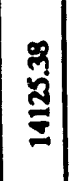 & 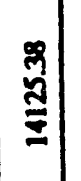 & 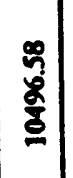 & $\begin{array}{l}5 \\
5 \\
\vdots \\
0\end{array}$ & $\begin{array}{l}\overline{5} \\
\vdots \\
\vdots \\
0 \\
0\end{array}$ \\
\hline 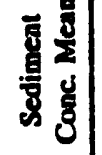 & 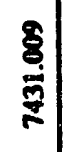 & ళ్ & 8 & $\frac{8}{0}$ & $\begin{array}{l}\bar{\Xi} \\
\bar{\Xi}\end{array}$ & 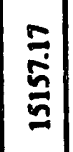 & $\begin{array}{l}5 \\
\overline{5} \\
\vdots \\
=\end{array}$ & శ్ & ్ㅣㅇ & 藁 & 음 & 이 & छ్ & छ్ & 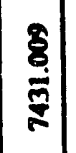 & ళ్రి & ళ్రి & 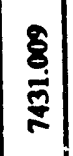 & శ్ర్చి & ళ్ర్ట్ర \\
\hline$\varepsilon \bar{z}$ & \&్ల & స్ & స్ & స్ & ڤ్రి & ڤ్ర & చ్ & $\Xi$ & $\Xi$ & $\Xi$ & 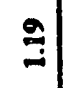 & ब, & ริ & ڤ్ & जे & $\dddot{a}$ & 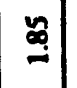 & $\stackrel{\square}{\square}$ & है & ติ \\
\hline $\begin{array}{l}\bar{\delta} \\
\overline{\mathbf{1}} \\
\bar{g}\end{array}$ & 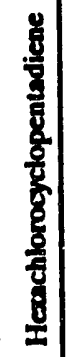 & 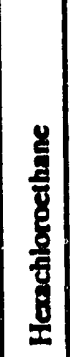 & 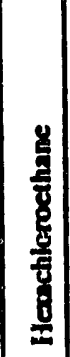 & 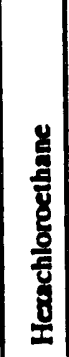 & 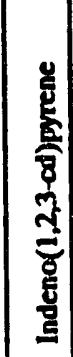 & 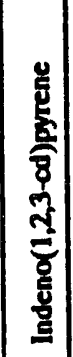 & 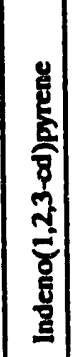 & $\begin{array}{l}0 \\
\vdots \\
0 \\
\frac{0}{0} \\
0\end{array}$ & 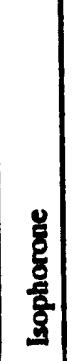 & 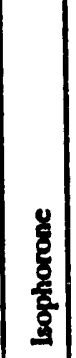 & 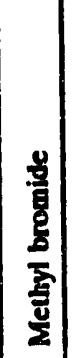 & 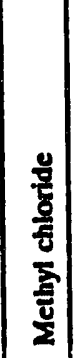 & 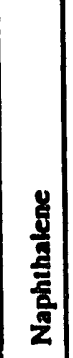 & 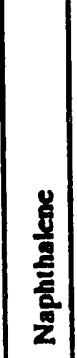 & 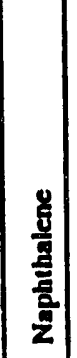 & 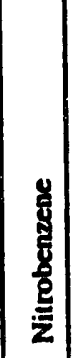 & 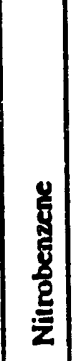 & 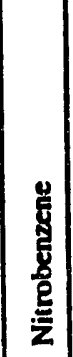 & 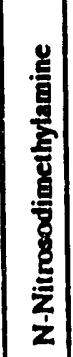 & 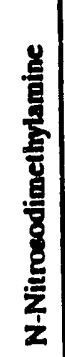 \\
\hline हृ & $m$ & - & $N$ & $m$ & - & $N$ & $m$ & -1 & $N$ & $m$ & $m$ & $m$ & -1 & $N$ & $m$ & -1 & $N$ & $m$ & - & $N$ \\
\hline
\end{tabular}




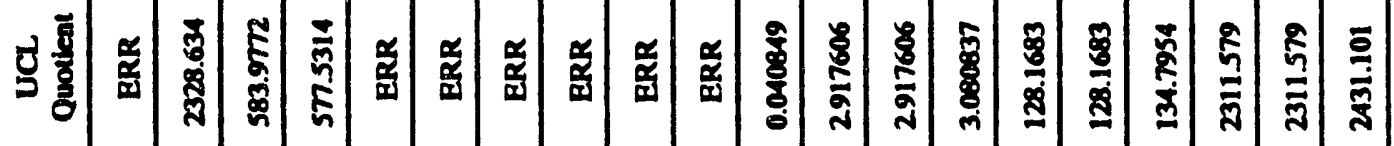

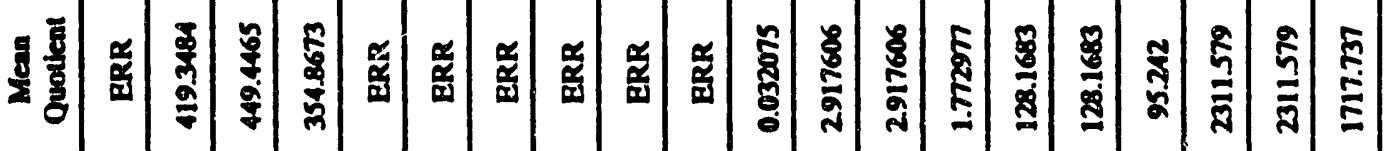

造

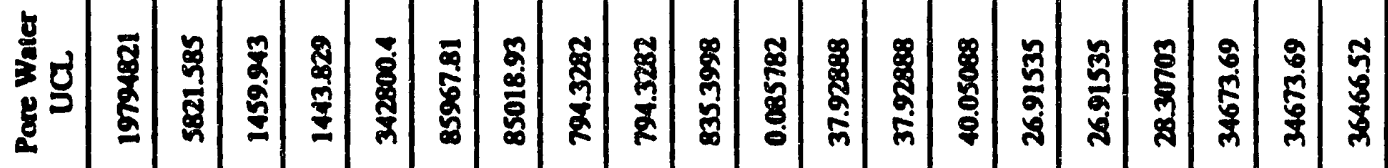

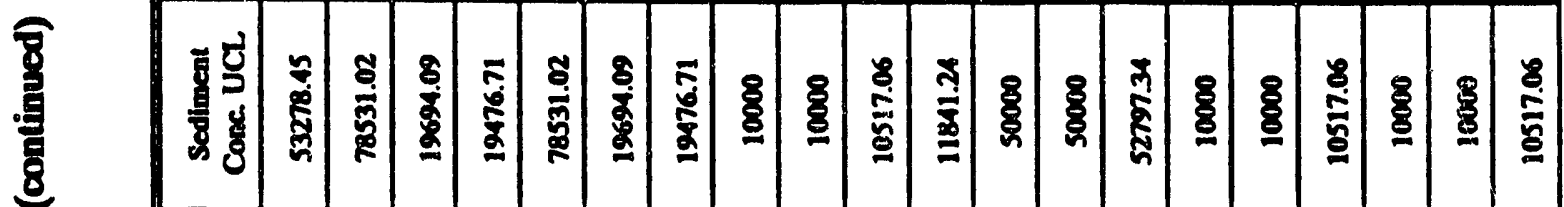

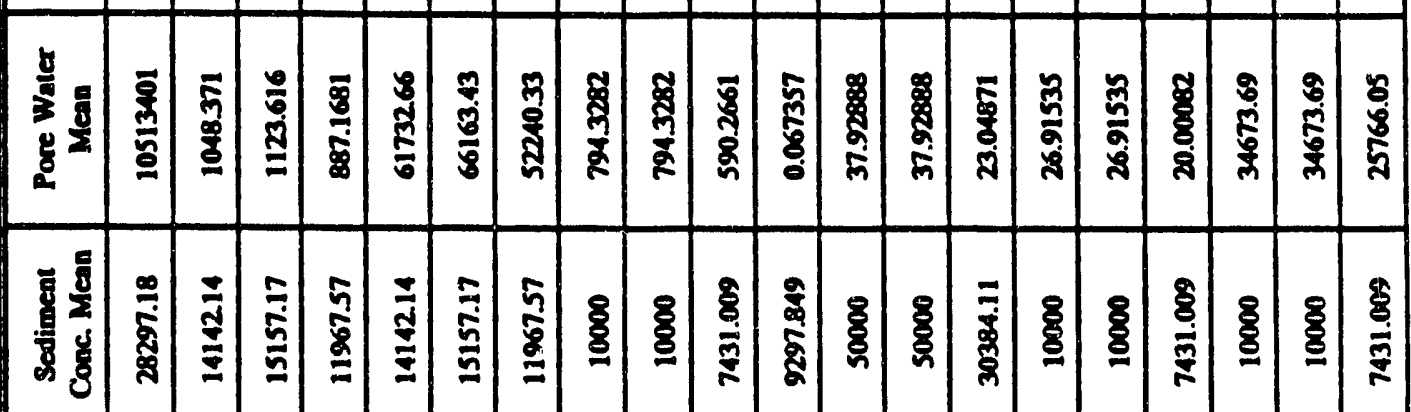

般

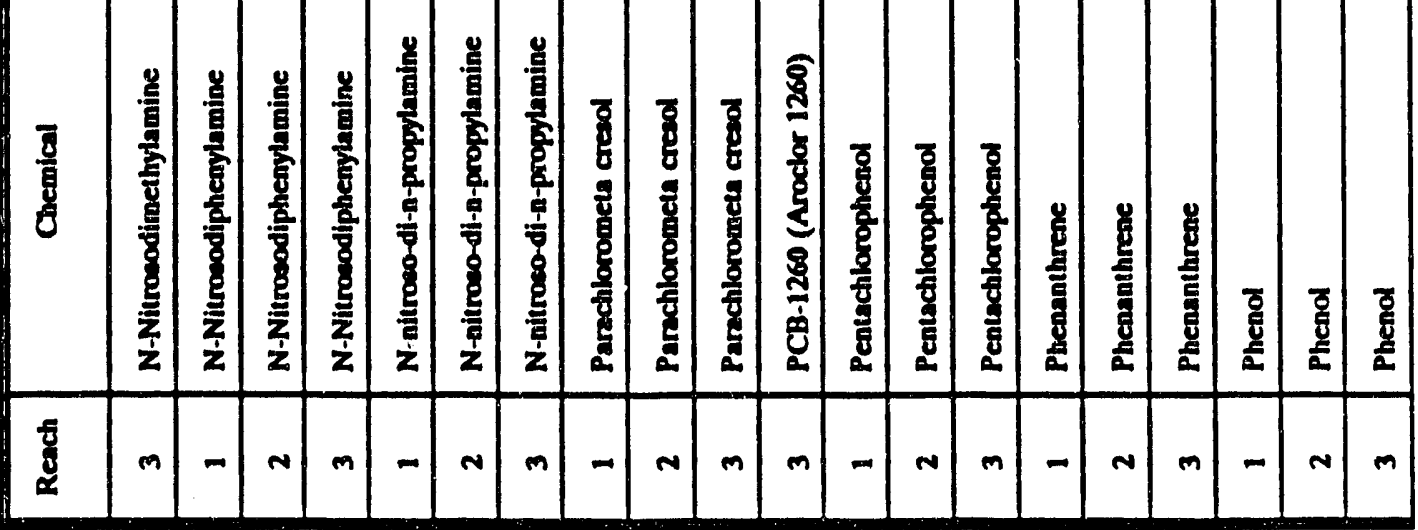




\begin{tabular}{|c|c|c|c|c|c|c|c|c|c|c|}
\hline ठ․ & 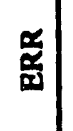 & $\begin{array}{l}\underset{\mathbf{x}}{\mathbf{u}} \\
\mathbf{v}\end{array}$ & $\begin{array}{l}\frac{\alpha}{\alpha} \\
\stackrel{\alpha}{a}\end{array}$ & $\underset{\mathbf{x}}{\stackrel{a}{\alpha}}$ & 蒿 & 总 & $\frac{a}{\bar{a}}$ & 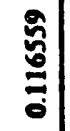 & $\begin{array}{l}\boldsymbol{\alpha} \\
\underset{\boldsymbol{\sigma}}{\boldsymbol{\sigma}}\end{array}$ & స్ ప్లై \\
\hline 量总 & 范 & 岕 & $\begin{array}{l}\stackrel{\alpha}{\alpha} \\
\text { 兽 }\end{array}$ & 蒙 & : & $\begin{array}{l}\tilde{8} \\
\text { జू }\end{array}$ & ह్ & $\underset{0}{0}$ & $\begin{array}{l}\underset{\mathbf{a}}{\mathbf{a}} \\
\mathbf{\alpha}\end{array}$ & స్ట్ \\
\hline 3 & & & & & nิ & ఫ్ & के & $\mp$ & & มุ \\
\hline $\begin{array}{l}\mathrm{y} \\
\mathrm{g} \\
\mathrm{g} \\
\mathrm{g} \\
\mathrm{g}\end{array}$ & ప్ & $\begin{array}{l}\bar{g} \\
\bar{a} \\
\square\end{array}$ & 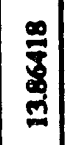 & & 总 & 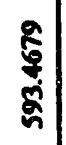 & 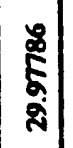 & $\begin{array}{c}\bar{z} \\
\overline{\mathbf{z}} \\
\overline{\mathrm{n}}\end{array}$ & స్స్ & $\stackrel{\text { 旁 }}{\bar{m}}$ \\
\hline 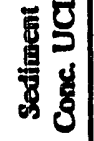 & 8 & 8 & 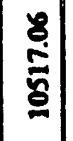 & క్రి & 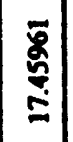 & 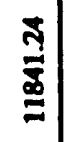 & : & ? & 이 & ᄋ \\
\hline 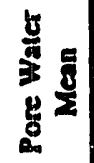 & $\frac{5}{a}$ & $\frac{\mathfrak{g}}{\stackrel{5}{m}}$ & 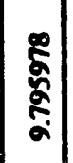 & & 产 & 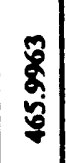 & 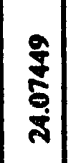 & 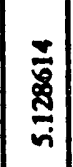 & ఫ్వ్రీ & $\frac{\bar{m}}{\bar{m}}$ \\
\hline 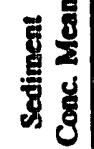 & 8 & 8 & 害 & శ్రి & 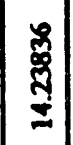 & 商 & 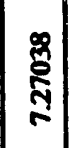 & 인 & 은 & 잉 \\
\hline$\Xi \bar{z}$ & $\stackrel{\$}{\square}$ & $\dddot{q}$ & $\not$ & & $\bar{m}$ & $m$ & $\stackrel{\infty}{\square}$ & స్తి & $\bar{y}$ & $\stackrel{q}{q}$ \\
\hline 8 & 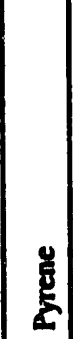 & 曾 & 总 & $\frac{5}{5}$ & 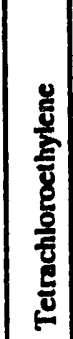 & 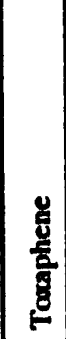 & 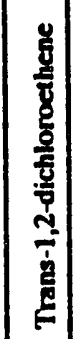 & 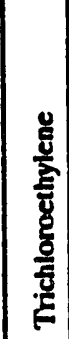 & 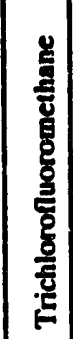 & 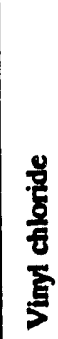 \\
\hline $\begin{array}{l}\text { f } \\
\text { d } \\
\text { a }\end{array}$ & - & $N$ & $m$ & $m$ & $m$ & m & $m$ & $m$ & $m$ & m \\
\hline
\end{tabular}




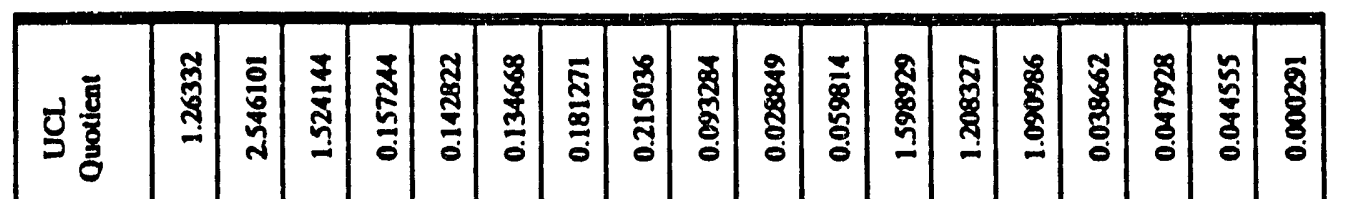

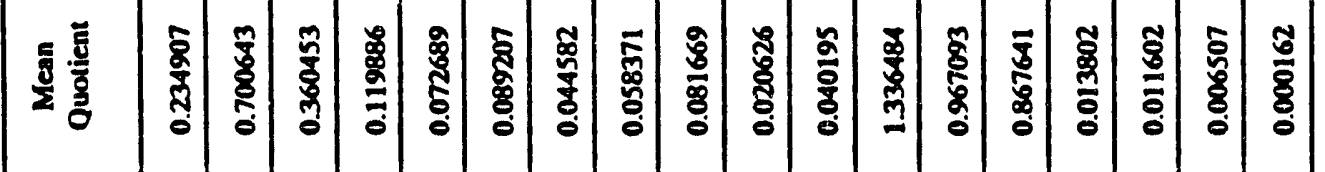

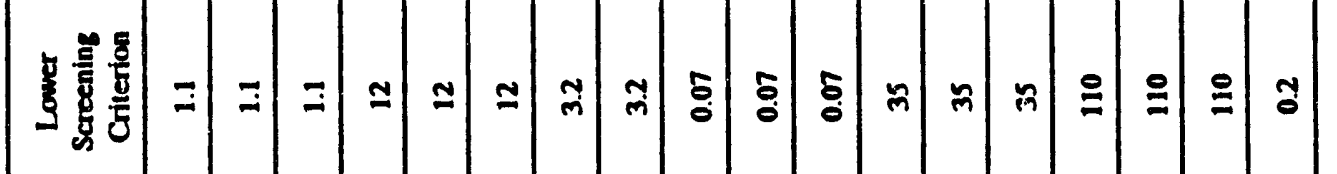

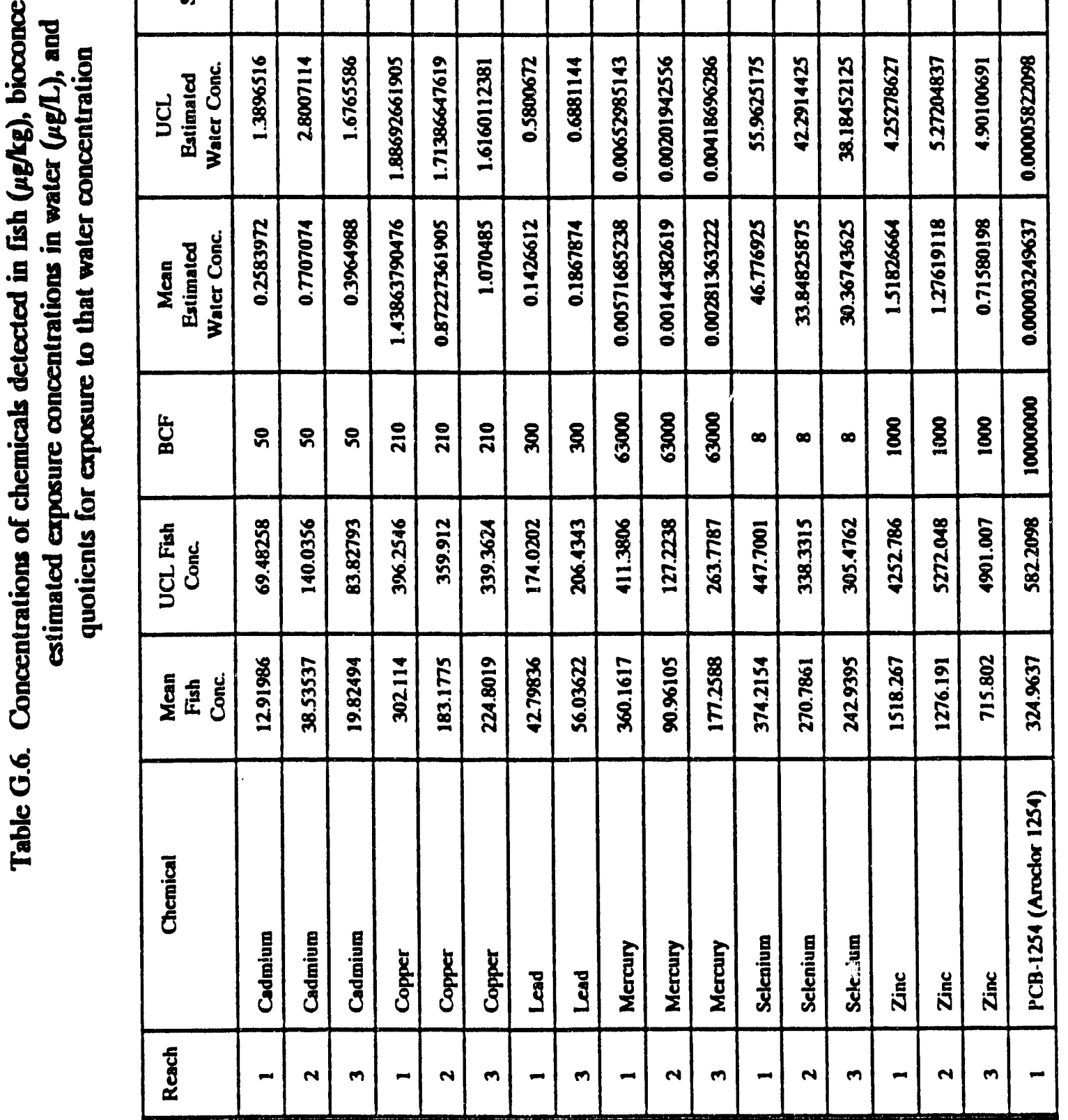


G-77

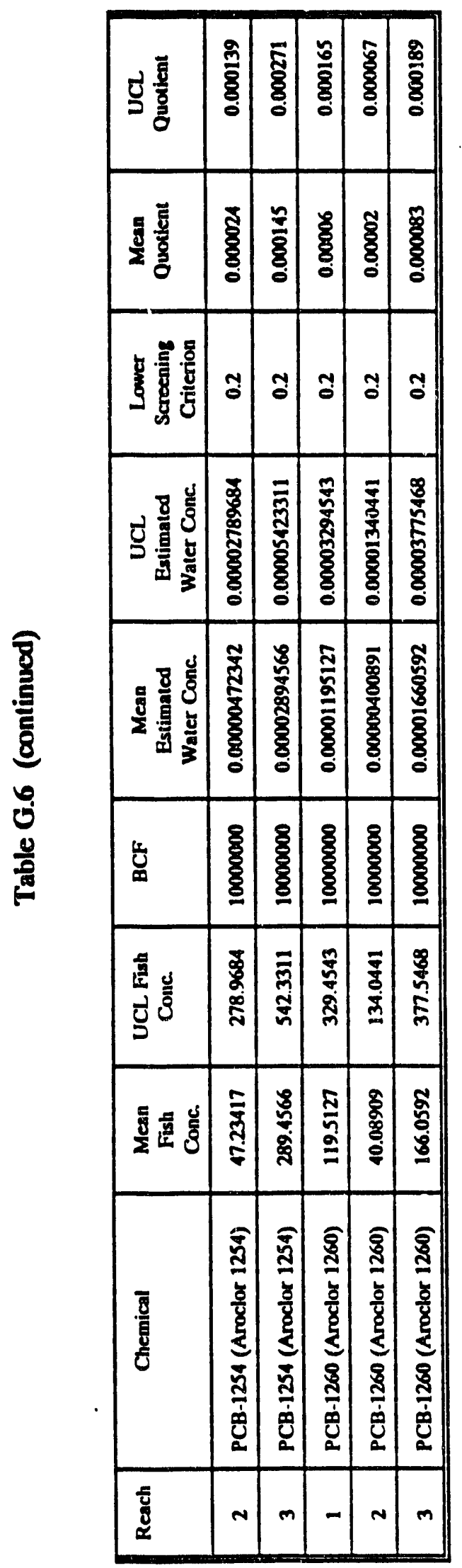




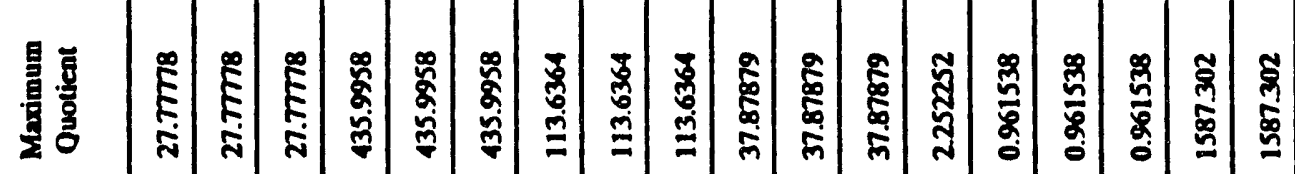

है 里 是

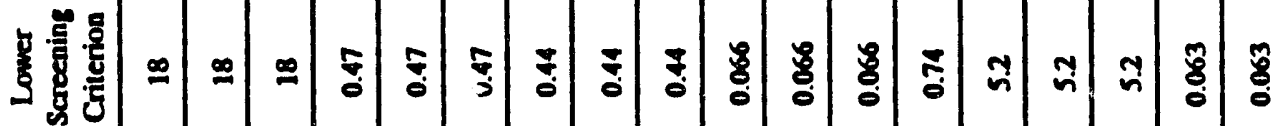

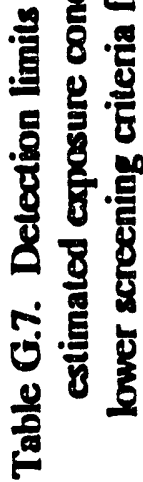

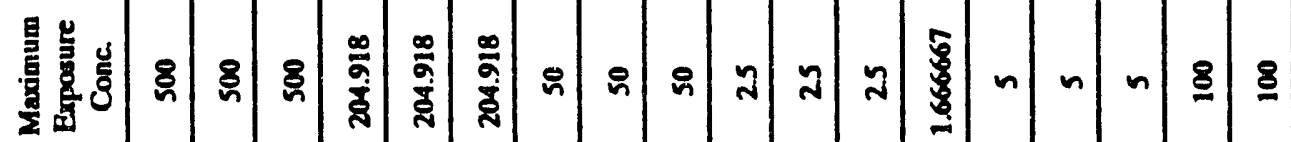

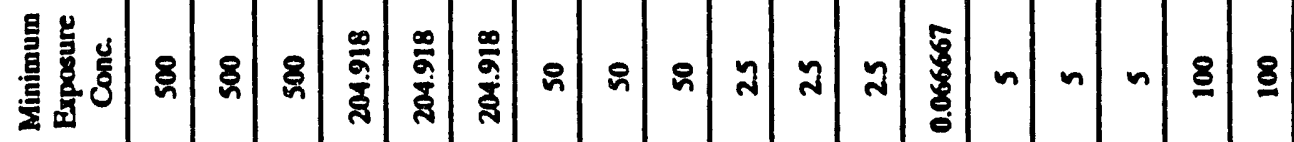

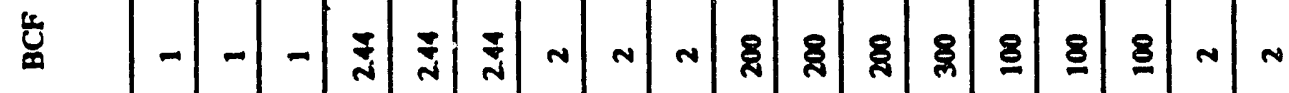

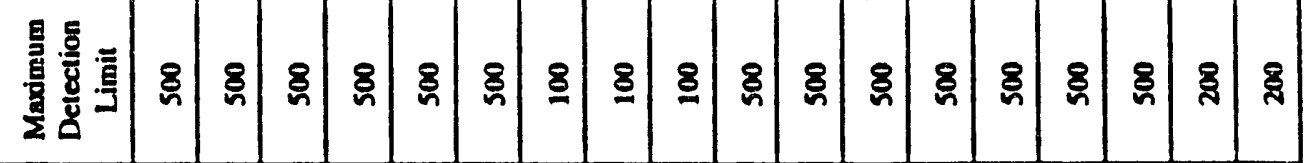

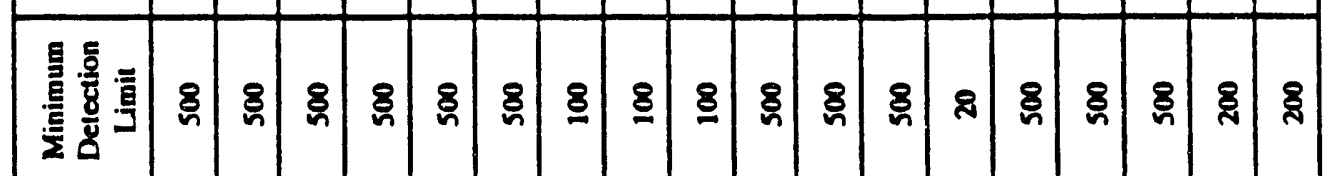

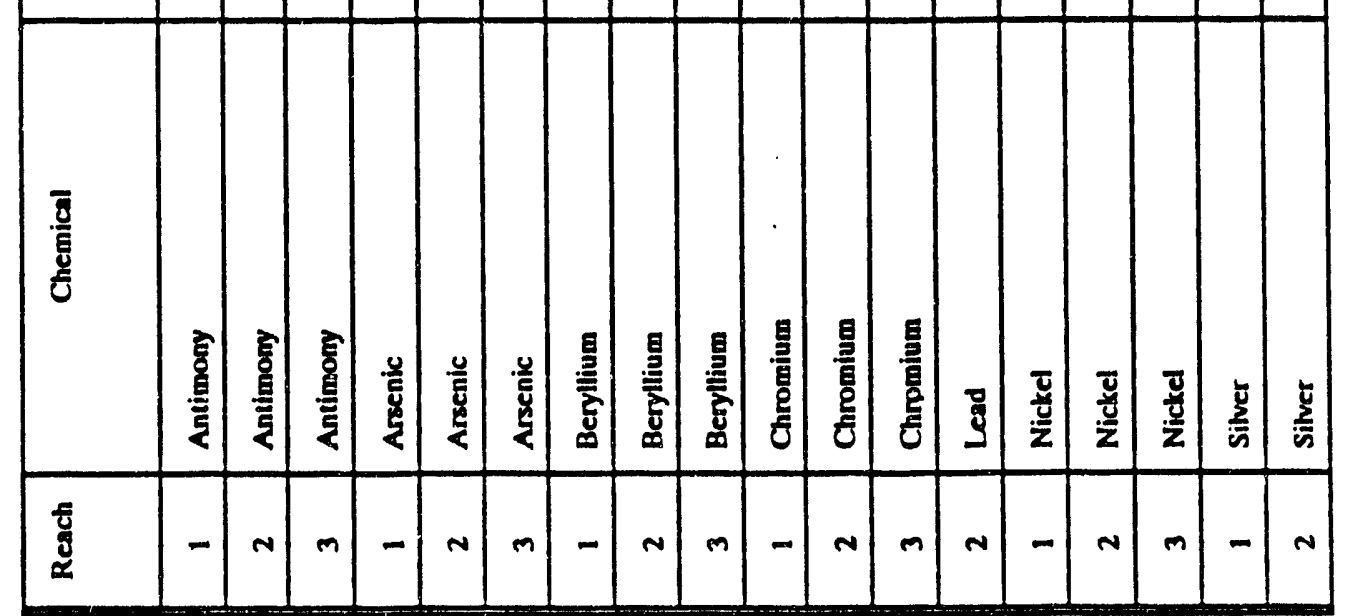




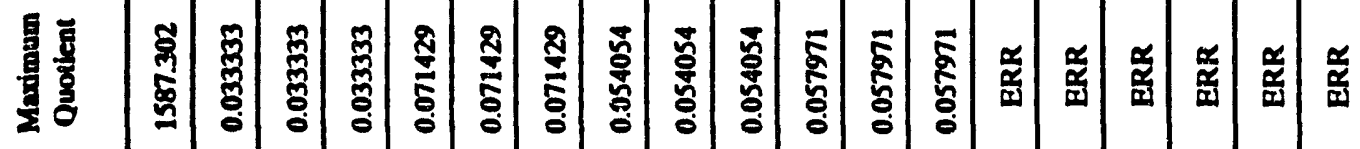

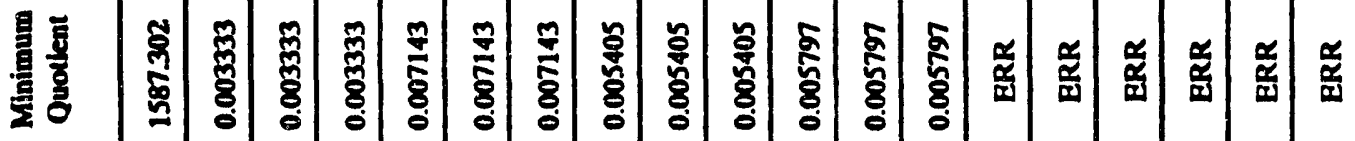

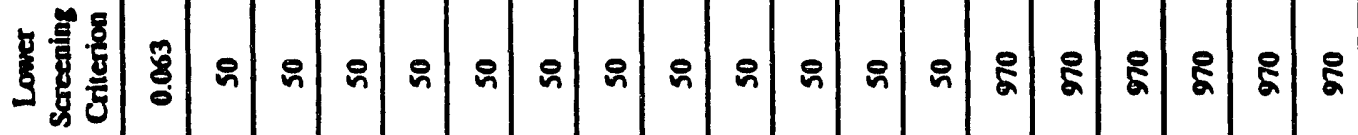

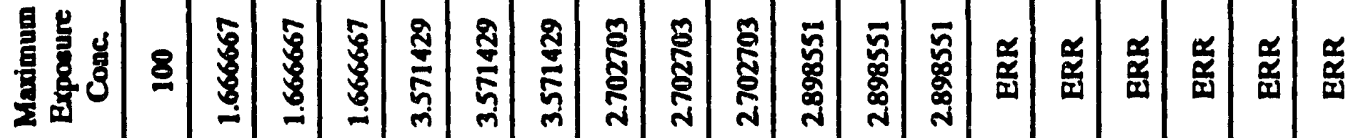

8ี

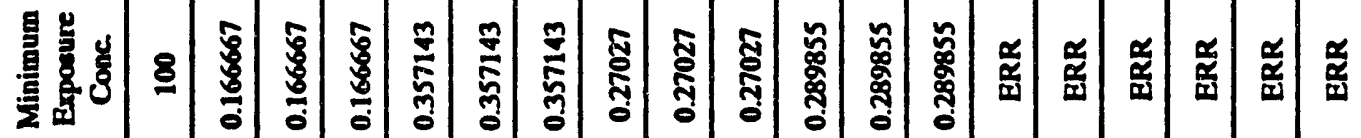

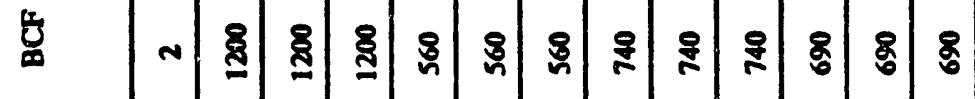

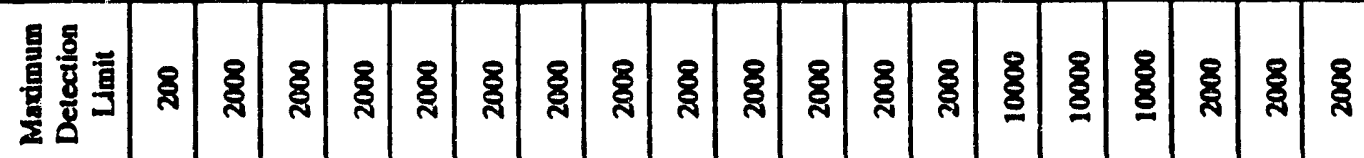

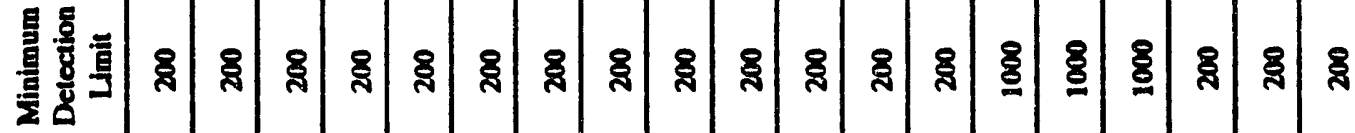

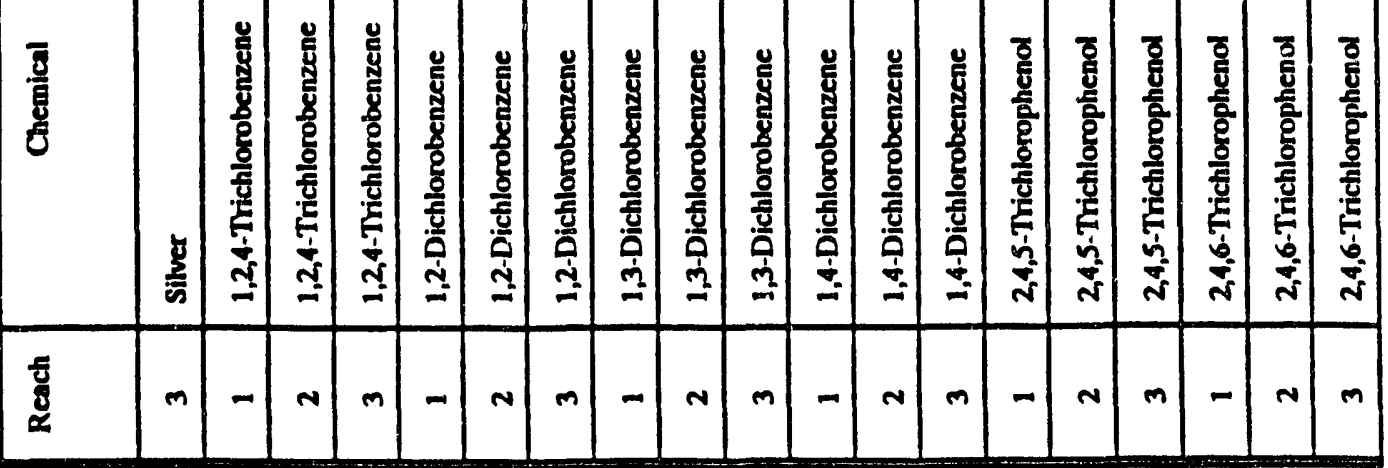




\section{II}

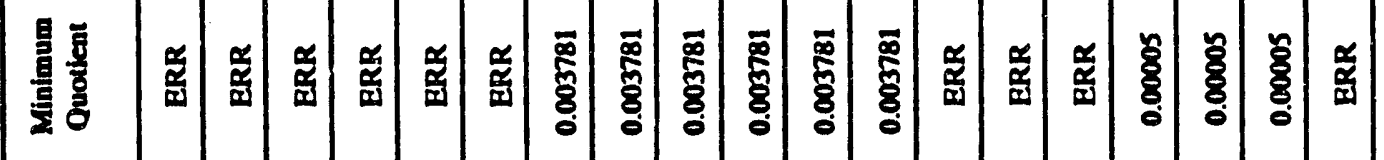

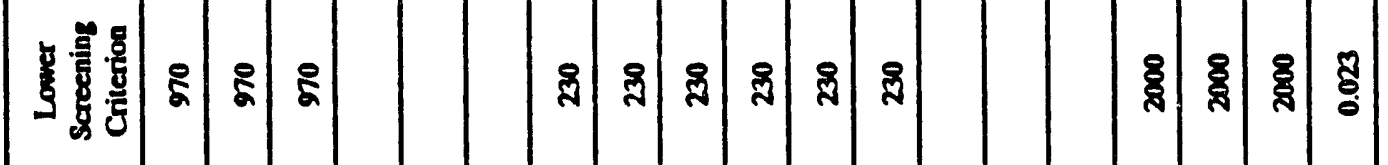

III

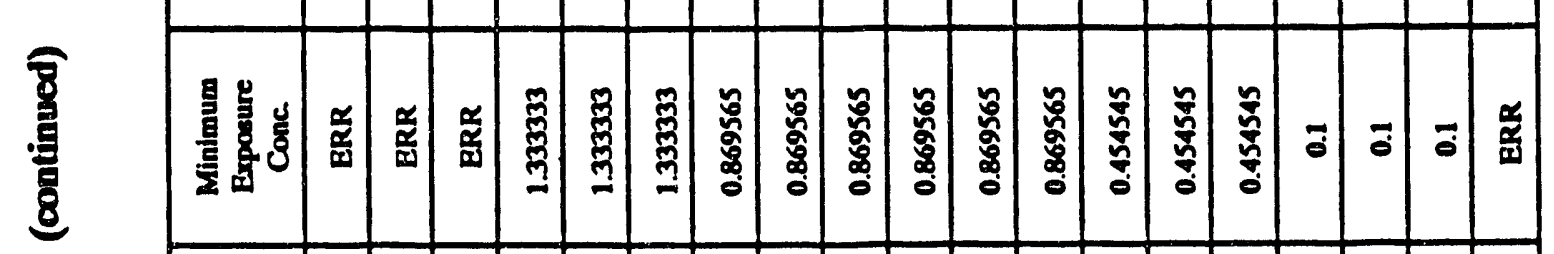

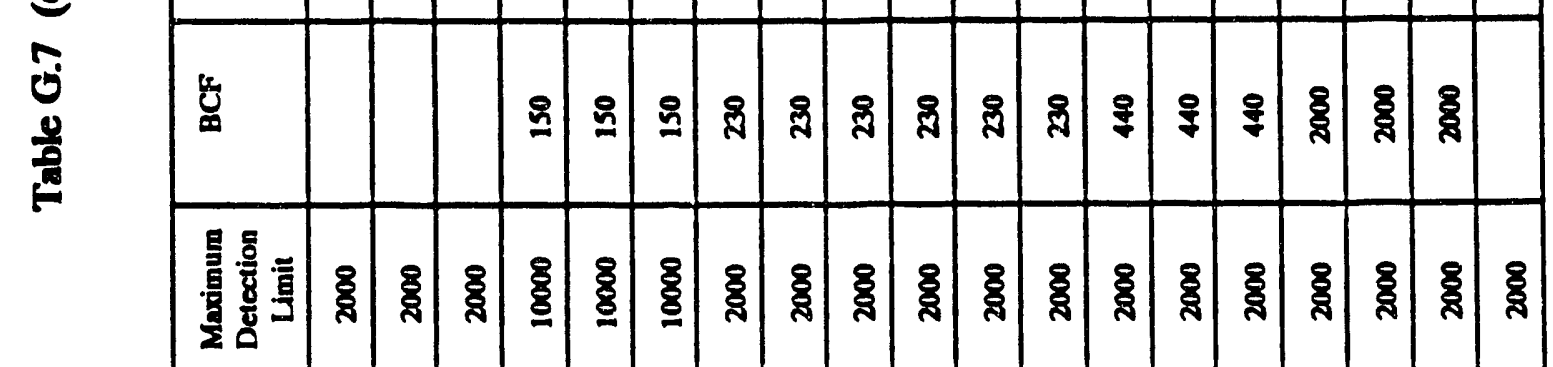

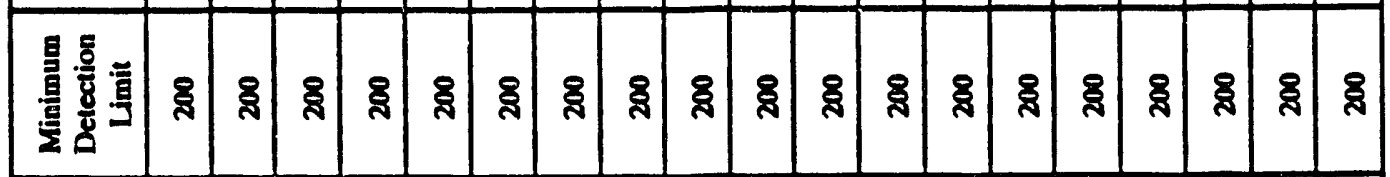

\begin{tabular}{|c|c|c|c|c|c|c|c|c|c|c|c|c|c|c|}
\hline$\frac{8}{1}$ & r & & $\dot{\sim}$ & $\dot{v}$ & 9 & $\frac{1}{N}$ & & $0^{\circ}$ & $\left|\begin{array}{|c|} \\
\vdots \\
\vdots \\
\vdots\end{array}\right|$ & & 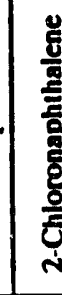 & $\dot{\sim}$ & & \\
\hline 站 & & m & -1 & $\sim$ & & $\sim$ & ol & & m & & 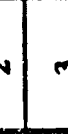 & & $\sim$ & \\
\hline
\end{tabular}




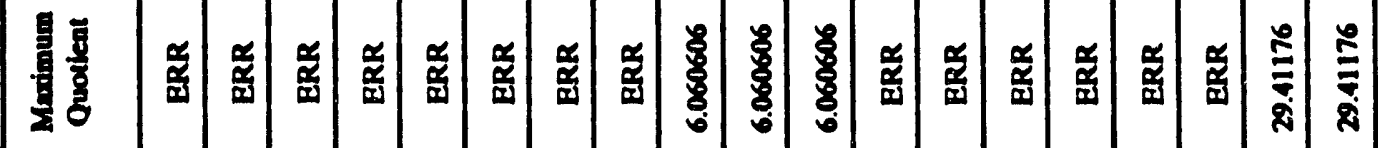

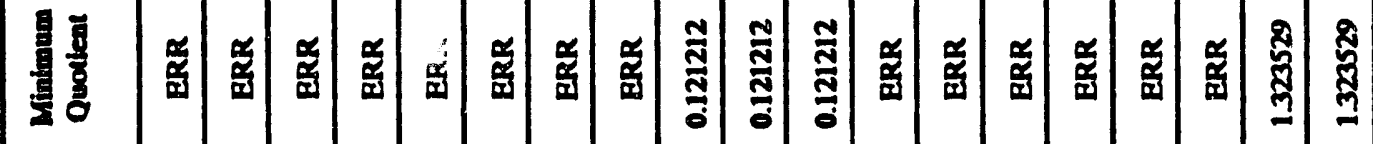

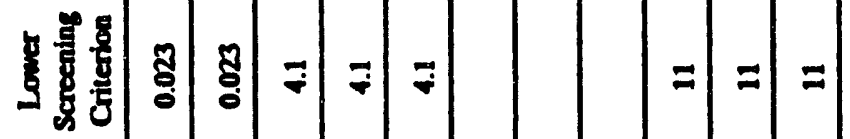

鿷

II

8
8
8

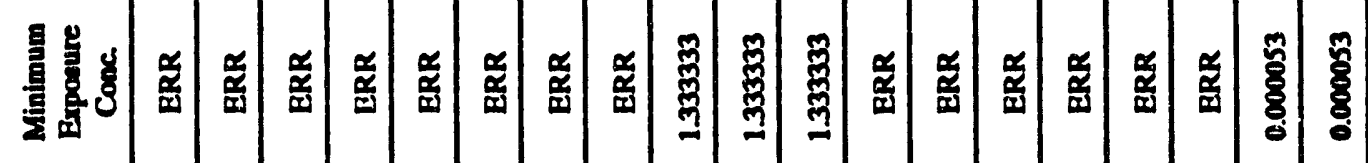

苟

$$
\text { 으은 }
$$

: ?

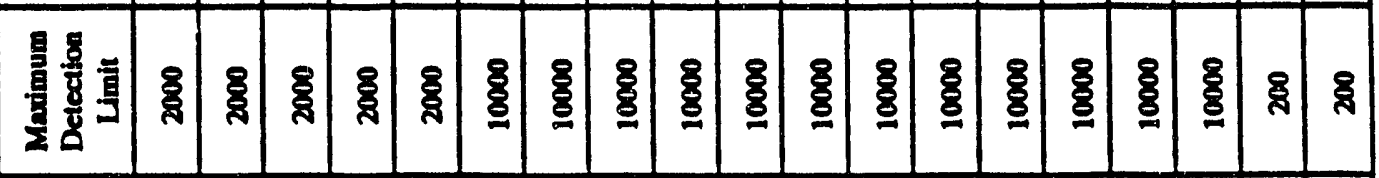

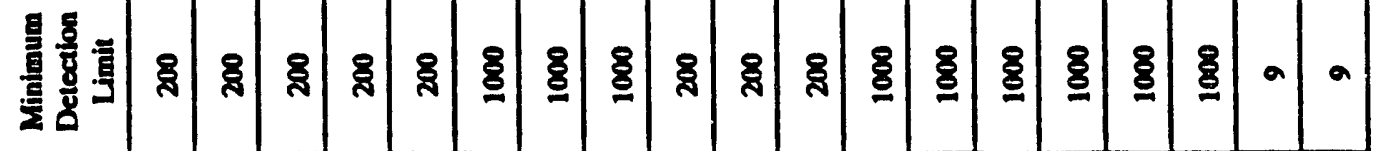

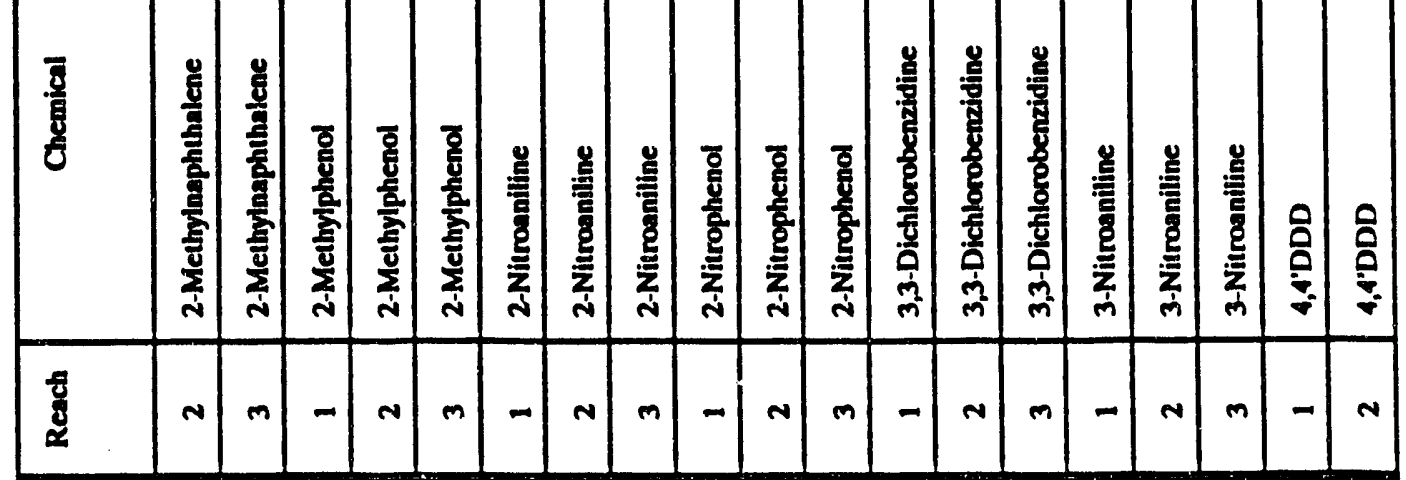




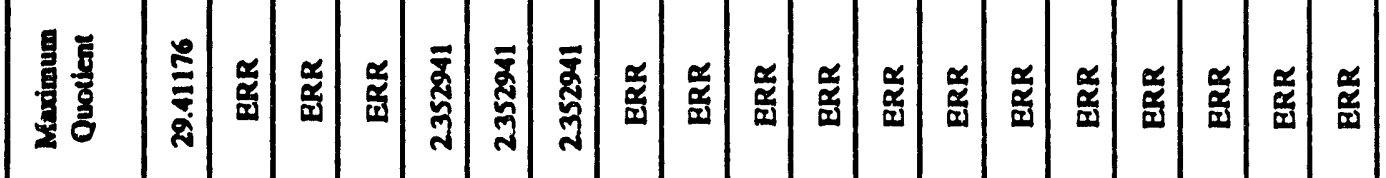

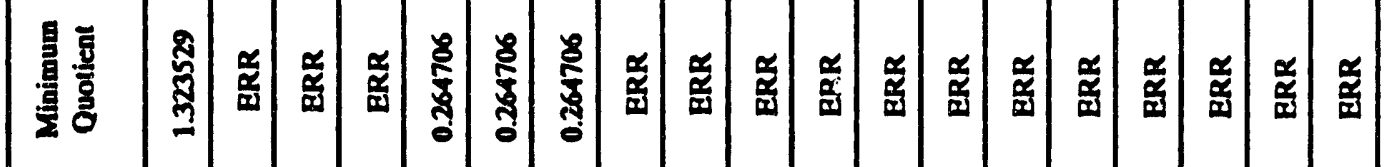

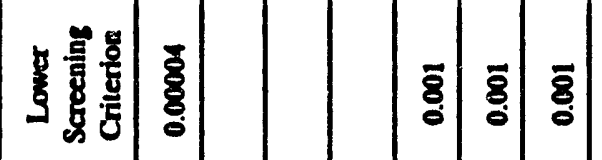

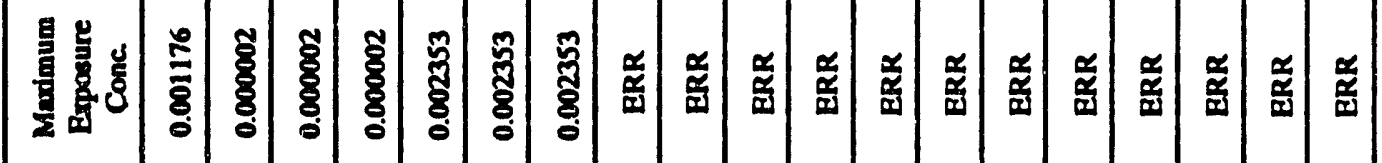

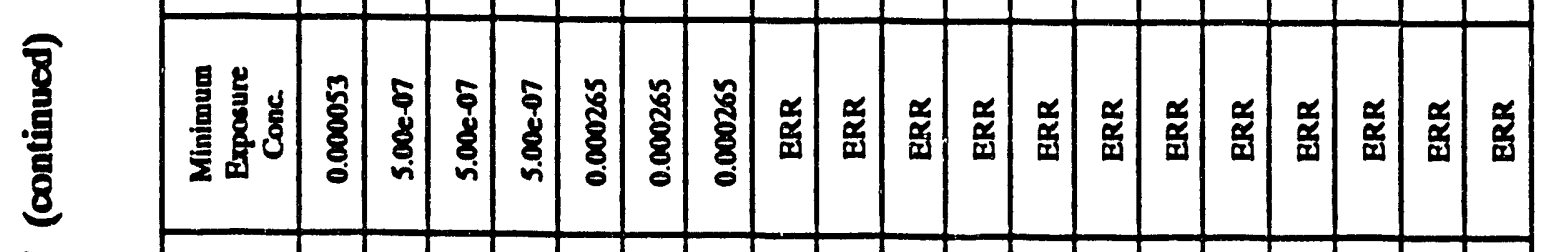

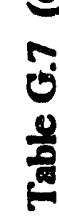

\begin{tabular}{|c|c|c|c|c|c|c|c|}
\hline 忽 & క్ర్రి & $\begin{array}{l}\text { ళ్ర్ర్ర్ } \\
\text { త్ర }\end{array}$ & 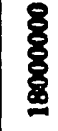 & క్ర్రి & $\frac{8}{8}$ & 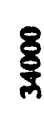 & $\frac{8}{8}$ \\
\hline
\end{tabular}

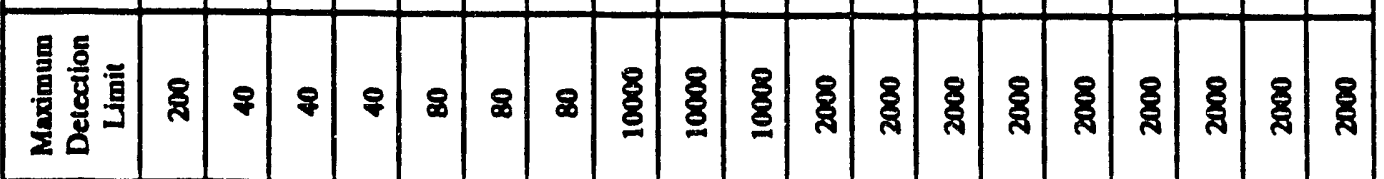

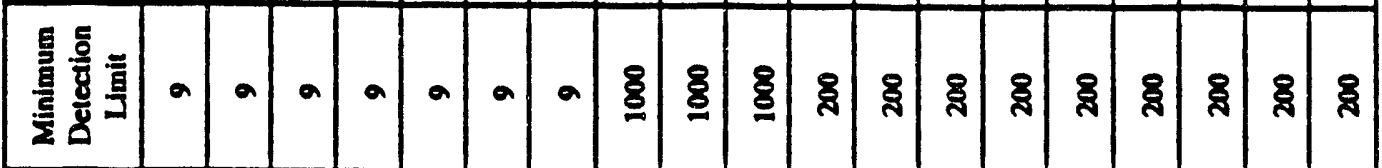

\begin{tabular}{|c|c|c|c|c|c|c|c|c|c|c|c|c|c|c|c|c|c|c|c|}
\hline 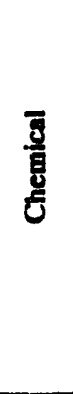 & 응 & $\begin{array}{l}\text { 㔛 } \\
\stackrel{0}{*}\end{array}$ & 罢 & 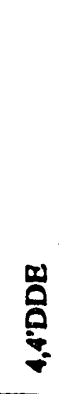 & $\stackrel{5}{\circ}$ & 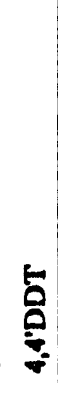 & 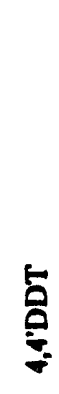 & 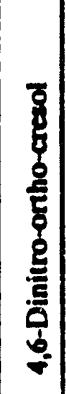 & 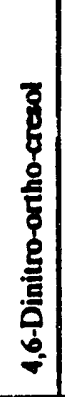 & 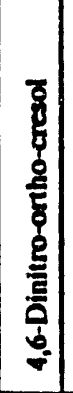 & 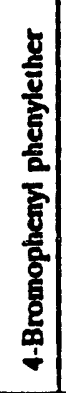 & 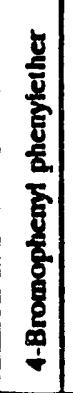 & 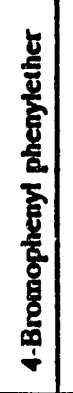 & 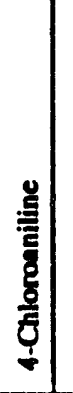 & 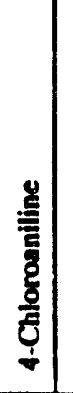 & 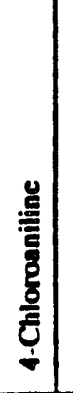 & 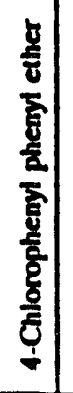 & 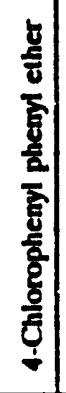 & 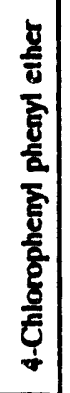 \\
\hline 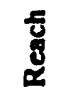 & $m$ & -1 & $N$ & $m$ & - & $\boldsymbol{N}$ & $m$ & - & $N$ & m & -1 & $N$ & $m$ & - & $N$ & $m$ & - & $N$ & $m$ \\
\hline
\end{tabular}




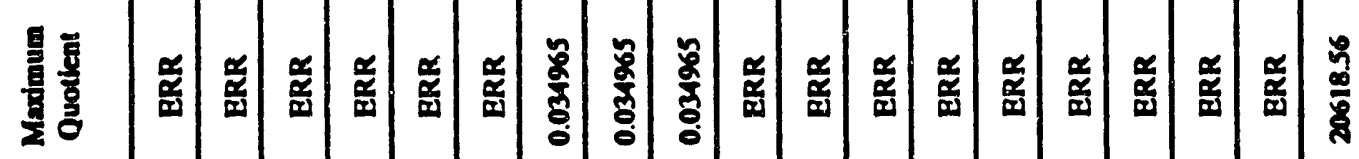

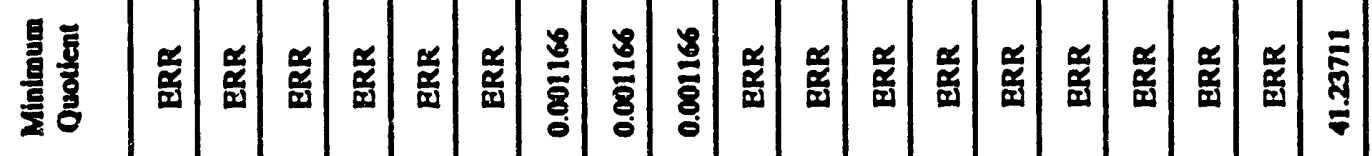

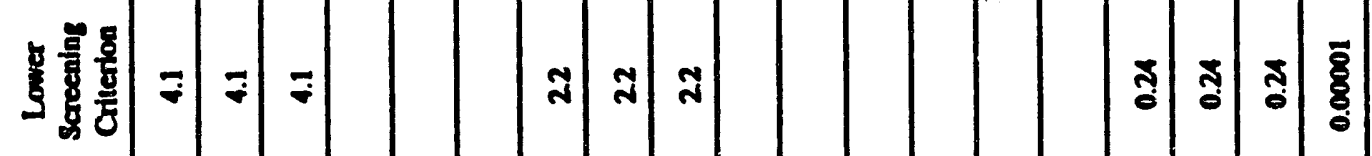

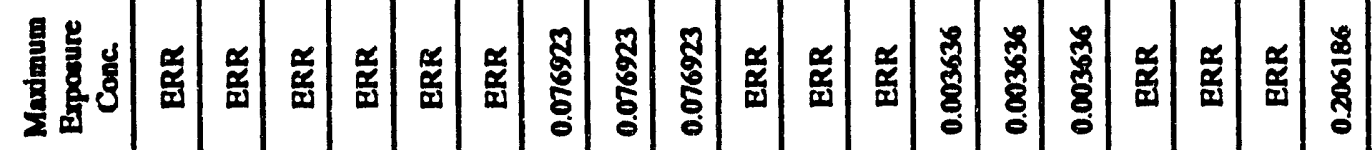

8
8
8
8
0
0
0
0
0

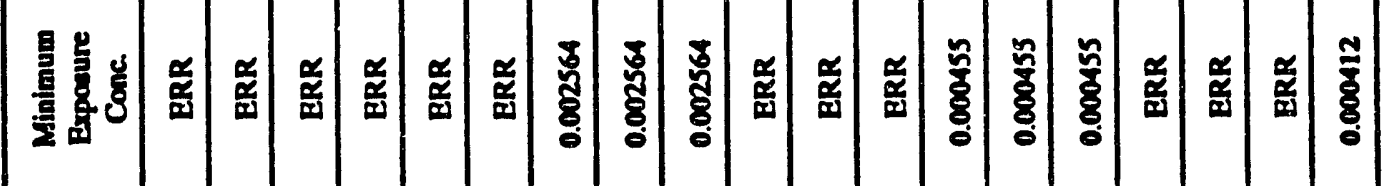

\& $\delta$

잉 옹 응

9

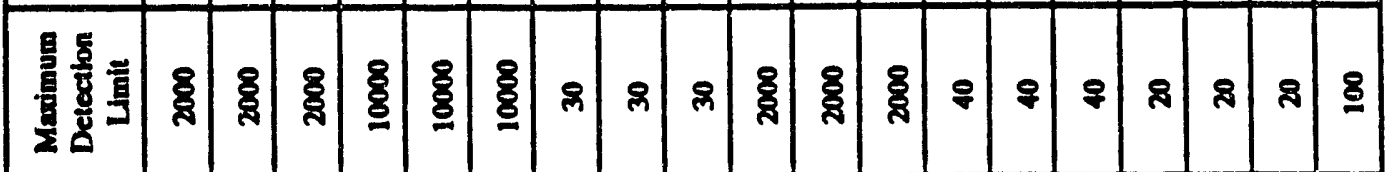

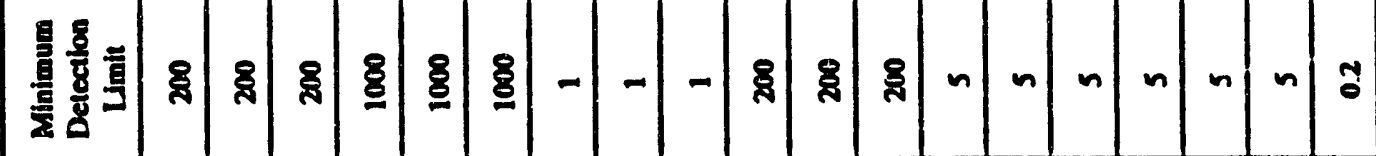

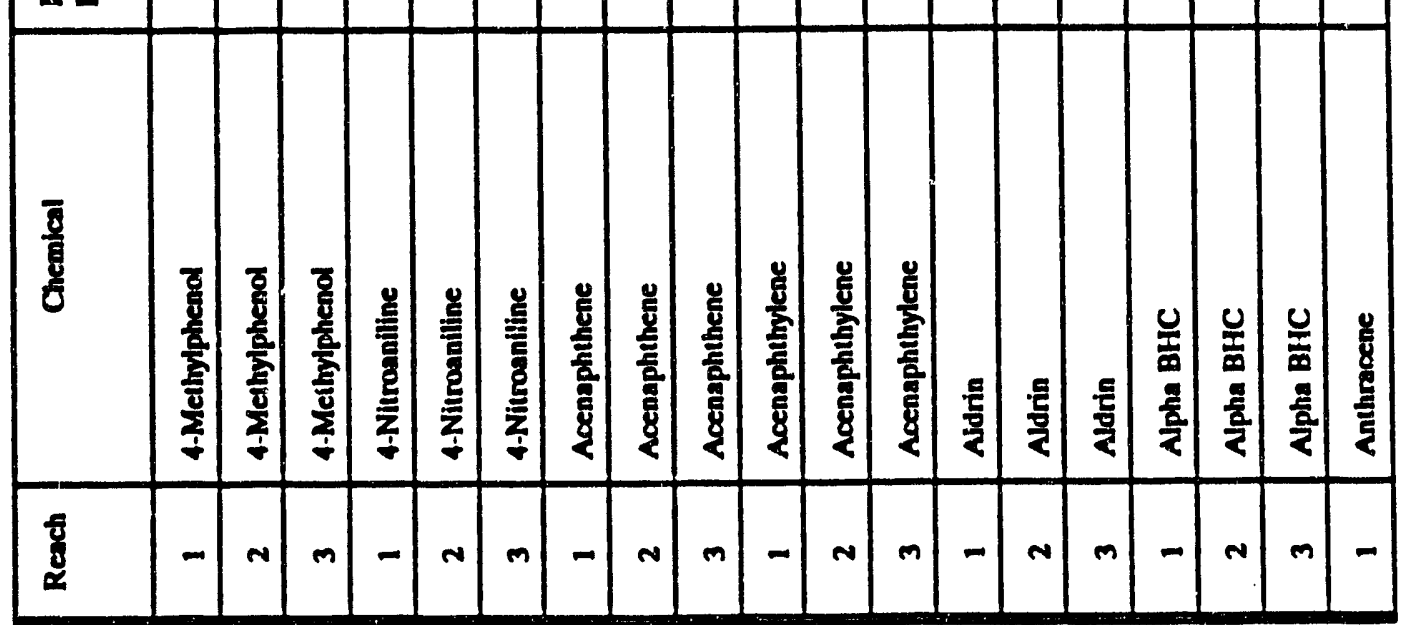




\begin{tabular}{|c|c|c|c|c|c|c|c|c|c|c|c|c|c|c|c|c|c|c|c|}
\hline 量焉 & 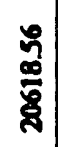 & 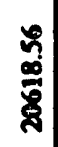 & 总 & 咅 & $\begin{array}{l}\text { 爻 } \\
\text { ฮै }\end{array}$ & 荌 & 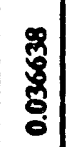 & $\begin{array}{l}0 \\
\vdots \\
\vdots \\
0\end{array}$ & $\begin{array}{l}\overline{\mathbf{D}} \\
\text { ప్ }\end{array}$ & $\begin{array}{c}\overline{5} \\
\overline{5} \\
5\end{array}$ & $\begin{array}{l}\overline{\mathbf{n}} \\
\text { ఏ్ }\end{array}$ & $\frac{a}{\tilde{y}}$ & 惢 & 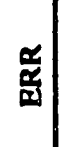 & 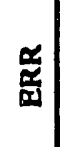 & $\begin{array}{l}\stackrel{\boldsymbol{z}}{\mathbf{z}} \\
\mathbf{\underline { y }}\end{array}$ & 总 & 善 & 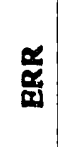 \\
\hline 最戛 & $\underset{\bar{F}}{\overline{7}}$ & స్ & 㺃 & 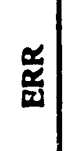 & 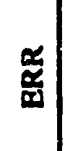 & శ్ & శ్ & శ్ & 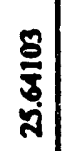 & 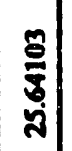 & 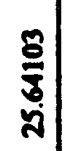 & $\underset{\mathbf{\alpha}}{\tilde{\alpha}}$ & 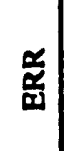 & 嘼 & 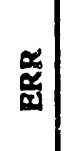 & 总 & 畓 & 畜 & 羊 \\
\hline $9 \frac{5}{5}$ & $\begin{array}{l}\bar{\delta} \\
\bar{\delta} \\
0\end{array}$ & $\begin{array}{l}\overline{8} \\
8 \\
\end{array}$ & ?ִ & $\frac{n}{0}$ & $\frac{n}{0}$ & ఫ్ర & ఫ్ర్ర్ర & ष్ర్రి & 吕 & 商 & $\frac{m}{8}$ & & & & & & & & \\
\hline 㟟气 & 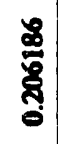 & జ్. & 艾 & 㺃 & 畓 & ह్ర్ర్ర్య & $\begin{array}{l}8 \\
\text { g్ } \\
\delta \\
\delta\end{array}$ & ఫ్ & $\frac{n}{0}$ & 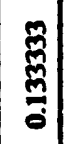 & 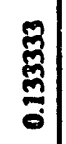 & $\frac{\approx}{\tilde{a}}$ & $\begin{array}{l}\stackrel{x}{\mathbf{y}} \\
\mathbf{y}\end{array}$ & 畓 & 罳 & $\underset{\mathbf{z}}{\mathbf{a}}$ & 恙 & $\frac{\mathfrak{x}}{\frac{z}{y}}$ & $\underset{\underset{z}{\alpha}}{\underline{z}}$ \\
\hline
\end{tabular}

8.

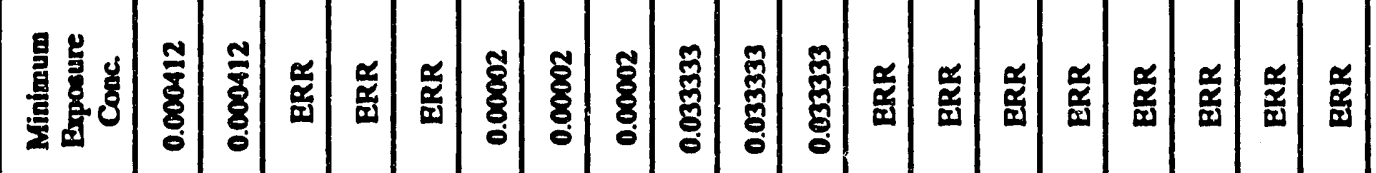

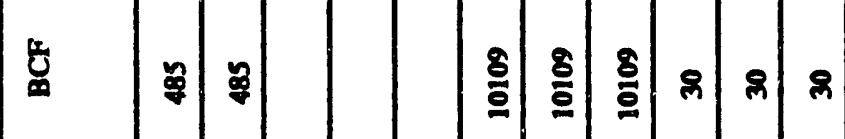

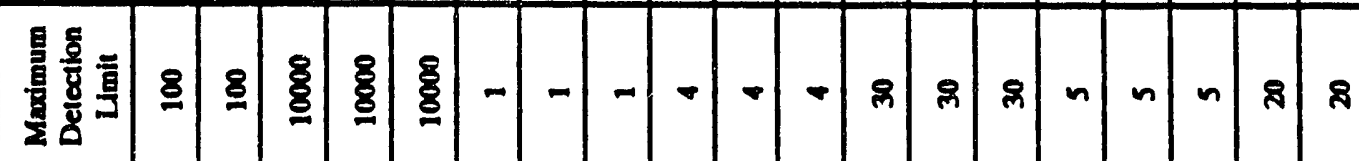

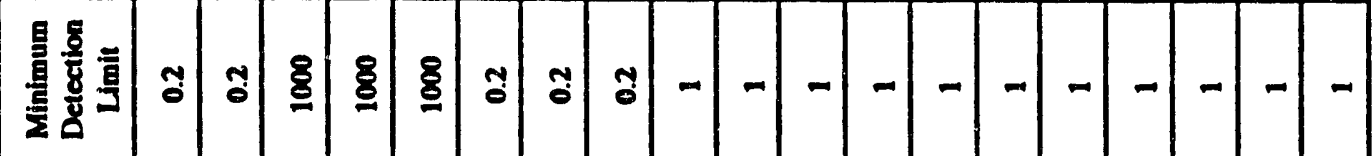

\begin{tabular}{|c|c|c|c|c|c|c|c|c|c|c|c|c|c|c|c|c|c|c|c|}
\hline 吾 & $\begin{array}{l}\text { 题 } \\
\text { 至 }\end{array}$ & 题 & 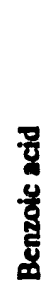 & 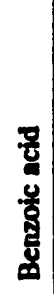 & 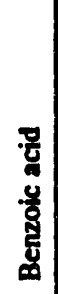 & 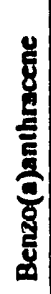 & 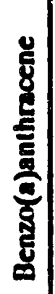 & 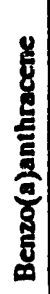 & 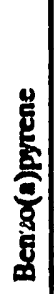 & 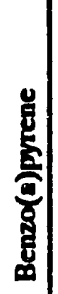 & 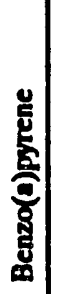 & 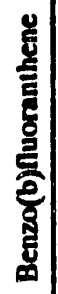 & 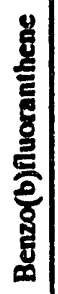 & 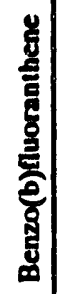 & 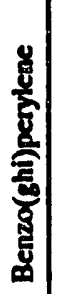 & 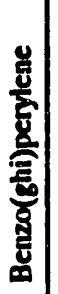 & 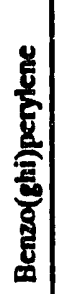 & 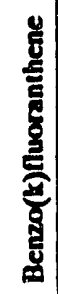 & 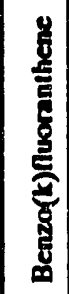 \\
\hline ]્ّ & $N$ & $m$ & - & $r$ & $m$ & $\rightarrow$ & $N$ & $m$ & - & $N$ & $m$ & -1 & $N$ & $m$ & -1 & $N$ & $m$ & - & $v$ \\
\hline
\end{tabular}




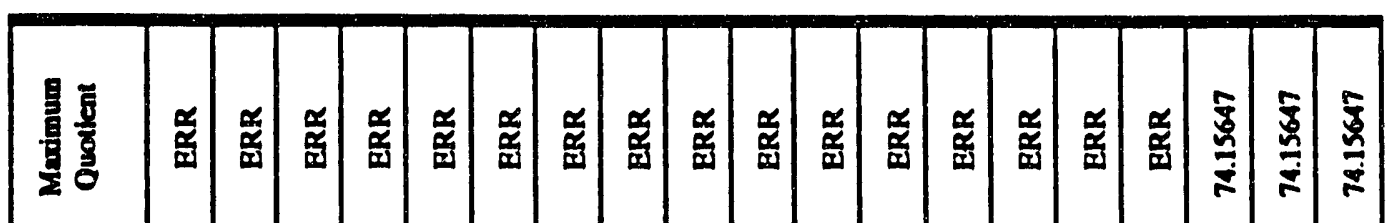

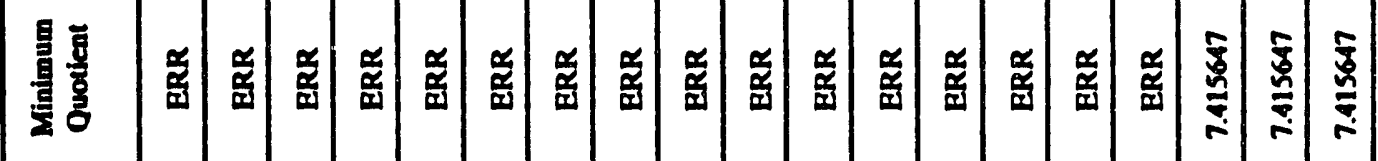

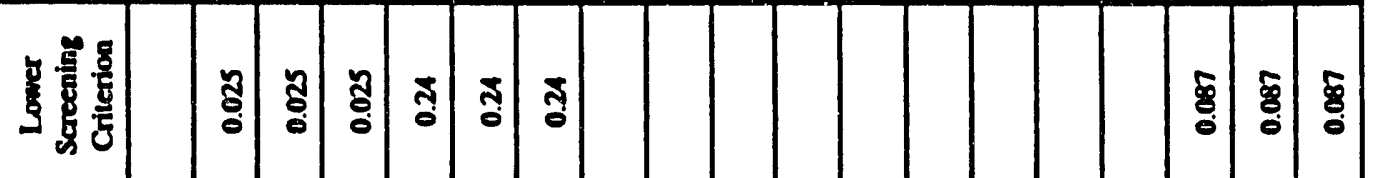

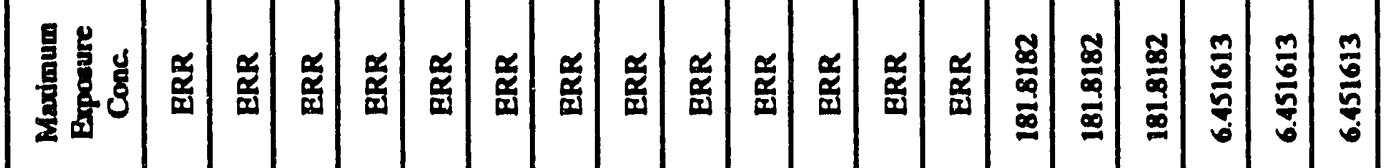

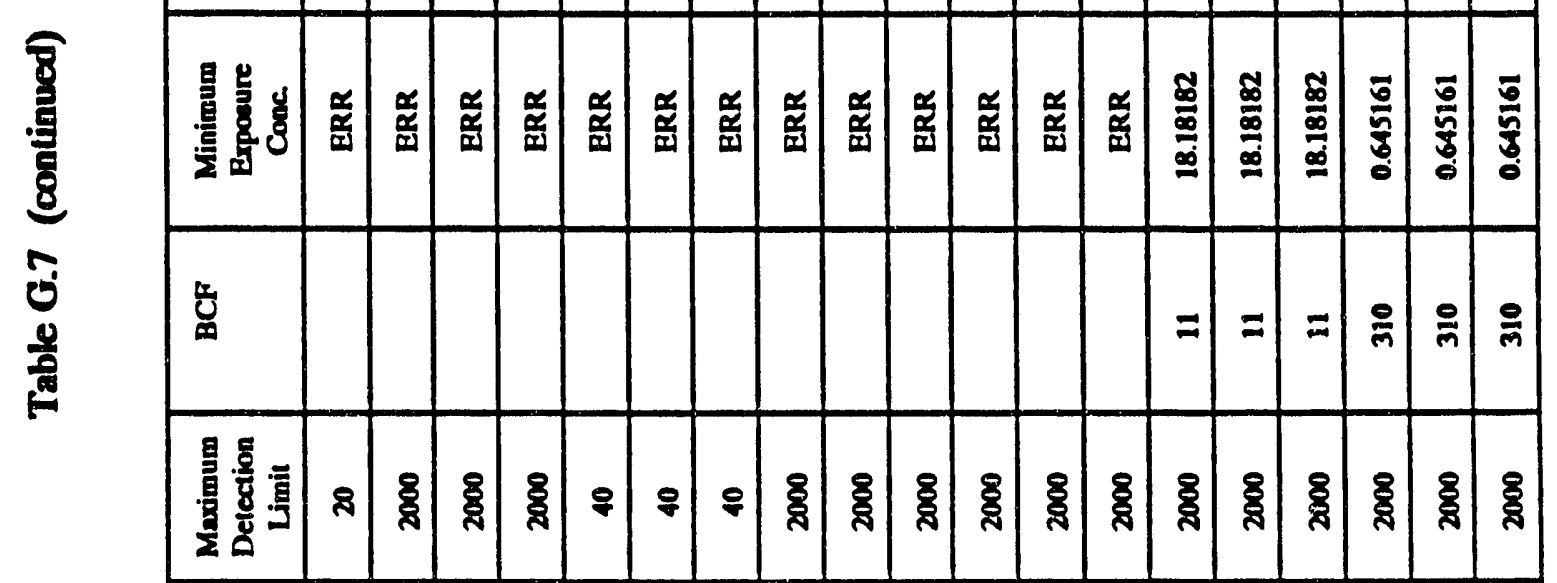

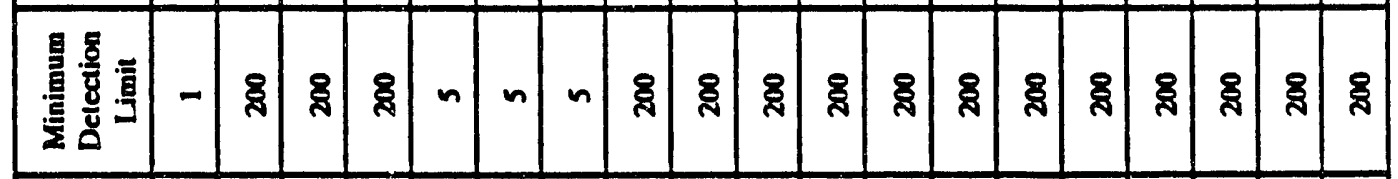

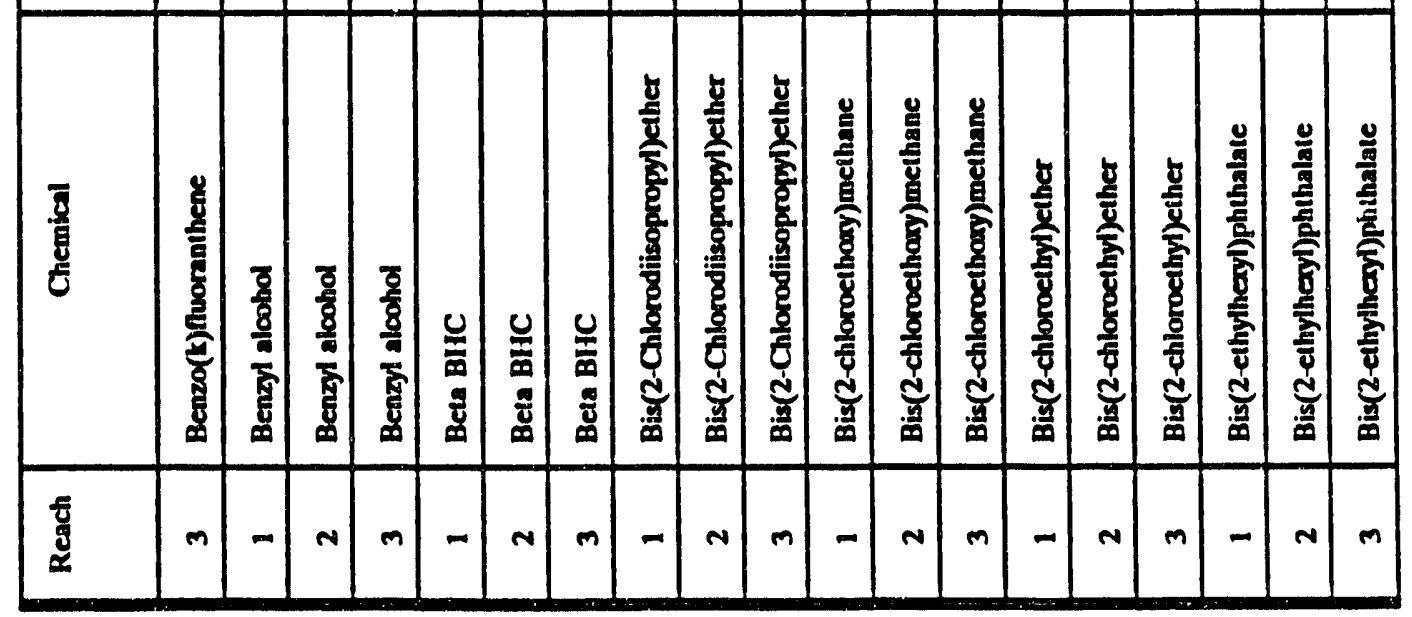




\begin{tabular}{|c|c|c|c|c|c|c|c|c|c|c|c|c|c|c|c|c|c|c|c|}
\hline 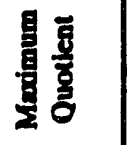 & $\begin{array}{l}\mathbf{z} \\
\frac{\mathbf{x}}{\mathbf{y}}\end{array}$ & 苗 & $\underset{\tilde{X}}{\tilde{Z}}$ & $\begin{array}{l}\mathbf{a} \\
\mathbf{a}\end{array}$ & 总 & 蛋 & 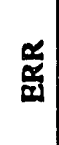 & 畄 & 䞤 & $\begin{array}{l}\stackrel{\alpha}{\mathbf{a}} \\
\text { 音 }\end{array}$ & 営 & 畄 & $\stackrel{\tilde{a}}{\mathbf{y}}$ & $\begin{array}{l}\text { 岃 } \\
\text { 岃 }\end{array}$ & 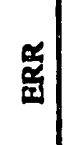 & 总 & 甯 & $\begin{array}{l}\frac{0}{0} \\
\frac{0}{0} \\
\frac{0}{6}\end{array}$ & 氶 \\
\hline 基哥 & 章 & 蜔 & 苝 & 䍃 & 总 & 总 & 总 & 咅 & 总 & 音 & 苟 & $\begin{array}{l}\text { 䍃 } \\
\text { | }\end{array}$ & $\begin{array}{l}\tilde{\mathscr{U}} \\
\mathbf{U}\end{array}$ & 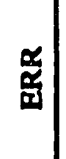 & 愛 & $\begin{array}{l}\text { : } \\
\text { : } \\
\text { : }\end{array}$ & $\begin{array}{l}\text { : } \\
\text { : } \\
\text { : }\end{array}$ & 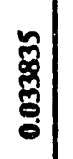 & $\frac{8}{8}$ \\
\hline s & & & & & & & శ్ర & శ్ & శ్ & $N$ & $N$ & $N$ & & & & 竒 & $\frac{a}{\dot{c}}$ & 啇 & $\Sigma$ \\
\hline 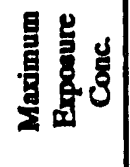 & $\frac{\pi}{g}$ & 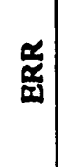 & 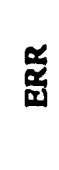 & $\overline{8}$ & $\overline{0}$ & $\overline{0}$ & 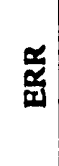 & 莺 & $\begin{array}{l}\tilde{z} \\
\tilde{y}\end{array}$ & 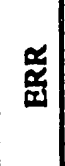 & 总 & 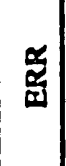 & 总 & $\begin{array}{l}\stackrel{x}{a} \\
\text { a }\end{array}$ & $\mid \begin{array}{l}\frac{\sigma}{\alpha} \\
\frac{\alpha}{\omega}\end{array}$ & 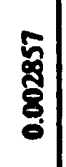 & $\begin{array}{l}5 \\
\bar{్} \\
\\
0\end{array}$ & $\begin{array}{l}\bar{్} \\
\bar{్} \\
0 \\
0\end{array}$ & $\begin{array}{l}5 \\
8 \\
0 \\
0\end{array}$ \\
\hline
\end{tabular}

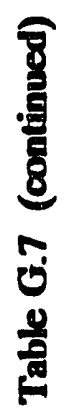

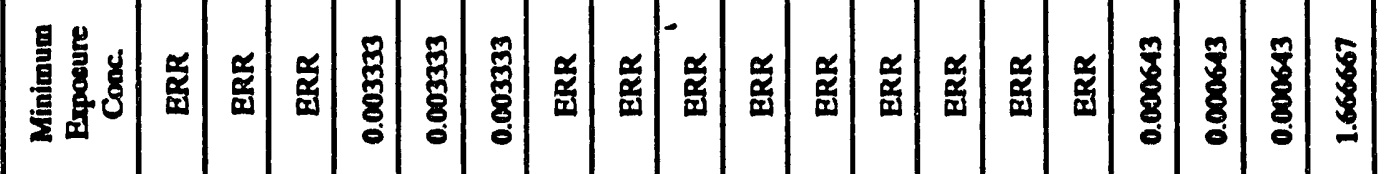

름

$$
\text { ళ్లి శ్లి శ్లి }
$$

害量得

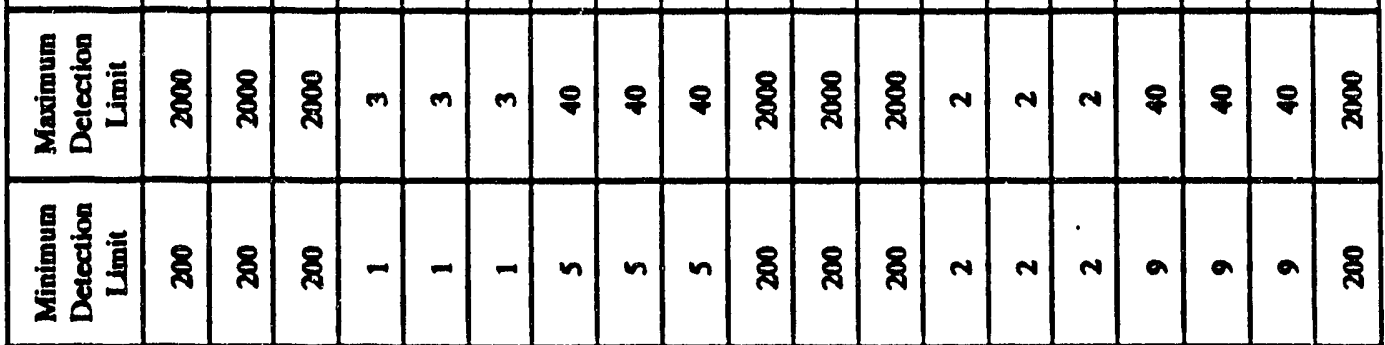

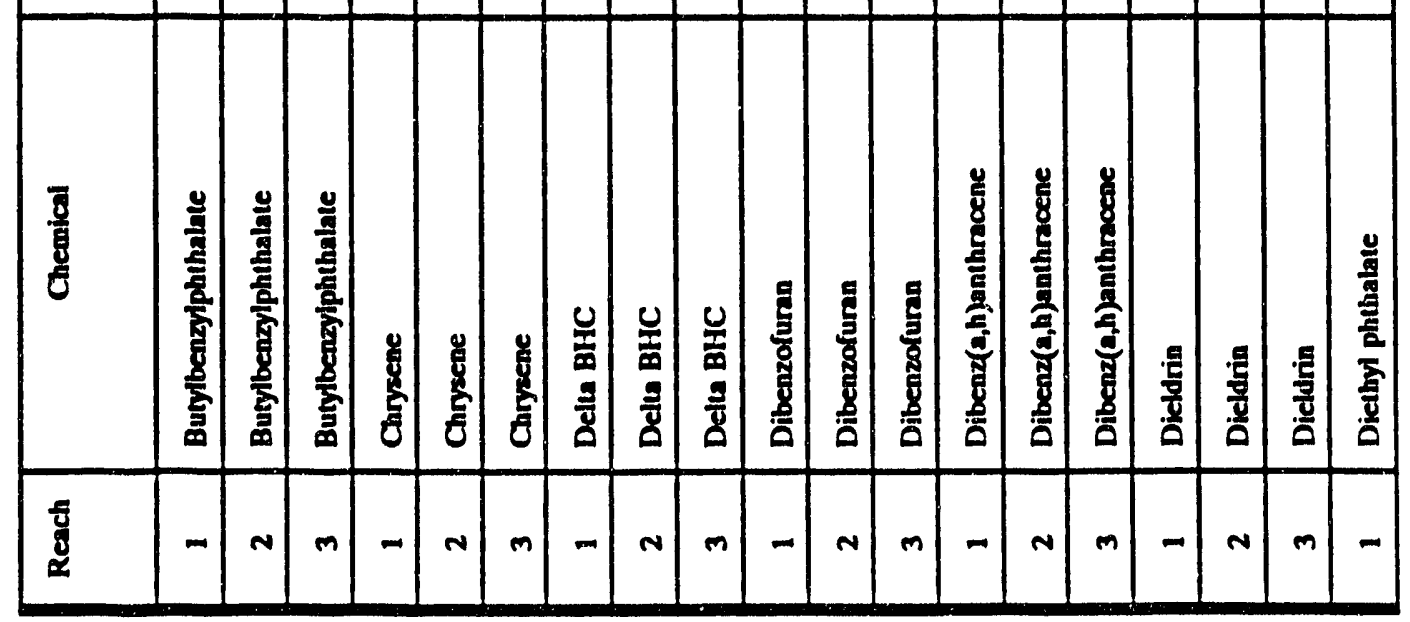




\begin{tabular}{|c|c|c|c|c|c|c|c|c|c|c|c|c|c|c|c|c|c|c|c|}
\hline 量昜 & 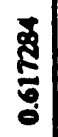 & 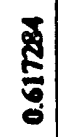 & 細 & $\mid \begin{array}{l}\mathbf{x} \\
\text { 忽 }\end{array}$ & 总 & 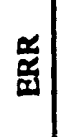 & 蚫 & $\frac{\mathfrak{z}}{\tilde{\alpha}}$ & క్ & క్ & 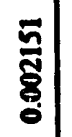 & $\underset{\mathbf{z}}{\mathbf{g}}$ & 悉 & 䀅 & 孚 & $\begin{array}{l}\mathbf{x} \\
\underline{\mathbf{y}}\end{array}$ & $\frac{\underline{u}}{\underline{a}}$ & $\frac{\alpha}{\frac{\alpha}{g}}$ & 畜 \\
\hline 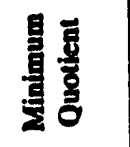 & 赵 & $\frac{8}{8}$ & 葛 & 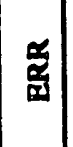 & 苗 & 总 & 总 & 兽 & 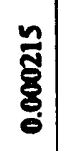 & ह్ & 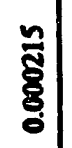 & 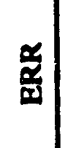 & 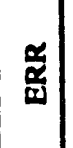 & 善 & $\mid \begin{array}{c}\frac{\alpha}{a} \\
\text { 尊 }\end{array}$ & $\begin{array}{l}\tilde{z} \\
\tilde{\mathbf{v}}\end{array}$ & 畓 & 疍 & 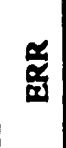 \\
\hline 马零 & $\boldsymbol{N}$ & $\bar{A}$ & & & & & & & 8 & 8 & 8 & 哭 & 号 & 号 & 苛 & 胳 & : & 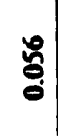 & 응 \\
\hline 晨量尊 & $\begin{array}{l}5 \\
5 \\
6\end{array}$ & $\begin{array}{l}5 \\
8 \\
8 \\
0\end{array}$ & 畓 & 咅 & $\frac{\mathbf{z}}{\mathrm{z}}$ & $\frac{\bar{a}}{\bar{a}}$ & $\overrightarrow{\bar{a}}$ & ब্ & ֻั & స్호 & 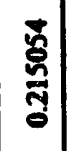 & $\underset{\mathbf{y}}{\mathbf{x}}$ & 茴 & 䋨 & 艾 & 畜 & 总 & 嵒 & $\underset{\mathbf{a}}{\mathbf{a}}$ \\
\hline
\end{tabular}

\begin{tabular}{|c|c|c|c|c|c|c|c|c|c|c|c|c|c|c|c|c|c|c|c|}
\hline 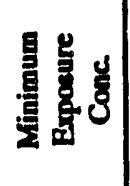 & 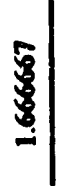 & $\begin{array}{l}5 \\
-5 \\
-3 \\
-3\end{array}$ & $\underset{\tilde{y}}{\tilde{y}}$ & 产 & 啚 & ָे & $\frac{\bar{a}}{a}$ & స్ & 产 & 望 & ̌ㅗㅀ & $\underset{\mathfrak{g}}{\mathfrak{g}}$ & 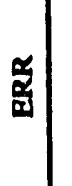 & 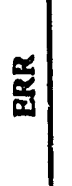 & 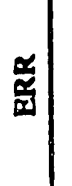 & 鉤 & $\begin{array}{l}\frac{\mathscr{z}}{\mathbf{z}} \\
\frac{\mathbf{g}}{2}\end{array}$ & 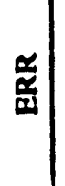 & $\begin{array}{l}\frac{\alpha}{\alpha} \\
\frac{z}{a}\end{array}$ \\
\hline 总 & $\Phi$ & జి & & & & 8 & षิ) & 8 & छू & ళ్రి & ళ్ & & & & & & & & \\
\hline 量昜 & ళ్రి & ళ్రి & ళ్రి & శ్రి & ఫ్రి & ళ్స & ళ్రి & ఫ్రి & శ్రి & ళ్రి & క్రి & 8 & 우 & \& & 8 & 8 & 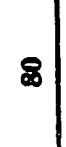 & ఫ్సి & ళ్ \\
\hline 量量戛 & ళ్సి & ళ్వి & ళ్సి & \&్రి & ళ్ & ఫి & క్సి & ళ్సి & ర్సి & శ్ని & ళ్ & $n$ & $n$ & $n$ & $a$ & a & $a$ & a) & $a$ \\
\hline
\end{tabular}

\begin{tabular}{|c|c|c|c|c|c|c|c|c|c|c|c|c|c|c|c|c|c|c|c|}
\hline 夏 & 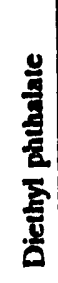 & 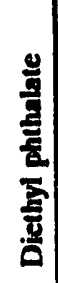 & 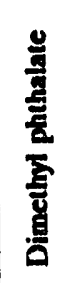 & 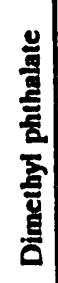 & 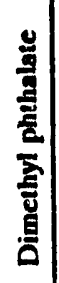 & 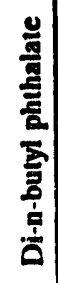 & 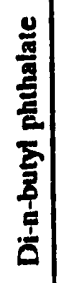 & 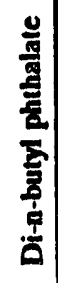 & 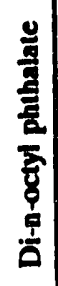 & 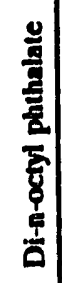 & 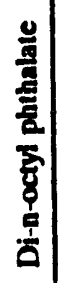 & 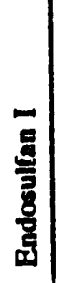 & 馬 & 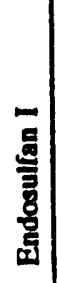 & 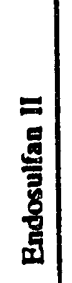 & 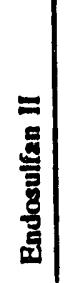 & 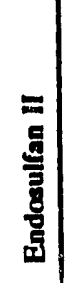 & 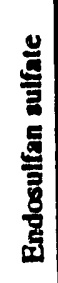 & 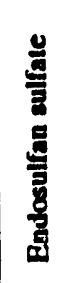 \\
\hline$\overline{7}$ & $\sim$ & $m$ & - & $N$ & $m$ & - & $N$ & $m$ & - & $N$ & $m$ & - & $N$ & $m$ & - & $N$ & $m$ & - & $N$ \\
\hline
\end{tabular}




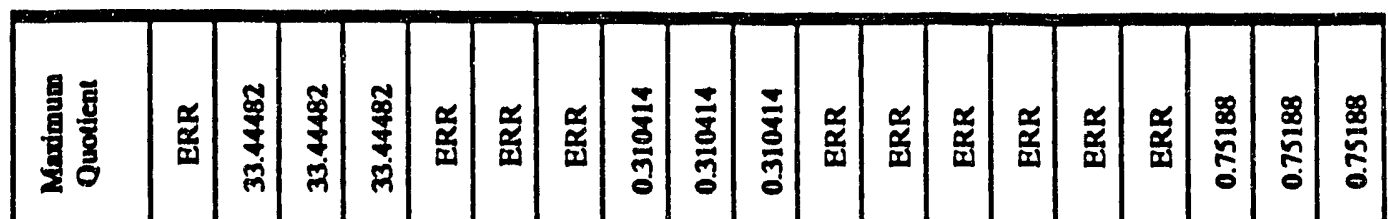

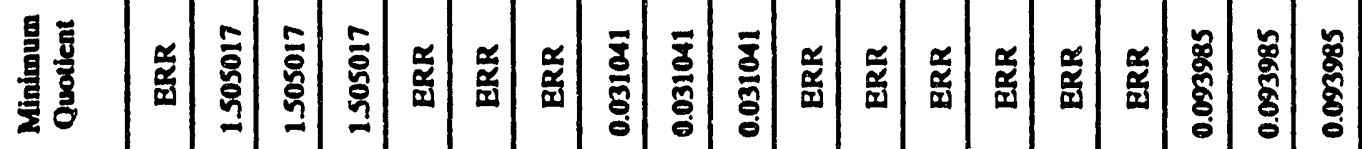

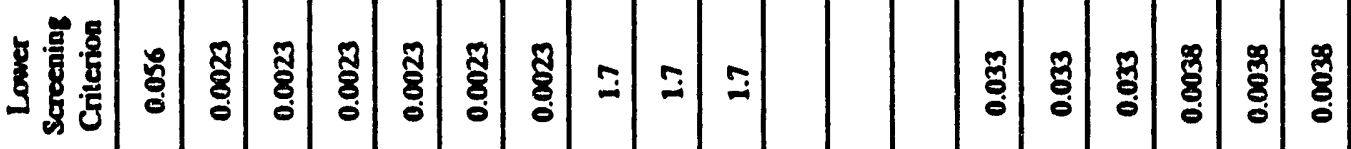

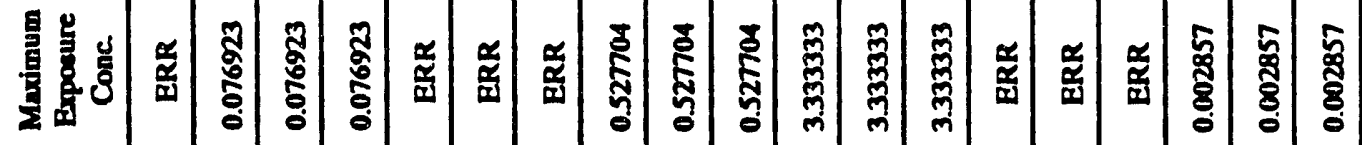

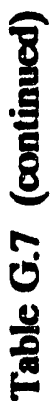

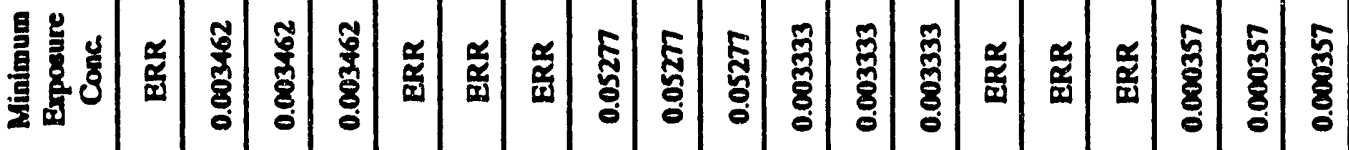

离

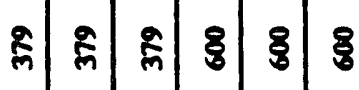

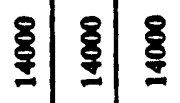

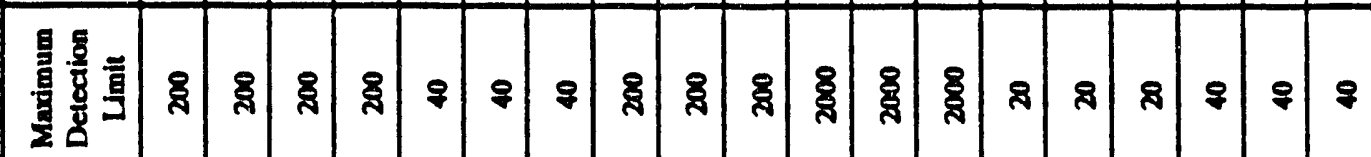

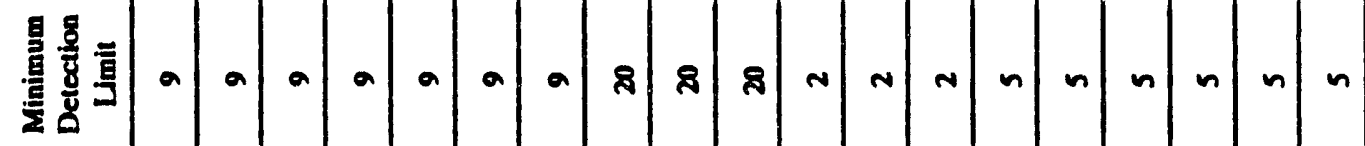

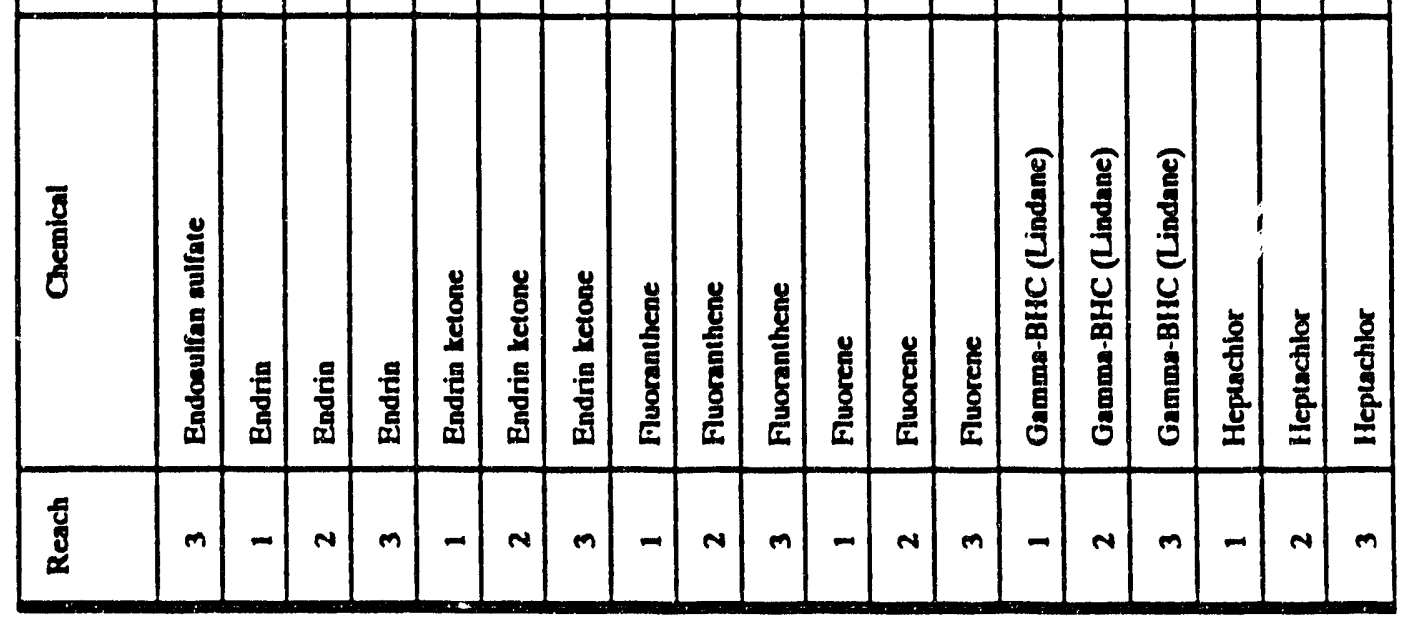




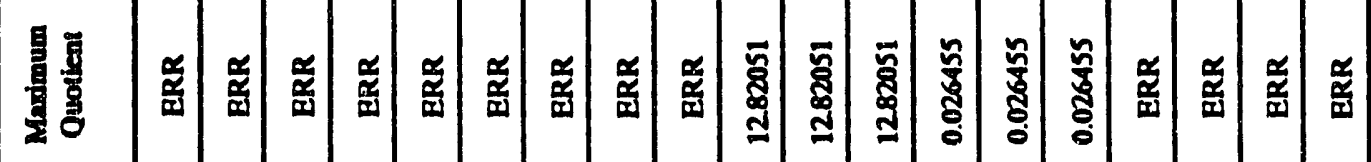

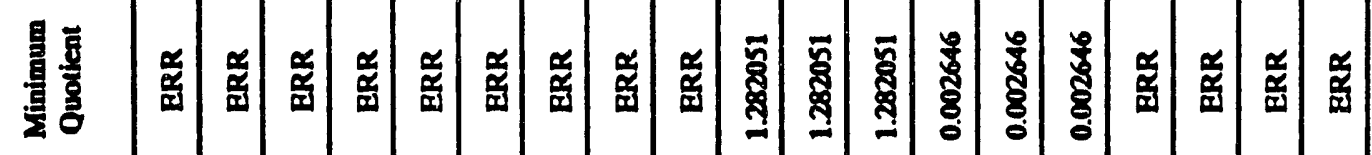

营

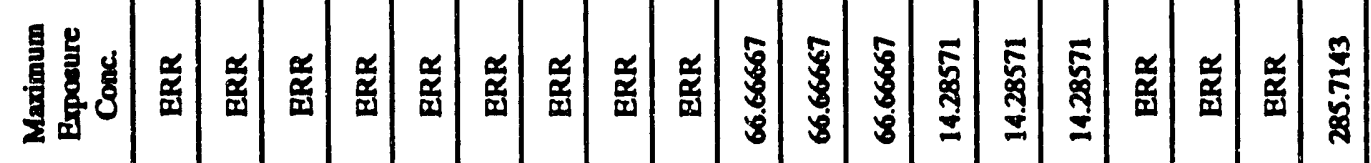

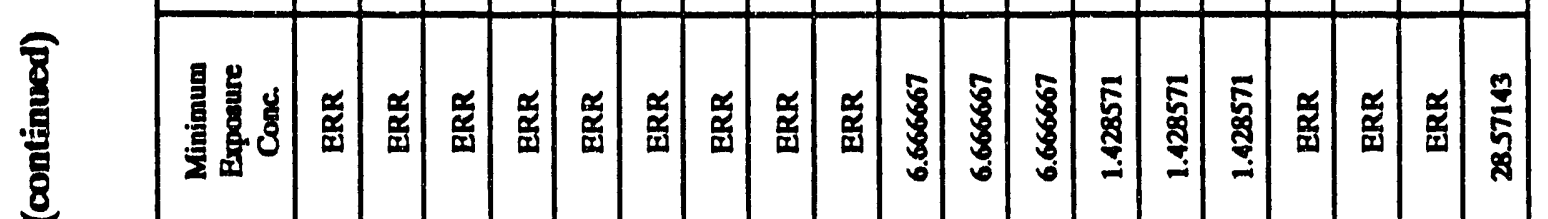

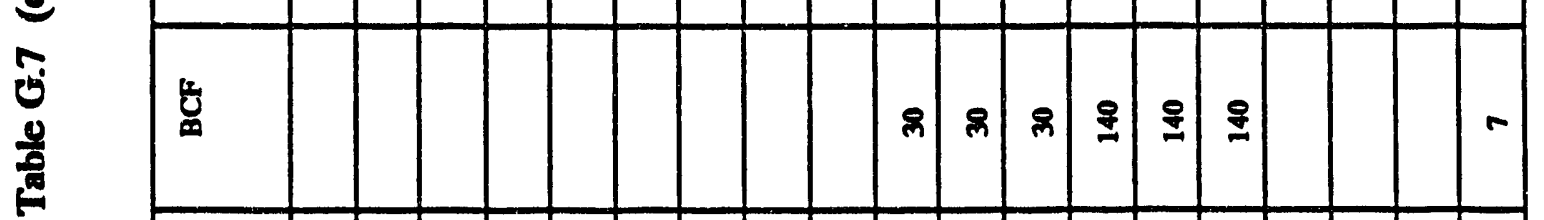

\begin{tabular}{|c|c|c|c|c|c|c|c|c|c|c|c|c|c|c|c|c|c|c|c|}
\hline & & & & & & & & & & & & & & & & & & & \\
\hline 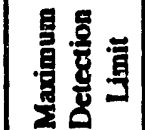 & \% & q & \% & ళ్రి & ళ్రి & క్సి & శ్రి & క్రి & ళ్రి & క్సి & క్రి & ళ్రి & క్రి & శ్రి & క్సి & 8 & ర్రి & 8 & ళ్ని \\
\hline
\end{tabular}

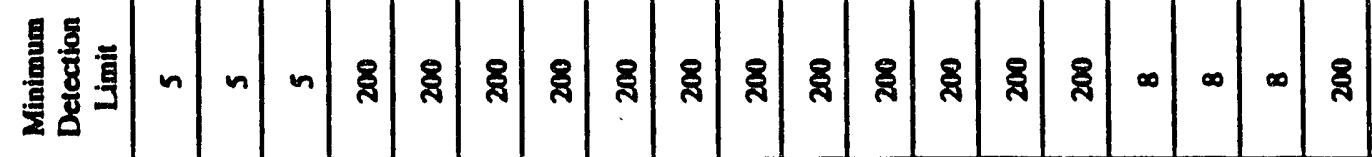

\begin{tabular}{|c|c|c|c|c|c|c|c|c|c|c|c|c|c|c|c|c|c|c|c|}
\hline$\frac{\bar{g}}{8}$ & 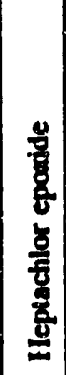 & 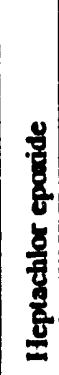 & 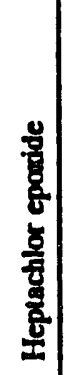 & 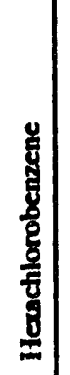 & 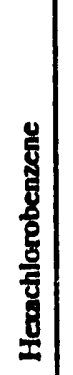 & 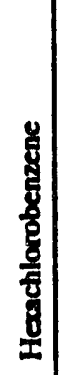 & 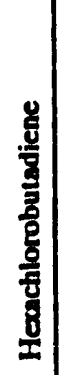 & 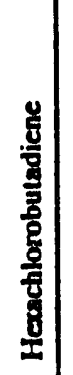 & 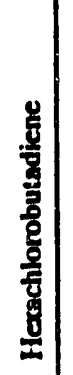 & 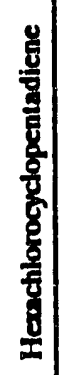 & 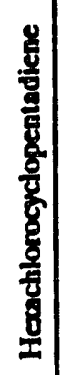 & 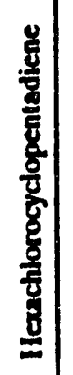 & 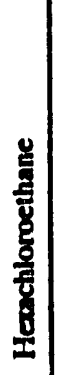 & 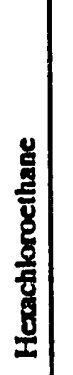 & 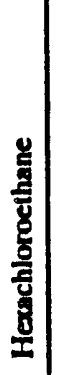 & 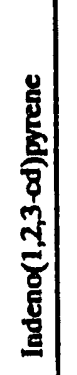 & 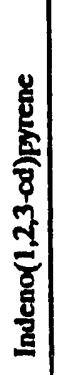 & 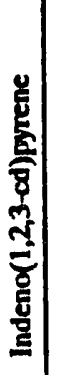 & 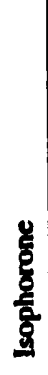 \\
\hline 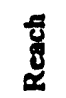 & - & $N$ & $\mathrm{~m}$ & -1 & $\mathbf{N}$ & $m$ & - & $N$ & $m$ & - & $N$ & $m$ & - & $N$ & $m$ & - & $N$ & $m$ & - \\
\hline
\end{tabular}




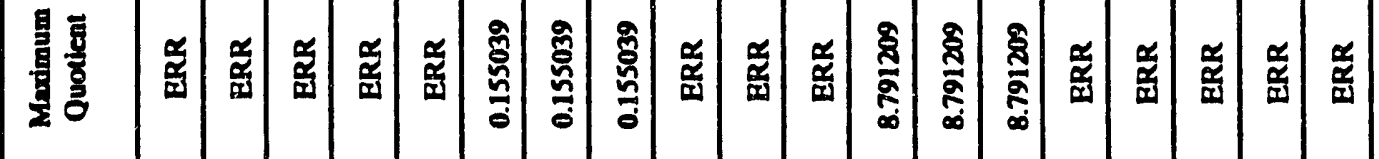

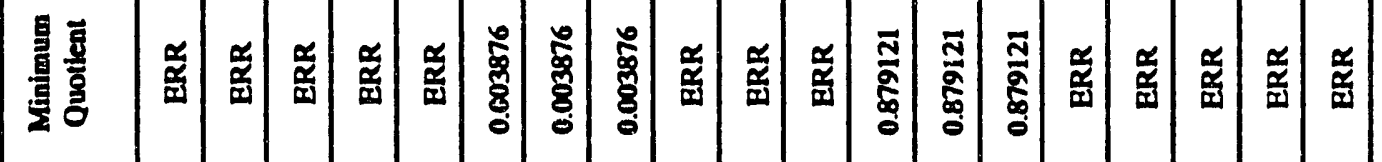

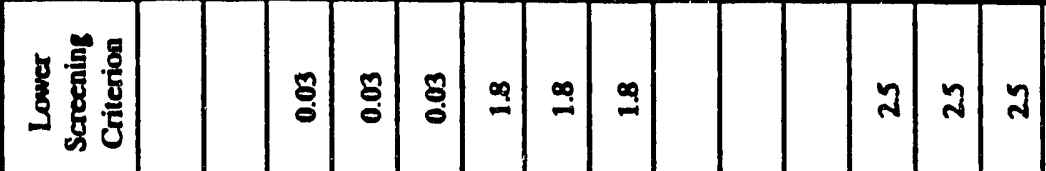

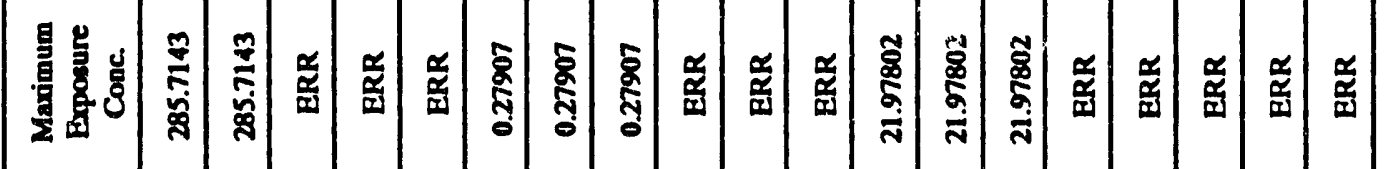

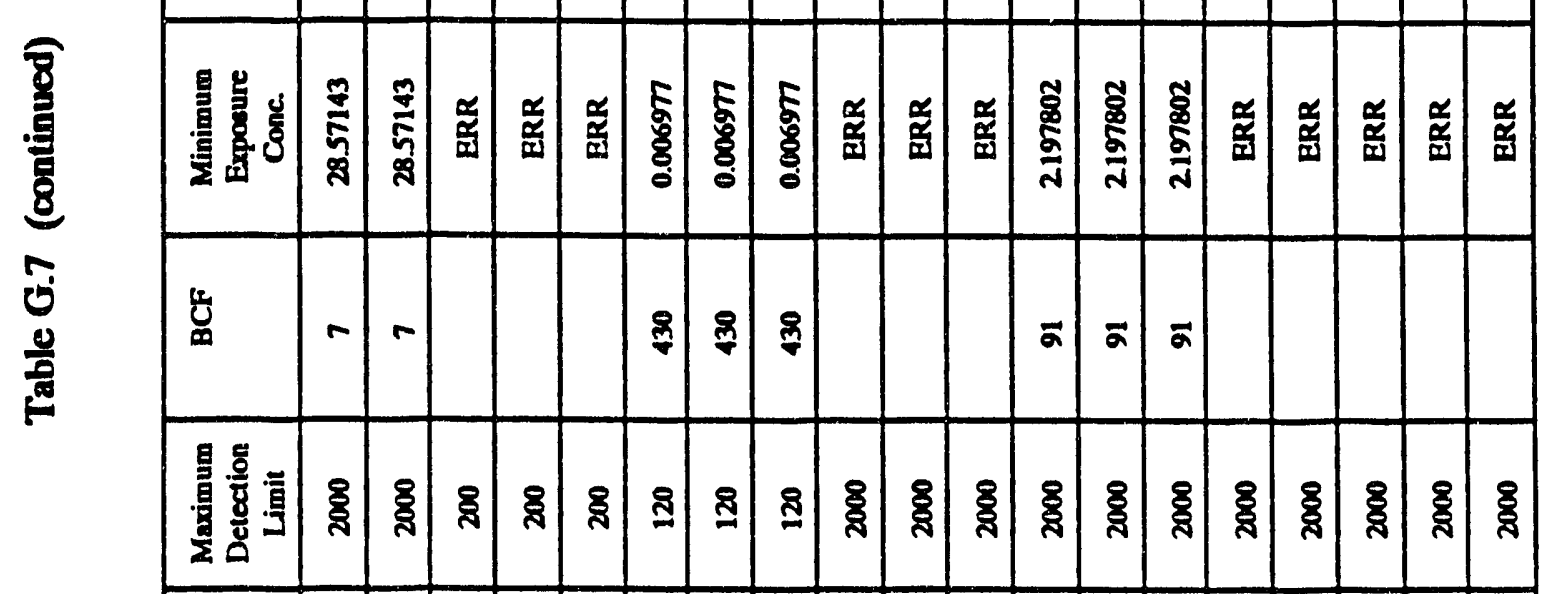

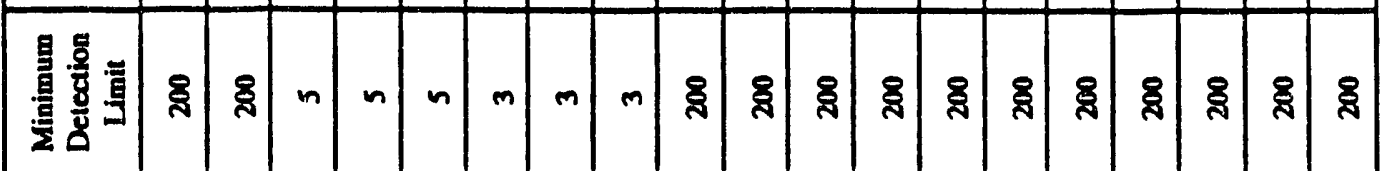

\begin{tabular}{|c|c|c|c|c|c|c|c|c|c|c|c|c|c|c|c|c|c|c|c|}
\hline $\begin{array}{l}\bar{\delta} \\
\text { E }\end{array}$ & 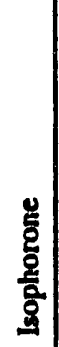 & $\begin{array}{l}\mathbf{g} \\
\text { 옹 } \\
\text { 홍 }\end{array}$ & 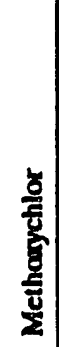 & 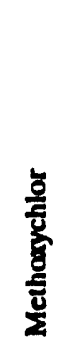 & 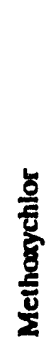 & 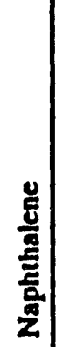 & 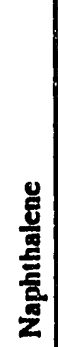 & 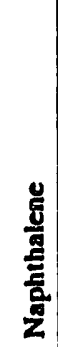 & $\begin{array}{l}\mathbf{u} \\
\overline{5} \\
\frac{8}{2} \\
\frac{2}{z}\end{array}$ & 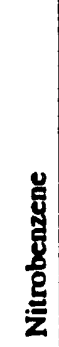 & 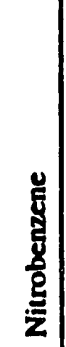 & 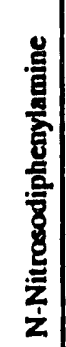 & 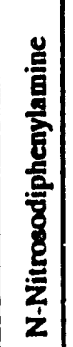 & 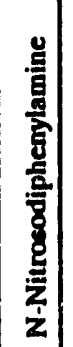 & 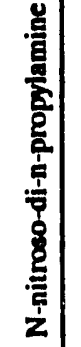 & 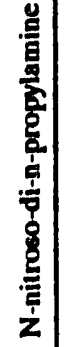 & 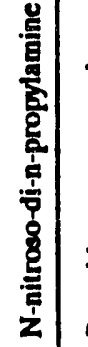 & 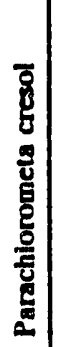 & 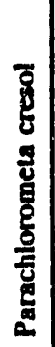 \\
\hline है & $N$ & $m$ & - & N & $m$ & -1 & $N$ & $m$ & - & $N$ & $m$ & - & $N$ & m & - & $N$ & $m$ & - & $N$ \\
\hline
\end{tabular}




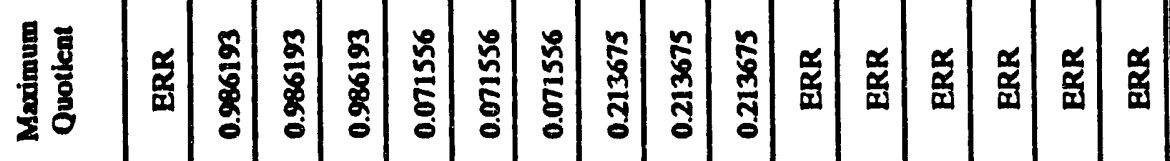

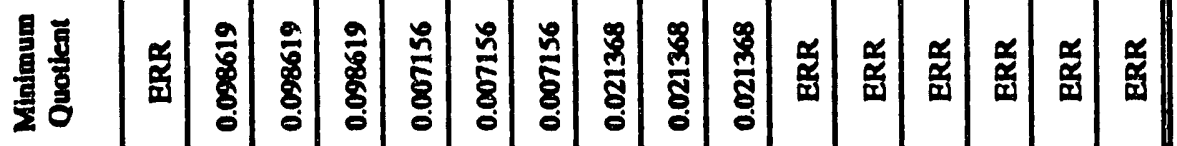

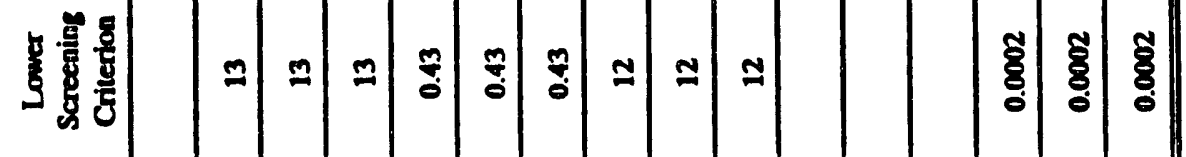

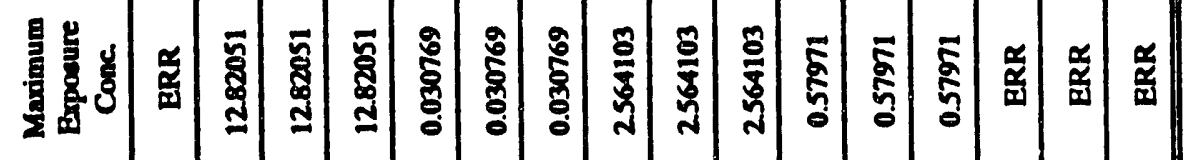

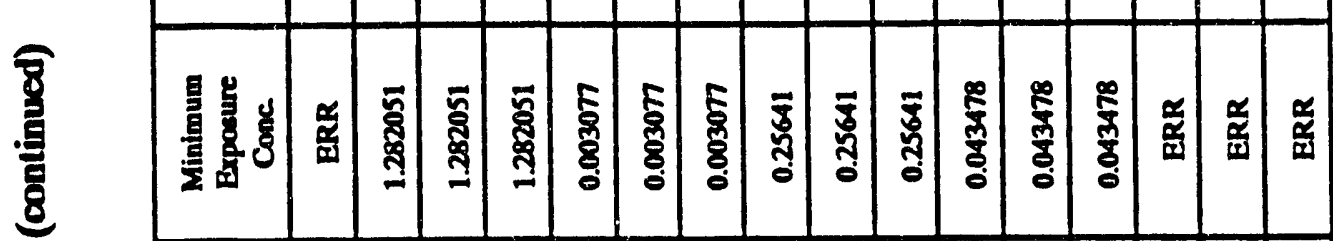

$\frac{1}{3}$

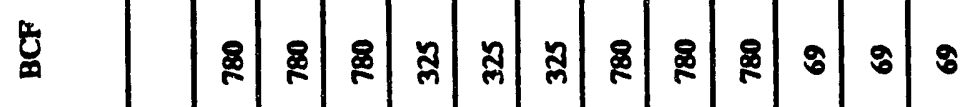

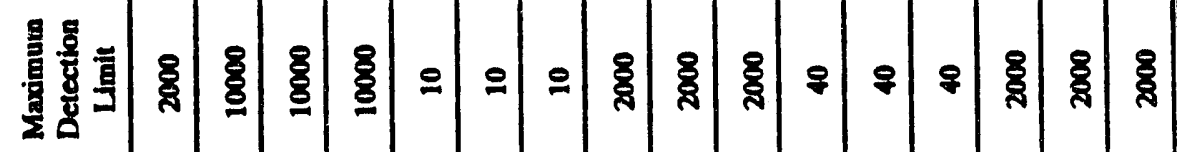

量客苜

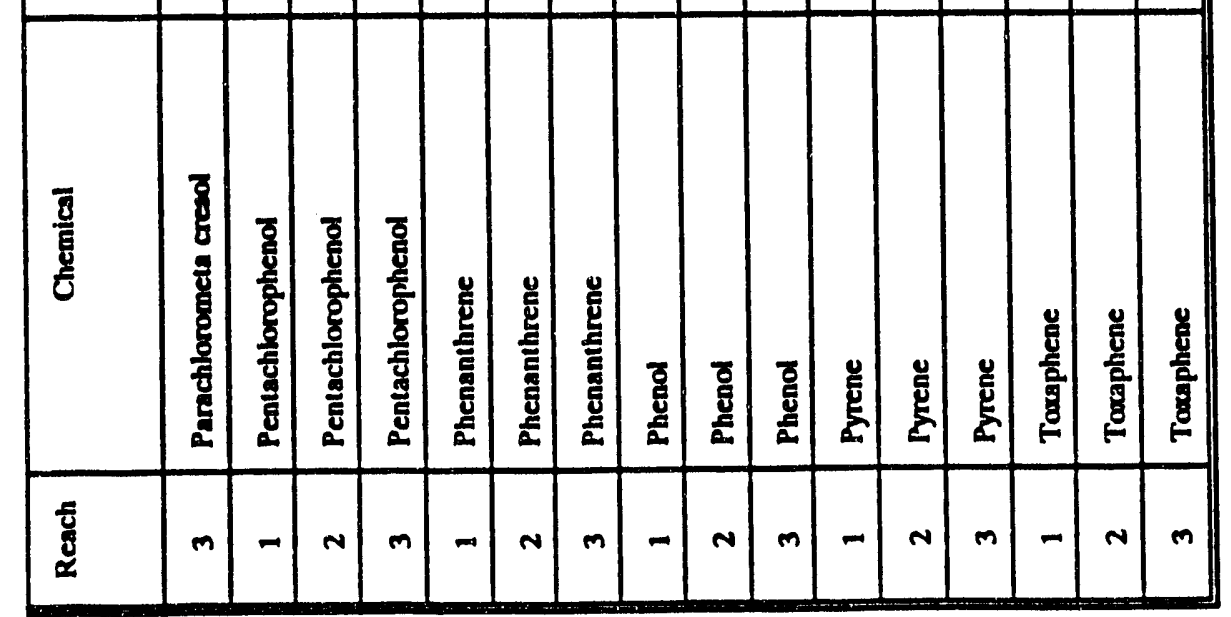




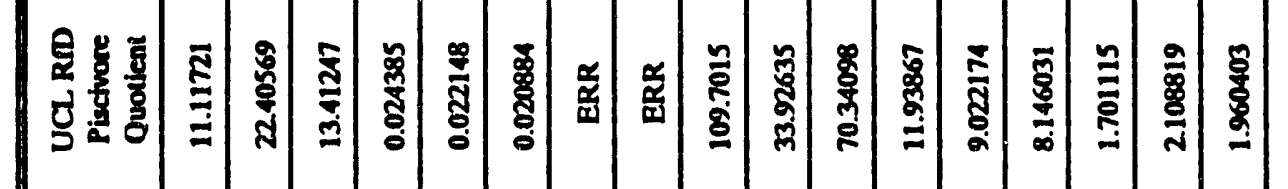

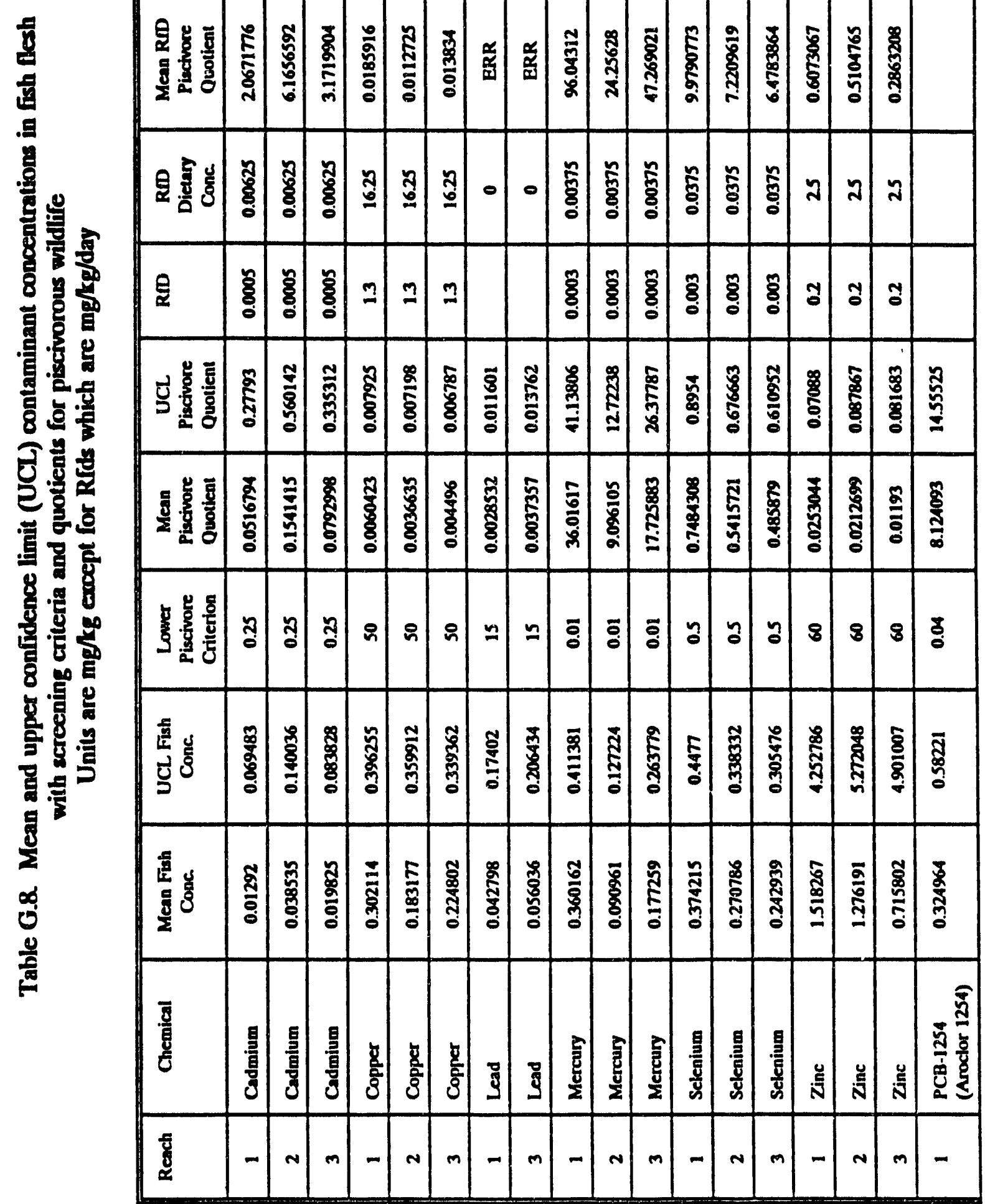




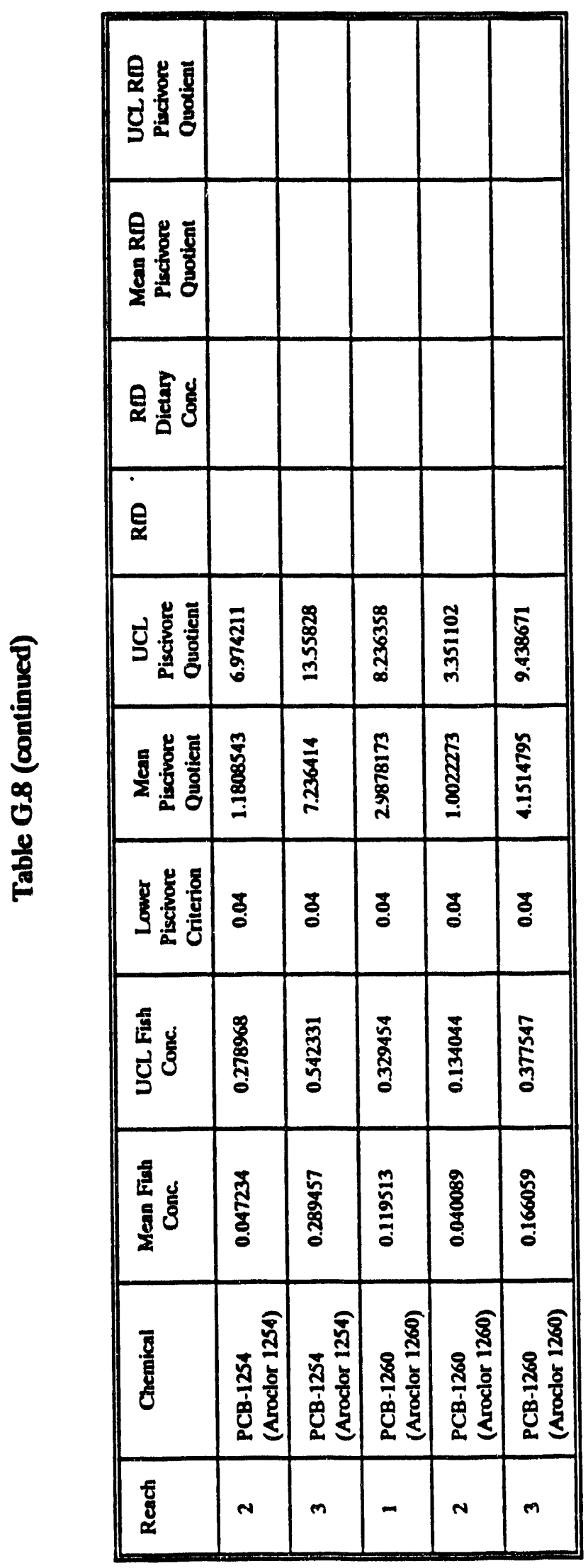


$\frac{8}{8}$

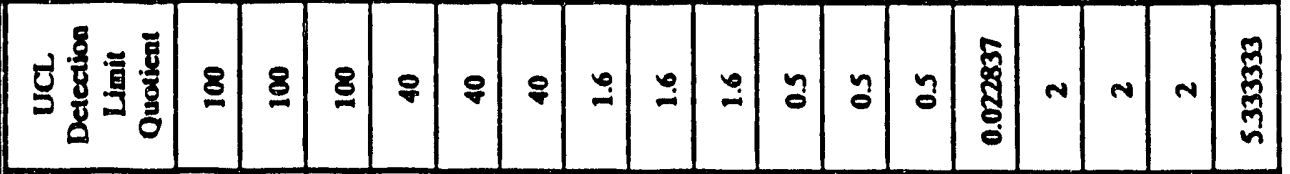

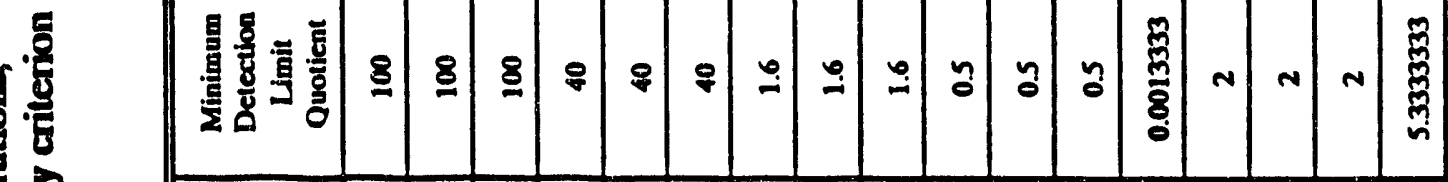

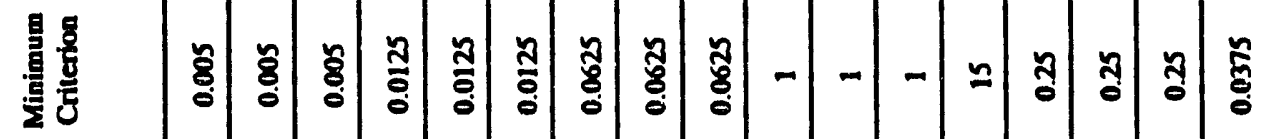

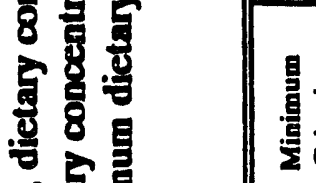
, 8 을 政尊

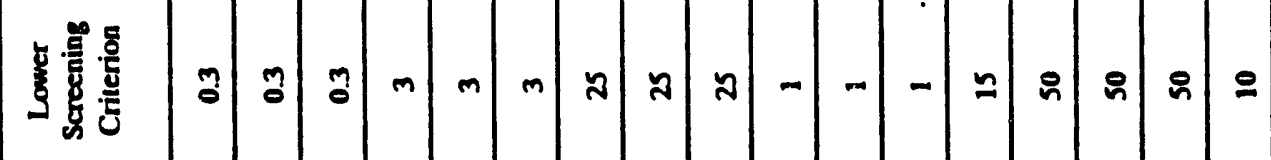
的 跑 훕.

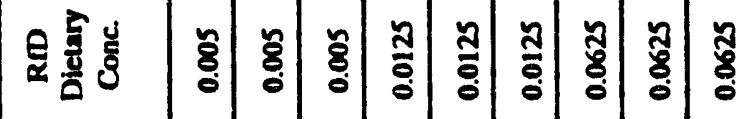
응

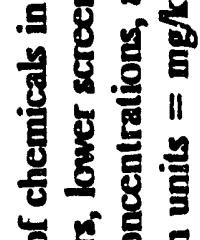
농 혼 글 . 8 80 氞 首尊

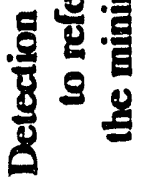

8ิ

卷

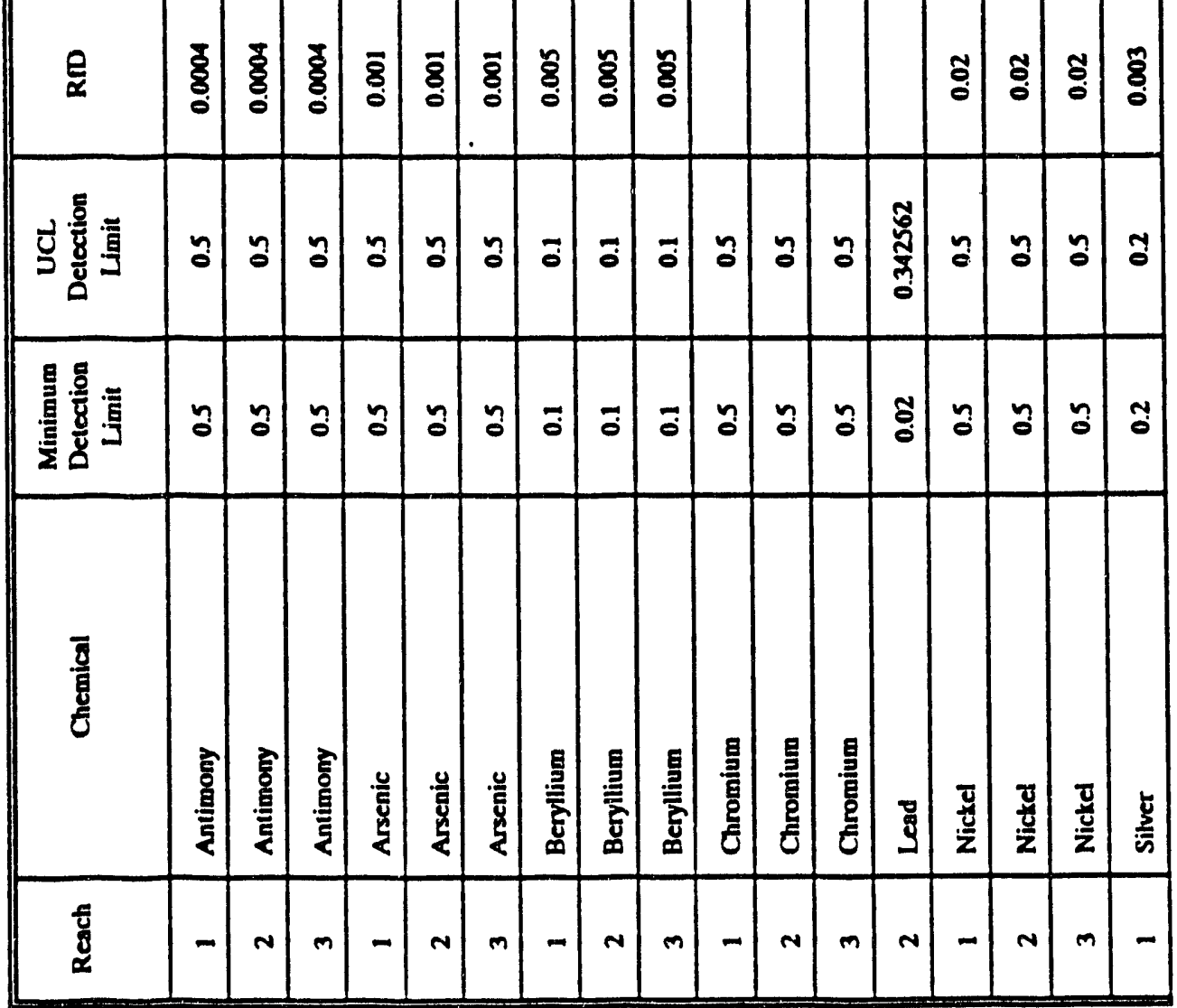




\begin{tabular}{|c|c|c|c|c|c|c|c|c|c|c|c|c|c|c|c|c|c|c|c|c|}
\hline 芿 & 㖞 & $\begin{array}{l}\bar{\Xi} \\
\vdots \\
\Xi\end{array}$ & స్ & 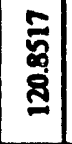 & $\stackrel{2}{\stackrel{2}{ \pm}}$ & हू & 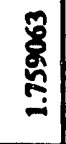 & 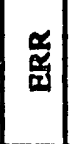 & 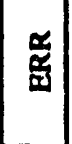 & $\mid \begin{array}{c}\alpha \\
\tilde{x}\end{array}$ & 嶨 & 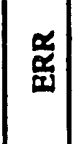 & $\mid \begin{array}{l}\mathbf{z} \\
\mathbf{y}\end{array}$ & 紊 & 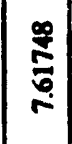 & 吝 & 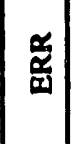 & $\frac{\tilde{a}}{\tilde{g}}$ & 响 & ๙ิ సે \\
\hline 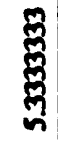 & 㤏 & $\frac{\sqrt[m]{n}}{\sqrt{2}}$ & $\frac{\sqrt[5]{n}}{\beth}$ & 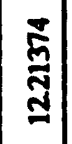 & $\frac{\mathscr{D}}{E}$ & $\frac{\infty}{E}$ & $\frac{\text { E }}{E}$ & 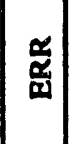 & $\frac{\widetilde{\alpha}}{\underline{\alpha}}$ & 总 & 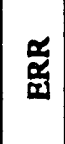 & 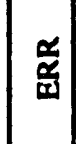 & $\mid \begin{array}{l}\mathbf{z} \\
\mathbf{z}\end{array}$ & $\stackrel{\infty}{0}$ & 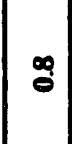 & \& & $\mid \begin{array}{l}\frac{\alpha}{\sigma} \\
\text { a }\end{array}$ & 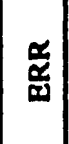 & 惢 & $\begin{array}{l}\text { p్ } \\
\text { n్ } \\
\text { nू }\end{array}$ \\
\hline
\end{tabular}

$$
\text { 旁 }
$$

으

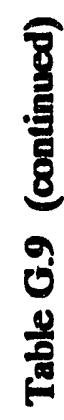

(c)

มุ มุ

蒫

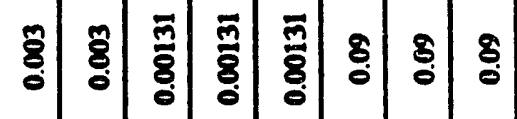

$\div \div \overline{0}$

है.

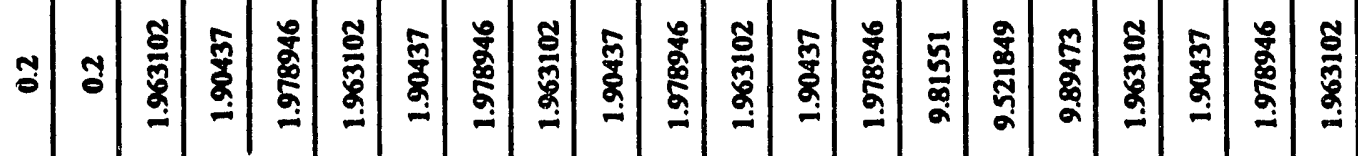

ว 2 :

\begin{tabular}{|c|c|c|c|c|c|c|c|c|c|c|c|c|c|c|c|c|c|c|c|c|}
\hline$\frac{\mathbf{z}}{5}$ & 站 & 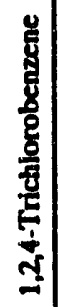 & 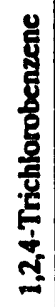 & 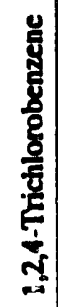 & 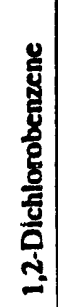 & 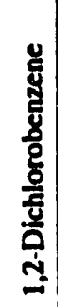 & 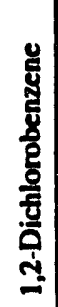 & 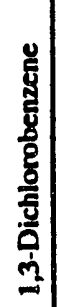 & 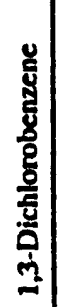 & 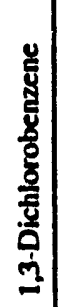 & 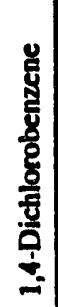 & 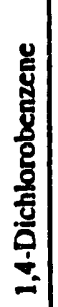 & 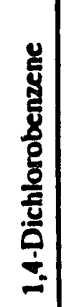 & 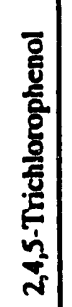 & 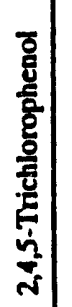 & 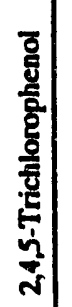 & 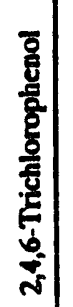 & 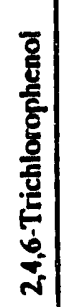 & 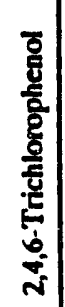 & 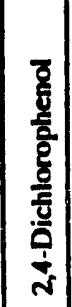 \\
\hline$N$ & $m$ & - & r & $m$ & - & N & $m$ & -1 & $N$ & $m$ & - & $N$ & m & - & $N$ & $m$ & - & $N$ & $m$ & - \\
\hline
\end{tabular}




\begin{tabular}{|c|c|c|c|c|c|c|c|c|c|c|c|c|c|c|c|c|c|c|c|c|}
\hline 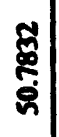 & 兽 & $\begin{array}{l}\text { 号 } \\
\text { बें }\end{array}$ & 葛 & 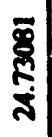 & 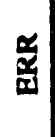 & $\frac{\widetilde{a}}{\underline{a}}$ & 啚 & 畓 & 茴 & 夢 & 宓 & 离 & 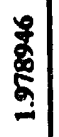 & 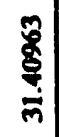 & 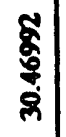 & $\begin{array}{c}\dot{\vec{n}} \\
\dot{m} \\
\dot{m}\end{array}$ & 苗 & 夠 & 总 & $\frac{\sigma}{\frac{\sigma}{n}}$ \\
\hline 苫 & 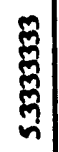 & $\stackrel{\infty}{0}$ & $\underset{0}{0}$ & $\stackrel{0}{0}$ & 茎 & 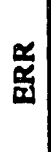 & 罟 & 茎 & 苅 & $\underset{\frac{\alpha}{g}}{\tilde{z}}$ & ร & ชี & : & mु & స్. & न & 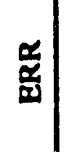 & 善 & 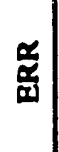 & กี้ \\
\hline : & 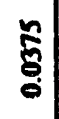 & ఫุ & ָุ & নุ & 㥯 & $\frac{a}{\tilde{y}}$ & 湆 & 容 & 萝 & 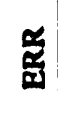 & - & - & - & శ్ర్రి & శ్ర్ర్ర & $\begin{array}{l}7 \\
8 \\
0\end{array}$ & 总 & 善 & $\underset{\mathrm{z}}{\mathrm{\alpha}}$ & z: \\
\hline
\end{tabular}

8
8
8
8
0
0
0
0
0

กิ

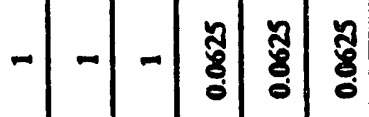

:

ళั

:

๕.

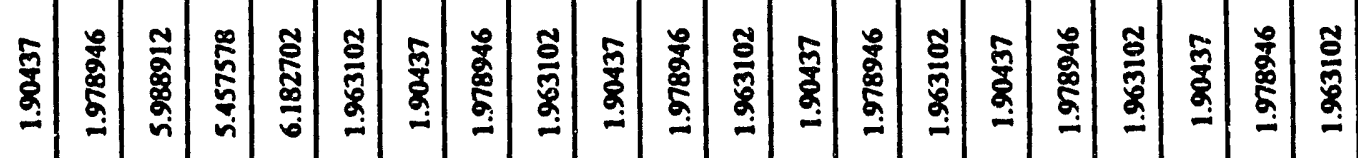

ว

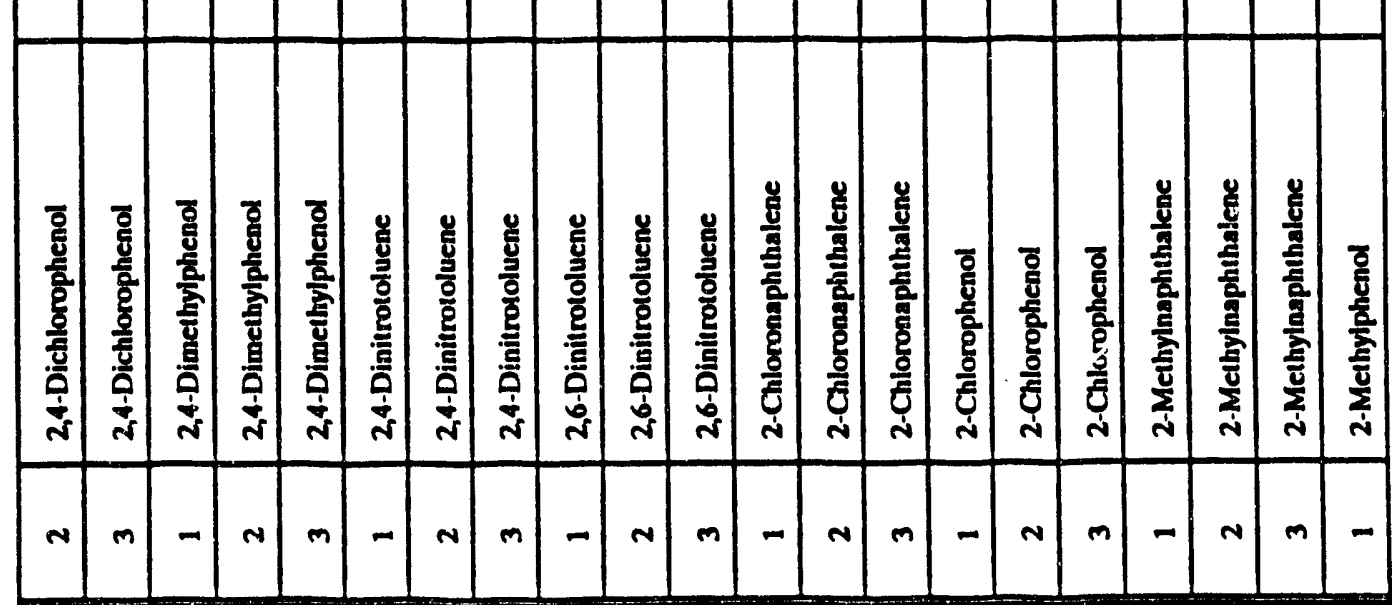




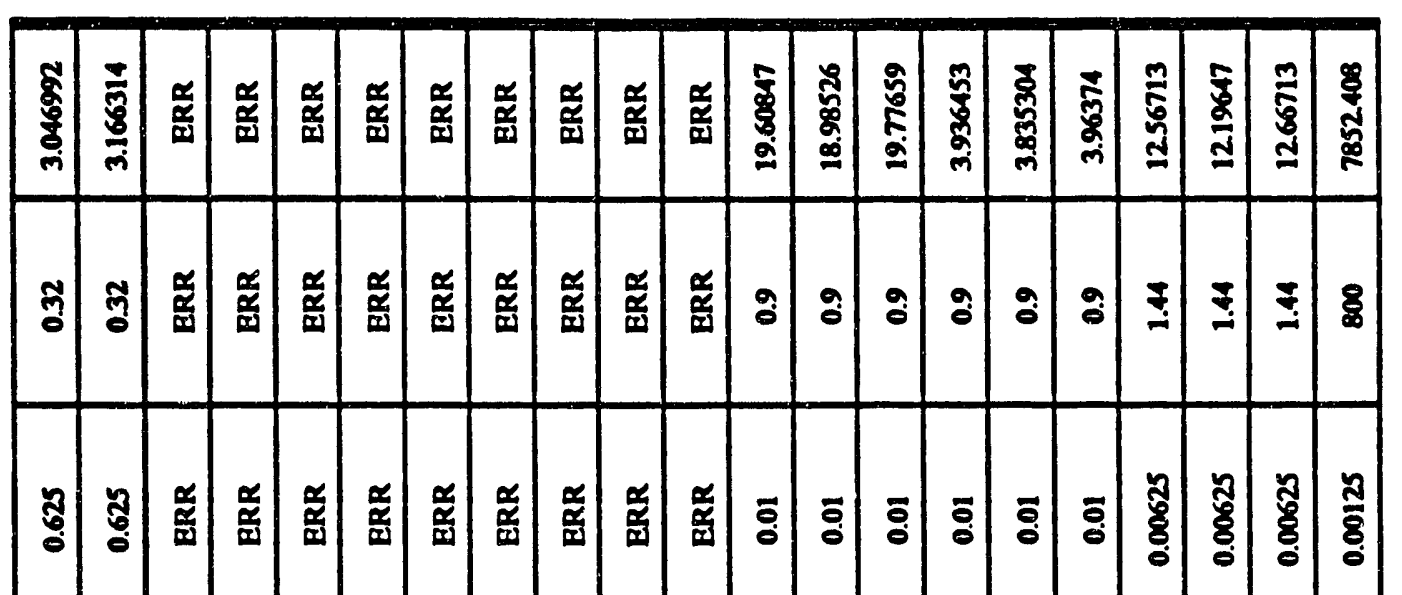

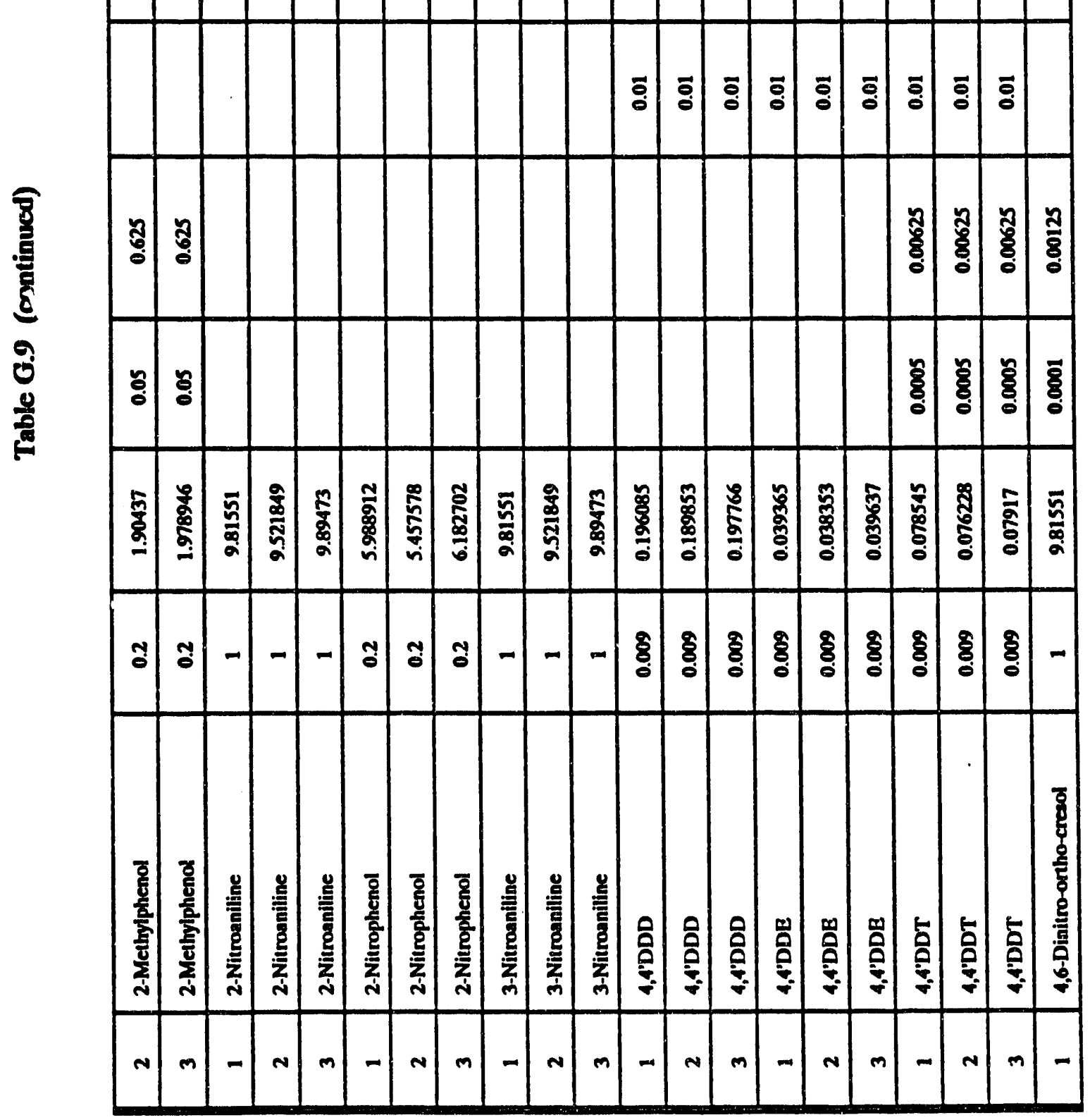




\begin{tabular}{|c|c|c|c|c|c|c|c|c|c|c|c|c|c|c|c|c|c|c|c|c|}
\hline 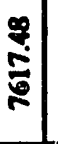 & 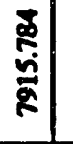 & 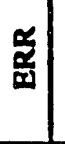 & $\underset{\mathbf{u}}{\stackrel{\alpha}{*}}$ & $\begin{array}{l}\mathbf{x} \\
\mathbf{u} \\
\mathbf{u}\end{array}$ & $\begin{array}{l}\text { ఫ్స్ర్ } \\
\text { స్ }\end{array}$ & $\begin{array}{l}\mathbf{\Phi} \\
\dot{8} \\
\dot{p}\end{array}$ & 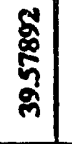 & 㲎 & $\begin{array}{l}\underline{x} \\
\frac{\alpha}{\sigma}\end{array}$ & 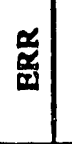 & $\frac{n}{\tilde{c}}$ & 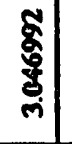 & 离 & $\begin{array}{l}\text { హे } \\
\text { హ్ }\end{array}$ & 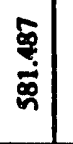 & $\begin{array}{l}\text { : } \\
\text { స్ } \\
\text { క్ర }\end{array}$ & 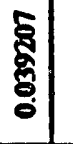 & 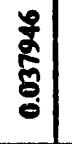 & $\begin{array}{l}\text { 号 } \\
\text { 恖 }\end{array}$ & 蒿 \\
\hline 8 & 8 & $\begin{array}{l}\stackrel{\alpha}{*} \\
\mathbf{y}\end{array}$ & 总 & 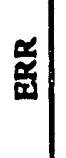 & + & -1 & -1 & $\begin{array}{l}\underset{\mathbf{a}}{\mathbf{x}} \\
\mathbf{a}\end{array}$ & $\begin{array}{l}\mathbf{u} \\
\frac{\tilde{U}}{\square}\end{array}$ & $\underset{\mathbf{y}}{\mathbf{y}}$ & ซ్ ช్ & กิ้ & กิ & 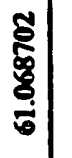 & $\begin{array}{l}\mathbf{5} \\
\overline{6} \\
\frac{8}{6} \\
\overline{6}\end{array}$ & 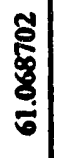 & 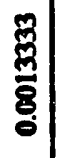 & 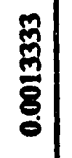 & 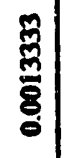 & 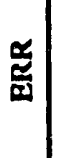 \\
\hline 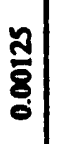 & 妾 & 咅 & $\begin{array}{l}\stackrel{\alpha}{a} \\
\text { 畄 }\end{array}$ & 善 & : & \% & ¿ू. & $\begin{array}{l}\text { 舀 } \\
\text { 芴 }\end{array}$ & $\begin{array}{l}\mathbf{z} \\
\text { 总 }\end{array}$ & 总 & శ్ర: & ฉ્. & ఫ్ర & 商 & 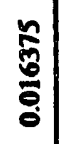 & 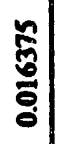 & šs & $\underset{0}{\sim}$ & 气̂. & $\frac{\mathfrak{\alpha}}{\frac{\tilde{y}}{\mathbf{y}}}$ \\
\hline $\begin{array}{l}\text { â } \\
\frac{8}{8} \\
0\end{array}$ & a & & & & $\ddot{0}$ & ¿ั: & 气̆ & & & & : & : & స్: & 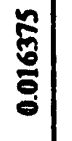 & $\frac{\kappa}{50}$ & 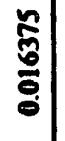 & $\frac{n}{0}$ & $\frac{2}{0}$ & $\begin{array}{c}a \\
0\end{array}$ & \\
\hline$\overline{8}$ & $\overline{8}$ & & & & 突 & ठ্ট్ర & $\begin{array}{l}\text { ఫ్ } \\
\end{array}$ & & & & है & : & ¿े. & 蒿 & 馬 & 商 & 8 & 8 & छ) & \\
\hline 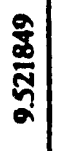 & 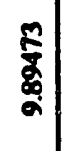 & $\frac{\delta}{\tilde{s}}$ & 亳 & 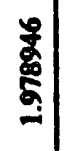 & 号 & 商 & 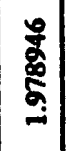 & 气ั & 章 & 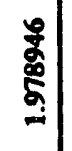 & s్ & 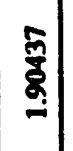 & 蜜 & 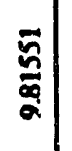 & 芫 & 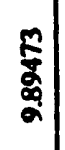 & 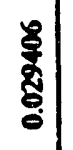 & 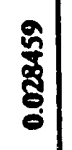 & 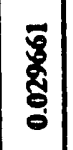 & 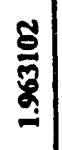 \\
\hline- & - & ชุ & 구 & 종 & శ & พั) & 리 & $\tilde{o}$ & ¿゙ & 핑 & तี & $\mathfrak{E}$ & ㄹ. & - & - & -1 & $\overline{8}$ & $\bar{\delta}$ & $\overline{8}$ & บี \\
\hline 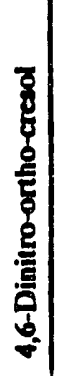 & 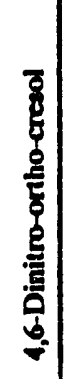 & 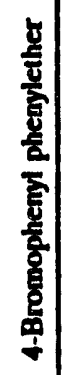 & 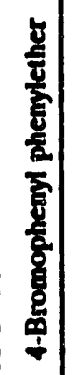 & 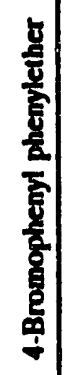 & 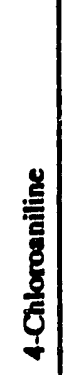 & 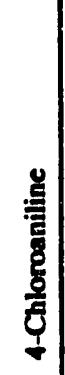 & 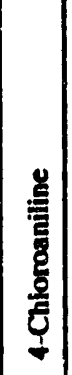 & 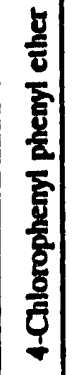 & 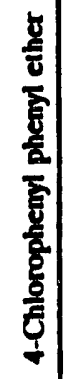 & 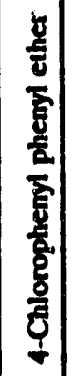 & 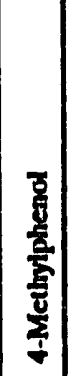 & 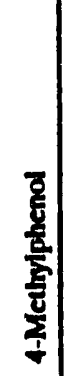 & 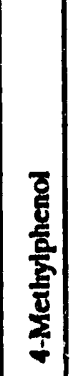 & 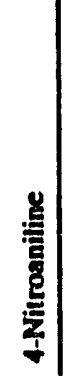 & 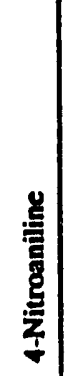 & 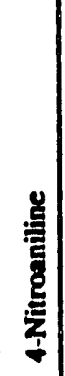 & 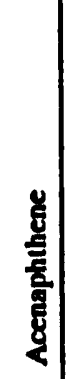 & 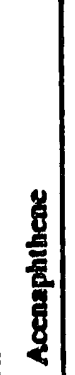 & 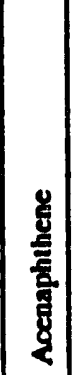 & 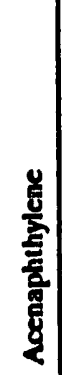 \\
\hline$N$ & $m$ & - & $N$ & $m$ & - & $N$ & $n$ & -1 & $N$ & $m$ & -1 & $N$ & $m$ & - & $N$ & $m$ & -1 & $N$ & $m$ & - \\
\hline
\end{tabular}




\begin{tabular}{|c|c|c|c|c|c|c|c|c|c|c|c|c|c|c|c|c|c|c|c|c|}
\hline 畄 & 尊 & 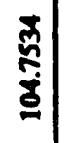 & $\begin{array}{l}\overline{\mathbf{\xi}} \\
\vdots \\
\vdots\end{array}$ & 气̂. & 曾 & 急 & 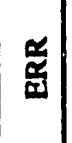 & 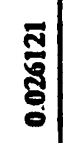 & 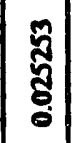 & 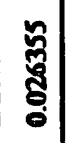 & $\begin{array}{l}\overline{\bar{\alpha}} \\
\overline{0}\end{array}$ & 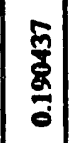 & $\left|\begin{array}{c}0 \\
\vdots \\
\vdots \\
\vdots \\
\vdots\end{array}\right|$ & $\mid$\begin{tabular}{|c|} 
\\
$\frac{\alpha}{2}$
\end{tabular} & $\mid \begin{array}{l}\alpha \\
\tilde{z}\end{array}$ & 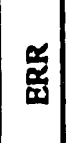 & 总 & $\mid$\begin{tabular}{|l} 
总 \\
\end{tabular} & 芯 & 畄 \\
\hline 罯 & 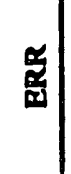 & 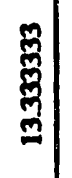 & 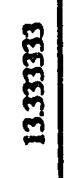 & 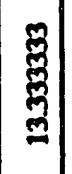 & $\frac{\mathscr{z}}{\mathbf{v}}$ & 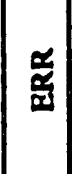 & 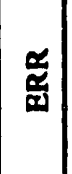 & 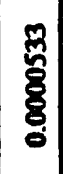 & 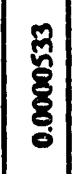 & 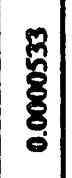 & : & : & : & $\mid \begin{array}{l}\mathbf{z} \\
\text { 音 }\end{array}$ & 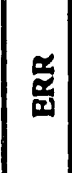 & 苗 & $\left|\begin{array}{l}\mathbf{x} \\
\mathbf{z}\end{array}\right|$ & 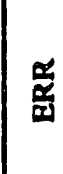 & 站 & $\frac{\tilde{z}}{\underline{y}}$ \\
\hline$\underline{z}$ & $\mid \begin{array}{l}\tilde{w} \\
\text { 离 }\end{array}$ & $\begin{array}{l}0 \\
0 \\
0 \\
0 \\
0\end{array}$ & ธิ & 命 & $\frac{\alpha}{\tilde{y}}$ & $\frac{2}{\frac{x}{2}}$ & $\mid \begin{array}{l}\alpha \\
\tilde{z}\end{array}$ & $\underset{m}{\tilde{m}}$ & $\tilde{m}$ & $\begin{array}{c}\tilde{\omega} \\
\mid\end{array}$ & 8 & \& & n & 畄 & $\mid \begin{array}{l}\text { 芴 } \\
\end{array}$ & $\mid \begin{array}{c}\mathbf{a} \\
\text { 画 }\end{array}$ & $\mid \begin{array}{l}\mathbf{\alpha} \\
\frac{\mathbf{v}}{\mathbf{v}}\end{array}$ & $\mid \begin{array}{l}\mathbf{z} \\
\text { 总 }\end{array}$ & $\frac{3}{3}$ & $\approx$ \\
\hline
\end{tabular}

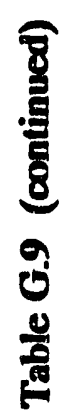

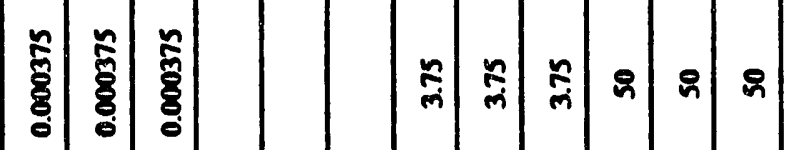

$$
\text { 密 }
$$

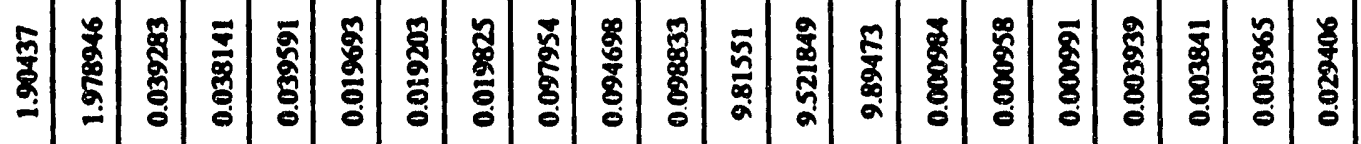

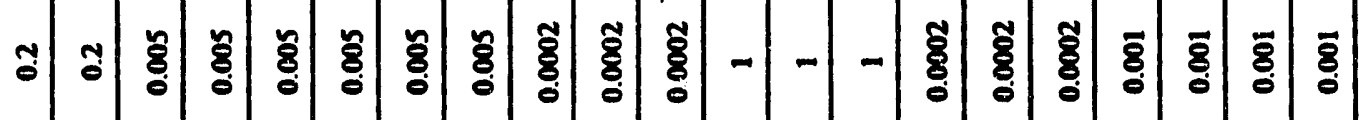

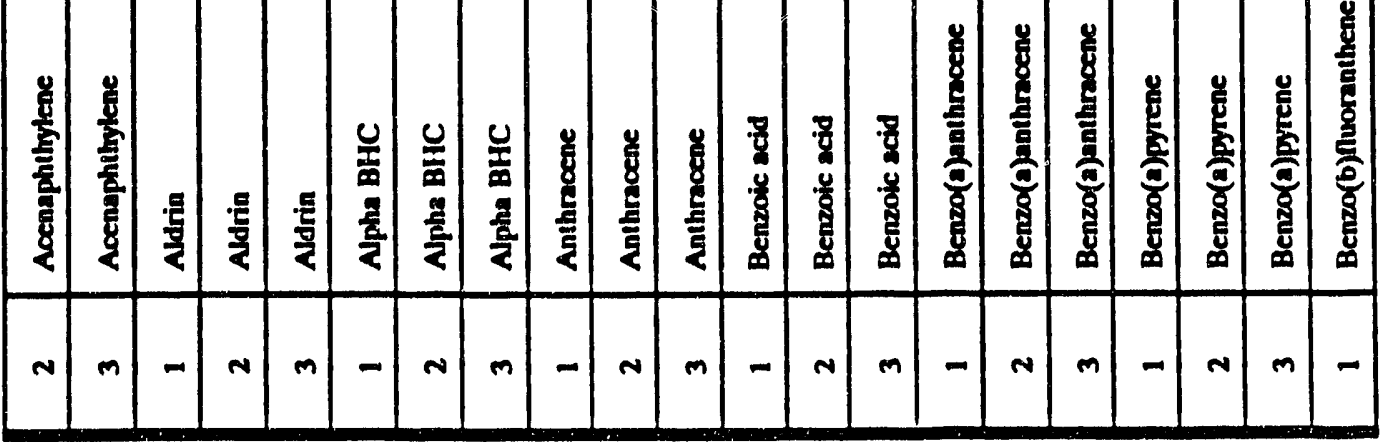




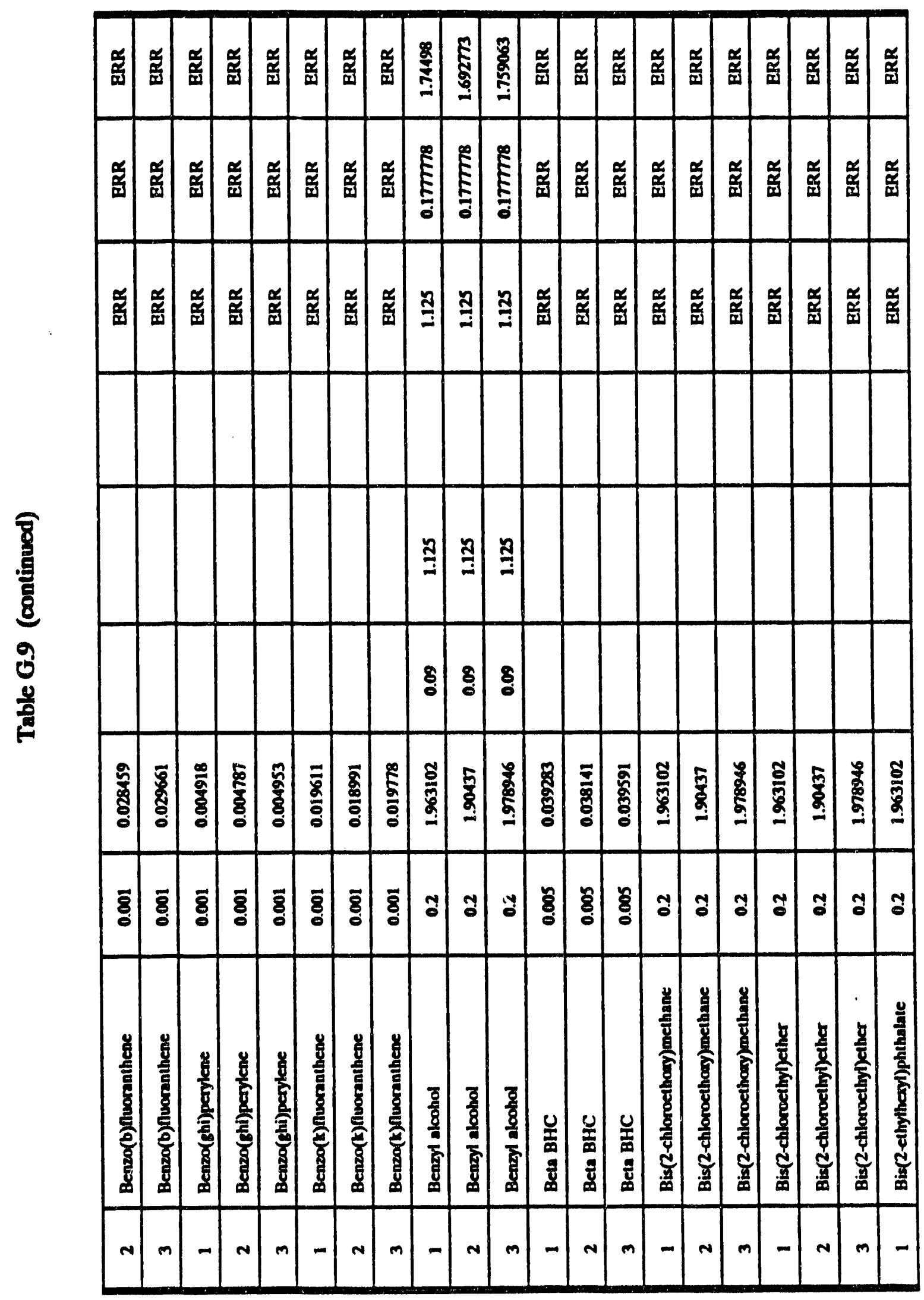




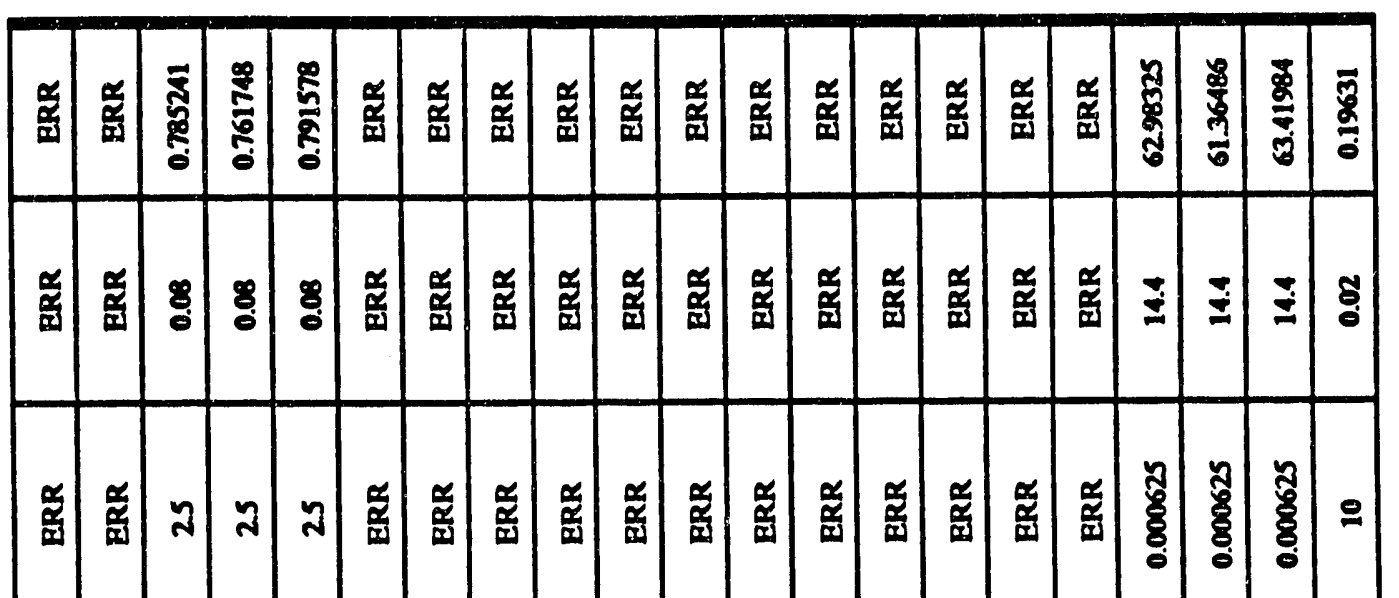

8
8
8
0
0
0
0
0
0

ป⿻一

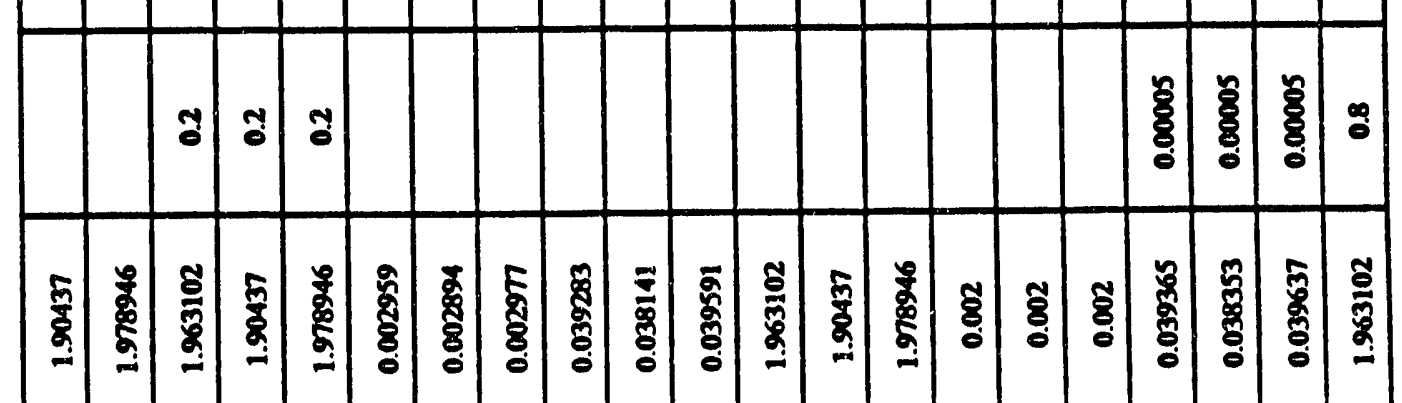

ริ วิ

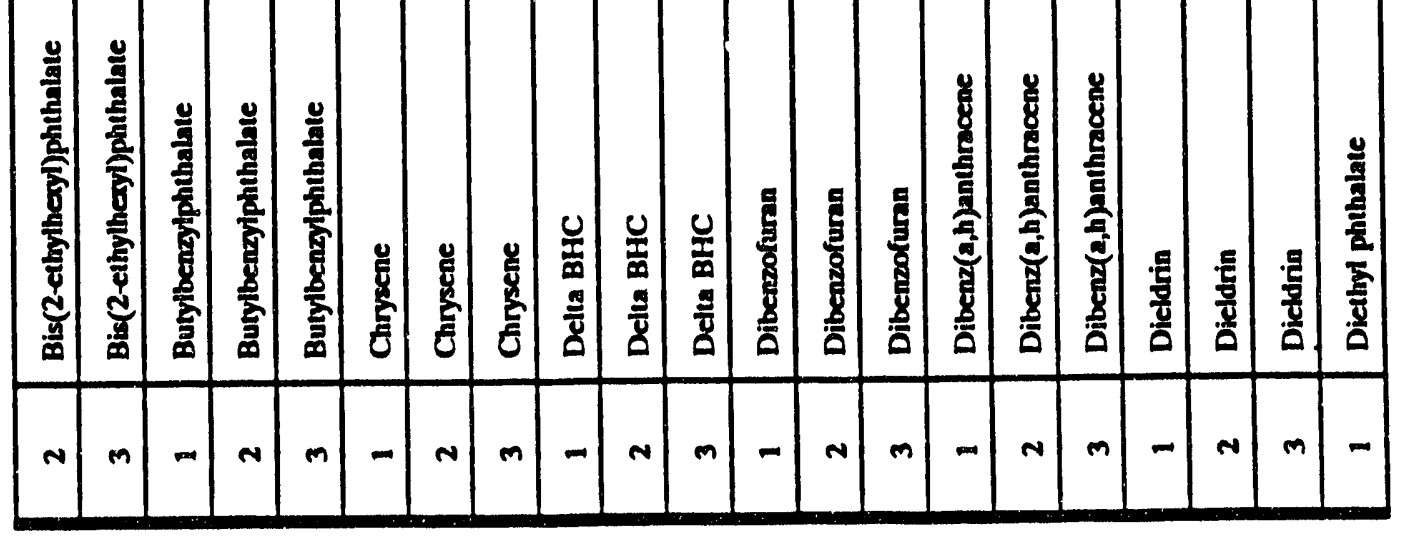




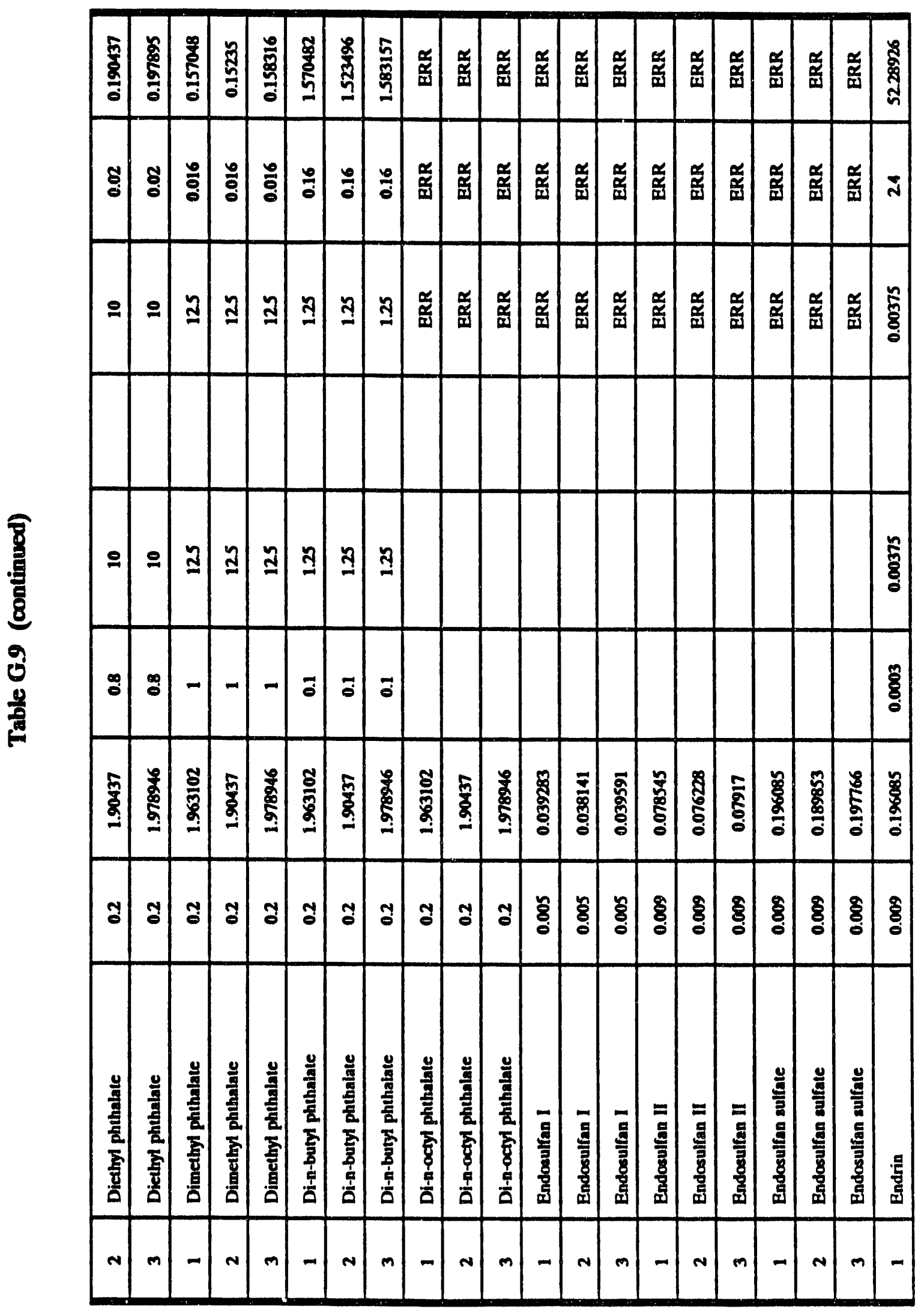




\begin{tabular}{|c|c|c|c|c|c|c|c|c|c|c|c|c|c|c|c|c|c|c|c|c|}
\hline 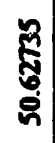 & 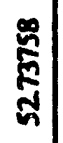 & 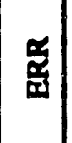 & 幽 & 总 & $\mid \begin{array}{c}\tilde{s} \\
\text { 心్ }\end{array}$ & $\begin{array}{l}\text { 悹 } \\
\text { \% }\end{array}$ & $\begin{array}{l}\text { 密 } \\
\text { 号 }\end{array}$ & 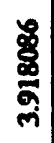 & 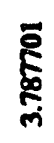 & $\begin{array}{l}\text { ఫ్ } \\
\text { హ్ }\end{array}$ & 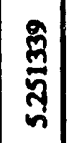 & 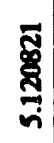 & 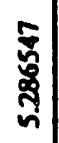 & 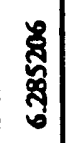 & $\frac{8}{5}$ & $\frac{2}{\mathbf{p}^{2}}$ & $\begin{array}{l}\frac{5}{0} \\
\vdots \\
\vdots\end{array}$ & & 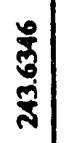 & \\
\hline $\bar{\lambda}$ & $\bar{\pi}$ & \begin{tabular}{|l|} 
細 \\
\end{tabular} & 蓄 & 㽞 & $\begin{array}{l}J \\
\vdots\end{array}$ & ప్ర & ఏ్ర & ఫ్ర్ & ర్ర్ర & ర్ర్ర & 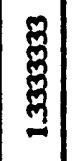 & 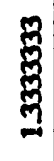 & 䞌 & $: \infty$ & : & $\stackrel{\infty}{0}$ & $\begin{array}{l}\bar{z} \\
\text { : } \\
\text { s. }\end{array}$ & & 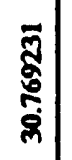 & \\
\hline & 商 & $\mid \begin{array}{l}\mathbf{z} \\
\mathbf{\alpha}\end{array}$ & 畄 & 獣 & : & ำ & ํ. & 믕 & ํ. & ำ & : & 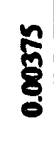 & 园 & $\mid \begin{array}{l}2 \\
8 \\
8 \\
0\end{array}$ & $\begin{array}{l}\text { ఫ్ర్ } \\
\text { : }\end{array}$ & वृ & 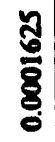 & & స్ & \\
\hline
\end{tabular}

象

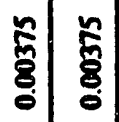

$$
\begin{aligned}
& \text { ๆ }
\end{aligned}
$$

:

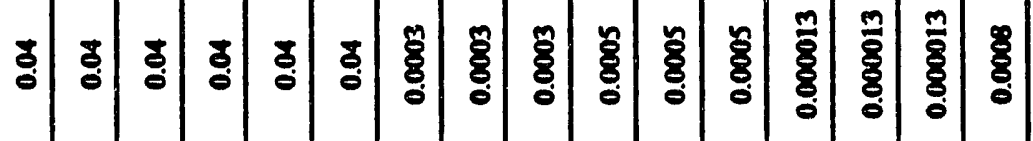

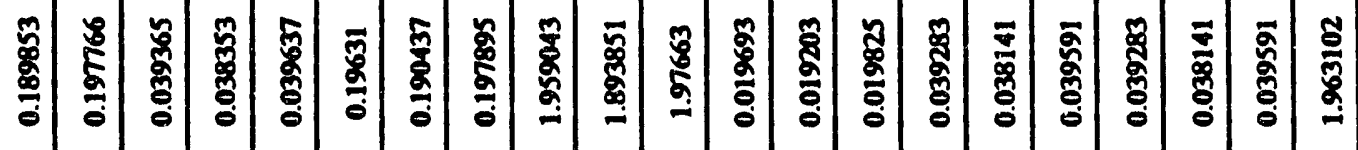

\begin{tabular}{|c|c|c|c|c|c|c|c|c|c|c|c|c|c|c|c|c|c|c|c|}
\hline $\begin{array}{l}\frac{2}{5} \\
\frac{1}{5}\end{array}$ & $\begin{array}{l}\frac{a}{\bar{v}} \\
\text { 音 }\end{array}$ & 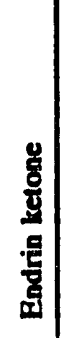 & 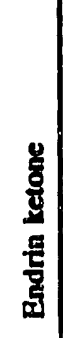 & 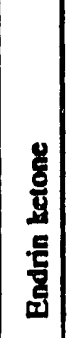 & 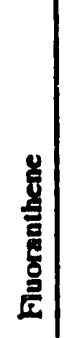 & 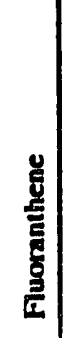 & 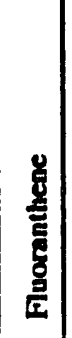 & 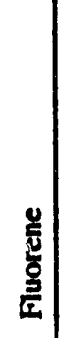 & 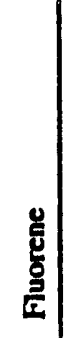 & $\begin{array}{l}0 \\
\frac{8}{2} \\
\frac{3}{x}\end{array}$ & 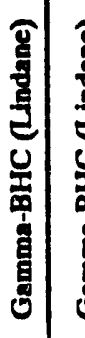 & 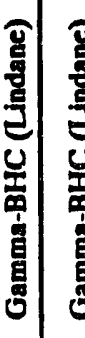 & 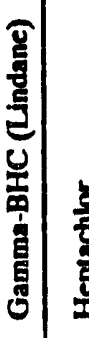 & 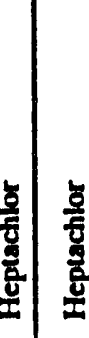 & 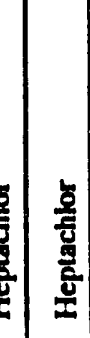 & 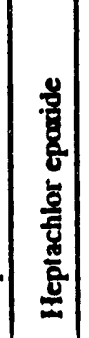 & 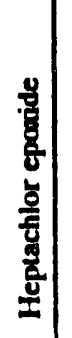 & 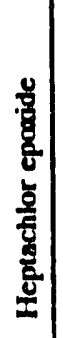 & 吾 \\
\hline $\mathrm{N}$ & $m$ & -1 & $N$ & $m$ & -1 & $N$ & $m$ & -1 & $N$ & $m$ & - & $N$ & $m$ & -1 & $4 \mathrm{~m}$ & -1 & $N$ & $m$ & - \\
\hline
\end{tabular}

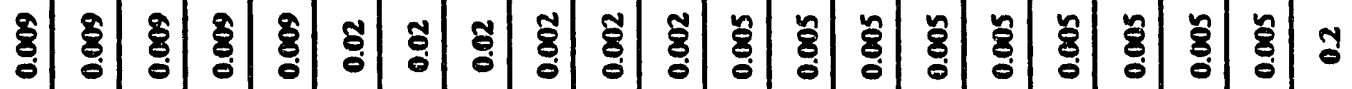




\begin{tabular}{|c|c|c|c|c|c|c|c|c|c|c|c|c|c|c|c|c|c|c|c|c|}
\hline 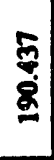 & 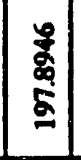 & 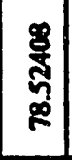 & 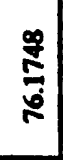 & 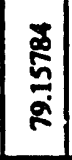 & 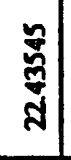 & 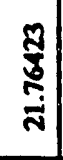 & 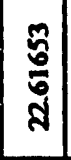 & $\begin{array}{l}\mathbf{5} \\
\vdots \\
\vdots \\
\vdots\end{array}$ & $\begin{array}{l}2 \\
\vdots \\
\vdots \\
2\end{array}$ & $\mid \begin{array}{c}\bar{n} \\
\bar{n} \\
\bar{n}\end{array}$ & 舀 & 童 & 总 & $\begin{array}{l}\overline{\mathbf{z}} \\
\vdots \\
0 \\
0\end{array}$ & $\mid \begin{array}{l}0 \\
0 \\
5 \\
0 \\
0 \\
\end{array}$ & 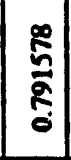 & $\frac{7}{\frac{7}{2}}$ & 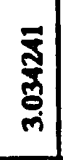 & $\begin{array}{l}3 \\
\frac{2}{0} \\
\dot{m}\end{array}$ & 哭 \\
\hline శి & 8 & $\infty$ & $\infty$ & $\infty$ & 离 & 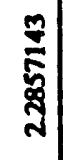 & 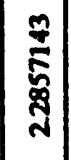 & 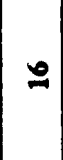 & 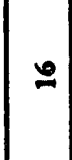 & $\simeq$ & 总 & 响 & $\left|\begin{array}{c}\mathbf{x} \\
\mathbf{y}\end{array}\right|$ & 8 & 8 & : & $\begin{array}{l}8 \\
0\end{array}$ & $\stackrel{\infty}{0}$ & $\begin{array}{c}0 \\
0 \\
0\end{array}$ & 8 \\
\hline$\overline{0}$ & $\ddot{0}$ & हू & : & בֶ. & $\begin{array}{c}n \\
\mathbf{s} \\
0\end{array}$ & $\begin{array}{l}\tilde{c} \\
\tilde{s} \\
0\end{array}$ & 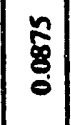 & ב⿱ & 离 & בุ & 产 & 善 & 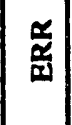 & $\lambda$ & $\eta$ & $y$ & $\mid \begin{array}{l}2 \\
\text { : } \\
0\end{array}$ & $\begin{array}{l}\text { चे } \\
0 \\
0\end{array}$ & $\mid \begin{array}{c}\text { ż } \\
\text { : }\end{array}$ & \%̆ \\
\hline
\end{tabular}

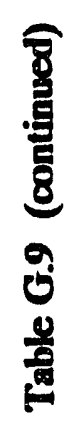

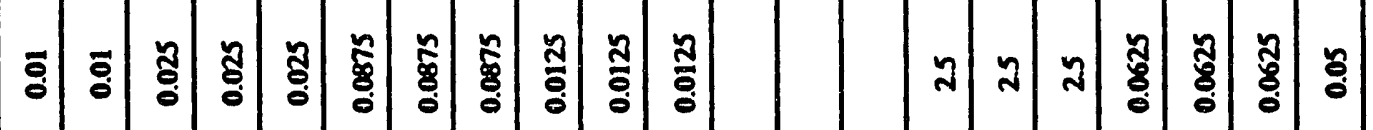

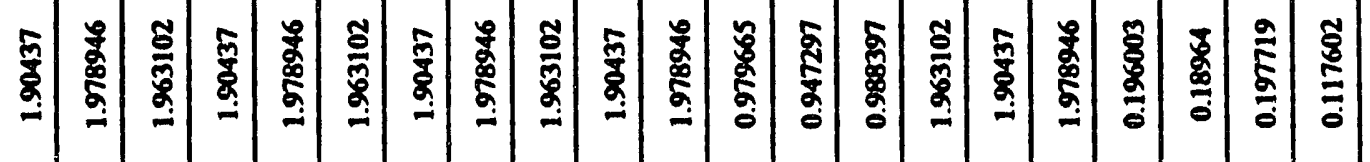$$
\text { ว }
$$

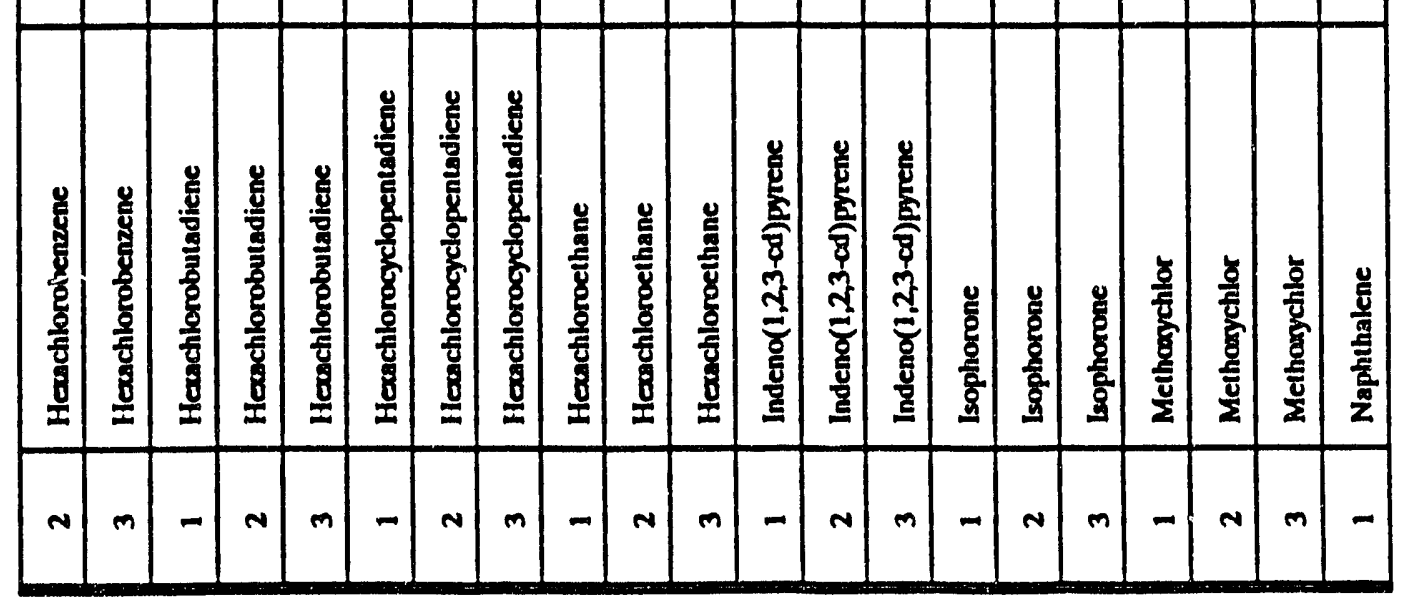




\begin{tabular}{|c|c|c|c|c|c|c|c|c|c|c|c|c|c|c|c|c|c|c|c|c|}
\hline 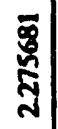 & $\frac{\tilde{3}}{\sqrt{n}}$ & \begin{tabular}{l} 
\% \\
\multirow{8}{*}{} \\
$\stackrel{+}{n}$
\end{tabular} & 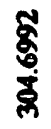 & $\begin{array}{l}\overrightarrow{7} \\
\text { है } \\
\text { ले }\end{array}$ & 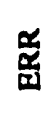 & 齐 & 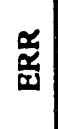 & $\begin{array}{l}\frac{\alpha}{\alpha} \\
\frac{\alpha}{w}\end{array}$ & 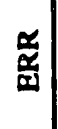 & 茎 & $\frac{\mathfrak{a}}{\mathbf{g}}$ & 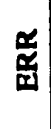 & 总 & $\frac{8}{\frac{8}{6}}$ & 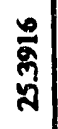 & 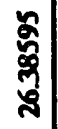 & $\begin{array}{l}\text { 学 } \\
\text {. }\end{array}$ & 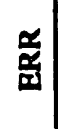 & 晃 & 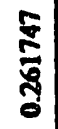 \\
\hline $\begin{array}{l}8 \\
0\end{array}$ & 8 & 요 & ల్ & బ్లి & $\frac{\tilde{z}}{\underline{a}}$ & $\begin{array}{l}\text { 啰 } \\
\end{array}$ & $\begin{array}{l}\stackrel{\mathscr{a}}{\mathbf{g}} \\
\text { }\end{array}$ & $\begin{array}{l}\stackrel{\alpha}{\alpha} \\
\frac{\alpha}{\mid r}\end{array}$ & 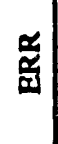 & 舀 & 丞 & 章 & 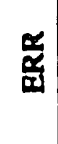 & $\begin{array}{l}5 \\
\mathbf{3} \\
\text { N }\end{array}$ & $\begin{array}{l}5 \\
\mathbf{8} \\
\mathbf{3} \\
\mathbf{3}\end{array}$ & $\begin{array}{l}5 \\
8 \\
3 \\
\text { స }\end{array}$ & 总 & 䀅 & $\frac{\mathscr{x}}{\mathbf{a}}$ & $\begin{array}{l}5 \\
5 \\
8 \\
0\end{array}$ \\
\hline
\end{tabular}

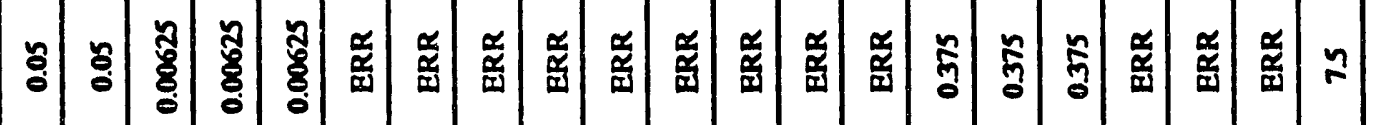

8
8
8
8
0
0
을 ๖.

कิ

$n$

ఫ్రి

:

$\because$

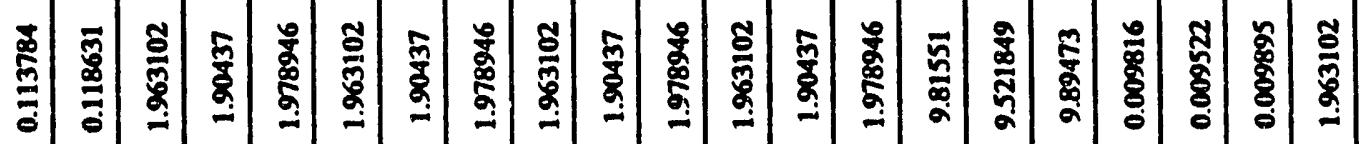

ฮิฮี่

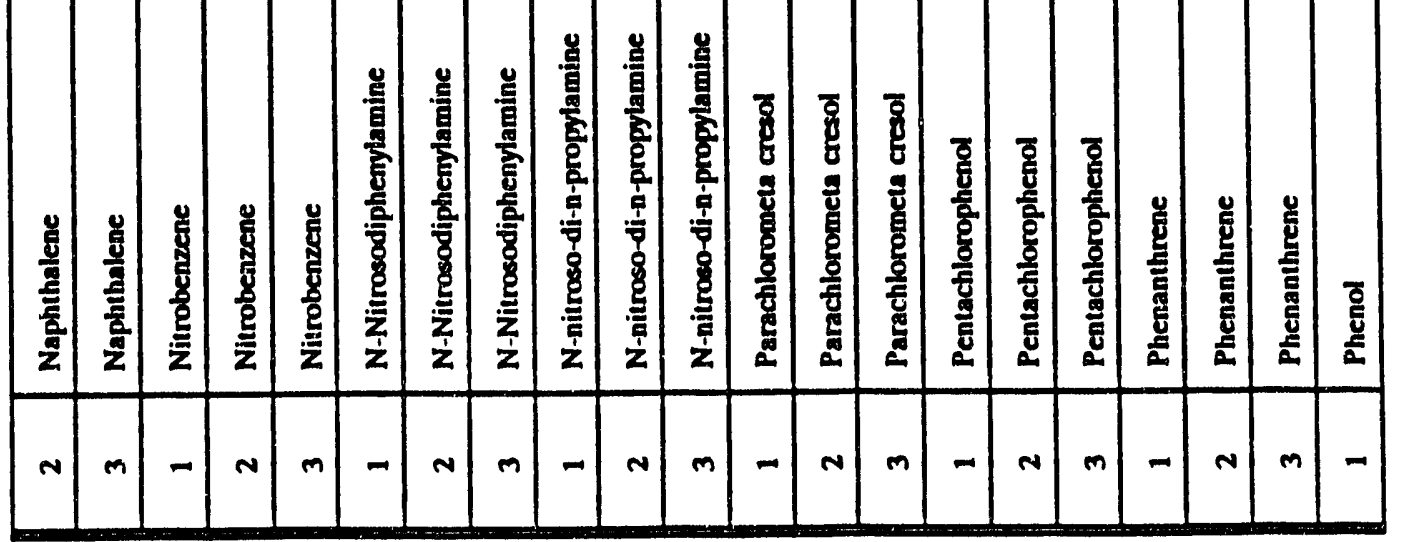


G-106

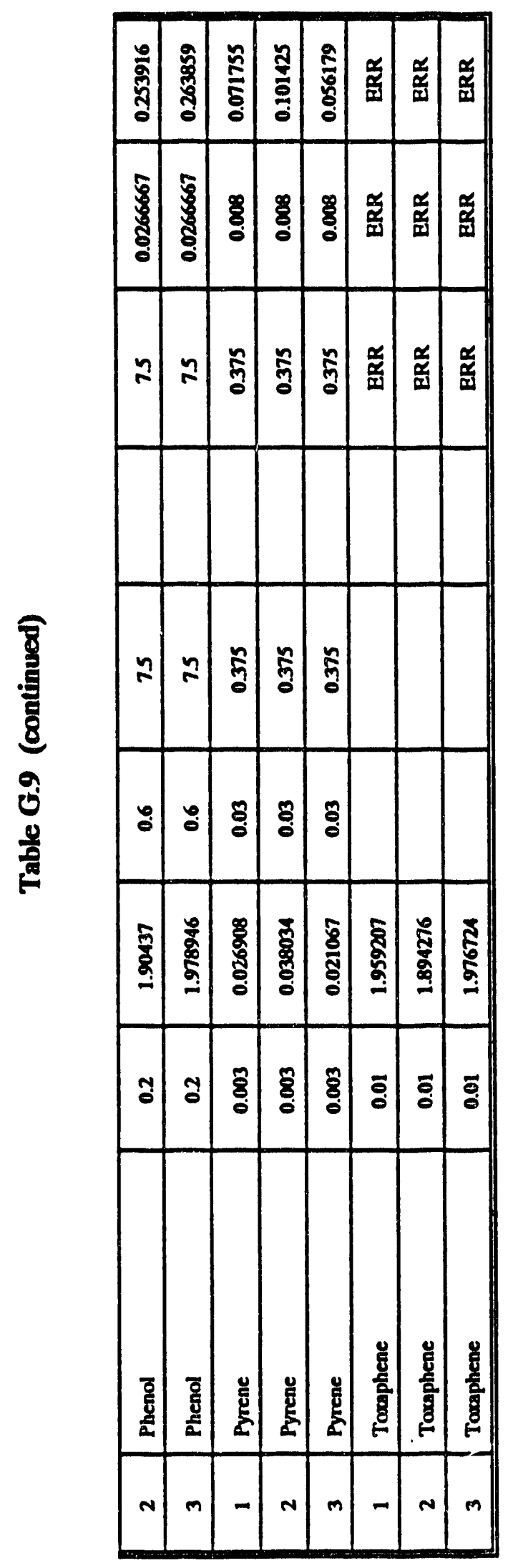


ORNL/ER-62/R1

\section{DISTRIBUTION}

\footnotetext{
1. T. L. Ashwood

2. L. D. Bates

3. B. G. Blaylock

4-23. H. L. Boston

24. J. B. Cannon

25. J. H. Cushman

26. M. F. P. DeLozier

27. D. E. Fowler

28. M. L. Frank

29. S. B. Garland II

30. C. W. Gehrs

31. C. D. Goins

32. P. J. Halsey

33. S. G. Hildebrand

34. F. O. Hoffman

35. L. A Hook

36. P. Kanciruk

37. B. L. Kimmel

38. A. J. Kuhaida, Jr.

39. V. Legg

40-42. D. M. Matteo
}

43. D. E. Miller

44-45. P. T. Owen

46. D. E. Reichle

47. G. E. Rymer

48. P. A. Schrandt

49. F. E. Sharples

50. D. S. Shriner

51. S. H. Stow

52 G. W. Suter

53. D. W. Swindle

54. R. I. Van Hook

55. D. R. Watkins

56. J. A. Watts

57. R. K. White

58-62. ER Document Management Center

64. Central Rescarch Library

64-68. ESD Library

69. ORNL Y-12 Technical Library

70-71. Laboratory Records Dept.

72. ORNL Patent Section

73. Office of Assistant Manager for Energy Research and Development, DOE Oak Ridge Field Office, P.O. Box 2001, Oak Ridge, TN 37831-8600

74. P. H. Edmonds, Radian Corporation, 120 South Jefferson Circle, Oak Ridge, TN 37830

75. J. F. Franklin, Bloedel Professor of Ecosystem Analysis, College of Forest Resources, University of Washington, Anderson Hall (AR-10), Seattle, WA 98195

76. R. C. Harriss, Institute for the Study of Earth, Oceans, and Space, Science and Engincering Research Building, University of New Hampshire, Durham, NH 03824

77. G. Y. Jordy, Director, Office of Program Anatysis, Office of Energy Research, ER-30, G-226, U.S. Department of Energy, Washington, DC 20545

78-79. J. R. Kannard, Program Manager, Bechtel National, Inc., P.O. Box 350, Oak Ridge Corporate Center, 151 Lafayette Drive, Oak Ridge, TN 37830

80-81. R. L. Nace, Branch Chief, Nonenrichment Facilities, Oak Ridge Program Division, Office of Eastern Area Programs, Office of Environmental Restoration, EM-423, Trevion 2, U.S. Department of Energy, Washington, DC 20585

82. R. H. Oisen, Professor, Microbiology and Immunology Department, University of Michigan, Medical Sciences II, \#5605, 1301 East Catherine Street, Ann Arbor, MI 48109-0620

83. A. Patrinos, Acting Director, Environmental Sciences Division, Office of Health and Environmental Research, ER-74, U.S. Department of Energy, Washington, DC 20585

84-85. R. C. Sleeman, DOE Oak Ridge Field Office, P.O. Box 2001, Oak Ridge, TN $37831-8541$

86-87. J. T. Sweeney, DOE Oak Ridge Field Office, P.O. Box 2001, Oak Ridge, TN $37831-8540$

88-89. H. M. Thron, Chief, Enrichment Facilities, Oak Ridge Program Division, Office of Eastern Area Programs, Office of Environmental Restoration, EM-423, Trevion 2, U. S. Department of Energy, Washington, DC 20585.

90. T. Wheeler, Radian Corporation, 120 S. Jefferson Circle, Oak Ridge, TN 37830

91. F. J. Wobber, Environmental Sciences Division, Office of Health and Environmental Research, Office of Energy Research, ER-74, U.S. Department of Energy, Washington, DC 20584

92-93. Office of Scientific and Technical Information, P.O. Box 62, Oak Ridge, TN 37831 

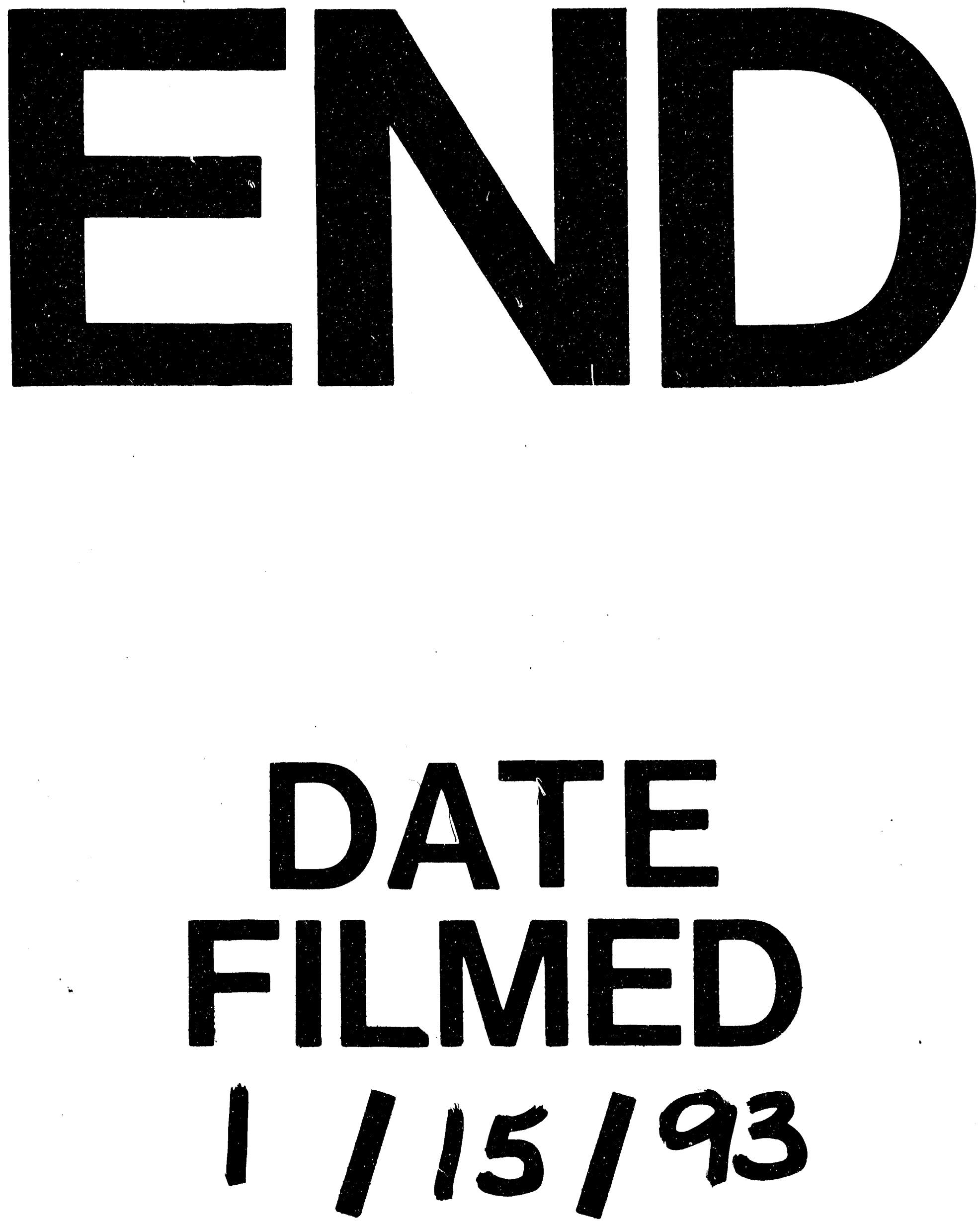

1 
